\title{
REACRO COPY
}

\section{NUCLEAR DIVISION}

Report No. RN-S-0082

(Revision 5)

\section{To}

AEC-NASA Space Nuclear Propulsion Office

SUPPORT EQUIPMENT

TECHNICAL DESCRIPTION HANDBOOK

Nerva Program

Contract SNP-1

January 1968

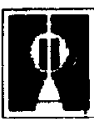




\section{DISCLAIMER}

This report was prepared as an account of work sponsored by an agency of the United States Government. Neither the United States Government nor any agency Thereof, nor any of their employees, makes any warranty, express or implied, or assumes any legal liability or responsibility for the accuracy, completeness, or usefulness of any information, apparatus, product, or process disclosed, or represents that its use would not infringe privately owned rights. Reference herein to any specific commercial product, process, or service by trade name, trademark, manufacturer, or otherwise does not necessarily constitute or imply its endorsement, recommendation, or favoring by the United States Government or any agency thereof. The views and opinions of authors expressed herein do not necessarily state or reflect those of the United States Government or any agency thereof. 


\section{DISCLAIMER}

Portions of this document may be illegible in electronic image products. Images are produced from the best available original document. 


\section{AEROJET}

ATh

GENERAL

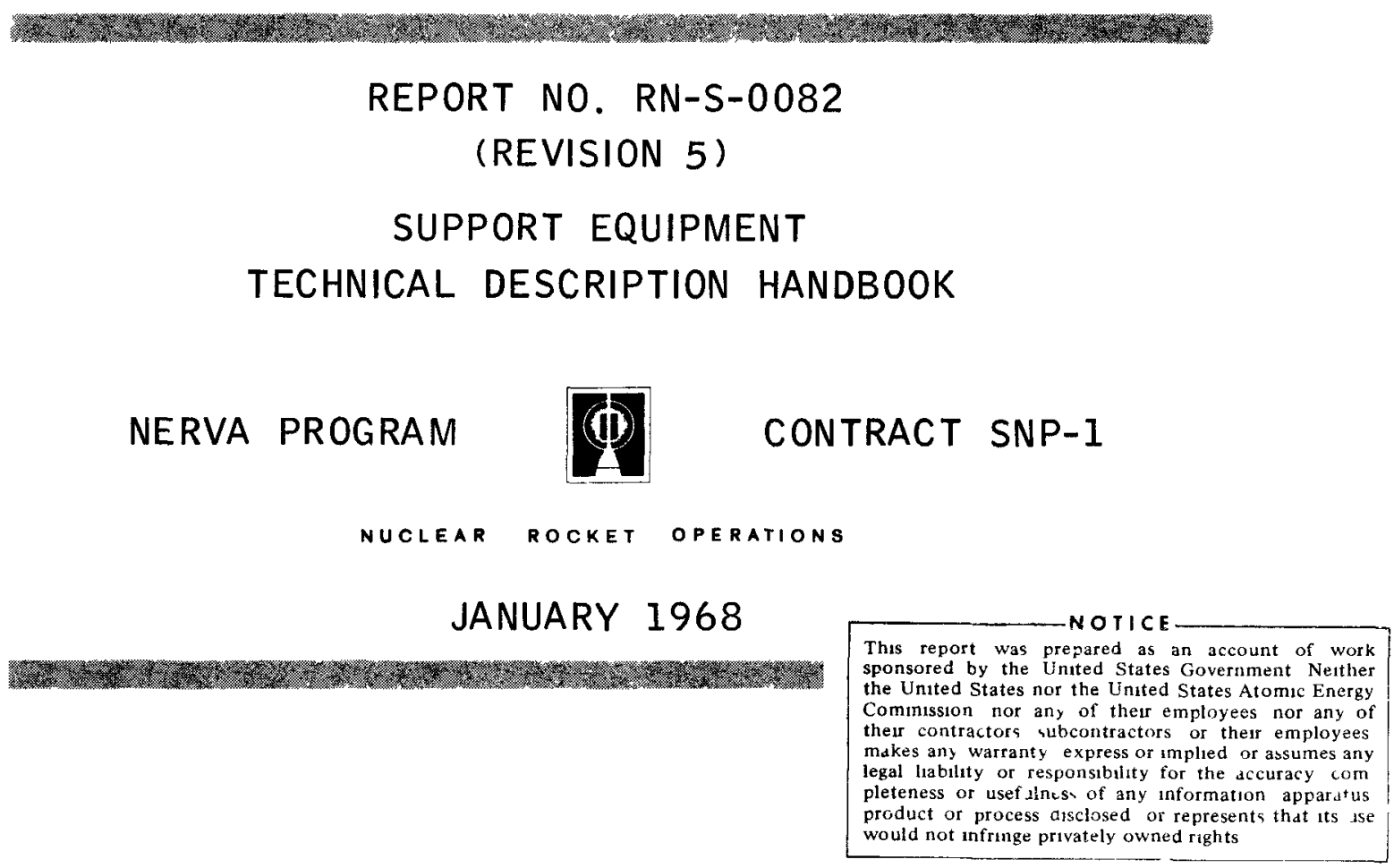

\section{CLASSIFICATION , CATEGORY}

\section{UNCLASSIFIED}

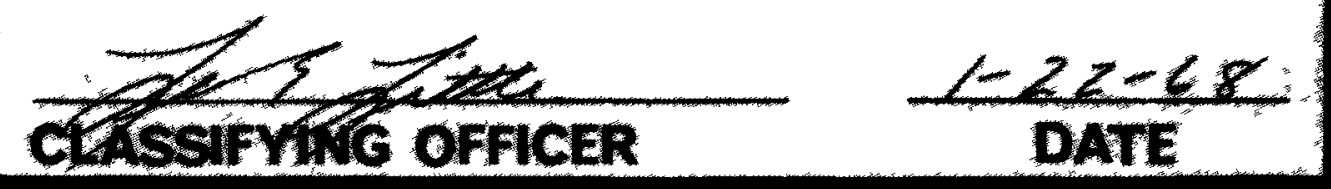

\section{AER OJET - GENERAL CORPORATION \\ A SUBSIDIARY OF THE gENERAL TIRE \& RUBBER COMPANY}




\section{BLANK}


REPORT NO. RN-S-0082

(REVISION 5)

SUPPORT EQUIPMENT

TECHNICAL DESCRIPTION HANDBOOK

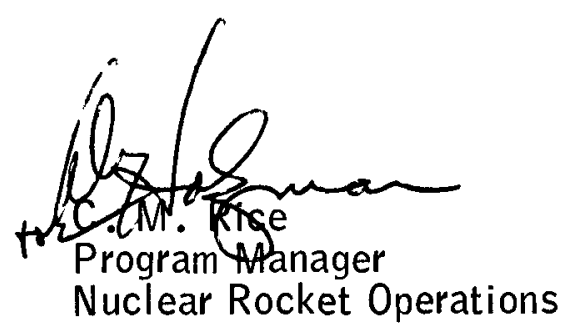




\section{INTRODUCTION}

The NERVA Support Equipment Technical Description Handbook, RN-S-0082, describes NERVA NRX and XE Ground Support Equipment. This issue (Revision 5) provides current descriptions of all nonnuclear GSE for the NRX and XE series and most of the nuclear GSE through the NRX-A5 series. The nuclear GSE for NRX-A6 and the XE series will be described in a later revision to this handbook. The equipment list and the data sheets of all items of existing equipment are in numerical order by Provisioning List Number. The items for which there are no data sheets at this time are marked in the equipment list by an asterisk.

Additional information concerning equipment in this handbook may be obtained from L. E. Little, Department 7890, NRO Support Systems, AerojetGeneral Corporation, Sacramento, California, Telephone (916) 355-3777. 
PROV. LIST ITEM NO.

9 Tool Kit, Rocket Disassembly, Remote

10 Tool, Bolt Removal, Forward Closure/Nozzle, Remote

11 Adapter, Right Angle, Remote Bolt Removal

14 Tool, Removal, Hot Bleed Port Nut

17 Cover, Nozzle, Cooldown, Remote

\section{EQUIPMENT LIST}

Tool Kit, Instrumentation Removal, Remote

Tool, Nut Removal, Radiation Shield

Puller, Hot Gas Bleed Port

Socket, Impact Wrench
DRAWING NO.

293752

1115360

276312

276470

1115786

1116471

1117491

1117516

276380

276450

293300

276462

276440

276300

276410

276465

276425

276389

276390

293235

293333

253371

1115803 
PROV. LIST ITEM

No.

469 Kit, Dimensional Checking, Rocket Engine

475 Closure, Reactor/Pressure Vessel Assembly Pressure Test

501 Stand, Turbopump, Remote

502 Sling, TPA, NRX/EST Assembly

503 Sling, Direct Radiation Shield
504 Fixtures, Handling, Propellant Lines, Remote

1115450 ,

1115030 ,

1115338 ,

1115339 ,

1115796

505 Stand, Direct Radiation Shield

506 Fixture, Holding, Turbine Inlet Line Elbow, Remote

704 Container, Shipping and Storage, Rocket Engine Nozzle

730

801

803

809

814

817

915

916

917

919

921

922

923

924

Fixture, Alignment, Coolant Manifold

1114651

1115864

278500

278509

Sling, Multiple Leg, Multiple Purpose, 3000 1b Capacity

278580

Fixture, Lifting, Rocket Engine Forward Closure 279150

Sling, Beam Type

278570

Beam, Hoisting, Nozzle, Rocket Engine

278660

Sling, Multiple Leg, 12,000-pound Capacity

278670

279050

279110

279160

279180

Stand, Nozzle, Rocket Engine

$$
279180
$$

Adapter, Handling, Pressure Vessel, Pneumatic

$$
\text { Fixture, Turnover, Forward Closure }
$$

278590

$$
\text { Fixture, Disassembly, Thrust Chamber/Reactor, Remote }
$$

1115427

$$
\text { Stand, Disassembly Fixture }
$$

1115636 
PROV. LIST ITEM

NO.

$* 1001$
$* 1002$
$* 1003$
$* 1021$
$* 1022$

*1023

*1024

*1027

*1032

*1036

*1060

*1062

*1063

*1065

*1067

$* 1068$

$* 1069$

*1080

1091

1092

1093

$* 1100$

1102

1103

1104
EQUIPMENT LIST

Spectrometer, 400 Channel (Gamma)

Proportional Beta Counting System, 2 Pi Gas Flow

Colorimeter

Wall Periscope

Shield, Beta Counter

Steromicroscope, Remotely Operated

Stage, Stereomicroscope

Balance, Remote

Tester, Remotely Operated Spring

Reader, Microdosimeter

Radio Chemical Equipment

Shield, 2 Pi Beta Counting

Balance, Marco

Adapter, Stereomicroscope

Meter, $\mathrm{pH}$

Crystal, Scintillation Detector, Harshaw

Spectrophotometer

Measuring Kit, No. 1

Table, Balance

Fixture, Coil Spring Testing

Fixture, Leaf Spring Testing

Hot Cell, Medium Duty Prefabricated

Too1, Remova1, Control Drum Bearing Housing Bolt

Fixture, Lifting, Control Drum Assembly

Stand, Storage, Control Drum Assembly
DRAWING NO.

E-675498

E-675496

NT650053

$\mathrm{E}-675482$

E-675476

NT650094

E-675500

NT650427

NT650372

NT650260

NT650262

Mod $12 S 12$

Mod $12000 \mathrm{~B}$

NT650275

NT650286

NT650418

NT650419

E-675494

NT650135

NT650011

NT650009 
PROV.

LIST ITEM

NO.

1105

1106

1110

*1119

*1122

1123

1126

*1131

1132

*1133

*1134

1135

*1138

1139

1143

1145

1149

1151

1153

1158

1160

*1162

*1163

1164

1168

\section{EQUIPMENT LIST}

Stand, Control Drum Disassembly

Fixture, Lifting, Outer Reflector Assembly

Fixture, Lifting, Outer Reflector Sector

Container, Lateral Support Parts

Stand, Inner Reflector Segment Assembly

Stand, Cylinder Slitting

Stand, Storage, Inner Shipping Container

Handling Fixture, Universal

Stand, Closure/Control

Fixture, Handling, Nozzle

Stand, Vessel/Nozzle Disassembly

Fixture, Handling, Shield

Stand, Privy Plug Assembly, Upper Portion

Inspection Equipment

Fixture, Handling, Reactor Assembly

Pallet, Simulated Shield

Fixture, Lifting, Nozzle End Support Ring, Outer Reflector

Fixture, Handling, Reactor Adapter Ring

Fixture, Handling, Screen

Stand, Drive Shaft Storage

Fixture, Lifting, Shipping Container

Pallet, Support, Top Cover

Pallet, Support, Inner Container Cover

Fixture, Handling, Control Drum

Container, Control Drum Hardware
DRAWING NO.

NT650015

NT650002

NT650012

NT650070

NT650016

NT650060

NT650006

3-509976

3-510221

3-510797

3-510276

3-509800

3-509958

NT650000

NT650138

NT650004

3-510004

3-509904

NT650141

NT650005

NT650007

NT650008

NT650014

NT650175

*Entry to be supplied at a later date. 
PROV. LIST ITEM

NO.

1171

1172

*1176

*1180

1181

1182

1193

*1195

1199

1200

1209

1211

1218

*1220

*1221

1224

*1225

*1226

1229

1230

*1232

*1233

*1235

1237

*1239

\section{EQUIPMENT LIST}

Tool, Outer Reflector Tie Bolt

Fixture, Handling, Cylinder Slitting Stand

Container, Shipping, Poison Wires

Tool, Instrumentation Seal Nut Removal

Fixture, Support, Instrumentation and Control Drum Shaft

Fixture, Trunnion, Reactor

Pallet, Disposal

Container, Support Too1 and Hardware

Rack, Tool Holder

Dril1, Mechanical Remote

Clips, Retainer, Control Shaft

Tool, Simulated Shield Nut Installation

Fixture, Chucking, Mechanical Remote Drill

Tool, Guide Tube Removal

Mill, Bolt Head

Instrumentation Recorders and Cabinets, Shipping

Closure, Leak Test

Fixture, Handling, Disposal Pallet

Fixture, Handling, Control Drum Disassembly Stand

Fixture, Closing, Large Disposal Pail

Fixture, Core Loading

Fixture, Handling, Core Barrel

Fixture, Seal Retainer

Fixture, Closing, Small Disposal Pail

Fixture, Cluster Assembly (Regular)
DRAWING NO.

NT650142

NT650124

976D166

3-512103

3-509937

3-510022

$566 \mathrm{~F} 441 \mathrm{D}$

3-507827

NT650143

NT650036

3-510299

NT650322

NT650020

3-510806

3-511854

3-511773

NT650331

NT650018

NT650329

NT650033

NT650021

NT650063

NT650328

NT600013

*Entry to be supplied at a later date. 
PROV. LIST ITEM

NO.

$* 1240$

*1241

*1242

*1243

*1247

1249

1251

*1256

1258

*1259

*1264

*1280

*1285

1290

*1302

*1304

*1305

1308

*1311

*1312

*1317

*1320

*1321

*1327

1334
EQUIPMENT LIST

Fixture, Cluster Assembly (Irregular)

Fixture, Lifting, Control Drum

Fixture, Lifting, Outer Reflector Sector

Storage Rack, Control Drum

Platform, Personnel, Reactor/Vesse1-Car

Semitrailer, Reactor and Shield Shipping

Trunnion Cage, Reactor/Vessel

Stand, Barrel Support

Insert, Element Cask

Container, No. 1 Hardware

Container, Simulated Shield

Container, Lateral Support Plunger and Tie Rod Groups

Tool, Seal Segment Withdrawal

Cutter, Control Drum Assembly

Trunnion Fixture, Post Operations

Tester, Air Flow Impedance

Rack No. 1, Transfer

Adapter, Periscope

Fixture, Seal Segment Guide

Too1, Drill Bushing Assembly, Seal Segment Removal

Container, Fuel Cluster Tie Rod

Container, Cluster Nut Hardware

Container, Fuel Cluster Support

Tester, Electrical Resistivity

Adapter, Drive Shaft Torque
DRAWING NO.

NT600014

NT600019

NT600020

NT650035

709J743

NT600082

3-510081

NT650023

NT650434

NT650074

710J071

NT650194

NT650200

NT650297

NT650309

NT650311

NT650312

NT650315

NT650318

NT650319

NT650064

NT650073

NT650068

NT650440

NT650131

*Entry to be supplied at a later date. 
PROV.

LIST ITEM

No.

EQUIPMENT LIST

DRAWING NO.

1337

Fixture, Retaining, Trunnion Cage

NT650326

1339

Gage, Drive Shaft Location

NT650072

*1340

AGC Transition Block

3-510510

*1341

Tool, Simulated Shield Nut, 1-1/2" Thd

NT650184

$\star 1342$

Tool, Simulated Shield Nut, 1-1/4" Thd

NT650185

1343

Tool, Simulated Shield Support Sleeve

NT650186

*1344

Handling Fixture - Key Cluster

NT650188

*1354

Oil Filter System

Mod 217-1

1355

Stand, Assembly and Installation

3-508159

$\star 1356$

Stand, Privy Plug Assembly, Lower Portion

3-505435

*1357

Cover, Protective Ports

NT600877

1358

Fixture, Handing, Postoperative, Sector

NT650333

1359

Cradle, Postoperative Sector

NT650334

1360

Fixture, Handling, Postoperative, Control Drum

NT650335

1363

Tool, Retraction, Poison and Calibration Wire

NT650338

1364

Gage, Reflector Assembly, Bow

NT650339

1369

System, Nozzle Hood Emplacement

NT650341

*1370

Lock, Control Drum

3-512003

*1371

Micrometer, Optical Gage (With Non-Browning Lens)

NT650307

*1372

Cask, Dosimeter

Mod CL. 6-44

$* 1374$

Scaffold, Dosimeter Recovery

NT650413

*1375

Trunnion Cage, Reactor

3-509940

*1376

Adapter, 25 Ton Crane Hook

NT650523

*1380

Container, Long Parts Disposal

NT650431

\footnotetext{
*Entry to be supplied at a later date.
} 
PROV. LIST ITEM

No.

$* 1381$

*1385

*1386

$* 1387$

*1389

*1392

*1394

*1395

*1401

$* 1402$

$* 1406$

$* 1407$

$* 1414$

*1418

$* 1421$

$* 1433$

*1435

$* 1500$

*1501

*1502

$* 1503$

$* 1504$

*1505

$* 1506$

$* 1507$
EQUIPMENT LIST

Container, Sector, Outer Reflector

Fixture, Reactor Assembly Handling

Puller, Cluster Nut

Fixture, Segment Lifting

Clamp, Slip Prevention

Fixture, Wrench Changing

Lock, Transfer, Jr Hot Cell

Sleeve, Periscope, $6 \mathrm{ft}$

Checker, Nuclear Channel Criticality and Safety

Checker, Control Drum Actuator

Checker, Wiring and Transducer

Calibration Sources and Containers

Neutron Source, Reactor Startup and Container

Tester, Eddy Current (WANL Type)

Transducer Test Equipment

Checker, Operational Control and Data Amplifier Test Cell "A" Radial Rabbit Gun

Stand, Adapter, Trunnion Fixture

Cutter, Plier Type, Instrumentation

Cutter Head, Guillotine Type, Instrumentation

Fixture, Instrumentation Cutter Changing

Tool, Tie Bolt Disassembly

Gage, Indicating Plus

Cask, Shipping, 3T-6DX14L

Cask, Shipping 4T-5DX14L
DRAWING NO.

NT650432

NT650436

NT650435

NT650438

NT650526

NT650439

NT650441

NT650529

9450411

$909 E 463$

$928 \mathrm{~F} 932 \mathrm{GOI}$

N5-5

$799 D 587$

928F918G01

1FC-1065

715J030

NT650530

NT650448

NT650449

NT650450

NT650451

Mod. $844 \mathrm{~V}$

NT650443

NT650444

*Entry to be supplied at a later date. 
PROV.

LIST ITEM

NO.

EQUIPMENT LIST

DRAWING NO.

*1508 Cask, Shipping, 4T-3DX30L

NT650445

*1509 Wrench, Air Impact, Cluster Nut

Skil. Mod. 1080

*1511 Tray, Folding Transfer

NT650442

*1512 Tool, Core Support Ring Bolt Removal

NT650453

*1513 Tool, Tie Rod Nut Removal

NT650455

*1514

Driver, Pneumatic Screw

NT650454

*1515

System, Remote Weighing

*1516

Stand, Sector Disassembly/Inspection

NT650531

*1517

Stand, Shielded Inspection

NT650532

*1518

Shaft, Interchangeable Reactor/Vessel Trunnion Cage

$* 1560$

Adapter, 0-MAN

NT650456

*1561

Wrench, Air Impact, 1 Inch Square Drive

NT650457

*1562

Adapter, Offset

*1564

Grinder, Pneumatic, Sidewall

NT650569

1702

Flat Car, Reactor Shipping

711J066

1703

Instrumentation Car, Reactor Shipping

$709 \mathrm{~J} 825$

*1706

Container, Shipping, NRX-A Reactor in Vessel

E-675544

2001

Vehicle, Engine Installation (EIV)

89-71-1000

2002

Car, Control, Manned (MCC)

89-73-1000

2003

System, Overhead Positioning (OPS)

$89-80-1000$

2012

Carriage, Mobile, Floor Mounted Handling System

$89-81-1100$

2013

Dolly, Remote Handling, Floor Mounted Handling System

2014

Turntable Assemb1y, Portable, 9-Foot, 6-Inch Diameter, Floor Mounted Handling System

2017

Turntable Assemb1y, Portable, 15-Foot Diameter, Floor Mounted Handling System

$89-81-1200$

$89-81-1800$

$80-81-1850$

*Entry to be supplied at a later date. 
PROV.

LIST ITEM

NO.

EQUIPMENT LIST

DRAWING NO.

2031

Stand, Reactor Positioning Head, Floor Mounted

$89-80-1950$ Handling System

4000 Stand, UTS/TSA Assemb1y

$1117448-9$

4008 Stand, External Shield

$1117127-9$

4009 Fixture, Lifting, External Shield

1117216-9

4011

Head Assembly, Positioning, Thrust Structures

1114421-9

4012 Stand, Positioning Head, Thrust Structure

1114447-9

4021

Stand, Engine Assembly

1117307-9

4027

Stand, Assembly, Storage, Upper Thrust Structure

$1116300-9$ Module

4043 Adapter Kit, Checkout, Remote

1117850

4045

System, Materials Transfer, Postoperative Cell

1115.585

4046

Sling, Intercell Transfer Car

1115598

4048

Sling, Handling, Mobile Table

1115589

4049

Cover, Fluid Line, Remote

1115155-9

4059

Platform, Maintenance, ETS-1

1118696-9

4087

Lifting Device, Turbopump Assembly

1117189-19

4088

Closure, Engine Nozzle

1116894

4090

Spacer, Installation, Test Stand Adapter

1116912

4094

Stand, PVARA

1116098

4095

Cover, Auxiliary Duct, ETS-1

1117881

4099

Stand, Engine Holding

1116222

4101

Lifting Device, Collar, Line Shielding

1117105

4102

Platform, Interna1, UTS

1115073

4103

Kit, Guide, Flange, Fluid Lines

1117996

4104

Wrench Assembly, Impact

1116315

4105

Clamp, Line Alignment, Remote

1116852 
PROV. LIST ITEM

No. EQUIPMENT LIST

DRAWING NO.

4108

Closure, Turbine Exhaust Nozzle

1118799

4111

Stand, External Shield, Ball Loading

1117236

4112 Tool, UTS/TSA Nut Removal, Remote

1117870

4115

Guides, Control Drum Drive Shaft Housing

1117666

4116

Fixture, Lifting, XE Lower Module

1116340

4117

Coupling Device, Fluid Line, Remote, 9.00-Inch $\mathrm{C}-\mathrm{C}$ Hex

A-06771-D

4118

Coupling Device, Fluid Line, Remote, 7.62-Inch C-C Hex

4119

Coupling Device, Fluid Line, Remote, 6.50-Inch C-C Hex

Coupling Device, Remote, 4.75-Inch C-C Hex

A-06760-D

4121

Device, Nut Actuation, Remote UTSM/TSA Lines

A-06799-D

4122

Stand, Engine Reassembly

1118465

4123

Tool, UTS Shield Nut, Remote

A-06863-D

4124

Kit Tool, Seal Installation

1133893

4125

Target Assembly, Para1le1

1117337

4126

Container, Shipping, Upper Module Assembly

1118743

4133

Adapter, Fixture, Lifting

1118664

4134

Fixture, Lifting, Insulating Shield, XE

1117458

4135

Protector, Flange, Pressure Vesse1

1118755

4142

Kit, Modification, Handling Fixture, Forward Closure, Remote

4143 Adapter, Poison Wire Retention, Nozzle Throat Plug

1134013

1134556

4400 Set, Functional Valve and Leak Test

1117286

4401

Set, Electrical Test

1117297

4402

Set, Detector, Helium Leak, Remote

1118395

4404

Kit, Closure, Engine Leak Testing

1117450

4408

Fixture, Retention, Central Core Poison Wire 
PROV.

LIST ITEM

No.

4409

4412

4420

4701

4708

4709

4746

4749

5002

5003

5006

5007

5009

5014

5015

5019

5021

5022

5023

5026

5029

5035

5036

5038

*5202
EQUIPMENT LIST

Simulator, Electrical

1118560

Closure Assembly, Vent Line

1134414

Simulated Engine Test Stand No. 1

SPE 69-1-65

Adapter, Handling, Thrust Structure

278930

Platform, Maintenance, Engine

1118630

278850

Fixture, Lifting, Rocket Engine

1117077

1117682

Shear, Bench, Hydraulic

P-03339-D

Cleaner, Vacuum Remote

Torch, Aćetylene Remote

Mounts, Binocular

Tester, Macrohardness, Remote

Shield, Personnel

Television System Equipment

Periscope, Wall Type, Hot Disassembly Bay

Car, Storage, High Activity

Remote, Durometer

Periscope, Wa11 Type, Post Mortem Cell

Transfer System, Plug Door

Spacer Car

Shears, Pneumatic, Hedge Type

Shears, Pneumatic, Hook Type

Screw Driver, Remote

Scanner, Incremental Gamma, Mechanical

*Entry to be supplied at a later date. 
PROV.

LIST ITEM

NO.

EQUIPMENT LIST

DRAWING NO.

*5203 Scanner, Gross Gamma, Electrical

E-675520A

*5204 Scanner, Incremental Gamma, Electrical

E-675521A

*5206 Pulverizer

E-675514

*5207 Blender, Remotely Operated

$\mathrm{E}-675515 \mathrm{~A}$

*5209

Library, Fuel Element

E-675542

*5210

Saw, Slitting

$\mathrm{E}-675524$

*5211

Metallograph, Remotely Operated

E-675508A

*5214

Grinder, Course

$\mathrm{E}-675530$

*5215

Polisher, Metallographic

E-675516

*5216

Cut-off Machine

E-675480

*521

Oven, Drying Vacuum

E-675531

*5218

Cleaner, U1trasonic

E-675526

*5219

Press, Mounting

E-67522

*5220

Etcher, Electrolytic

NT650521A

*5221

Etcher, Vacuum Cathodic

E-675523

*5222

Holder, Speciment

E-675536

*5223

Tester, Microhardness

E-675507

*5226

Dolly, Receiving

E-675532

*5227

Wrench, Impact, 1/2 Inch Drive

E-675533

*5228

Wrench, Impact, 3/4 Inch Drive

E-675534

*5229 Wrench, Impact, One Inch Drive

E-675535

*5230

Covers, Spent Fuel Storage Car

E-675519

$\star 5231$

Machine, Univeral Testing (Smal1)

E-675481

*5233

Load Ce11, Compressive

NT650415

*5237

Stereomicroscope, Remotely Operated, No. 2

E-675510

*Entry to be supplied at a later date. 
PROV.

LIST ITEM

No.

$\begin{array}{ll}* 5238 & \text { Stand, Shielding, FEPS, Gross Gamma Scanner } \\ * 6035 & \text { FEPS Installation Miscellaneous Hardware } \\ * 6036 & \text { Tray, FEPS Receiving, Gross Gamma Scanner } \\ * 6037 & \text { Fixture, Lifting, FEPS, Conveyor } \\ * 6038 & \text { Stand, Shielding, FEPS, Gross Gamma Scanner }\end{array}$

*6039 FEPS Equipment Mounting Hardware

*6040 Fuel Element Photography Equipment

*6042 Fuel Element Electrical Resistivity Tester Equipment

*6044 Scanner, Gross Gamma, Electrical and Mechanical

*6045 Mirror Assembly, FEPS Conveyor

*6046 Positioner and Table Assembly, FEPS Element

*6047 FEPS Conveyor Equipment

*6048 FEPS Master Control Sequencers

*6049 FEPS Master Conveyor Control

*6051 Checker, Pneumatic Actuator

*6114 Adapter, 40 Ton Hook

*6147

*6150

$\star 6151$

*6152

$\star 6153$

*6156

*6157

*6158

*6159
Cluster Transfer System

Cluster Disassembly Table

Element Cast Insert and Fixture

Stand, Center Element Disassembly
DRAWING NO.

WT-650462A

WT-650590B

WT-650586A

3-513360B

3-513069D

WT-650587C

$9375860 \mathrm{~B}$

WT-650579A

WT- 650580

WT-650581A

WT-650583A

*Entry to be supplied at a later date. 
PROV.

LIST ITEM

No.

EQUIPMENT LIST

DRAWING NO.

*6173 Plate, Nozzle Guide

938J037H01

*6174 Fixture, Lifting, Reactor Vessel Assemb1y

NT601102A

*6180

Tool, Actuator Clamp Removal

WT-650572A

*6181 Tool, Actuator Remova1

WT-650571B

*6182

Stand, Actuator Storage

WT-650575A

*6183

Tool, Drive Shaft Installation

WT-650589A

*6193

Tool, Control Shaft Removal

WT-650573A

*6195

Tool, Pedestal Connector Nut Removal

WT-650576A

*6196

Tool, Pedestal Handling Tool

*6198 Fixture, Handling, Inner Reflector Segment

*6199 Tooling, Retractor Plate

WT- 650596

*7000 Stand, Reactor Disassembly

*7001 Fixture, Reactor Retaining

*7003 Fixture, Handling, Reactor

*7004 Fixture, Removal, Tie Bo1t Nut

*7006 Tool, Dome End, Seal Screw Removal

*7009 Tool, Instrumentation Assembly Ring Screw Removal

*7010 Tool, Core Support Screw Removal

*7011 Tool, Control Drum Bearing Housing Screw Removal.

*7014 Too1, P1unger Spring Retention Cap Remova1

*7015 Fixture, Handling, Nozzle End Locating Ring

WT-650544A

*7017 Tool, Backup, Seal Removal

WT-650546A

*7018 Fixture, Handling, Core

WT-650547C

*7019 Fixture, Handling, Reflector

WT-650548D

*Entry to be supplied at a later date. 
PROV. LIST ITEM

NO.

$* 7021$

*7022

$* 7023$

$* 7024$

$* 7025$

$* 7027$

$* 7028$

$* 7029$

$* 7030$

*7031

*7032

*7033

$* 7034$

*7037

$* 7038$

*7039

*7040

*7041

*7042

*7043

*7044

*7045

*7046
EQUIPMENT LIST

Stand, Disassembly, Reflector

Tool, Handling, Reflector Segment

Rack, Tool Holder

Fixture Filler Strip Retaining

Rods, Poison

Tool, Reflector Grooving

Too1, Reflector Parting

Tools, Grinding, Reflector

Collector, Dust

Fixture, Handling, Reactor Disassembly Stand

Too1, Plunger Removal

Tool, Reactor/Vesse1 Bolt Removal

Cutter, Anchor Tie Bolt

Stand, Insulating Cylinder Removal

Cutter Insulating Cylinder

Clamp Retention, Reflector

Rack, Parting and Grooving Tool

Poison Wire Cups and Bails

Tester, Permeability

Gage, Reflector, Bow

Stripper, Line

Gage, Reflector Thickness

Gage, Reflector Ring Length
DRAWING NO.

WT-650550C

WT-650551A

WT-650552B

WT-650553A

WT-650554C

WT-650556D

WT-650598A

WT-650558D

WT-650559B

WT-650560B

WT-650561A

WT-650562B

WT-650563B

WT-650566A

WT-650567A

WT-650568B

WT-650463A

WT-650594A

WT-650599A

WT-650597A

WT-650600B

WT-650601A

WT-650602A

*Entry to be supplied at a later date. 
TECHNICAL DESCRIPTION SHEETS 


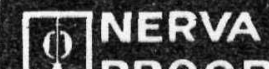

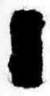

EQUIPMENT TITLE

TOOL KIT, ROCKET ENGINE DISASSEMBLY
SUPPORT EQUIPMENT

TECHNICAL DESCRIPTION HANDBOOK
PROV. LIST

ITEM NO.

DATE

January 1968

REVISION

C

DESCRIPTION: The Rocket Engine Disassembly Tool Kit is used for the remote removal of the forward closure and nozzle bolts during engine disassembly.

The kit consists of a seven-inch-long flank-drive socket, a universal adapter which is enclosed in a $15^{\circ}$ housing, and an impact-wrench adapter, all in a special tool box.

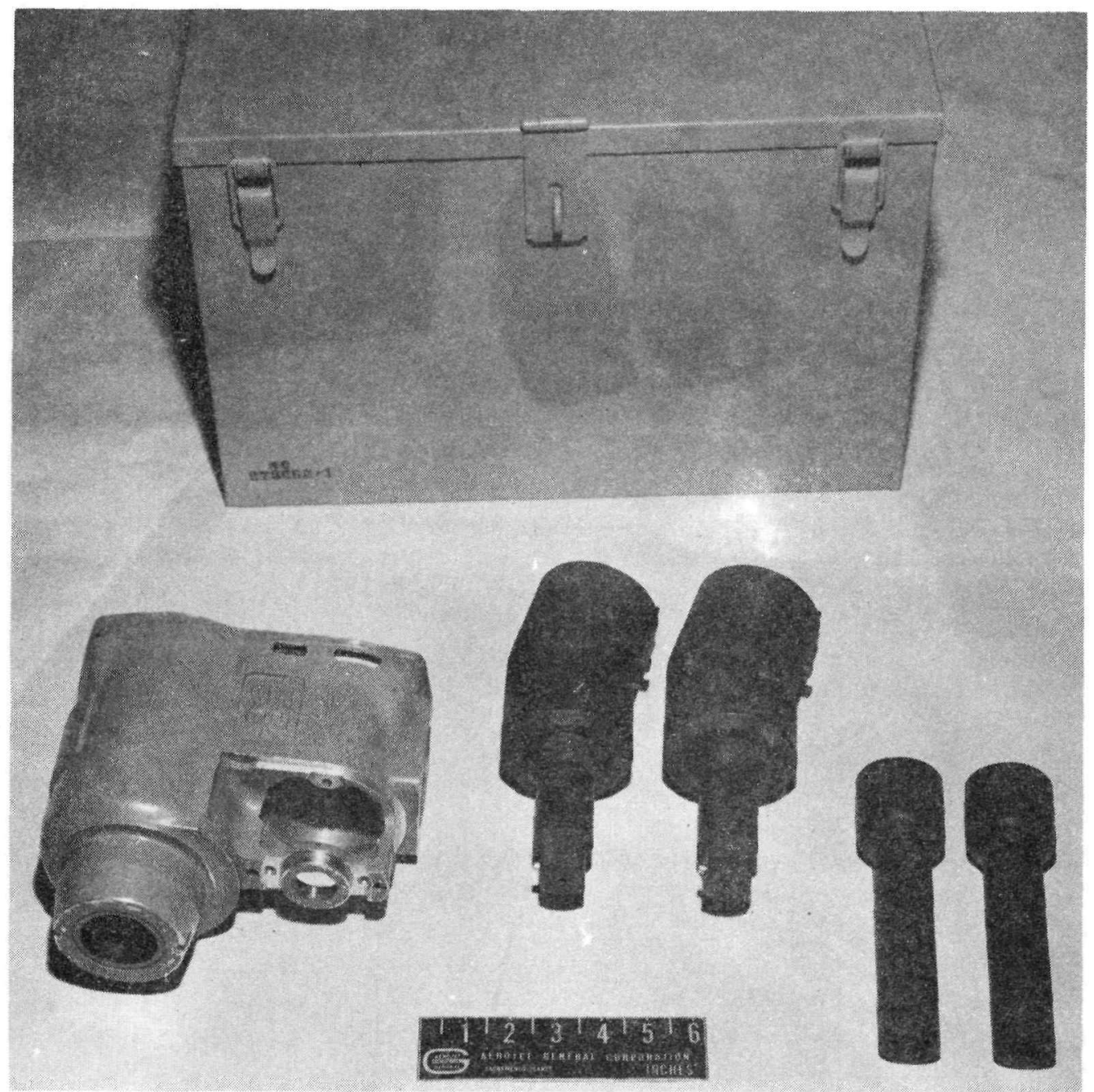


PROVISIONING LIST ITEM NUMBER

DRAWING NUMBER

PART NUMBER

CONTRACTOR
293752

293752-9

AGC
9

FIRST PROVISIONED FOR NRX-A2 GOVT. INV. CONTROL NUMBER NASA SNP1-L-630 $\operatorname{cosT} \$ \$ 950.00$

\begin{tabular}{|l||c|}
\hline \multicolumn{1}{|c||}{ USE LOCATION } & QTY REQ'D \\
\hline A. AGC SACRAMENTO & \\
\hline B. WANL & \\
\hline C. & 1 \\
\hline D. NRDS TOTAL & 1 \\
\hline
\end{tabular}

\section{DIMENSIONS AND CAPACITY}

DIA N/A

WEIGHT $\frac{30}{\text { FLOOR AREA REQUIRED } 1.5^{L}}$

ADDITIONAL DATA
GASES_N N/A PRESSURE

ELECTRICAL N/A

LIQUIDS

SPEED

MEASURING ACCURACY

N/A

$\mathrm{N} / \mathrm{A}$

N/A
LENGTH $18^{\prime \prime}$ SQ FT
WIDTH $12^{\prime \prime}$

LB PROOF LOAD

OPERATING FLOOR LOAD
L B $L B / S Q I N$

CALIBRATION INTERVAL

ADDITIONAL DATA $\frac{\text { Operation and Maintenance Instructions Manual available for this }}{\text { item from AGC (no number issued) }}$

VOLTS

PRESSURE IN./MIN (RPM)
LB/SQ IN. VOLUME

CPS

$L B / S Q$ IN

CUTTING

HORIZONTAL
CFM LUBRICATION

PHASE

QTY REQ'D VERTICAL

\section{OPERATING EQUIPMENT}

MANIPULATOR

Sidewall or 0-MAN

LOAD CAPACITY

LB MAX

CRANE

LOAD CAPACITY

LB MAX

ADDITIONAL DATA

R-MAD Remote Operated Wrenches

PART OR ITEM Forward Closure \& Nozzle Bolts DRAWING NO. P/N 286664-1 \& - 13

REMARKS 
PROVISIONING LIST ITEM NUMBER 10

DRAWING NUMBER

PART NUMBER

CONTRACTOR
$111 \overline{5360}$

1115360-19

AGC
FIRST PROVISIONED FOR

NRX/EXT GOVT. INV. CONTROL NUMBER

$\cos T$ $\$ \$ 4,911$

\begin{tabular}{|l||c|}
\hline \multicolumn{1}{|c||}{ USE LOCATION } & QTY REQ'D \\
\hline A. AGC SACRAMENTO & \\
\hline B. WANL & \\
\hline C. & 1 \\
\hline D. NRDS TOTAL & 1 \\
\hline \multicolumn{2}{|c||}{} \\
\hline
\end{tabular}

DIMENSIONS AND CAPACITY

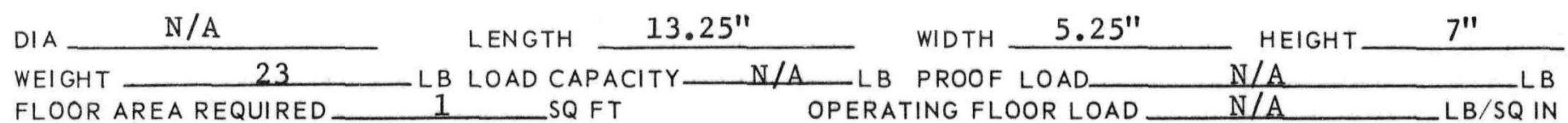
ADDITIONAL DATA Output torque 450 lb-ft with 90 psi air pressure.

GASES Air ELECTRICAL

LIQUIDS

SPEED

MEASURING ACCURACY

PRESSURE

115

N/A N/A

CALIBRATION INTERVAL N/A

ADDITIONAL DATA
LB/SQIN. VOLUME VOLTS_ 60 PRESSURE IN./MIN (RPM) See $\mathrm{RN}-\mathrm{S}-0264$
CPS

$L B / S Q I N$

CUTTING SPEED N/A

HORIZONTAL
CFM LUBRICATION Facility Air Lube PHASE K KVA QTY REQ'D

VERTICAL MANIPULATOR $\frac{\text { Model } 300}{\text { N/A }}$

CRANE.
LOAD CAPACITY

LOAD CAPACITY
LB MAX

LB MAX

ADDITIONAL DATA

EQUIPMENT_Model 300 Manipulator PART OR ITEM Forward Closure or Nozzle Bolts DRAWING NO. REMARKS 13/16" (.817") socket size. AGC 286664-1 and 298725-3

REMARKS 
PROV. LIST

ITEM NO.

11

DATE

January 1968

EQUIPMENT TITLE

REVISION

ADAPTER, RIGHT ANGLE, REMOTE BOLT REMOVAL

DESCRIPTION: The Remote Bolt Removal Right Angle Adapter is a one-inch square-drive, right-angle, impact-wrench adapter used with the socket of remote rocket engine disassembly tool kit, P/L 9. It can also be used as a one-inch drive impact-wrench for removing nozzle bolts. Maximum input-torque to the adapter is $650 \mathrm{lb}-\mathrm{ft}$. Output-torque at the socket is $585 \mathrm{lb}-\mathrm{ft}$. 
TECHNICAL SUMMARY

PROVISIONING LIST ITEM NUMBER

DRAWING NUMBER

PART NUMBER

CONTRACTOR
$276 \overline{312}$

276312-9

AGC
FIRST PROVISIONED FOR $\mathrm{NRX}-\mathrm{A} 1$

11

-
GOVT. INV. CONTROL NUMBER

SNP-1-L-662

\begin{tabular}{|l||c|}
\hline \multicolumn{1}{|c||}{ USE LOCATION } & QTY REQ'D \\
\hline A. AGC SACRAMENTO & \\
\hline B. WANL & \\
\hline C. & \\
\hline D. NRDS TOTAL & 1 \\
\hline
\end{tabular}

\section{DIMENSIONS AND CAPACITY}

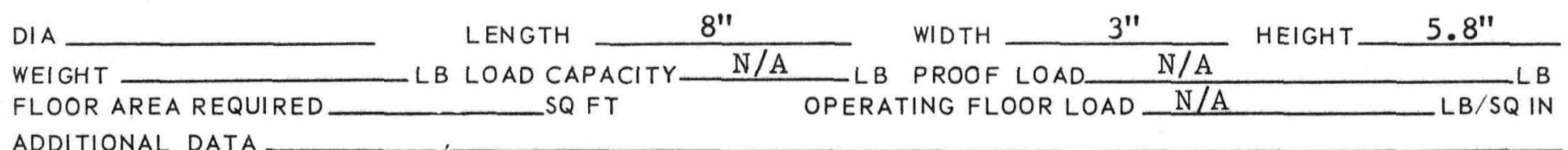

ADDITIONAL DATA

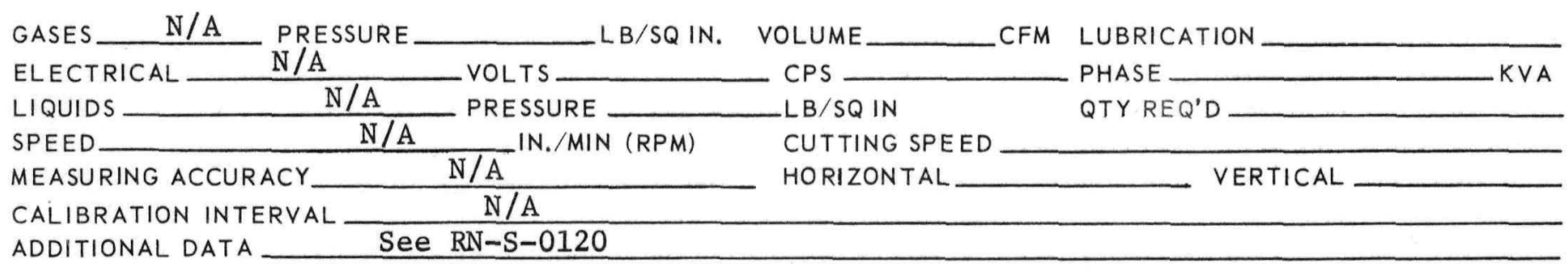

\section{OPERATING EQUIPMENT}

$\begin{array}{ll}\text { MANIPULATOR } & \text { N/A } \\ \text { CRANE } & \text { N/A }\end{array}$

LOAD CAPACITY

LOAD CAPACITY

LB MAX

L B MAX

ADDITIONAL DATA

EQUIPMENT_ACFI P/N 3-520517 (Housing P/N 293751-1 P/L Item 9) and Socket P/N 293750 PART OR ITEM Nozzle or F/C Bolts DRAWING NO.

REMARKS 
EQUIPMENT TITLE

TOOL, REMOVAL, HOT BLEED PORT NUT

DESCRIPTION: The Hot Bleed Port Nut Removal Tool is a commercial, 12-point socket, ratchet-wrench attachment used to remove the sixteen 7/16-inch nuts which secure the hot gas port to the nozzle. It is used with a Gardner-Denver 17C3-12 air motor modified for manipulator usage. 
PROVISIONING LIST ITEM NUMBER 14

DRAWING NUMBER

PART NUMBER Gardner-Denver AA-9D-6096-15

CONTRACTOR AGC
FIRST PROVISIONED FOR NRX/EST

GOVT. INV. CONTROL NUMBER

None Assigned

COST $\$ \$ 95.00$

\begin{tabular}{|l||c|}
\hline \multicolumn{1}{|c||}{ USE LOCATION } & QTY REQ'D \\
\hline A. AGC SACRAMENTO & \\
\hline B. WANL & \\
\hline C. & \\
\hline D. NRDS TOTAL & 1 \\
\hline \multicolumn{2}{|c|}{1} \\
\hline
\end{tabular}

\section{DIMENSIONS AND CAPACITY}

DIA

WEIGHT

FLOOR AREA REQUIRED

ADDITIONAL DATA
LENGTH LB LOAD CAPACITY $S Q F T$
WIDTH LB PROOF LOAD OPERATING FLOOR LOAD
HEIGHT $L B / S Q I N$
GASES

ELECTRICAL

LIQUIDS

SPEED

MEASURING ACCURACY

PRESSURE

VOLTS

LB/SQIN. VOLUME

PRESSURE IN./MIN (RPM)

CALIBRATION INTERVAL

ADDITIONAL DATA

This

at NRDS and not supplied as a part of this provisioning ist item.
LUBRICATION

PHASE KVA

$L B / S Q I N$

CUTTING SPEED

HORIZONTAL
QTY REQ'D

VERTICAL

OPERATING EQUIPMENT

MANIPULATOR

LOAD CAPACITY

LB MAX

CRANE

LOAD CAPACITY

LB MAX

ADDITIONAL DATA The air motor is provided with a manipulator grip handle which is compatible with any of the R-MAD or E-MAD manipulators. 
EQUIPMENT TITLE

COVER, NOZZLE, COOLDOWN, REMOTE

DESCRIPTION: The Remote Cooldown Nozzle Cover is a closure containing three concentric internal screen filters to protect the nozzle and reactor against airborne contaminants during post-operative cooldown on the test stand. It is designed to cover the nozzle, prohibiting entrance of atmospheric debris while still permitting outflow of cooldown gas. A lifting bail permits remote installation and handling. Three rubber-covered wedges are used to position the cover when it is placed on the nozzle.

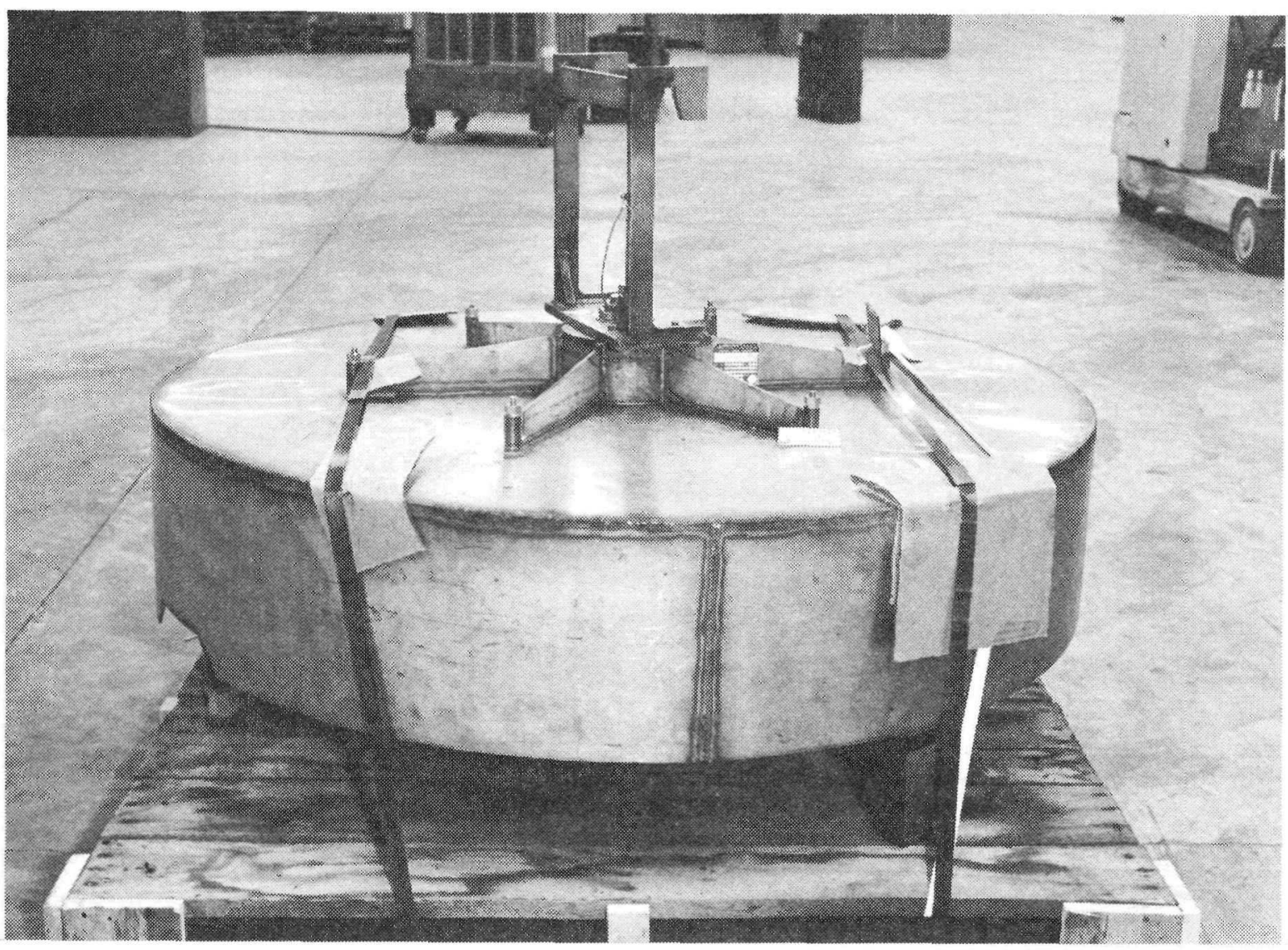


PROVISIONING LIST ITEM NUMBER 276470

DRAWING NUMBER

PART NUMBER

17

CONTRACTOR

276470-9

AGC

FIRST PROVISIONED FOR NRX-A2

GOVT. INV. CONTROL NUMBER NASA SNP1-L-652

$\cos T+\$ 2,500$

\begin{tabular}{|l||c|}
\hline \multicolumn{1}{|c||}{ USE LOCATION } & QTY REQ'D \\
\hline A. AGC SACRAMENTO & \\
\hline B. WANL & \\
\hline C. & \\
\hline D. NRDS TOTAL & 1 \\
\hline
\end{tabular}

DIMENSIONS AND CAPACITY

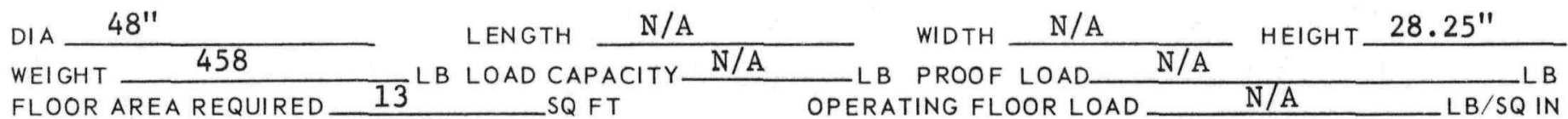

ADDITIONAL DATA

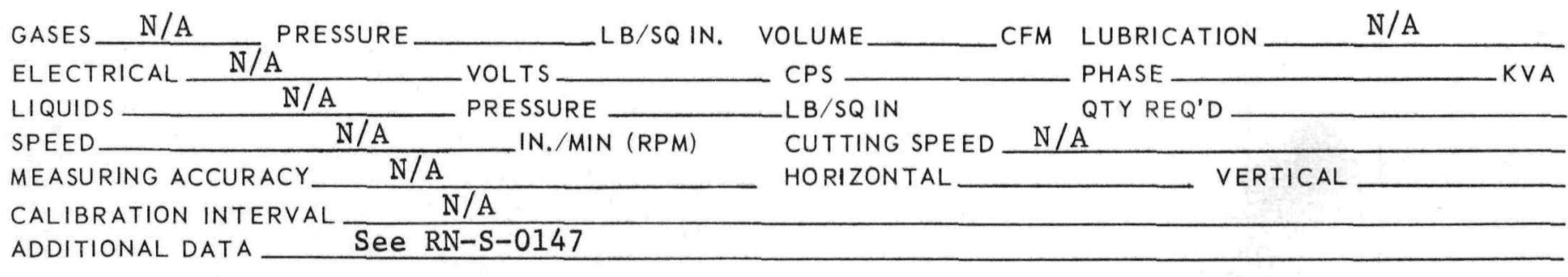

\section{OPERATING EQUIPMENT}

\begin{tabular}{|c|c|c|}
\hline MANIPULATOR $\quad$ N/A & LOAD CAPACITY & L $B$ MAX \\
\hline CRANE_ Test Cell "A" & LOAD CAPACITY & LBMAX \\
\hline
\end{tabular}

EQUIPMENT_ Test Cel1 "A" Crane

PART OR ITEM Nozzle

DRAWING NO. $707630-9,1114263-39$

REMARKS 
PROVISIONING LIST ITEM NUMBER 18

DRAWING NUMBER

PART NUMBER

CONTRACTOR
$11157 \overline{86}$

1115786-9

AGC
FIRST PROVISIONED FOR

NRX/EST GOVT. INV. CONTROL NUMBER

$\cos T$ $\$ 1800.00$

\begin{tabular}{|c|c|}
\hline USE LOCATION & QTY REQ'D \\
\hline A. AGC SACRAMENTO & \\
\hline B. WANL & \\
\hline C. & \\
\hline D. NRDS & 1 \\
\hline TOTAL & 1 \\
\hline
\end{tabular}

\section{DIMENSIONS AND CAPACITY}

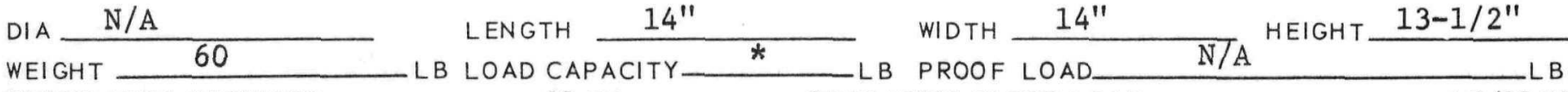
FLOOR AREA REQUIRED—SQ ADDITIONAL DATA *Size of wrenches are $7 / 16^{\prime \prime}, 1 / 2^{\prime \prime}, 9 / 16^{\prime \prime}, 11 / 16^{\prime \prime}, 5 / 8^{\prime \prime}, 3 / 4^{\prime \prime}, 13 / 16^{\prime \prime}$, $7 / 8^{\prime \prime}, 15 / 16^{\prime \prime}, 1^{\prime \prime}, 1-1 / 16^{\prime \prime}, 1-3 / 16^{\prime \prime}, 1-1 / 8^{\prime \prime}, 1-1 / 4^{\prime \prime}$ (14 wrenches tota1)

GASES_N/A PRESSURE

ELECTRICAL N N/A

LIQUIDS

SPEED

MEASURING ACCURACY

$\mathrm{N} / \mathrm{A}$

CALIBRATION INTERVAL

ADDITIONAL DATA $\mathrm{N} / \mathrm{A}$
$L B / S Q I N$. VOLUME VOLTS PRESSURE IN./MIN (RPM) $\mathrm{N} / \mathrm{A}$ $\mathrm{N} / \mathrm{A}$
CPS

- $B / S Q$ IN

CUTTING SPEED N N/A HORIZONTAL
CFM LUBRICATION N/A PHASE QTY REQ'D QTY

EQUIPMENT O-MAN or Sidewa11 Manipulator

PART OR ITEM *Transducers (External)

DRAWING NO.

REMARKS *Not for removal of transducers on the interior of the pressure vessel 


\begin{tabular}{l}
$\begin{array}{l}\text { (1) NERVA } \\
\text { PROGRAM }\end{array}$ \\
EQUIPMENT TITLE \\
\\
TOOL, NUT REMOVAL, RADIATION SHIELD \\
\hline
\end{tabular}

PROV. LIST

ITEM NO.

DATE

January 1968

REVISION

DESCRIPTION: The Radiation Shield Nut Removal Tool consists of a commercial 1350-ft-1b, one-inch square-drive, pneumatic impact-wrench equipped with a 16-inch extension bar and a 1 7/8-inch socket. The extension bar and socket are attached with pins and rubber 0-rings. The tool is provided with a manipulator grip-frame for use in the remote disassembly bay of the E-MAD Building.
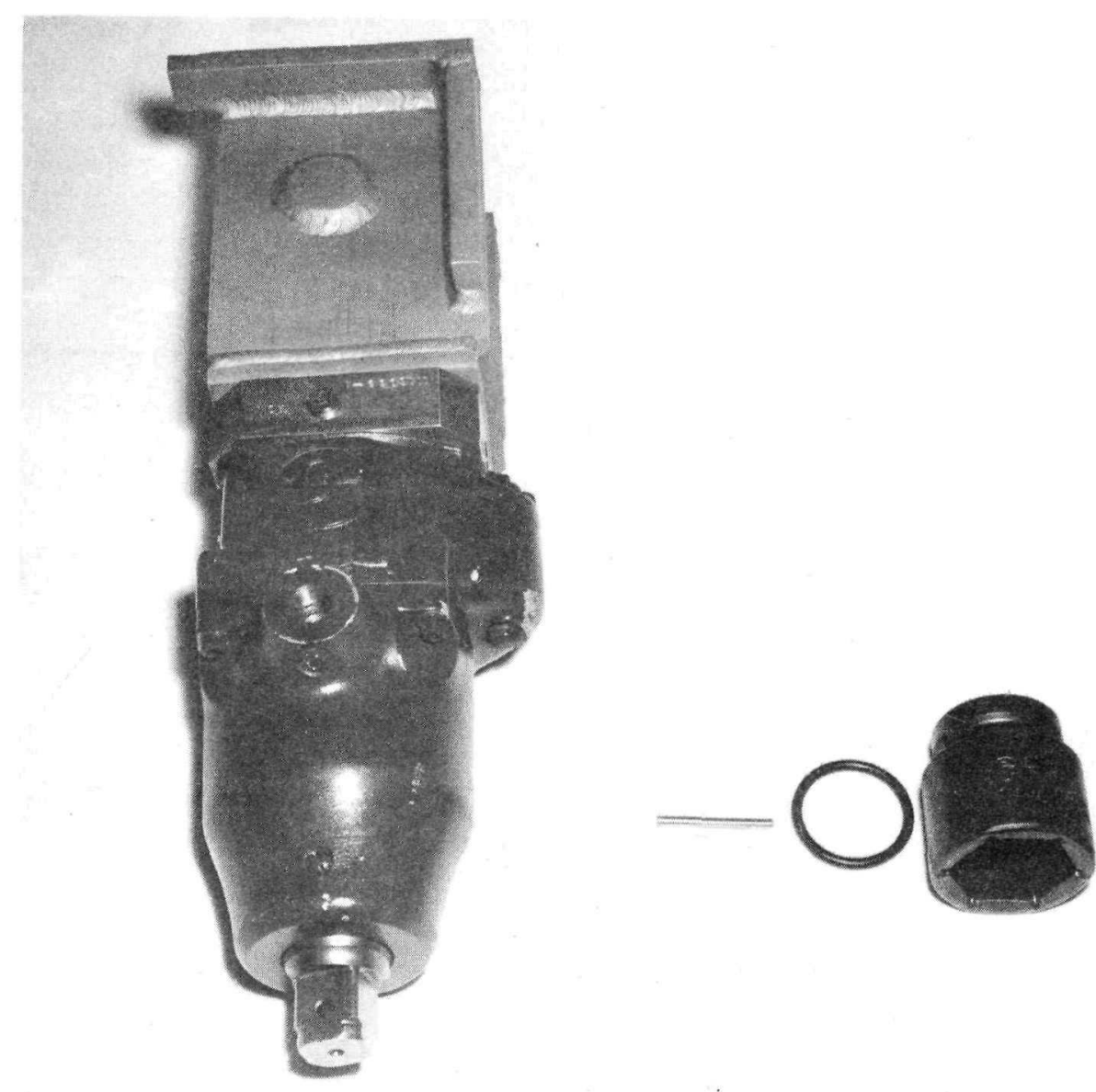
PROVISIONING LIST ITEM NUMBER 19

DRAWING NUMBER

PART NUMBER 1116035

CONTRACTOR AGC
FIRST PROVISIONED FOR NRX/EST GOVT. INV. CONTROL NUMBER SNP-1-L-1309

$\cos T$

\begin{tabular}{|c||c|}
\hline \multicolumn{1}{|c||}{ USE LOCATION } & QTY REQ'D \\
\hline A. AGC SACRAMENTO & \\
\hline B. WANL & \\
\hline C. & 1 \\
\hline D. NRDS TOTAL & 1 \\
\hline
\end{tabular}

DIMENSIONS AND CAPACITY

DIA 5.65" LENGTH 35.25" WIDTH \begin{tabular}{llllll}
\hline WEIGHT & 27 & LB LOAD CAPACITY N/A & LB PROOF LOAD & N/A \\
FLOOR AREA REQUIRED & 1.5 & SQFT & OPERATING FLOOR LOAD N N N N
\end{tabular} HEIGHT ADDITIONAL DATA Output Torque - $1350 \mathrm{ft}-1 \mathrm{~b}$ when operated at 90 psi input air pressure.

\section{OPERATING DATA}

GASES Air PRESSURE 90 LB/SQ IN. VOLUME

ELECTRICAL_ N/A CPS

LIQUIDS N/A

SPEED

MEASURING ACCURACY

CALIBRATION INTERVAL

ADDITIONAL DATA
PRESSURE IN./MIN (RPM) N/A N/A
$L B / S Q I N$ CUTTING SPEED HORIZONTAL
CFM LUBRICATION Facility Air Lub. PHASE KVA QTY REQ'D $\mathrm{N} / \mathrm{A}$ VERTICAL
MANIPULATOR $\frac{\text { Class A }}{\text { N/A }}$

ADDITIONAL DATA
LOAD CAPACITY LOAD CAPACITY
L B MAX

LB MAX 
PROV. LIST

ITEM NO. 20

DATE

January 1968

REVISION

EQUIPMENT TITLE

PULLER, HOT GAS BLEED PORT

DESCRIPTION: The Hot Gas Bleed Port Puller is used for removing the hot-bleedport from the nozzle after the 16 fastening nuts have been removed. The puller consists of a standard manipulator grip-frame attached to a four-arm puller assembly. The end of each arm has a contoured pawl to interface with the underside of the Marman-type flange of the hot-bleed-port. The pulling force is provided by the manipulator. 
PROVISIONING LIST ITEM NUMBER

DRAWING NUMBER

PART NUMBER

CONTRACTOR
1116471

1116471-19

AGC
20

FIRST PROVISIONED FOR NRX/EST GOVT. INV. CONTROL NUMBER

$\cos T$

\begin{tabular}{|l||c|}
\hline \multicolumn{1}{|c||}{ USE LOCATION } & QTY REQ'D \\
\hline A. AGC SACRAMENTO & \\
\hline B. WANL & \\
\hline C. & 1 \\
\hline D. NRDS TOTAL & 1 \\
\hline \multicolumn{2}{|c||}{} \\
\hline
\end{tabular}

\section{DIMENSIONS AND CAPACITY}

DIA

WEIGHT

FLOOR AREA REQUIRED

ADDITIONAL DATA
LENGTH

$8^{\prime \prime}$ LB LOAD CAPACITY 100 N/A SQFT
WIDTH

$10^{\prime \prime}$

LB PROOF LOAD OPERATING FLOOR LOAD
HEIGHT_ $10^{\prime \prime}$

$L B$
GASES N N/A

ELECTRICAL

LIQUIDS

SPEED

MEASURING ACCURACY

N/A CALIBRATION INTERVAL N/A

ADDITIONAL DATA
PRESSURE $\mathrm{N} / \mathrm{A}$ $\mathrm{N} / \mathrm{A}$ $\mathrm{N} / \mathrm{A}$ VOLTS PRESSURE IN./MIN (RPM)
LB/SQIN. VOLUME

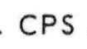

CPS

$L B / S Q$ IN

CUTTING SPEED HORIZONTAL
CFM

LUBRICATION

PHASE

QTY REQ'D

EQUIPMENT R-MAD Sidewall Manipulator - Mode1 300 
PROV. LIST

ITEM NO.

21

DATE

TECHNICAL DESCRIPTION HANDBOOK

EQUIPMENT TITLE

REVISION

TOOL, BOLT REMOVAL, REMOTE

DESCRIPTION: The Remote Bolt Removal Tool is a pneumatically operated, electrically actuated impact-wrench which grips the forward closure or nozzle bolt heads for removal. The tool provides a maximum output-torque of 1350 1b-ft. It provides: (1) a self-contained retraction feature to eliminate the need to retract the manipulator while unscrewing the bolts; and (2) a boltejection feature for positive release of the bolts after their removal.

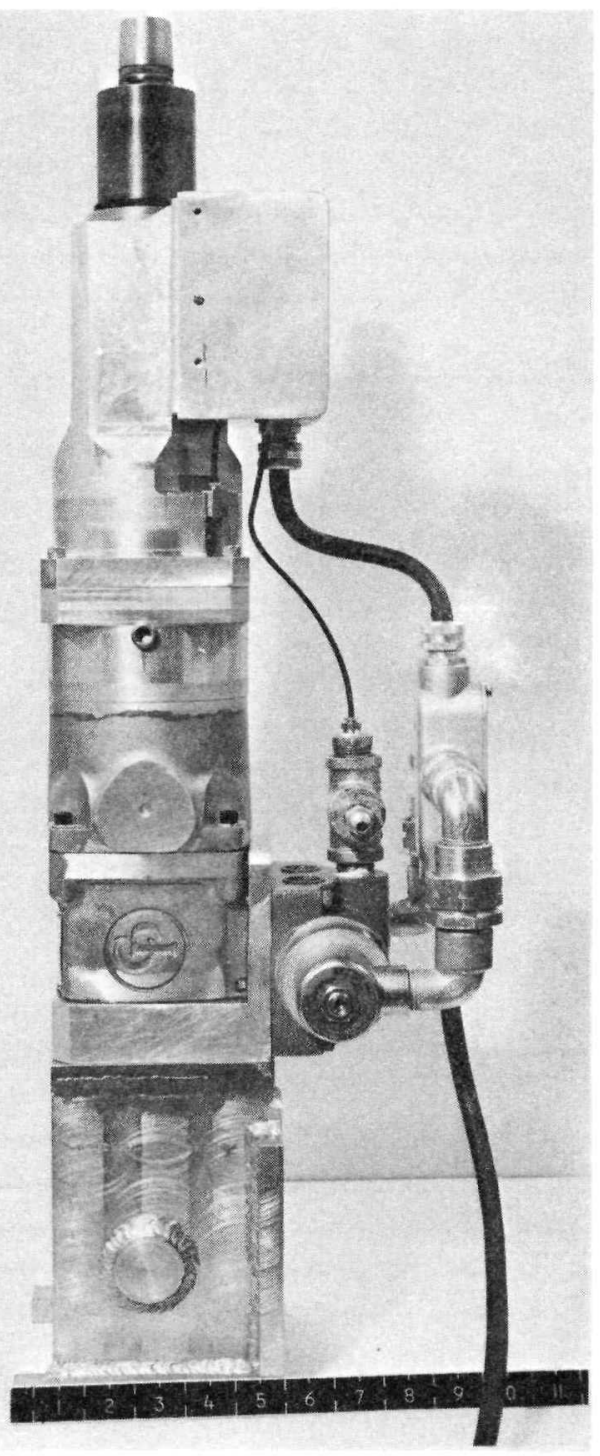


PROVISIONING LIST ITEM NUMBER DRAWING NUMBER 1117491

PART NUMBER CONTRACTOR
21

1117491-9

AGC
FIRST PROVISIONED FOR NRX-A5

GOVT. INV. CONTROL NUMBER SNP-1-L-1350

$\operatorname{cosT}$

\begin{tabular}{|l||c|}
\hline \multicolumn{1}{|c||}{ USE LOCATION } & QTY REQ'D \\
\hline A. AGC SACRAMENTO & \\
\hline B. WANL & \\
\hline C. & \\
\hline D. NRDS TOTAL & 1 \\
\hline \multicolumn{2}{|c|}{1} \\
\hline
\end{tabular}

\section{DIMENSIONS AND CAPACITY}

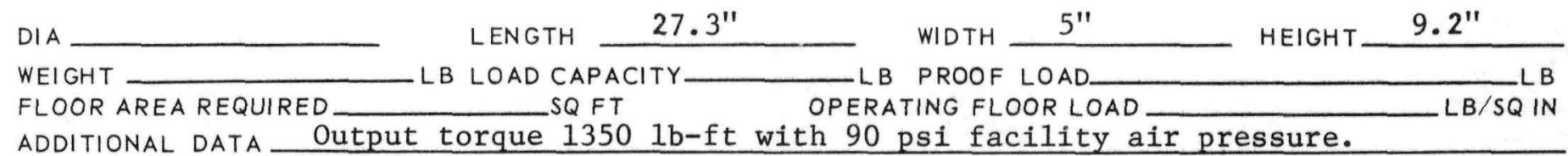

ADDITIONAL DATA Output torque 1350 1b-ft with 90 psi facility air pressure.

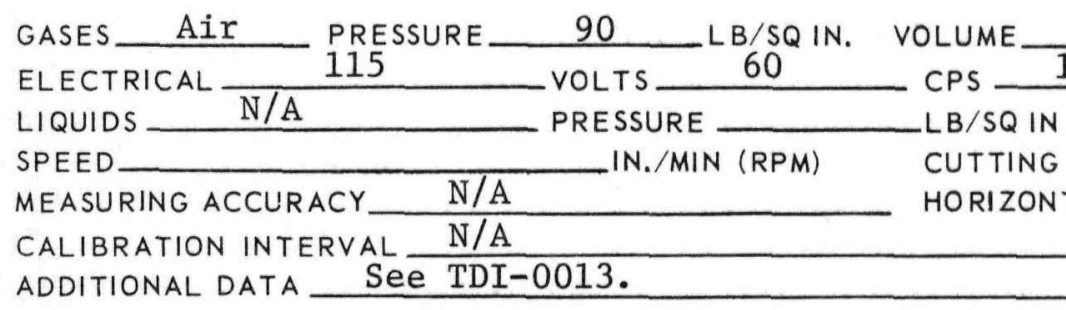

\section{OPERATING EQUIPMENT}

MANIPULATOR $\frac{\text { Class A }}{\text { N/A }}$ LOAD CAPACITY LOAD CAPACITY

LB MAX LB MAX ADDITIONAL DATA 
DESCRIPTION: The Impact Wrench Socket is a 13/16-inch, 12-point, flank-drive socket with a 1-inch square-drive. It is used with the radiation shield nut removal tool, P/L 19, for remote removal of forward closure and nozzle bolts. 
PROVISIONING LIST ITEM NUMBER

22

\begin{tabular}{ll} 
DRAWING NUMBER & 1117516 \\
\cline { 2 - 2 } PART NUMBER & $1117516-1$ \\
CONTRACTOR & AGC
\end{tabular}

CONTRACTOR AGC
FIRST PROVISIONED FOR NRX-A5 GOVT. INV. CONTROL NUMBER $\cos T$

\begin{tabular}{|l||c|}
\hline \multicolumn{1}{|c||}{ USE LOCATION } & QTY REQ'D \\
\hline A. AGC SACRAMENTO & \\
\hline B. WANL & \\
\hline C. & 3 \\
\hline D. NRDS TOTAL & 3 \\
\hline \multicolumn{2}{|c|}{} \\
\hline
\end{tabular}

\section{DIMENSIONS AND CAPACITY}
DIA 2"
WEIGHT 2.4
LENGTH 7.50"
FLOOR AREA REQUIRED
LB LOAD CAPACITY N/A
SQ FT
WIDTH
LB PROOF LOAD
$\mathrm{N} / \mathrm{A}$
-LB
ADDITIONAL DATA
OPERATING FLOOR LOAD $L B / S Q I N$

GASES N/A

ELECTRICAL

LIQUIDS

SPEED

MEASURING ACCURACY

$\frac{\text { N/A }}{\text { N/A }}$

PRESSURE

N/A

N/A

CALIBRATION INTERVAL N/A

ADDITIONAL DATA
VOLTS

PRESSURE

IN./MIN (RPM)
LB/SQIN. VOLUME

CPS

LB/SQ IN

CUTTING SPEED

HORIZONTAL
CFM LUBRICATION

PHASE

QTY REQ'D N/A

VERTICAL

\section{OPERATING EQUIPMENT}

MANIPULATOR LOAD CAPACITY

ADDITIONAL DATA This item is used with P/L Item 19, Too1, Nut Removal, Radiation Shield and a Sidewall, 0-MAN, or OPS Manipulator

\section{INTERFACES}

EQUIPMENT P/L Item 19, Too1, Nut Removal, Radiation Shield

PART OR ITEM Nozzle \& Forward Closure Bolts DRAWING NO. AGC 298725 and 702999

REMARKS Socket Proof Tested to $1000 \pm 50 \mathrm{ft}-1 \mathrm{~b}$ torque using the above bolts. 
EQUIPMENT TITLE

\section{DATE} REVISION

STAND, PRESSURE VESSEL, ROCKET ENGINE

DESCRIPTION: The Rocket Engine Pressure Vessel Stand supports the NRX pressure vessel during manual or remote assembly, disassembly, maintenance, and postoperative operations as follows: (1) supports the pressure vessel during remote removal of the trunnion cage-reactor vesse1, P/L 1150, in the disassembly bay; (2) supports the pressure vessel during installation and removal of handling adapters; and (3) supports the pressure vessel/nozzle assembly during nozzleremoval operations.

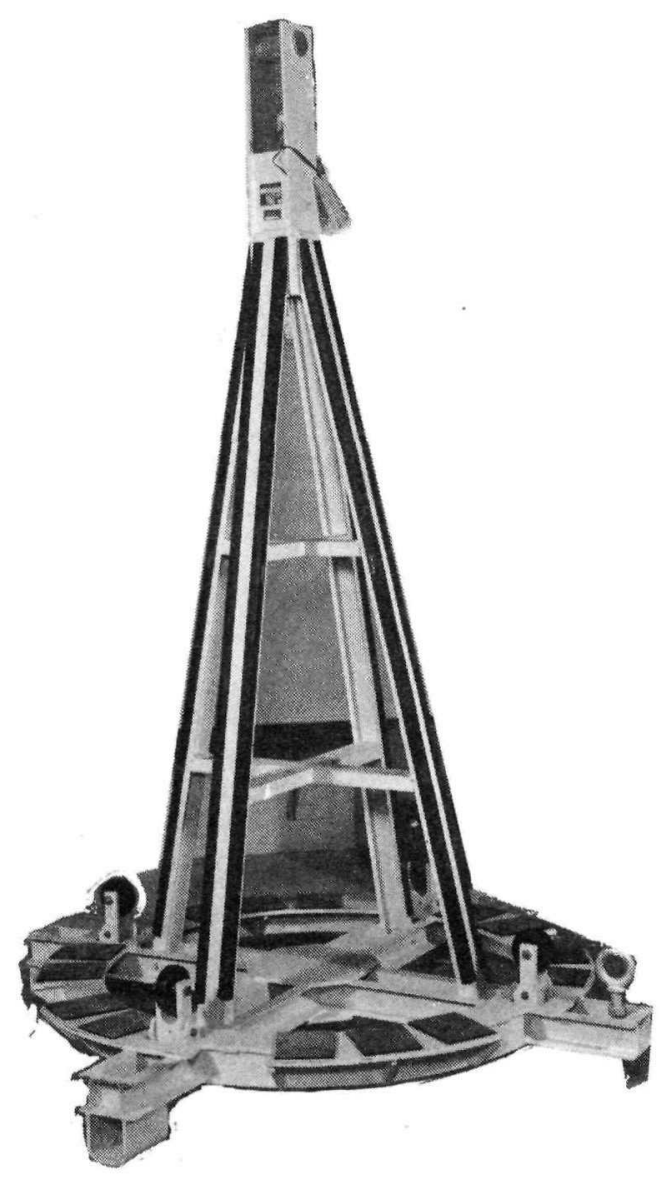


PROVISIONING LIST ITEM NUMBER

135

$\begin{array}{ll}\text { DRAWING NUMBER } & 276380 \\ \text { PART NUMBER } & 276380-9\end{array}$

FIRST PROVISIONED FOR

$\mathrm{NRX}-\mathrm{A} 2$

PART NUMBER

AGC

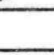

$\cos T$ $\$ 3,500$

\begin{tabular}{|c|c|}
\hline USE LOCATION & QTY REQ'D \\
\hline A. AGC SACRAMENTO & \\
\hline B. WANL & \\
\hline C. & \\
\hline D. NRDS & 1 \\
\hline TOTAL & 1 \\
\hline
\end{tabular}

\section{DIMENSIONS AND CAPACITY}
DIA $5^{\prime} 8^{\prime \prime}$
WEIGHT 1000 


\section{(i) NERVA \\ LIPROGRAM \\ SUPPORT EQUIPMENT \\ TECHNICAL DESCRIPTION HANDBOOK}

EQUIPMENT TITLE

FIXTURE, NOZZLE EXAMINATION
PROV. LIST

ITEM NO.

137

DATE

$\frac{\text { January } 1968}{\text { REV!SION }}$

DESCRIPTION: The Nozzle Examination Fixture supports and positions the nozzle for remote visual examination and for sectioning of the nozzle for post-operative examination. The fixture consists of an H-shaped base with two vertical support members. A nozzle adapter ring mates to the vertical members through a manipulator-drive gearbox system and provides nozzle rotation capability. The adapter ring is provided with four manipulator-operated clamps contoured to mate with the nozzle/pressure vessel flange to clamp the nozzle into the fixture. The photograph shows the fixture with the remote floor mounted support equipment lifting fixture, P/L 213, attached.

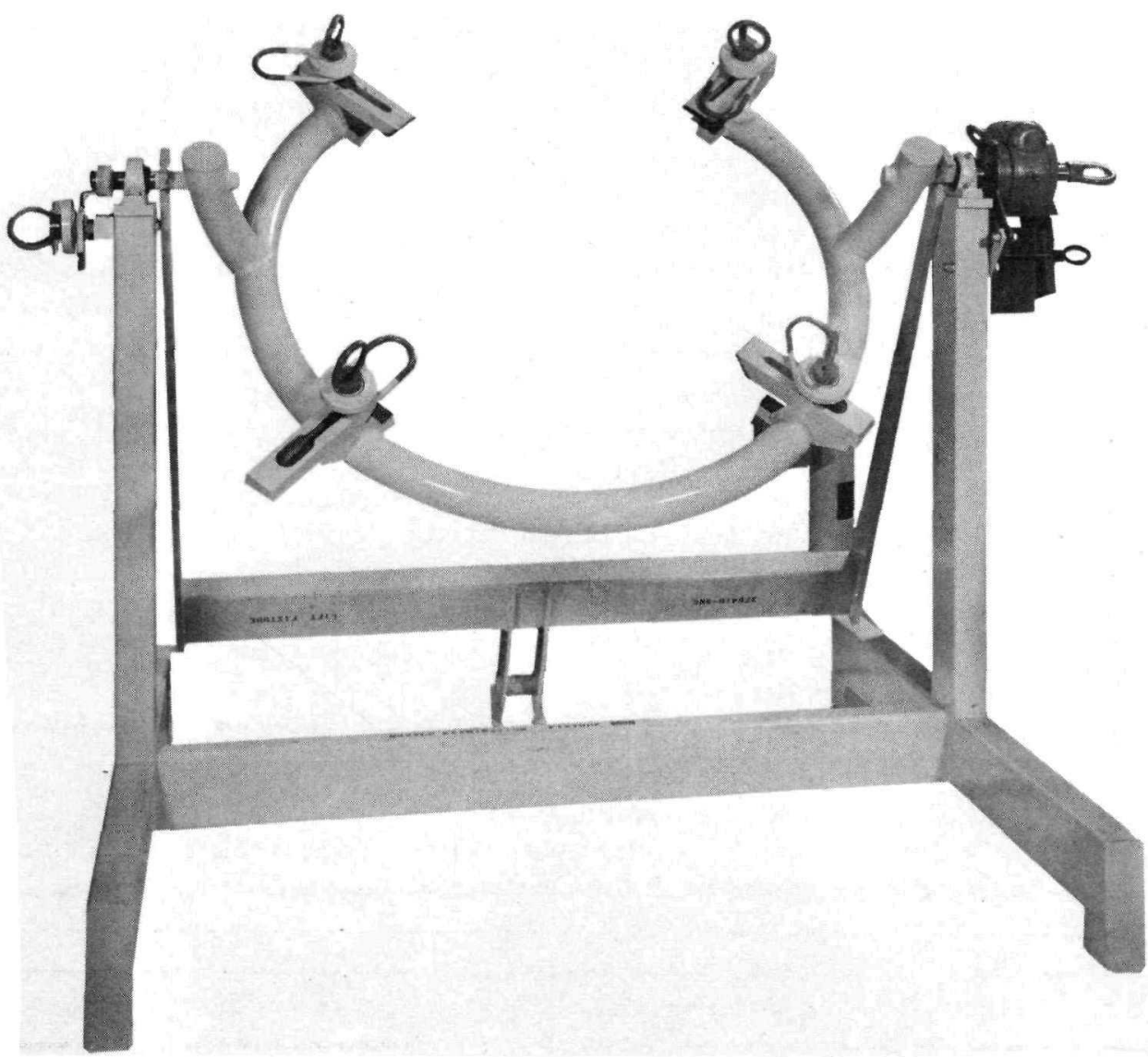


PROVISIONING LIST ITEM NUMBER 137

DRAWING NUMBER 276450

PART NUMBER

CONTRACTOR
276450-9

AGC
FIRST PROVISIONED FOR NRX-A2 GOVT. INV. CONTROL NUMBER NASA-SNP1-L-649

$\cos T \$ 3,210.00$

\begin{tabular}{|l||c|}
\hline \multicolumn{1}{|c||}{ USE LOCATION } & QTY REQ'D \\
\hline A. AGC SACRAMENTO & \\
\hline B. WANL & \\
\hline C. & 1 \\
\hline D. NRDS TOTAL & 1 \\
\hline
\end{tabular}

\section{DIMENSIONS AND CAPACITY}

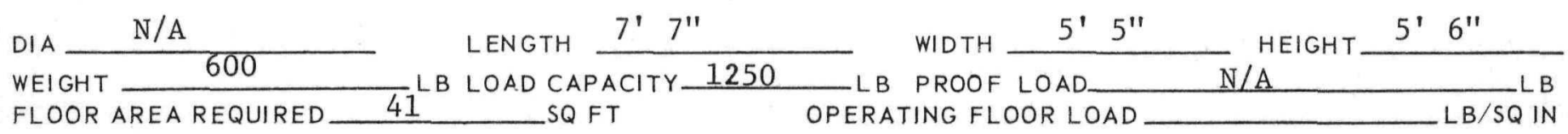

ADDITIONAL DATA

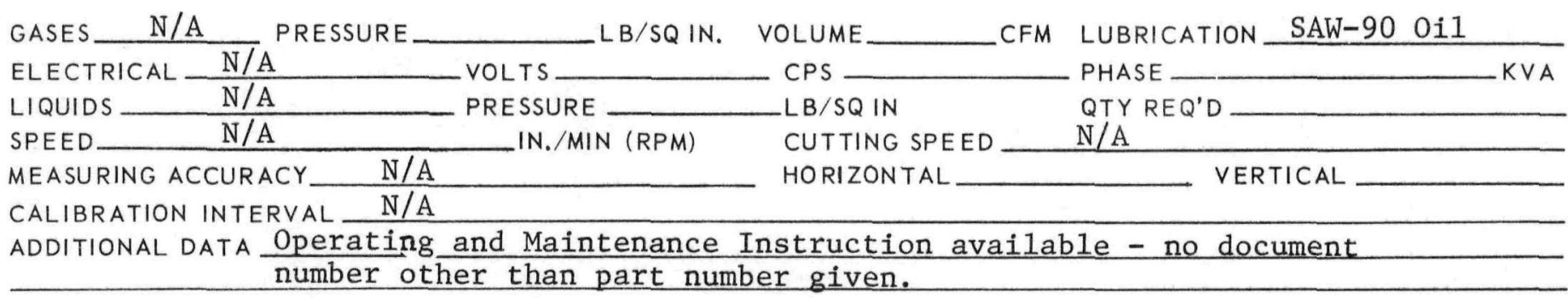

\section{OPERATING EQUIPMENT}

MANIPULATOR $\frac{\text { *Sidewa11 }}{\text { R-MAD }}$ LOAD CAPACITY
CRANE
ADDITIONAL DATA *Not to be used for 1ifting fixture.

EQUIPMENT Item 218, Fixture, Lifting, Crane

PART OR ITEM NOZZle DRAWING NO. 284800, 707630-9
REMARKS




\section{() NERVA \\ C. PROGRAM \\ SUPPORT EQUIPMENT TECHNICAL DESCRIPTION HANDBOOK}

EQUIPMENT TITLE

FIXTURE, BOLT HOLDING, REMOTE
PROV. LIST

ITEM NO.

142

DATE

$\frac{\text { January } 1968}{\text { REVISION C }}$

DESCRIPTION: The Remote Bolt Holding Fixture retains 12 nozzle or forward-closure bolts selected for post-operative examination during engine disassembly. The fixture consists of an aluminum H-member with 12 drilled holes to accept the bolts and a lifting bail for handling within the hot disassembly areas. It performs the following functions: (1) Positions the bolts for easy manipulatorhandling during post-mortem operations; (2) provides a means of holding the bolts for decontamination cleaning; and (3) safeguards the bolts from physical damage.

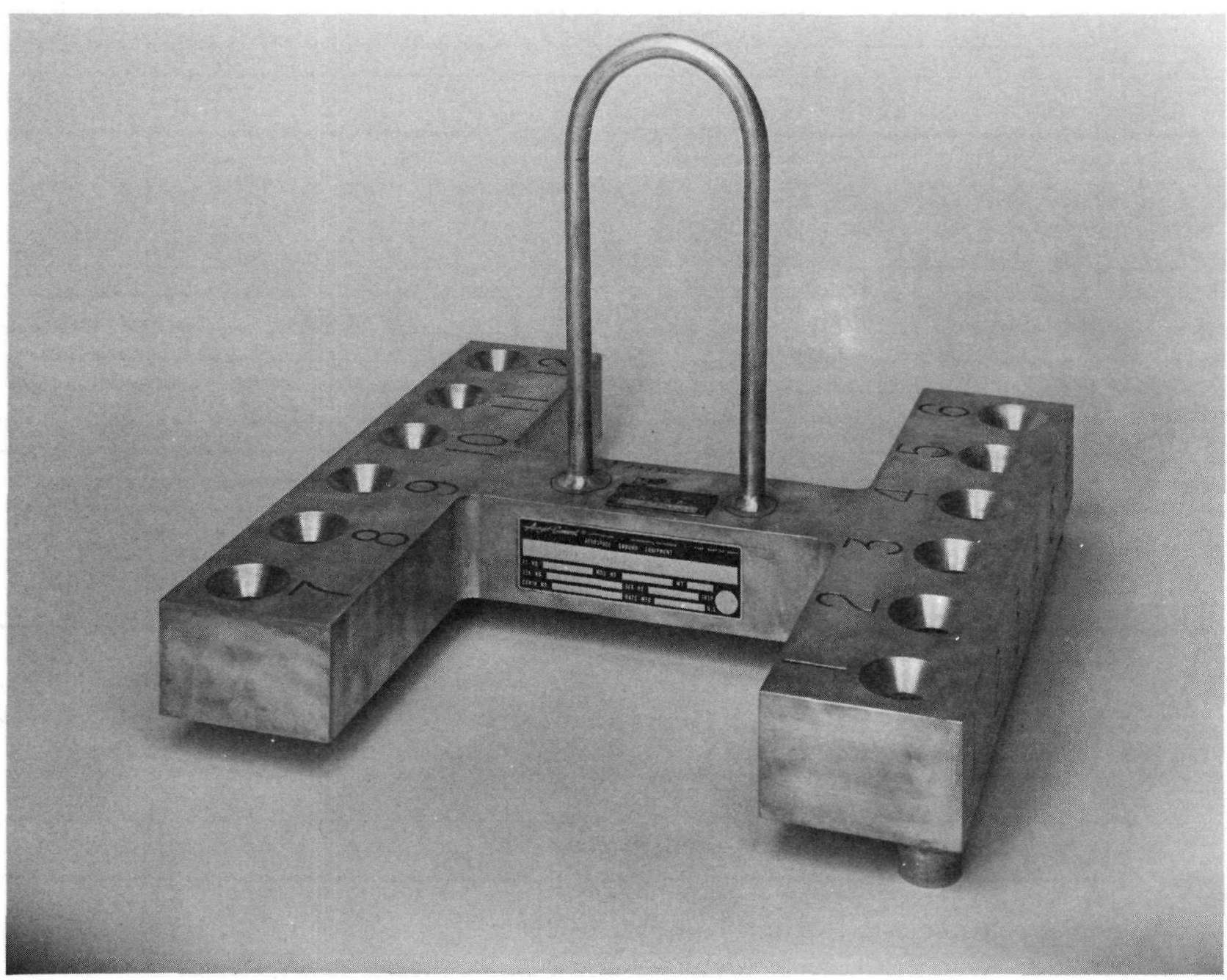


PROVISIONING LIST ITEM NUMBER

DRAWING NUMBER

PART NUMBER

CONTRACTOR
142

293300

293300-9

AGC
FIRST PROVISIONED FOR NRX-A2 GOVT. INV. CONTROL NUMBER

NASA-SNP1-I- $632 \& 633$ $\operatorname{cosT} \$ 275.00 \quad(550.00$ Tota1 $)$

\begin{tabular}{|c|c|}
\hline USE LOCATION & QTY REQ'D \\
\hline A. AGC SACRAMENTO & \\
\hline B. WANL & \\
\hline C. & \\
\hline D. NRDS & 2 \\
\hline TOTAL & 2 \\
\hline
\end{tabular}

\section{DIMENSIONS AND CAPACITY}

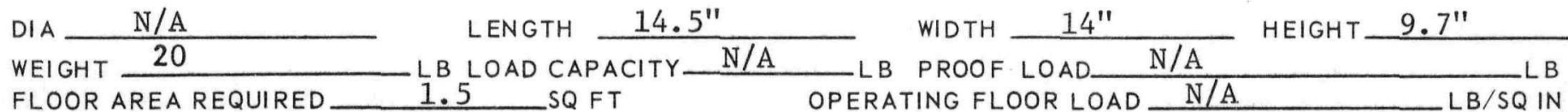
ADDITIONAL DATA

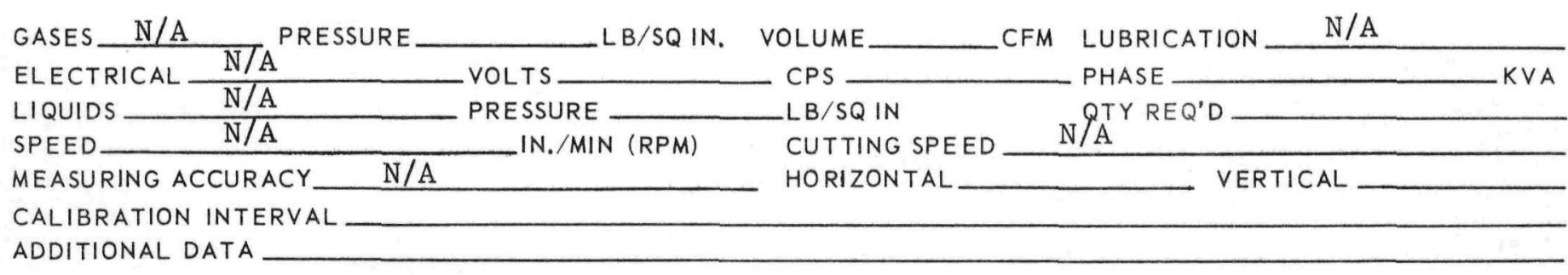

MANIPULATOR Sidewa11

CRANE N/A

ADDITIONAL DATA
LOAD CAPACITY

LOAD CAPACITY
65

N/A
LB MAX

LB MAX

EQUIPMENT_Sidewal1 Manipulator

PART OR ITEM Nozzle \& Forward Closure Bolts DRAWING NO. $286664-1 \&-13$

REMARKS 


\section{T) NERVA LPROGRAM SUPPORT EQUIPMENT TECHNICAL DESCRIPTION HANDBOOK}

EQUIPMENT TITLE

TOOL SET, LAPPING, NUCLEAR ENGINE
PROV. LIST

ITEM NO.

151

DATE

January 1968

REVISION

DESCRIPTION: The Lapping Tool Set refinishes the seal surfaces of the pressure vessel and forward closure, pressure vessel and nozzle, and seal surfaces of the forward-closure instrumentation ports. The set is used to remove minor imperfections if leakage at the seal surfaces occurs during pressure testing. Large scratches or dents however, cannot be removed from seal surfaces.
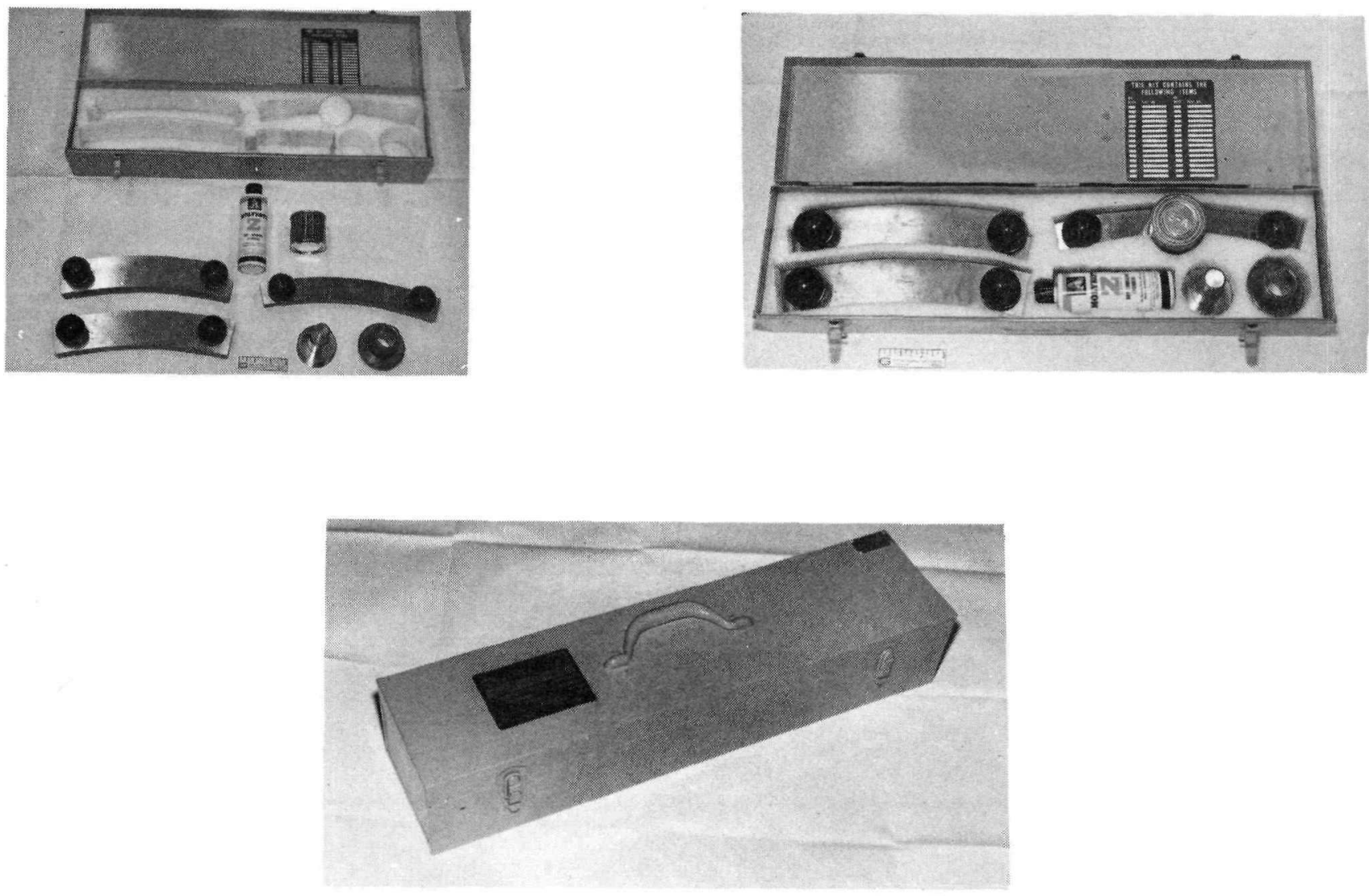
PROVISIONING LIST ITEM NUMBER DRAWING NUMBER 276462

PART NUMBER

CONTRACTOR
276462-9 AGC
151

FIRST PROVISIONED FOR NRX-A3 GOVT. INV. CONTROL NUMBER NASA-SNP1-L-1118 $\&-1132$

\begin{tabular}{|l||c|}
\hline USE LOCATION & QTY REQ'D \\
\hline A. AGC SACRAMENTO & 1 \\
\hline B. WANL & \\
\hline C. & 1 \\
\hline D. NRDS TOTAL & 2 \\
\hline
\end{tabular}

\section{DIMENSIONS AND CAPACITY}

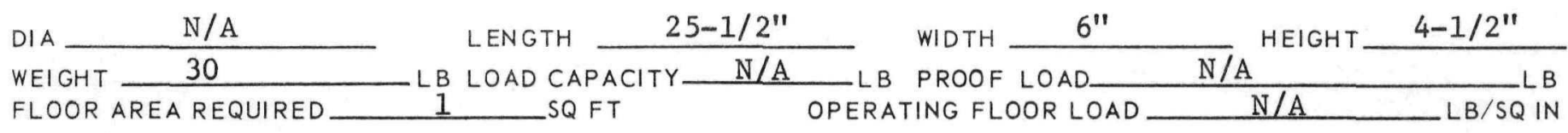

ADDITIONAL DATA

GASES N/A PRESSURE ELECTRICAL_ N N / A

LIQUIDS N/A

SPEED

MEASURING ACCURACY

CALIBRATION INTERVAL

ADDITIONAL DATA
$-L B / S Q I N . \quad$ VOLUME

CPS

$L B / S Q I N$

CUTTING SPEED N/A

HORIZONTAL
CFM LUBRICATION

PHASE

QTY REQ'D KVA

PRESSURE

N/A
N/A
IN./MIN (RPM)

OPERATING EQUIPMENT

MANIPULATOR

CRANE

$\mathrm{N} / \mathrm{A}$ $\mathrm{N} / \mathrm{A}$ LOAD CAPACITY LOAD CAPACITY
L B MAX LB MAX

ADDITIONAL DATA

EQUIPMENT_ N/A

PART OR ITEM Pressure Vesse1, Forward ClosuredRAWING NO. 294053-49(PV) 706989-3 (PV)

REMARKS and Nozzle 


\section{(1) NERVA \\ LIPROGRAM \\ SUPPORT EQUIPMENT \\ TECHNICAL DESCRIPTION HANDBOOK}

EQUIPMENT TITLE

FIXTURE, LIFTING, PROPELLANT INLET LINE, REMOTE
PROV. LIST

ITEM NO.

210

\section{REVISION}

DESCRIPTION: The Remote Propellant Inlet Line Lifting Fixture permits remote lifting and handling of the horizontal section of the propellant inlet line during its removal from the NRX test car. It consists of two clamp halves mounted on a common pivot and actuated by a drive screw. Eyes are provided on the drive screw for remote actuation by a sidewall manipulator. A lifting bail provides a means of lifting the fixture with a 5-ton crane hook.

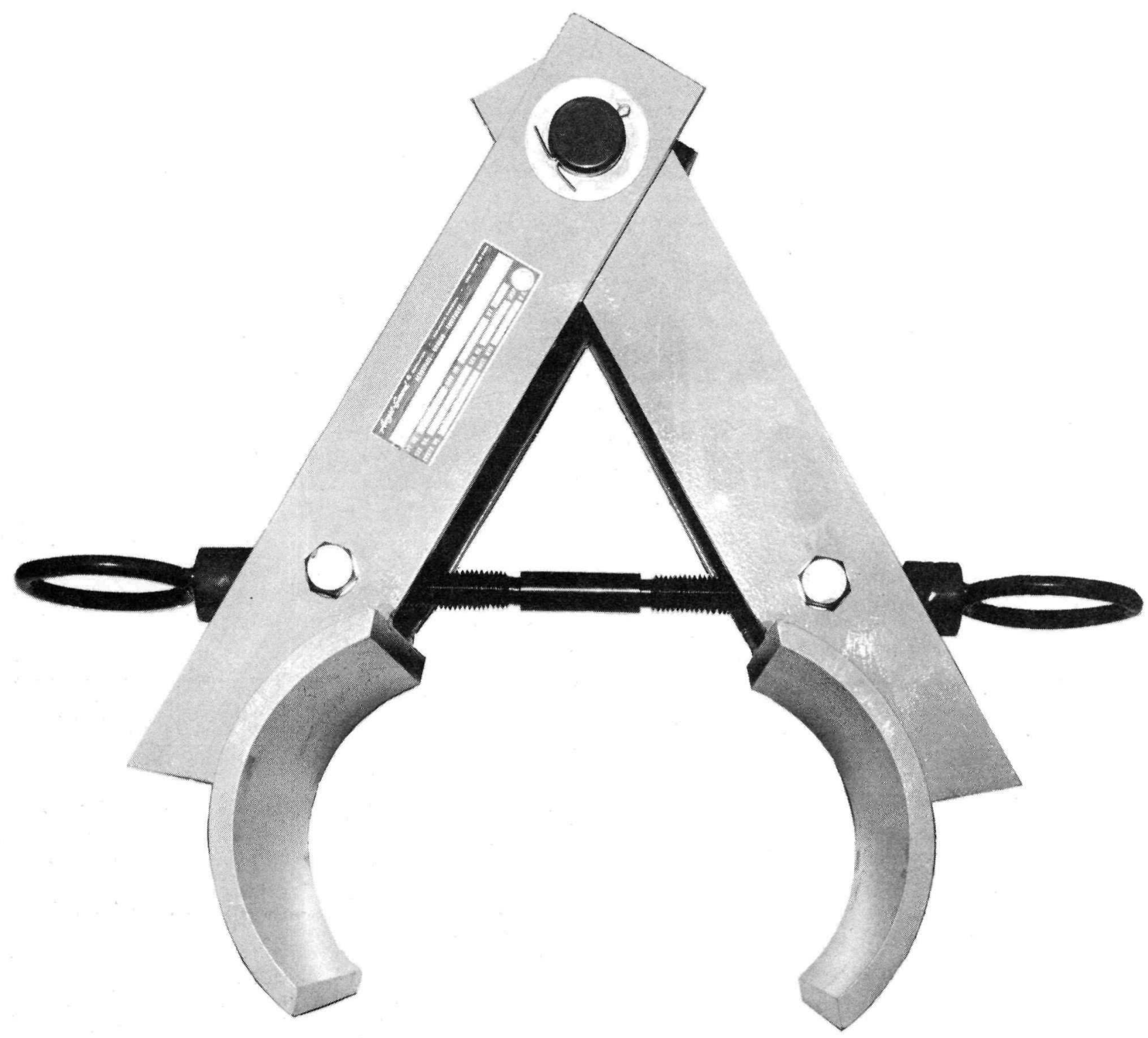


PROVISIONING LIST ITEM NUMBER DRAWING NUMBER 276440

PART NUMBER CONTRACTOR
210

276440-9

AGC
FIRST PROVISIONED FOR NRX-A2 GOVT. INV. CONTROL NUMBER NASA-SNP1-L-634 $\$ 350.00$

\begin{tabular}{|l||c|}
\hline \multicolumn{1}{|c||}{ USE LOCATION } & QTY REQ'D \\
\hline A. AGC SACRAMENTO & \\
\hline B. WANL & \\
\hline C. & 1 \\
\hline D. NRDS TOTAL & 1 \\
\hline \multicolumn{2}{|c||}{} \\
\hline
\end{tabular}

DIMENSIONS AND CAPACITY

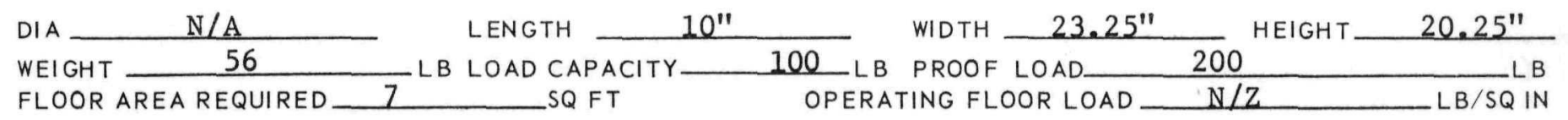

ADDITIONAL DATA

MANIPULATOR *Sidewa11

CRANE R-MAD Facility (Auxiliary Hook)
LB/SQIN. VOLUME

CPS

LB/SQ IN

CUTTING SPEED

HORIZONTAL
Oil-Working Joints CFM LUBRICATION and Screws PHASE KVA QTY REQ'D
SPEED $\frac{\text { N/A }}{\text { MEASURING ACCURACY }}$ CALIBRATION INTERVAL 6 Months ADDITIONAL DATA Operation and maintenance instructions available, no number other than $\mathrm{P} / \mathrm{N}$ given.

VOLTS IN./MIN (RPM)

ADDITIONAL DATA For Closing the fixture only

LOAD CAPACITY LOAD CAPACITY y
65

10,000

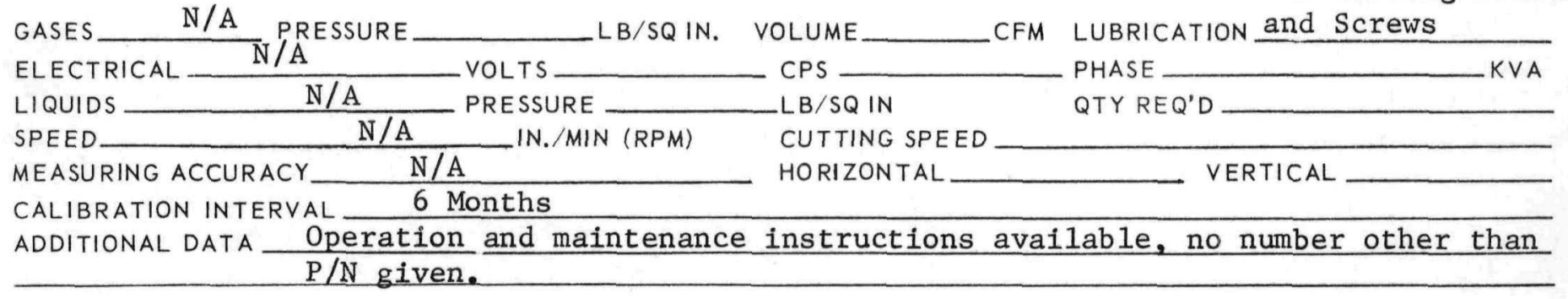

EQUIPMENT PART OR ITEM Crane \& Sidewall Manipulator REMARKS
Propellant Inlet Line DRAWING NO. 298065-19, 1114090-29 


\section{(1) NERVA IPROGRAM SUPPORT EQUIPMENT
TECHNICAL DESCRIPTION HANDE}

EQUIPMENT TITLE

FIXTURE, LIETING, ROCKET ENGINE FORWARD CLOSURE, REMOTE
PROV. LIST

ITEM NO.

211

DATE

REVISION

$\mathrm{B}$

DESCRIPTION: The Remote Rocket Engine Forward Closure Lifting Fixture has a frame-mounted, split-ring clamping device which closes around the neck of the forward closure flange by means of a screw jack which is manipulator operated. A bail is provided so the fixture can be used to lift and position the forward closure during disassembly operations.

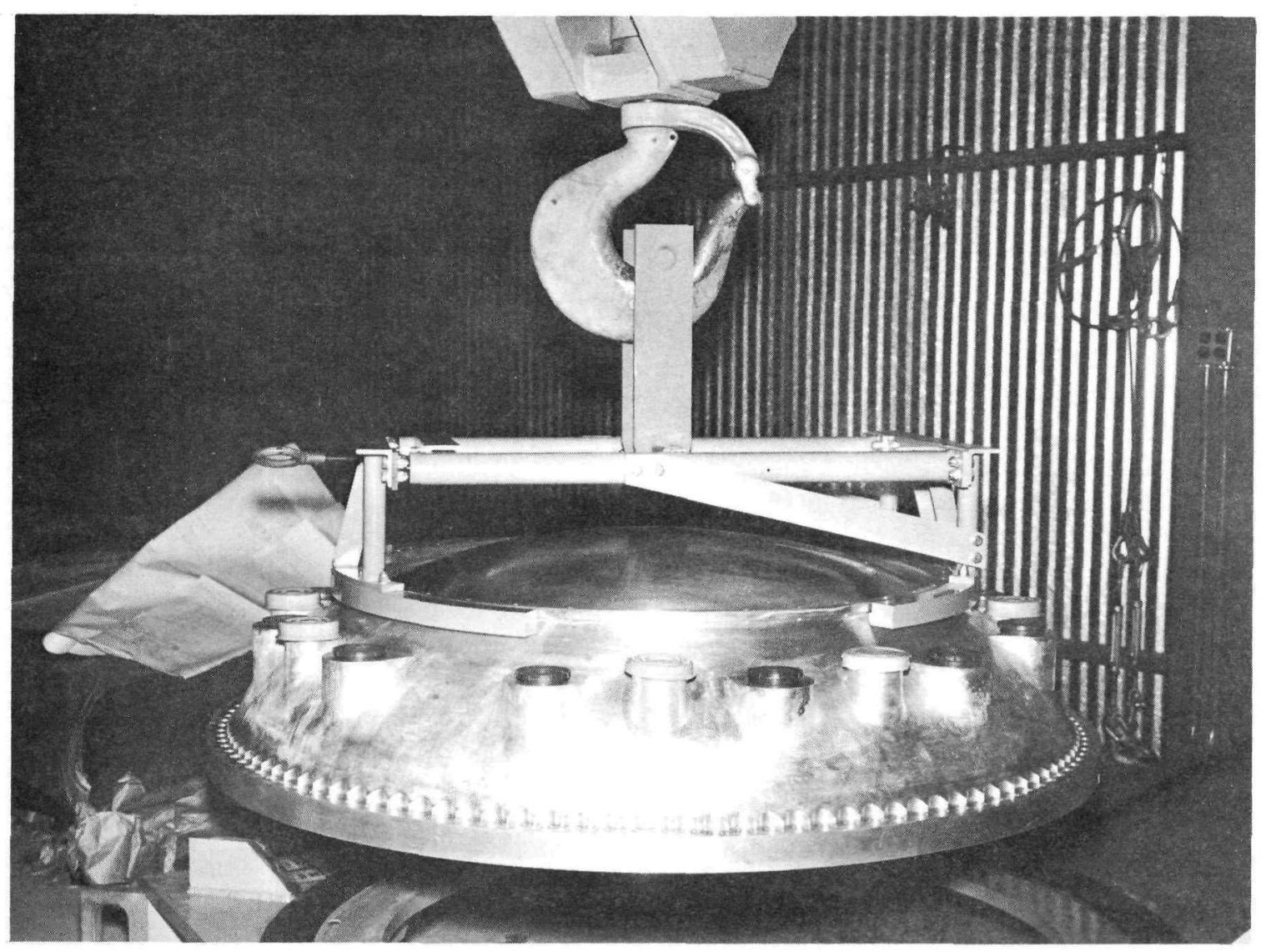


PROVISIONING LIST ITEM NUMBER

DRAWING NUMBER $\quad 276300$

PART NUMBER

CONTRACTOR
211 $276300-9$ AGC
FIRST PROVISIONED FOR NRX-A2 GOVT. INV. CONTROL NUMBER NASA-SNP1-L-548 $\$ 2,500$

\begin{tabular}{|l||c|}
\hline \multicolumn{1}{|c||}{ USE LOCATION } & QTY REQ'D \\
\hline A. AGC SACRAMENTO & \\
\hline B. WANL & \\
\hline C. & 1 \\
\hline D. NRDS TOTAL & 1 \\
\hline
\end{tabular}

\section{DIMENSIONS AND CAPACITY}

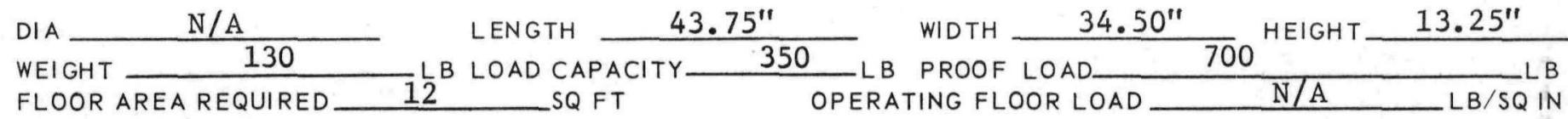

ADDITIONAL DATA

GASES_N N/A PRESSURE ELECTRICAL N N/A

LIQUIDS

SPEED

MEASURING ACCURACY

CALIBRATION INTERVAL

$\mathrm{N} / \mathrm{A}$ $\mathrm{N} / \mathrm{A}$ $\mathrm{N} / \mathrm{A}$ N/A $L B / S Q I N$. VOLUM CPS $L B / S Q$ IN CUTTING SPEED HORIZONTAL
CFM LUBRICATION

PHASE KVA QTY REQ'D
VOLTS
PRESSURE IN./MIN (RPM)

VERTICAL

MANIPULATOR * * *

CRANE R-MAD Facility (Auxiliary Hook)

ADDITIONAL DATA
LOAD CAPACITY LOAD CAPACITY *Not to be used for lifting the fixture
LB MAX 10,000 LB MAX

\section{INTERFACES}

EQUIPMENT Crane, Manipulator (Sidewal1) PART OR ITEM Forward Closure DRAWING NO. P/N 283095-9, 298252-9

REMARKS 
0

0 W NERVA

PROGRAM

SUPPORT EQUIPMENT

PROV. LIST

ITEM NO.

218

DATE

TECHNICAL DESCRIPTION HANDBOOK

EQUIPMENT TITLE

REVISION

January 1968

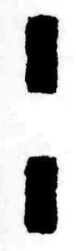

FIXTURE, LIFTING, FLOOR MOUNTED SUPPORT EQUIPMENT, REMOTE

7 DESCRIPTION: The Remote Floor Mounted Support Equipment Lifting Fixture lifts the remote nozzle examination fixture, P/L 137, with or without the nozzle installed. The fixture consists of a strong back with lifting bail and two rigid, vertical legs which attach to the trunnions of the remote nozzle examination fixture. The lifting bail is used with a remotely controlled five-tone crane.

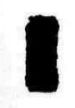

8

0

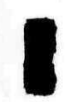

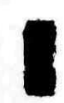

8

0

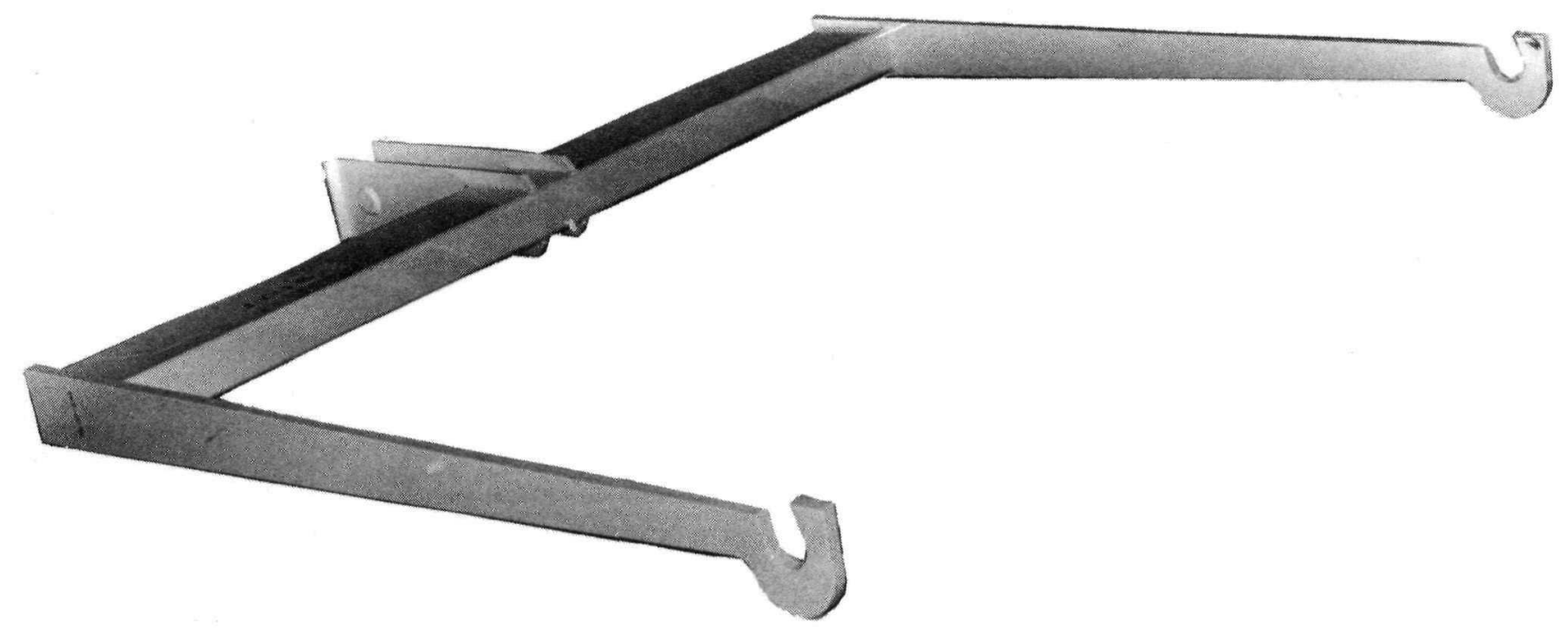

0

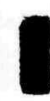

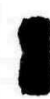

1

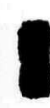

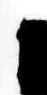




\section{TECHNICAL SUMMARY}

PROVISIONING LIST ITEM NUMBER 218

DRAWING NUMBER

PART NUMBER 276410

CONTRACTOR

276410-9 AGC
FIRST PROVISIONED FOR NRX-A1 GOVT. INV. CONTROL NUMBER None $\operatorname{cosT} \$ 500.00$

\begin{tabular}{|l||c|}
\hline \multicolumn{1}{|c||}{ USE LOCATION } & QTY REQ'D \\
\hline A. AGC SACRAMENTO & \\
\hline B. WANL & \\
\hline C. & 1 \\
\hline D. NRDS TOTAL & 1 \\
\hline \multicolumn{2}{|c||}{} \\
\hline
\end{tabular}

\section{DIMENSIONS AND CAPACITY}

DIA

WEIGHT

FLOOR AREA REQUIRED

ADDITIONAL DATA $\begin{array}{lll}\text { LENGTH } \frac{65^{\prime \prime}}{1500} \text { WIDTH } & \\ \text { LB LOAD CAPACITY L PROOF LOAD }\end{array}$

$30 \quad S Q F T$

$5^{\prime \prime}$ 3000

HEIGHT OPERATING FLOOR LOAD $64.6^{\prime \prime}$
GASES N/A

ELECTRICAL

LIQUIDS

SPEED

MEASURING ACCURACY

CALIBRATION INTERVAL

ADDITIONAL DATA
PRESSURE $\mathrm{N} / \mathrm{A}$ $\mathrm{N} / \mathrm{A}$

$N / A$
VOLTS PRESSURE IN./MIN (RPM) N/A $\mathrm{N} / \mathrm{A}$
LB/SQ IN. VOLUME

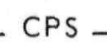

HORIZONTAL
CFM LUBRICATION

PHASE

QTY REQ'D
MANIPULATOR

$\mathrm{N} / \mathrm{A}$

CRANE Remote Overhead Crane
Operation and Maintenance Instructions available from NRO - GSE, no number other than part number given.

ADDITIONAL DATA

LOAD CAPACITY

LOAD CAPACITY
LB MAX 10,000 LB MAX

\section{INTERFACES}

EQUIPMENT PART OR ITEM P/L Item 137 and Hot Bay 5 Ton Crane

REMARKS DRAWING NO. 


\section{(1) NERVA \\ LIPROGRAM \\ SUPPORT EQUIPMENT TECHNICAL DESCRIPTION HANDBOOK}

EQUIPMENT TITLE

POLISHER AND GRINDER, REMOTE

DESCRIPTION: The Remote Polisher and Grinder consists of a commercial pneumatic grinder, an adapter for manipulator use, a slotted rubber cone, and abrasive cloth cones to mount on the rubber cone. The abrasive cones are held on the grinder during operation by centrifugal force on the slotted rubber cone which causes it to expand and grip the inside of the abrasive cones. When the grinder spindle is not rotating, the slotted cone contracts and the tapered abrasive, cones can be easily removed and replaced. The unit is used to remove burrs and sharp edges from specimens.

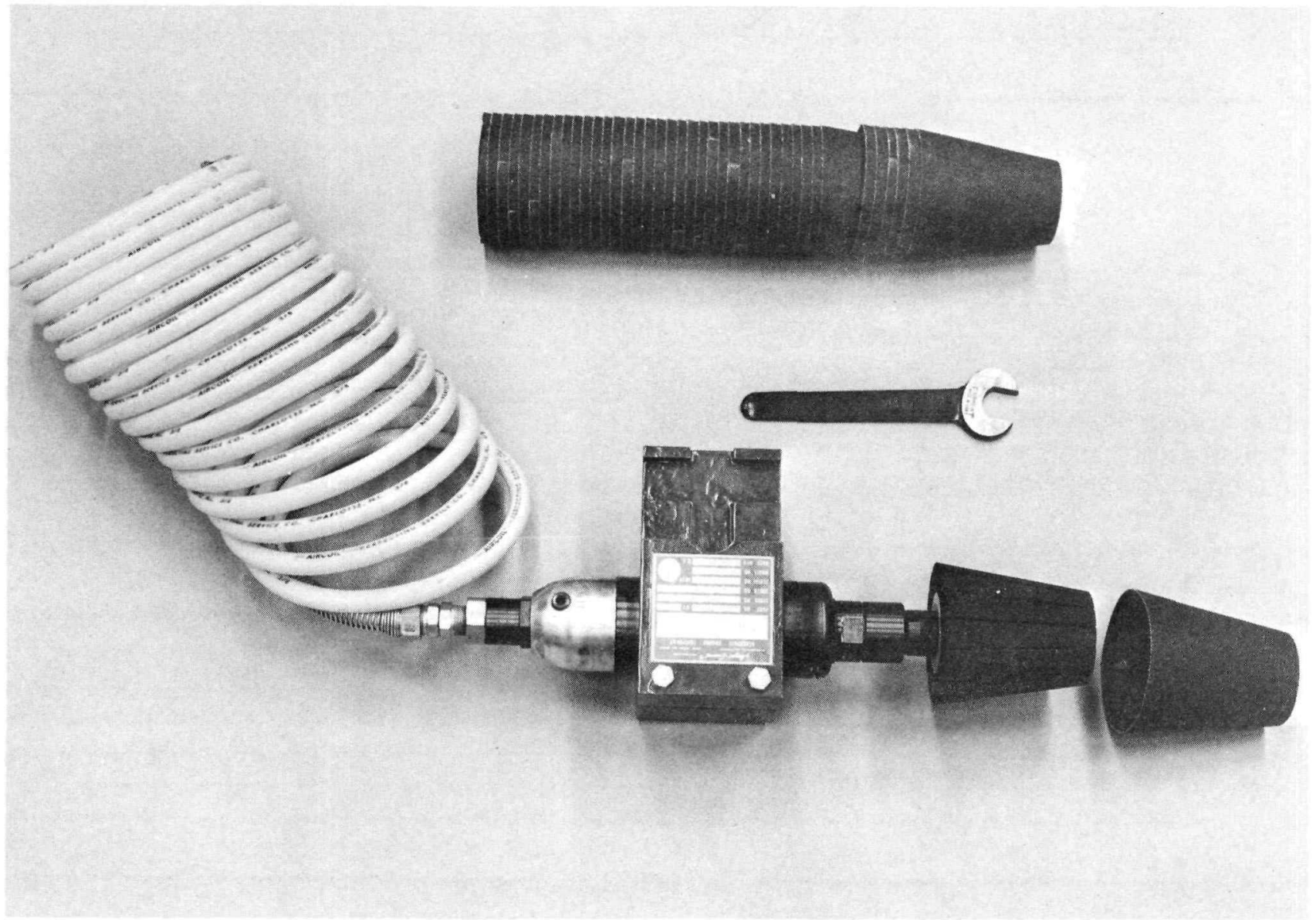




\section{TECHNICAL SUMMARY}

PROVISIONING LIST ITEM NUMBER

DRAWING NUMBER

PART NUMBER

CONTRACTOR
276465

276465-9
265 AGC
FIRST PROVISIONED FOR _ NRX-A2 GOVT. INV. CONTROL NUMBER NASA-SNP1-L-651 COST $\$ 507.00$

\begin{tabular}{|c|c|}
\hline USE LOCATION & QTY REQ'D \\
\hline A. AGC SACRAMENTO & \\
\hline B. WANL & \\
\hline C. & \\
\hline D. NRDS & 1 \\
\hline TOTAL & 1 \\
\hline
\end{tabular}

\section{DIMENSIONS AND CAPACITY}

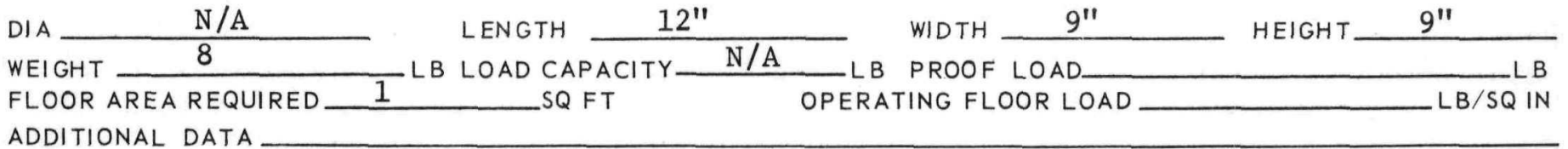

ADDITIONAL DATA

GASES Air ELECTRICAL

LIQUIDS SPEED $* 12,000$ RPM(No Load) MEASURING ACCURACY PRESSURE $\quad 100$ $\mathrm{N} / \mathrm{A}$ $\mathrm{N} / \mathrm{A}$ - VOLTS PRESSURE $\mathrm{N} / \mathrm{A}$ IN./MIN (RPM) ADDITIONAL DATA See RN-S-0111 * Speed is Governed to prevent exceeding this speed **At maximum power $(1.3 \mathrm{HP})$, volume at maximum speed (no 1 oad) is $20 \mathrm{CFM}$

\section{$* *$}

LB/SQ IN. VOLUME_ 43 CFM

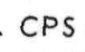

VERTICAL

LUBRICATION Oil in Air Supply PHASE KVA 


\section{(i) NERVA LPROGRAM

EQUIPMENT TITLE

SAW, SPECIMEN METAL CUTPING, REMOTE
PROV. LIST

ITEM NO.

267

DATE January 1968

REVISION C

DESCRIPTION: The Remote Metal Cutting Specimen Saw, remotely operated and pneumatically driven, is used to section the nozzle, pressure vessel, and other components for post-operative specimen examination. The saw blades can be changed with manipulators, and are capable of cutting stainless steels and aluminum alloys to a maximum thickness of six inches.

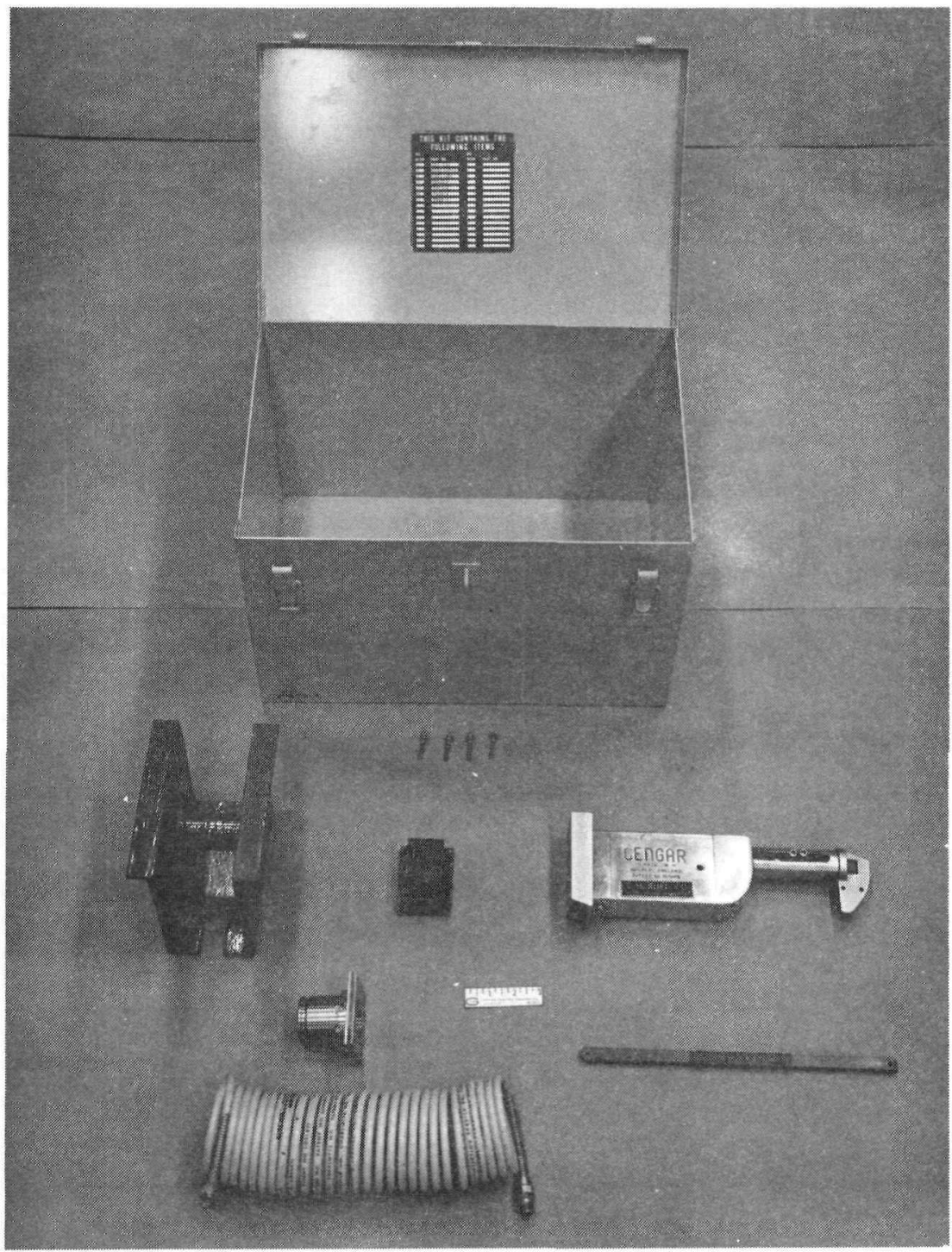


PROVISIONING LIST ITEM NUMBER DRAWING NUMBER PART NUMBER CONTRACTOR
267 276425 276425-9 AGC
FIRST PROVISIONED FOR $\mathrm{NRX}-\mathrm{A} 2$ GOVT. INV. CONTROL NUMBER NASA-SNP1-I $=650$

\begin{tabular}{|l||c|}
\hline \multicolumn{1}{|c||}{ USE LOCATION } & QTY REQ'D \\
\hline A. AGC SACRAMENTO & \\
\hline B. WANL & \\
\hline C. & 1 \\
\hline D. NRDS TOTAL & 1 \\
\hline
\end{tabular}

\section{DIMENSIONS AND CAPACITY}

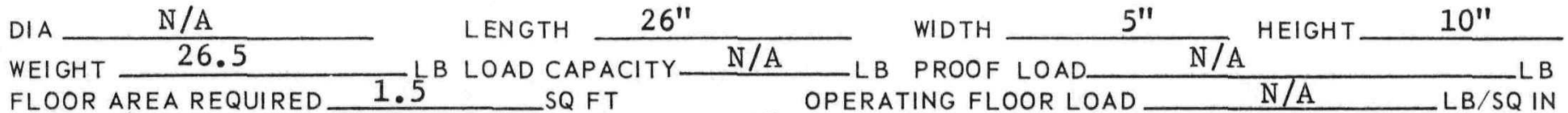
FLOOR AREA REQUIRED $\frac{1.5}{\text { Maximum depth of cut is } 6 "}$

GASES_Air PRESSURE_ 100 LB/SQIN. VOLUME_6 CFM LUBRICATION 0 II in air suppIy

ELECTRICAL N/A

LIQUIDS

$\mathrm{N} / \mathrm{A}$

VOLTS

CPS PHASE KVA

SPEED *1100 Strokes per minutAN./MIN (RPM)

MEASURING ACCURACY N/A

$L B / S Q I N$

CUTTING SPEED N/A

QTY REQ'D

HORIZONTAL

VERTICAL

CALIBRATION INTERVAL

ADDITIONAL DATA See RN-S-0112

Length of cutting stroke $1.75^{\prime \prime}$

*Adjustable from 1 to 1100 strokes/min.

\section{OPERATING EQUIPMENT}

MANIPULATOR $\frac{\text { Sidewall or Master/Slave }}{\text { N/A }}$ LOAD CAPACITY 65 or $100 \& 10$
CRANE LOAD CAPACITY
ADDITIONAL DATA
Also the O-Man may be used

EQUIPMENT_Sidewa11 manipulator, Master/Slave, O-man

PART OR ITEM DRAWING NO.

REMARKS Any metallic item within its cutting capacity 


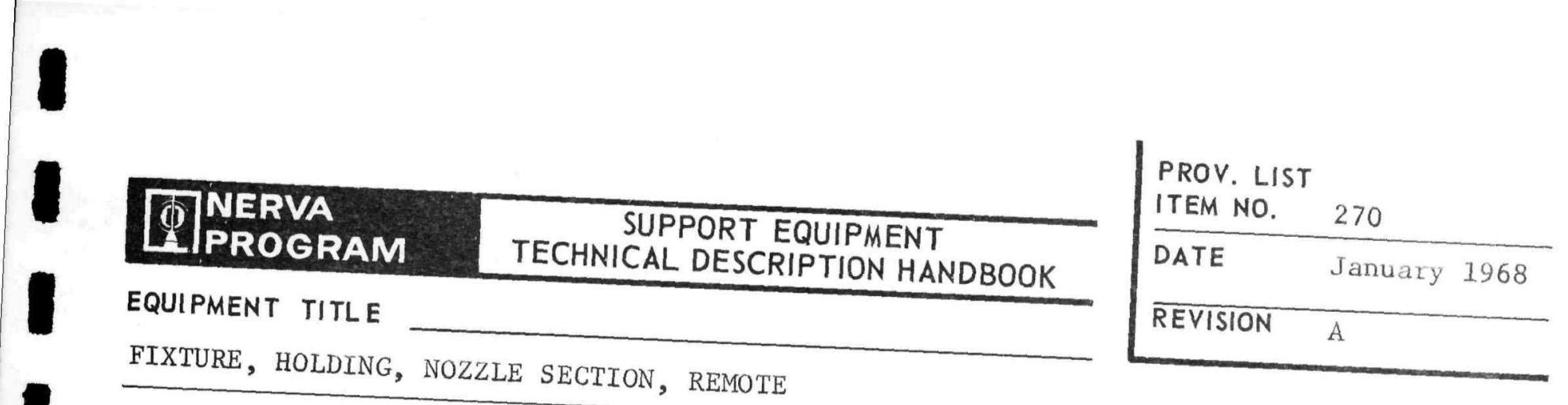

DESCRIPTION: The Remote Nozzle Section Holding Fixture is used to remotely
support and position sections of the nozzle to pert support and position sections of the nozzle to permit cutting of smaller test and an adjustable jaw opening. 4.5 inches and the power stroke is 1.5 jaw opening is 11.0 inches, jaw width is

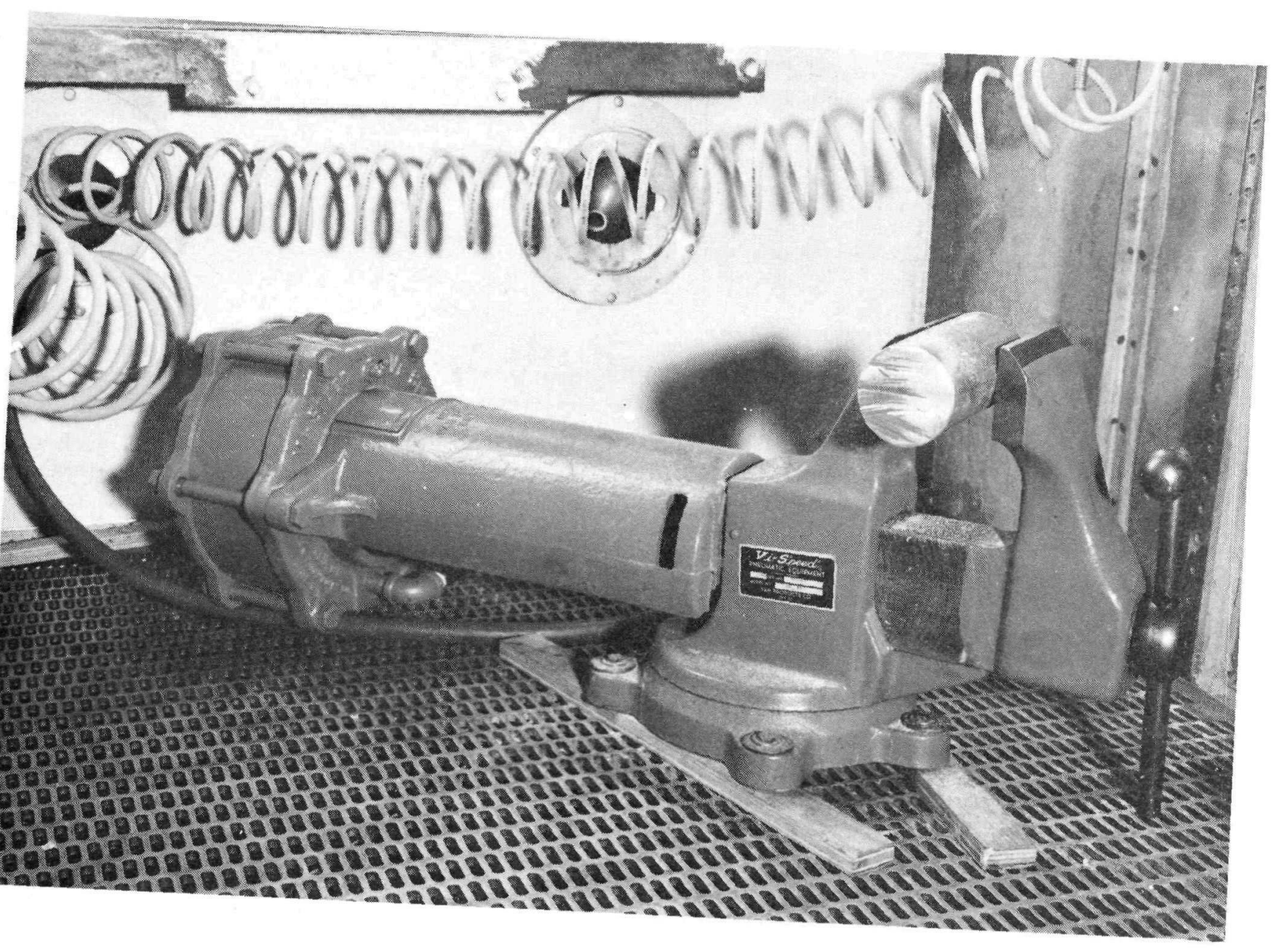


TECHNICAL SUMMARY

PROVISIONING LIST ITEM NUMBER 270

DRAWING NUMBER

PART NUMBER

CONTRACTOR
276389-

AGC
276389
FIRST PROVISIONED FOR NRX-A2 GOVT. INV. CONTROL NUMBER

$\cos T$ $\$ 373$

\begin{tabular}{|l||c|}
\hline \multicolumn{1}{|c||}{ USE LOCATION } & QTY REQ'D \\
\hline A. AGC SACRAMENTO & \\
\hline B. WANL & \\
\hline C. & \\
\hline D. NRDS TOTAL & 1 \\
\hline
\end{tabular}

DIMENSIONS AND CAPACITY

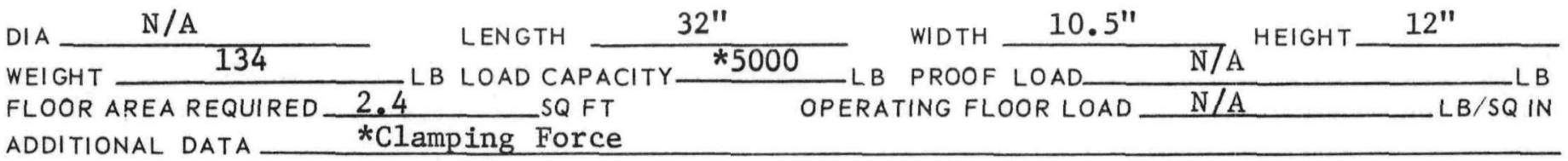
*Clamping Force

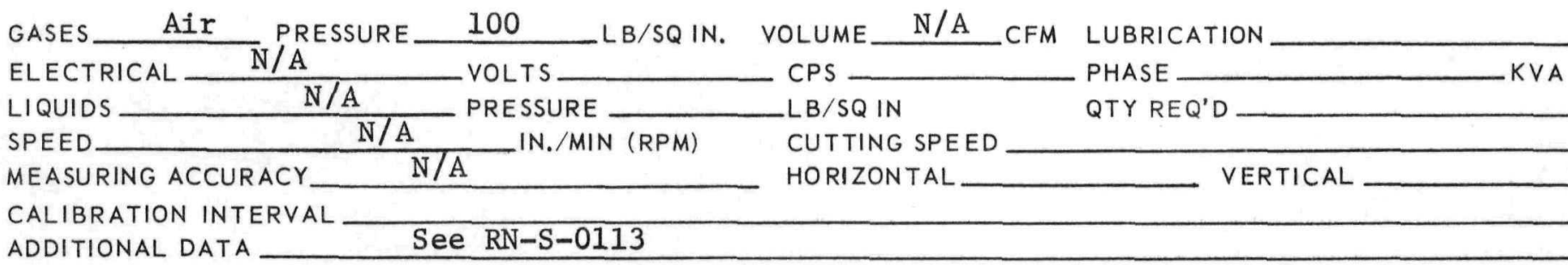

See $\mathrm{RN}-\mathrm{S}-0113$ 


\begin{tabular}{l|l|c|}
\hline 6) NERVA & SUPPORT EQUIPMENT \\
\hline PROGRAM & TECHNICAL DESCRIPTION HANDBOOK \\
\hline
\end{tabular}

EQUIPMENT TITLE

CUTTER, SEAL MANIFOLD, REMOTE
PROV. LIST

ITEM NO.

273

DATE

$\frac{\text { Januar }}{\text { REVISION A }}$

DESCRIPTION: The Remote Cutter Seal Manifold is used to remove the welded seal-manifold from the pressure vessel/forward closure while the NRX assembly is on the test car. The cutter has a ring unit mounted on the outside of the

pressure vessel on which a self-propelled cutting machine is mounted. The cutting machine is propelled around the ring by a geared air-motor. The cutter head of the machine is driven by another geared air-motor at the proper speed for the particular diameter cutter being used and the material being cut. Depth of cut is adjustable to the limit of the depth-control wheel. The cutter must be protected during storage.

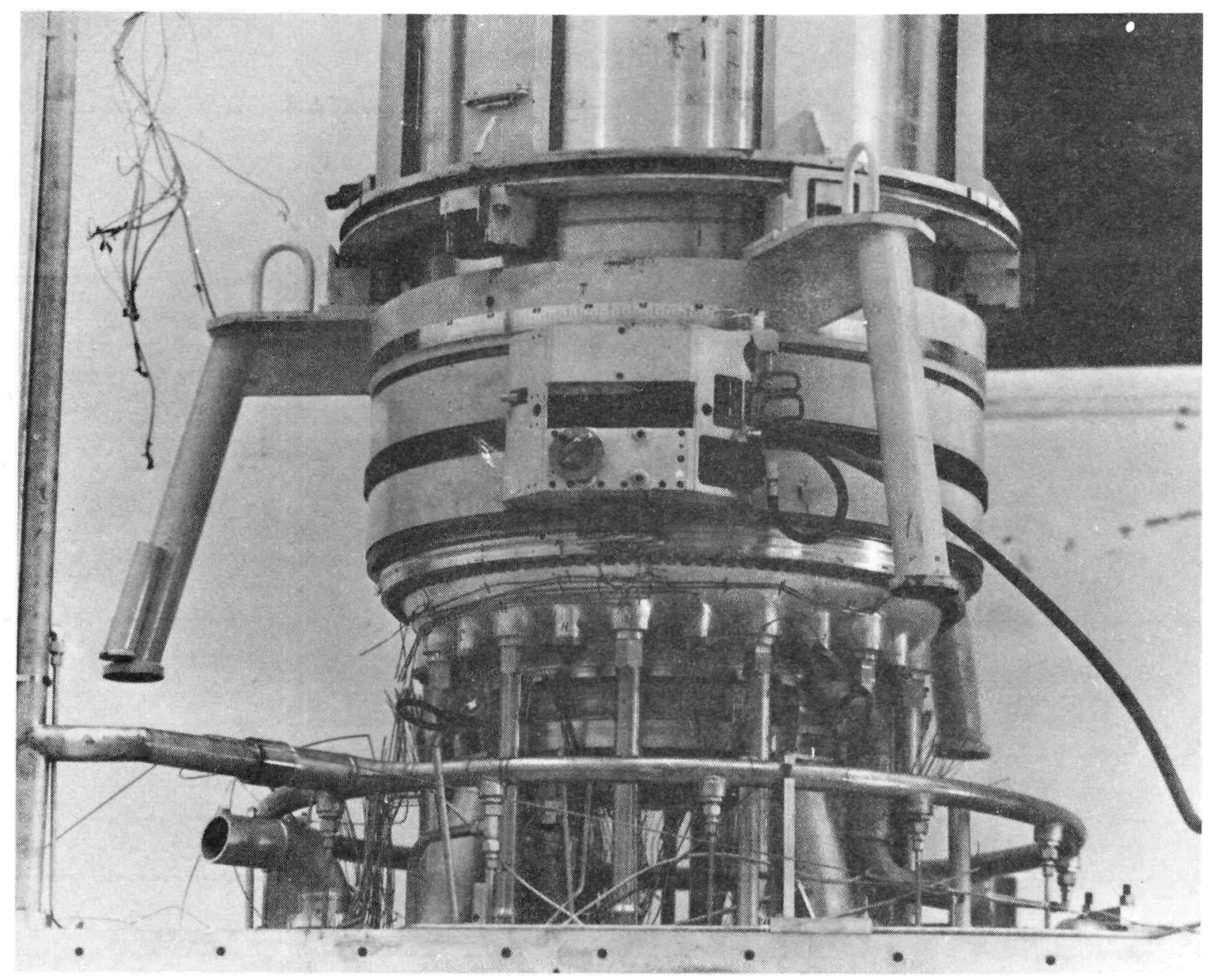


PROVISIONING LIST ITEM NUMBER DRAWING NUMBER 276390

PART NUMBER CONTRACTOR
273

276390-9

AGC
FIRST PROVISIONED FOR NRX-A3 GOVT. INV. CONTROL NUMBER

\begin{tabular}{|l||c|}
\hline \multicolumn{1}{|c||}{ USE LOCATION } & QTY REQ'D \\
\hline A. AGC SACRAMENTO & \\
\hline B. WANL & \\
\hline C. & 1 \\
\hline D. NRDS TOTAL & 1 \\
\hline
\end{tabular}

DIMENSIONS AND CAPACITY

\begin{tabular}{|c|c|c|c|c|c|c|c|c|}
\hline $\mathrm{N} / \mathrm{A}$ & & LENGTH & $84 "$ & & & $94 "$ & & $33^{\prime \prime}$ \\
\hline 1910 & & LOAD CA & ACITY N/A & & & & $\mathrm{N} / \mathrm{A}$ & \\
\hline
\end{tabular}

ADDITIONAL DATA

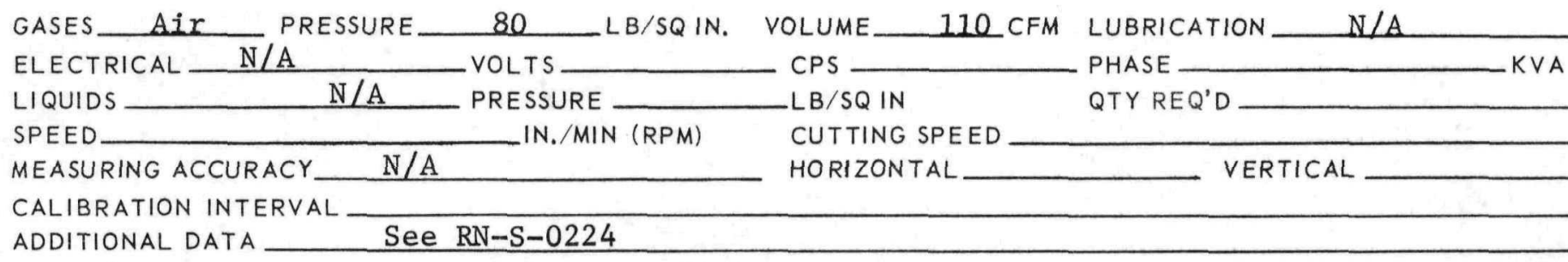

MANIPULATOR 0-Man, Sidewal1

CRANE R-MAD Facility
LOAD CAPACITY $500 \& 65$

LOAD CAPACITY 50,000
$L B M A X$

LB MAX

ADDITIONAL DATA

EQUIPMENT_ Crane, O-Man, Sidewa11 Manipulators

PART OR ITEM Pressure Vessel/Forward Closure DRAWING NO.

REMARKS 


\section{(1) NERVA \\ LIPROGRAM \\ SUPPORT EQUIPMENT \\ TECHNICAL DESCRIPTION HANDBOOK}

EQUIPMENT TITLE

CLOSURE KIT, PRESSURE TESTING, ROCKET ENGINE
PROV. LIST

ITEM NO.

452

DATE

January 1968

REVISION

$\mathrm{C}$

DESCRIPTION: The Rocket Engine Pressure Testing Closure Kit consists of the equipment necessary to close and seal inlet and instrumentation ports and control drum actuator openings on the forward closure of NRX assemblies. This item, used in conjunction with the nozzle throat pressure testing closure kit, Item P/L 453, permits pressure testing of the NRX assembly. The closures are cover plates and plugs, together with fasteners and seals which interface with the various external NRX ports. They are designed for manual installation and removal. Maximum leakage rate is $10^{-2} \mathrm{lb} / \mathrm{sec} /$ inch of seal diameter during NRX systems leak tests. A storage/ carrying case is provided with adequate space and support to store the closures, accessories, and spare parts.
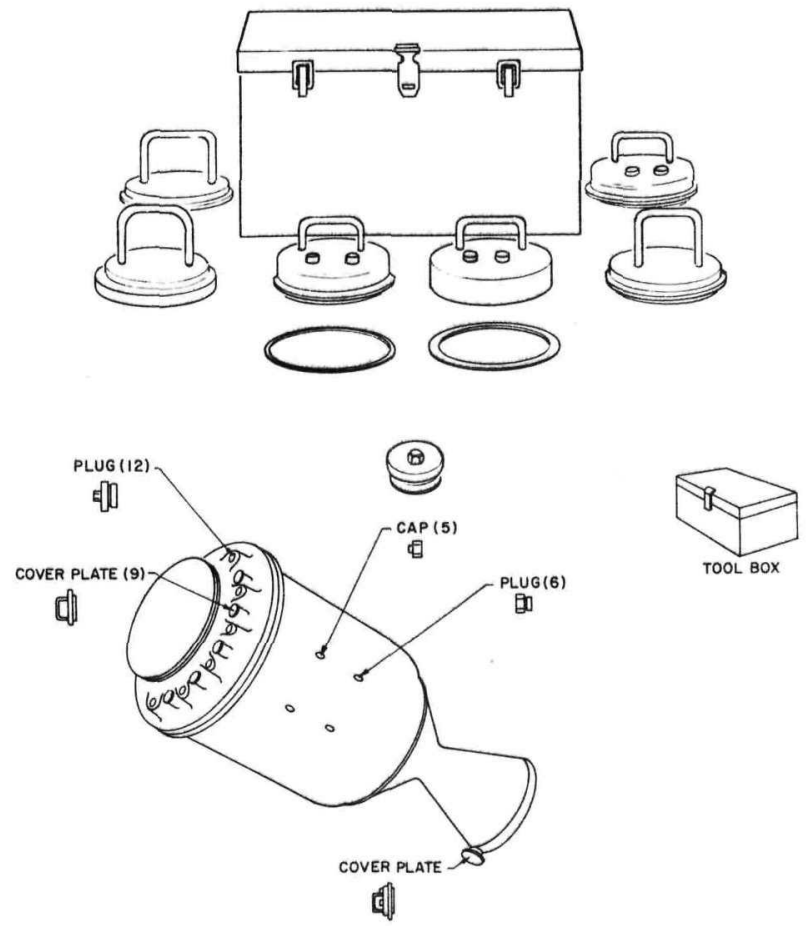

绕 


\section{TECHNICAL SUMMARY}

PROVISIONING LIST ITEM NUMBER 452

DRAWING NUMBER

PART NUMBER 293235

293235-39

CONTRACTOR AGC

FIRST PROVISIONED FOR NRX-AI GOVT. INV. CONTROL NUMBER NASA-SNP1-L-551

\begin{tabular}{|l||c|}
\hline USE LOCATION & QTY REQ'D \\
\hline A. AGC SACRAMENTO & \\
\hline B. WANL & \\
\hline C. & 1 \\
\hline D. NRDS TOTAL & 1 \\
\hline
\end{tabular}

\section{DIMENSIONS AND CAPACITY}

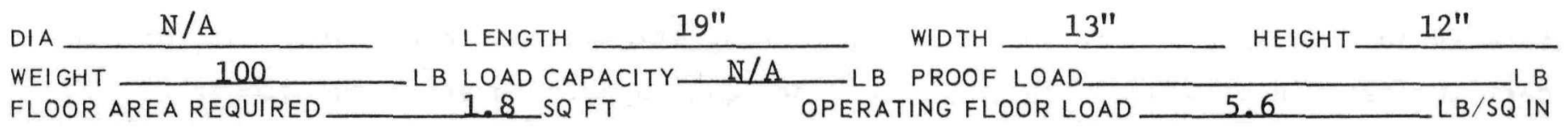
ADDITIONAL DATA

GASES N/A PRESSURE ELECTRICAL _ N/A

LIQUIDS

SPEED

MEASURING ACCURACY

N/A N/A VOLTS LB/SQ IN. VOLUME PRESSURE IN./MIN (RPM)

CALIBRATION INTERVAL ADDITIONAL DATA See Operation and Maintenance Instruction, Number 9792:01:0021
LUBRICATION

PHASE KVA
MANIPULATOR

CRANE None
LOAD CAPACITY

LOAD CAPACITY
L B MAX

LB MAX

ADDITIONAL DATA

INTERFACES

EQUIPMENT

PART OR ITEM

NRX Assembly

DRAWING NO. 2 299066-9

REMARKS 


\section{(1) NERVA \\ LIPROGRAM \\ SUPPORT EQUIPMENT TECHNICAL DESCRIPTION HANDBOOK}

EQUIPMENT TITLE

CLOSURE KIT, PRESSURE TESTING, NOZZLE THROAT,

ROCKET ENGINE (MODIFIED)

DESCRIPTION: The Rocket Engine Nozzle Throat Pressure Testing Closure Kit consists of a nozzle plug, seals, fasteners, pressure application and relief system, storage/carrying case, and accessories. The kit seals the nozzle throat of Aerojet or Rocketdyne nozzles on NRX assemblies. When used in conjunction with the pressure testing closure kit, P/L 452, a NRX assembly can be leak tested. The plug withstands an internal working pressure of $50 \pm 3$ psi, and incorporates a safety pressure-relief-valve set of $56 \pm 3$ psi. A case is provided to store the nozzle plug assembly, accessories, hardware, and spare parts for the closure kit.

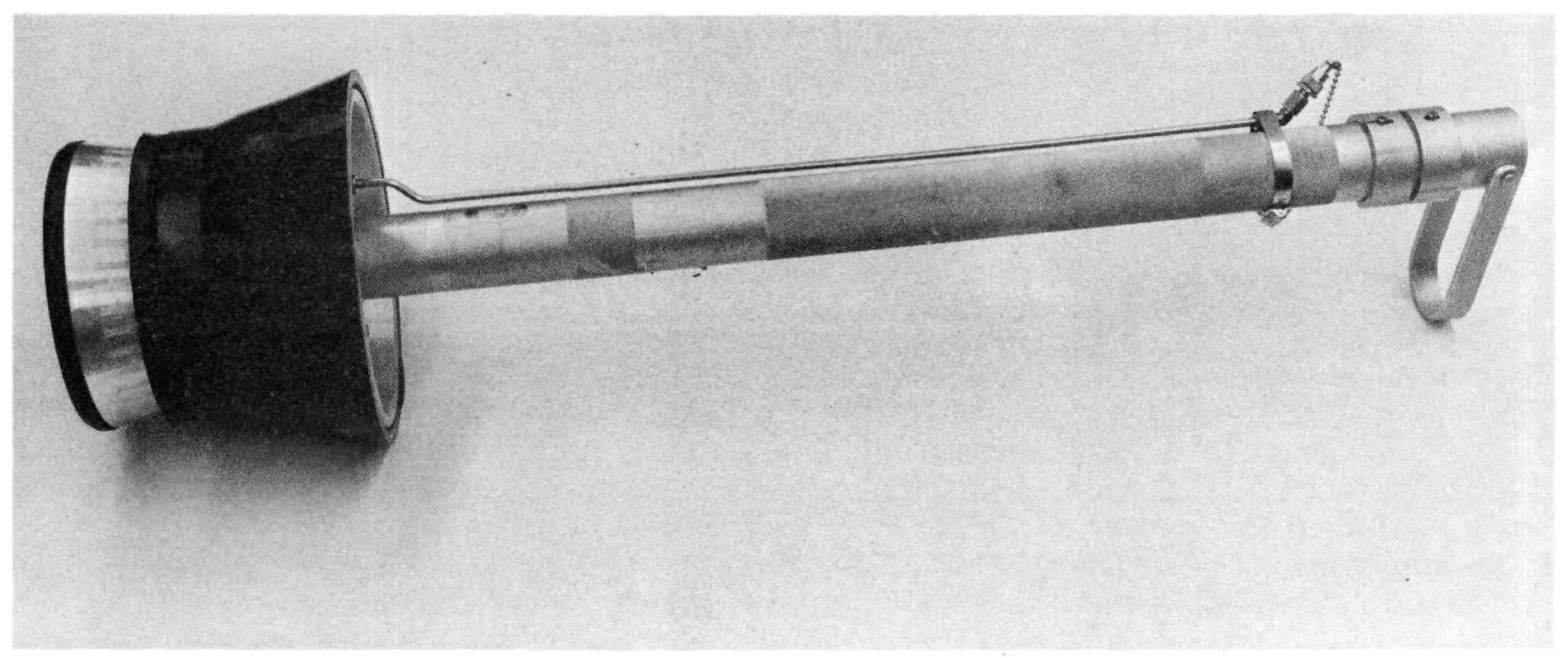


PROVISIONING LIST ITEM NUMBER

DRAWING NUMBER

PART NUMBER

CONTRACTOR
453

293333

293333-9

AGC
FIRST PROVISIONED FOR NRX-AI GOVT. INV. CONTROL NUMBER NASA-SNP1-L-552 $\cos T+\$ 5,000$

\begin{tabular}{|l||c|}
\hline \multicolumn{1}{|c||}{ USE LOCATION } & QTY REQ'D \\
\hline A. AGC SACRAMENTO & \\
\hline B. WANL & \\
\hline C. & 1 \\
\hline D. NRDS TOTAL & 1 \\
\hline \multicolumn{2}{|c|}{} \\
\hline
\end{tabular}

\section{DIMENSIONS AND CAPACITY}

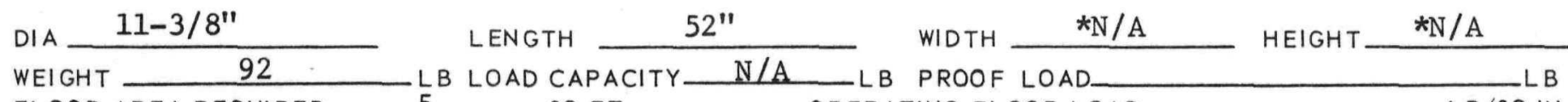
FLOOR AREA REQUIRED 5 - 5 OPERATING FLOOR LOAD LB/SQ IN ADDITIONAL DATA *When closure kit is packaged in its carrying case, the width is 14", height is 13-1/4".

GASES_He PRESSURE $50 \pm 3$

ELECTRICAL_N N/A

LIQUIDS

SPEED

MEASURING ACCURACY

N/A VOLTS PRESSURE $\mathrm{N} / \mathrm{A}$ $\mathrm{N} / \mathrm{A}$ IN./MIN (RPM)
LB/SQIN. VOLUME 660 CFM CPS $L B / S Q I N$ CUTTING SPEED HORIZONTAL
LUBRICATION PHASE QTY REQ'D
$\mathrm{N} / \mathrm{A}$ KVA

See Operation and Maintenance Instruction, Number 9790:01:0024, Pressur Relief Valve set at $56 \pm 3$ psig

\section{OPERATING EQUIPMENT}

MANIPULATOR

CRANE

None

None
LOAD CAPACITY

LOAD CAPACITY
$L B M A X$

LB MAX

ADDITIONAL DATA

INTERFACES

$\begin{array}{ll}\text { EQUIPMENT_ } & \text { None } \\ \text { PART OR ITEM N Nozzle }\end{array}$

REMARKS For use during cold Assembly DRAWING NO. $289800,707630-9,1114263-39$ 


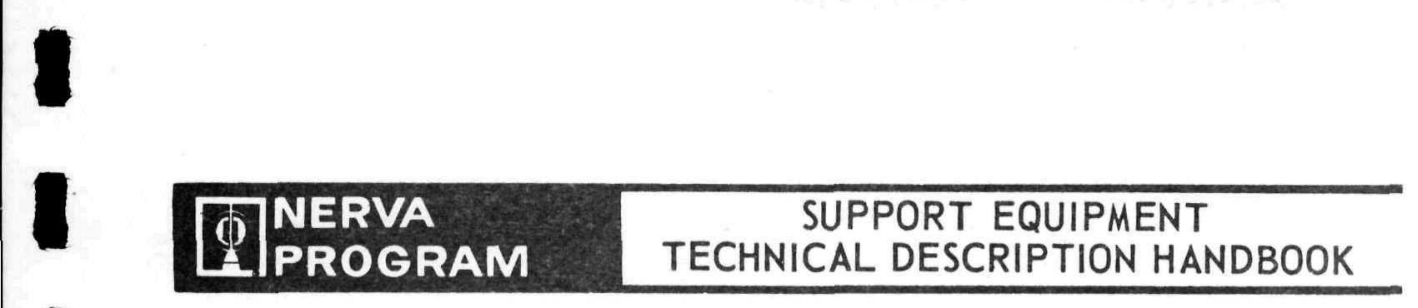

EQUIPMENT TITLE

PROTECTOR, FLANGE, PRESSURE VESSEL

DESCRIPTION: The Pressure Vessel Protector Flange protects the pressure-vessel forward flange and the forward-closure seal surface during reactor and shield installation and other operations performed prior to installation of the forward closure. It consists of a flat three-segmented plastic ring with indexing pins which engage the bolt holes in the pressure-vessel forward-closure flange.

NOTE: The protector has been superseded by the pressure vessel flange protector, P/L 4135.

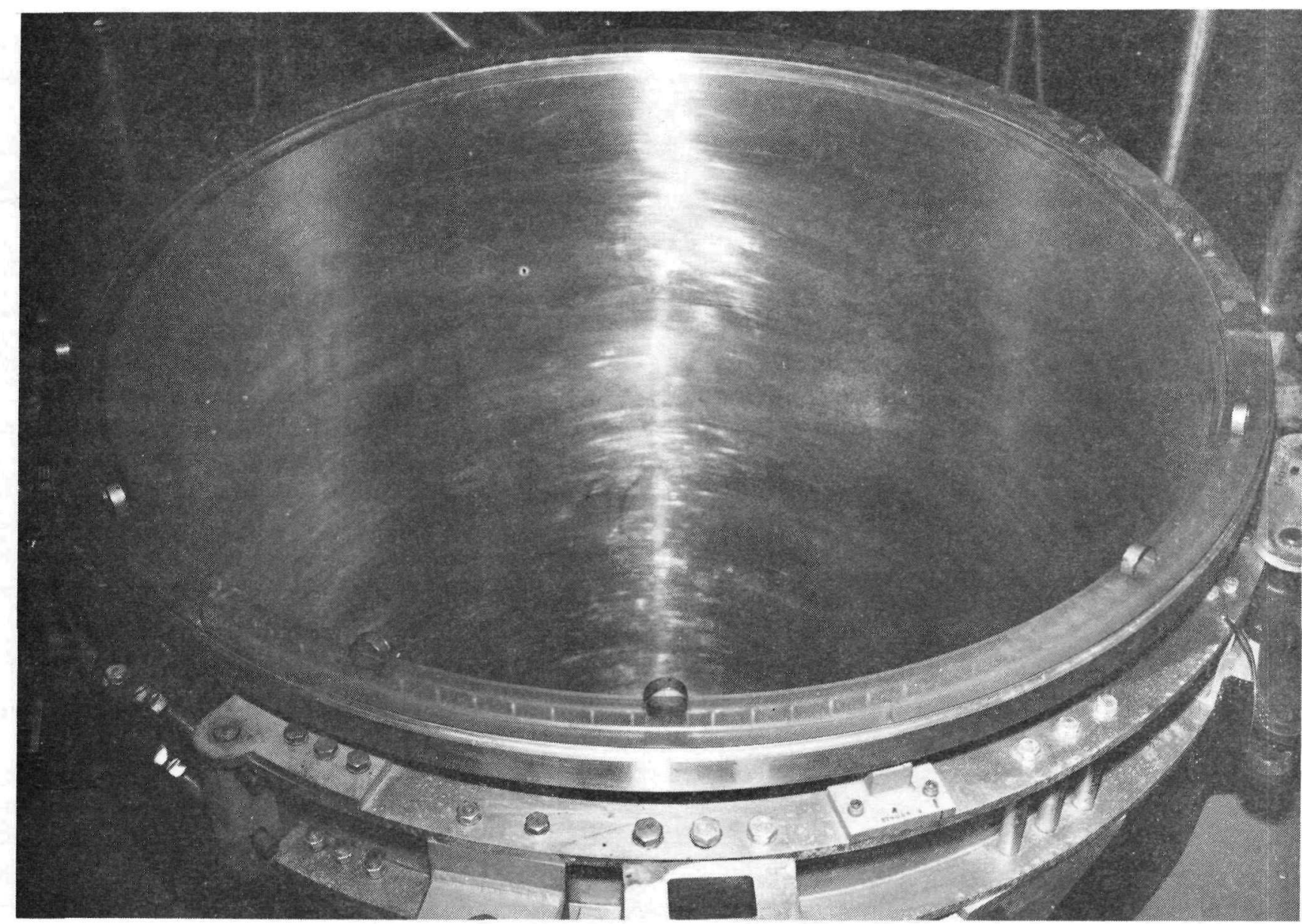


PROVISIONING LIST ITEM NUMBER 455

DRAWING NUMBER

PART NUMBER

CONTRACTOR
253371

253371-9

AGC
FIRST PROVISIONED FOR NRX-A3 GOVT. INV. CONTROL NUMBER NASA-SNP1-L-1115 $\operatorname{cosT} \$ 1200.00$ each (set)

\begin{tabular}{|l||c|}
\hline \multicolumn{1}{|c|}{ USE LOCATION } & QTY REQ'D \\
\hline A. AGC SACRAMENTO & 9 \\
\hline B. WANL & \\
\hline C. & 6 \\
\hline D. NRDS TOTAL & $* 15$ \\
\hline \multicolumn{2}{|c|}{} \\
\hline
\end{tabular}

\section{DIMENSIONS AND CAPACITY}

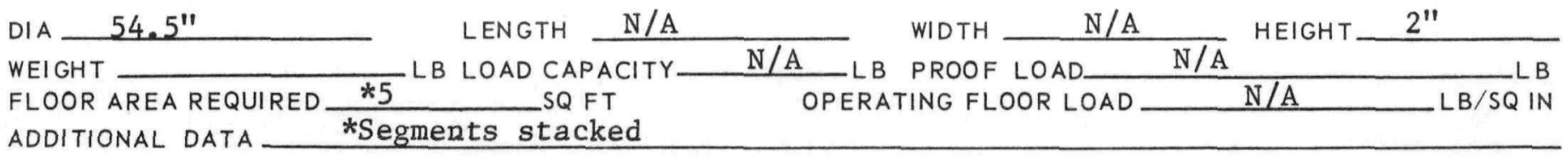

GASES_N/A PRESSURE

ELECTRICAL _ N/A

LIQUIDS

SPEED

MEASURING ACCURACY

$\mathrm{N} / \mathrm{A}$

N/A

CALIBRATION INTERVAL

ADDITIONAL DATA
PRESSURE IN./MIN (RPM)
LB/SQIN. VOLUME

CPS

LB/SQ IN

CUTTING SPEED

HORIZONTAL
CFM

PHASE

QTY REQ'D N/A

N/A

\section{Complete Assemblies}


(1) NERVA

LIPROGRAM

SUPPORT EQUIPMENT TECHNICAL DESCRIPTION HANDBOOK

EQUIPMENT TITLE

MODIFICATION KIT, NOZZLE THROAT CLOSURE PLUG
PROV. LIST

ITEM NO.

456

DATE

January 1968

REVISION

DESCRIPTION: The Nozzle Throat Closure Plug Modification Kit consists of an impact wrench, lifting bail, and weight to adapt the nozzle throat plug, P/L 453, for remote operation. The 100-pound weight is installed at the base of the plug to seat the plug as it is remotely installed in the nozzle with an overhead crane or manipulator. The impact wrench and lifting-bail assembly mates to the plug actuation-shaft to secure the plug in the nozzle throat.

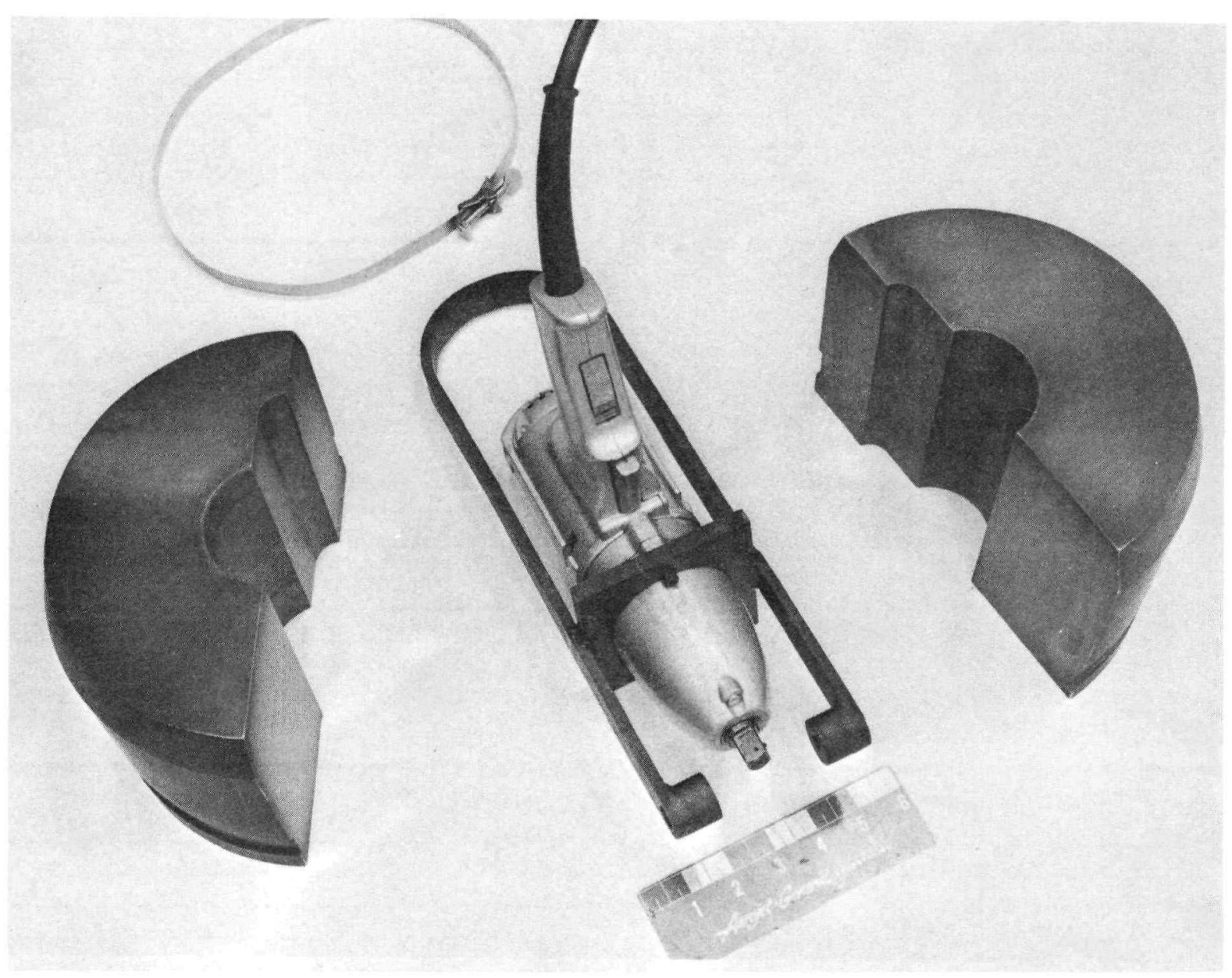


PROVISIONING LIST ITEM NUMBER DRAWING NUMBER

PART NUMBER CONTRACTOR
1115803

1115803-29

AGC
FIRST PROVISIONED FOR GOVT. INV. CONTROL NUMBER

$\cos T$ $\$ 2,397.00$
NRX/EST

\begin{tabular}{|c|}
\hline QTY REQ'D \\
\hline \\
\hline \\
\hline \\
\hline 1 \\
\hline 1 \\
\hline
\end{tabular}

\section{DIMENSIONS AND CAPACITY}

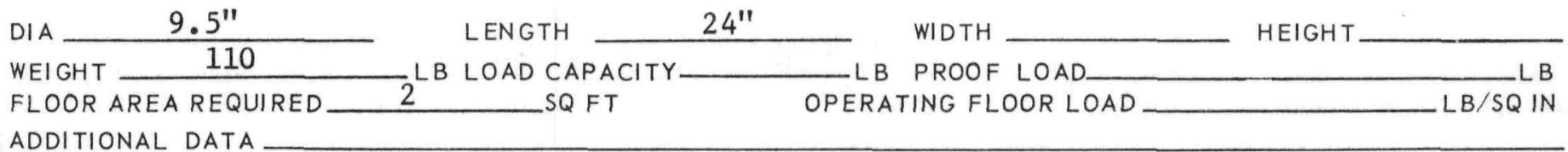

ADDITIONAL DATA

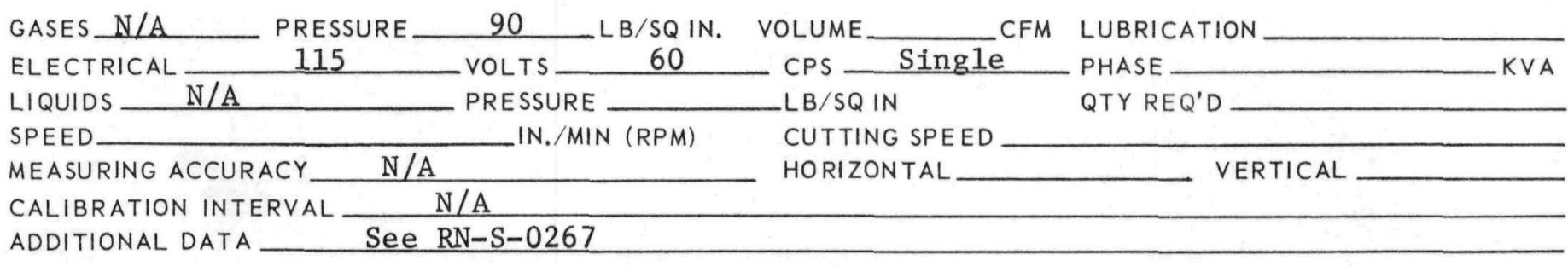




\section{(1) NERVA \\ LIPROGRAM \\ SUPPORT EQUIPMENT \\ TECHNICAL DESCRIPTION HANDBOOK}

EQUIPMENT TITLE

KIT, DIMENSIONAL CHECKING, ROCKET ENGINE

DESCRIPTION: The Rocket Engine Dimensional Checking Kit consists of gages and measuring devices to measure the critical dimensions of the nozzle, nozzle bolts, and forward-closure bolts of the NRX assembly. Included in the kit are (1) measuring devices adapted for use with the master slave manipulator in the remote areas; and (2) standard measuring devices which are used for making dimensional checks manually.
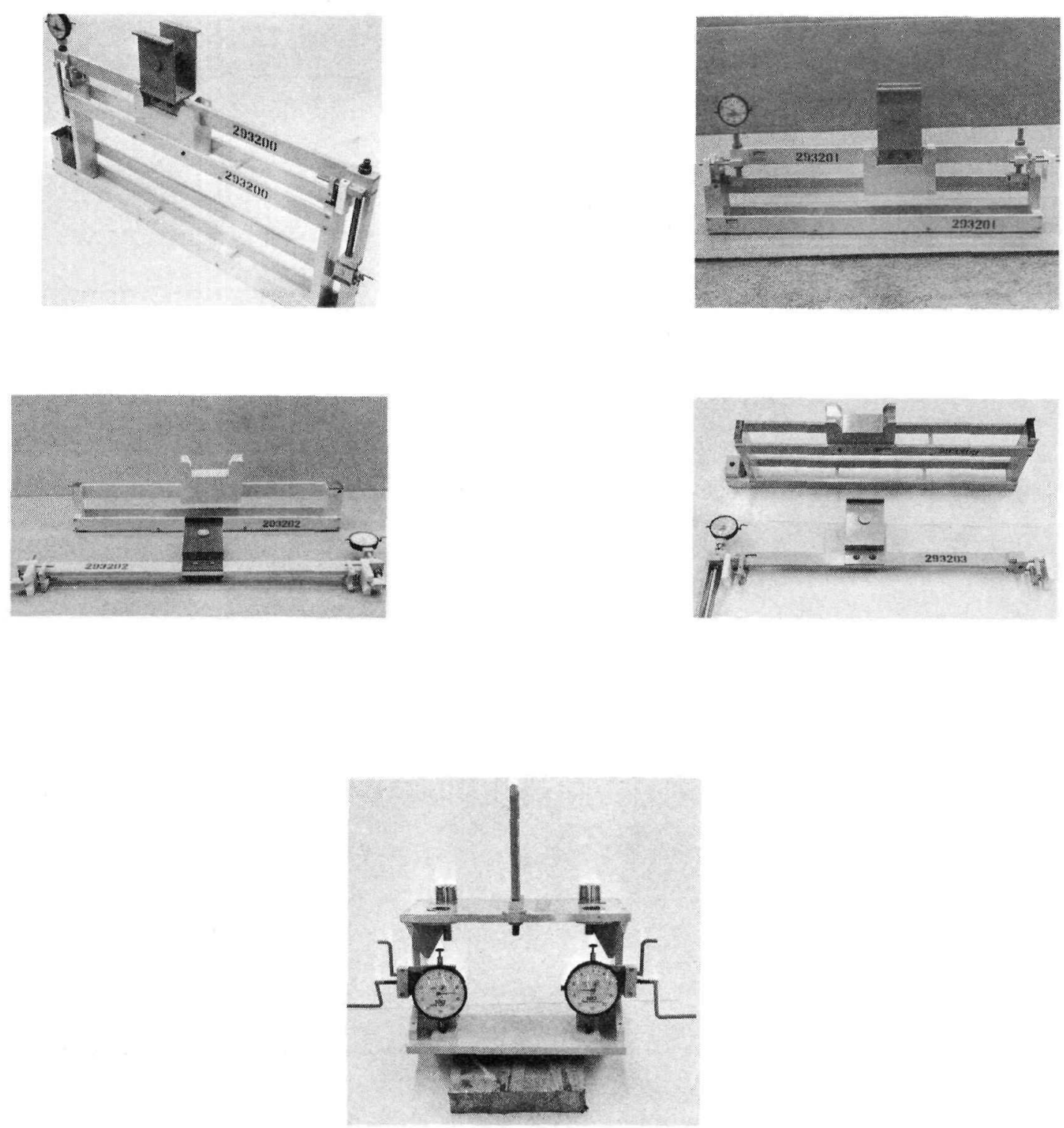


\section{TECHNICAL SUMMARY}

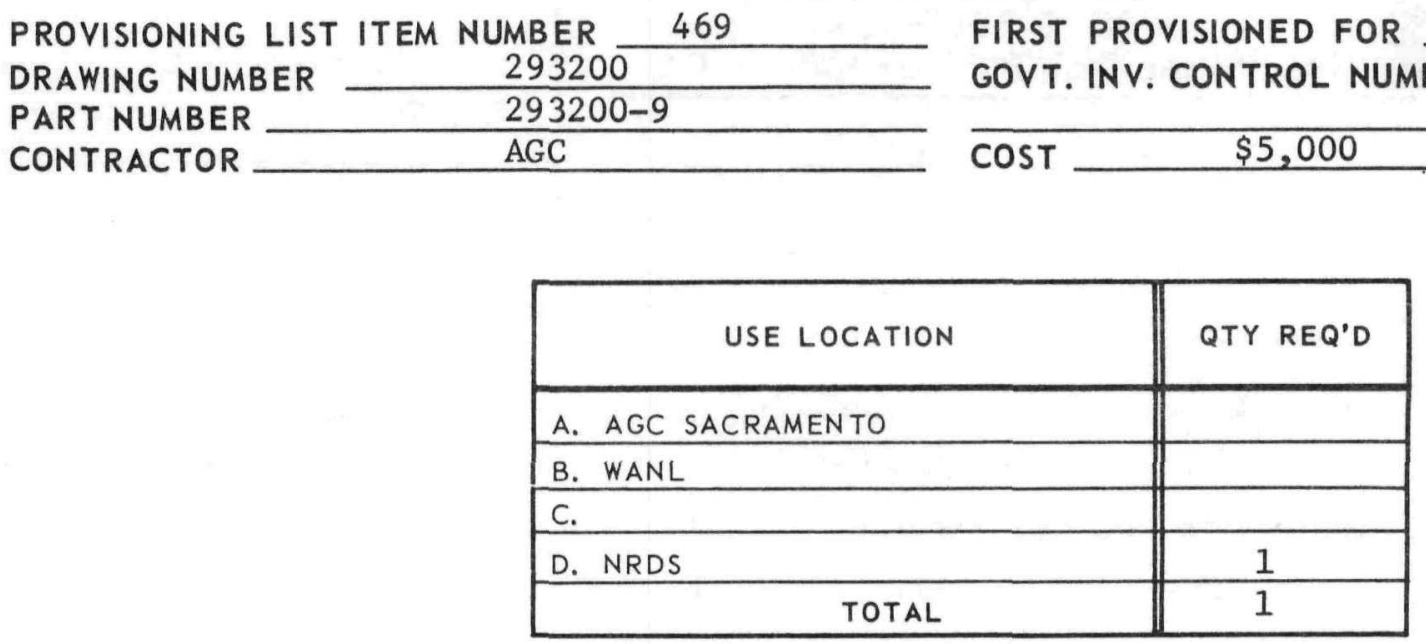

\section{DIMENSIONS AND CAPACITY}

DIA N/A

WEIGHT

FLOOR AREA REQUIRED

ADDITIONAL DATA
LENGTH LB LOAD CAPACITY $S Q F T$
WIDTH - LB PROOF LOAD OPERATING FLOOR LOAD
HEIGHT

LB

No size given for the items that comprise this kit. Kit is composed of standard "off-the-shelf" items, with specially made handles to adapt them to remote operation.

OPERATING DATA

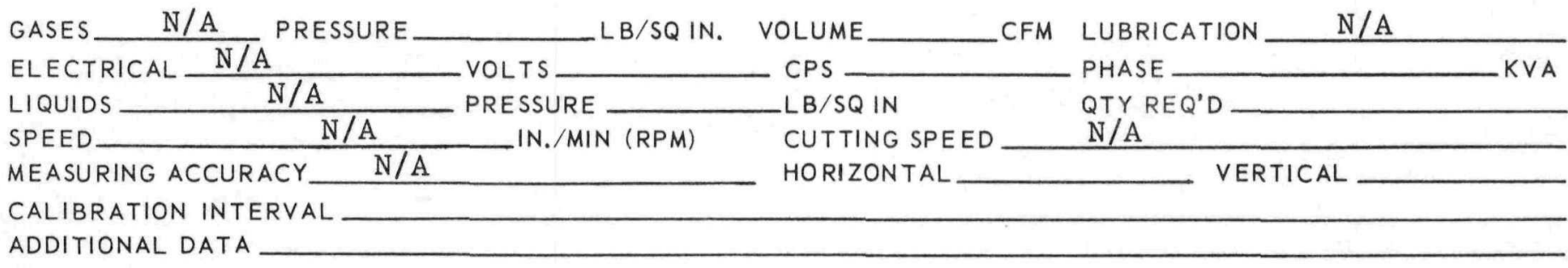

MANIPULATOR O-MAN, Sidewall \& Master/Slave LOAD CAPACITY CRANE—N/A LOAD CAPACITY $500,65,100 \& 10$ LB MAX LB MAX ADDITIONAL DATA

\section{INTERFACES}

EQUIPMENT_O-MAN \& Sidewall Manipulator PART OR ITEM NOZZle DRAWING NO. 284800-9 


\section{(1) NERVA \\ LIPROGRAM \\ SUPPORT EQUIPMENT TECHNICAL DESCRIPTION HANDBOOK}

EQUIPMENT TITLE

CLOSURE, REACTOR/PRESSURE VESSEL ASSEMBLY PRESSURE TEST
PROV. LIST

ITEM NO. 475

DATE

January 1968

REVISION

DESCRIPTION: The Reactor/Pressure Vessel Assembly Pressure Test Closure seals the nozzle end of the pressure vessel/reactor assembly during leak tests. When used with the nozzle guide plate, P/L 6173, it is utilized to ship the Reactor/Pressure Vesse1 Assemb1y from WANL to NRDS in the shipping container, P/L 1706. The closure, which is used for cold, manual operations only, is made of aluminum, and does not have a protective finish. The closure is provided with a wooden box which also contains 100 nozzle bolts, $100 \mathrm{~K}$-seals, three-eyebolts, and a three-legged wire-rope sling.

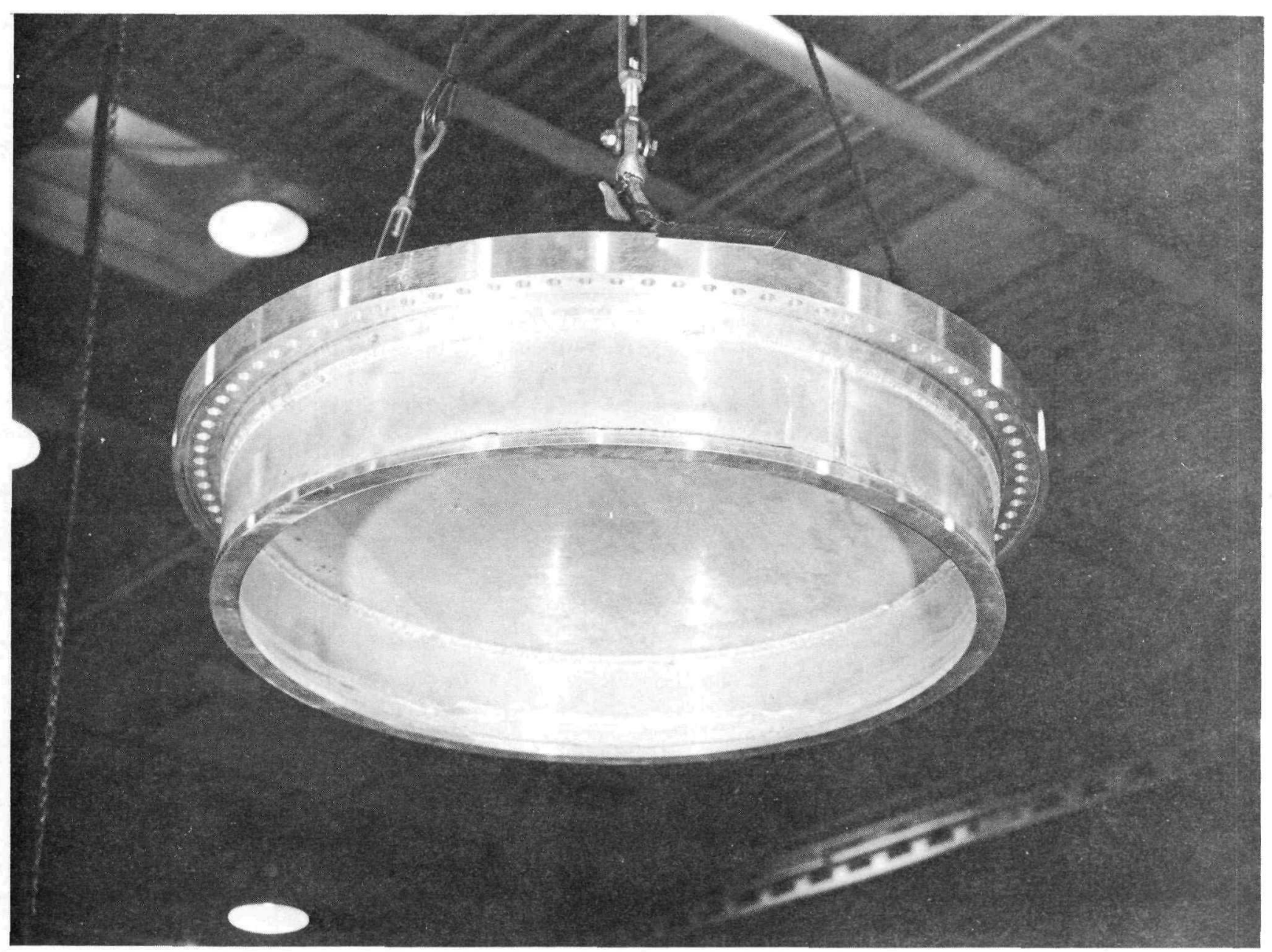


PROVISIONING LIST ITEM NUMBER $\quad 475$

DRAWING NUMBER 1114363

PART NUMBER

CONTRACTOR
1114363-9

AGC
FIRST PROVISIONED FOR NRX/EST GOVT. INV. CONTROL NUMBER

$\cos T$

\begin{tabular}{|c||c|}
\hline USE LOCATION & QTY REQ'D \\
\hline A. AGC SACRAMENTO & 2 \\
\hline B. WANL & \\
\hline C. & \\
\hline D. NRDS TOTAL & 2 \\
\hline
\end{tabular}

DIMENSIONS AND CAPACITY

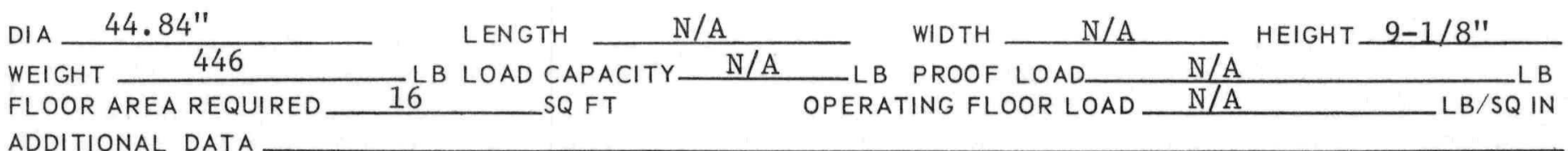

ADDITIONAL DATA

OPERATING DATA

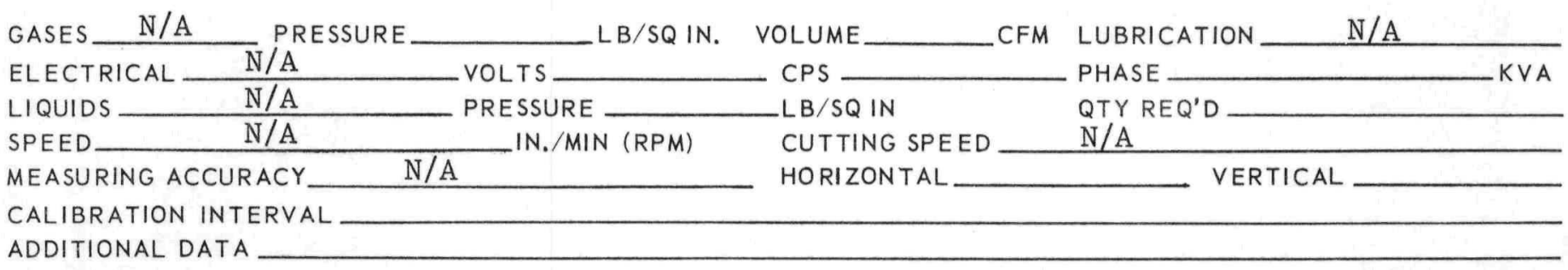

OPERATING EQUIPMENT

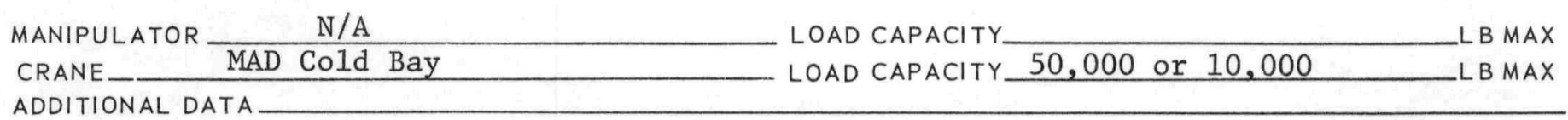

ADDITIONAL DATA

PART OR ITEM PRAWING NO.

REMARKS Reactor Shipping Ring Guide Plate 


\section{(1) NERVA \\ IIPROGRAM \\ SUPPORT EQUIPMENT \\ TECHNICAL DESCRIPTION HANDBOOK}

EQUIPMENT TITLE

STAND, TURBOPUMP, REMOTE
PROV. LIST

ITEM NO.

501

DATE

January 1968

REVISION

DESCRIPTION: The Remote Turbopump Stand supports the TPA during cold assembly, remote (hot) disassembly, and post-operative operations. The stand can be rotated $360^{\circ}$ around the longitudinal horizontal axis by a manipulator-operated gear reducer, which is self-locking at any rotation point. A bail is provided for lifting the stand with the TPA to permit rotation of the stand around its vertical axis.
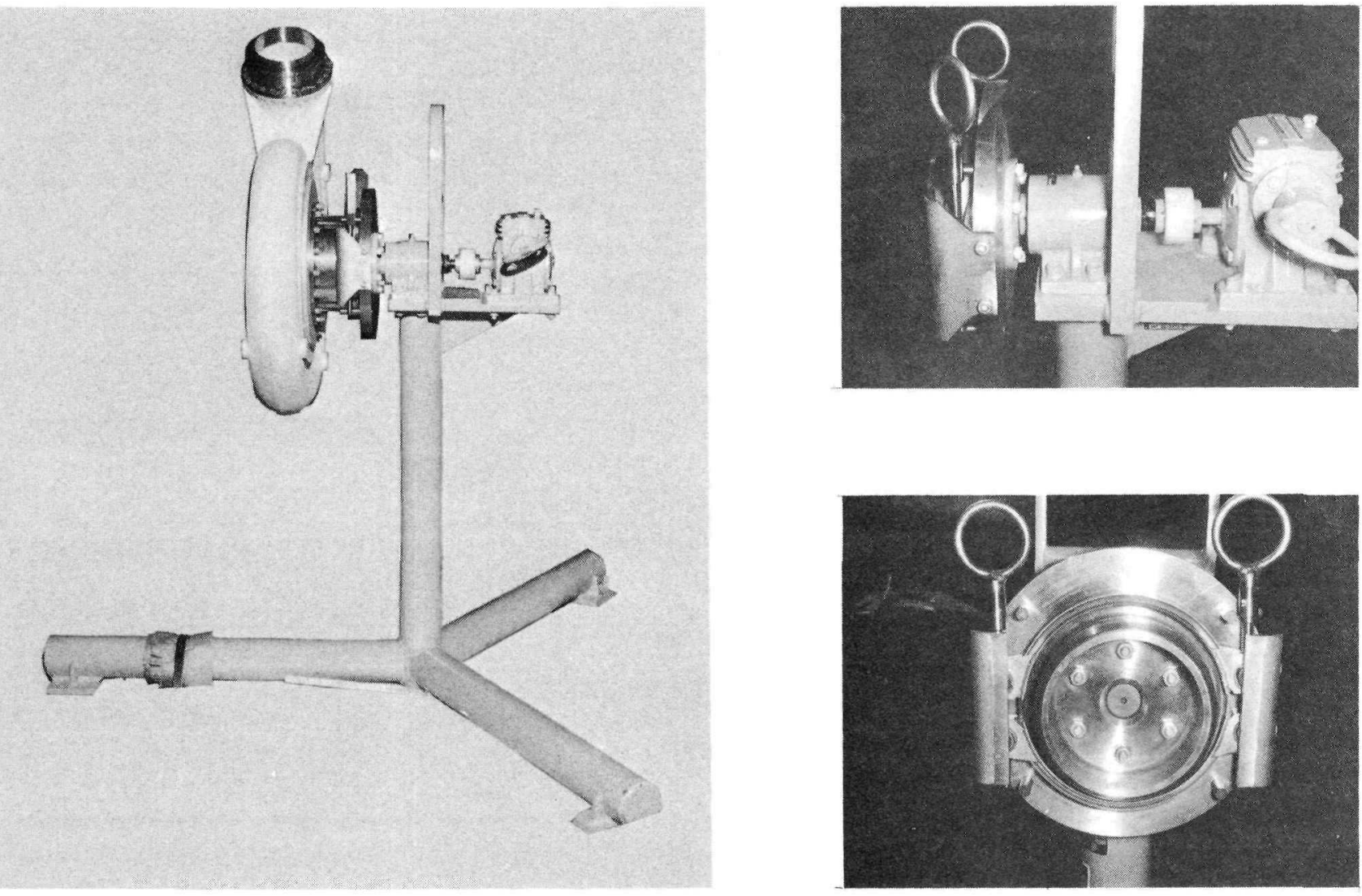


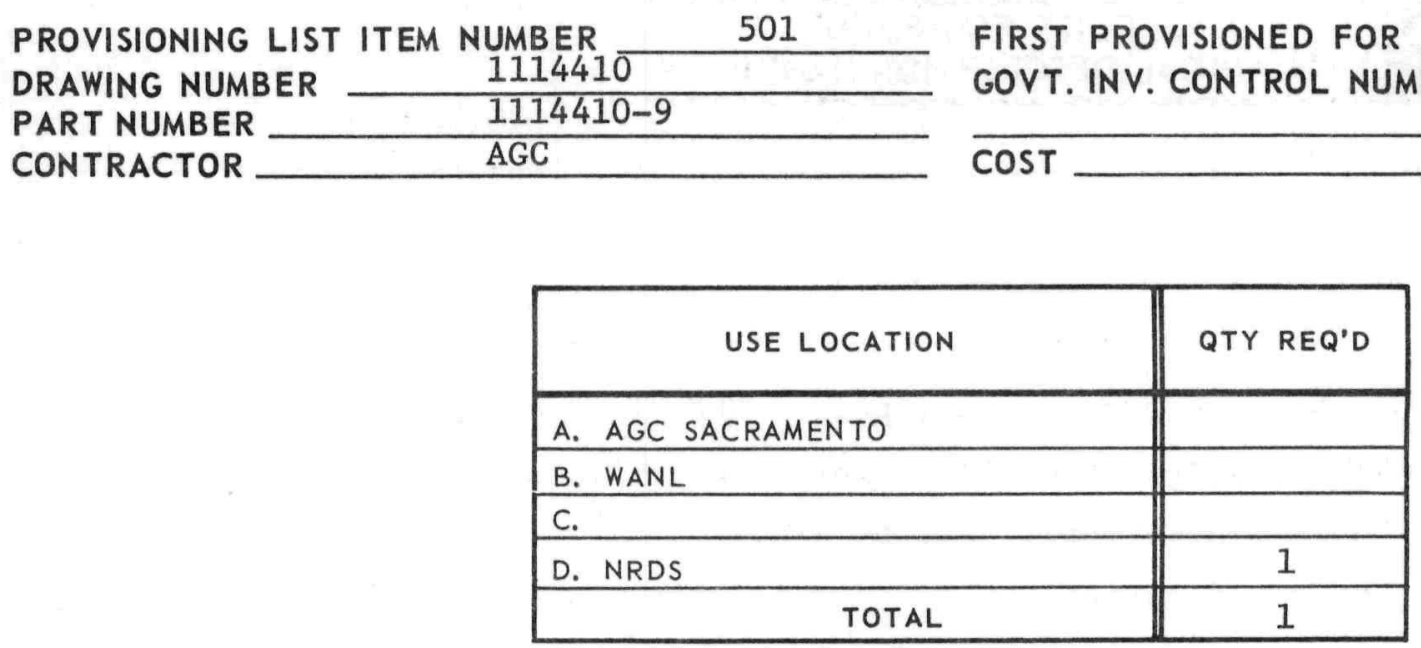

\section{DIMENSIONS AND CAPACITY}

DIA

WEIGHT

N/A

260

FLOOR AREA REQUIRED $\quad 15$

LENGTH

$42.75^{\prime \prime}$

LB LOAD CAPACITY

ADDITIONAL DATA *This includes weight of stand and TPA.
NRX/EST

RASA-SNP1-I-1215

\section{OPERATING DATA}

GASES N/A PRESSURE

ELECTRICAL N N/A

LIQUIDS

SPEED

MEASURING ACCURACY

$\mathrm{N} / \mathrm{A}$

$\mathrm{N} / \mathrm{A}$

$\mathrm{N} / \mathrm{A}$
N/A VOLTS

PRESSURE IN./MIN (RPM)

CALIBRATION INTERVAL $\mathrm{N} / \mathrm{A}$

ADDITIONAL DATA Stand is rotated by 0-Man in in the horizontal axis. See $\mathrm{RN}-\mathrm{S}-0227$
CFM LUBRICATION

PHASE

QTY REQ'D

$L B / S Q I N$

CUTTING SPEED

HORIZONTAL

VERTICAL
MANIPULATOR 0-Man and *Sidewall

CRANE R-MAD Facility

ADDITIONAL DATA *Not to be used fo
LOAD CAPACITY_ $500 \& 65$

LOAD CAPACITY 50000

LB MAX

LB MAX Operations only 


\section{(1) NERVA \\ LIPROGRAM \\ SUPPORT EQUIPMENT \\ TECHNICAL DESCRIPTION HANDBOOK}

EQUIPMENT TITLE

SLING, TPA, NRX/EST ASSEMBLY
PROV. LIST

ITEM NO.

502

DATE

January 1968

REVISION

DESCRIPTION: The NRX/EST Assembly TPA Sling is a beam type with an adjustment to compensate for variations in the TPA center-of-gravity. Sling legs and clamps can be adjusted approximately 5/8 of an inch along the beam for variations in location of the TPA pickup-point. The sling legs automatically engage two special pick-up lugs spaced $180^{\circ}$ apart on the TPA pump section. The turbine clamps have rubber cushioning on the pick-up surfaces. The clamp is opened or closed by a manipulator operated turnbuckle.
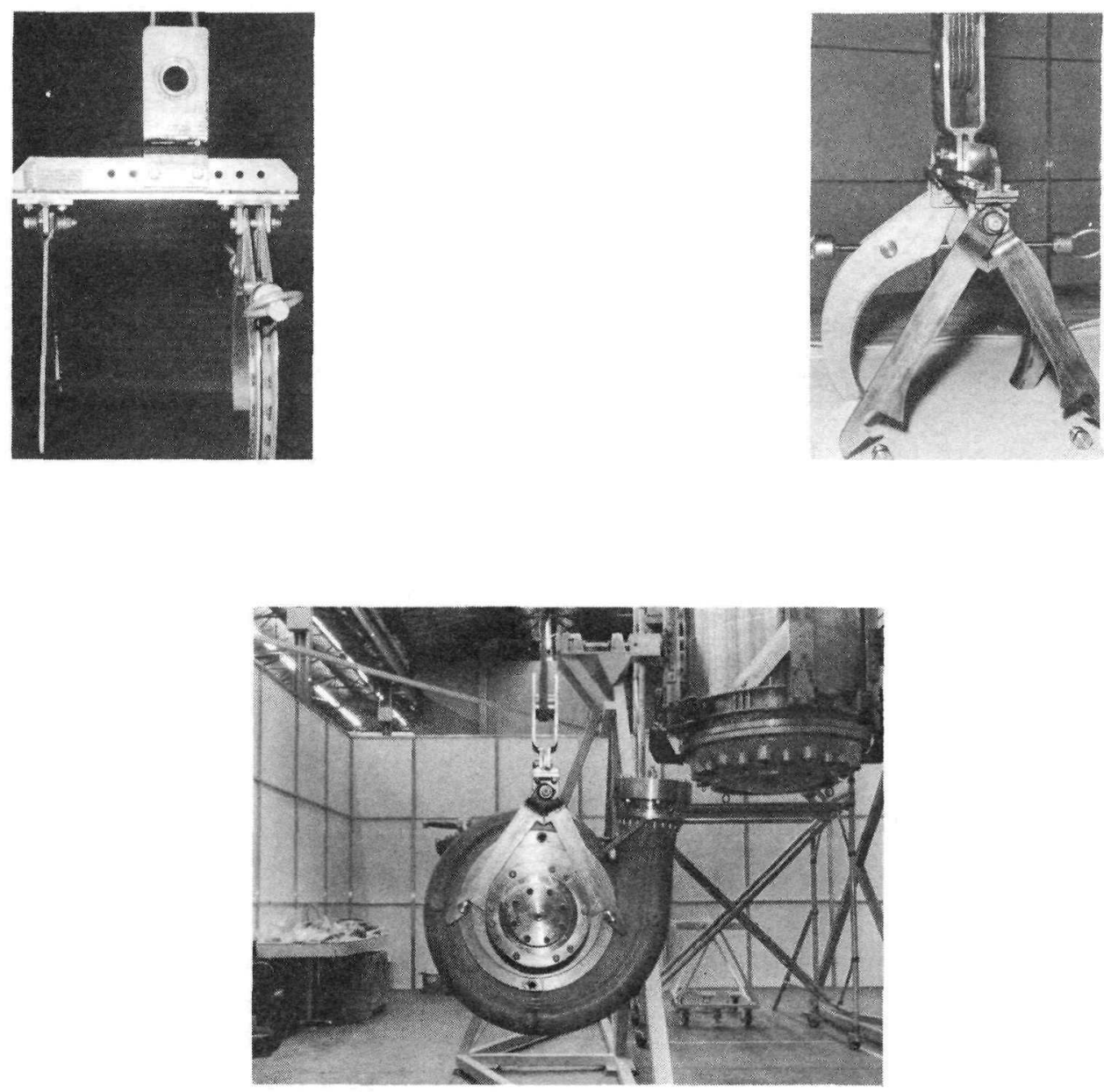
PROVISIONING LIST ITEM NUMBER

DRAWING NUMBER

PART NUMBER

CONTRACTOR
502

1114392

1114392-9

AGC
FIRST PROVISIONED FOR

NRX/EST

GOVT. INV. CONTROL NUMBER NASA-SNP1-L-1124

\begin{tabular}{|c||c|}
\hline \multicolumn{1}{|c||}{ USE LOCATION } & QTY REQ'D \\
\hline A. AGC SACRAMENTO & \\
\hline B. WANL & \\
\hline C. & \\
\hline D. NRDS TOTAL & 1 \\
\hline
\end{tabular}

DIMENSIONS AND CAPACITY

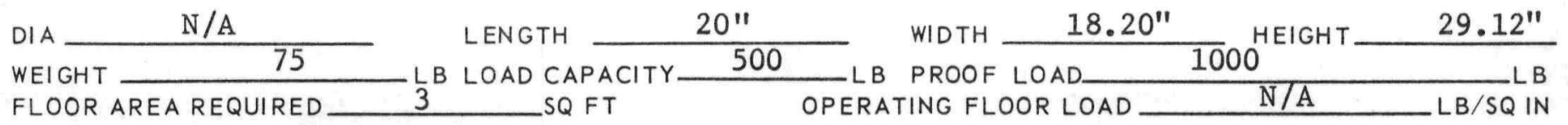

ADDITIONAL DATA

GASES N/A PRESSURE

ELECTRICAL_N N/A

LIQUIDS

SPEED

MEASURING ACCURACY

VOLTS

$\mathrm{N} / \mathrm{A}$ PRESSURE $\mathrm{N} / \mathrm{A}$
LB/SQIN. VOLUME

CPS

$L B / S Q I N$

CUTTING SPE

HORIZONTAL
CFM LUBRICATION

PHASE

QTY REQ'D

CALIBRATION INTERVAL

See RN-S-0223. Crane picks up sling, the sidewall manipulator operates turnbuckle (clamp) screw and assists in attaching the sling legs to the TPA lifting bolts.

\section{OPERATING EQUIPMENT}

MANIPULATOR * * * Sidewal1

CRANE R-MAD Facility LOAD CAPACITY LOAD CAPACITY *Not

\section{sed \\ for lifting the fixture, loaded or unloaded.}

EQUIPMENT_Crane, Sidewal1 Manipulator

PART OR ITEM TPA

REMARKS
DRAWING NO. 
PROVISIONING LIST ITEM NUMBER 503 DRAWING NUMBER

PART NUMBER

CONTRACTOR
$111 \overline{4652}$

1114652-9

AGC
FIRST PROVISIONED FOR NRX/EST GOVT. INV. CONTROL NUMBER NASA-SNP1-L-1123

$\cos T$

\begin{tabular}{|c||c|}
\hline \multicolumn{1}{|c||}{ USE LOCATION } & QTY REQ'D \\
\hline A. AGC SACRAMENTO & \\
\hline B. WANL & \\
\hline C. & \\
\hline D. NRDS TOTAL & 1 \\
\hline \multicolumn{2}{|c||}{1} \\
\hline
\end{tabular}

DIMENSIONS AND CAPACITY

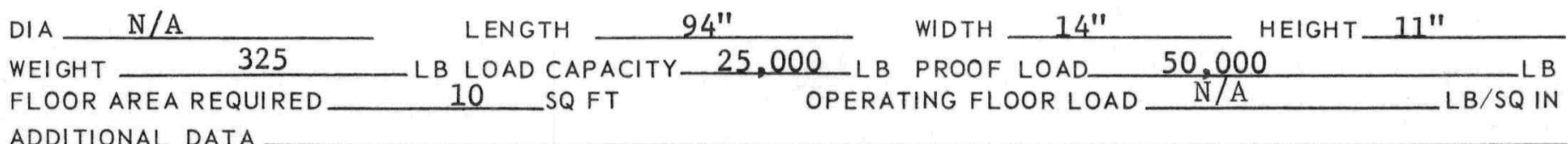

ADDITIONAL DATA

GASES_N/A PRESSURE

ELECTRICAL N N/A

LIQUIDS

SPEED

MEASURING ACCURACY

$\mathrm{N} / \mathrm{A}$ N/A
VOLTS

PRESSURE

IN./MIN (RPM)

CALIBRATION INTERVAL

ADDITIONAL DATA

LB/SQIN. VOLUME

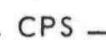

$L B / S Q I N$

CUTTING SPEED

HORIZONTAL N/A
CFM LUBRICATION

PHASE

QTY REQ'D

N/A

RIZONTAL — VERTICAL 


\section{N NERVA \\ LIPROGRAM \\ SUPPORT EQUIPMENT \\ TECHNICAL DESCRIPTION HANDBOOK}

EQUIPMENT TITLE

FIXTURES, HANDLING, PROPELLANT LINES, REMOTE

DESCRIPTION: Fixed and adjustable Remote Propellant Lines Handling Fixtures are used. While the two adjustable types are reusable, the fixed types are not. All are handled either by the 0-Man or sidewall manipulator. Drawings for the items comprising P/L 504 are listed below:
1115450 - Bail Clamp, Adjustable, 30 to 8-inch Pipe
1115030 - Sling, Double Hook
1115338 - Bail, Clamp, 3-1/2 inch OD Pipe
1115339 - Bail, Clamp, 1.9 inch OD Pipe
1115796 - Bail, Lifting Turbine Exhaust
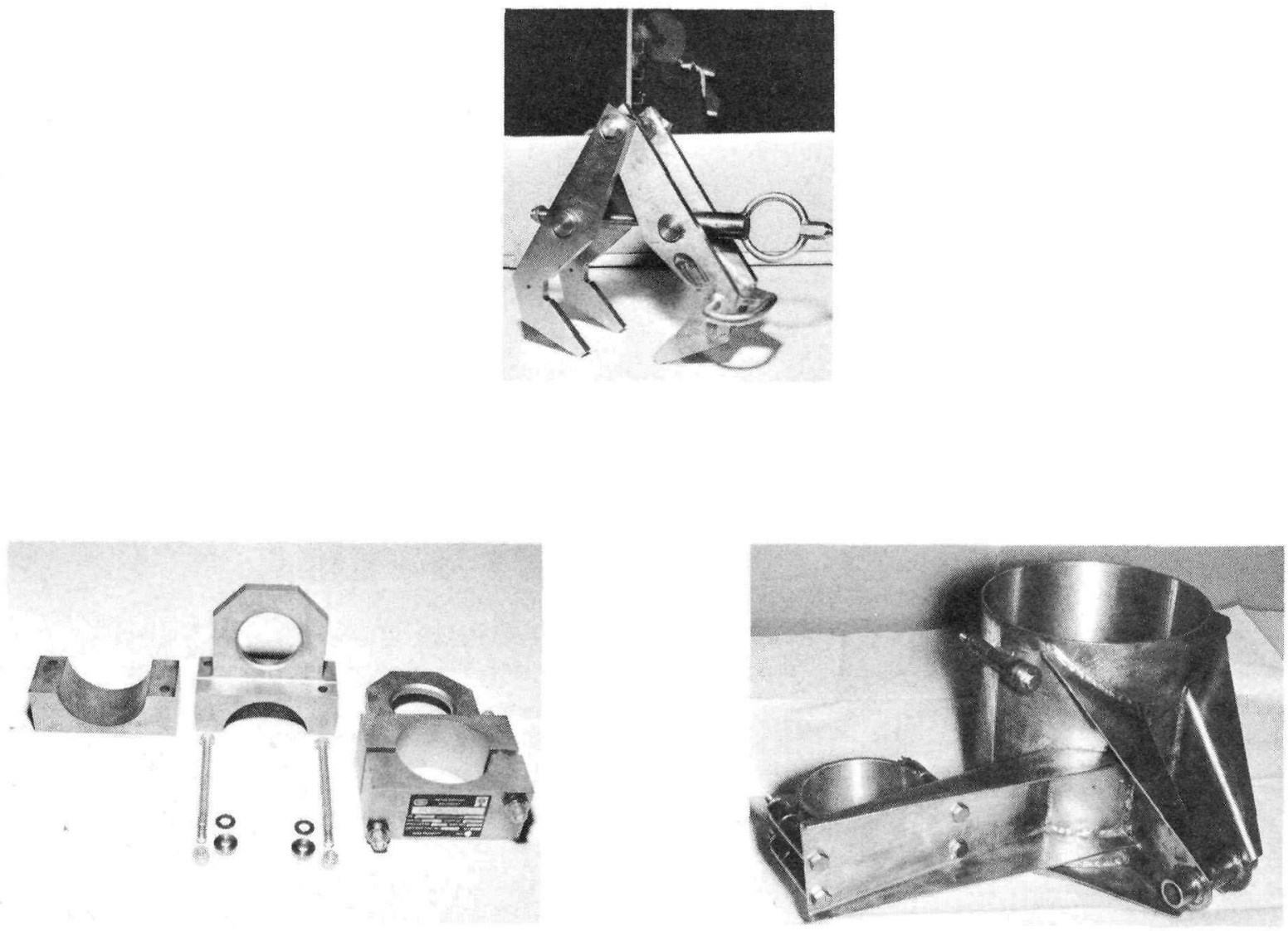


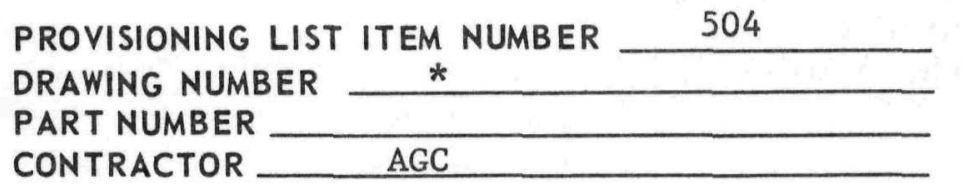

\begin{tabular}{l} 
FIRST PROVISIONED FOR $\frac{\text { NRX/EST }}{\text { GOVT. INV. CONTROL NUMBER }}$ \\
\hline COST $\$ 7500.00$ (est.)
\end{tabular}

\begin{tabular}{|l||c|}
\hline \multicolumn{1}{|c|}{ USE LOCATION } & QTY REQ'D \\
\hline A. AGC SACRAMENTO & \\
\hline B. WANL & \\
\hline C. & \\
\hline D. NRDS TOTAL & 1 \\
\hline \multicolumn{2}{|c|}{1} \\
\hline
\end{tabular}

\section{DIMENSIONS AND CAPACITY}

DIA $\frac{*}{\text { LENGTH }}$ LB LOAD CAPACITY
$\begin{aligned} & \text { WEIGHT } \\ & \text { FLOOR AREA REQUIRED }\end{aligned}$
ADDITIONAL DATA $\frac{\text { *See the drawings listed on the front of this sheet for the size of }}{\text { the items comprising this system. }}$

GASES_N/A PRESSURE ELECTRICAL N/A LIQUIDS N/A SPEED N/A MEASURING ACCURACY N/A CALIBRATION INTERVAL_N/A ADDITIONAL DATA VOLTS _ CPS $L B / S Q$ IN CUTTING SPEED N/A HORIZONTAL. IN./MIN (RPM)
CFM LUBRICATION

PHASE QTY REQ'D VERTICAL

\section{OPERATING EQUIPMENT}

MANIPULATOR O-MAN \& Sidewa11s

CRANE R-MAD Facility

ADDITIONAL DATA
LOAD CAPACITY_ $500 \& 65$

LOAD CAPACITY 50,000

LB MAX

LB MAX

\section{INTERFACES}

EQUIPMENT_Crane, 0-MAN \& Sidewa11 Manipulators, Lifting Fixture of Item 1251 PART OR ITEM NOZZle DRAWING NO. 1114263

REMARKS 


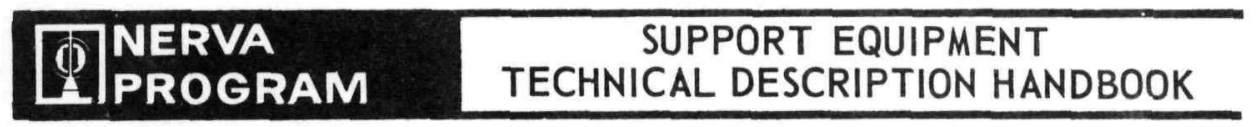

EQUIPMENT TITLE

STAND, DIRECT RADIATION SHIELD
PROV. LIST

ITEM NO.

505

DATE

January 1968

REVISION

A

DESCRIPTION: The Direct Radiation Shield Stand supports the shield during cold assembly or hot disassembly. The stand (either loaded or unloaded) is lifted by a crane utilizing $\mathrm{P} / \mathrm{L} 503$ with the direct radiation shield sling. The sling is hooked to the lifting eyes provided on the stand when unloaded. When loaded, the sling is hooked to lifting eyes on the direct radiation shield and the stand locked to the shield so both can be lifted together.
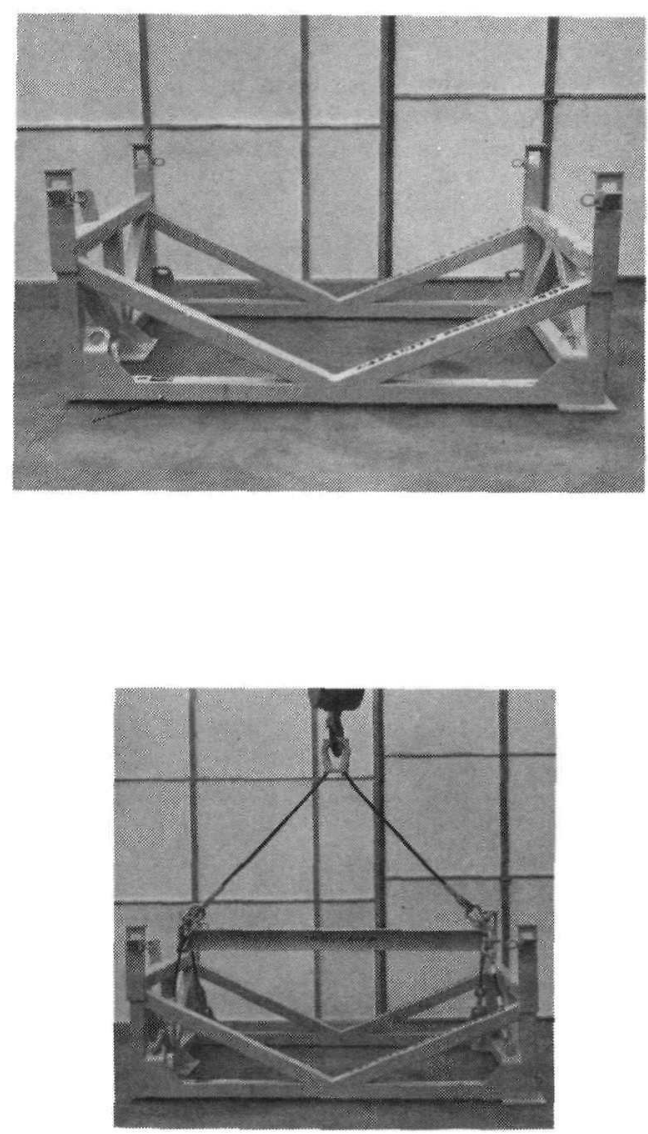


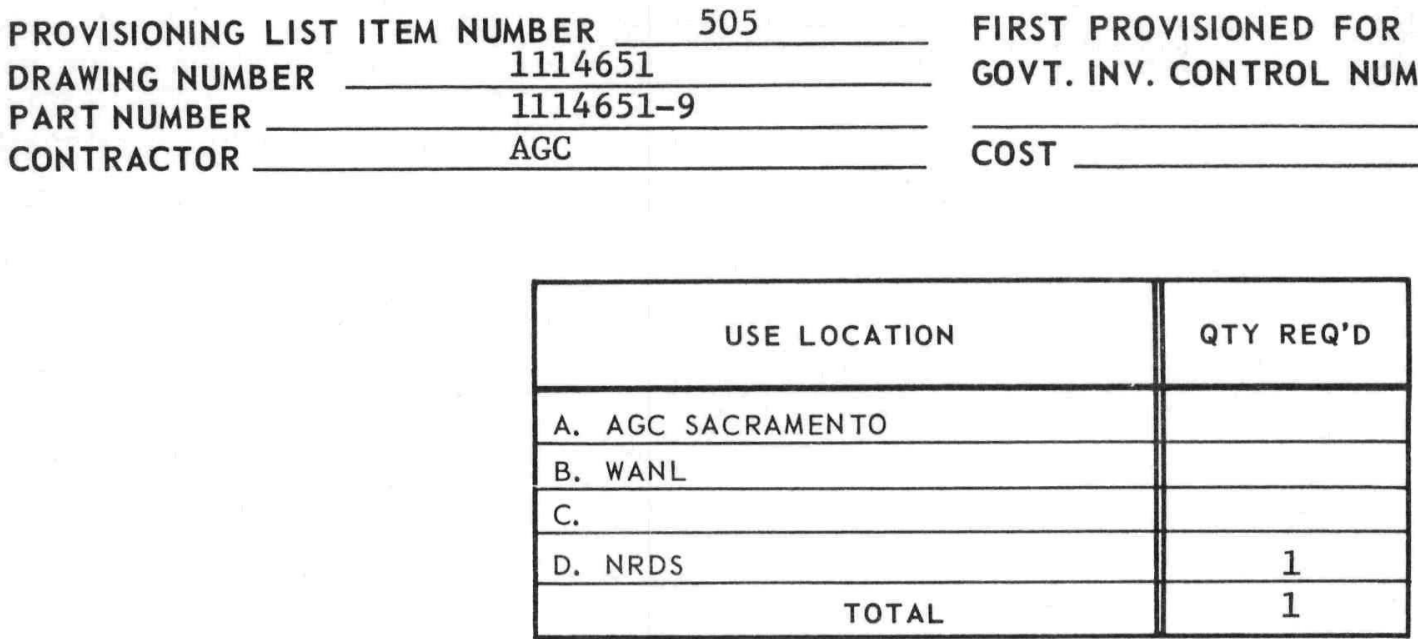

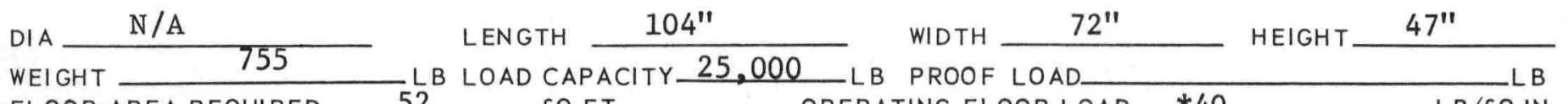
FLOOR AREA REQUIRED_ 52 SQ FT OPERATING FLOOR LOAD $\quad$ *40 LB/SQ IN ADDITIONAL DATA *Shield weight plus stand weight

GASES

ELECTRICAL

LIQUIDS

SPEED

MEASURING ACCURACY

CALIBRATION INTERVAL

ADDITIONAL DATA
PRESSURE VOLTS PRESSURE IN./MIN (RPM)
LB/SQIN. VOLUME CPS $L B / S Q I N$ CUTTING SPEED HORIZONTAL
CFM LUBRICATION

PHASE QTY REQ'D
NRX/EST

NASA-SNP1-L-1122
MANIPULATOR *O-MAN or *Sidewa11

CRANE R-MAD Facility

LOAD CAPACITY $500 \& 65$

LOAD CAPACITY 50,000

ADDITIONAL DATA *Not to be used for lifting, use for sling hook attachment only (remote operations)
LB MAX 


\begin{tabular}{l|l|c}
\hline CINERA & SUPPORT EQUIPMENT \\
PROGRAM & TECHNICAL DESCRIPTION HANDBOOK \\
\hline
\end{tabular}

EQUIPMENT TITLE

FIXTURE, HOLDING, TURBINE INLET LINE ELBOW, REMOTE
PROV. LIST

ITEM NO.

506

DATE

January 1968

REVISION

DESCRIPTION: The Turbine Inlet Line Elbow Holding Fixture consists of a lineclamping device attached (through two $90^{\circ}$-opposed gearboxes) to a tripod stand mounted on a rectangular base. The fixture is capable of rotating the turbine inlet line elbow in two planes as required to position it for post-operative cutting operations with abrasive-disc cutters. Rotational movements and line clamping action is manipulator-operated. The fixture also provides a lifting bail for movement within the hot areas with an overhead crane.

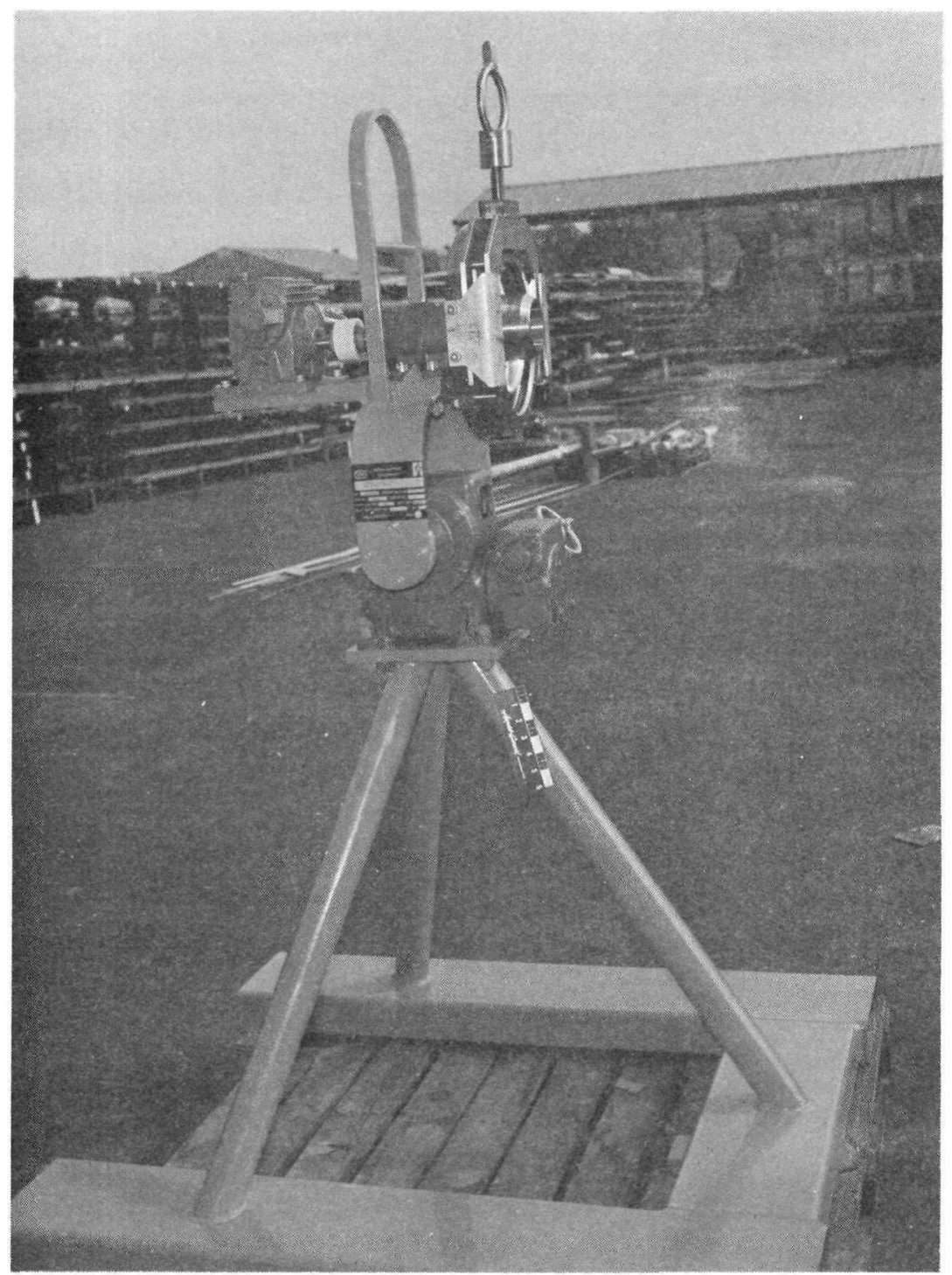


PROVISIONING LIST ITEM NUMBER 506

DRAWING NUMBER

115864

FIRST PROVISIONED FOR NRX/EST

PART NUMBER

1115864-9

CONTRACTOR AGC GOVT. INV. CONTROL NUMBER

$\cos T \_\$ 3,799.00$

\begin{tabular}{|l||c|}
\hline \multicolumn{1}{|c||}{ USE LOCATION } & QTY REQ'D \\
\hline A. AGC SACRAMENTO & \\
\hline B. WANL & \\
\hline C. & 1 \\
\hline D. NRDS TOTAL & 1 \\
\hline \multicolumn{2}{|c|}{} \\
\hline
\end{tabular}

\section{DIMENSIONS AND CAPACITY}

DIA

WEIGHT 414

LENGTH 44" LB LOAD CAPACITY LLOR AREA REQUIRED 12.5 SQ FT ADDITIONAL DATA
WIDTH $40^{\prime \prime}$ LB PROOF LOAD OPERATING FLOOR LOAD HEIGHT $65^{\prime \prime}$
GASES N/A ELECTRICAL LIQUIDS SPEED. MEASURING ACCURACY $\mathrm{N} / \mathrm{A}$ N/A $\mathrm{N} / \mathrm{A}$ CALIBRATION INTERVAL ADDITIONAL DATA See RN-S-0262 $\mathrm{N} / \mathrm{A}$
LB/SQIN. VOLUME VOLTS PRESSURE IN./MIN (RPM)
CPS

$L B / S Q$ IN

CUTTING SPEED HORIZONTAL
CFM

\section{PHASE}

QTY REQ'D
LB

$L B / S Q I N$

ADDITIONAL DATA SEe RN-S-0262

\section{OPERATING EQUIPMENT}

MANIPULATOR O-MAN or Sidewa11 


\section{(1) NERVA \\ LIPROGRAM \\ SUPPORT EQUIPMENT \\ TECHNICAL DESCRIPTION HANDBOOK}

EQUIPMENT TITLE

CONTAINER, SHIPPING AND STORAGE, ROCKET ENGINE NOZZLE
PROV. LIST

ITEM NO.

704

DATE

\begin{tabular}{lc}
\hline & January \\
\hline REVISION & C
\end{tabular}

DESCRIPTION: The Rocket Engine Nozzle Shipping and Storage Container is a reusable container designed to provide a means of transporting an engine nozzle from the manufacturing facility to the engine test site. The container also provides temporary storage for the nozzle. The primary functions of this container are to provide environmental protection and storage, safety, and efficiency during transportation and handling, and a means of securing the nozzle against unauthorized observation in accordance with security regulations.

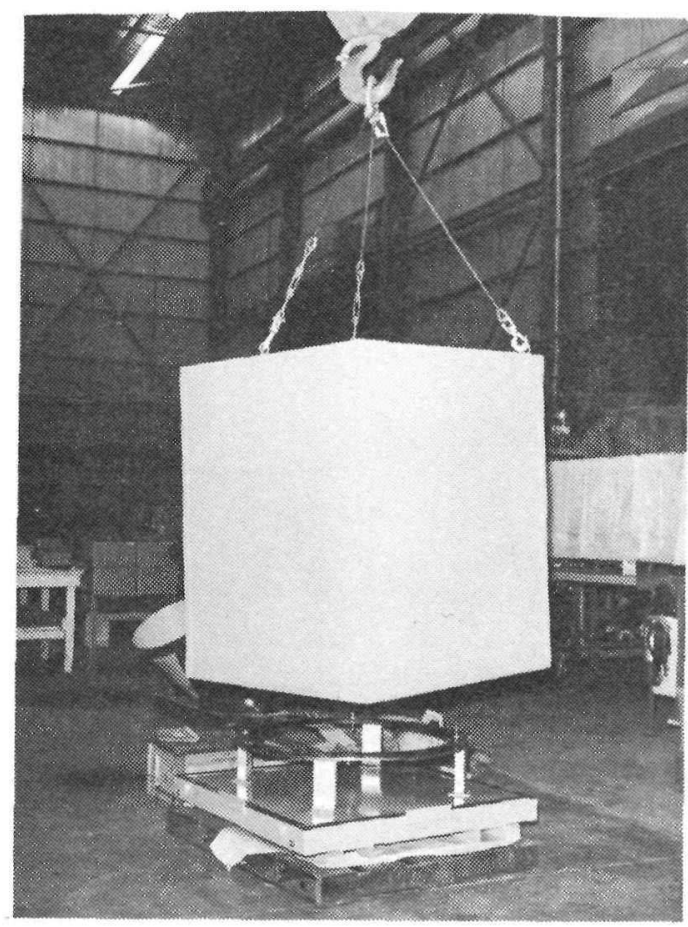


PROVISIONING LIST ITEM NUMBER 704 DRAWING NUMBER

PART NUMBER 278500

CONTRACTOR
278500-29

AGC
FIRST PROVISIONED FOR NRX-AI GOVT. INV. CONTROL NUMBER NASA-SNP1-L-553 $\& 554$

\begin{tabular}{|l||c|}
\hline \multicolumn{1}{|c||}{ USE LOCATION } & QTY REQ'D \\
\hline A. AGC SACRAMENTO & 1 \\
\hline B. WANL & \\
\hline C. & 1 \\
\hline D. NRDS TOTAL & 2 \\
\hline \multicolumn{2}{|c||}{} \\
\hline
\end{tabular}

\section{DIMENSIONS AND CAPACITY}

DIA N/A

WEIGHT 375 (empty)

FLOOR AREA REQUIRED Cover of crane. Containe

LENGTH 53-1/2"

WIDTH

$53-1 / 2^{\prime \prime}$ OPERATING FLOOR LOAD

N/A

HEIGHT_ 73" is provided with lifting eyes for use with sling and

\section{OPERATING DATA}

GASES N/A PRESSURE

ELECTRICAL_ N N $/ A$

LIQUIDS N/A

SPEED

MEASURING ACCURACY

CALIBRATION INTERVAL

ADDITIONAL DATA

$\mathrm{N} / \mathrm{A}$

$\mathrm{N} / \mathrm{A}$ $\mathrm{N} / \mathrm{A}$ N/A VOLTS PRESSURE IN./MIN (RPM) Operation and Maintenance instruction available, no number given other than $\mathrm{P} / \mathrm{N}$.
$L B / S Q I N$. VOLUME

\section{CPS}

$L B / S Q I N$

CUTTING SPE

HORIZONTAL
CFM LUBRICATION

PHASE

QTY REQ'D

VERTICAL

\section{OPERATING EQUIPMENT}

MANIPULATOR N/A

CRANE MAD Facility (Auxiliary Hook)

ADDITIONAL DATA
LOAD CAPACITY

LOAD CAPACITY

$\mathrm{N} / \mathrm{A}$

10,000

LB MAX LB MAX 
PROV. LIST

ITEM NO.

730

DATE TECHNICAL DESCRIPTION HANDBOOK

EQUIPMENT TITLE

FIXTURE, ALIGNMENT COOLANT MANIFOLD

DESCRIPTION: The Coolant Manifold Alignment Fixture consists of a 1.5-inch-diameter tube, bent into an arc of $140^{\circ}$ with a radius of 22 inches and provided with a support and handling frame. It is used during NRX assembly to assure proper alignment of the coolant manifold brackets while tightening the pressure vessel to the nozzle. 
PROVISIONING LIST ITEM NUMBER DRAWING NUMBER

PART NUMBER CONTRACTOR
730 278509

AGC
FIRST PROVISIONED FOR NRX-A2 GOVT. INV. CONTROL NUMBER SNP-1-L-661

\begin{tabular}{|r||c|}
\hline \multicolumn{1}{|c||}{ USE LOCATION } & QTY REQ'D \\
\hline A. AGC SACRAMENTO & \\
\hline B. WANL & \\
\hline C. & 1 \\
\hline D. NRDS TOTAL & 1 \\
\hline
\end{tabular}

\section{DIMENSIONS AND CAPACITY}

DIA

WEIGHT FLOOR AREA REQUIRED

ADDITIONAL DATA
LENGTH LB LOAD CAPACITY SQ FT $47^{\prime \prime}$ N/A LB PROOF LOAD OPERATING FLOOR LOAD
HEIGHT $1.5^{\prime \prime}$
$\mathrm{N} / \mathrm{A}$
GASES N/A PRESSURE

ELECTRICAL N/A

LIQUIDS

SPEED

MEASURING ACCURACY

CALIBRATION INTERVAL N/A

ADDITIONAL DATA
N/A $\mathrm{N} / \mathrm{A}$
VOLTS

PRESSURE IN./MIN (RPM)
LB/SQIN. VOLUME

CPS

$L B / S Q$ IN

CUTTING SPEED

HORIZONTAL
CFM LUBRICATION

PHASE

QTY REQ'D 


\section{(1) NERVA \\ LIPROGRAM \\ SUPPORT EQUIPMENT TECHNICAL DESCRIPTION HANDBOOK}

EQUIPMENT TITLE

SLING, MULTIPLE LEG, MULTIPLE PURPOSE, 3000 LB CAPACITY
PROV. LIST

ITEM NO. 801

DATE

REVISION

January 1968

A

DESCRIPTION: The Multiple Purpose Multiple Leg Sling is a three-legged wire rope sling with safety hooks. The three legs are joined together through a pear-shaped lifting link. Two of the three legs are provided with turnbuckles for leveling. The sling lifts various components, including the nozzle and forward closure, during assembly operations when used in conjunction with other support equipment.

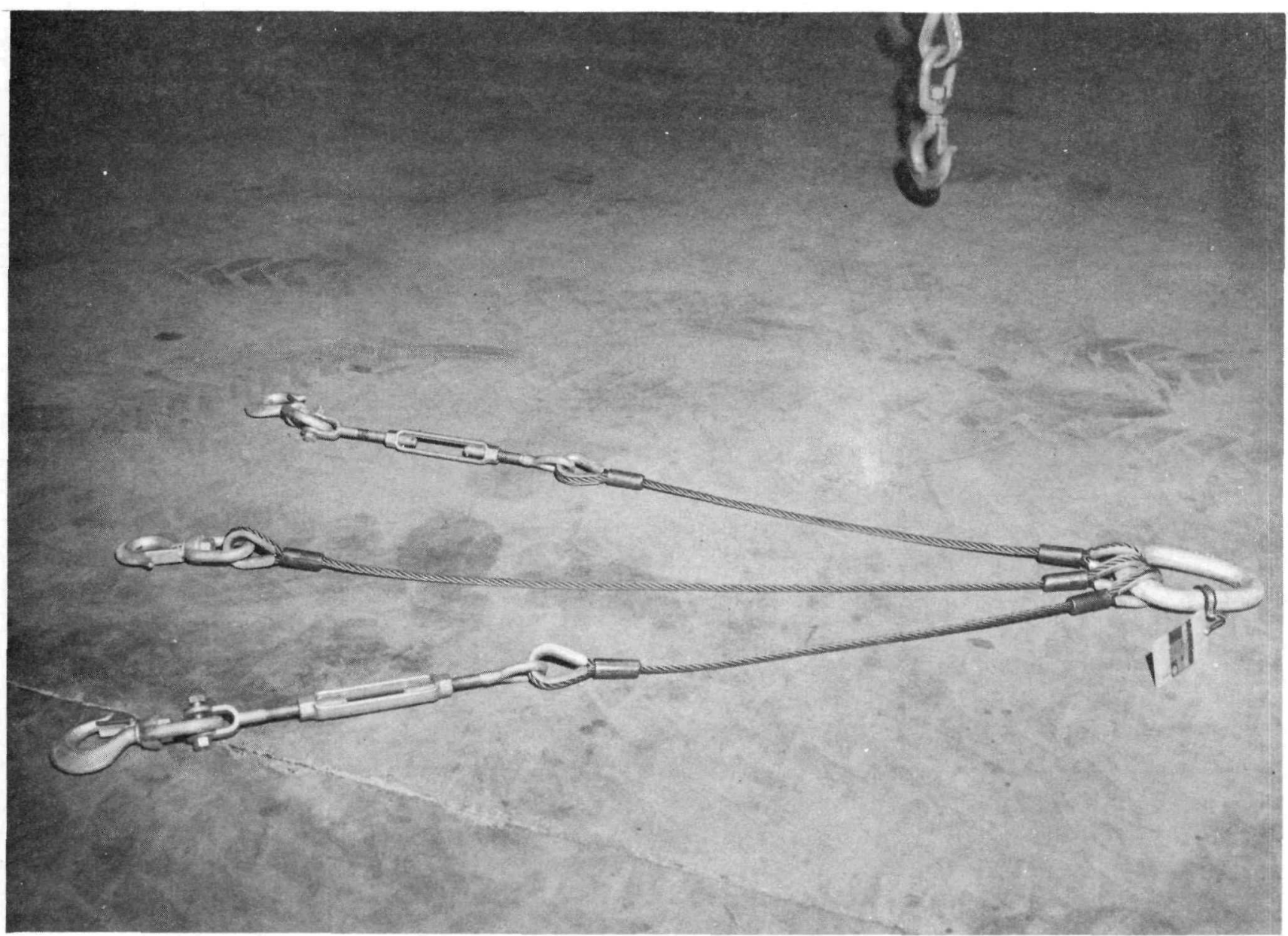


PROVISIONING LIST ITEM NUMBER

DRAWING NUMBER

PART NUMBER

CONTRACTOR 278580

278580-9

801 AGC
FIRST PROVISIONED FOR $\mathrm{NRX}-\mathrm{A} 1$ GOVT. INV. CONTROL NUMBER NASA-SNP I-L-557 THRU 561 (INCL.) $\cos T$

\begin{tabular}{|l||c|}
\hline \multicolumn{1}{|c||}{ USE LOCATION } & QTY REQ'D \\
\hline A. AGC SACRAMENTO & 3 \\
\hline B. WANL & \\
\hline C. & 2 \\
\hline D. NRDS TOTAL & 5 \\
\hline
\end{tabular}

\section{DIMENSIONS AND CAPACITY}

DIA

WEIGHT

FLOOR AREA REQUIRED

ADDITIONAL DATA
LENGTH 25" WIDTH

$25^{\prime \prime}$ LB LOAD CAPACITY 3.000 LB PROOF LOAD 6 OPERATING FLOOR LOAD N N/A HEIGHT $63^{\prime \prime}$

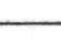

GASES N/A

ELECTRICAL

LIQUIDS

SPEED

MEASURING ACCURACY

PRESSURE $\mathrm{N} / \mathrm{A}$ $\mathrm{N} / \mathrm{A}$ $\mathrm{N} / \mathrm{A}$ VOLTS PRESSURE IN./MIN (RPM)

CALIBRATION INTERVAL

ADDITIONAL DATA N/A LB/SQIN. VOLUME

\section{CPS}

LB/SQ IN

CUTTING SPEED HORIZONTAL
CFM

LUBRICATION

PHASE KVA
VERTICAL

\section{OPERATING EQUIPMENT}




\section{(1) NERVA \\ LIIPROGRAM \\ SUPPORT EQUIPMENT \\ TECHNICAL DESCRIPTION HANDBOOK}

EQUIPMENT TITLE

FIXTURE, LIFTING, ROCKET ENGINE FORWARD CLOSURE
PROV. LIST

ITEM NO.

803

DATE

January 1968
REVISION

DESCRIPTION: The Rocket Engine Forward Closure Lifting Fixture consists of

a 0.625 -inch-thick steel ring which bolts to the forward closure with 12 bolts. The ring provides three eyes for lifting with a three-legged sling and overhead crane.

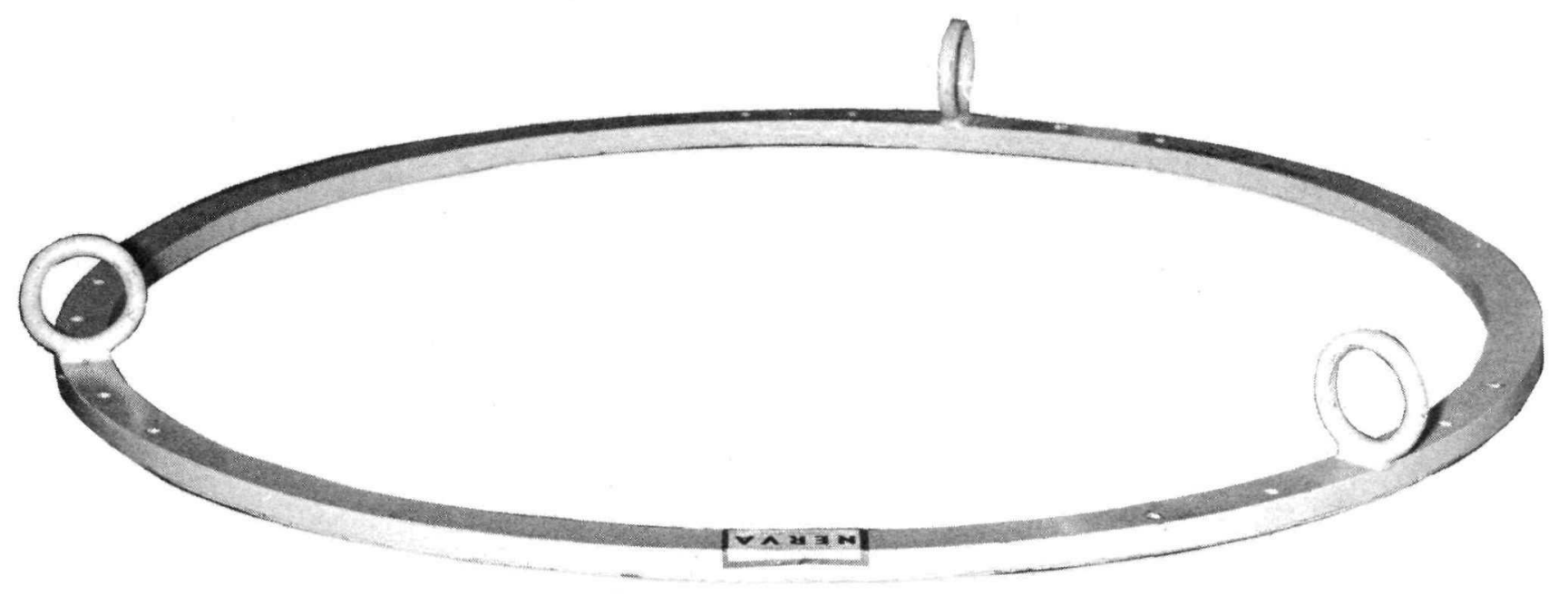


TECHNICAL SUMMARY

PROVISIONING LIST ITEM NUMBER

DRAWING NUMBER

PART NUMBER

CONTRACTOR
803

279150

279150-9

AGC
FIRST PROVISIONED FOR NRX-AI GOVT. INV. CONTROL NUMBER

NASA-SNP1-L-562, 563, 564 $\cos T+\$ 600.00$

\begin{tabular}{|l||c|}
\hline \multicolumn{1}{|c||}{ USE LOCATION } & QTY REQ'D \\
\hline A. AGC SACRAMENTO & 2 \\
\hline B. WANL & \\
\hline C. & 1 \\
\hline D. NRDS TOTAL & 3 \\
\hline
\end{tabular}

DIMENSIONS AND CAPACITY

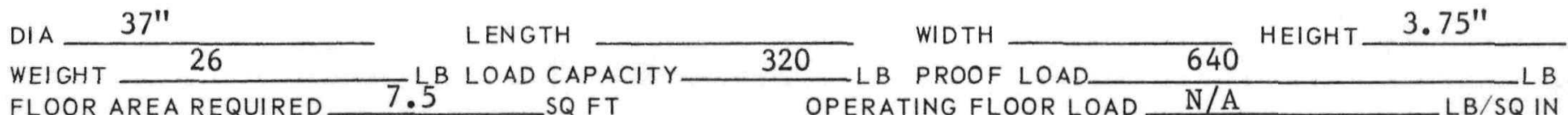

$\begin{array}{lll}\text { FLOOR AREA REQUIRED } 1.5 & \text { SQ FT OPERATING FLOOR LOAD N N A } \\ \text { ADDITIONAL DATA } & \end{array}$

OPERATING DATA

GASES N/A ELECTRICAL N N N $/ A$

LIQUIDS

SPEED

MEASURING ACCURACY

CALIBRATION INTERVAL

PRESSURE

$\mathrm{N} / \mathrm{A}$

$\mathrm{N} / \mathrm{A}$ $\mathrm{N} / \mathrm{A}$ $\mathrm{N} / \mathrm{A}$ VOLTS

PRESSURE IN./MIN (RPM)

ADDITIONAL DATA See Operating
LB/SQIN. VOLUME

CPS

$L B / S Q I N$

CUTTING SPEED

HORIZONTAL
CFM LUBRICATION

PHASE

QTY REQ'D
MANIPULATOR

CRANE

ADDITIONAL DATA
LOAD CAPACITY

LOAD CAPACITY
LB MAX

LB MAX

EQUIPMENT_ P.L. Item 801 (Three Legged Sling)

PART OR ITEM Forward Closure DRAWING NO. 283095

REMARKS 


\begin{tabular}{|c|c|}
\hline \begin{tabular}{l|l} 
(1) NERVA \\
PROGRAM
\end{tabular} & $\begin{array}{c}\text { SUPPORT EQUIPMENT } \\
\text { TECHNICAL DESCRIPTION HANDBOOK }\end{array}$ \\
\hline
\end{tabular}

EQUIPMENT TITLE

SLING, BEAM TYPE
PROV. LIST

ITEM NO.

809

DATE

January 1968

B

DESCRIPTION: The Beam Type Sling is a lifting device with a box-beam main structure. It is provided with a movable lifting-eye to compensate for any shift in center of gravity. Eyes are also used to attach lifting legs (4 cables) to each end. The sling lifts, positions, and lowers the NRX non-nuclear assembly and/or pressure vessel in a horizontal position during assembly, disassembly, and other moving operations.

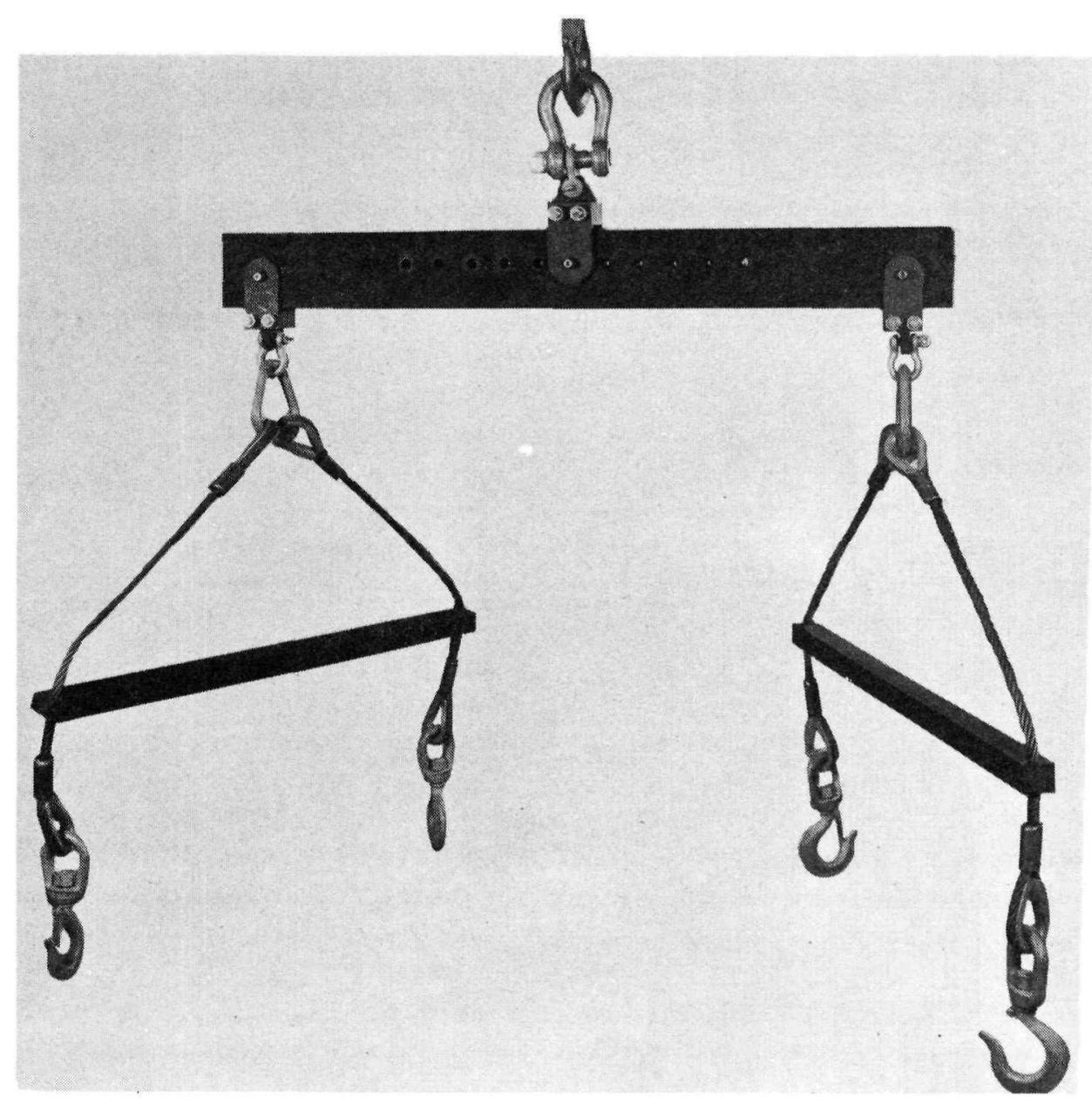


PROVISIONING LIST ITEM NUMBER DRAWING NUMBER

PART NUMBER CONTRACTOR
809 278570 $278570-$ AGC
FIRST PROVISIONED FOR GOVT. INV. CONTROL NUMBER NASA-SNP1-L-565, $\cos T$

\section{6}

\begin{tabular}{|l||c|}
\hline \multicolumn{1}{|c||}{ USE LOCATION } & QTY REQ'D \\
\hline A. AGC SACRAMENTO & 1 \\
\hline B. WANL & \\
\hline C. & 1 \\
\hline D. NRDS TOTAL & 2 \\
\hline
\end{tabular}

\section{DIMENSIONS AND CAPACITY}

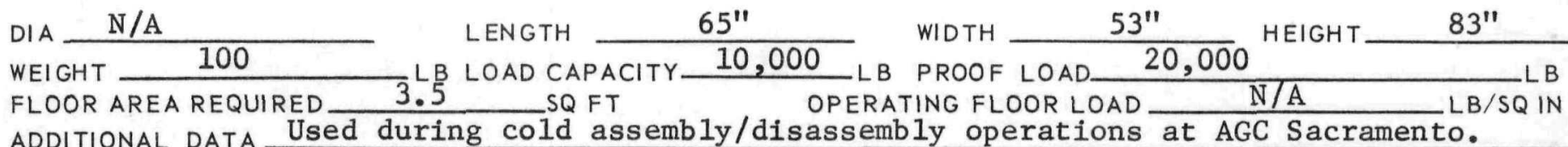

GASES N N/A PRESSURE

ELECTRICAL N/A

LIQUIDS

SPEED

MEASURING ACCURACY $\mathrm{N} / \mathrm{A}$ $\mathrm{N} / \mathrm{A}$ N/A VOLTS LB/SQ IN. VOLUME PRESSURE IN./MIN (RPM)

CALIBRATION INTERVAL

ADDITIONAL DATA

Operating Instructions N-809

\section{CPS}

$L B / S Q$ IN

CUTTING SPEED N/A

HORIZONTAL
CFM LUBRICATION N/A PHASE QTY REQ'D

\section{OPERATING EQUIPMENT}

MANIPULATOR SIdewa11

LOAD CAPACITY

65

VERTICAL

CRANE Bldg 2002 (Sacto), R-MAD Facility LOAD CAPACITY ADDITIONAL DATA

EQUIPMENT Crane (Sacto), Crane (R-MAD Facility)

PART OR ITEM 914-Adapter DRAWING NO. 
PROV. LIST

ITEM NO.

814

DATE January 1968

REVISION B

EQUIPMENT TITLE

BEAM, HOISIING, NOZZLE, ROCKET ENGINF

DESCRIPTION: The Rocket Engine Nozzle Hoisting Beam lifts the engine nozzle during cold assembly. It is a three-legged (equally spaced), steel T-section frame fitted with three contoured clamps (one per leg) for attaching the beam to the nozzle inlet torus. A lifting eye fitted with a shackle is provided to attach the beam to a crane. 
PROVISIONING LIST ITEM NUMBER

DRAWING NUMBER

PART NUMBER

CONTRACTOR
278660

278660-9
814

AGC
FIRST PROVISIONED FOR NRX-A2 GOVT. INV. CONTROL NUMBER NASA-SNP1-L-567
$\$ 1,500$

B. WANL

C.

D. NRDS

TOTAL

1

1

DIMENSIONS AND CAPACITY

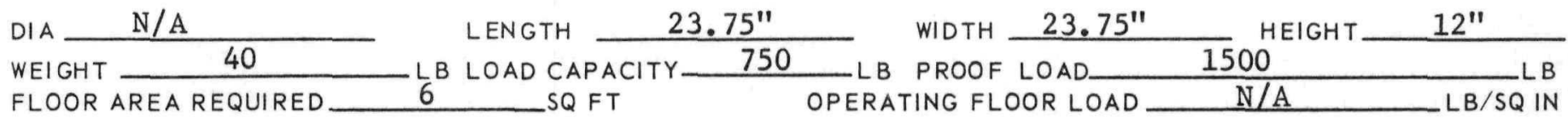

ADDITIONAL DATA

GASES N/A PRESSURE

ELECTRICAL

LIQUIDS

SPEED

MEASURING ACCURACY

CALIBRATION INTERVAL

$\mathrm{N} / \mathrm{A}$ $\mathrm{N} / \mathrm{A}$ N/A

\section{Months} VOLTS LB/SQIN. VOLUME PRESSURE IN./MIN (RPM)

ADDITIONAL DATA Operating Instructions $\mathrm{N}-814$

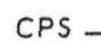
HORIZONTAL CFM LUBRICATION $\mathrm{N} / \mathrm{A}$ PHASE QTY REQ'D $\mathrm{N} / \mathrm{A}$ N/A VERTICAL 
SLING, MULTIPLE LEG, 12,000-POUND CAPACITY

DESCRIPTION: The 12,000-Pound Capacity Multiple Leg Sling is a rigid, box-shaped, cross-membered frame of square steel-tubing with four, flexible steel cables. The cables are connected by pins to the frame corners (two cables are adjustable to level the load) and all have safety lifting-hooks. The four lifting cables on the top of the sling are connected by clevises and pins to the frame corners. One cable is adjustable and all are attached to a single lifting eye.

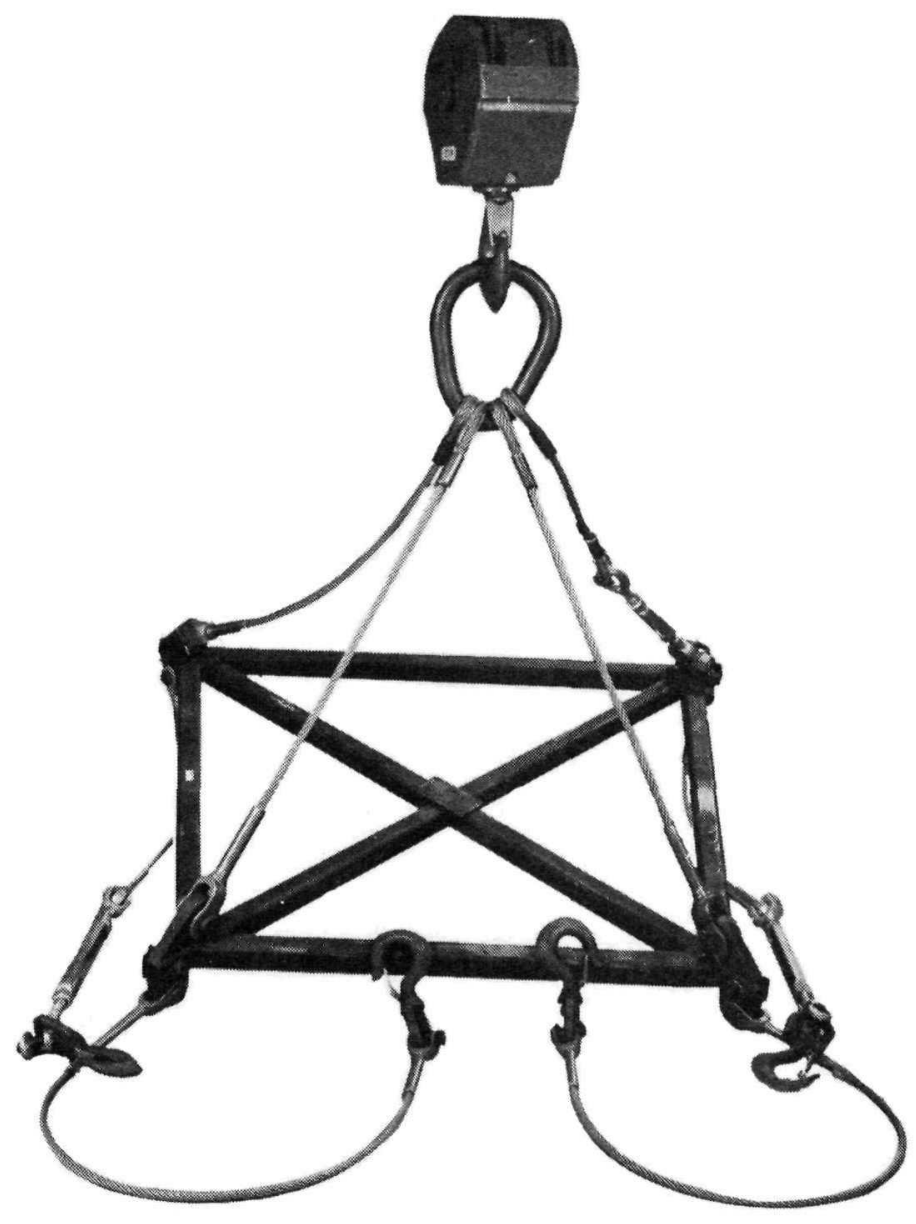


PROVISIONING LIST ITEM NUMBER 817 DRAWING NUMBER

PART NUMBER CONTRACTOR
278670

278670-9

AGC
FIRST PROVISIONED FOR NRX-AI GOVT. INV. CONTROL NUMBER NASA-SNP1-L-568, $\cos T$

\begin{tabular}{|c||c|}
\hline \multicolumn{1}{|c||}{ USE LOCATION } & QTY REQ'D \\
\hline A. AGC SACRAMENTO & 1 \\
\hline B. WANL & \\
\hline C. & 1 \\
\hline D. NRDS TOTAL & 2 \\
\hline
\end{tabular}

DIMENSIONS AND CAPACITY

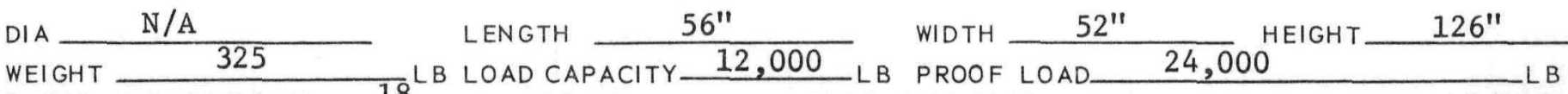
$\begin{array}{cccc}\text { WEIGHT } & \text { FLOOR AREA REQUIRED } 18 & 18 \text { LOAD CAPACITY } & 12,000 \\ \text { SQFT } & \text { OPERATING FLOOR LOAD }\end{array}$ ADDITIONAL DATA

GASES_N N/A PRESSURE ELECTRICAL $\frac{\mathrm{N} / \mathrm{A}}{\mathrm{N} / \mathrm{A}}$ SPEED $\frac{\text { N/A }}{\text { MEASURING ACCURACY N/A }}$ CALIBRATION INTERVAL ADDITIONAL DATA
Wire Rope, Use MIL-P-116, Type VOLTS CPS PRESSURE LB/SQIN. VOLUME $L B / S Q$ IN CUTTING SPEED HORIZONTAL LUBRICATION $\frac{\mathrm{P}-11 \text { Perservative }}{\text { PHASE KVA }}$ CFM QTY REQ'D

\section{Months (Proof Load)}

VERTICAL IN./MIN (RPM) Every

\section{OPERATING EQUIPMENT}

MANIPULATOR $\frac{\mathrm{N} / \mathrm{A}}{\mathrm{R} \text { MAD Facility }}$ LOAD CAPACITY L N L LAD CAPACITY L
CRANEL




\begin{tabular}{l|l|}
\hline (1) NERVA & SUPPORT EQUIPMENT \\
\hline PROGRAM & TECHNICAL DESCRIPTION HANDBOOK \\
\hline
\end{tabular}

EQUIPMENT TITLE

STAND, ROCKET ENGINE
PROV. LIST

ITEM NO.

915

DATE January 1968

REVISION

A

DESCRIPTION: The Rocket Engine Stand is a floor-mounted structure which supports the engine assembly during cold assembly and disassembly operations. It is constructed of 5-inch-square steel tubing and includes a set of manually-fastened couplings for connection to the trunnion mounts of the pneumatic pressure vessel handling adapter, P/L 921, or the thrust chamber/reactor disassembly fixture, P/L 923, which adapt the engine to the stand. The stand is capable of rotating the engine $360^{\circ}$ about a transverse axis by means of an electrically driven and controlled hydraulic motor system. It is capable of being locked by a disc-brake system at any point of rotation.

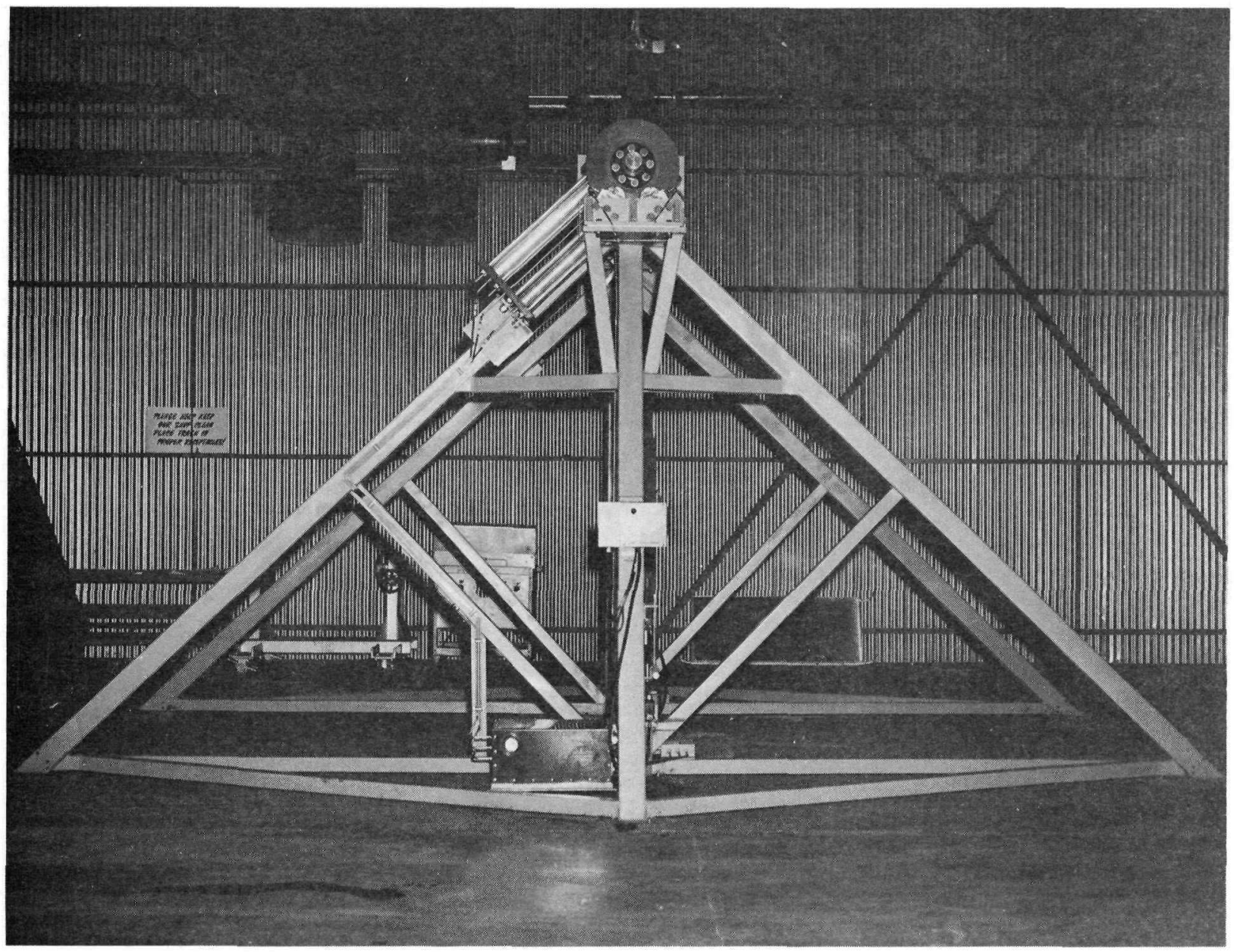


PROVISIONING LIST ITEM NUMBER 915 DRAWING NUMBER 279050

PART NUMBER CONTRACTOR
FIRST PROVISIONED FOR NRX-A1 GOVT. INV. CONTROL NUMBER NASA-SNP1-L-571 $\cos T$

\begin{tabular}{|c|c|}
\hline USE LOCATION & QTY REQ'D \\
\hline A. AGC SACRAMENTO & $2 *$ \\
\hline B. WANL & \\
\hline C. & \\
\hline D. NRDS & \\
\hline TOTAL & 2 \\
\hline
\end{tabular}

\section{DIMENSIONS AND CAPACITY}

DIA

WEIGHT 2,500 FLOOR AREA REQUIRED ADDITIONAL DATA
LENGTH $17^{\prime} 6^{\prime \prime}$ WIDTH $14^{\circ}$ LB LOAD CAPACITY 11,500 LB PROOF LOAD OPERATING FLOOR LOAD SQ FT
- HEIGHT $10^{\prime}$
GASES N/A PRESSURE

ELECTRICAL $\frac{115}{\text { Hydr. Fluid* }}$

SPEED

MEASURING ACCURACY

$\mathrm{N} / \mathrm{A}$

$\mathrm{N} / \mathrm{A}$

LB/SQ IN. VOLUME PRESSURE IN./MIN (RPM)

CALIBRATION INTERVAL N/A

ADDITIONAL DATA *0nly one stand is equipped with a hydraulic drive system for rotation of the engine. Operating Instructions $\mathrm{N}-915$.

\section{OPERATING EQUIPMENT}

$\begin{array}{ll}\text { MANIPULATOR } & \text { N/A } \\ \text { CRANE } & \text { N/A }\end{array}$
LOAD CAPACITY 


\section{(1) NERVA LIPROGRAM \\ SUPPORT EQUIPMENT TECHNICAL DESCRIPTION HANDBOOK}

EQUIPMENT TITLE

MAINTENANCE PLATFORM, ROCKET ENGINE
PROV. LIST

ITEM NO.

916

DATE

\begin{tabular}{lc}
\multicolumn{2}{c}{ January 1968} \\
\hline REVISION & A
\end{tabular}

DESCRIPTION: The Rocket Engine Maintenance Platform consists of two caster-mounted aluminum tubing scaffolds which are fastened together by removable platform panels which fit between the two scaffolds to complete the platform around the engine assembly. It provides work levels at 7 - and 13-ft heights. The platform is used in conjunction with the rocket engine stand, P/L 915. The platform, designed to support manual, cold operations on NRX assemblies, provides adequate work space, access, and support for men and materials at major working levels.
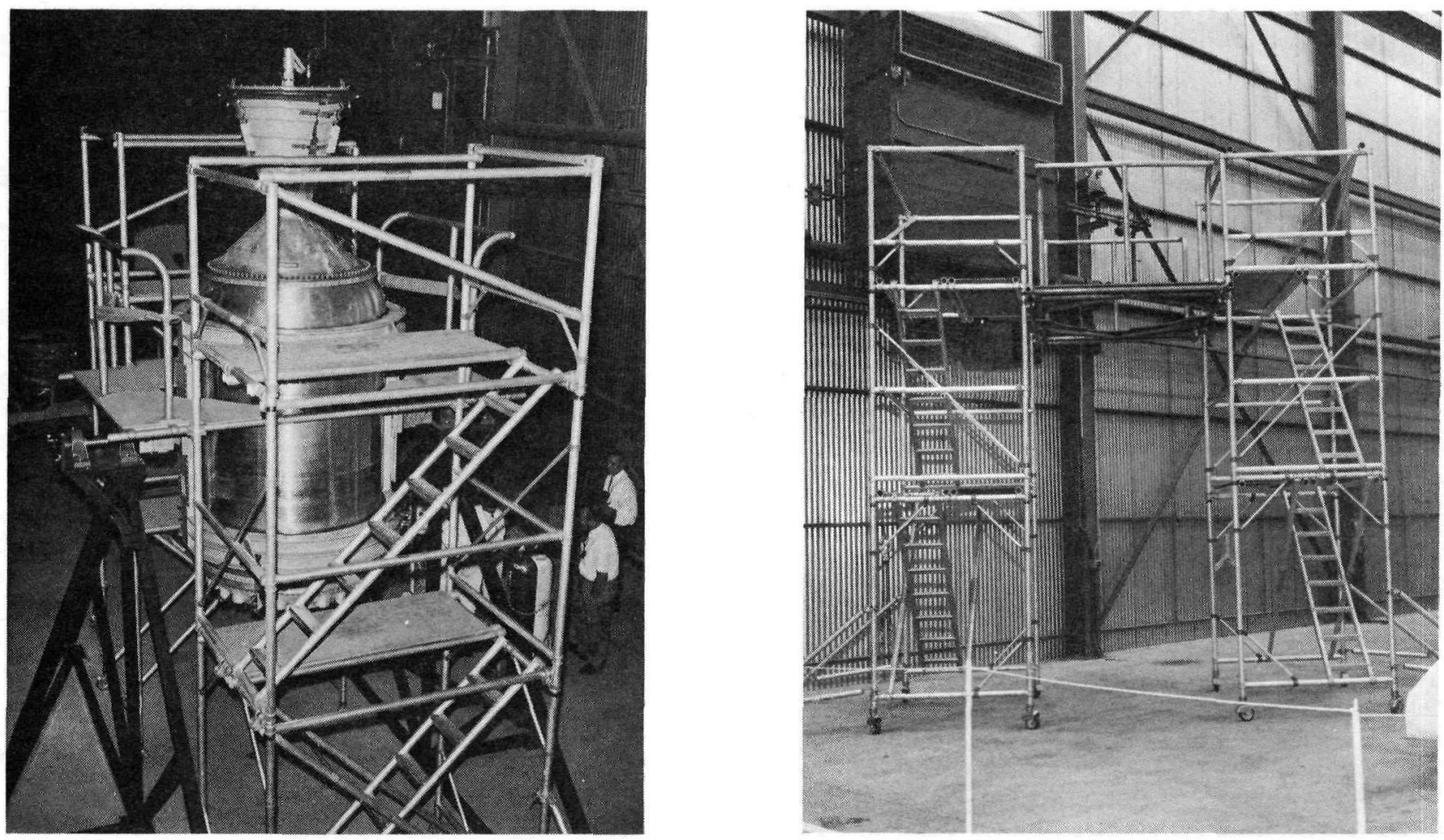
PROVISIONING LIST ITEM NUMBER 916

DRAWING NUMBER

PART NUMBER

CONTRACTOR
279110

AGC
DIA

WEIGHT 700

FLOOR AREA REQUIRED 135

ADDITIONAL DATA
GASES N/A

ELECTRICAL $\frac{\mathrm{N} / \mathrm{A}}{\mathrm{N} / \mathrm{A}}$

LIQUIDS

MEASURING ACCURACY

CALIBRATION INTERVAL

ADDITIONAL DATA

\section{N/A} N/A
MANIPULATOR

$\mathrm{N} / \mathrm{A}$

CRANE

ADDITIONAL DATA

$\mathrm{N} / \mathrm{A}$
FIRST PROVISIONED FOR NRX-AI GOVT. INV. CONTROL NUMBER

NASA-SNP1-L- 572 and 573

COST $\$ 7,775$

\begin{tabular}{|l||c|}
\hline \multicolumn{1}{|c||}{ USE LOCATION } & QTY REQ'D \\
\hline A. AGC SACRAMENTO & 2 \\
\hline B. WANL & \\
\hline C. & \\
\hline D. NRDS TOTAL & 2 \\
\hline
\end{tabular}

DIMENSIONS AND CAPACITY
LENGTH $180^{\prime \prime}$
WIDTH 108"

L OPERATING FLOOR LOAD
HEIGHT

$18^{\prime} 6^{\prime \prime}$
SQ FT

$L B / S Q I N$
VOLTS

PRESSURE IN./MIN (RPM)
LB/SQIN. VOLUME

CPS

LB/SQ IN

CUTTING SPEED

HORIZONTAL
CFM LUBRICATION

PHASE

QTY REQ'D KVA

VERTICAL
Operating Instructions $\mathrm{N}-916$
,

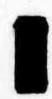

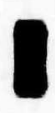

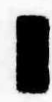

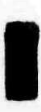

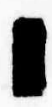

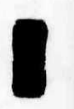

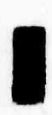

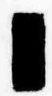

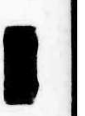

LOAD CAPACITY

L B MAX

LOAD CAPACITY

L B MAX 
STAND, FORWARD CLOSURE, ROCKET ENGINE

DESCRIPTION: The Rocket Engine Forward Closure Stand is a flat-plate structure with a 4l-inch hole in the center for weight reduction. The stand is mounted on four 11-inch legs. Each leg is provided with an elongated hole which serves as a lifting eye when used with a multiple-leg sling and overhead crane. The stand supports the NRX forward-closure during storage, manual assembly, and remote disassembly or maintenance operations. A rubber-pad on the interface surface protects the forward-closure flanges.
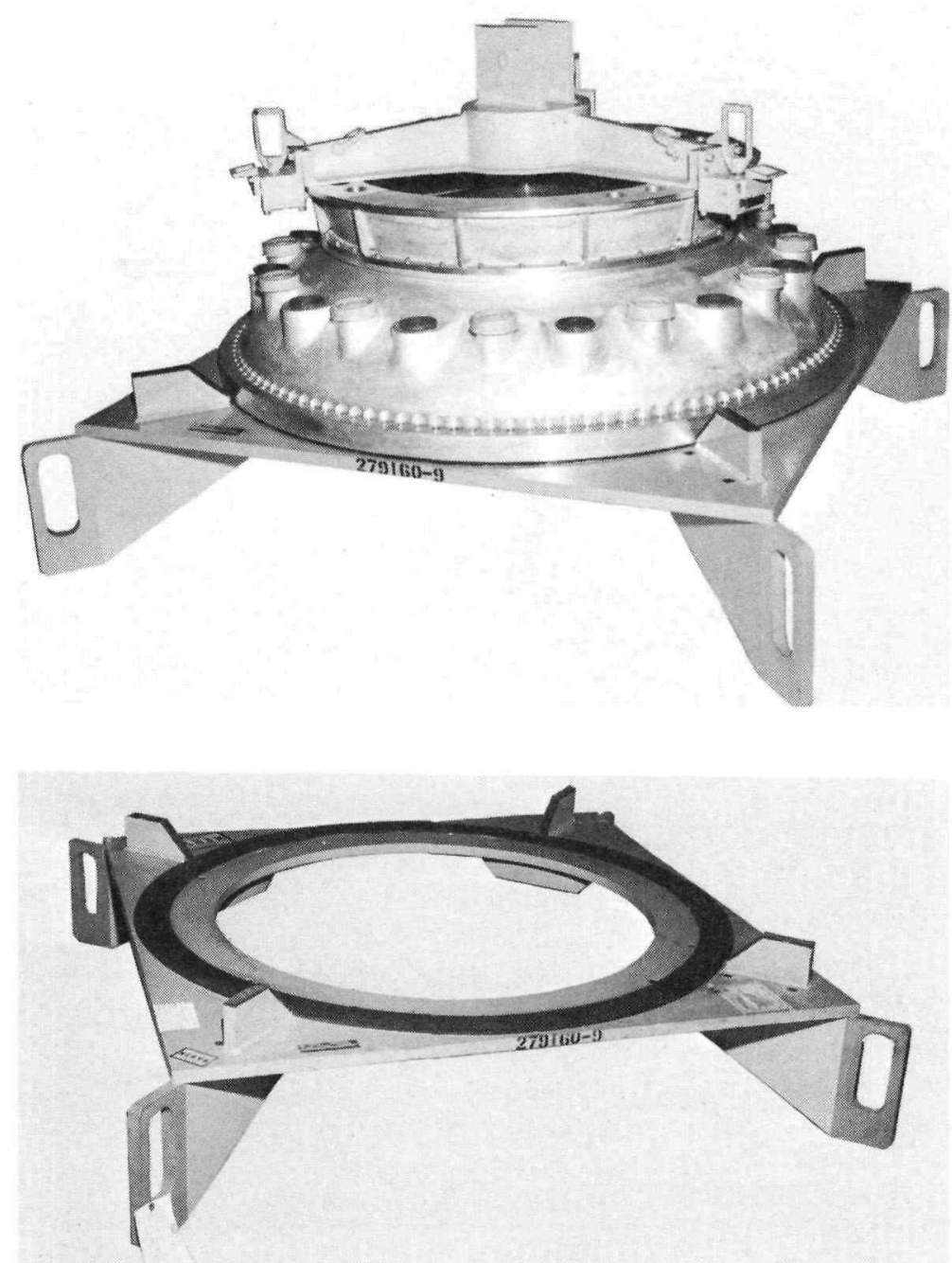
PROVISIONING LIST ITEM NUMBER

DRAWING NUMBER

PART NUMBER

CONTRACTOR
917

279160

279160-9

AGC
FIRST PROVISIONED FOR NRX-AI GOVT. INV. CONTROL NUMBER NASA-SNPI-I-577, 578

\begin{tabular}{|l||c|}
\hline \multicolumn{1}{|c||}{ USE LOCATION } & QTY REQ'D \\
\hline A. AGC SACRAMENTO & 1 \\
\hline B. WANL & \\
\hline C. & 2 \\
\hline D. NRDS TOTAL & 3 \\
\hline
\end{tabular}

DIMENSIONS AND CAPACITY

DIA

WEIGHT 378

FLOOR AREA REQUIRED

ADDITIONAL DATA
LENGTH $62^{\prime \prime}$ SQ FT
WIDTH 36
350 LB PROOF LOAD OPERATING FLOOR LOAD $\mathrm{N} / \mathrm{A}$ HEIGHT $12^{\prime \prime}$ L B $L B / S Q$ IN

\section{OPERATING DATA}

GASES N/A PRESSURE ELECTRICAL N N N $/ A$ LIQUIDS SPEED MEASURING ACCURACY CALIBRATION INTERVAL ADDITIONAL DATA

A

$\mathrm{N} / \mathrm{A}$

$\mathrm{N} / \mathrm{A}$
- VOLTS PRESSURE IN./MIN (RPM) $\mathrm{N} / \mathrm{A}$ N/A
LB/SQIN. VOLUME CPS

$L B / S Q$ IN CUTTING SPEED HORIZONTAL
CFM LUBRICATION $\mathrm{N} / \mathrm{A}$ PHASE QTY REQ'D $\mathrm{N} / \mathrm{A}$ - VERTICAL
MANIPULATOR *Sidewa11 CRANE MAD Facility (Auxiliary Hook) ADDITIONAL DATA
LOAD CAPACITY LOAD CAPACITY the stand
65

10,000
LB MAX

LB MAX

INTERFACES

EQUIPMENT_Crane, Manipulator (Sidewa11)

PART OR ITEM_ Forward Closure

DRAWING NO. P P/N 283095-9, 298252-9

REMARKS 
EQUIPMENT TITLE

\section{REVISION}

C

STAND, NOZZLE, ROCKET ENGINE

DESCRIPTION: The Rocket Engine Nozzle Stand is a flat-plate structure with a 40-inch diameter hole in the center to reduce weight. The stand is mounted on four 12-inch legs. Each leg is provided with an elongated hole which serves as a lifting eye when used with a multiple-leg sling and an overhead crane. The stand supports the NRX nozzle assembly during storage, manual assembly, and remote disassembly and maintenance operations. A rubber-pad on the interface surface protects the surface area of the nozzle/pressure vessel interface-flange.

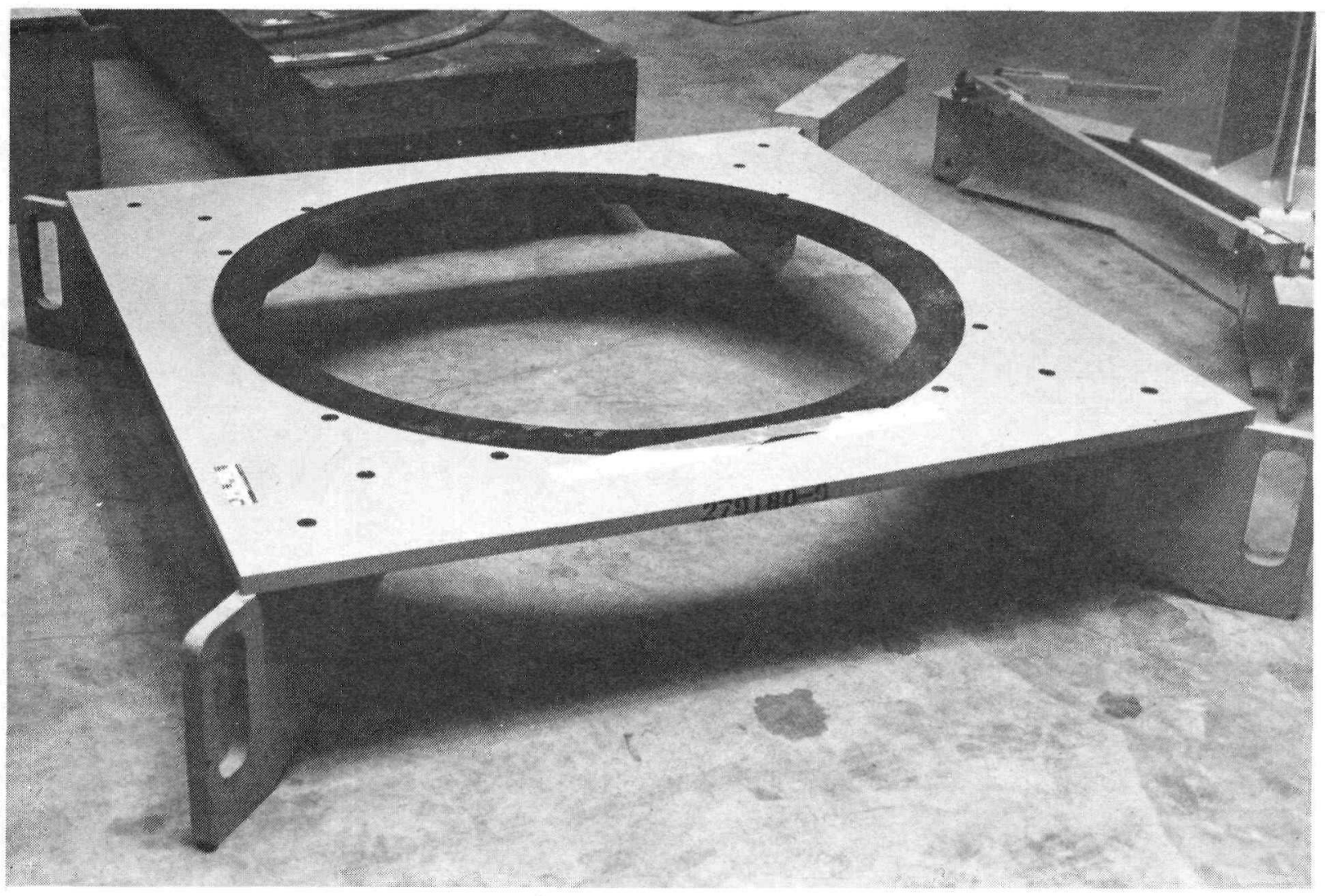


PROVISIONING LIST ITEM NUMBER

DRAWING NUMBER

PART NUMBER

CONTRACTOR
919

279180

279180-19
FIRST PROVISIONED FOR NRX-A2 GOVT. INV. CONTROL NUMBER NASA-SNP1-L-574. 575,576

\begin{tabular}{|l||c|}
\hline \multicolumn{1}{|c|}{ USE LOCATION } & QTY REQ'D \\
\hline A. AGC SACRAMENTO & 1 \\
\hline B. WANL & \\
\hline C. & 2 \\
\hline D. NRDS TOTAL & 3 \\
\hline
\end{tabular}

\section{DIMENSIONS AND CAPACITY}

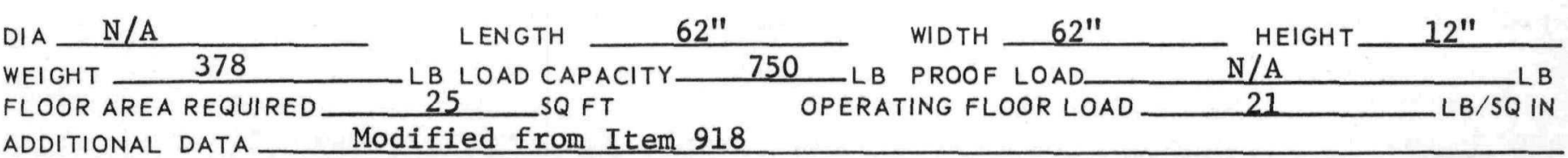
ADDITIONAL DATA Modified from Item 918

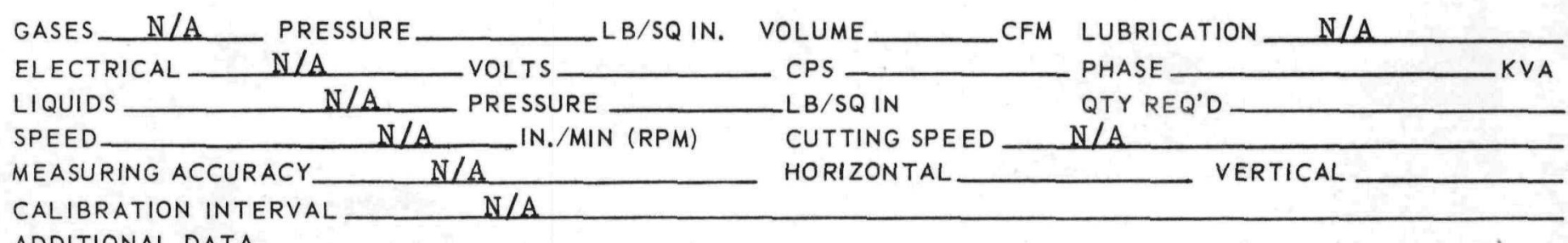

ADDITIONAL DATA

\section{OPERATING EQUIPMENT}

MANIPULATOR *Sidewal1

LOAD CAPACITY CRANE MAD Facility (Auxiliary Hook)

LOAD CAPACITY 65 10,000 L B MAX ADDITIONAL DATA *Not to be used for lifting, stand, use for attaching the sling hooks.

EQUIPMENT_Sidewall Manipulator, R-MAD Crane

PART OR ITEM NOZZle DRAWING NO. P/N 298650-29


PROV. LIST

ITEM NO.

921

DATE

TECHNICAL DESCRIPTION HANDBOOK

EQUIPMENT TITLE

ADAPTER, HANDLING, PRESSURE VESSEL, PNEUMATIC
January 1968

REVISION

DESCRIPTION: The Pneumatic Pressure Vessel Handling Adapter provides a means of attachment to the pressure vessel, or various engine subassembly configurations which contain the pressure vessel. The adapter consists of two structural rings joined by longitudinal members to form a cage structure. The inner circumference of each ring contains two pneumatic tires which press against the outer surface of the pressure vessel when inflated to provide a friction grip. The longitudinal members provide trunnion blocks for attachment of the adapter to the engine assembly stand, P/L 915. Mechanical safety catches prevent dropping of the pressure vessel assembly in the event of pneumatic-system failure. Eyes are provided for lifting the adapter either horizontally or vertically.
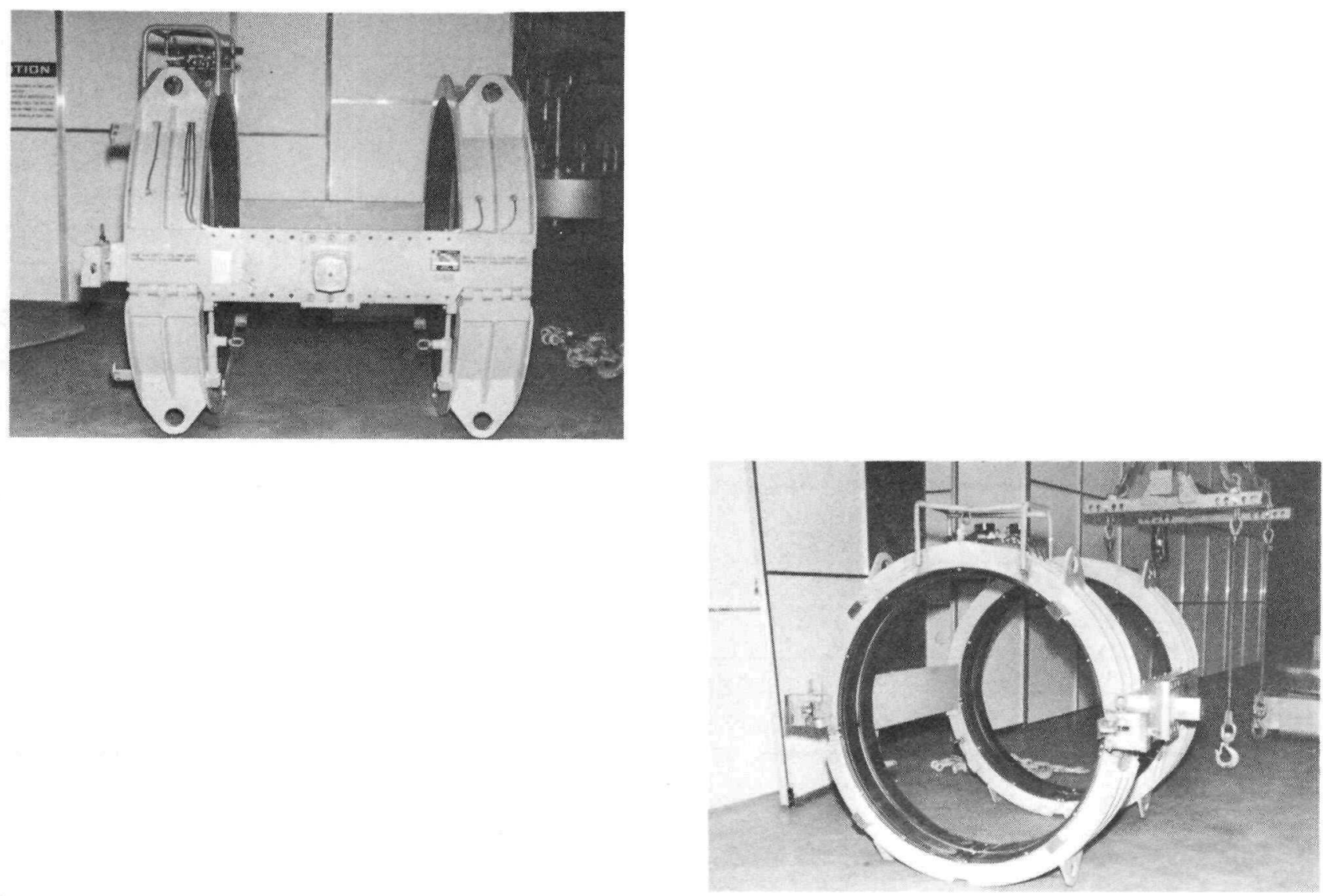
PROVISIONING LIST ITEM NUMBER 921

DRAWING NUMBER

PART NUMBER

CONTRACTOR

\section{6}

AGC
FIRST PROVISIONED FOR NRX-A2 GOVT. INV. CONTROL NUMBER

$\cos T$

$\$ 12,378$

\begin{tabular}{|l||c|}
\hline \multicolumn{1}{|c||}{ USE LOCATION } & QTY REQ'D \\
\hline A. AGC SACRAMENTO & 1 \\
\hline B. WANL & \\
\hline C. & \\
\hline D. NRDS TOTAL & 1 \\
\hline
\end{tabular}

\section{DIMENSIONS AND CAPACITY}

DIA 65" 6. 6. WIDTH - 64" HEIGHT

WEIGHT LB LOAD CAPACITY 25,000 LB PROOF LOAD $50,000 \mathrm{lb}(12, \overline{500} \mathrm{lb} / \mathrm{tire})$ FLOOR AREA REQUIRED— $\quad 23$ SQ FT OPERATING FLOOR LOAD—LB/SQ IN ADDITIONAL DATA

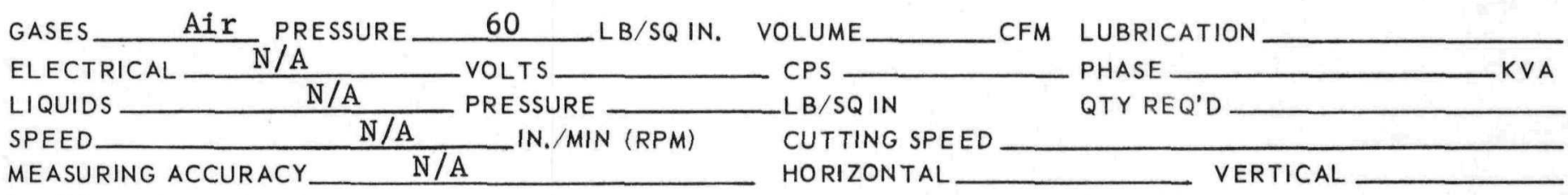

CALIBRATION INTERVAL

ADDITIONAL DATA

\section{OPERATING EQUIPMENT}


PROV. LIST

ITEM NO.

922

DATE

TECHNICAL DESCRIPTION HANDBOOK REVISION

EQUIPMENT TITLE

A

FIXTURE, TURNOVER, FORWARD CLOSURE

DESCRIPTION: The Forward Closure Turnover Fixture has a structural ring-base to hold the forward closure. The base is provided with a rubber surface to protect the closure seal-surface. The forward closure, with guide tubes installed, is clamped to the padded surface of the ring base by four swing-away clamps. The structural ring-base is connected to the tubular-ring frame through two pivot joints which lock the ring frame in either of two horizontal positions, $180^{\circ}$ apart, with manually inserted ball-detent pins. The lock pins are secured to the frame by a nylon lanyard. The fixture is intended for cold-assembly use only.
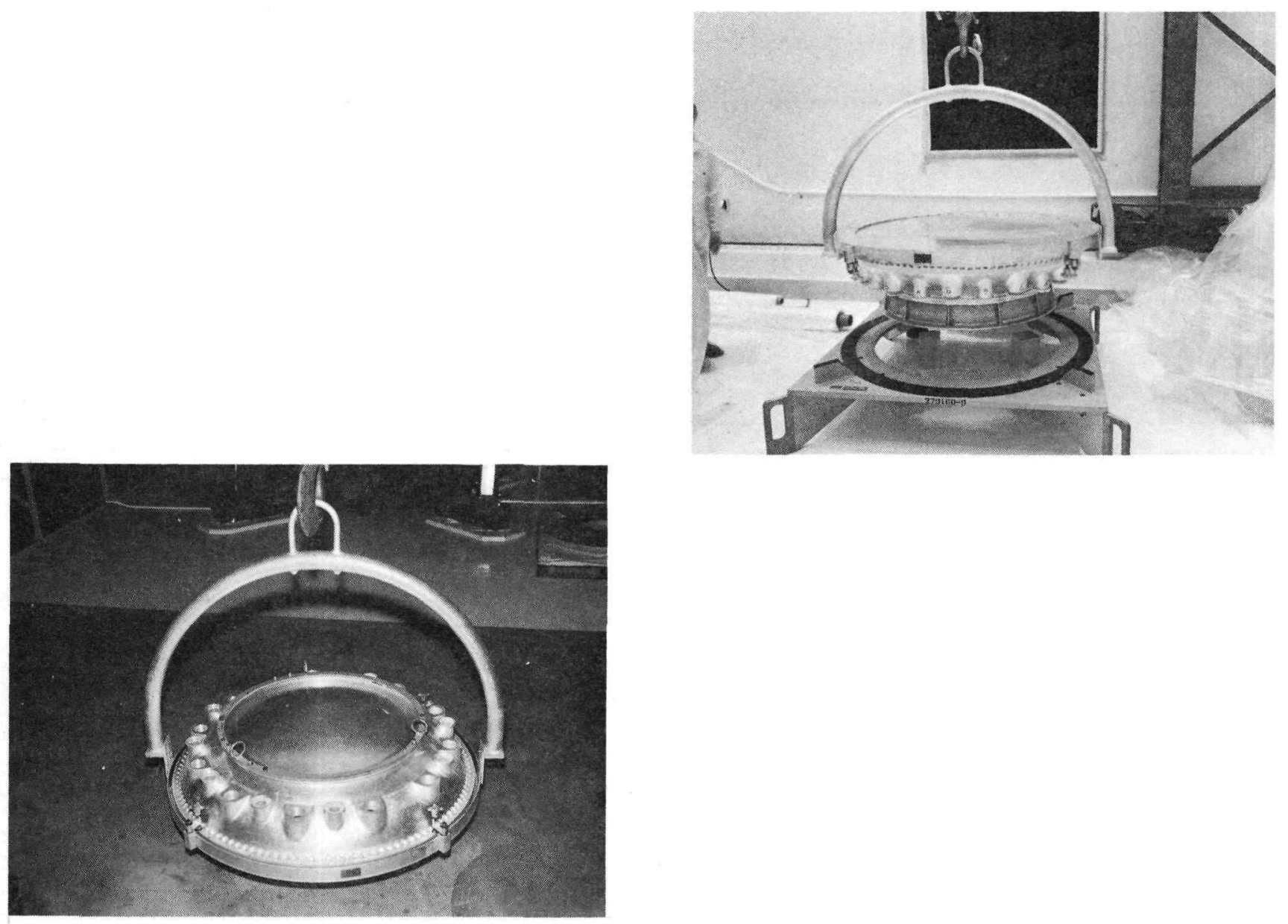
TECHNICAL SUMMARY

PROVISIONING LIST ITEM NUMBER

DRAWING NUMBER

PART NUMBER

CONTRACTOR
922

278590

278590-9

AGC
FIRST PROVISIONED FOR $\mathrm{NRX}-\mathrm{A} 3$ GOVT. INV. CONTROL NUMBER NASA-SNP1-L-955 $\operatorname{COST} \_\$ 1430.00$

\begin{tabular}{|l||c|}
\hline \multicolumn{1}{|c||}{ USE LOCATION } & QTY REQ'D \\
\hline A. AGC SACRAMENTO & \\
\hline B. WANL & \\
\hline C. & \\
\hline D. NRDS TOTAL & 1 \\
\hline \multicolumn{2}{|c||}{} \\
\hline
\end{tabular}

\section{DIMENSIONS AND CAPACITY}

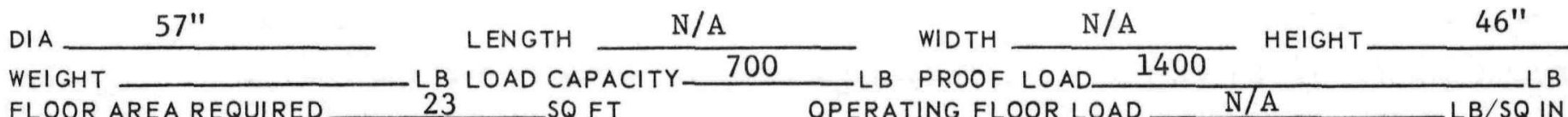

ADDITIONAL DATA

GASES N/A

ELECTRICAL N N $/$ A

LIQUIDS

SPEED

MEASURING ACCURACY N/A

CALIBRATION INTERVAL 6 Months

ADDITIONAL DATA
VOLTS

PRESSURE IN./MIN (RPM)
LB/SQIN. VOLUME

CPS

$L B / S Q$ IN

CUTTING SPEED

HORIZONTAL
CFM

LUBRICATION

PHASE KVA
MANIPULATOR N/A

CRANE E-MAD Facility (Auxiliary Hook) ADDITIONAL DATA
LOAD CAPACITY

LOAD CAPACITY 10,000

B MAX LB MAX

INTERFACES

EQUIPMENT

Crane

PART OR ITEM

Forward Closure

DRAWING NO. P/N 703887-5

REMARKS 
PROV. LIST

ITEM NO.

DATE

January 1968

REVISION

EQUIPMENT TITLE

FIXTURE, DISASSEMBLY, THRUST CHAMBER/REACTOR - REMOTE

DESCRIPTION: The Remote Thrust Chamber/Reactor Disassembly Fixture provides a means of remote attachment to the nozzle flange of the thrust chamber reactor assembly for lifting the assembly from the NRX test car. It also adapts the assembly to the reactor trunnion fixture, P/L 1182, to support and rotate the assembly during remote disassembly operations. The fixture minimizes the number of instrumentation transducers that must be removed prior to disassembly and maintains maximum accessibility for manipulators and remote tools used in disassembly. The fixture consists of a hexogon-shaped structural ring provided with six manipulator-operated clamps for attachment to the nozzle/pressure vessel flange. Two legs, each approximately 40 inches long, extend from the ring to provide trunnion blocks on the approximate center of gravity of the thrust chamber/ reactor assembly for attachment to $\mathrm{P} / \mathrm{L} 1182$.
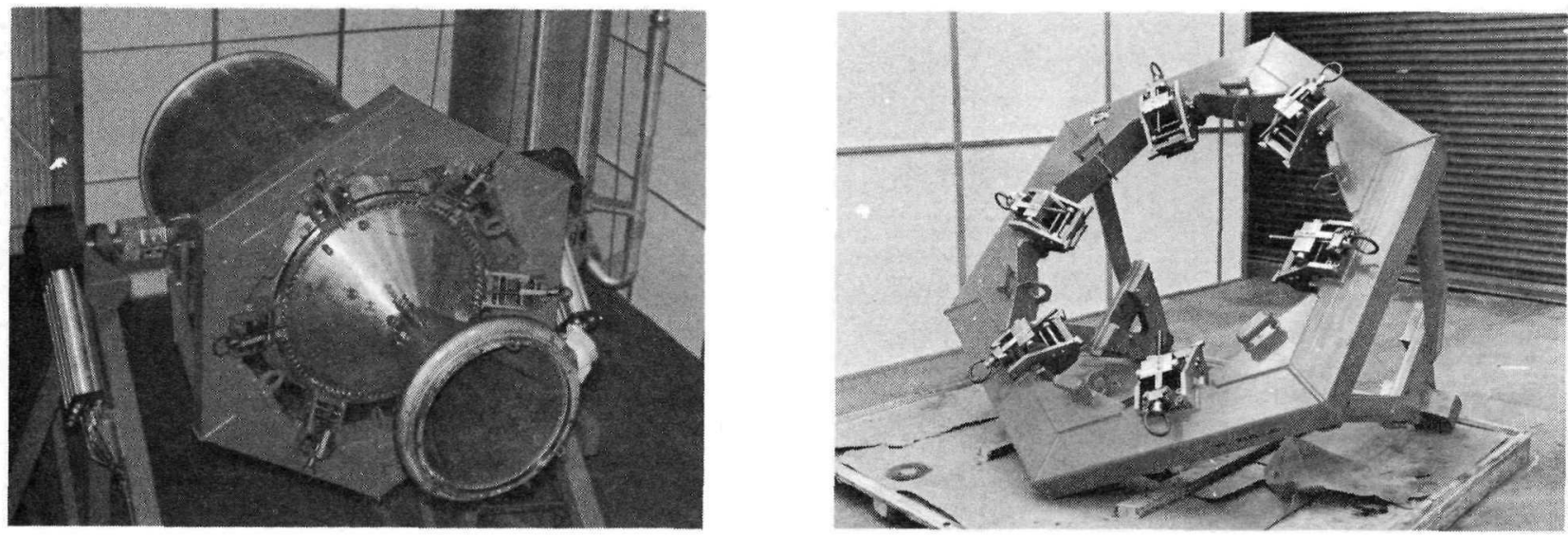
PROVISIONING LIST ITEM NUMBER 923

DRAWING NUMBER

PART NUMBER

CONTRACTOR
1115427

1115427-29

AGC
FIRST PROVISIONED FOR NRX/EST INV. CON TROL
SNP-1-L-1292 $\cos T$

\begin{tabular}{|l||c|}
\hline \multicolumn{1}{|c||}{ USE LOCATION } & QTY REQ'D \\
\hline A. AGC SACRAMENTO & \\
\hline B. WANL & \\
\hline C. & 1 \\
\hline D. NRDS TCTAL & 1 \\
\hline
\end{tabular}

DIA $77^{\prime \prime}$

WEIGHT 2,175 FLOOR AREA REQUIRED ADDITIONAL DATA

LENGTH 38 $S Q F T$ OPERATING FLOOR LOAD N/A 13,000 pound maximum load to be rotated, 40,000 pounds in static

WIDTH * LB PROOF LOAD 26,000

\section{OPERATING DATA}

GASES N/A PRESSURE ELECTRICAL N N/A

LIQUIDS SPEED MEASURING ACCURACY CALIBRATION INTERVAL ADDITIONAL DATA

\section{N/A} $N / A$ $\mathrm{N} / \mathrm{A}$ $\mathrm{N} / \mathrm{A}$ See RN-S-0276 PRESSURE $L B / S Q I N$. VOLUME VOLTS CPS IN./MIN (RPM)
CPS CUTTING SPEED HORIZONTAL
CFM LUBRICATION

PHASE -

QTY REQ'D

MANIPULATOR MAD Sidewal1* LOAD CAPACITY CRANE LOAD CAPACITY ADDITIONAL DATA Overhead crane and lifting fixture portion of P. L. Item 1251 used for lifting operations.

*Used for closing and opening clamps

EQUIPMENT_ P. L. Items 1182, 1251 (1ifting fixture only), 924 PART OR ITEM Nozzle Flange DRAWING NO. 1114263 
(1) NERVA

LIPROGRAM

EQUIPMENT TITLE

STAND, DISASSEMBLY FIXTURE
SUPPORT EQUIPMENT

TECHNICAL DESCRIPTION HANDBOOK
PROV. LIST

ITEM NO.

924

DATE

January 1968

REVISION

DESCRIPTION: The Disassembly Fixture Stand supports the thrust chamber/reactor disassembly fixture, P/L 923, when it is not in use. The stand is a three-legged structure attached to an upper ring which supports the fixture. A central lifting bail is provided for moving the stand with an overhead crane.

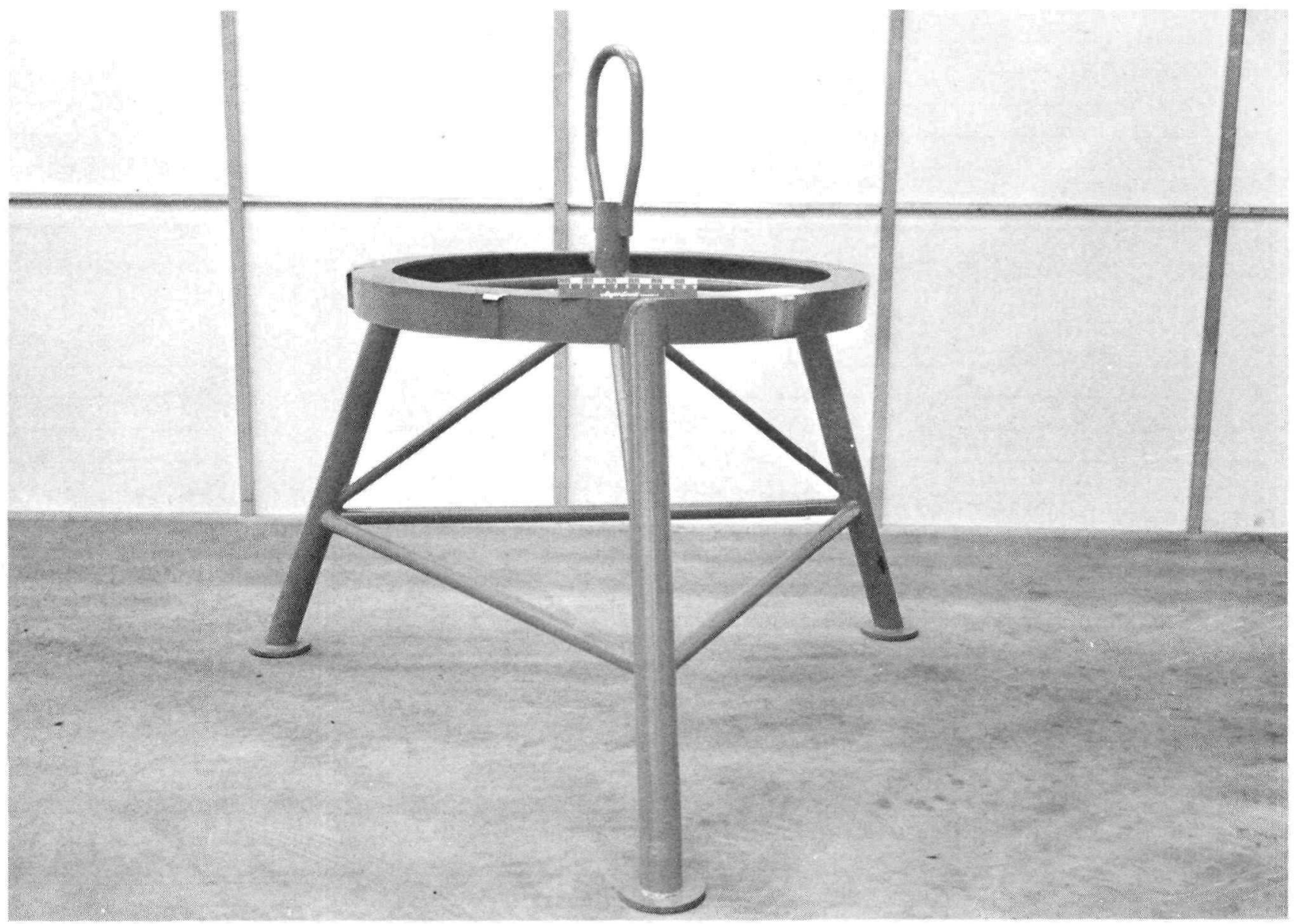


TECHNICAL SUMMARY

PROVISIONING LIST ITEM NUMBER

DRAWING NUMBER

PART NUMBER

CONTRACTOR 1115636

1115636-29 AGC
924

FIRST PROVISIONED FOR NRX/EST

GOVT. INV. CONTROL NUMBER

SNP-1-L-1293

\begin{tabular}{|c|c|}
\hline USE LOCATION & QTY REQ'D \\
\hline A. AGC SACRAMENTO & \\
\hline B. WANL & \\
\hline C. & \\
\hline D. NRDS & 1 \\
\hline TOTAL & 1 \\
\hline
\end{tabular}

\section{DIMENSIONS AND CAPACITY}

DIA $92^{\prime \prime}$

WEIGHT

FLOOR AREA REQUIRED

ADDITIONAL DATA
LENGTH

LB LOAD CAPACITY 38 SQ FT

WIDTH HEIGHT_ $67^{\prime \prime}$

LB PROOF LOAD OPERATING FLOOR LOAD
$L B$ $L B / S Q$ IN
GASES_N/A PRESSURE

ELECTRICAL N N/A

LIQUIDS

SPEED.

MEASURING ACCURACY

CALIBRATION INTERVAL

ADDITIONAL DATA
$\mathrm{N} / \mathrm{A}$ N/A $\mathrm{N} / \mathrm{A}$ $\mathrm{N} / \mathrm{A}$

See $\mathrm{RN}-\mathrm{S}-0276$
LB/SQIN. VOLUME VOLTS PRESSURE IN./MIN (RPM) CPS $L B / S Q I N$ CUTTING SPEED HORIZONTAL
CFM LUBRICATION

PHASE QTY REQ'D KVA VERTICAL
MANIPULATOR CRANE $\mathrm{N} / \mathrm{A}$ ADDITIONAL DATA
LOAD CAPACITY LOAD CAPACITY
LB MAX

LB MAX

Overhead Crane

EQUIPMENT_ Fixture, Disassembly. Thrust Chamber/Reactor-Remote 


\section{(6) NERVA I.PROGRAM \\ SUPPORT EQUIPMENT \\ TECHNICAL DESCRIPTION HANDBOOK}

EQUIPMENT TITLE

TABLE, BALANCE
PROV. LIST

ITEM NO.

1091

DATE

January 1968

REVISION

DESCRIPTION: The Balance Table supports and protects the balance ( $\mathrm{P} / \mathrm{L}$ 1027) from vibration during remote readout operations. The table can be remotely leveled. Bubble level indicators and lifting eyes are provided.

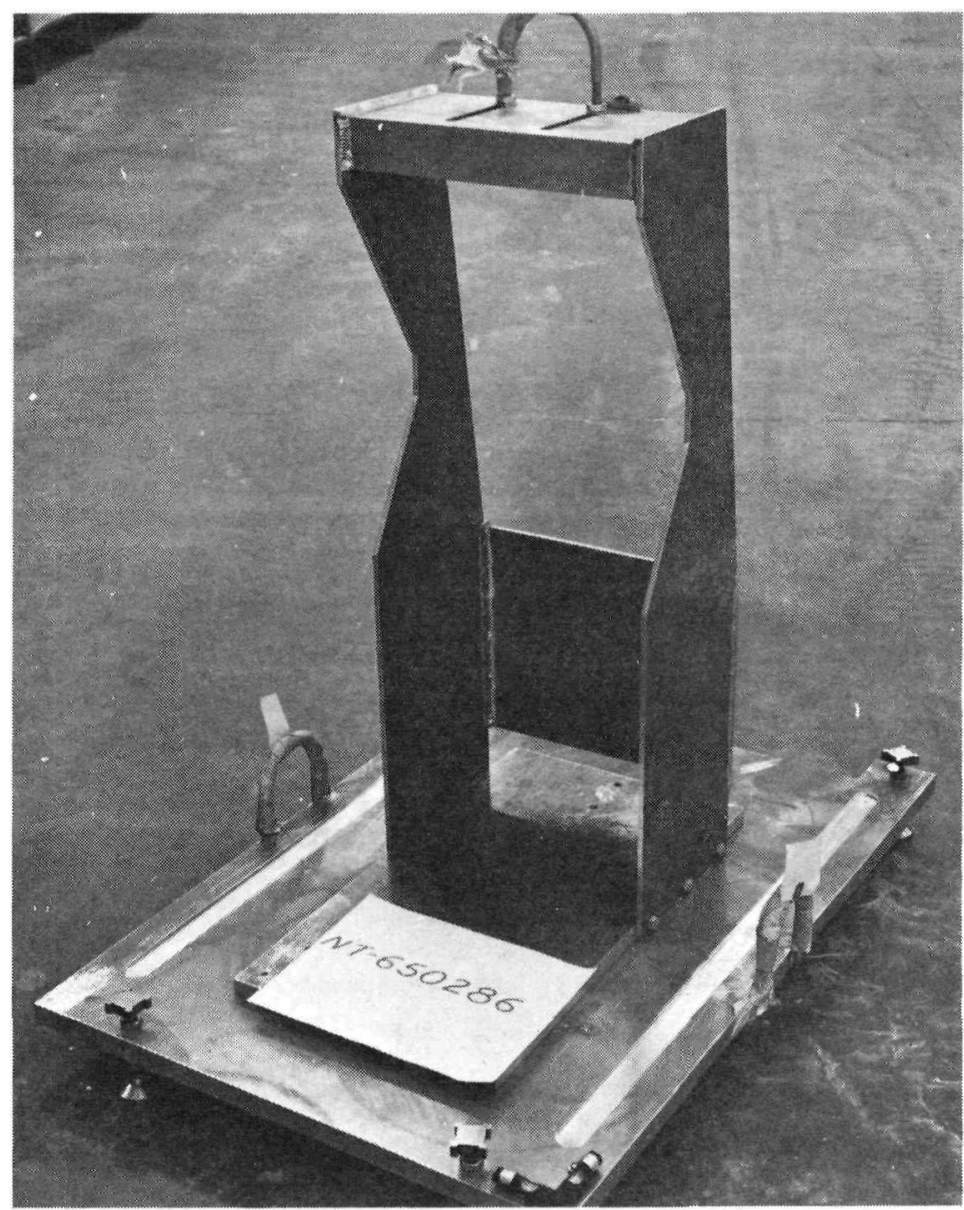


PROVISIONING LIST ITEM NUMBER 1091

DRAWING NUMBER

PART NUMBER

CONTRACTOR
NT650286

NT650286

WANL
FIRST PROVISIONED FOR GOVT. INV. CONTROL NUMBER

$\mathrm{NRX}-\mathrm{A} 2$ $\cos T \$ 630.00$

\begin{tabular}{|c||c|}
\hline \multicolumn{1}{|c||}{ USE LOCATION } & QTY REQ'D \\
\hline A. AGC SACRAMENTO & \\
\hline B. WANL & \\
\hline C. & \\
\hline D. NRDS TOTAL & 1 \\
\hline
\end{tabular}

\section{DIMENSIONS AND CAPACITY}

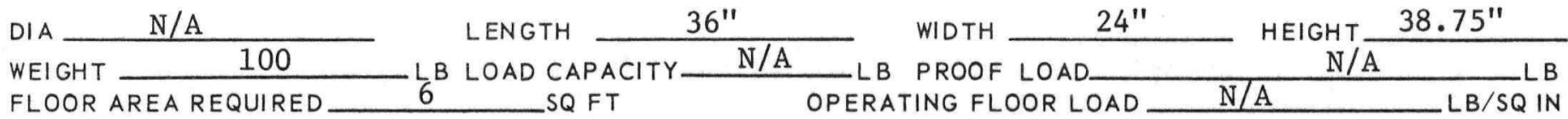

ADDITIONAL DATA

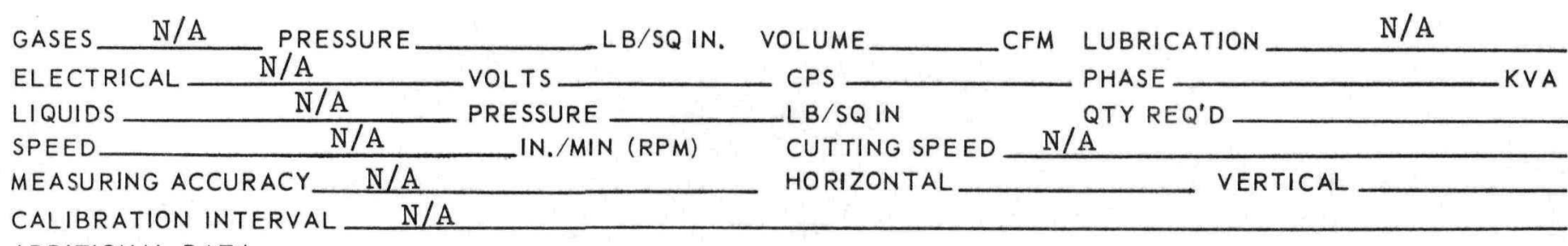

ADDITIONAL DATA

MANIPULATOR

CRANE

ADDITIONAL DATA
Master/Slave R-MAD Facility
LOAD CAPACITY LOAD CAPACITY
10 or 100

L B MAX

LB MAX

INTERFACES

EQUIPMENT Manipulator, Master/Slave

PART OR ITEM Balance, Item 2027 DRAWING NO. 


\section{(i) NERVA LPROGRAM SUPPORT EQUIPMENT TECHNICAL DESCRIPTION HANDBOOK}

EQUIPMENT TITLE

FIXTURE, COIL SPRING TESTING

\section{PROV. LIST}

ITEM NO.

DATE

$\frac{\text { January } 1968}{\text { REVISION }}$

A

DESCRIPTION: The Coil Spring Testing Fixture when used in the Remotely Operated Spring Tester (P/L 1032) is utilized for postoperative compression testing of coil springs used in the NRX engine.

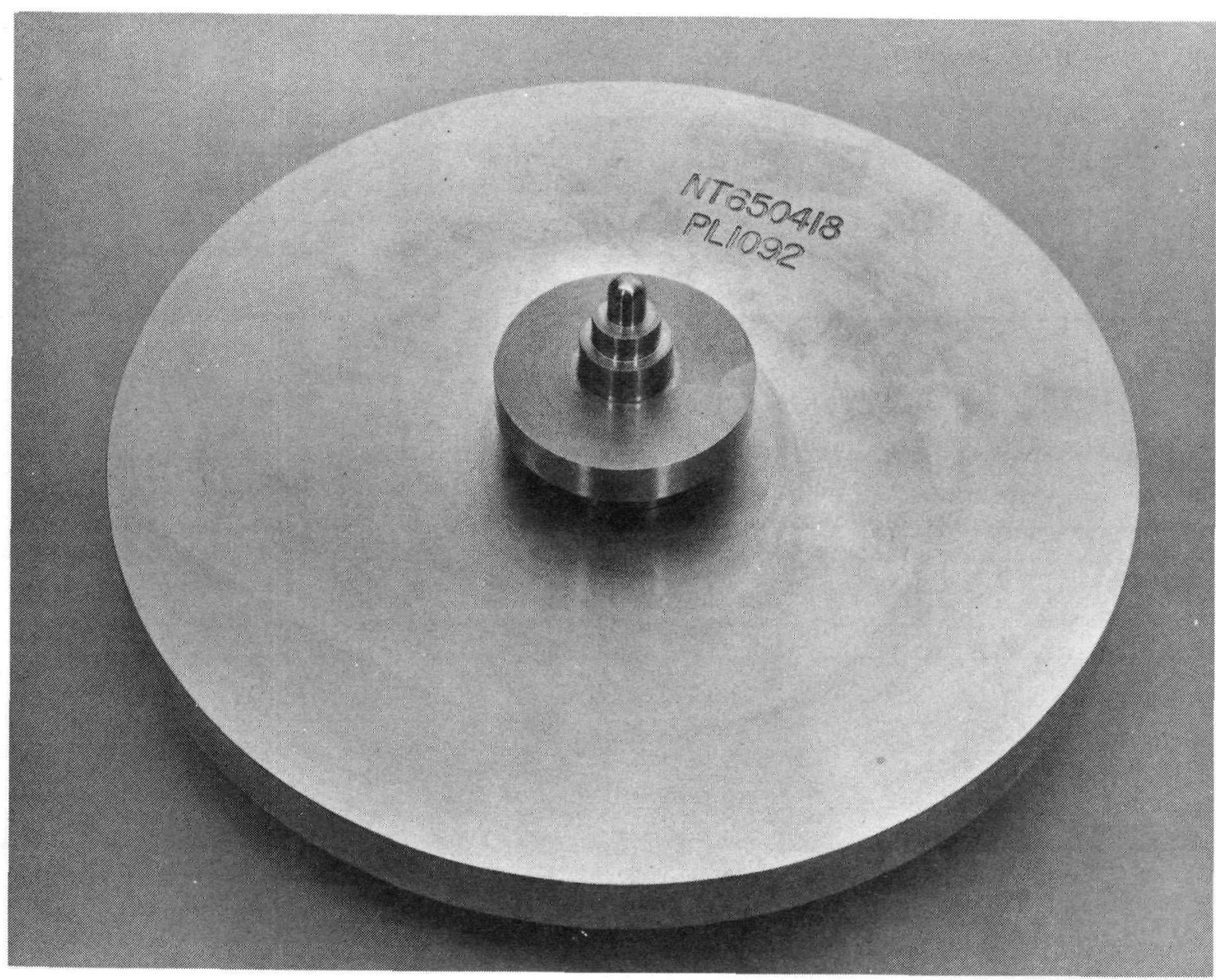


PROVISIONING LIST ITEM NUMBER 1092

DRAWING NUMBER

PART NUMBER

CONTRACTOR
NT650418

WANL
FIRST PROVISIONED FOR GOVT. INV. CONTROL NUMBER

$\cos T$
$\mathrm{NRX}-\mathrm{A} 3$

\begin{tabular}{|l||c|}
\hline \multicolumn{1}{|c||}{ USE LOCATION } & QTY REQ'D \\
\hline A. AGC SACRAMENTO & \\
\hline B. WANL & \\
\hline C. & \\
\hline D. NRDS & 1 \\
\hline & 1 \\
\hline
\end{tabular}

\section{DIMENSIONS AND CAPACITY}

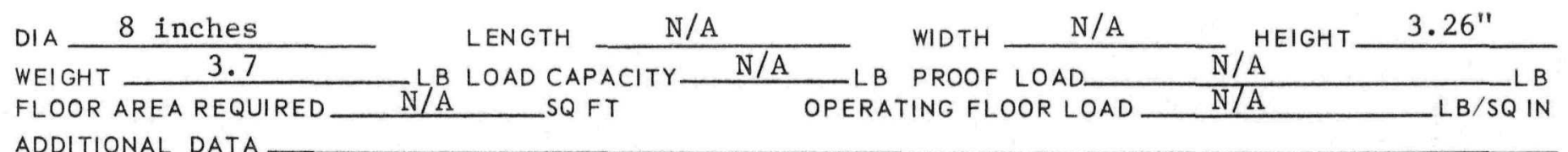

ADDITIONAL DATA

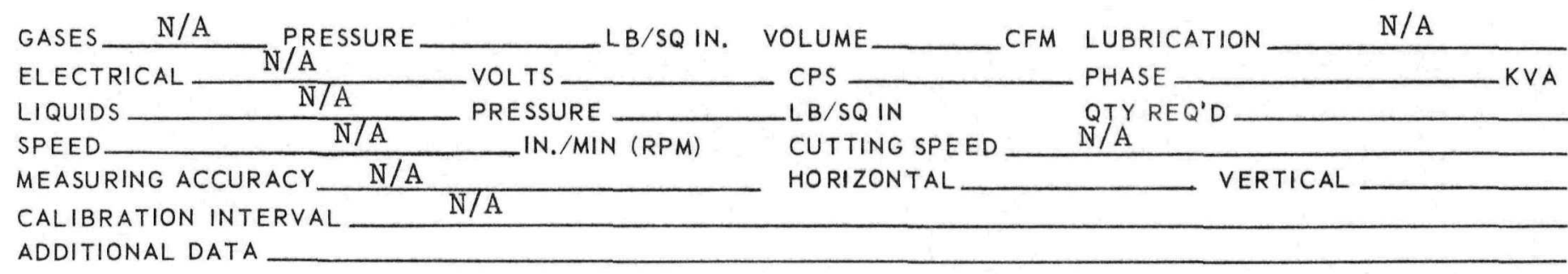

CALIBRATION INTERVAL

ADDITIONAL DATA

MANIPULATOR
CRANE

ADDITIONAL DATA

EQUIPMENT_Remotely Operated Spring Tester, P/L 1032

PART OR ITEM *963B483, B484, B702, B993, B994DRAWING NO.

REMARKS $\frac{\text { *Used with P/L } 1032 \text { to support coil springs listed above during compression }}{\text { testing of each spring. }}$ 


\section{(1) NERVA \\ LIPROGRAM}

EQUIPMENT TITLE

\section{SUPPORT EQUIPMENT}

TECHNICAL DESCRIPTION HANDBOOK

FIXTURE, LEAF SPRING TESTING

DESCRIPTION: The Leaf Spring Testing Fixture when used with the remotely operated spring tester $(\mathrm{P} / \mathrm{L}$ 1032) is utilized for postoperative testing of leaf springs used in the NRX engine.

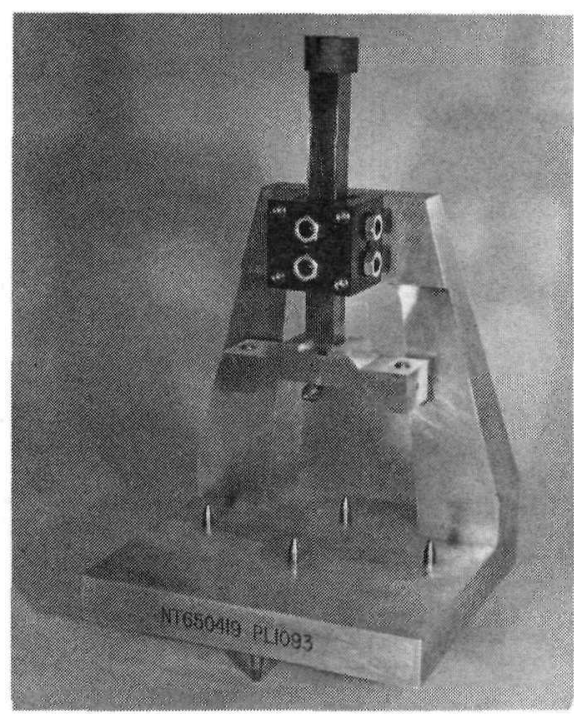

FIXTURE ONLY

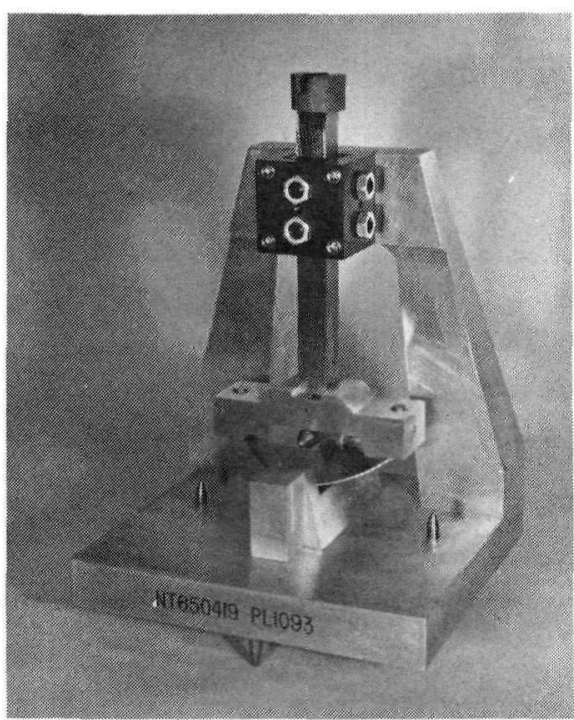

FIXTURE WITH

TEST SPRING

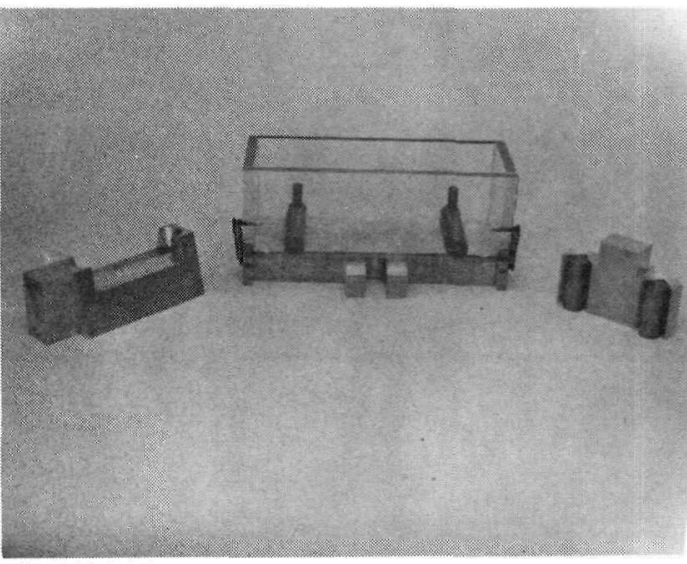

FIXTURE \& SAFETY EINCLOSURE

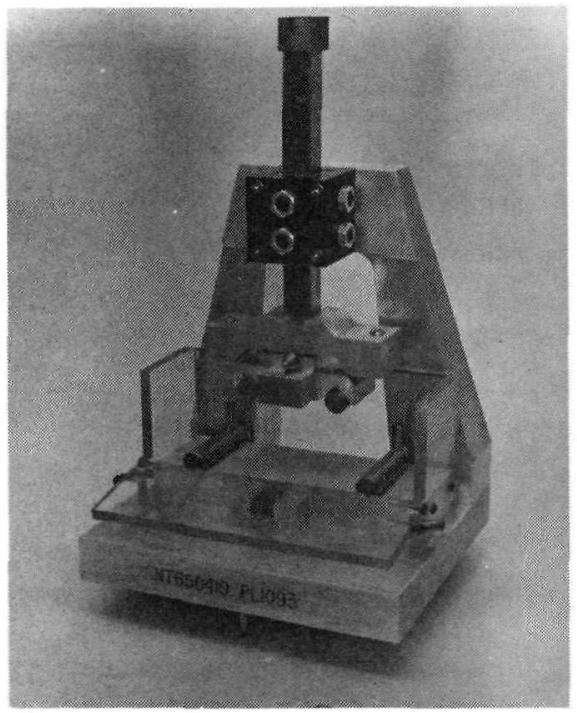

W/SAFETY ENCLOSURE 
TECHNICAL SUMMARY

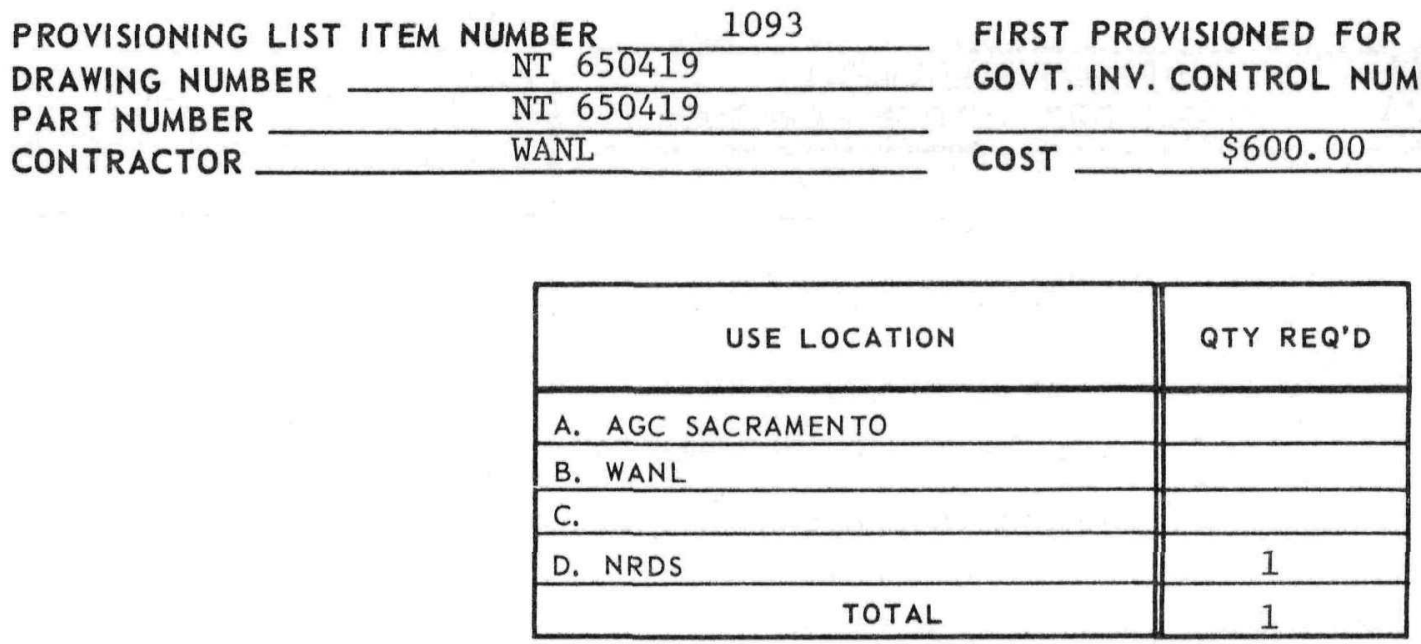

\section{DIMENSIONS AND CAPACITY}

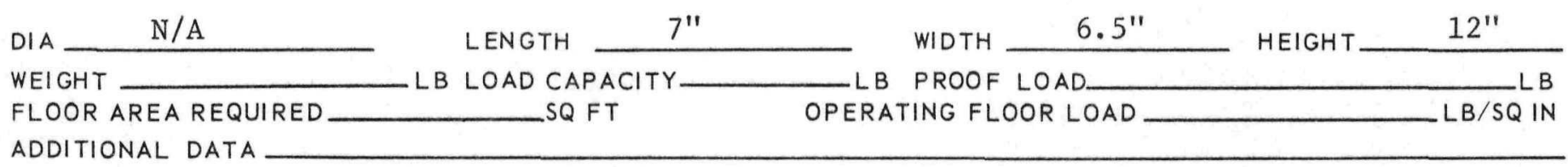

\section{OPERATING DATA}

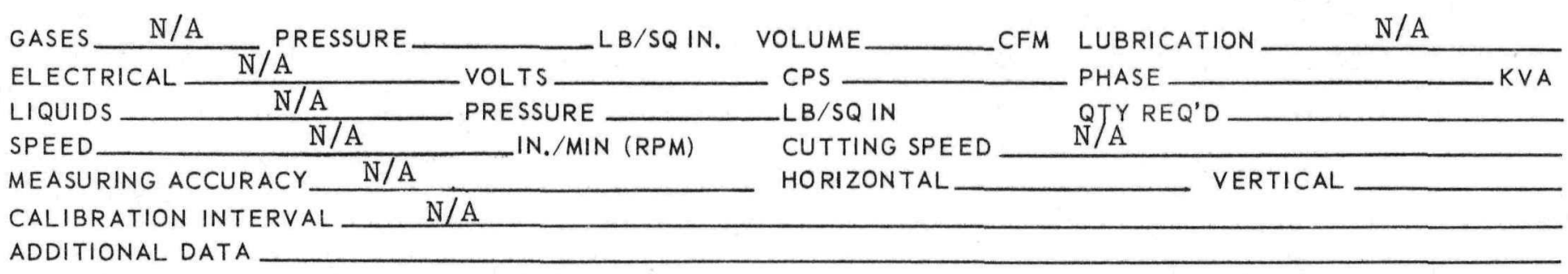

MANIPULATOR L Master/SIave LOAD CAPACITY L L L LAD CAPACITY
CRANE N/A
ADDITIONAL DATA
CRANE
ADDITIONAL DATA

EQUIPMENT_Remotely Operated Spring Tester, P/L 1032

PART OR ITEM 977D851 and D852
REMARKS $\frac{\text { URAWING NO }}{\text { during testing of each spring. }}$ during testing of each spring. 
TOOL, REMOVAL, CONTROL DRUM BEARING HOUSING BOLT

DESCRIPTION: The Control Drum Bearing Housing Bolt Removal Tool is an 18-inch long extension wrench with a 1/2-inch square drive on one end and a 7/16-inch socket on the other. An internal spring-loaded sliding shaft provides linear retraction motion while the tool is being rotated in a fixed plane.

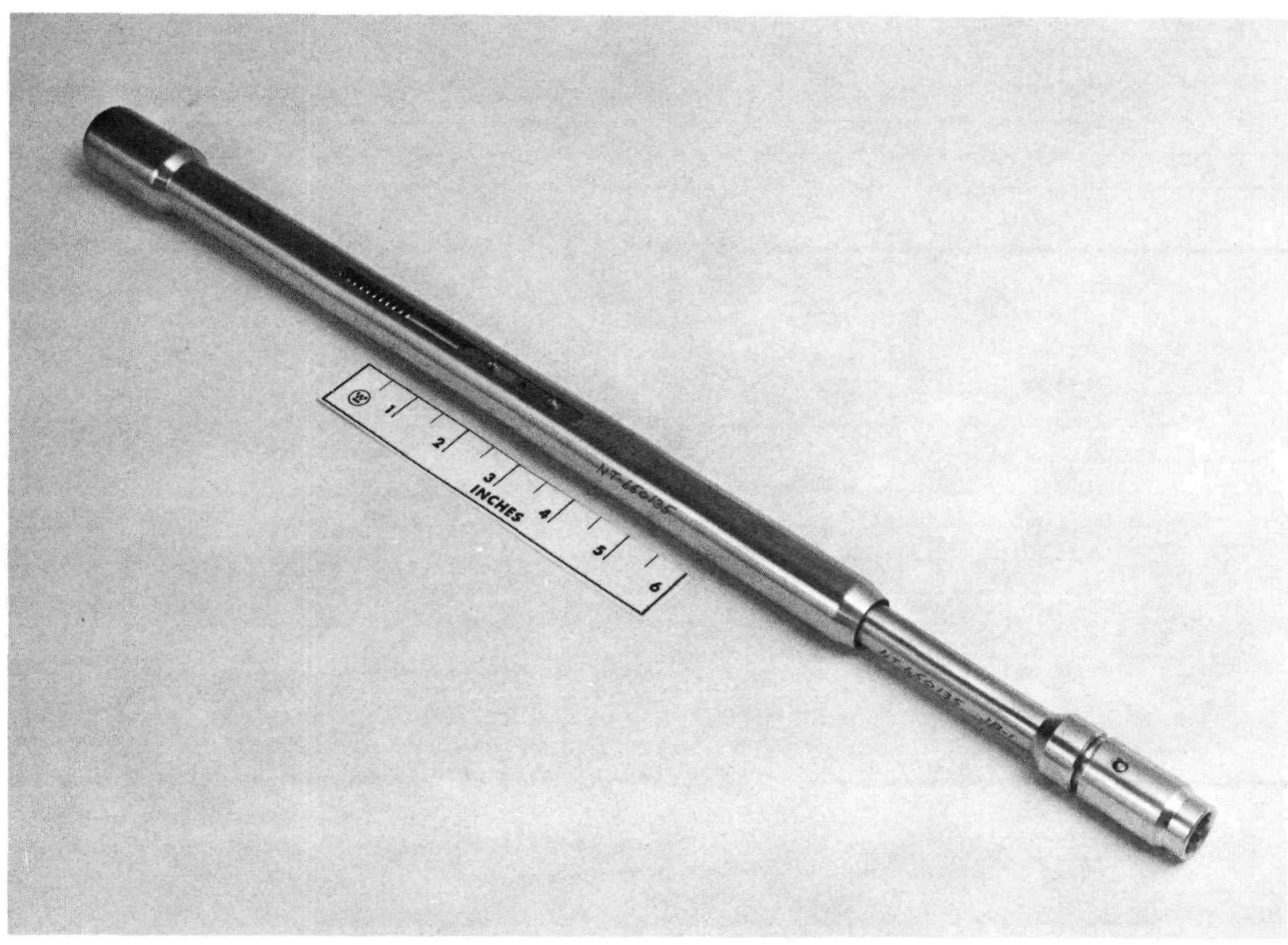


PROVISIONING LIST ITEM NUMBER

DRAWING NUMBER

PART NUMBER

CONTRACTOR
1102 NT650135 NT650135 WANL
FIRST PROVISIONED FOR $\mathrm{NRX}-\mathrm{A} 2$ GOVT. INV. CONTROL NUMBER NT650135-001 $\operatorname{cosT} \$ \$ 734.00$

\begin{tabular}{|c||c|}
\hline \multicolumn{1}{|c||}{ USE LOCATION } & QTY REQ'D \\
\hline A. AGC SACRAMENTO & \\
\hline B. WANL & \\
\hline C. & \\
\hline D. NRDS TOTAL & 1 \\
\hline \multicolumn{2}{|c|}{1} \\
\hline
\end{tabular}

\section{DIMENSIONS AND CAPACITY}

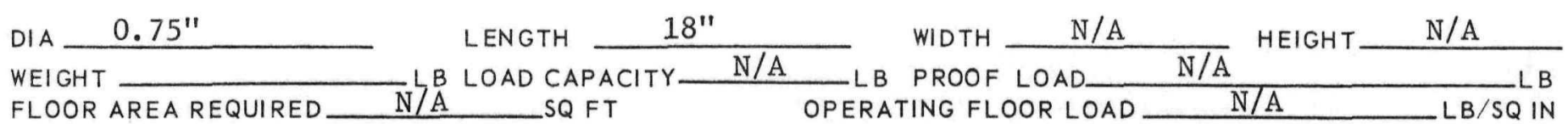
ADDITIONAL DATA

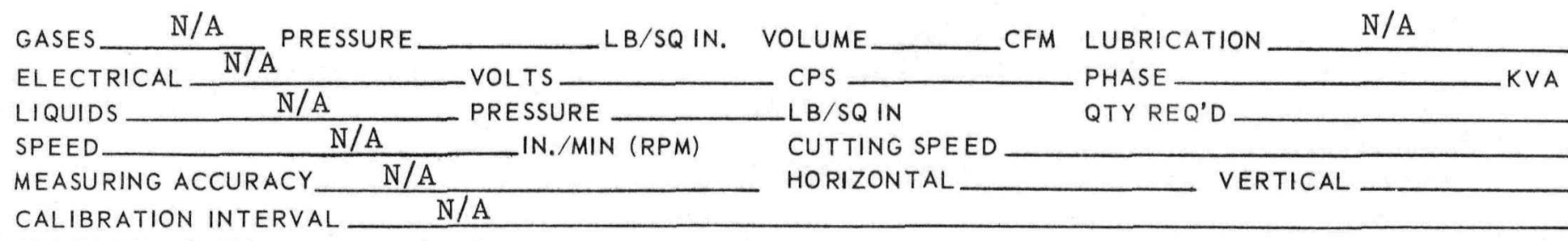
ADDITIONAL DATA

$\begin{array}{llll}\text { MANIPULATOR } & \text { Class A LOAD CAPACITY } & 65 \\ \text { CRANE L/A LOAD CAPACITY N/A } & \text { LBMAX } \\ \text { ADDITIONAL DATA } & \text { LB MAX }\end{array}$

ADDITIONAL DATA 
PROV. LIST

ITEM NO.

1103

\section{DATE}

January 1968

REVISION

\section{$B$}

EQUIPMENT TITLE

\section{TECHNICAL DESCRIPTION HANDBOOK}

FIXTURE, LIFTING, CONTROL DRUM ASSEMBLY

DESCRIPTION: The Control Drum Assembly Lifting Fixture is attached to the control-drum drive shaft coupling. This fixture uses a Class A manipulator to remove the drum from the outer reflector and to place it in a storage stand. It also lifts the control drum assembly in subsequent disassembly operations.

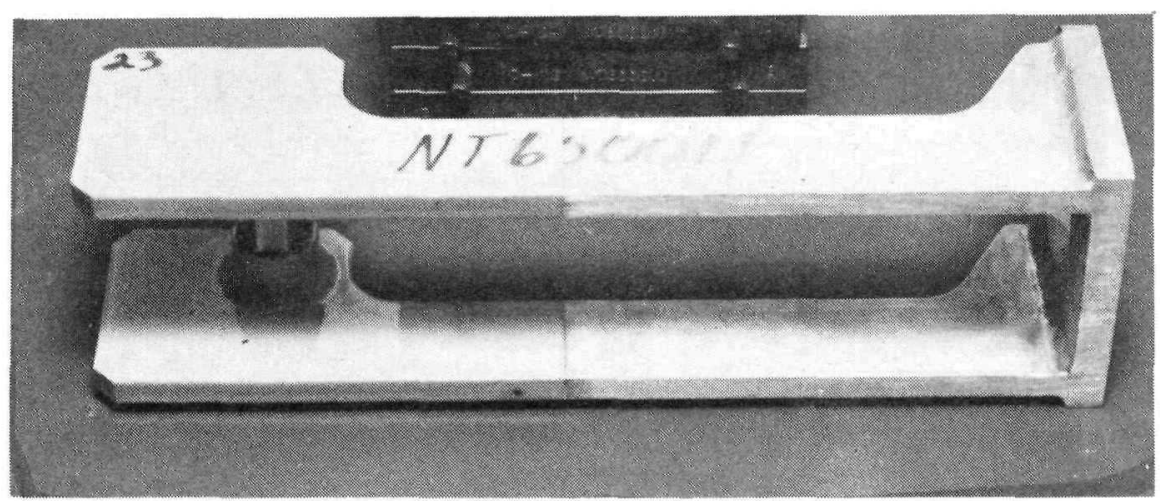


PROVISIONING LIST ITEM NUMBER DRAWING NUMBER

PART NUMBER CONTRACTOR
NT 650011

NT 650011

WANL
1103

FIRST PROVISIONED FOR NRX-A2 GOVT. INV. CONTROL NUMBER NT 650011-001

$\cos T$

\begin{tabular}{|l||c|}
\hline \multicolumn{1}{|c||}{ USE LOCATION } & QTY REQ'D \\
\hline A. AGC SACRAMENTO & \\
\hline B. WANL & \\
\hline C. & \\
\hline D. NRDS TOTAL & 1 \\
\hline
\end{tabular}

\section{DIMENSIONS AND CAPACITY}

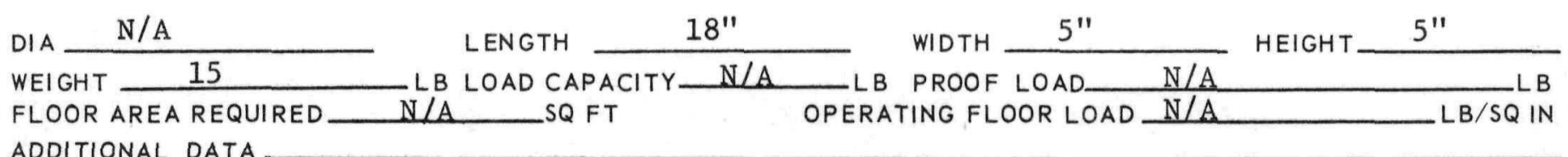
ADDITIONAL DATA

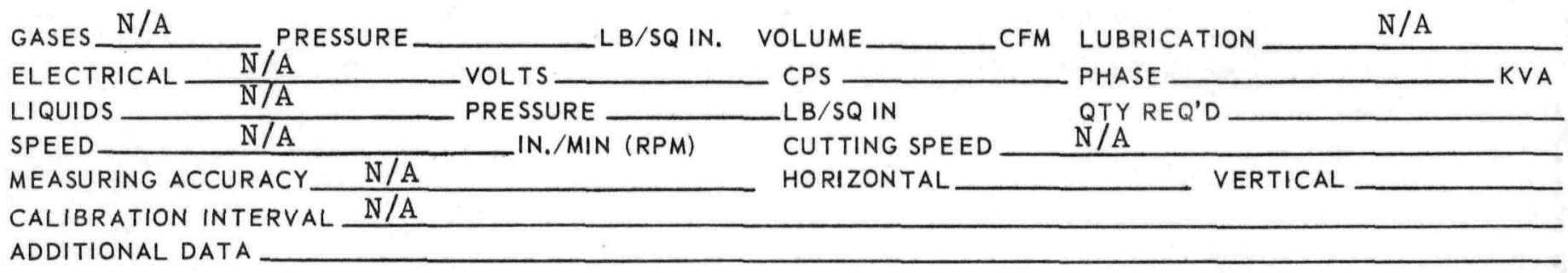

MANIPULATOR $\frac{\text { Class A }}{\text { N/A }}$

CRANE

LOAD CAPACITY 500 or 65

$B$ MAX

ADDITIONAL DATA
LOAD CAPACITY N/A

\section{INTERFACES}

EQUIPMENT_Class A Manipulator

PART OR ITEM Control Drum Coupling DRAWING NO. $928 \mathrm{~F} 578 \mathrm{HO} 1 \mathrm{~B}$

REMARKS 


\section{() NERVA LIPROGRAM \\ SUPPORT EQUIPMENT \\ TECHNICAL DESCRIPTION HANDBOOK}

EQUIPMENT TITLE

STAND, STORAGE, CONTROL DRUM ASSEMBLY
PROV. LIST

ITEM NO.

1104

DATE January 1968

REVISION

DESCRIPTION: The Control Drum Assembly Storage Stand holds 12 control drums in a vertical position. It consists of 12 flared-end cylindrical containers welded onto a base and supported by an upper plate below each tube flaring.

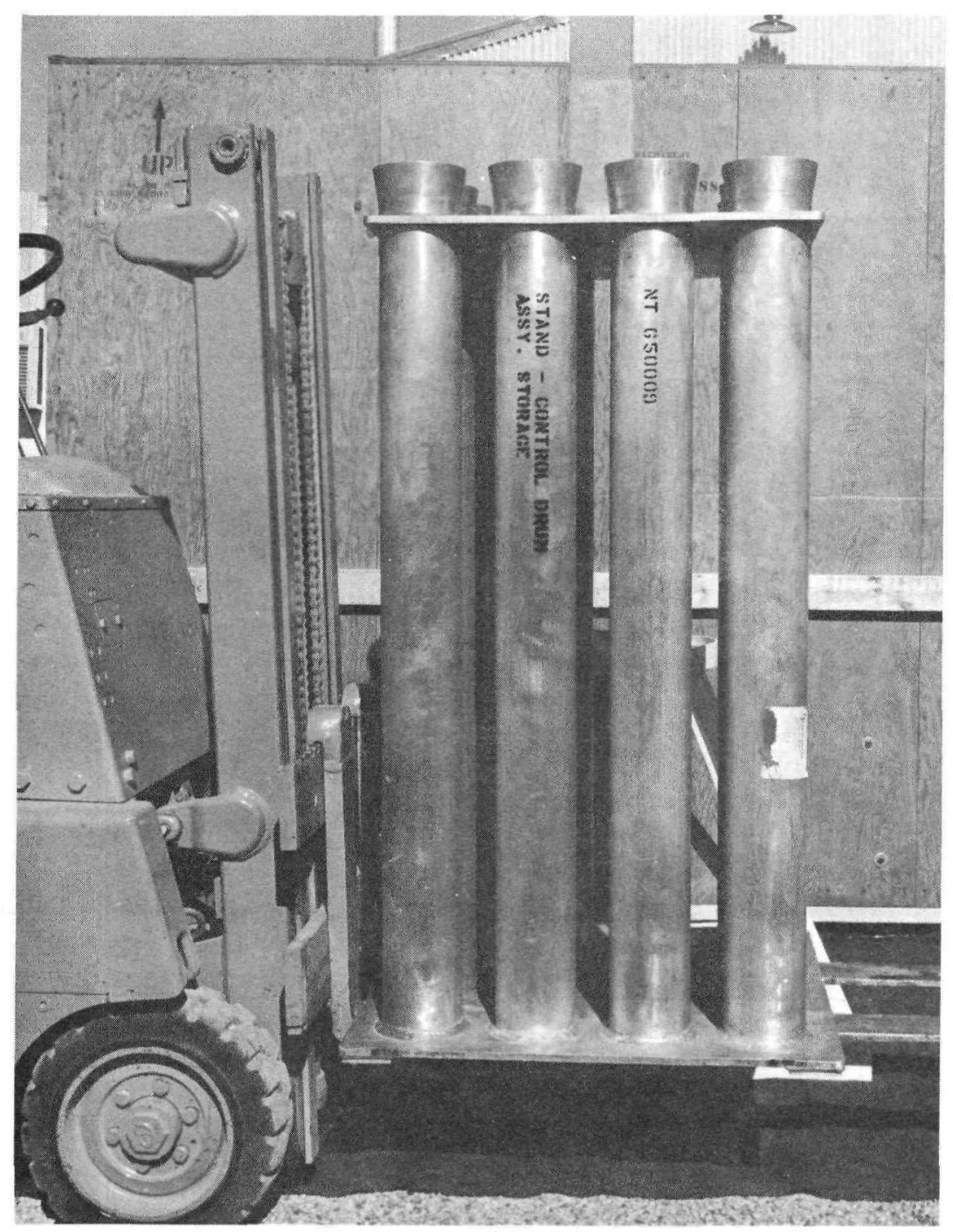


PROVISIONING LIST ITEM NUMBER 1104

DRAWING NUMBER NT 650009

PART NUMBER

CONTRACTOR
NT 650009

WANL
FIRST PROVISIONED FOR $\mathrm{NRX}-\mathrm{A} 2$ GOVT. INV. CONTROL NUMBER NT 650009-001 $\cos T-\$ 1352.00$

\begin{tabular}{|l||c|}
\hline \multicolumn{1}{|c||}{ USE LOCATION } & QTY REQ'D \\
\hline A. AGC SACRAMENTO & \\
\hline B. WANL & \\
\hline C. & \\
\hline D. NRDS TOTAL & 1 \\
\hline \multicolumn{2}{|c|}{1} \\
\hline
\end{tabular}

\section{DIMENSIONS AND CAPACITY}

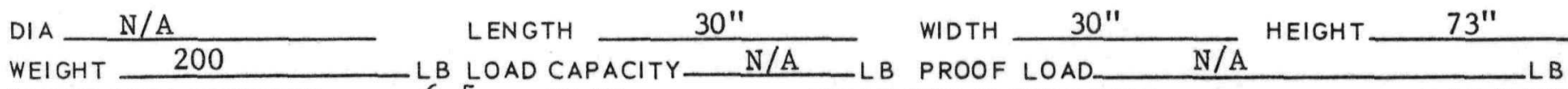
FLOOR AREA REQUIRED 6.5 SQ FT OPERATING FLOOR LOAD—LB/SQ IN ADDITIONAL DATA

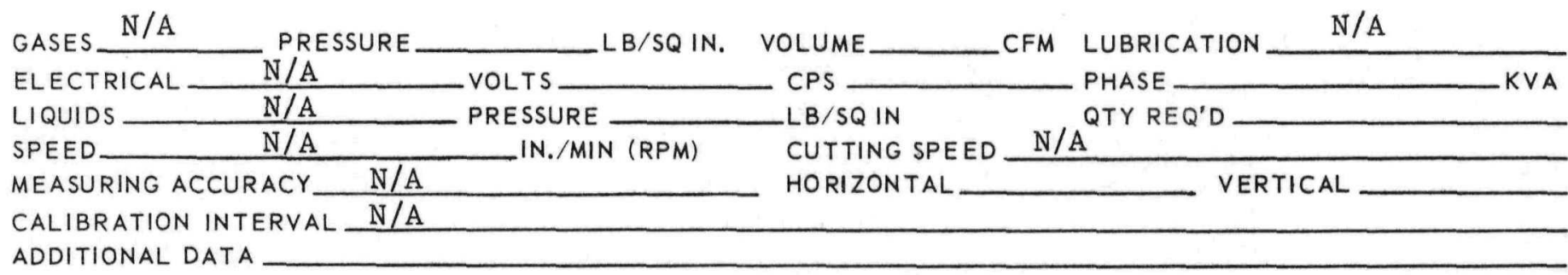




\section{(i) NERVA}

LIPROGRAM

SUPPORT EQUIPMENT

TECHNICAL DESCRIPTION HANDBOOK

EQUIPMENT TITLE

STAND, CONTROL DRUM DISASSEMBLY

DESCRIPTION: The Contro1 Drum Disassembly Stand consists of a complex of airoperated special clamps and tools for control drum disassembly operations. All are mounted on a table and provided with the necessary air hoses, controls, and connections. The stand can accept a control drum assembly in the vertical position and turn it to the horizontal position. It also permits the clamping (using air-operated trunnion clamps) and removal of all hardware components from the control drum by means of remote tools (which are an integral part of the stand) operated by a Class A manipulator.

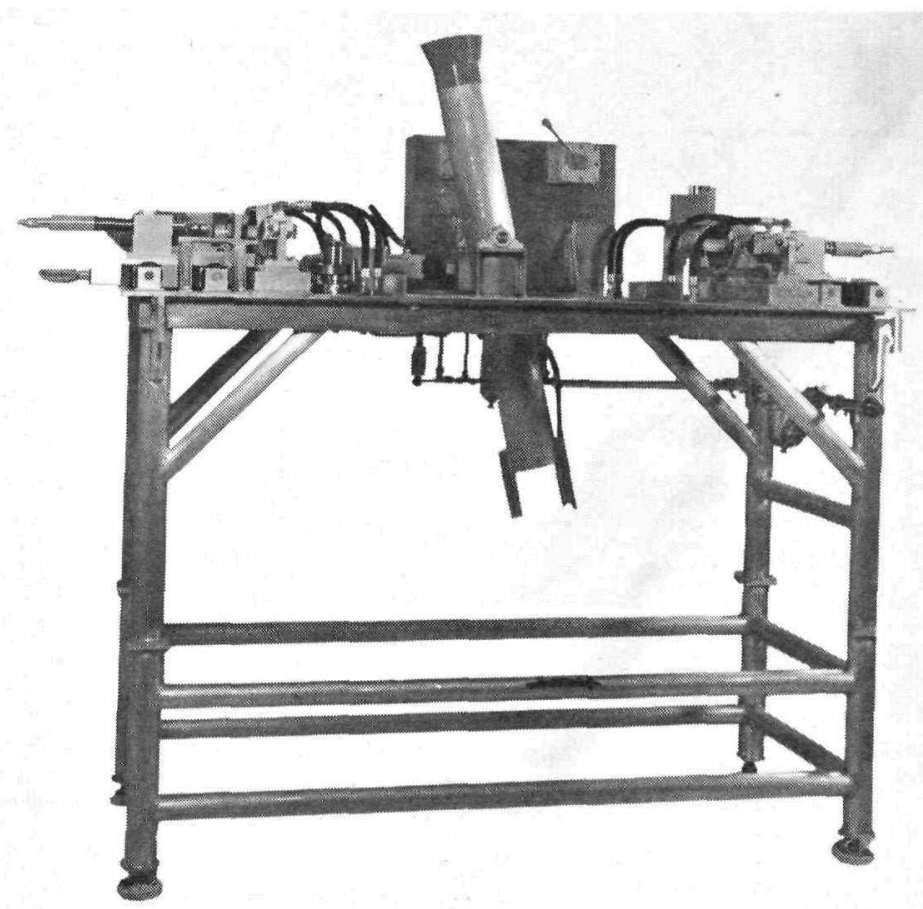


PROVISIONING LIST ITEM NUMBER

DRAWING NUMBER NT650015

PART NUMBER

CONTRACTOR
1105

NT650015

WANL
FIRST PROVISIONED FOR NRX-A2 GOVT. INV. CONTROL NUMBER NT650015-001

\begin{tabular}{|l||c|}
\hline \multicolumn{1}{|c||}{ USE LOCATION } & QTY REQ'D \\
\hline A. AGC SACRAMENTO & \\
\hline B. WANL & \\
\hline C. & 1 \\
\hline D. NROS TOTAL & 1 \\
\hline \multicolumn{2}{|c|}{} \\
\hline
\end{tabular}

DIMENSIONS AND CAPACITY

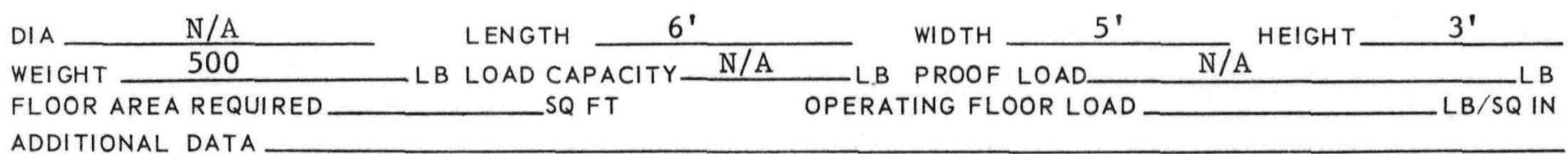

ADDITIONAL DATA

GASES Air PRESSURE 80-100 LB/SQIN. VOLUME

ELECTRICAL N/A VOLTS CPS

LIQUIDS N/A

SPEED N/A

MEASURING ACCURACY

CALIBRATION INTERVAL N/A

PRESSURE

IN./MIN (RPM)

ADDITIONAL DATA Operation and Maintenance Instruction, WANL-EOM-008
CFM LUBRICATION

PHASE KVA

$L B / S Q I N$

CUTTING SPEED

HORIZONTAL

\section{OPERATING EQUIPMENT}

MANIPULATOR Class A

LOAD CAPACITY 500 and 65

LOAD CAPACITY 10,000

L B MAX

CRANE

Class A

CRANE
ADDITIONAL DATA ${ }^{*}$ Crane is used to lift entire stand and to position it.

\section{INTERFACES}

EQUIPMENT_Handling Fixture (P/L 1229) and Manipulators

PART OR ITEM Control Drum Assembly DRAWING NO.

REMARKS 


\section{(1) NERVA IIPROGRAM \\ SUPPORT EQUIPMENT \\ TECHNICAL DESCRIPTION HANDBOOK}

EQUIPMENT TITLE

FIXTURE, LIFTING, OUTER REFLECTOR ASSEMBLY
PROV. LIST

ITEM NO.

1106

DATE

REVISION

DESCRIPTION: The Outer Reflector Lifting Fixture is a 3-legged device for lifting either the entire outer-reflector assembly with the dome-end support ring attached or the dome end support ring alone. Threaded eyebolts on the end of each leg position the movable lugs to the flange of the dome-end support ring. The eyebolts are turned by a Class A manipulator.

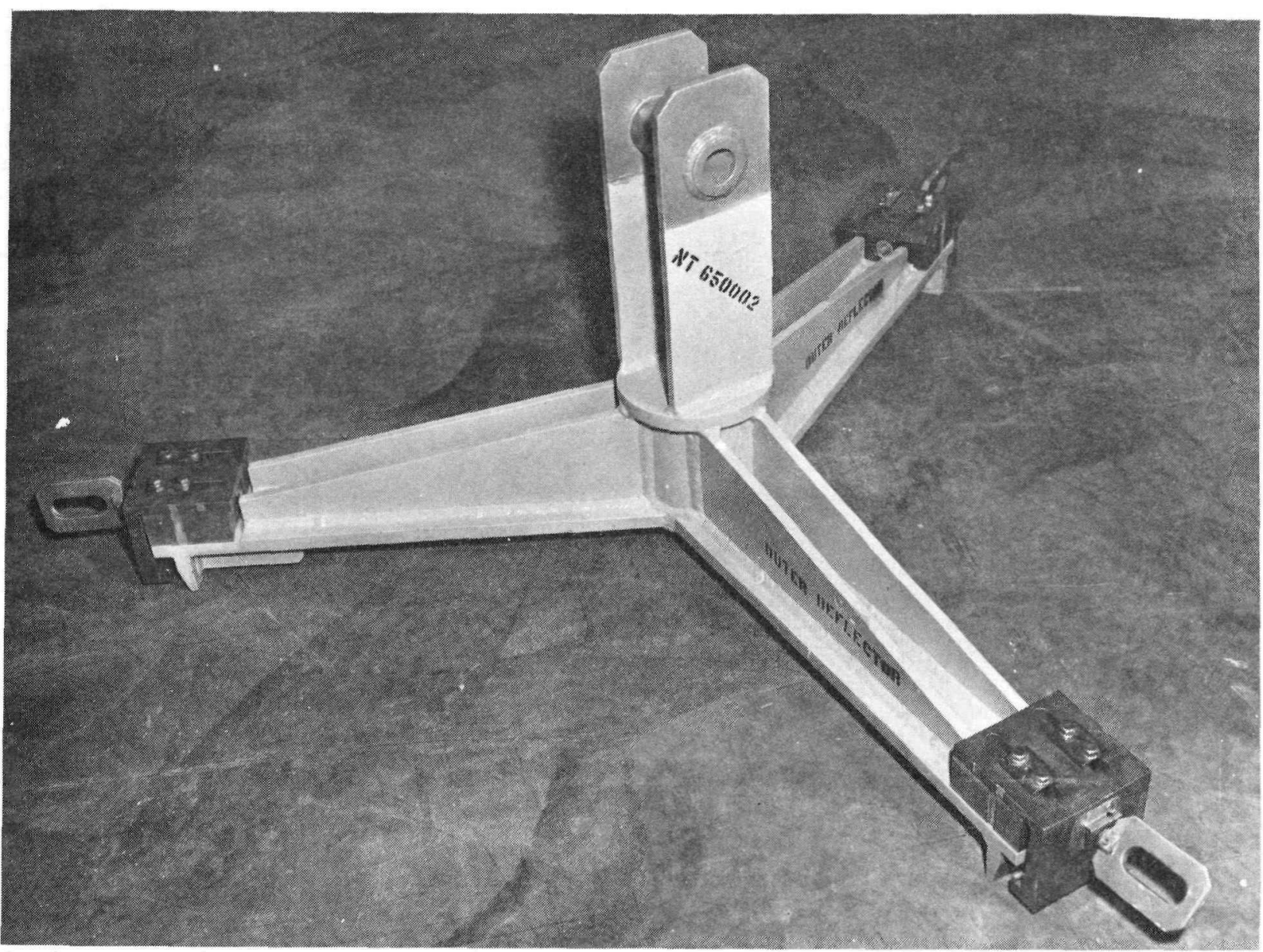


TECHNICAL SUMMARY

PROVISIONING LIST ITEM NUMBER 1106

DRAWING NUMBER NT 650002

PART NUMBER ㄴ. NT 650002

CONTRACTOR WANL

FIRST PROVISIONED FOR NRX-A2 GOVT. INV. CONTROL NUMBER NT 650002-001

$\operatorname{cosT} \$ \$ 1755.00$

\begin{tabular}{|l||c|}
\hline \multicolumn{1}{|c||}{ USE LOCATION } & QTY REQ'D \\
\hline A. AGC SACRAMENTO & \\
\hline B. WANL & \\
\hline C. & \\
\hline D. NRDS TOTAL & 1 \\
\hline
\end{tabular}

DIMENSIONS AND CAPACITY

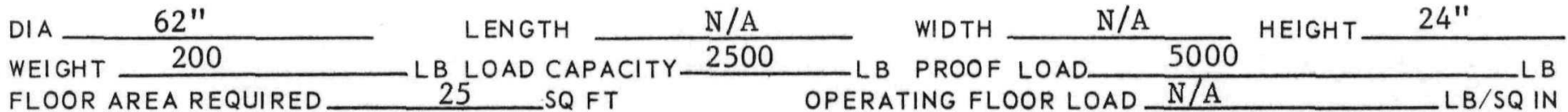
ADDITIONAL DATA

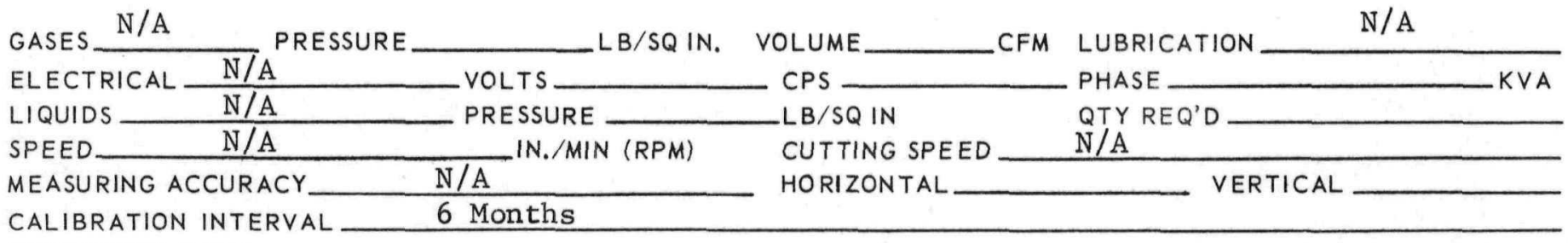
ADDITIONAL DATA

MANIPULATOR Class A

CRANE

ADDITIONAL DATA
LOAD CAPACITY_ 65

LOAD CAPACITY
LB MAX

L. B MAX

\section{INTERFACES}

EQUIPMENT Crane and Class A Manipulator

PART OR ITEM Dome End Support Assembly and

REMARKS

Outer Reflector

DRAWING NO. 937J081G01 
PROV. LIST

ITEM NO.

1110

(1) NERVA

SUPPORT EQUIPMENT

DATE

TECHNICAL DESCRIPTION HANDBOOK

EQUIPMENT TITLE

REVISION C

FIXTURE, LIFTING, OUTER REFLECTOR SECTOR

DESCRIPTION: The Outer Reflector Sector Lifting Fixture is used to lift an outer reflector sector by first entering the control-drum cavity, then expanding to obtain a frictional grip on the cavity wall through neoprene-covered friction shoes. The fixture is comprised of three major items: the lifting fixture assembly, a storage stand and a test fixture. The frictional gripping mechanism is operated by rotating the lifting bail approximately $90^{\circ}$ after releasing the shaft lock with a Class $\mathrm{A}$ manipulator.

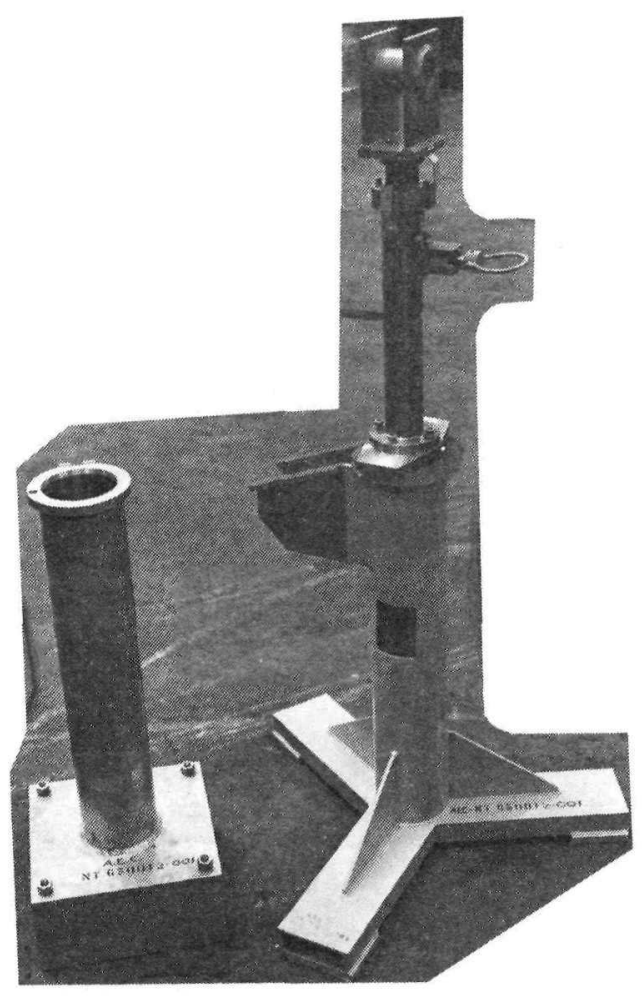


PROVISIONING LIST ITEM NUMBER

DRAWING NUMBER

PART NUMBER

CONTRACTOR
1110 NT650012 NT650012 WANL
FIRST PROVISIONED FOR NRX-A2 GOVT. INV. CONTROL NUMBER

\begin{tabular}{|r||c|}
\hline \multicolumn{1}{|c||}{ USE LOCATION } & QTY REQ'D \\
\hline A. AGC SACRAMENTO & \\
\hline B. WANL & \\
\hline C. & 1 \\
\hline D. NRDS TOTAL & 1 \\
\hline
\end{tabular}

DIMENSIONS AND CAPACITY

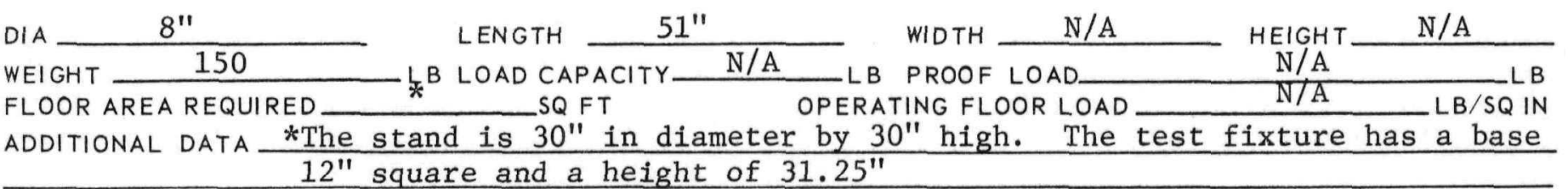

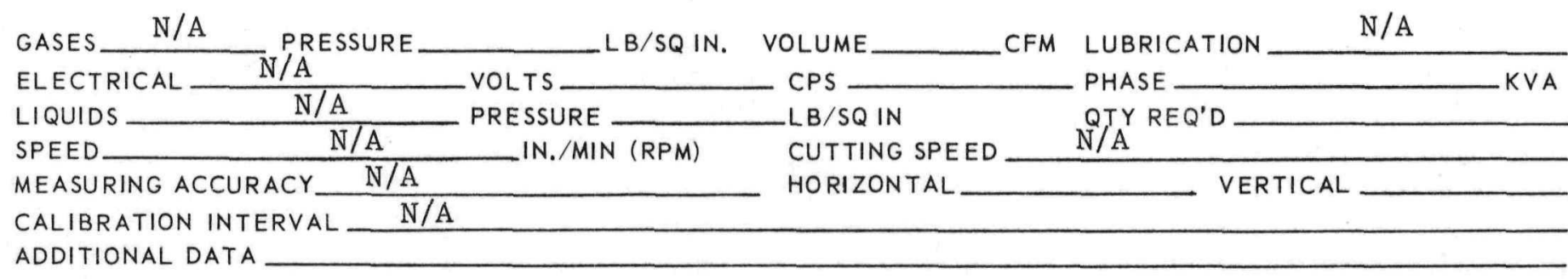

\section{OPERATING EQUIPMENT}

MANIPULATOR Class A LOAD CAPACITY 500 and 65 LB MAX CRANE_ N/A ADDITIONAL DATA Class A manipulators are used to lock the item to the reflector sector,
and to unlock the frictional shoe operating mechanism. 


\section{(1) NERVA PROGRAM SUPPORT EQUIPMENT TECHNICAL DESCRIPTION HANDBOOK}

EQUIPMENT TITLE

STAND, CYLINDER SLITTING
PROV. LIST

ITEM NO.

1123

DATE

January 1968

REVISION $\mathrm{K}$

DESCRIPTION: The Cylinder Slitting Stand receives the core assembly and supports it for removal of the cluster nuts, core support plates, and the inner reflector hold-down spring components. It is capable of trunnioning the core assembly 90 degrees to a horizontal position and continuous rotation around the longitudinal axis of the cylinder. The cutting head has feed, traverse, and plunge-cut action and is equipped with a vacuum cleaning unit for removal of cutting dust. The top section of the stand cage can be elevated for component removal when positioned horizontally.

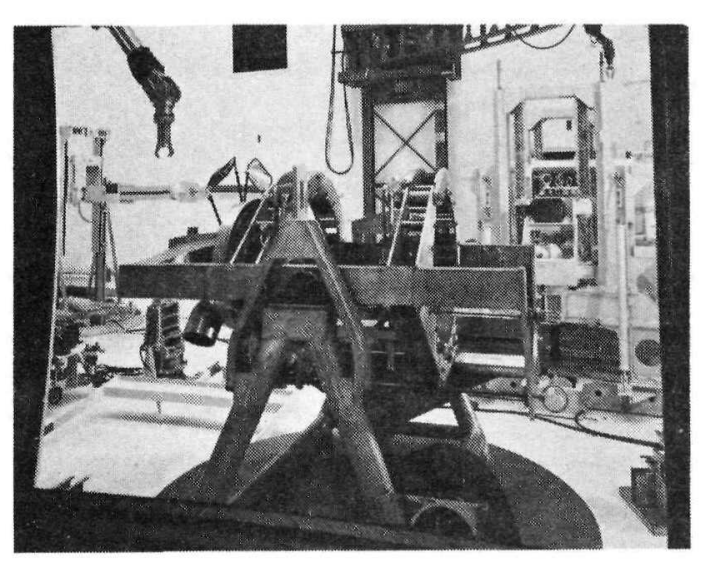

SIDE VIEW

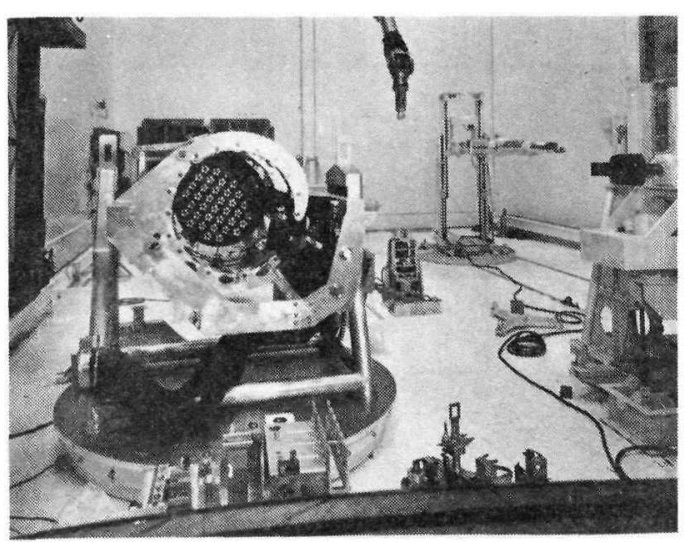

END VIEW 
PROVISIONING LIST ITEM NUMBER

DRAWING NUMBER

PART NUMBER

CONTRACTOR
1123

NT650060

NT650060

WANL
FIRST PROVISIONED FOR

$\mathrm{NRX}-\mathrm{A} 2$

GOVT. INV. CONTROL NUMBER NT650060-001

Cost $\$ 99,743.00$ (Includes Modification)

\begin{tabular}{|l||c|}
\hline \multicolumn{1}{|c||}{ USE LOCATION } & QTY REQ'D \\
\hline A. AGC SACRAMENTO & \\
\hline B. WANL & \\
\hline C. & 1 \\
\hline D. NRDS TOTAL & 1 \\
\hline
\end{tabular}

\section{DIMENSIONS AND CAPACITY}

DIA

LENGTH

$10^{\prime}$

WIDTH $9^{\prime}, 4^{\prime \prime}$ HEIGHT $7^{\prime}, 8^{\prime \prime}$ WEIGHT LB LOAD CAPACITY 2600 L FLOOR AREA REQUIRED_ 100 SQ FT OPERATING FLOOR LOAD $65 \quad 6$ ADDITIONAL DATA

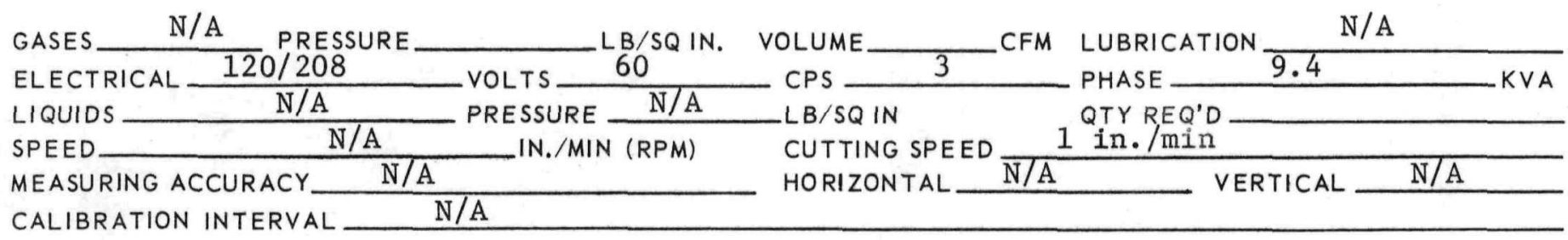
ADDITIONAL DATA

OPERATING EQUIPMENT

MANIPULATOR

CRANE

ADDITIONAL DATA
Class A

$\star$
LOAD CAPACITY

LOAD CAPACITY
65

50,000 or 10,000

LB MAX

LB MAX
EQUIPMENT

PART OR ITEM

REMARKS
Cylinder Slitting stand Handling Fixture

1172

DRAWING NO.
NT650124 
PROV. LIST

ITEM NO.

1126

DATE

January 1968 TECHNICAL DESCRIPTION HANDBOOK

EQUIPMENT TITLE
A

STAND, STORAGE, INNER SHIPPING CONTAINER

DESCRIPTION: The Inner Shipping Container Storage Stand is a structural-steel stand designed to support a loaded inner portion of the reactor shipping container by the three lugs of the inner container. It also provides personnel access to the dome end of the reactor when the container cover is removed. The stand has a circular opening in the center to receive the inner container. A handrail, one section of which is removable, encloses the work platform. The legs of the stand are provided with leveling jacks. A ladder is attached for access.

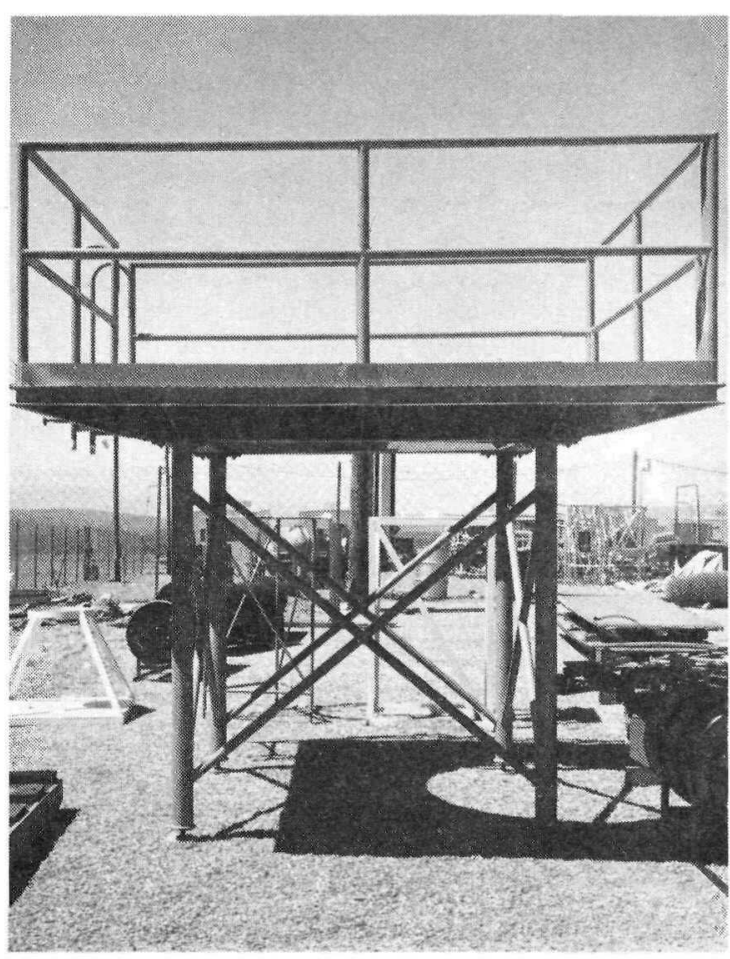




\section{TECHNICAL SUMMARY}

PROVISIONING LIST ITEM NUMBER 1126

DRAWING NUMBER

PART NUMBER

CONTRACTOR
NT650006

\section{NT650006}

WANL
FIRST PROVISIONED FOR NRX-AI GOVT. INV. CONTROL NUMBER NT650006-001

\section{$\$ 1219.00$}

\begin{tabular}{|l||c|}
\hline \multicolumn{1}{|c||}{ USE LOCATION } & QTY REQ'D \\
\hline A. AGC SACRAMENTO & \\
\hline B. WANL & \\
\hline C. & \\
\hline D. NRDS TOTAL & 1 \\
\hline
\end{tabular}

\section{DIMENSIONS AND CAPACITY}

DIA

WEIGHT ADDITIONAL DATA

\section{LENGTH} $10^{\prime}$ LB LOAD CAPACITY N/A $100 \quad S Q F T$
WIDTH $10^{\prime}$
N/A HEIGHT $9^{\prime}$

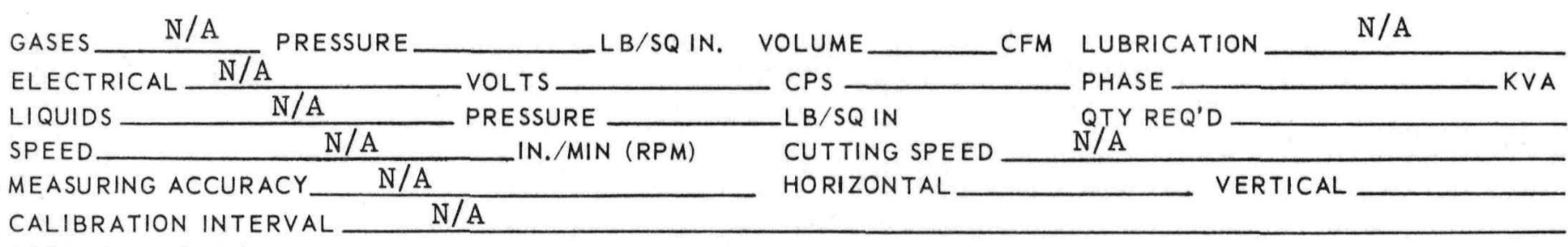

ADDITIONAL DATA

MANIPULATOR N/A

CRANE N/A

ADDITIONAL DATA
LOAD CAPACITY LOAD CAPACITY LB MAX LB MAX

INTERFACES

EQUIPMENT

Portable Crane

PART OR ITEM Inner Container DRAWING NO. 


\section{(1) NERVA \\ LIPROGRAM \\ SUPPORT EQUIPMENT \\ TECHNICAL DESCRIPTION HANDBOOK}

EQUIPMENT TITLE

STAND, CLOSURE/CONTROL
PROV. LIST

ITEM NO.

1132

DATE January 1968

REVISION B

DESCRIPTION: The Closure/Control Stand consists of a three-legged steel-pipe stand, a top ring and clamp assembly (composed of 12 shaft-retainer brackets) and three clamps. A ring and pad are also provided to support the vessel closure. Three locating plugs facilitate centering on the portable turntable. The design also includes a load ring assembly, which may be raised or lowered remotely, and an elevator drive assembly used to raise and lower the load ring assembly.

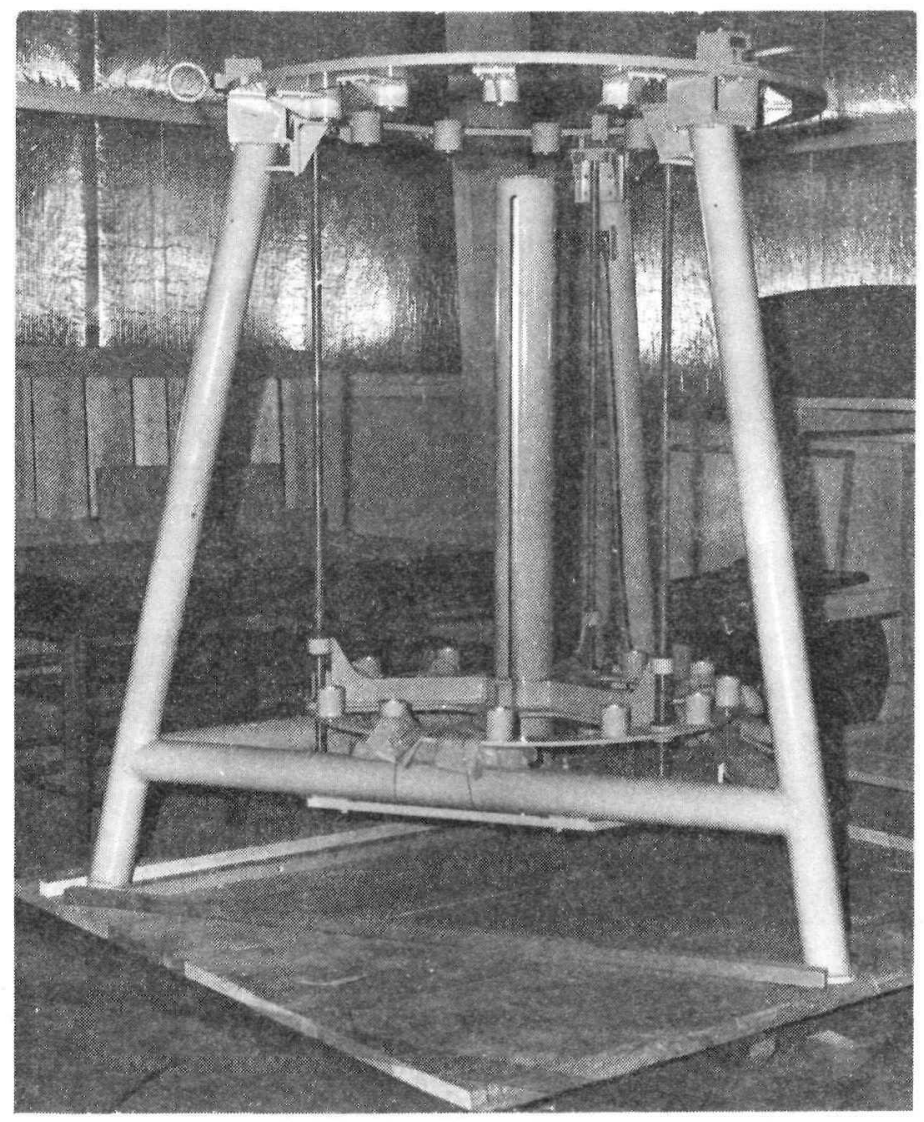


PROVISIONING LIST ITEM NUMBER

1132

DRAWING NUMBER

PART NUMBER

CONTRACTOR
3-510221

WANL/ACFI
FIRST PROVISIONED FOR

$\mathrm{NRX}-\mathrm{A} 2$

\section{GOVT. INV. CONTROL NUMBER}

$\cos T$

\begin{tabular}{|l||c|}
\hline \multicolumn{1}{|c||}{ USE LOCATION } & QTY REQ'D \\
\hline A. AGC SACRAMENTO & \\
\hline B. WANL & \\
\hline C. & 1 \\
\hline D. NRDS TOTAL & 1 \\
\hline \multicolumn{2}{|c||}{} \\
\hline
\end{tabular}

\section{DIMENSIONS AND CAPACITY}

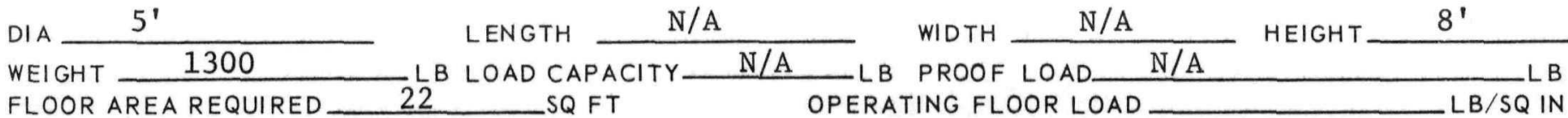
ADDITIONAL DATA

GASES N/A PRESSURE

ELECTRICAL $\frac{220 / 440}{N / A}$

LIQUIDS

SPEED

MEASURING ACCURACY N/A

CALIBRATION INTERVAL

ADDITIONAL DATA

N/A

LB/SQIN. VOLUME 60 VOLTS
PRESSURE IN./MIN (RPM)

(A
N/A
CPS

LB/SQ IN

CUTTING SPEED

HORIZONTAL
CFM LUBRICATION

PHASE

NTY REQ'D 
PROV. LIST

ITEM NO.

1135

DATE

January 1968

REVISION $\quad$ C

EQUIPMENT TITLE

FIXTURE, HANDLING, SHIELD

DESCRIPTION: The Shield Handling Fixture is a strongback used to pick up either the simulated shield or the reactor shield. The three pick-up points engage lifting lugs, located $120^{\circ}$ apart, which can be operated manually or by a manipulator. Positive locks are incorporated with the lugs. The fixture can be used with either an overhead crane or a Class A manipulator.

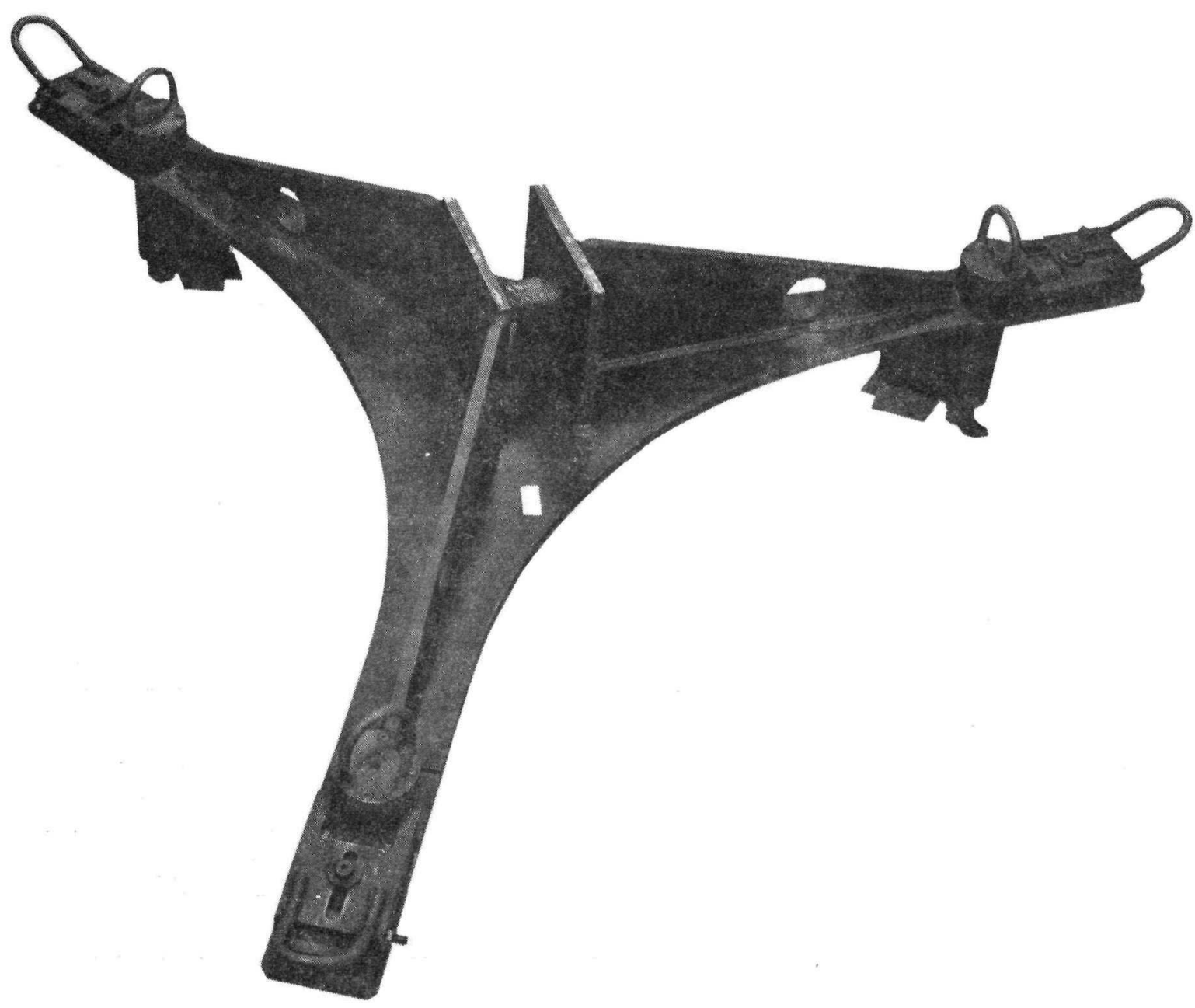


PROVISIONING LIST ITEM NUMBER

1135

DRAWING NUMBER

PART NUMBER

CONTRACTOR

$\frac{3-509800}{3-509800}$

FIRST PROVISIONED FOR NRX-A1 GOVT. INV. CONTROL NUMBER 3-509800-001 $\cos T$

\begin{tabular}{|l||l|}
\hline \multicolumn{1}{|c||}{ USE LOCATION } & QTY REQ'D \\
\hline A. AGC SACRAMENTO & \\
\hline B. WANL & \\
\hline C. & \\
\hline D. NRDS TOTAL & 1 \\
\hline \multicolumn{2}{|c|}{1} \\
\hline
\end{tabular}

\section{DIMENSIONS AND CAPACITY}

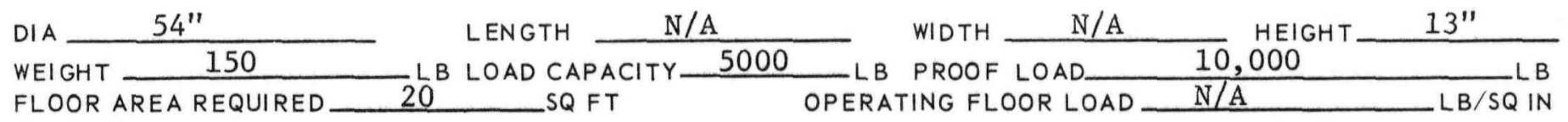

ADDITIONAL DATA

\begin{tabular}{|c|c|c|c|}
\hline PRESSURE & \multirow{2}{*}{ PRESSURE_L L $L / S Q I N$. } & \multirow{2}{*}{ VOLUME_CFM } & LUBRICATION N N/A \\
\hline ELECTRICAL N/A & & & PHASE \\
\hline LIQUIDS & PRESSURE & $L B / S Q I N$ & QTY REQ'D \\
\hline SPEED & IN./MIN (RPM) & CUTTING SPEED & $\mathrm{N} / \mathrm{A}$ \\
\hline MEASURING ACCURACY N/A & & HORIZONTAL & - VERTICAL \\
\hline CALIBRATION INTERVAL N/A & & & \\
\hline
\end{tabular}
ADDITIONAL DATA

MANIPULATOR Class A

CRANE

ADDITIONAL DATA
LOAD CAPACITY LOAD CAPACITY
LB MAX LB MAX 


\section{(1) NERVA \\ LIPROGRAM \\ SUPPORT EQUIPMENT \\ TECHNICAL DESCRIPTION HANDBOOK}

EQUIPMENT TITLE
PROV. LIST

ITEM NO.

1139

DATE

January 1968

REVISION B

DESCRIPTION: The Inspection Equipment consists of typical, standard precision hand-tools: e.g., vernier calipers, inside and outside micrometers, thread micrometers, depth micrometers, hole micrometers, and dial gages.

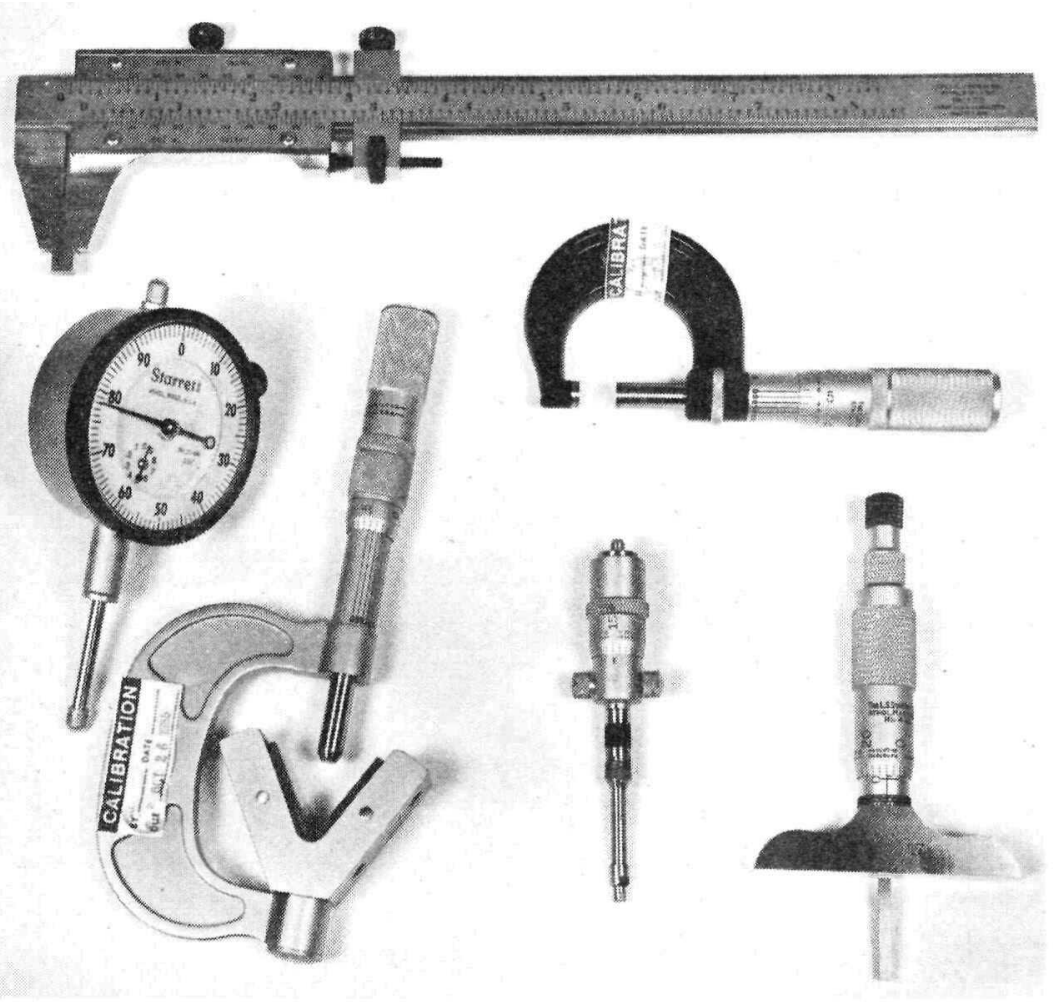




\section{TECHNICAL SUMMARY}

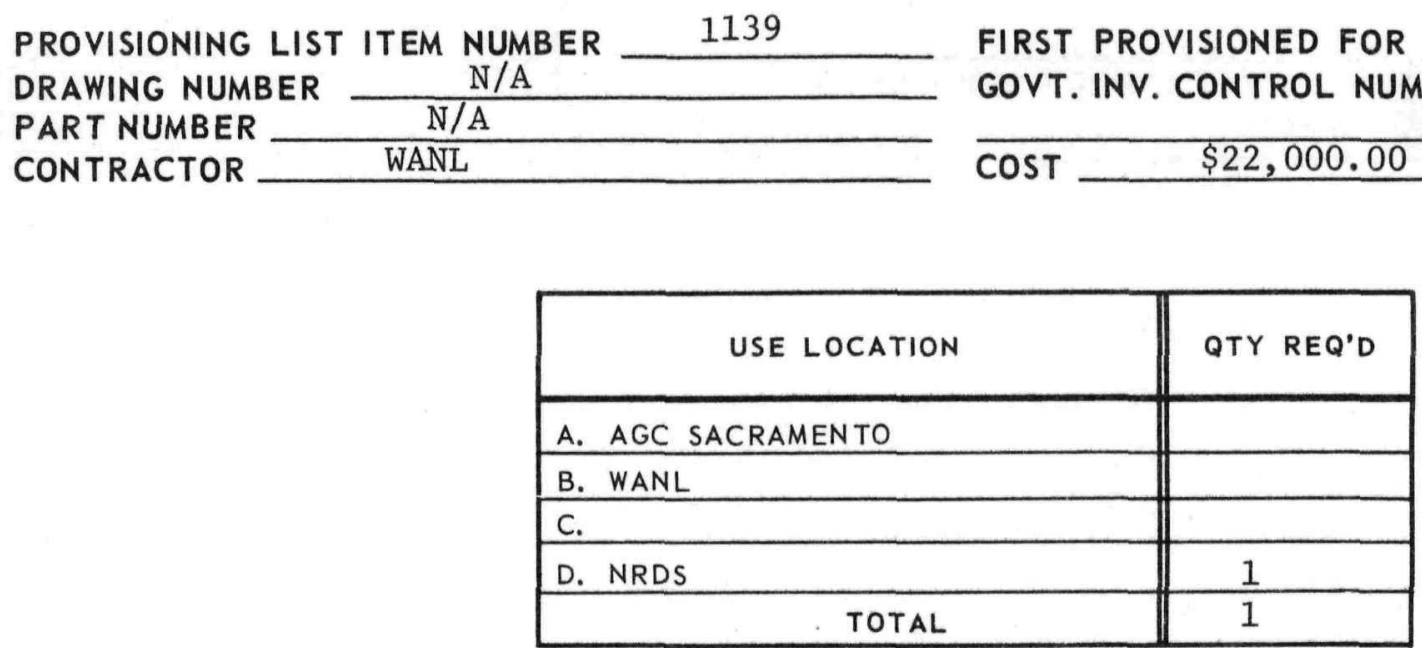

\section{DIMENSIONS AND CAPACITY}

DIA

WEIGHT

FLOOR AREA REQUIRED

ADDITIONAL DATA
LENGTH WIDTH

LENGTH WIDTH

LB LOAD CAPACITY SQ FT

- LB PROOF LOAD. OPERATING FLOOR LOAD
$\mathrm{NRX}-\mathrm{A} 1$

ER 


\section{(1) NERVA \\ IIPROGRAM \\ SUPPORT EQUIPMENT \\ TECHNICAL DESCRIPTION HANDBOOK}

EQUIPMENT TITLE
PROV. LIST

ITEM NO.

DATE

REVISION
1143

January 1968

B

FIXTURE, HANDLING, REACTOR ASSEMBLY

DESCRIPTION: The Reactor Assembly Handling Fixture handles the reactor assembly by three lugs which engage the underside of the core support plate when the reactor is in the nozzle-down position. The fixture is a rigid, three-legged, welded-steel device with a centrally located lifting bail, designed for manual operation with an overhead crane or for remote operation with a Class A manipulator and overhead crane. Positive locking and lifting-lug position indication are provided to insure safe handling of the reactor assembly.

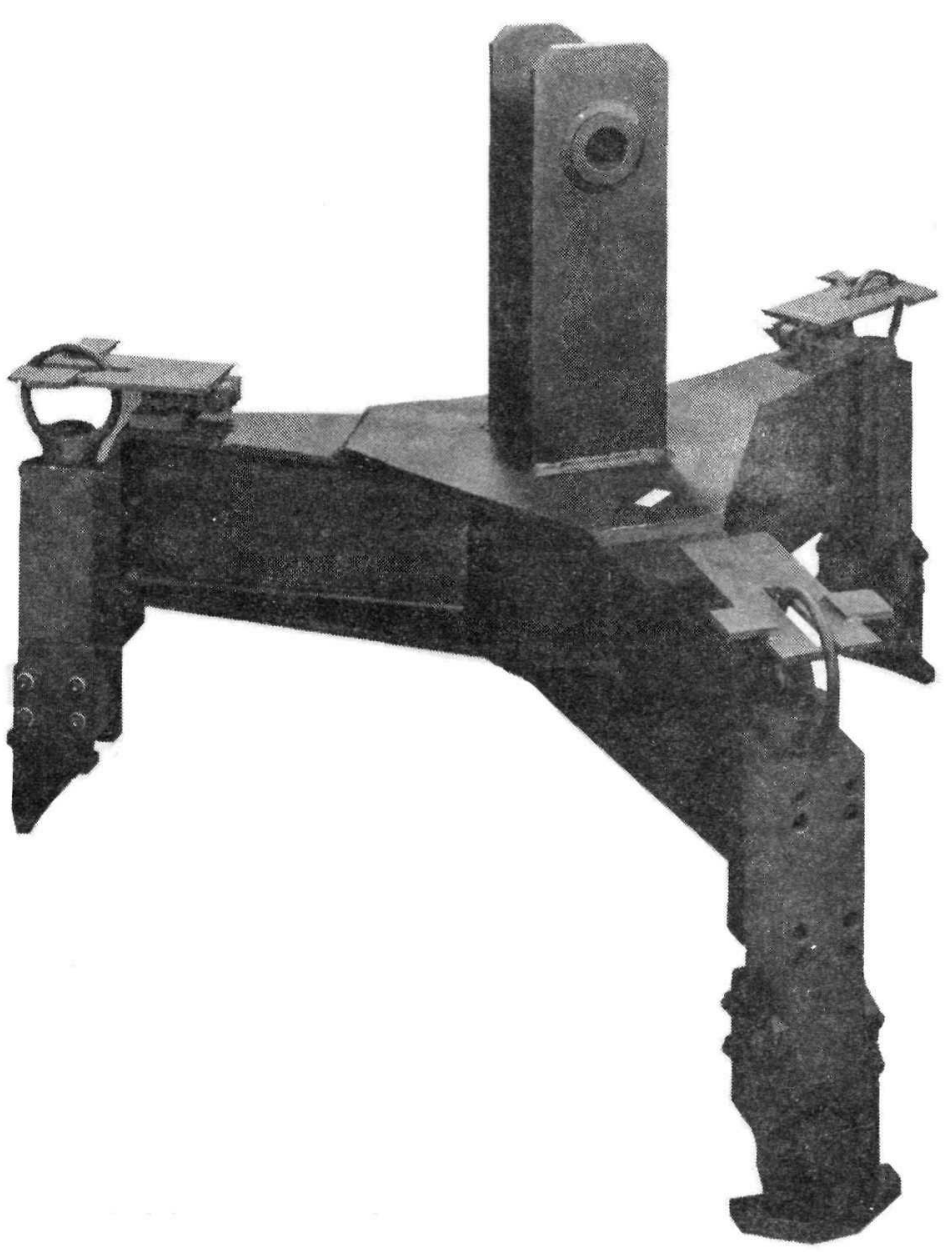


PROVISIONING LIST ITEM NUMBER 1143

DRAWING NUMBER

PART NUMBER

CONTRACTOR
NT650000

NT650000

WANL
FIRST PROVISIONED FOR NRX-AI GOVT. INV. CONTROL NUMBER NT650000-001 $\operatorname{cosT} \quad \$ 1372.00$

\begin{tabular}{|l||c|}
\hline \multicolumn{1}{|c|}{ USE LOCATION } & QTY REQ'D \\
\hline A. AGC SACRAMENTO & \\
\hline B. WANL & \\
\hline C. & 1 \\
\hline D. NRDS TOTAL & 1 \\
\hline
\end{tabular}

\section{DIMENSIONS AND CAPACITY}

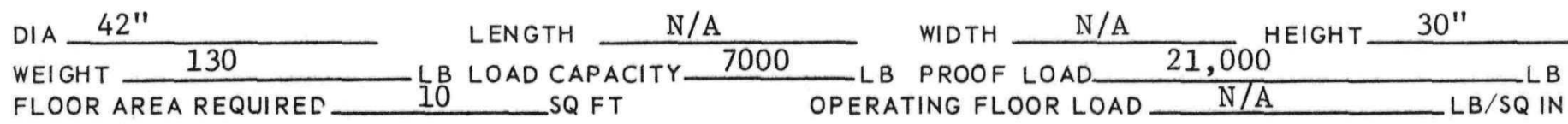

ADDITIONAL DATA

GASES_N N/A ELECTRICAL LIQUIDS SPEED MEASURING ACCURACY $\mathrm{N} / \mathrm{A}$ N/A $\mathrm{N} / \mathrm{A}$ CALIBRATION INTERVAL ADDITIONAL DATA
LB/SQIN. VOLUME VOLTS

PRESSURE IN./MIN (RPM) N/A

CPS

$-L B / S Q I N$

CUTTING SPEED

HORIZONTAL
CFM

LUBRICATION

N/A

PHASE

KVA

QTY $\underset{N}{\mathrm{R}} \mathrm{Q}^{\prime} \mathrm{D}$

VERTICAL

\section{OPERATING EQUIPMENT}

MANIPULATOR Class A

CRANE

ADDITIONAL DATA
LOAD CAPACITY

LOAD CAPACITY $\quad 50,000$

LB MAX

$L B M A X$

\section{INTERFACES}

EQUIPMENT_Crane and Class A Manipulator

PART OR ITEM Reactor Assembly

DRAWING NO. 937J250G01A

REMARKS 


\section{() NERVA LIPROGRAM SUPPORT EQUIPMENT TECHNICAL DESCRIPTION HANDBOOK}

EQUIPMENT TITLE

PALLET, SIMULATED SHIELD
PROV. LIST

ITEM NO.

1145

DATE

$\frac{\text { January } 1968}{\text { REVISION }}$

DESCRIPTION: The Simulated Shield Pallet is an aluminum structure fitted with neoprene pads to protect the simulated shield while it is moved. The pallet consists of a ring (supported and reinforced with a triangular truss) and fitted with lifting eyes on three vertical support arms.

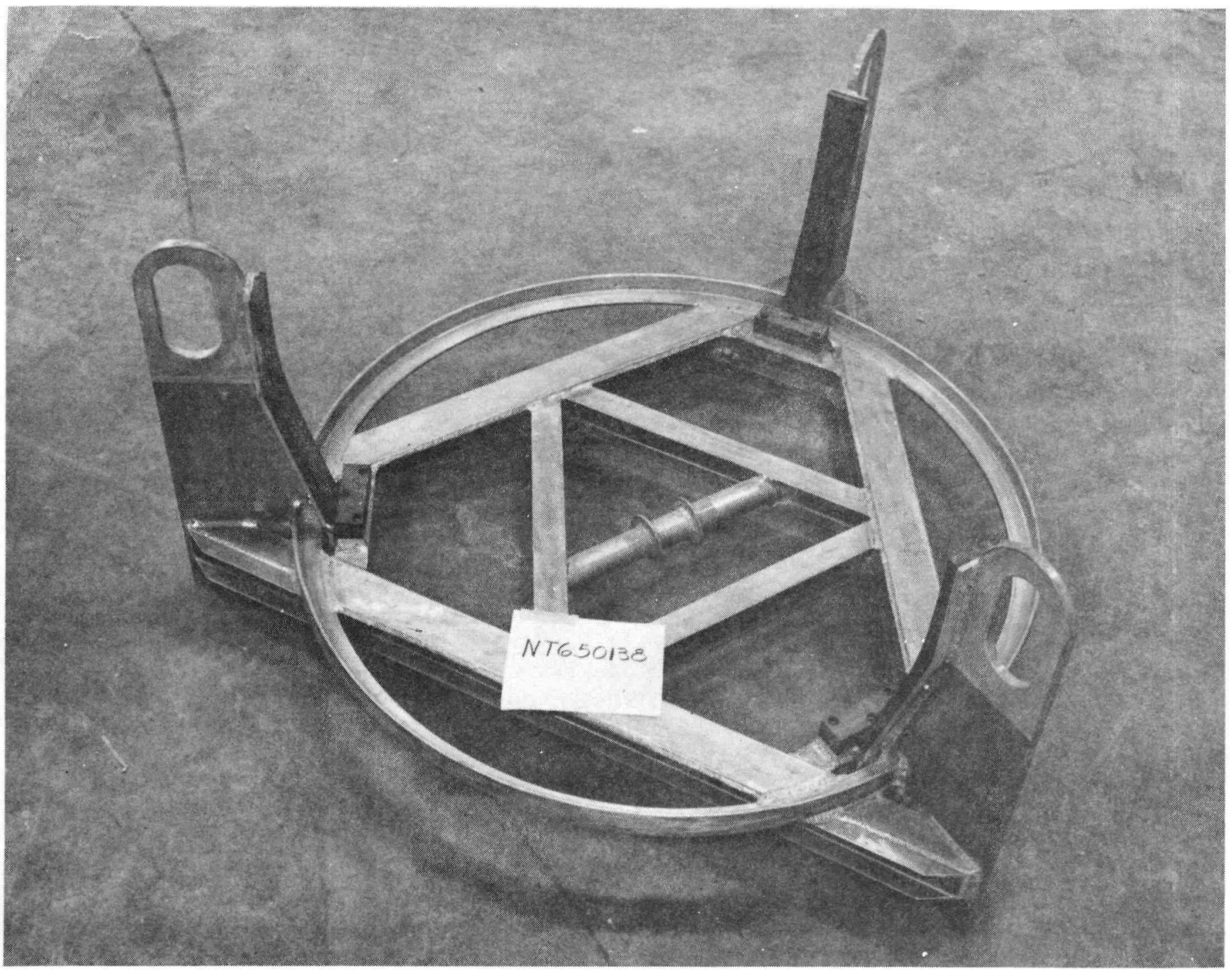


PROVISIONING LIST ITEM NUMBER

DRAWING NUMBER

PART NUMBER

CONTRACTOR
1145

NT650138

NT650138

WANL
FIRST PROVISIONED FOR NRX-A2 GOVT. INV. CONTROL NUMBER NT650138-001

COST $\$ 1115.00$

\begin{tabular}{|l||c|}
\hline \multicolumn{1}{|c||}{ USE LOCATION } & QTY REQ'D \\
\hline A. AGC SACRAMENTO & \\
\hline B. WANL & \\
\hline C. & \\
\hline D. NRDS TOTAL & 1 \\
\hline
\end{tabular}

\section{DIMENSIONS AND CAPACITY}

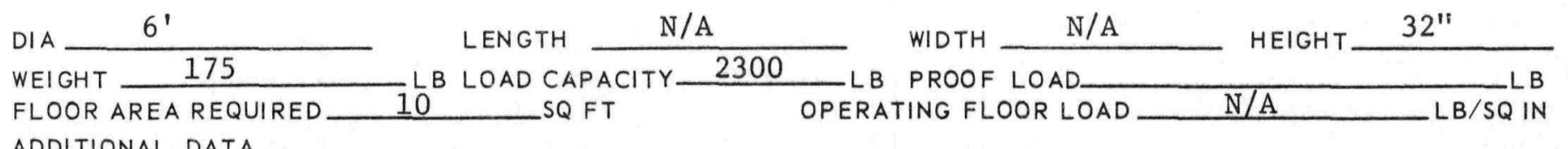

ADDITIONAL DATA

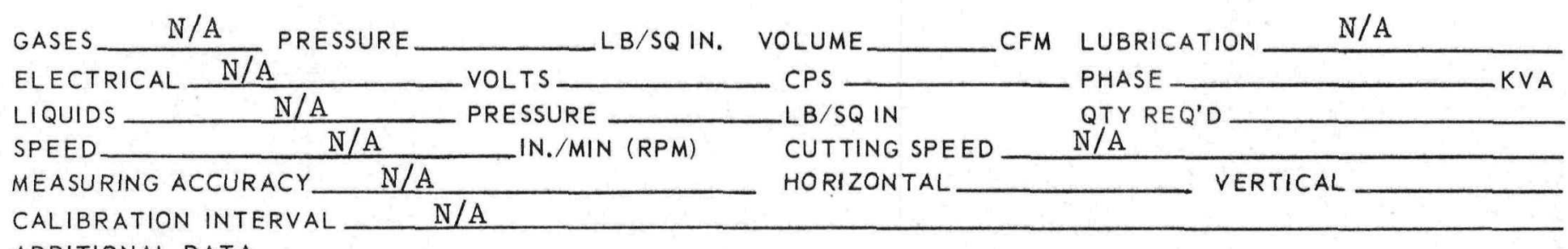

ADDITIONAL DATA

OPERATING EQUIPMENT

MANIPULATOR Class A*

CRANE R-MAD Facility (Auxiliary Hook)

LOAD CAPACITY

LOAD CAPACITY 10,000

L B MAX CRANE
ADDITIONAL DATA *Not for lifting pallet; use to attach the lifting sling to the pallet.

EQUIPMENT

PART OR ITEM

Simulated Shield

REMARKS
DRAWING NO.

936J387GOIE 
EQUIPMENT TITLE

PROV. LIST

ITEM NO.

1149

DATE

REVISION

January 1968

B

FIXTURE, LIFTING, NOZZLE END SUPPORT RING, OUTER REFLECTOR

DESCRIPTION: The Outer Reflector Nozzle End Support Ring Lifting Fixture is used to lift the nozzle end support ring of the outer reflector from the reactor trunnion cage after is has been remotely disassembled and removed from the cage. The fixture can be handled by either a Class A manipulator or an overhead crane.

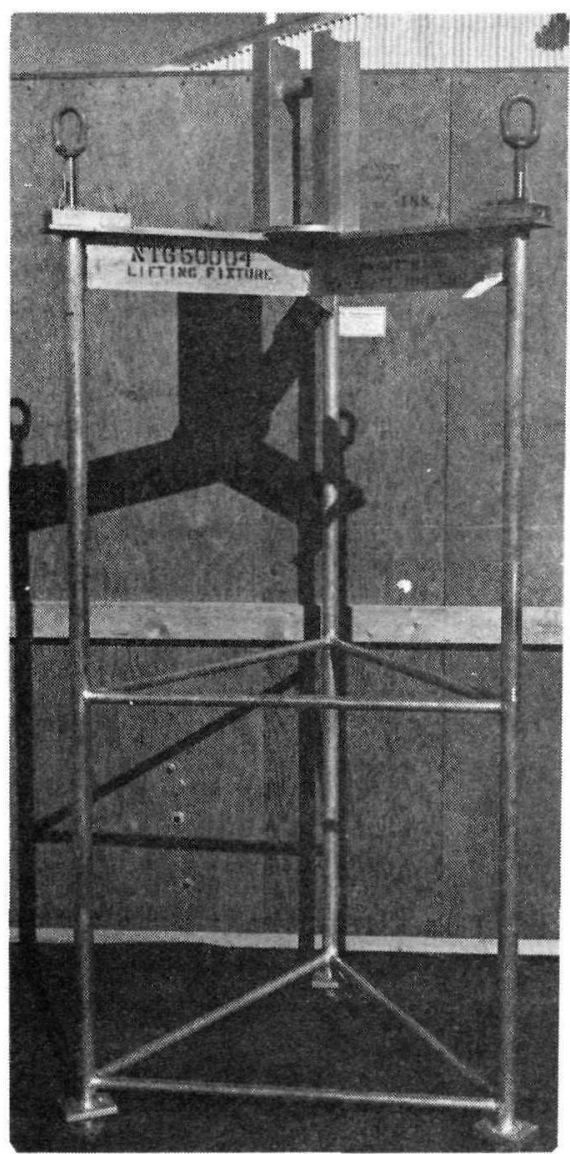


PROVISIONING LIST ITEM NUMBER

DRAWING NUMBER

PART NUMBER

CONTRACTOR NT650004

1149

WANL
FIRST PROVISIONED FOR NRX-A2 GOVT. INV. CONTROL NUMBER NT650004-001 $\cos T$
$\$ 1418.00$

\begin{tabular}{|l||c|}
\hline \multicolumn{1}{|c|}{ USE LOCATION } & QTY REQ'D \\
\hline A. AGC SACRAMENTO & \\
\hline B. WANL & \\
\hline C. & 1 \\
\hline D. NRDS TOTAL & 1 \\
\hline \multicolumn{2}{|c|}{} \\
\hline
\end{tabular}

\section{DIMENSIONS AND CAPACITY}

DIA 42"

WEIGHT 100

FLOOR AREA REQUIRED

ADDITIONAL DATA

\begin{tabular}{|c|c|c|c|}
\hline $\mathrm{N} / \mathrm{A}$ & 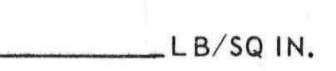 & CFM & N/A \\
\hline ELECTRICAL N/A & VOLTS _ & + & KVA \\
\hline LIQUIDS & PRESSURE & $-L B / S Q I N$ & QTY REQ'D \\
\hline SPEED & IN./MIN (RPM) & CUTTING SPEED. & N/A \\
\hline MEASURING ACCURACY_N/A & & HORIZONTAL & VERTICAL _ \\
\hline CALIBRATION INTERVAL N & A & & \\
\hline
\end{tabular}

ADDITIONAL DATA

MANIPULATOR Class A

CRANE

ADDITIONAL DATA
LOAD CAPACITY LOAD CAPACITY
N/A HEIGHT_ 85"
LB LOAD CAPACITY 100 LB PROOF LOAD SQ FT 
PROV. LIST

ITEM NO.

1151

DATE

January 1968

REVISION B

EQUIPMENT TITLE

FIXTURE, HANDLING, REACTOR ADAPTER RING

DESCRIPTION: The Reactor Adapter Ring Handling Fixture is a three-point strongback lifting device designed for either manual or remote handling of the adapter ring or the forward closure with the adapter ring attached. It is used with an adjustable chain sling and is equipped with a safety locking device to insure a positive lift.

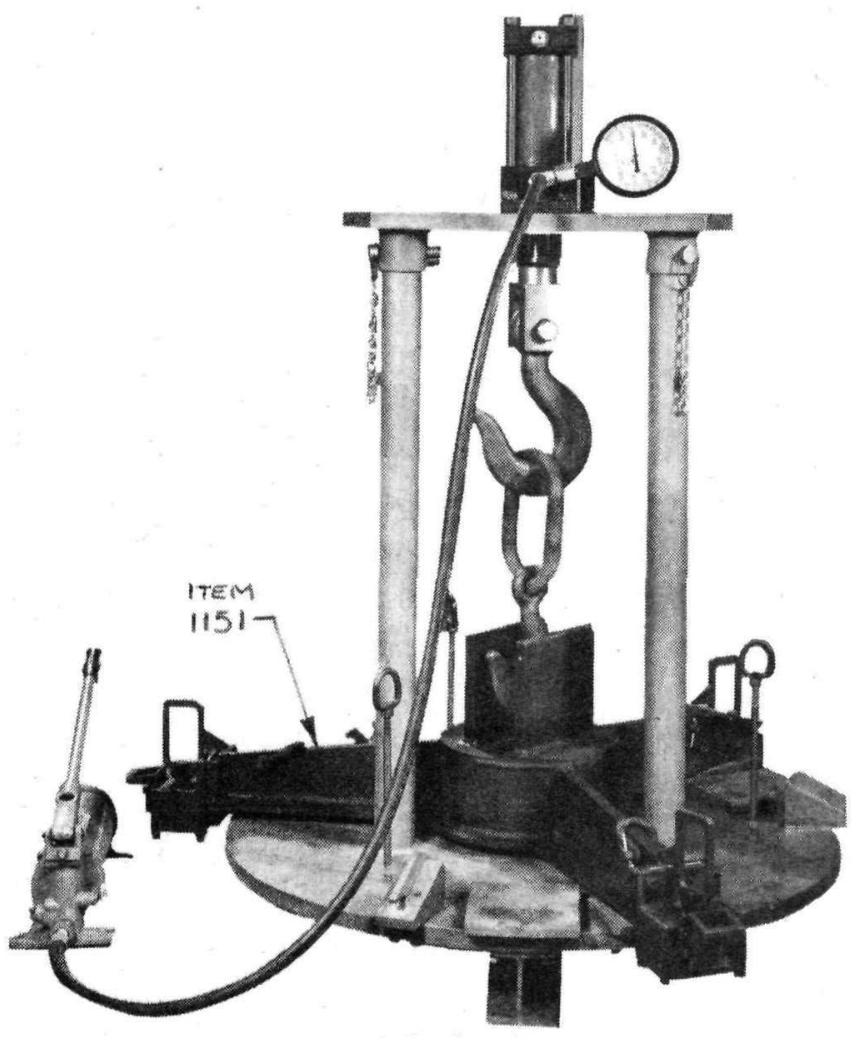


PROVISIONING LIST ITEM NUMBER

1151

DRAWING NUMBER

PART NUMBER

CONTRACTOR
3-510004 WANL/ACFI
FIRST PROVISIONED FOR NRX-AI GOVT. INV. CONTROL NUMBER NT650237-001

$\cos T$

\begin{tabular}{|l||c|}
\hline \multicolumn{1}{|c||}{ USE LOCATION } & QTY REQ'D \\
\hline A. AGC SACRAMENTO & \\
\hline B. WANL & \\
\hline C. & 1 \\
\hline D. NRDS TOTAL & 1 \\
\hline
\end{tabular}

DIMENSIONS AND CAPACITY

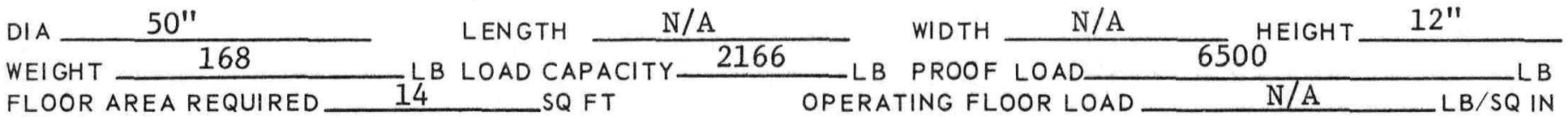
ADDITIONAL DATA

\begin{tabular}{|c|c|c|c|}
\hline GASES & \multirow{2}{*}{ PRESSURE_L LB/SQ IN. } & \multirow{2}{*}{$\begin{array}{l}\text { VOLUME CFM } \\
\text { CPS }\end{array}$} & LUBRICATION_ N/A \\
\hline ELEC & & & \multirow{2}{*}{ - PHASE KVA } \\
\hline LIQUII & $\mathrm{N} / \mathrm{A} \quad$ PRESSURE & LB/SQ IN & \\
\hline SPEED & IN./MIN (RPM) & \multirow{3}{*}{$\begin{array}{l}\text { CUTTING SPEED } \\
\text { HORIZONTAL }\end{array}$} & $\mathrm{N} / \mathrm{A}$ \\
\hline MEASL & $\mathrm{CY} \quad \mathrm{N} / \mathrm{A}$ & & \multirow[t]{2}{*}{ VERTICAL } \\
\hline CALIB & $\mathrm{N} / \mathrm{A}$ & & \\
\hline
\end{tabular}
ADDITIONAL DATA

MANIPULATOR N/A

CRANE

ADDITIONAL DATA
LOAD CAPACITY

LOAD CAPACITY
10,000

L B MAX

LB MAX 
() NERVA

LIPROGRAM

SUPPORT EQUIPMENT

TECHNICAL DESCRIPTION HANDBOOK

EQUIPMENT TITLE

FIXTURE, HANDLING, SCREEN
DATE

January 1968

REVISION

B

DESCRIPTION: The Screen Handling Fixture is a three-legged aluminum strongback which engages the screen with three spring clips located at the ends of the three legs. The fixture can be used with a three-legged sling or handled by the central lifting bail, in either manual or remote operations.

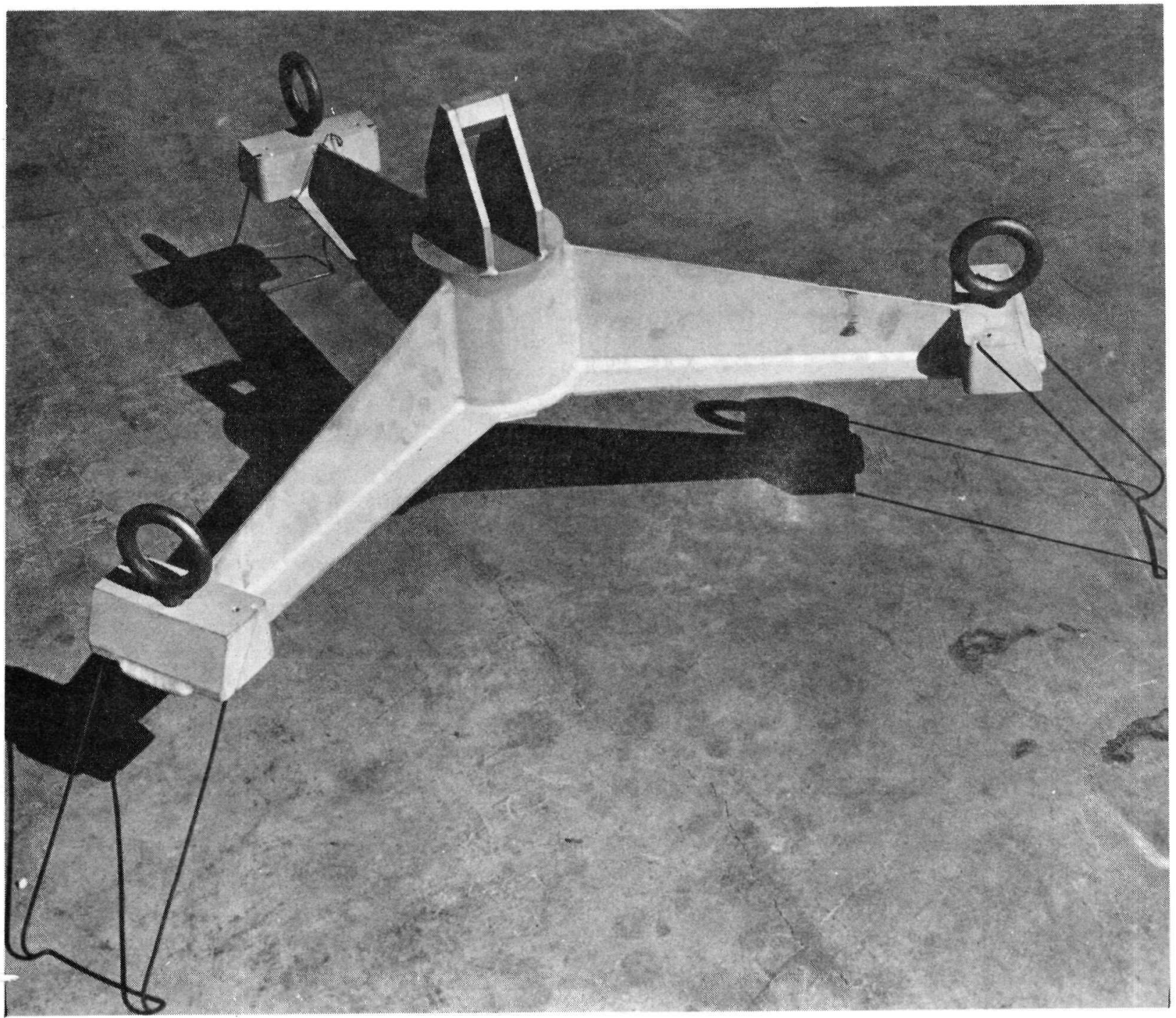


PROVISIONING LIST ITEM NUMBER

1153

DRAWING NUMBER

PART NUMBER

CONTRACTOR
3-509904

3-509904

WANL/ACFI
FIRST PROVISIONED FOR NRX-A1 GOVT. INV. CONTROL NUMBER NT650234-001

\begin{tabular}{|l||c|}
\hline \multicolumn{1}{|c||}{ USE LOCATION } & QTY REQ'D \\
\hline A. AGC SACRAMENTO & \\
\hline B. WANL & \\
\hline C. & 1 \\
\hline D. NRDS TOTAL & 1 \\
\hline \multicolumn{2}{|c|}{} \\
\hline
\end{tabular}

\section{DIMENSIONS AND CAPACITY}

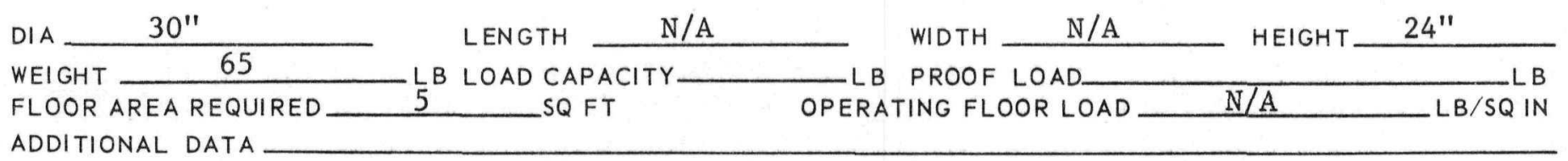

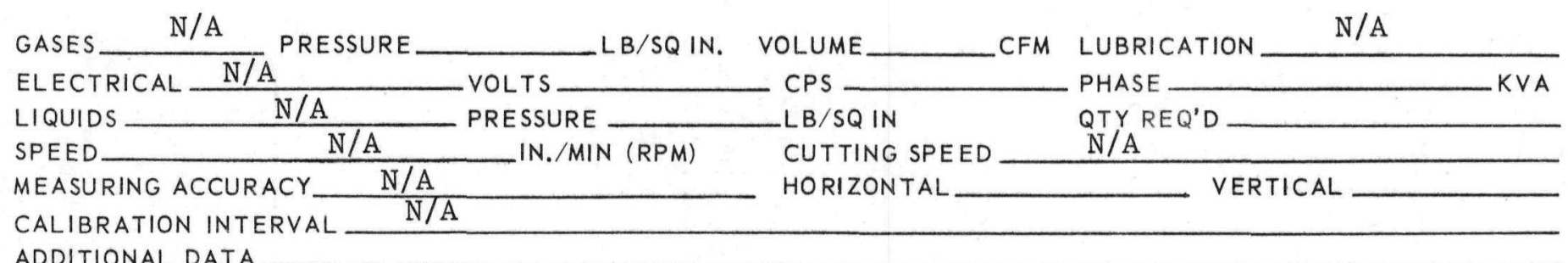
ADDITIONAL DATA

MANIPULATOR C1ass A

CRANE

ADDITIONAL DATA
LOAD CAPACITY

LOAD CAPACITY

10,000

LB MAX LB MAX

\section{INTERFACES}

EQUIPMENT

Class A Manipulator

PARTORITEM Screen and Crane DRAWING NO.

REMARKS 
DESCRIPTION: The Drive Shaft Storage Stand provides storage for 12 contro1-drum shafts during cold or hot disassembly. It is equipped to be handled by a Class A manipulator or an overhead crane with a five-ton capacity.

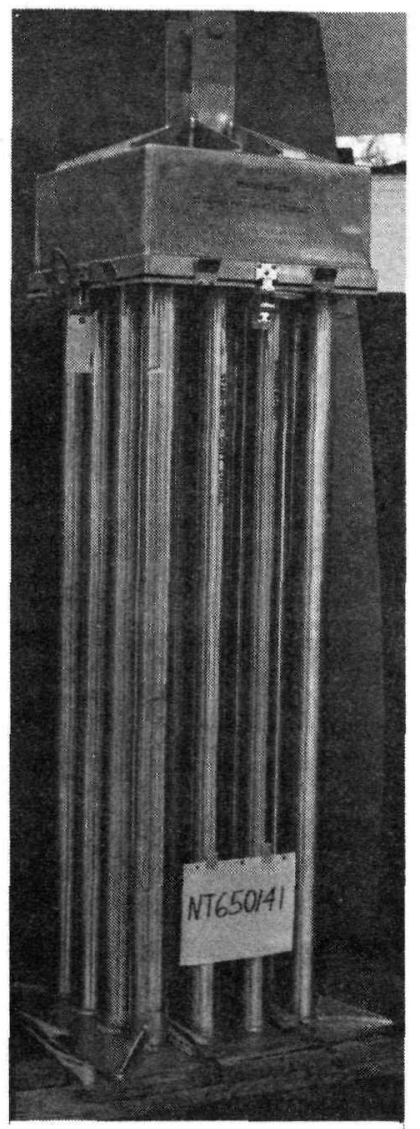


PROVISIONING LIST ITEM NUMBER 1158 DRAWING NUMBER NT650141

PART NUMBER CONTRACTOR NT650141 WANL

FIRST PROVISIONED FOR NRX-A2 GOVT. INV. CONTROL NUMBER NT650141-001 $\cos T$ $\$ 2100.00$

\begin{tabular}{|l||c|}
\hline \multicolumn{1}{|c||}{ USE LOCATION } & QTY REQ'D \\
\hline A. AGC SACRAMENTO & \\
\hline B. WANL & \\
\hline C. & \\
\hline D. NRDS TOTAL & 1 \\
\hline
\end{tabular}

\section{DIMENSIONS AND CAPACITY}

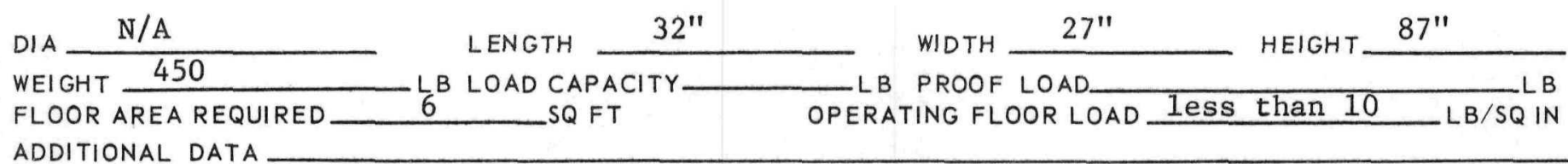

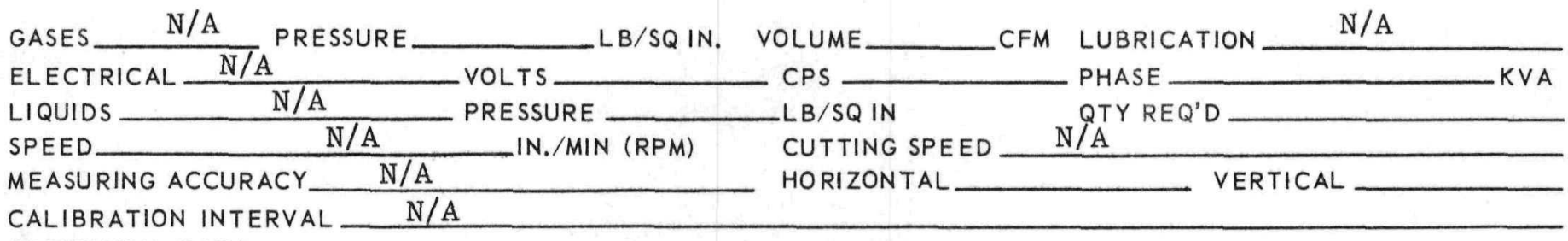
ADDITIONAL DATA

MANIPULATOR Class A

CRANE ADDITIONAL DATA
LOAD CAPACITY LOAD CAPACITY 10,000
- $B$ MAX L B MAX

INTERFACES

EQUIPMENT PART OR ITEM REMARKS
Class A Manipulator and Crane Control Drum Shafts DRAWING NO. 


\section{6) NERVA \\ LIPROGRAM \\ SUPPORT EQUIPMENT \\ TECHNICAL DESCRIPTION HANDBOOK}

EQUIPMENT TITLE

FIXTURE, LIFTING, SHIPPING CONTAINER
PROV. LIST

ITEM NO.

1160

DATE

REVISION

January 1968

F

DESCRIPTION: The Shipping Container Lifting Fixture is a steel, three-legged strongback with extension arms capable of handling a loaded shipping container or its cover. The three equally spaced legs are joined at the center, and welded to cover plates and a centrally located lifting bail. The extension arms engage the lifting lugs of the container or its cover with quick-acting mechanical ball-lock pins. A large pear link is located on the lifting bail to accommodate the various sizes and shapes of crane hooks which might be employed in lifting operations.

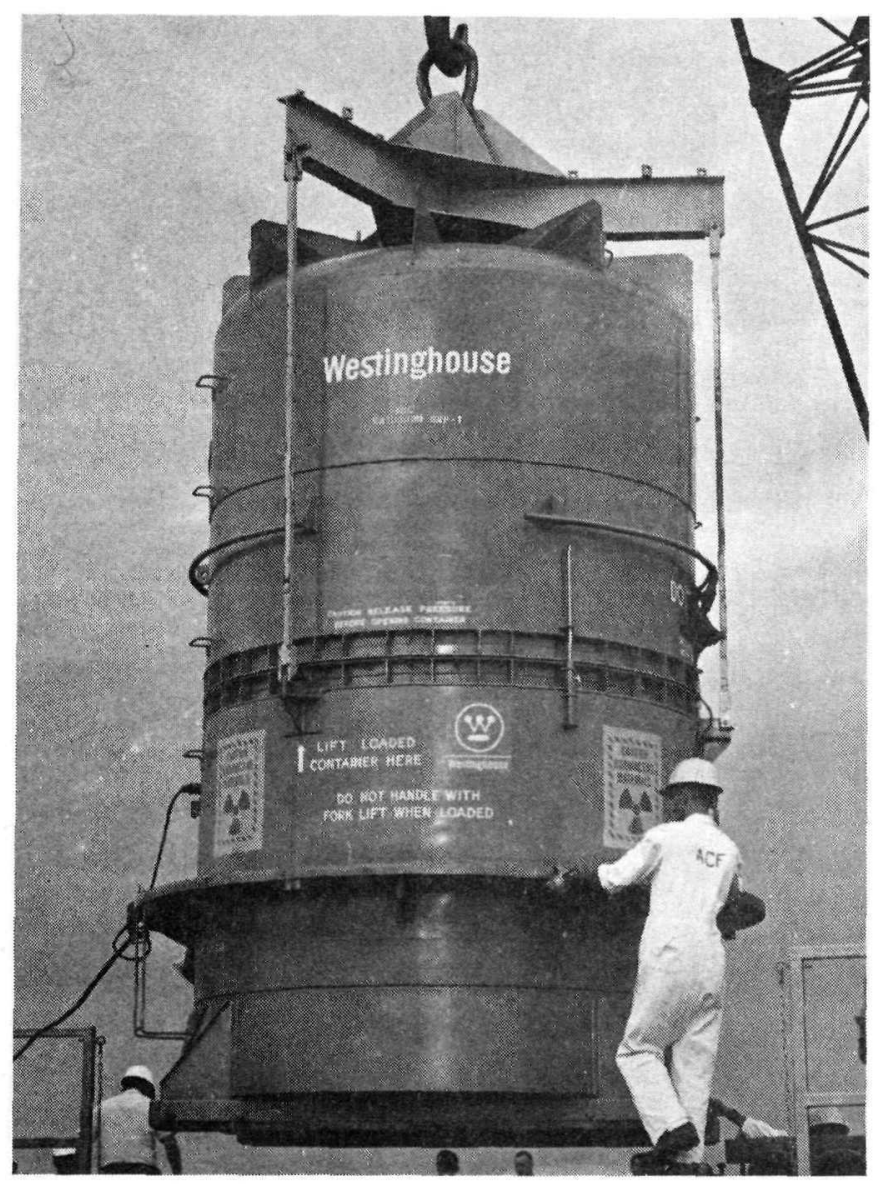


PROVISIONING LIST ITEM NUMBER

DRAWING NUMBER

PART NUMBER

CONTRACTOR
1160

NT 650005 WANL
FIRST PROVISIONED FOR NRX-AI GOVT. INV. CONTROL NUMBER NT65005-001 and NT650005-002

CosT Unit 1137 total 2274

\begin{tabular}{|c||c|}
\hline \multicolumn{1}{|c||}{ USE LOCATION } & QTY REQ'D \\
\hline A. AGC SACRAMENTO & \\
\hline B. WANL & 1 \\
\hline C. & \\
\hline D. NRDS TOTAL & 1 \\
\hline
\end{tabular}

DIMENSIONS AND CAPACITY

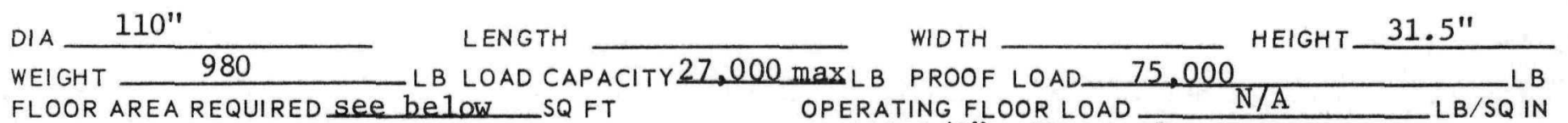
FLOOR AREA REQUIRED see below SQ FT OPERATING FLOOR LOAD
ADDITIONAL DATA Will fit in rectangular space $100-1 / 2 ", 60 \mathrm{sq}$. ft. ADDITIONAL DATA $\frac{\text { Will fit in rectangular space } 100-1 / 2^{\prime \prime}, 60 \mathrm{sq} \text {. ft }}{\text { Will fit in circular space } 56^{\prime \prime} \text { radius, } 69 \mathrm{sq} \text {. ft. }}$

GASES N/A PRESSURE

ELECTRICAL N N/A

LIQUIDS N/A

SPEED $\mathrm{N} / \mathrm{A}$

MEASURING ACCURACY

CALIBRATION INTERVAL

ADDITIONAL DATA
$L B / S Q I N$. VOLUME VOLTS

PRESSURE IN./MIN (RPM)
CPS

$L B / S Q I N$

CUTTING SPEED

HORIZONTAL
CFM LUBRICATION

PHASE

QTY REQ'D $\mathrm{N} / \mathrm{A}$

$\mathrm{N} / \mathrm{A}$

N/A

EQUIPMENT_ NRX Shipping Container and Crane Hook 


\begin{tabular}{l|l|c}
\hline 6) NERVA & SUPPORT EQUIPMENT \\
PROGRAM & TECHNICAL DESCRIPTION HANDBOOK \\
\hline
\end{tabular}

EQUIPMENT TITLE

FIXTURE, HANDLING, CONTROL DRUM
PROV. LIST

ITEM NO.

1164

\section{DATE}

January 1968

REVISION

DESCRIPTION: The Control Drum Handling Fixture grips the control drum by its stub shaft on the dome end for handling after all hardware components have been removed. Adapter jaws are used with a Class A manipulator.

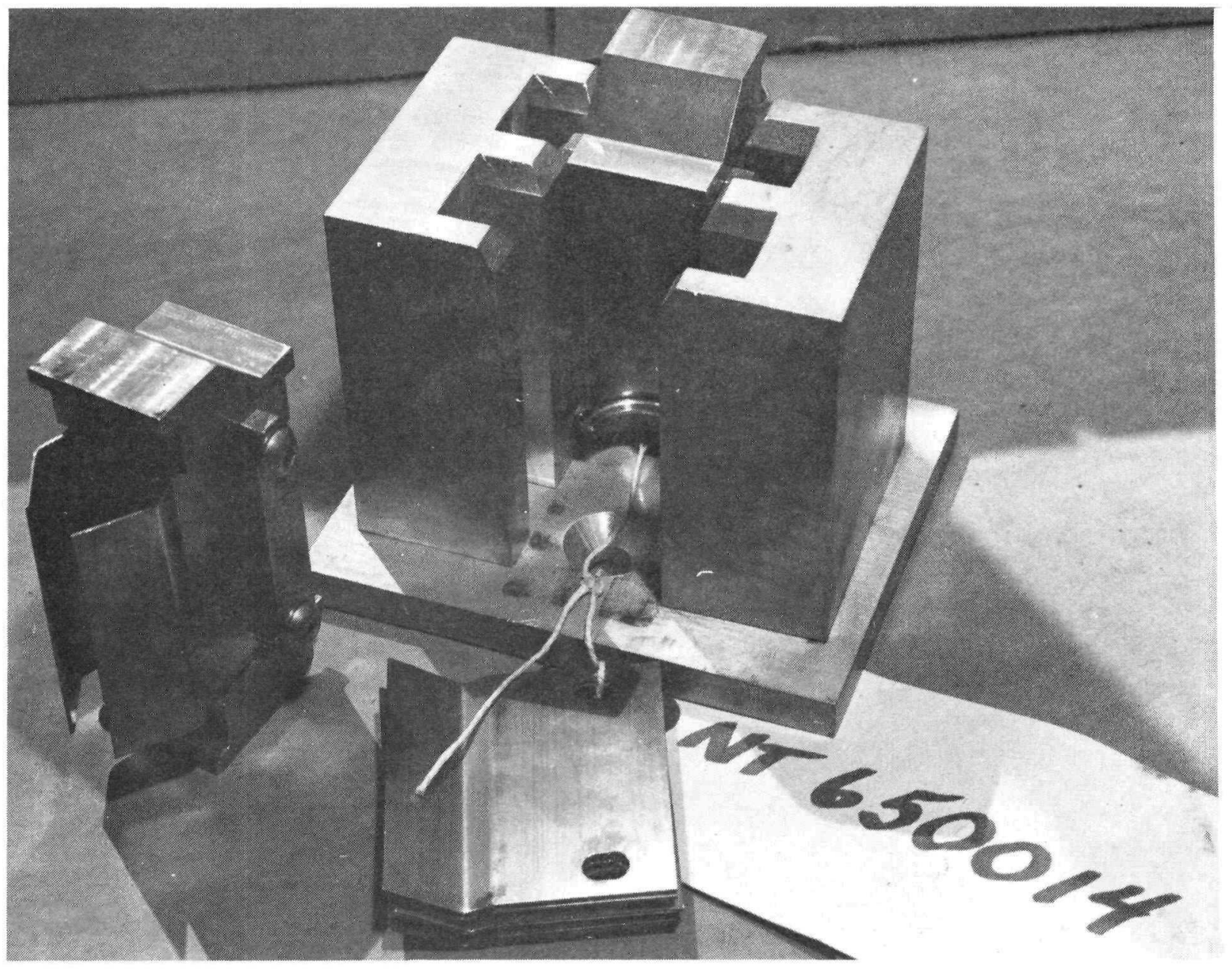


PROVISIONING LIST ITEM NUMBER 1164 DRAWING NUMBER NT650014

PART NUMBER $\quad$ NT650014

CONTRACTOR WANL

FIRST PROVISIONED FOR NRX-A2 GOVT. INV. CONTROL NUMBER NT650014-001

\begin{tabular}{|c|c|}
\hline USE LOCATION & QTY REQ'D \\
\hline A. AGC SACRAMENTO & \\
\hline B. WANL & \\
\hline C. & \\
\hline D. NRDS & 2 \\
\hline TOTAL & 2 \\
\hline
\end{tabular}

\section{DIMENSIONS AND CAPACITY}

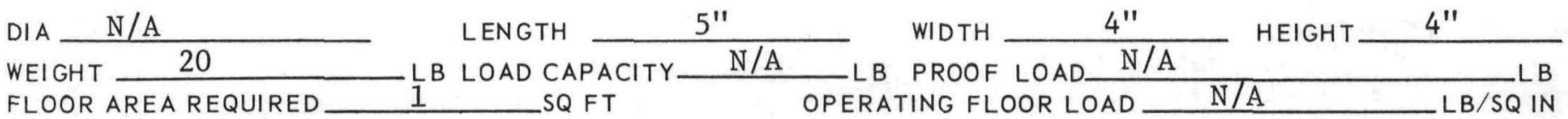

ADDITIONAL DATA

OPERATING DATA

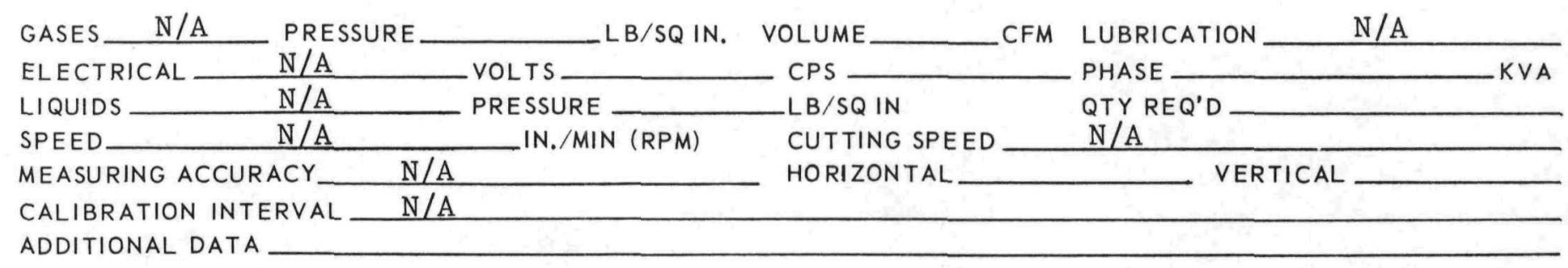

MANIPULATOR Class A

CRANE N/A

ADDITIONAL DATA
LOAD CAPACITY

LOAD CAPACITY
LB MAX

LB MAX

INTERFACES

EQUIPMENT_Class A Manipulator

PART OR ITEM Control Drum

DRAWING NO.

REMARKS 


\begin{tabular}{|l|l|}
\hline GERVA & NERVAPRORT EQUIPMENT \\
\hline PROGRA & TECHNICAL DESCRIPTION HANDBOOK \\
\hline
\end{tabular}

EQUIPMENT TITLE

CONTAINER, CONTROL DRUM HARDWARE

DESCRIPTION: The Control Drum Hardware Container is used to store bearings, retaining nuts, and other control drum assembly hardware during post-operative disassembly and before examination. The container is fitted with lifting lugs.

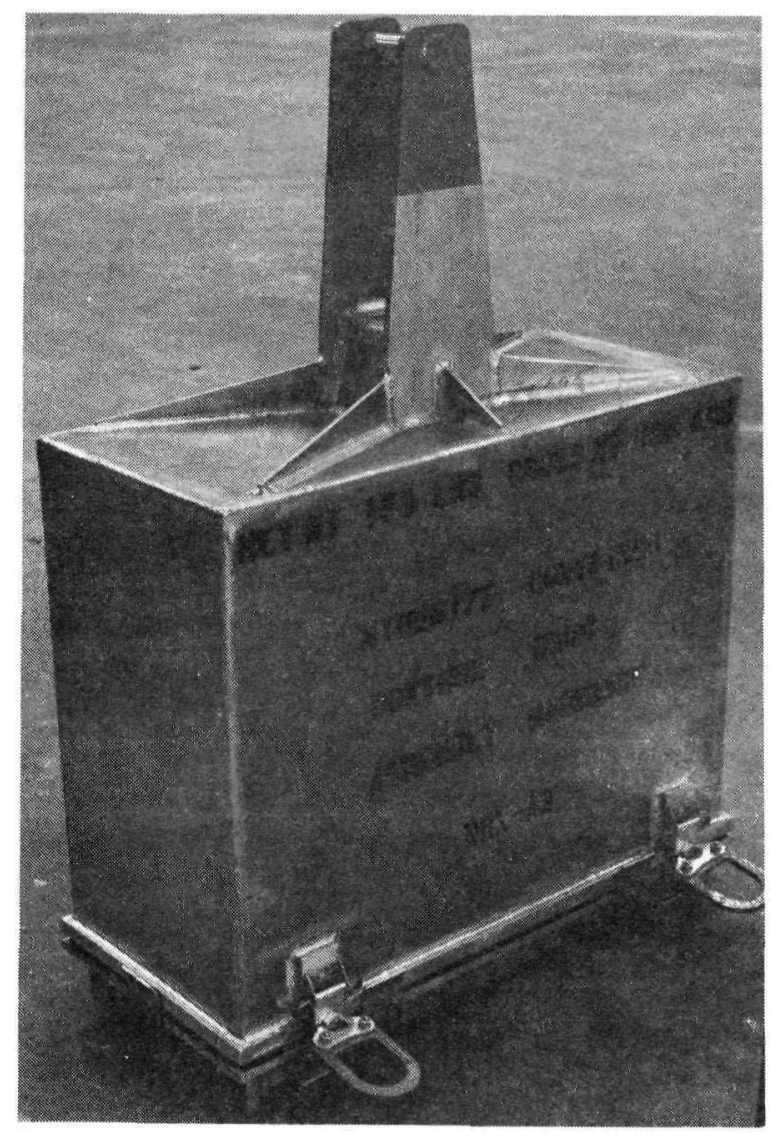


PROVISIONING LIST ITEM NUMBER 1168

DRAWING NUMBER

PART NUMBER

CONTRACTOR NT650175 NT650175 WANL
FIRST PROVISIONED FOR NRX-A2 GOVT. INV. CONTROL NUMBER NT650175-001 $\cos T+\$ 2600.00$

\begin{tabular}{|l||c|}
\hline \multicolumn{1}{|c||}{ USE LOCATION } & QTY REQ'D \\
\hline A. AGC SACRAMENTO & \\
\hline B. WANL & \\
\hline C. & \\
\hline D. NRDS TOTAL & 1 \\
\hline \multicolumn{2}{|c||}{1} \\
\hline
\end{tabular}

\section{DIMENSIONS AND CAPACITY}

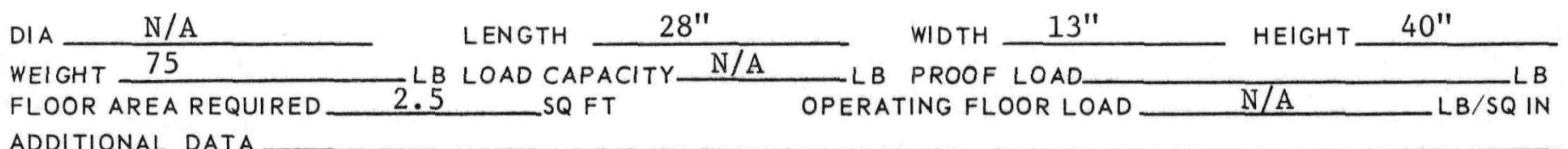
ADDITIONAL DATA

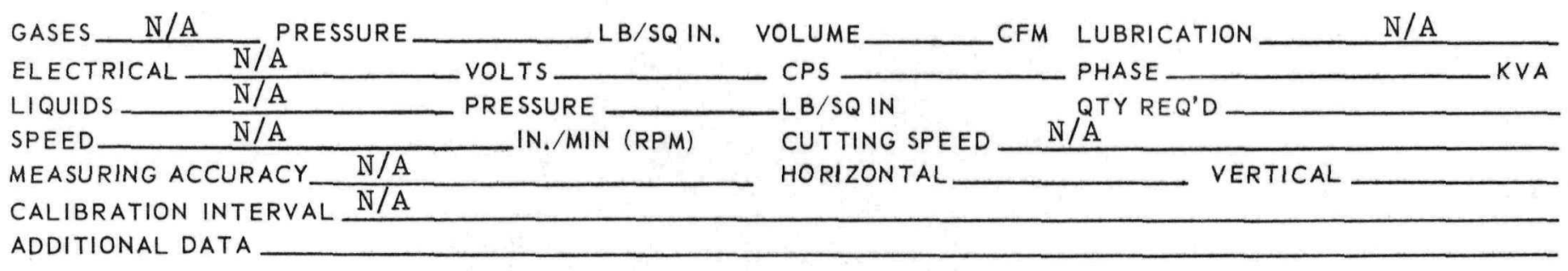

MANIPULATOR _ O-MAN Class A

CRANE

ADDITIONAL DATA
LOAD CAPACITY

LOAD CAPACITY 10,000
LB MAX LB MAX

EQUIPMENT Class A Manipulator

PART OR ITEM Control Drum Assembly Hardware DRAWING NO.

REMARKS 


\begin{tabular}{|l|l|}
\hline CDERVA & SUPPORT EQUIPMENT \\
\hline PROGRAM & TECHNICAL DESCRIPTION HANDBOOK \\
\hline
\end{tabular}

EQUIPMENT TITLE

TOOL, OUTER REFLECTOR TIE BOLT
PROV. LIST

ITEM NO.

1171

DATE

REVISION C

DESCRIPTION: The Outer Reflector Tie Bolt tool is a modified electric hammer designed for use with a Class A manipulator. It is used to dislodge the outer reflector tie bolt from the tie bolt locking device and the dome and support. It may also be used as a back-up tool for other operations. 
PROVISIONING LIST ITEM NUMBER

DRAWING NUMBER

PART NUMBER

CONTRACTOR
1171 NT650142 NT650142 WANL
FIRST PROVISIONED FOR

$\mathrm{NRX}-\mathrm{A} 2$ GOVT. INV. CONTROL NUMBER NT650142-001 $\operatorname{cosT} \$ 3.498 .00$

\begin{tabular}{|l||c|}
\hline \multicolumn{1}{|c||}{ USE LOCATION } & QTY REQ'D \\
\hline A. AGC SACRAMENTO & \\
\hline B. WANL & \\
\hline C. & \\
\hline D. NRDS TOTAL & 1 \\
\hline \multicolumn{2}{|c|}{1} \\
\hline
\end{tabular}

\section{DIMENSIONS AND CAPACITY}

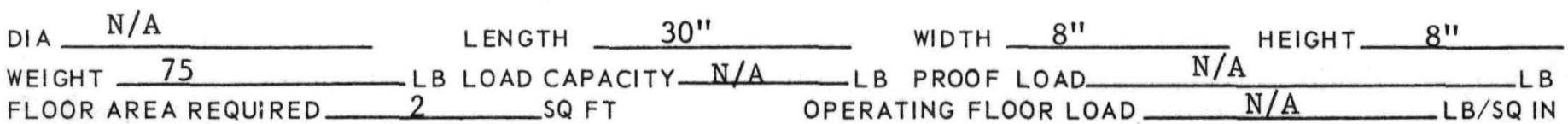
ADDITIONAL DATA

\section{OPERATING DATA}

GASES N/A PRESSURE

ELECTRICAL 115

LIQUIDS

SPEED.

MEASURING ACCURACY

CALIBRATION INTERVAL

ADDITIONAL DATA

\section{5}

$\mathrm{N} / \mathrm{A}$ $\mathrm{N} / \mathrm{A}$ N/A $\mathrm{N} / \mathrm{A}$ VOLTS 60 PRESSURE -IN./MIN (RPM)
LB/SQIN. VOLUME

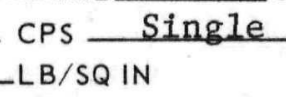
CFM LUBRICATION
PHASE QTY REQ'D KVA VERTICAL
MANIPULATOR Class A

CRANE N/A

ADDITIONAL DATA
LOAD CAPACITY

LOAD CAPACITY

EQUIPMENT_C Class A Manipulator

PART OR ITEM Outer Reflector Tie Bolt DRAWING NO. 978D319H01

REMARKS 


\section{(D) NERVA LIPROGRAM \\ SUPPORT EQUIPMENT \\ TECHNICAL DESCRIPTION HANDBOOK}

EQUIPMENT TITLE

FIXTURE, HANDLING, CYLINDER SLITTING STAND
PROV. LIST

ITEM NO.

DATE

January 1968

REVISION

DESCRIPTION: The Cylinder Slitting Stand Handling Fixture hooks into mating eyes on the cylinder slitting stand for handling of the stand and core during the core disassembly operations. It is used with an overhead crane or a Class A manipulator.

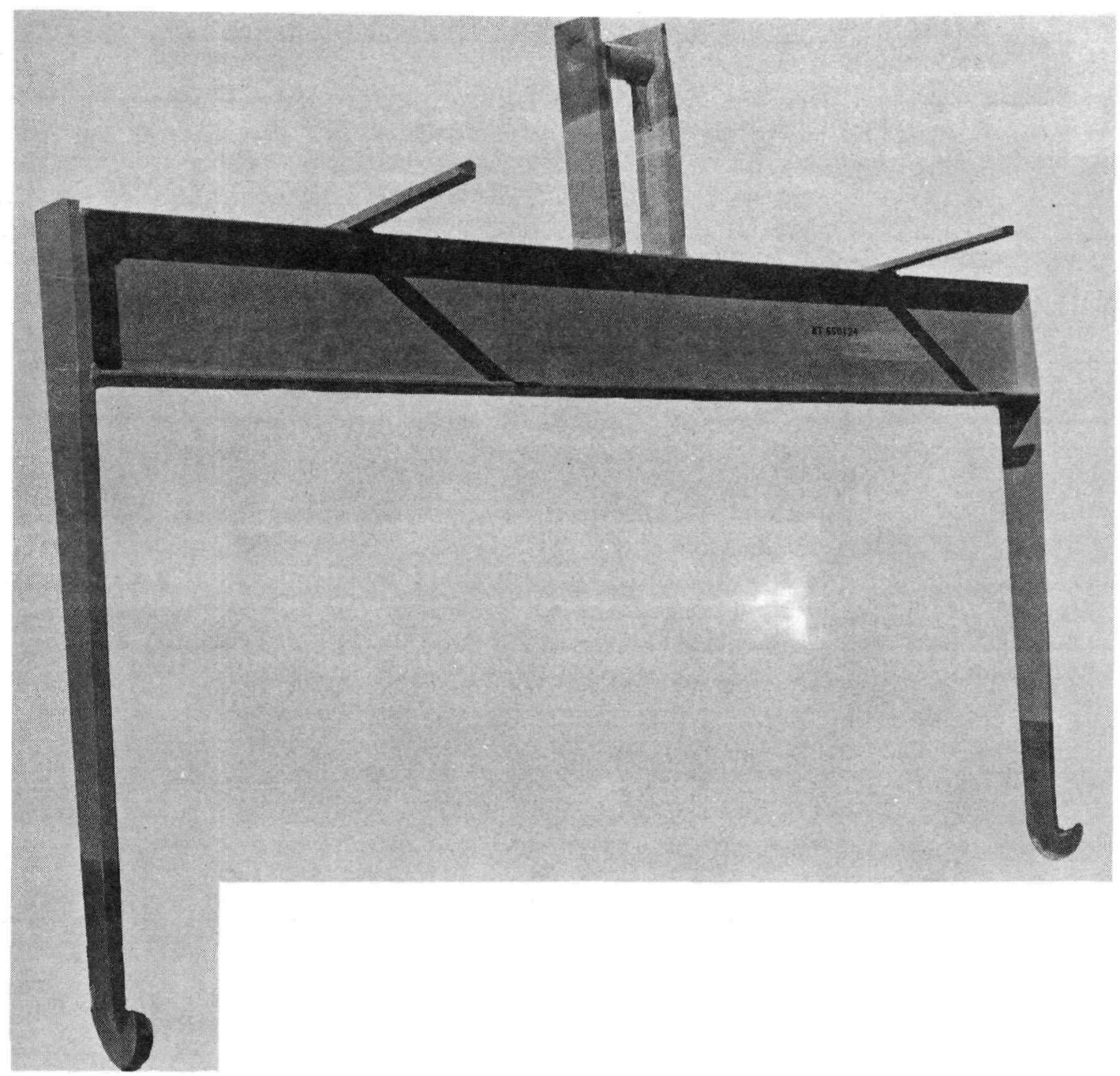


PROVISIONING LIST ITEM NUMBER 1172

DRAWING NUMBER

PART NUMBER

NT650 24

CONTRACTOR

NT650124

WANL

FIRST PROVISIONED FOR

NRX-A2 GOVT. INV. CONTROL NUMBER NT650124-001

$\cos T$

$\$ 1123.00$

\begin{tabular}{|l||c|}
\hline \multicolumn{1}{|c||}{ USE LOCATION } & QTY REQ'D \\
\hline A. AGC SACRAMENTO & \\
\hline B. WANL & \\
\hline C. & \\
\hline D. NRDS TOTAL & 1 \\
\hline
\end{tabular}

DIMENSIONS AND CAPACITY

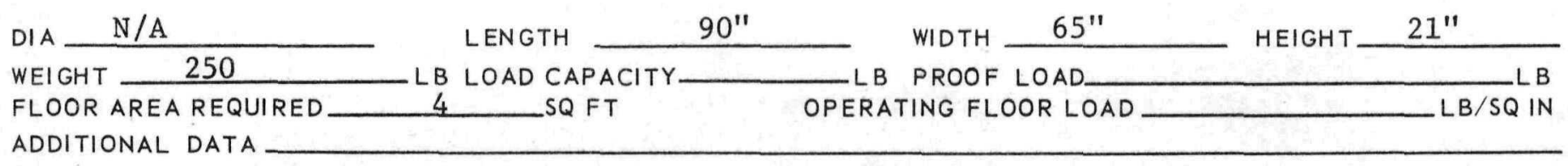

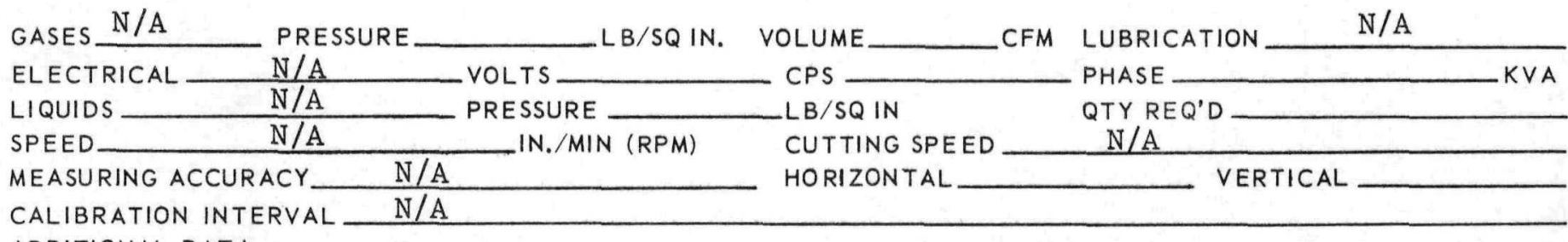

ADDITIONAL DATA

MANIPULATOR Class A

CRANE

ADDITIONAL DATA
LOAD CAPACITY

LOAD CAPACITY
LB MAX LB MAX

Class A Manipulator and Crane

PQUIPMENT T OR ITEM Cylinder Slitting Stand, DRAWING NO. NT650060 REMARKS P/L 1123 


\begin{tabular}{|l|l}
\hline TINERVA & SUPPORT EQUIPMENT \\
\hline PROGRAM & TECHNICAL DESCRIPTION HANDBOOK \\
\hline
\end{tabular}

EQUIPMENT TITLE

FIXTURE, SUPPORT, INSTRUMENTATION AND CONTROL DRUM SHAFT

DESCRIPTION: The Instrumentation and Control Drum Shaft Support Fixture is designed to be used for assembly only in conjunction with the Reactor/Vessel Trunnion Cage (P/L 1150 or 1251) to maintain the vertical alignment of the control-drum shafts during installation of the forward closure. The fixture is of aluminum construction and basically consists of two rings separated by twelve rods, each of which contain two spring-loaded shaft supports.

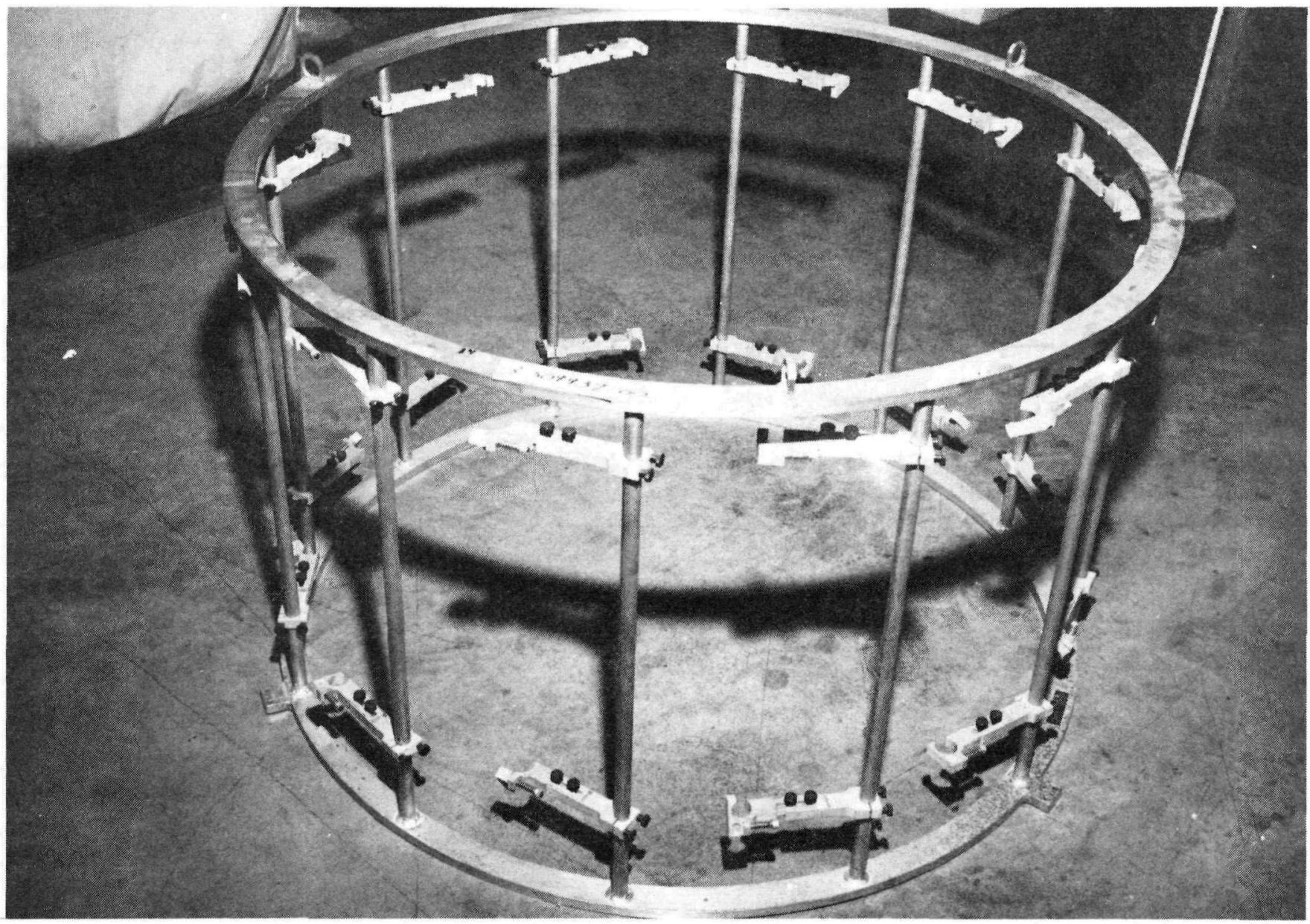




\section{TECHNICAL SUMMARY}

PROVISIONING LIST ITEM NUMBER

DRAWING NUMBER 3-509937

PART NUMBER

CONTRACTOR
1181

FIRST PROVISIONED FOR NRX-AI GOVT. INV. CONTROL NUMBER NT650235-001

\begin{tabular}{|l||c|}
\hline \multicolumn{1}{|c||}{ USE LOCATION } & QTY REQ'D \\
\hline A. AGC SACRAMENTO & \\
\hline B. WANL & \\
\hline C. & \\
\hline D. NRDS TOTAL & 1 \\
\hline
\end{tabular}

\section{DIMENSIONS AND CAPACITY}

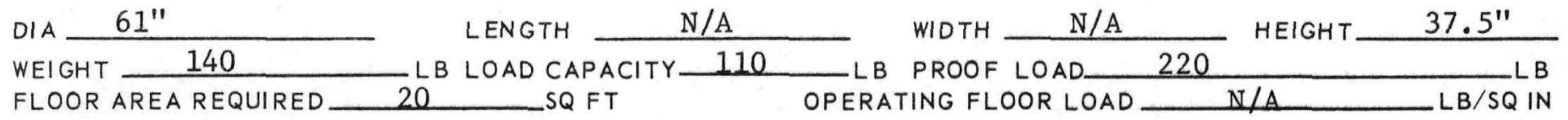

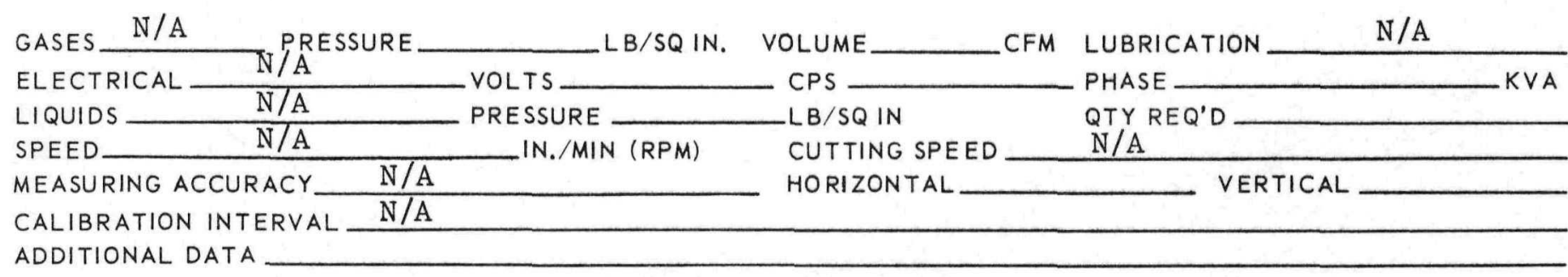

MANIPULATOR N N/A

CRANE

ADDITIONAL DATA
LOAD CAPACITY LOAD CAPACITY
10,000

LB MAX

L B MAX 


\section{(1) NERVA L. PROGRAM \\ SUPPORT EQUIPMENT \\ TECHNICAL DESCRIPTION HANDBOOK}

EQUIPMENT TITLE

FIXTURE, TRUNNION, REACTOR
PROV. LIST

ITEM NO.

1182

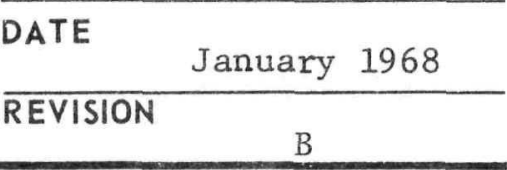

DESCRIPTION: The Reactor Trunnion Fixture is designed to receive either the reactor trunnion cage (P/L 1147 or 1278) or the reactor/vessel trunnion cage ( $\mathrm{P} / \mathrm{L} 1150$ or 1251) during cold assembly and disassembly operations or remote disassembly operations. The fixture provides a means of elevating either of the two cages and has the capability of continuous rotation at a speed of $0.5 \mathrm{rpm}$. An output torque of 116,000 inch pounds is produced at the trunnion by a double worm-gear speed reducer and $3 \mathrm{hp}$ motor. The trunnion clamps are designed to permit either cage to be inserted, rotated 180 degrees, and removed. Construction is primarily mild steel with an epoxy coating. The fixture is complete with various personnel platforms and a lifting fixture for handling the empty fixture.

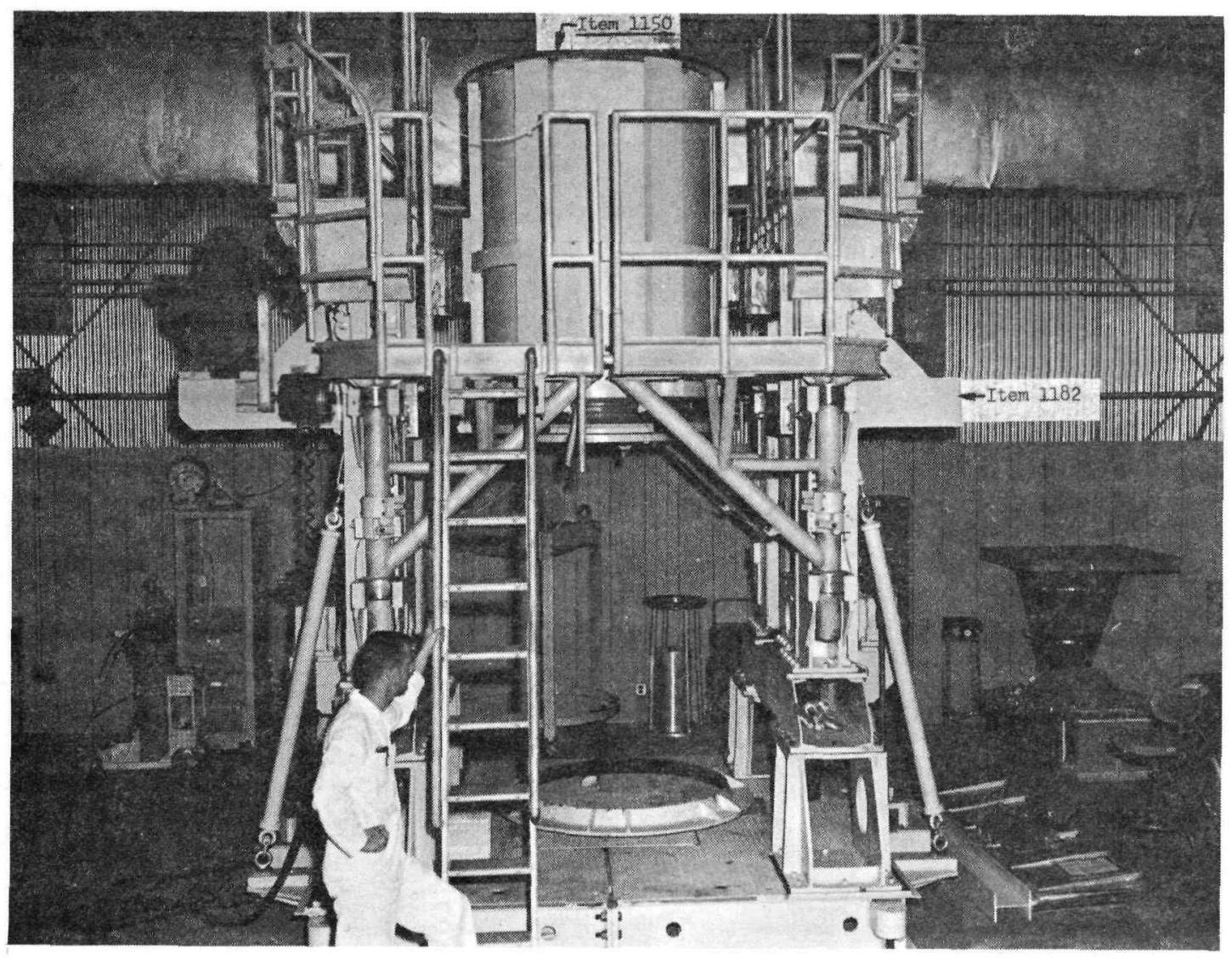


PROVISIONING LIST ITEM NUMBER

1182

DRAWING NUMBER $3-510022$

FIRST PROVISIONED FOR NRX-AI

PART NUMBER

CONTRACTOR WANL/ACF1

\begin{tabular}{|l||c|}
\hline \multicolumn{1}{|c||}{ USE LOCATION } & QTY REQ'D \\
\hline A. AGC SACRAMENTO & \\
\hline B. WANL & \\
\hline C. & \\
\hline D. NRDS TOTAL & 1 \\
\hline
\end{tabular}

\section{DIMENSIONS AND CAPACITY}

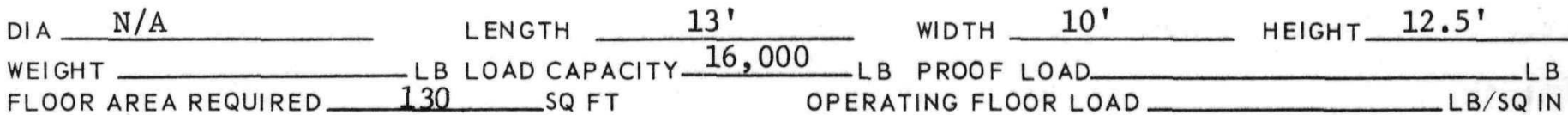

ADDITIONAL DATA

GASES N/A ELECTRICAL LIQUIDS SPEED MEASURING ACCURACY CALIBRATION INTERVAL ADDITIONAL DATA
$L B / S Q I N$. VOLUME 60 PRESSURE IN./MIN (RPM)

\section{OPERATING EQUIPMENT}

MANIPULATOR Class A Manipulators CRANE ADDITIONAL DATA
LOAD CAPACITY LOAD CAPACITY
CFM LUBRICATION Oils \& greases as PHASE KVA $L B / S Q I N$ CUTTING SPEED HORIZONTAL
QTY REQ'D VERTICAL $L B / S Q$ IN 


\begin{tabular}{l|l}
\hline CIIPROA & SER \\
\hline PUPPORT EQUIPMENT & TECHNICAL DESCRIPTION HANDBOOK \\
\hline
\end{tabular}

EQUIPMENT TITLE

PALLET, DISPOSAL

DESCRIPTION: The Disposal Pallet is used to handle disposal pails, reactor parts, and scrap. A pallet can be lifted by a handling fixture or a fork lift. Construction is steel tubing and hardwood decking.

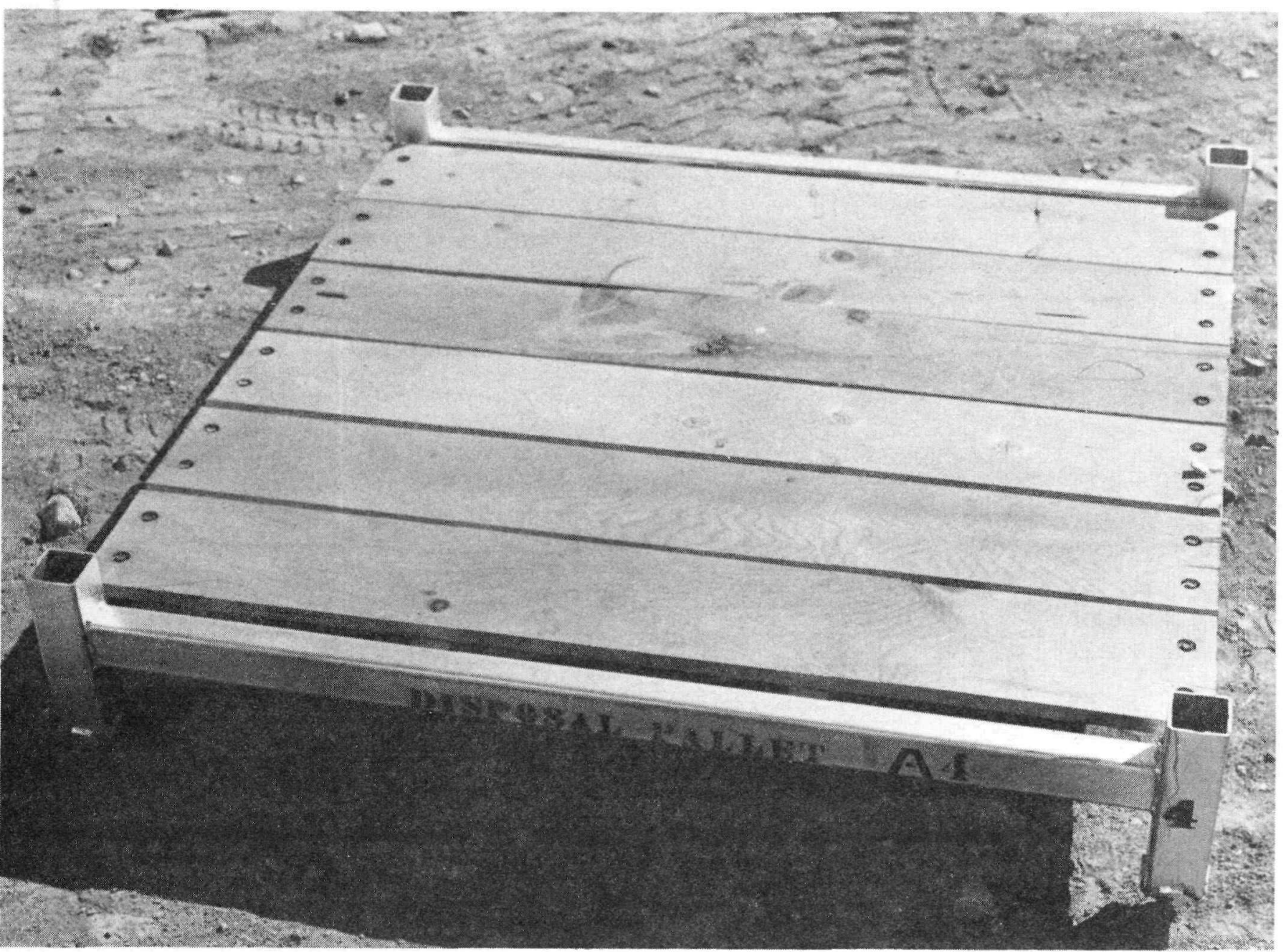


PROVISIONING LIST ITEM NUMBER 1193-B4 DRAWING NUMBER $566 \mathrm{~F} 441$

PART NUMBER

CONTRACTOR
WANL
FIRST PROVISIONED FOR NRX-A3

GOVT. INV. CONTROL NUMBER NT650330-012-022

Cost $\$ 65.00$ to $\$ 676.00$

\begin{tabular}{|l||c|}
\hline \multicolumn{1}{|c||}{ USE LOCATION } & QTY REQ'D \\
\hline A. AGC SACRAMENTO & \\
\hline B. WANL & \\
\hline C. & 10 \\
\hline D. NRDS TOTAL & 10 \\
\hline
\end{tabular}

\section{DIMENSIONS AND CAPACITY}

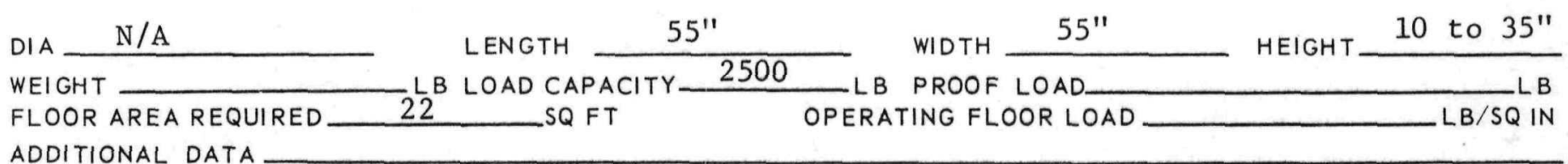

ADDITIONAL DATA

GASES N/A PRESSURE ELECTRICAL N/A NOLTS

LIQUIDS

SPEED

$\mathrm{N} / \mathrm{A}$

MEASURING ACCURACY

CALIBRATION INTERVAL N/A

ADDITIONAL DATA

A

PRESSURE IN./MIN (RPM)
$L B / S Q I N$. VOLUME

CPS

$L B / S Q$ IN

CUTTING SPEED

HORIZONTAL
CFM LUBRICATION

PHASE

QTY REQ'D $\mathrm{N} / \mathrm{A}$
VERTICAL

$\mathrm{N} / \mathrm{A}$ KVA

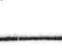

MANIPULATOR N/A

CRANE

ADDITIONAL DATA
LOAD CAPACITY LOAD CAPACITY 50,000
LB MAX LB MAX

\section{INTERFACES}

EQUIPMENT Fixture and Fork Lift 


\section{() NERVA L PROGRAM \\ SUPPORT EQUIPMENT TECHNICAL DESCRIPTION HANDBOOK}

EQUIPMENT TITLE

RACK, TOOL HOLDER
PROV. LIST

ITEM NO.

1199

DATE REVISION

$\mathrm{C}$

DESCRIPTION: The Tool Holder Rack provides positioned storage for interface tools and is used with Class A and sidewall manipulators. It consists of a caster-wheeled table (fitted with storage slots, fixtures, and tool holders) and is provided with a lifting bail to permit handling by a crane or a Class A manipulator.

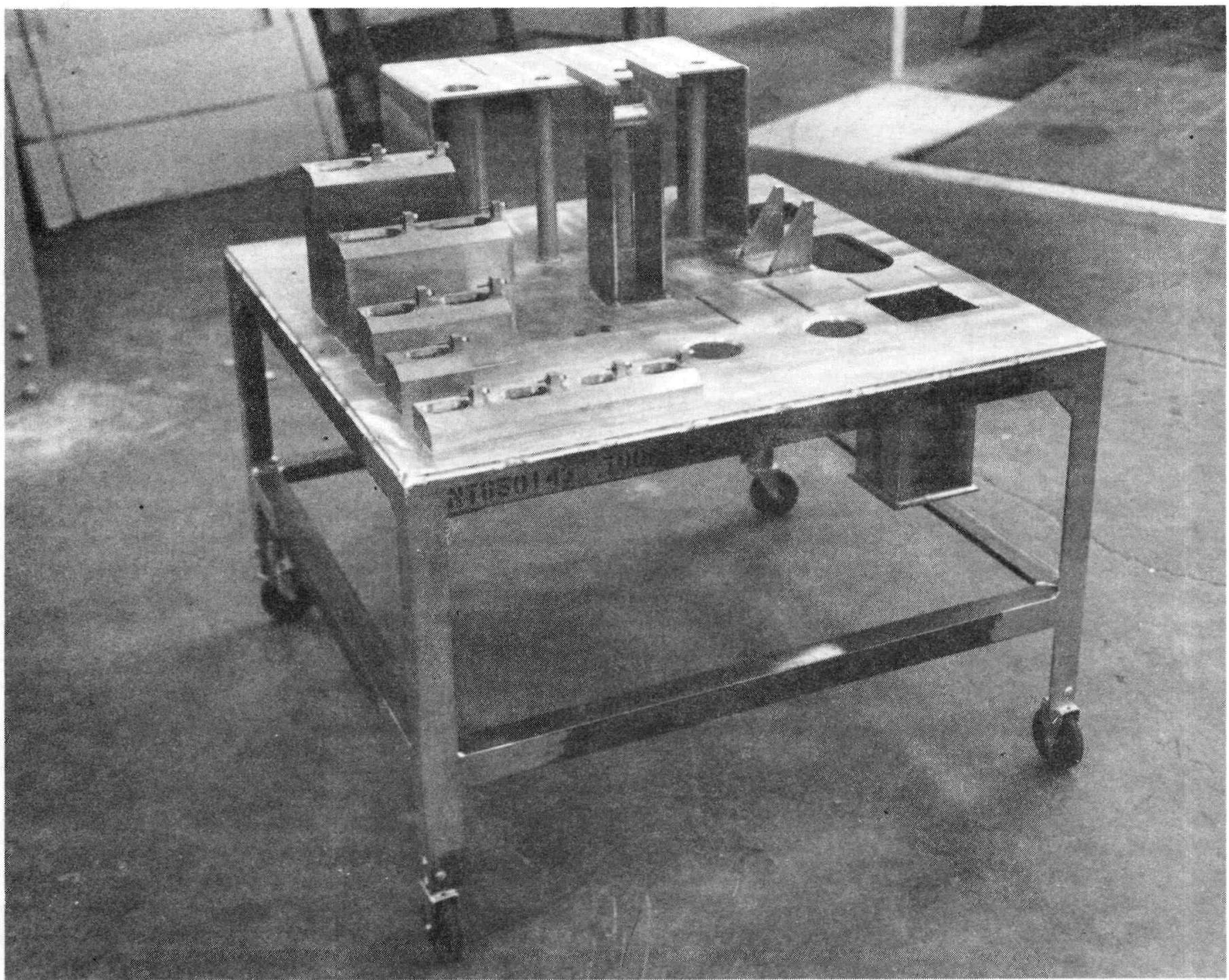


PROVISIONING LIST ITEM NUMBER 1199

DRAWING NUMBER NT650143

PART NUMBER

NT650143

CONTRACTOR WANL

FIRST PROVISIONED FOR N NRX-A2 GOVT. INV. CONTROL NUMBER NT650143-001 COST $\$ 2999.00$

\begin{tabular}{|l||c|}
\hline \multicolumn{1}{|c||}{ USE LOCATION } & QTY REQ'D \\
\hline A. AGC SACRAMENTO & \\
\hline B. WANL & \\
\hline C. & 1 \\
\hline D. NRDS TOTAL & 1 \\
\hline \multicolumn{2}{|c||}{} \\
\hline
\end{tabular}

\section{DIMENSIONS AND CAPACITY}

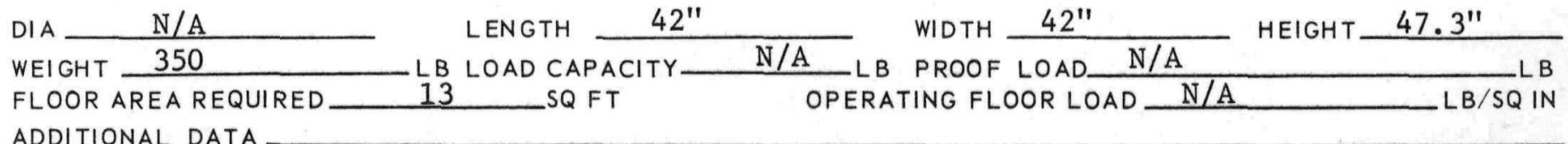

ADDITIONAL DATA

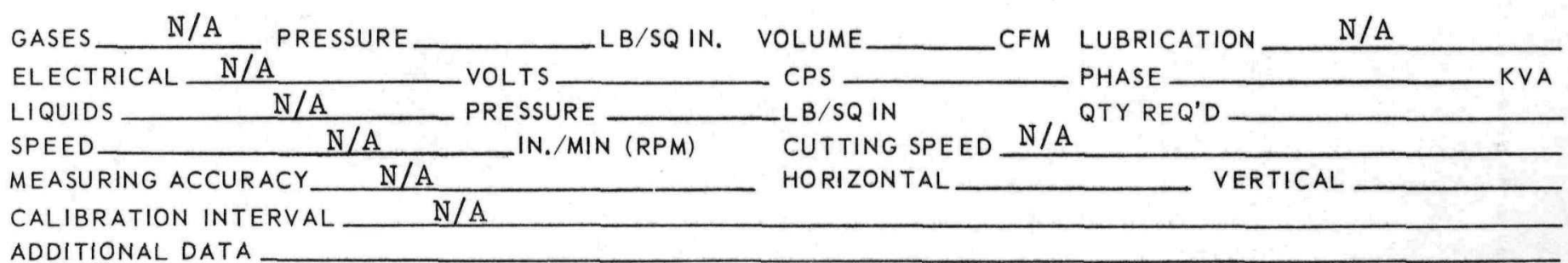
ADDITIONAL DATA

\section{OPERATING EQUIPMENT}

MANIPULATOR Class A

CRANE

ADDITIONAL DATA
LOAD CAPACITY

LOAD CAPACITY 10,000
$L B M A X$ LB MAX

EQUIPMENT_Class A Manipulators, Facility Crane

PART OR ITEM Tools for Manipulators DRAWING NO.

REMARKS 


\section{6) NERVA [IIPROGRAM

EQUIPMENT TITLE

DRILL, MECHANICAL, REMOTE
PROV. LIST

ITEM NO.

DATE

January 1968

REVISION

DESCRIPTION: The Mechanical Remote Drill is a back-up tool used to remove galled or frozen threaded-fasteners. The unit uses standard, high-speed drills from 3/8- to 7/8-inch diameter. It is used with a Class A manipulator.

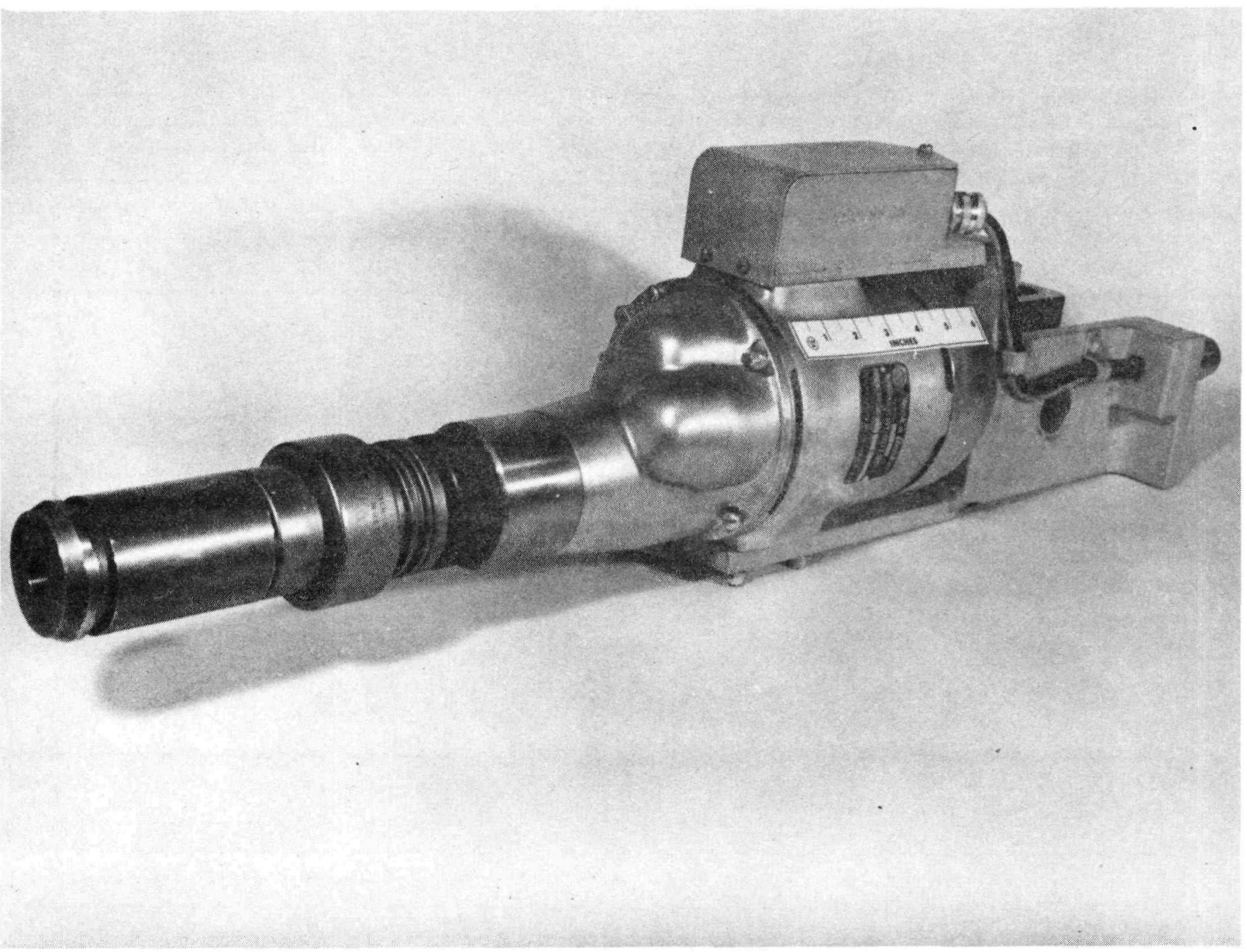


PROVISIONING LIST ITEM NUMBER 1200

DRAWING NUMBER

PART NUMBER

CONTRACTOR
NT650036

NT650036

WANL
FIRST PROVISIONED FOR NRX-A2 GOVT. INV. CONTROL NUMBER NT650036-001 $\$ 2797.00$ $\cos T$

TOTAL

QTY REQ'D

A. AGC SACRAMENTO

B. WANL

C.

D. NRDS

1

1

\section{DIMENSIONS AND CAPACITY}

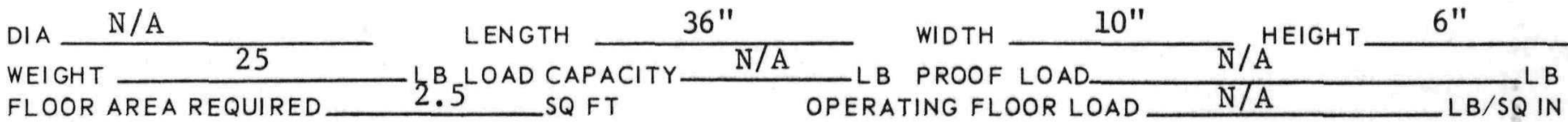
ADDITIONAL DATA

GASES N/A PRESSURE

LIQUIDS

SPEED

MEASURING ACCURACY

CALIBRATION INTERVAL

ADDITIONAL DATA

N/A

$\mathrm{N} / \mathrm{A}$

VOLTS $\quad 60$

PRESSURE

IN./MIN (RPM)
LB/SQIN. VOLUME CPS Single $-L B / S Q$ IN CUTTING SPEED HORIZONTAL
CFM LUBRICATION

PHASE KVA

QTY REQ'D $\mathrm{N} / \mathrm{A}$ 


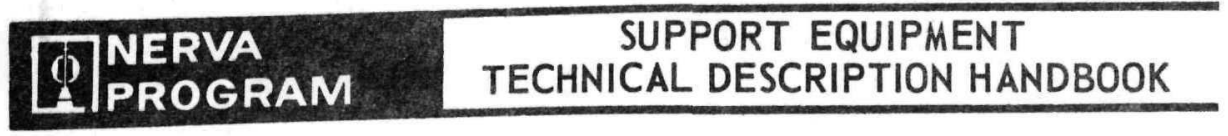

EQUIPMENT TITLE

CLIPS, RETAINER, CONTROL SHAFT
PROV. LIST

ITEM NO.

1209

DATE

REVISION January 1968

DESCRIPTION: The Control Shaft Retainer Clips attach to and hold the control shafts to the guide tubes during remote disassembly of the forward closure from the pressure vessel. Each clip is a spring wire with a plastic handle. It is manufactured from 1045 spring steel wire, 0.090 inch in diameter. The plastic handle is cast adiprene.

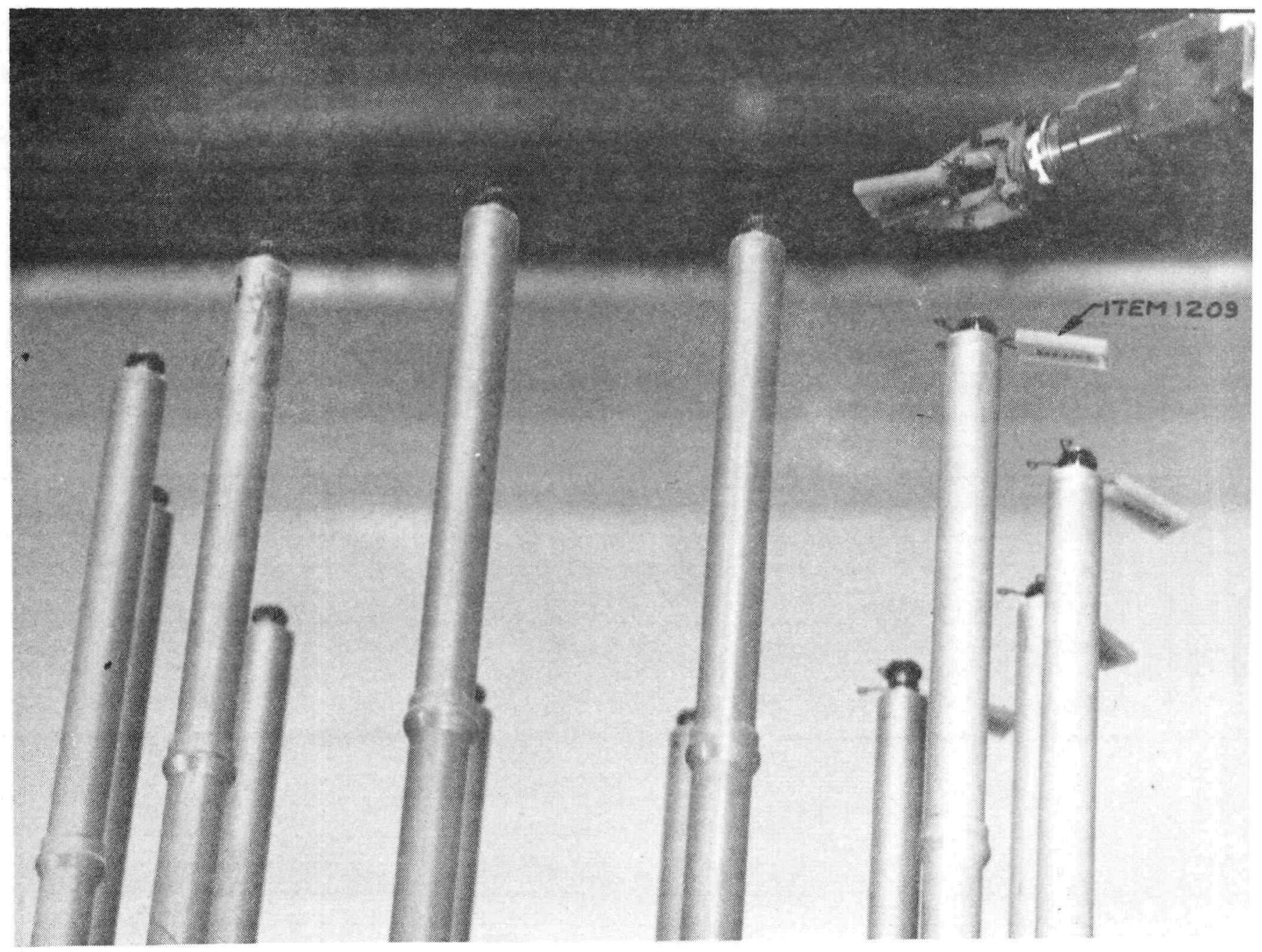


PROVISIONING LIST ITEM NUMBER 1209

DRAWING NUMBER

PART NUMBER

CONTRACTOR WANL/ACF1
FIRST PROVISIONED FOR NRX-A2 GOVT. INV. CONTROL NUMBER 3-510299-001 $\cos T$

\begin{tabular}{|l||c|}
\hline \multicolumn{1}{|c||}{ USE LOCATION } & QTY REQ'D \\
\hline A. AGC SACRAMENTO & \\
\hline B. WANL & \\
\hline C. & 1 set \\
\hline D. NRDS TOTAL & 1 set \\
\hline
\end{tabular}

\section{DIMENSIONS AND CAPACITY}

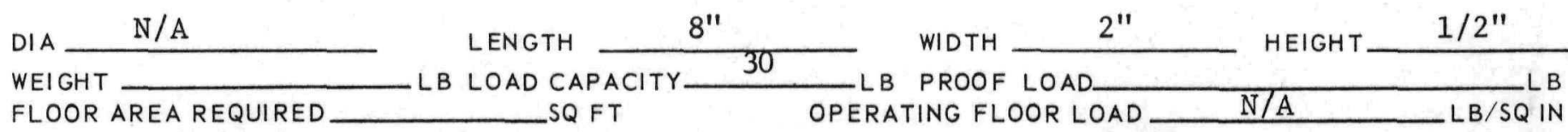

ADDITIONAL DATA

GASES N/A

ELECTRICAL LIQUIDS

SPEED

MEASURING ACCURACY

CALIBRATION INTERVAL N/A

ADDITIONAL DATA
$\mathrm{N} / \mathrm{A}$

PRESSURE

N/A

N/A

N/A VOLTS

PRESSURE IN./MIN (RPM)
LB/SQIN. VOLUME

\section{CPS}

LB/SQ IN

CUTTING SPEED

HORIZONTAL
CFM

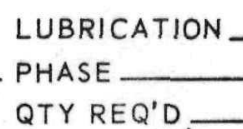

$\mathrm{N} / \mathrm{A}$

VERTICAL

\section{OPERATING EQUIPMENT}

MANIPULATOR_Class A

CRANE

N/A
LOAD CAPACITY

LOAD CAPACITY
LB MAX

LB MAX

ADDITIONAL DATA

EQUIPMENT_Class A Manipulator

PART OR ITEM Control Shafts and Guide Tubes DRAWING NO.

REMARKS 


\section{(1) NERVA 2. PROGRAM \\ SUPPORT EQUIPMENT TECHNICAL DESCRIPTION HANDBOOK}

EQUIPMENT TITLE

TOOL, SIMULATED SHIELD NUT INSTALLATION
PROV. LIST

ITEM NO.

1211

DATE

January 1968

C

DESCRIPTION: The Simulated Shield Nut Installation Tool is used to install the simulated shield nut into the instrumented reactor assembly. This tool is a spanner adapted for use with a manual 1/2-inch square-drive torque wrench.

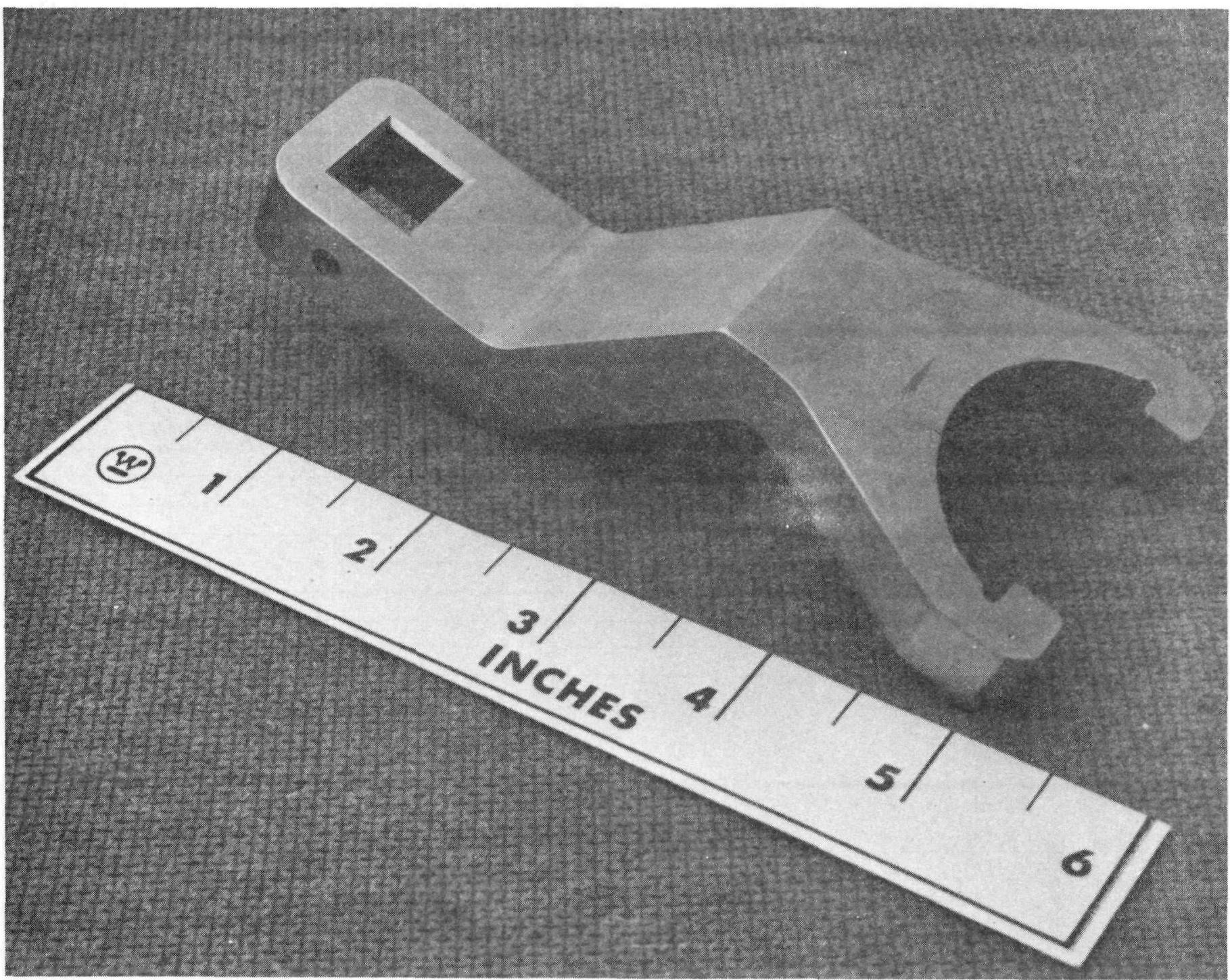


PROVISIONING LIST ITEM NUMBER

DRAWING NUMBER

PART NUMBER

CONTRACTOR
1211

NT650322

NT650322

WANL
FIRST PROVISIONED FOR NRX-A2 GOVT. INV. CONTROL NUMBER NT650322-001

$\cos T$ $\$ 295.00$

\begin{tabular}{|l||c|}
\hline \multicolumn{1}{|c||}{ USE LOCATION } & QTY REQ'D \\
\hline A. AGC SACRAMENTO & \\
\hline B. WANL & \\
\hline C. & 1 \\
\hline D. NRDS TOTAL & 1 \\
\hline \multicolumn{2}{|c||}{} \\
\hline
\end{tabular}

DIMENSIONS AND CAPACITY

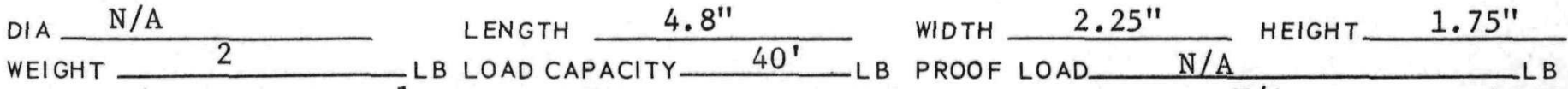
FLOOR AREA REQUIRED___ 1 OPERATING FLOOR LOAD ADDITIONAL DATA

GASES N/A

ELECTRICAL

LIQUIDS

SPEED

MEASURING ACCURACY

CALIBRATION INTERVAL

ADDITIONAL DATA
PRESSURE VOLTS

LB/SQIN. VOLUME

CPS

$L B / S Q I N$

CUTTING SPEED

HORIZONTAL IN./MIN (RPM)
CFM LUBRICATION

PHASE

QTY REQ'D
$\mathrm{N} / \mathrm{A}$

N/A
MANIPULATOR

CRANE

$\mathrm{N} / \mathrm{A}$

$\mathrm{N} / \mathrm{A}$

ADDITIONAL DATA

Torque Wrench $-1 / 2^{\prime \prime}$

LOAD CAPACITY

LOAD CAPACITY

LB MAX

\section{INTERFACES}

EQUIPMENT_Torque Wrench, $1 / 2^{\prime \prime}$ square drive, under $40 \mathrm{ft}-1 \mathrm{~b}$

PART OR ITEM Simulated Shield Nut

DRAWING NO. 946C110H01

REMARKS 
PROVISIONING LIST ITEM NUMBER 1218 DRAWING NUMBER

PART NUMBER CONTRACTOR
NT650020

NT650020

WANL
FIRST PROVISIONED FOR GOVT. INV. CONTROL NUMBER NT650020-001

$\cos T$ $\$ 1200.00$

\begin{tabular}{|c||c|}
\hline \multicolumn{1}{|c||}{ USE LOCATION } & QTY REQ'D \\
\hline A. AGC SACRAMENTO & \\
\hline B. WANL & \\
\hline C. & \\
\hline D. NRDS TOTAL & 1 \\
\hline
\end{tabular}

DIMENSIONS AND CAPACITY

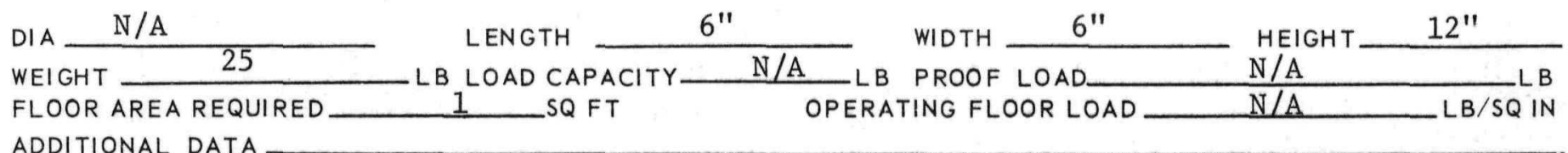

ADDITIONAL DATA

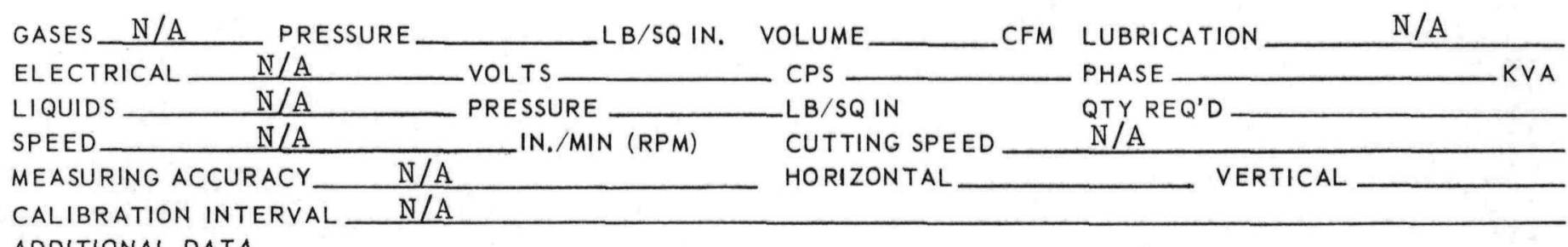

ADDITIONAL DATA

OPERATING EQUIPMENT

MANIPULATOR

CRANE

$\mathrm{N} / \mathrm{A}$

$N / A$
LOAD CAPACITY

LOAD CAPACITY
L B MAX

LB MAX

ADDITIONAL DATA

EQUIPMEN'T $\mathrm{N} / \mathrm{A}$

PART OR ITEM Dri11, Mechanical, Remote, REMARKS P/L 1200 DRAWING NO. 
DESCRIPTION: The Shipping Instrumentation Recorders and Cabinets consist of four brush electric-pen oscillographs (with associated amplifiers and signal conditioning equipment) shock mounted by pairs in weatherproof transporation cabinets. A time-pulse generator is also furnished for providing trace timing-marks. The cabinets are secured to the reactor and shield shipping semi-trailer (P/L 1249). The recorders are connected by cables to transducers installed on and in the reactor shipping container. This item records transporation and environmental data obtained from reactor instrumentation during shipment. Electrical power for the recorders and instrumentation is provided by a diesel-generator mounted on the semi-trailer.

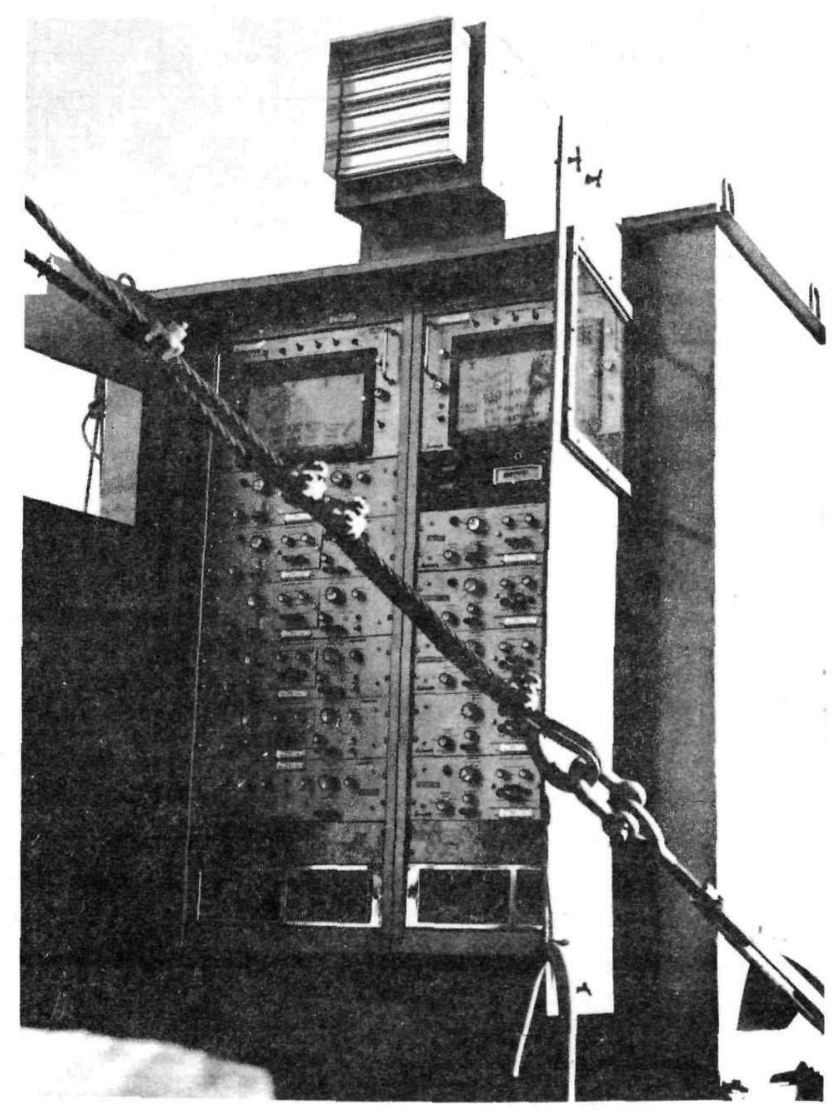


PROVISIONING LIST ITEM NUMBER 1224

DRAWING NUMBER

PART NUMBER

CONTRACTOR
WANL
FIRST PROVISIONED FOR NRX-AI GOVT. INV. CONTROL NUMBER

$\cos T$

\begin{tabular}{|l||c|}
\hline \multicolumn{1}{|c||}{ USE LOCATION } & QTY REQ'D \\
\hline A. AGC SACRAMENTO & \\
\hline B. WANL & \\
\hline C. & \\
\hline D. NRDS TOTAL & 1 set \\
\hline & 1 set \\
\hline
\end{tabular}

\section{DIMENSIONS AND CAPACITY}

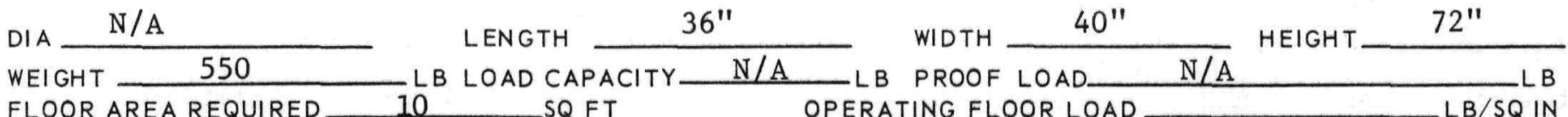
ADDITIONAL DATA

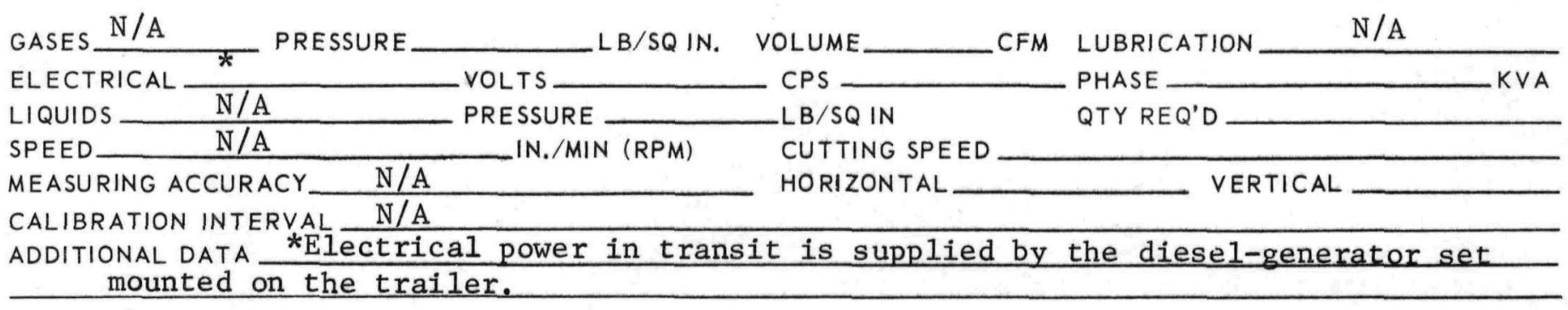

\section{OPERATING EQUIPMENT}

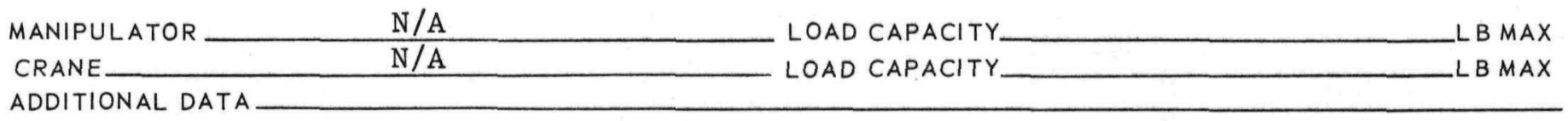

ADDITIONAL DATA

EQUIPMENT_ Reactor Shipping Semi-Trailer, Reactor Transportation Instrumentation PART OR ITEM DRAWING NO.

REMARKS 


\section{6) NERVA \\ LIPROGRAM \\ SUPPORT EQUIPMENT \\ TECHNICAL DESCRIPTION HANDBOOK}

EQUIPMENT TITLE

FIXTURE, HANDLING, CONTROL DRUM DISASSEMBLY STAND
PROV. LIST

ITEM NO.

1229

DATE

January 1968

REVISION

DESCRIPTION: The Control Drum Disassembly Stand Handling Fixture is used to lift the control drum disassembly stand. A Class A manipulator or an overhead crane with a five-ton capacity attaches to the four lifting lugs on the stand.

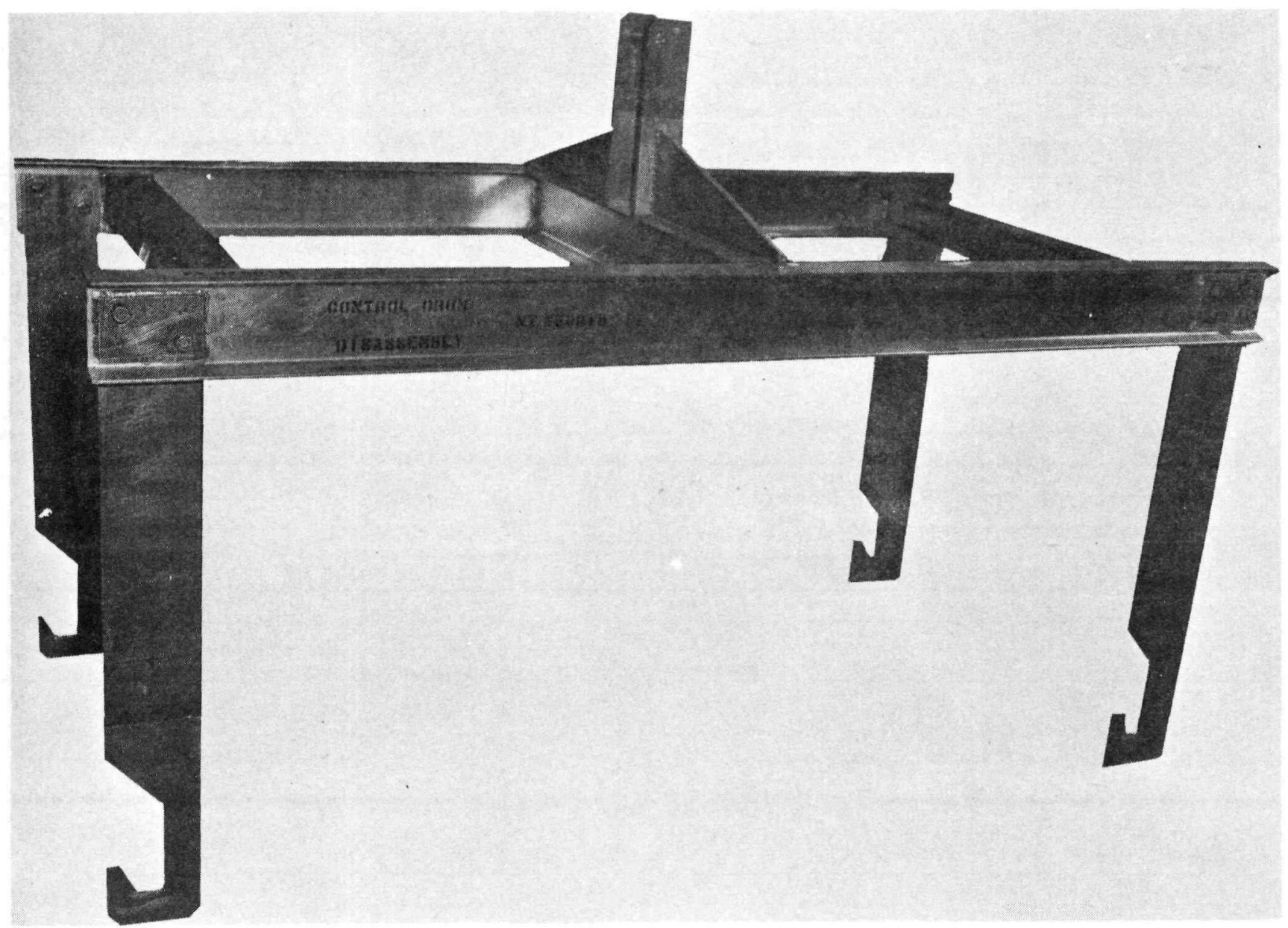


PROVISIONING LIST ITEM NUMBER

1229

DRAWING NUMBER
PART NUMBER

CONTRACTOR
NT650018

NT650018

WANL
FIRST PROVISIONED FOR NRX-A2 GOVT. INV. CONTROL NUMBER NT650018-001

COST

$\$ 770.00$

\begin{tabular}{|c||c|}
\hline \multicolumn{1}{|c||}{ USE LOCATION } & QTY REQ'D \\
\hline A. AGC SACRAMENTO & \\
\hline B. WANL & \\
\hline C. & 1 \\
\hline D. NRDS TOTAL & 1 \\
\hline \multicolumn{2}{|c|}{} \\
\hline
\end{tabular}

\section{DIMENSIONS AND CAPACITY}

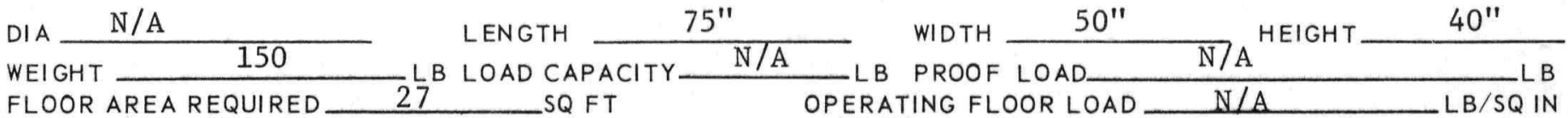

ADDITIONAL DATA

\section{OPERATING DATA}

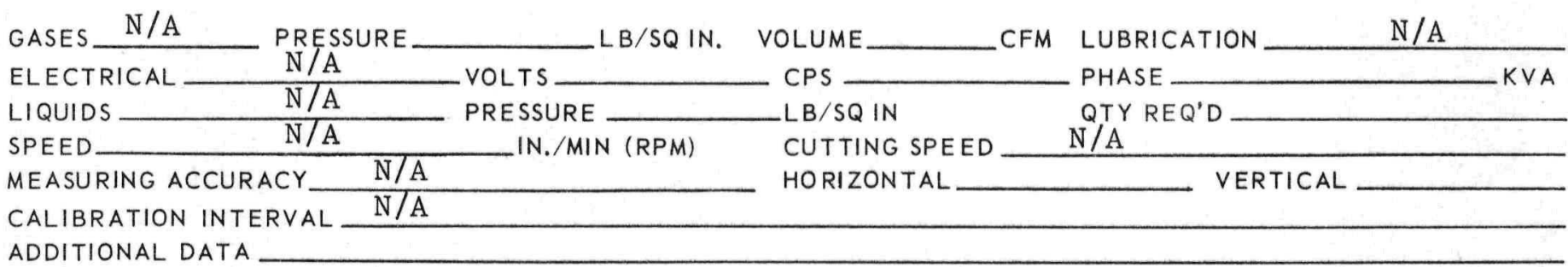

\section{OPERATING EQUIPMENT}

MANIPULATOR Class A

CRANE

ADDITIONAL DATA
LOAD CAPACITY

LOAD CAPACITY 10,000
LB MAX LB MAX 


\section{() NERVA \\ LIPROGRAM \\ SUPPORT EQUIPMENT \\ TECHNICAL DESCRIPTION HANDBOOK}

EQUIPMENT TITLE

FIXTURE, CLOSING, LARGE DISPOSAL PAIL
PROV. LIST

ITEM NO. 1230

DATE REVISION

January 1968

C

DESCRIPTION: The Large Disposal Pail Closing Fixture is used to remotely crimp and seal the lugs on covers of the large disposal pails. It consists of a commercial closing tool, air motor and adaption framework, linkage, and air accessories. The pail to be closed is placed on the base of the frame and slid into position under the closing tool. The tool is brought down onto the pail and actuated by the air cylinder, locking the cover on the pail.

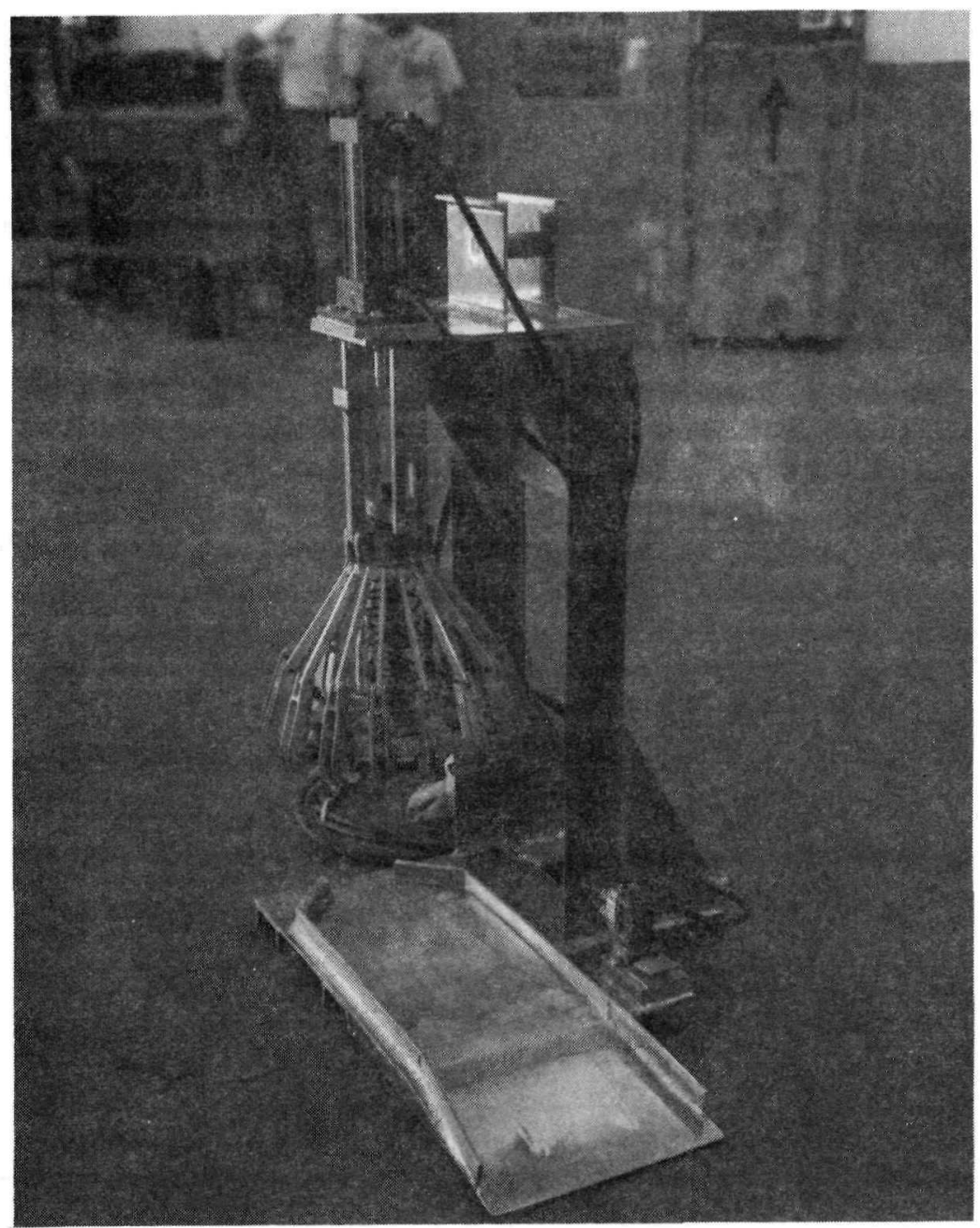


PROVISIONING LIST ITEM NUMBER 1230

DRAWING NUMBER NT650329

PART NUMBER

CONTRACTOR
NT650329

WANL
FIRST PROVISIONED FOR

$\mathrm{NRX}-\mathrm{A} 2$ GOVT. INV. CONTROL NUMBER NT650329-001

\begin{tabular}{|l||c|}
\hline \multicolumn{1}{|c||}{ USE LOCATION } & QTY REQ'D \\
\hline A. AGC SACRAMENTO & \\
\hline B. WANL & \\
\hline C. & 1 \\
\hline D. NRDS TOTAL & 1 \\
\hline \multicolumn{2}{|c|}{} \\
\hline
\end{tabular}

DIMENSIONS AND CAPACITY

DIA N/A

WEIGHT

FLOOR AREA REQUIRED

ADDITIONAL DATA
$\operatorname{cosT} \$ 1915.00$
GASES Air

GASES Air

LIQUIDS

SPEED

MEASURING ACCURAC

ADDITIONAL DATA

CALIBRATION INTERVAL N N N

LENGTH 9 SQ FT
WIDTH

2 OPERATING FLOOR LOAD $51^{\prime \prime}$ L B B $L B / S Q$ IN

OPERATING DATA PRESSURE

100 LB/SQIN. VOLUME $\mathrm{N} / \mathrm{A}$ CFM VOLTS PRESSURE CPS LUBPICATION N/A PHASE KVA $-L B / S Q$ IN IN./MIN (RPM) CUTTING SPE HORIZONTAL QTY REQ'D N/A N/A VERTICAL

\section{OPERATING EQUIPMENT}

MANIPULATOR $\frac{\text { Class A }}{\text { N/A }}$ 


\section{(1) NERVA \\ LIPROGRAM \\ SUPPORT EQUIPMENT \\ TECHNICAL DESCRIPTION HANDBOOK}

EQUIPMENT TITLE

FIXTURE, CLOSING, SMALL DISPOSAL PAIL
PROV. LIST

ITEM NO.

1237

DATE

REVISION

DESCRIPTION: The Small Disposal Pail Closing Fixture is used to remotely press covers on small disposal pails. It consists of a frame, an air cylinder, a pressure plate, and necessary air accessories. The frame is a vertical column with cylinder spacers, a base, pail guides, and a lifting bail. The base is rectangular and suitable for bench mounting. The cylinder is vertically attached to the column over the pail guides and by the cylinder spacers with the push-rod acting downward. It is a spring-return type and includes the push rod and pressure plate. An air hose, leveroperated valve, and remote connector are included.

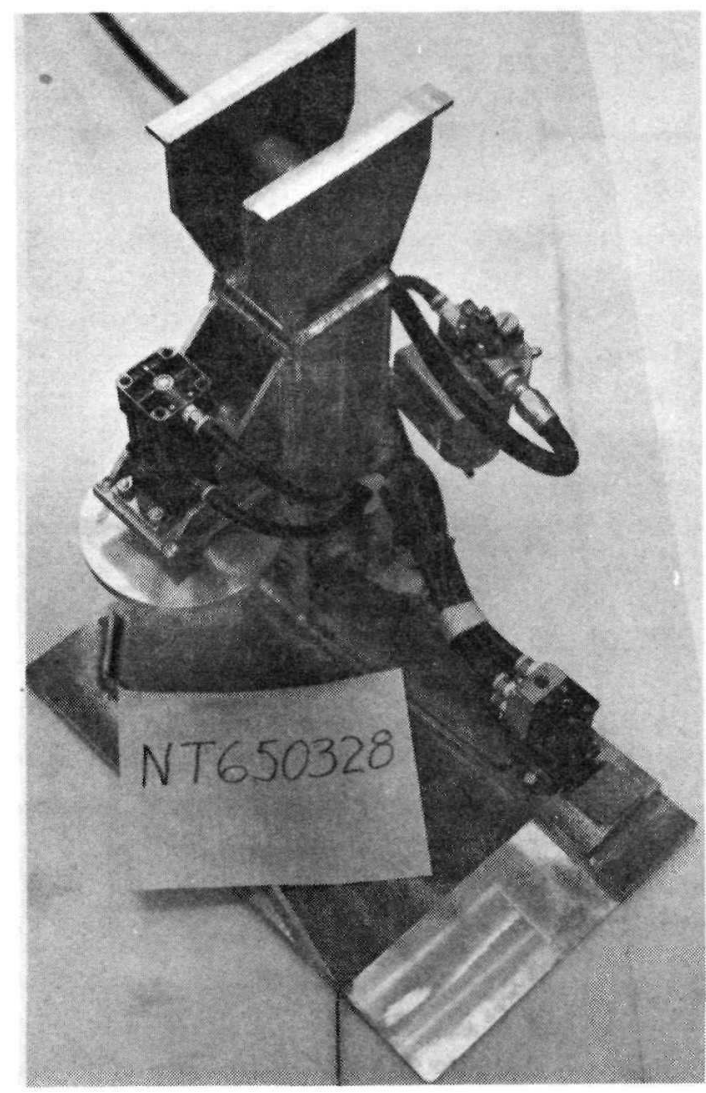


PROVISIONING LIST ITEM NUMBER

DRAWING NUMBER

PART NUMBER

CONTRACTOR
NT650328

NT650328

WANL
FIRST PROVISIONED FOR GOVT. INV. CONTROL NUMBER

$\mathrm{NRX}-\mathrm{A} 2$

1237 $\operatorname{cosT} \$ 650.00$

\begin{tabular}{|l||c|}
\hline \multicolumn{1}{|c||}{ USE LOCATION } & QTY REQ'D \\
\hline A. AGC SACRAMENTO & \\
\hline B. WANL & \\
\hline C. & 1 \\
\hline D. NRDS TOTAL & 1 \\
\hline \multicolumn{2}{|c||}{} \\
\hline
\end{tabular}

DIMENSIONS AND CAPACITY

DIA N/A

WEIGHT

FLOOR AREA REQUIRED

ADDITIONAL DATA Maximum closing force 300 pounds

\section{LENGTH $22^{\prime \prime}$ \\ WIDTH \\ 13-5/8" HEIGHT 23-1/2"}

N/A LB

N/A $L B / S Q$ IN

\section{OPERATING DATA}

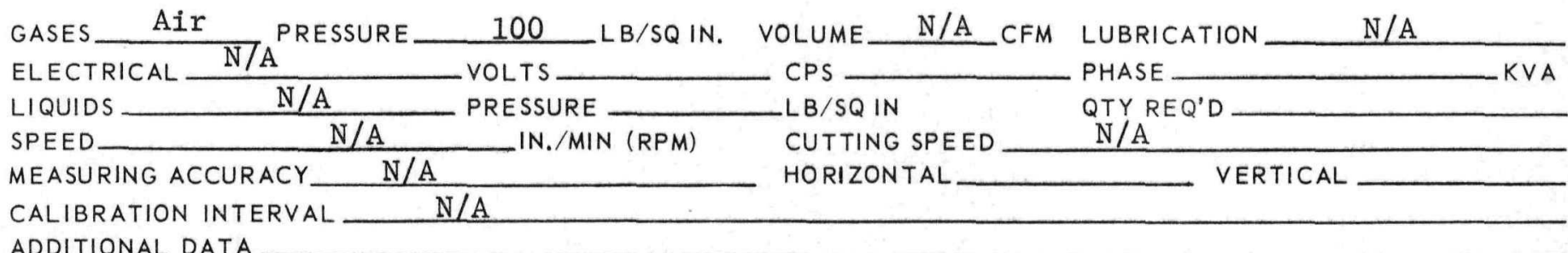
ADDITIONAL DATA

MANIF ULATOR Class A

CRANE N/A

ADDITIONAL DATA
LOAD CAPACITY

LOAD CAPACITY $\angle B M A X$

LB MAX
EQUIPMENT_Class A Manipulators

PART OR ITEM Small Disposal Pail

REMARKS
DRAWING NO. 


\section{(1) NERVA LIPROGRAM \\ SUPPORT EQUIPMENT TECHNICAL DESCRIPTION HANDBOOK}

EQUIPMENT TITLE

SEMI-TRAILER, REACTOR AND SHIELD SHIPPING
PROV. LIST

ITEM NO.

1249

DATE

REVISION January 1968

C

DESCRIPTION: The Reactor and Shield Shipping Semi-Trailer is a modified 30-ton, double-drop, low-bed trailer with an air-cushion ride and spring-loaded safety brakes. Tie downs and anchors are provided for the reactor and shield shipping container. Mounts for the diesel generator, control cabinets, and nitrogen supply bottles are also provided. The trailer is equipped with adequate signs and lights for "over-the-road" use.

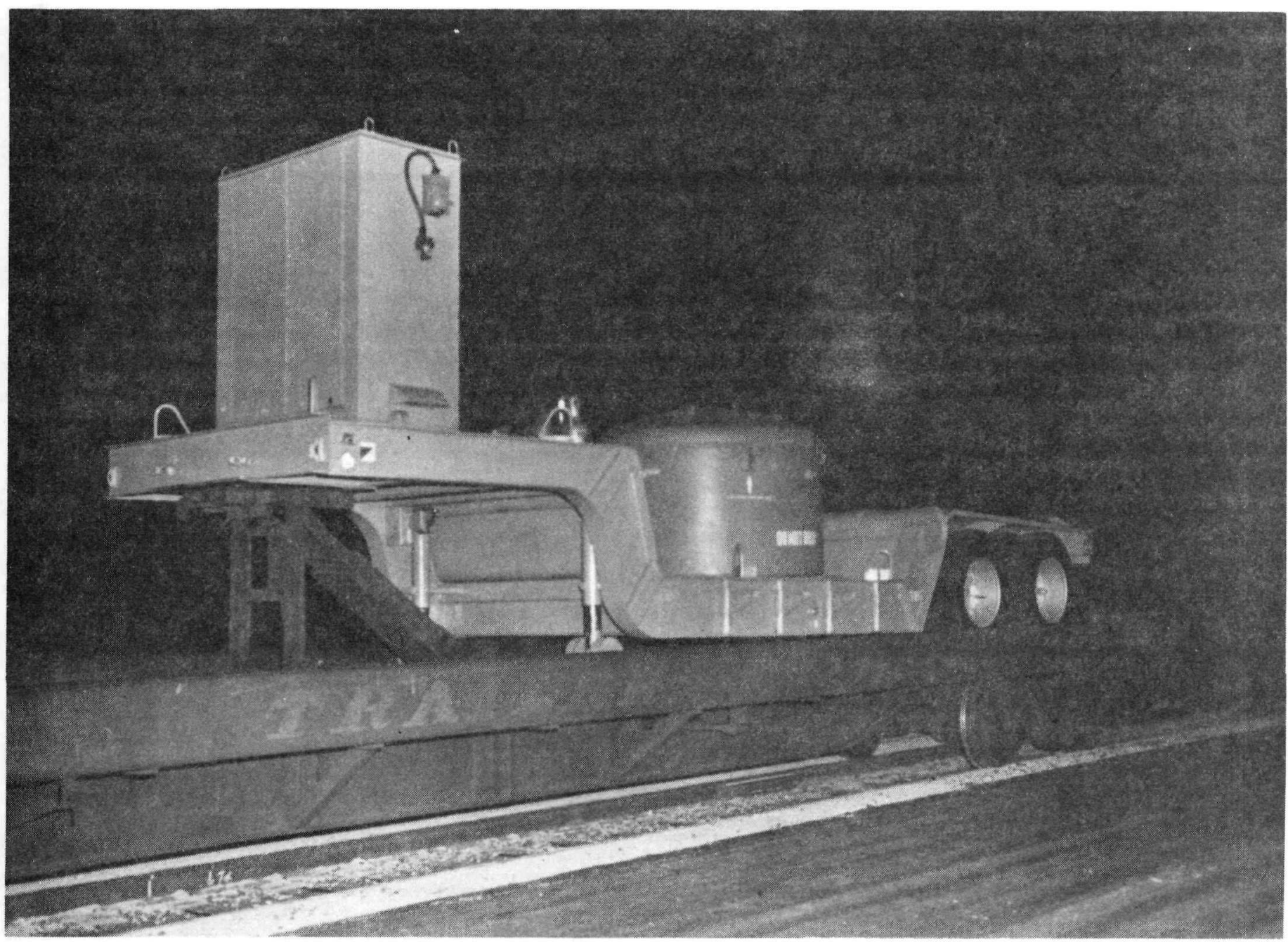


PROVISIONING LIST ITEM NUMBER

1249

DRAWING NUMBER NT600082

FIRST PROVISIONED FOR $\quad$ NRX $-A 2$

PART NUMBER NT600082

CONTRACTOR WANL

\begin{tabular}{|l||c|}
\hline \multicolumn{1}{|c||}{ USE LOCATION } & QTY REQ'D \\
\hline A. AGC SACRAMENTO & \\
\hline B. WANL & \\
\hline C. & \\
\hline D. NRDS TOTAL & 1 \\
\hline
\end{tabular}

\section{DIMENSIONS AND CAPACITY}

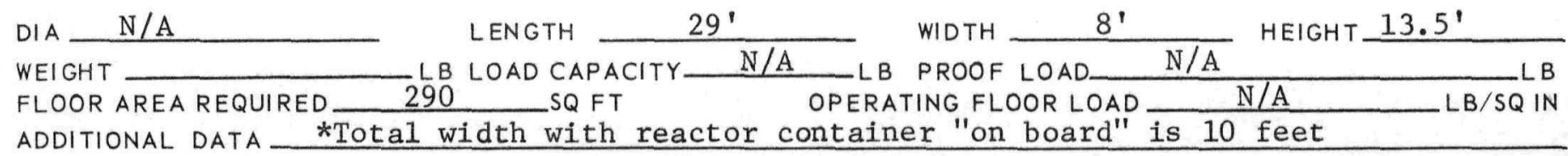

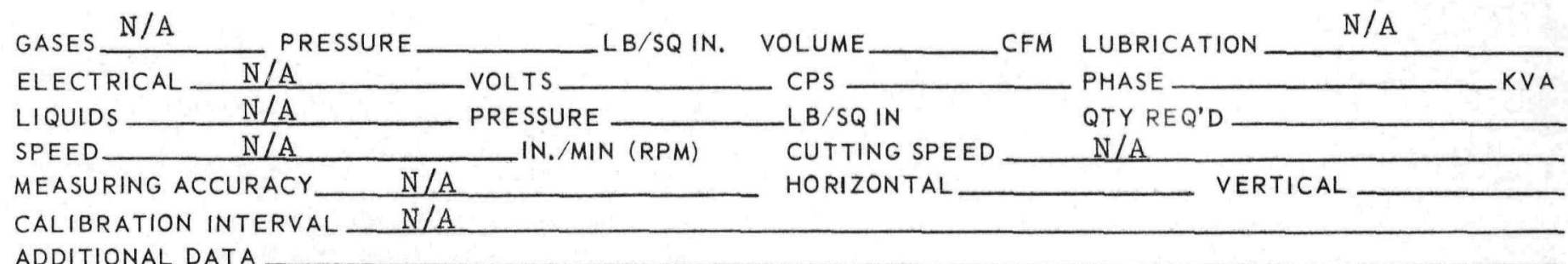

EQUIPMENT_ Truck Tractor, Standard Railroad Flat Car PART OR ITEM Reactor/Shield- DRAWING NO. REMARKS 


\section{(1) NERVA LIPROGRAM SUPPORT EQUIPMENT TECHNICAL DESCRIPTION HANDBOOK}

EQUIPMENT TITLE

TRUNNION CAGE, REACTOR/VESSEL
PROV. LIST

ITEM NO.

\section{DATE}

January 1968

\section{REVISION}

DESCRIPTION: The Reactor/Vessel Trunnion Cage is used with the reactor trunnion fixture and is designed to handle the following components or assemblies in either manual or remote operations: (1) the pressure vessel alone; (2) the pressure vessel and nozzle; and (3) the NRX vessel/reactor assembly. A strongback lifting fixture is provided for handling of the cage, either loaded or unloaded, from either end. The cage is capable of being lowered over a complete NRX assembly in the nozzle-up position.
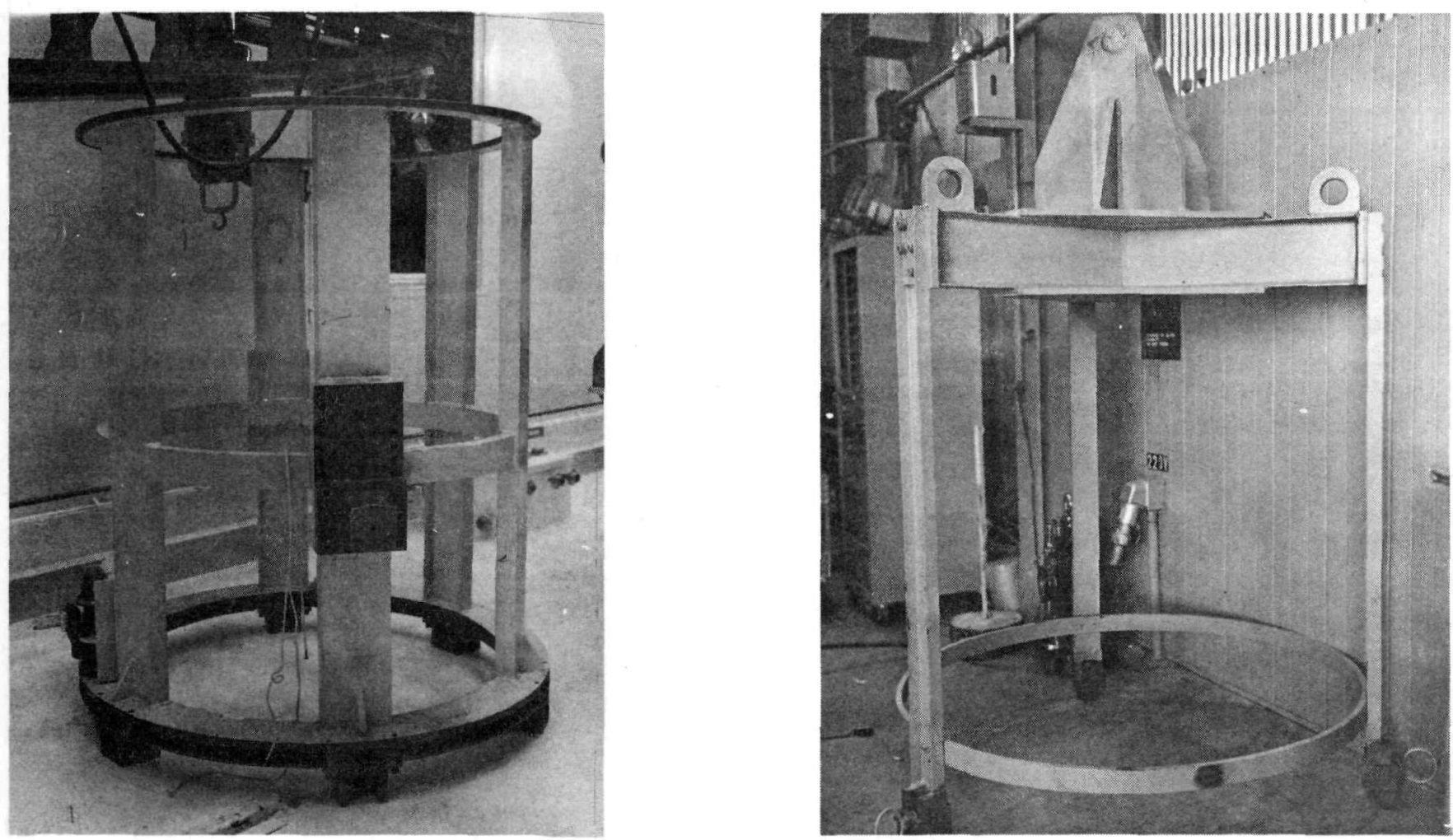
PROVISIONING LIST ITEM NUMBER 1251

DRAWING NUMBER

PART NUMBER

CONTRACTOR
3-510081

3-510081

WANL/ACFI
FIRST PROVISIONED FOR

$\mathrm{NRX}-\mathrm{A} 2$ GOVT. INV. CONTROL NUMBER NT650232-001

\begin{tabular}{|l||c|}
\hline \multicolumn{1}{|c||}{ USE LOCATION } & QTY REQ'D \\
\hline A. AGC SACRAMENTO & \\
\hline B. WANL & \\
\hline C. & \\
\hline D. NRDS (R-MAD) & 1 \\
\hline \multicolumn{2}{|c|}{ TOTAL } \\
\hline
\end{tabular}

\section{DIMENSIONS AND CAPACITY}

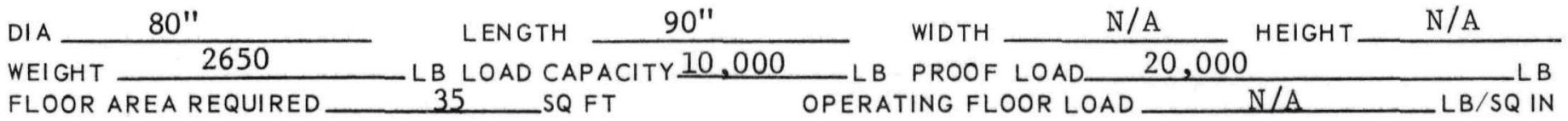

ADDITIONAL DATA

\section{OPERATING DATA}

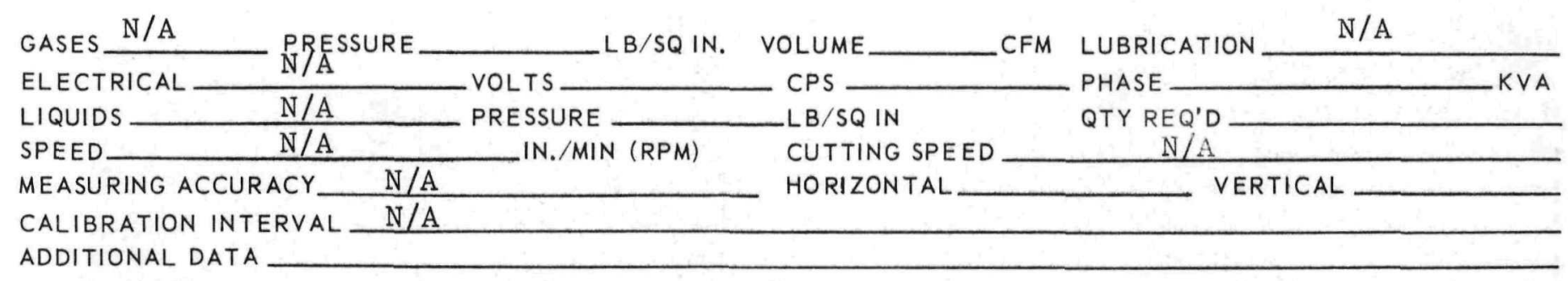

MANIPULATOR_N/A

CRANE ADDITIONAL DATA
LOAD CAPACITY

rane lifts the cage by use of the lifting fixture.
LB MAX

LB MAX

EQUIPMENT Lifting Fixture (part of this item) and Reactor Trunnion Fixture (P/L 1182) PART OR ITEM Reactor/Pressure Vessel Assem. DRAWING NO.

REMARKS This item was made from P/L 1150 . 


\section{(1) NERVA \\ LIPROGRAM \\ SUPPORT EQUIPMENT \\ TECHNICAL DESCRIPTION HANDBOOK}

EQUIPMENT TITLE

INSERT, ELEMENT CASK
PROV. LIST

ITEM NO.

1258

DATE $\frac{\text { Ja }}{\text { REVISION }}$ 1968

A

DESCRIPTION: The Element Cask Insert is used for storing fuel elements after a test. It is fabricated of aluminum plates and boral poisoning. Its size and shape are compatible with existing LASL shielded shipping containers. One set of 20 inserts is required for each reactor.

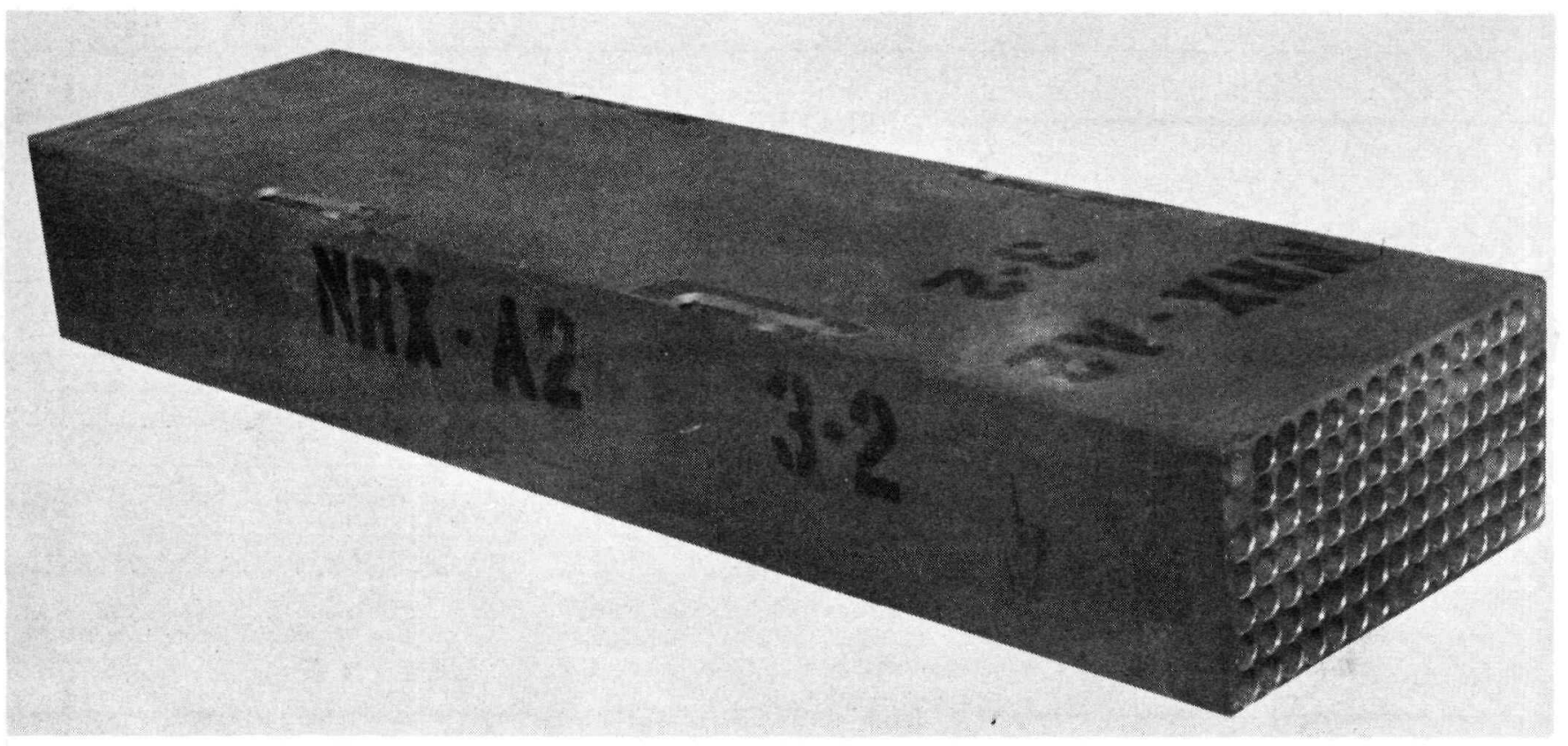


PROVISIONING LIST ITEM NUMBER 1258

DRAWING NUMBER

PART NUMBER

CONTRACTOR
NT650434

NT650434

WANL
FIRST PROVISIONED FOR

$\mathrm{NRX}-\mathrm{A} 3$

COST $\$ 635.00$ each

\begin{tabular}{|l||r|}
\hline \multicolumn{1}{|c||}{ USE LOCATION } & QTY REQ'D \\
\hline A. AGC SACRAMENTO & \\
\hline B. WANL & \\
\hline C. & $* 1$ set \\
\hline D. NRDS TOTAL & 1 set \\
\hline
\end{tabular}

* Set is composed of 20 inserts for one reactor.

DIMENSIONS AND CAPACITY

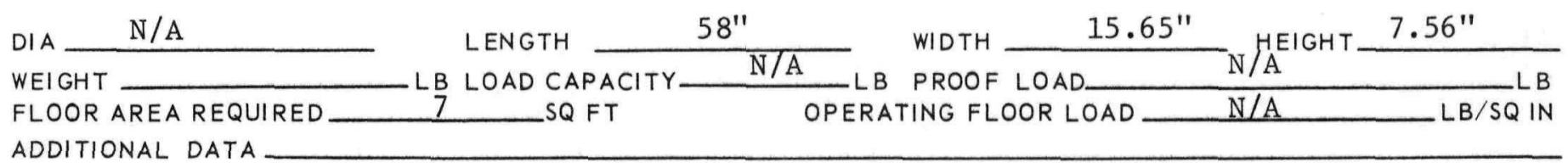

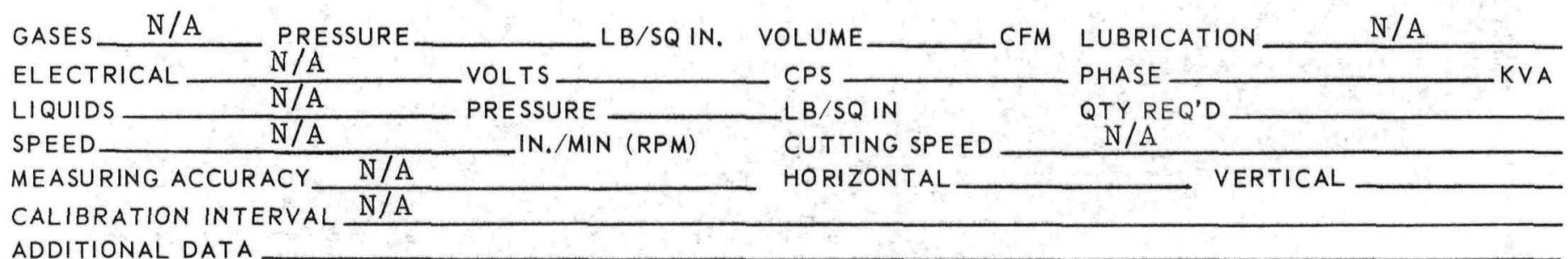

ADDITIONAL DATA

OPERATING EQUIPMENT

MANIPULATOR $\frac{\text { Class A }}{\mathrm{N} / \mathrm{A}}$
CRANE

LOAD CAPACITY

LB MAX

LOAD CAPACITY

LB MAX

ADDITIONAL DATA

INTERFACES

EQUIPMENT_Lifting Fixture and Class A Manipulator

PART OR ITEM Fuel Elements

DRAWING NO.

REMARKS 


\section{(1) NERVA \\ LIPROGRAM \\ SUPPORT EQUIPMENT TECHNICAL DESCRIPTION HANDBOOK}

EQUIPMENT TITLE

PROV. LIST

ITEM NO.

1290

DATE

REVISION

January 1968

CUTTER, CONTROL DRUM ASSEMBLY

DESCRIPTION: The Control Drum Assembly Cutter consists of two motor-driven rotating support rollers, a motor driven cutter, a support base, and necessary electrical controls and connections. The unit is remotely operated and is used to cut the aluminum control drum cylinders at the drive shaft end to permit removal of the poison plate without cutting the toxic material within the control drum. A control drum is held horizontally by the two sets of motor-driven rollers. The pivoted grinding head is positioned over the drum and the drum is cut while being rotated by the support rollers. The cutter is provided with lifting eyes for remote lifting.

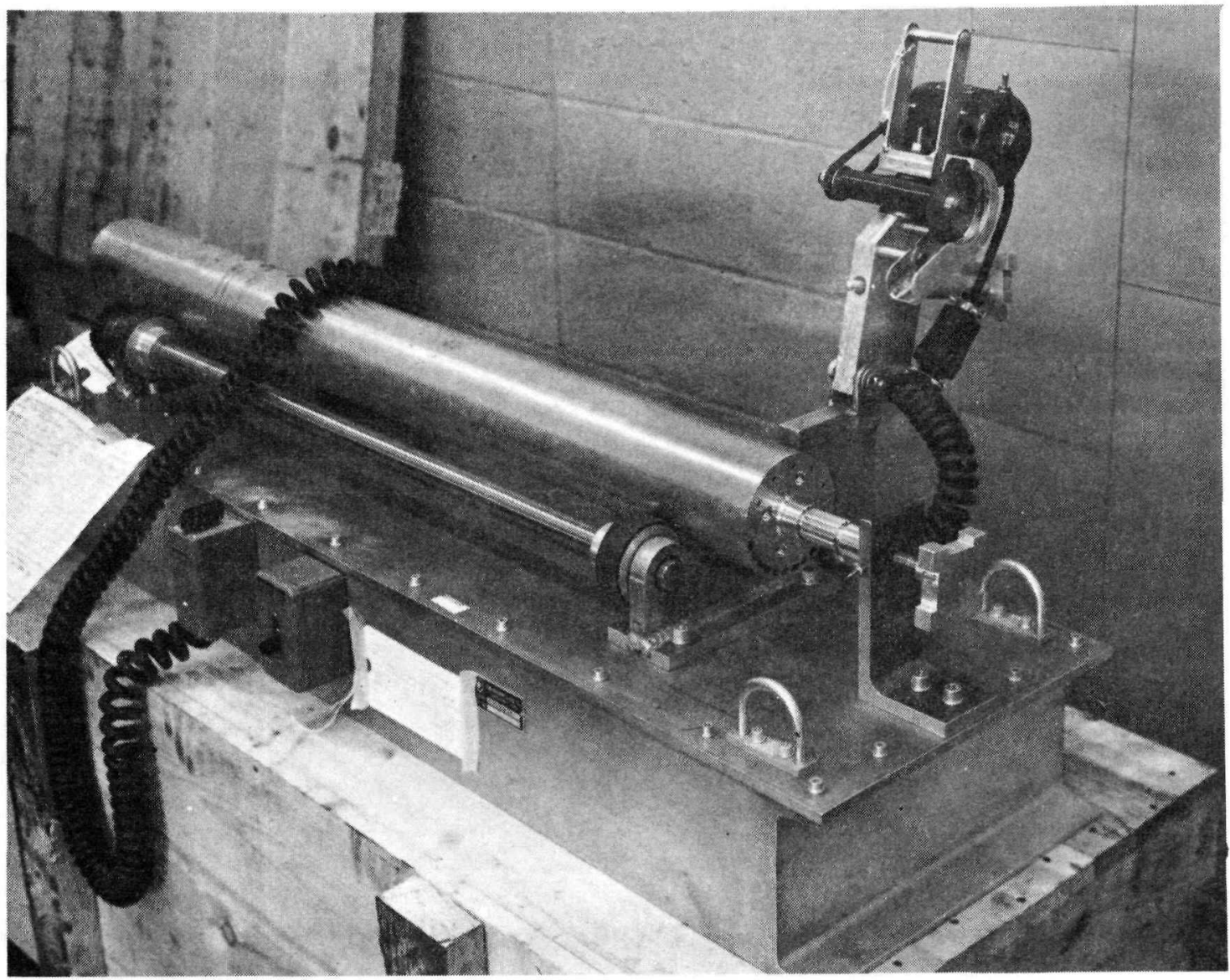


PROVISIONING LIST ITEM NUMBER DRAWING NUMBER NT650297

PART NUMBER CONTRACTOR
1290

NT650297

WANL
FIRST PROVISIONED FOR

$\mathrm{NRX}-\mathrm{A} 2$
GOVT. INV. CONTROL NUMBER

$\cos T \$ 1000.00$

\begin{tabular}{|c||c|}
\hline \multicolumn{1}{|c||}{ USE LOCATION } & QTY REQ'D \\
\hline A. AGC SACRAMENTO & \\
\hline B. WANL & \\
\hline C. & \\
\hline D. NRDS TOTAL & 1 \\
\hline
\end{tabular}

DIMENSIONS AND CAPACITY

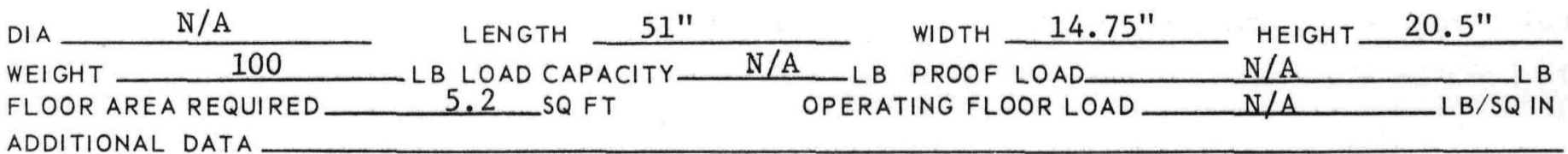

ADDITIONAL DATA

GASES N N/A PRESSURE ELECTRICAL_ 115 LIQUIDS N/A SPEED MEASURING ACCURACY

CALIBRATION INTERVAL N/A ADDITIONAL DATA
$L B / S Q I N$. VOLUME 60
60 VOLTS IN./MIN (RPM) $L B / S Q I N$

OPERATING EQUIPMENT

MANIPULATOR_Master/Slave LOAD CAPACITY CRANE ADDITIONAL DAT

LOAD CAPACITY LB MAX AL DATA *Used for moving the item, not for operation

EQUIPMENT_Class A Manipulator

PART OR ITEM Control Drum Assembly DRAWING NO.

LUBRICATION PHASE KVA CUTTING SPEED QTY REQ'D 


\section{(6) NERVA \\ LIPROGRAM \\ SUPPORT EQUIPMENT \\ TECHNICAL DESCRIPTION HANDBOOK}

EQUIPMENT TITLE

ADAPTER, PERISCOPE

DESCRIPTION: The Periscope Adapter permits the periscope to penetrate a hot cell wall. The unit minimizes air flow through the penetration from the hot area and provides radiation protection equal to that of the hot cell wall.

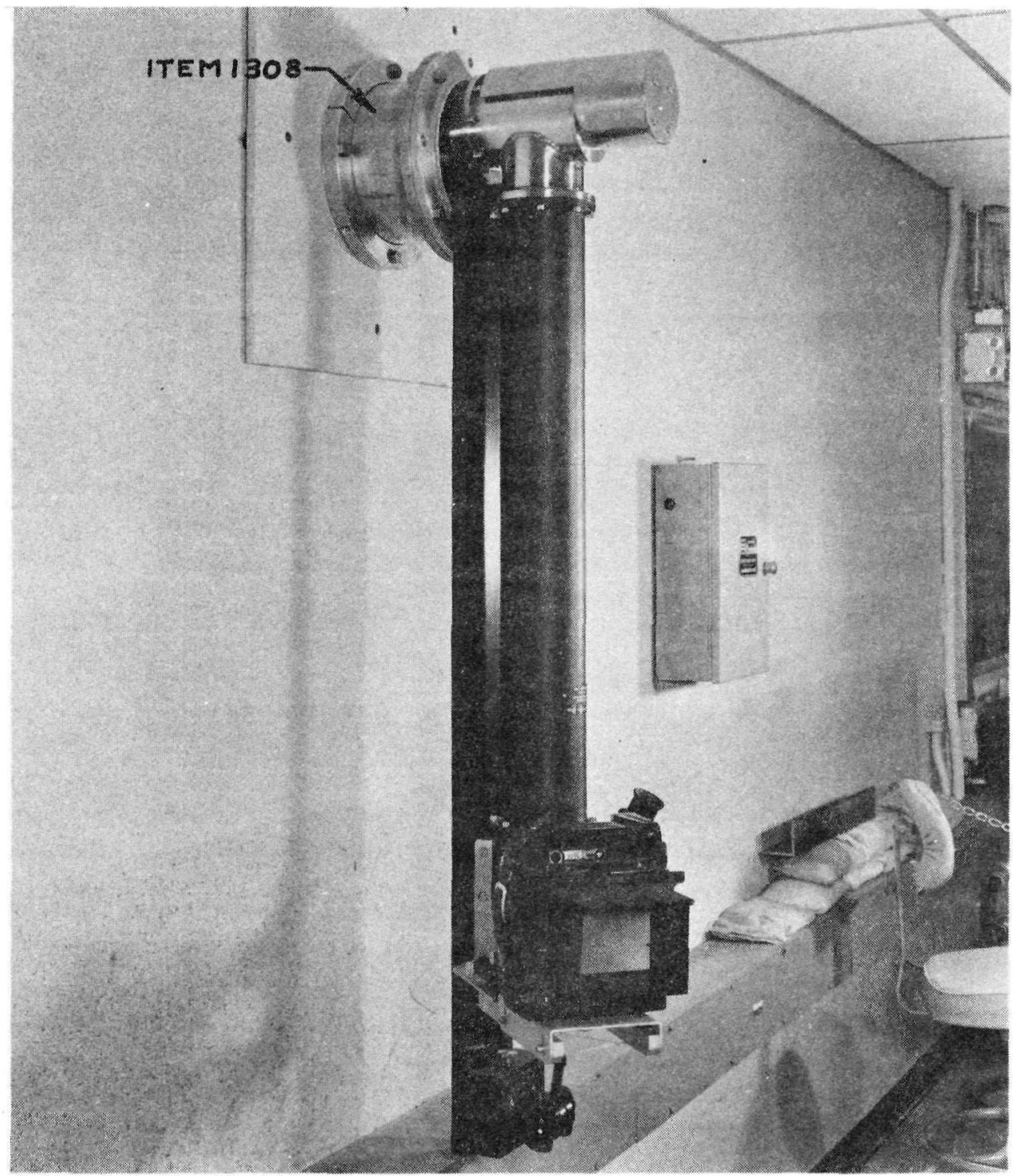


PROVISIONING LIST ITEM NUMBER 1308

DRAWING NUMBER NT650315

PART NUMBER NT650315

CONTRACTOR
WANL
FIRST PROVISIONED FOR NRX-A2 GOVT. INV. CONTROL NUMBER NT650315-00

\begin{tabular}{|r||c|}
\hline \multicolumn{1}{|c||}{ USE LOCATION } & QTY REQ'D \\
\hline A. AGC SACRAMENTO & \\
\hline B. WANL & \\
\hline C. & 1 \\
\hline D. NRDS TOTAL & 1 \\
\hline
\end{tabular}

\section{DIMENSIONS AND CAPACITY}

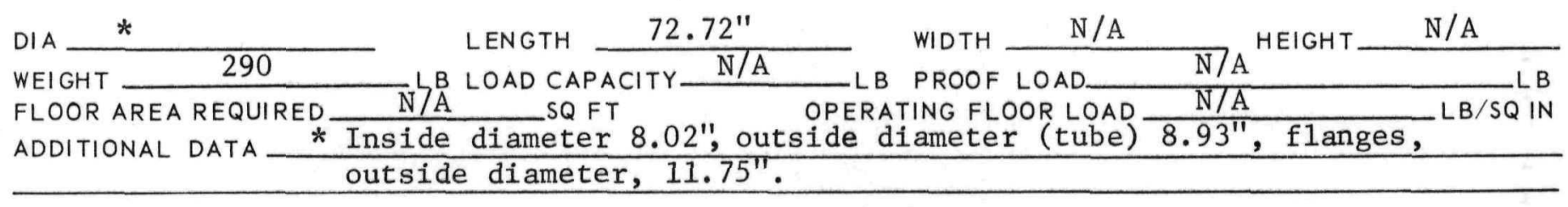

OPERATING DATA

\begin{tabular}{|c|c|c|c|}
\hline GASES N/A & PRESSURE. & VOLUME_ & $\mathrm{N} / \mathrm{A}$ \\
\hline ELECTRICAL & VOLTS & CPS & PHASE \\
\hline LIQUIDS. & PRESSURE & $-L B / S Q$ IN & QTY REQ'D \\
\hline SPEED - & IN./MIN (RPM) & CUTTING SPEED & $\mathrm{N} / \mathrm{A}$ \\
\hline MEASURING ACCU & $A C Y \quad N / A$ & HORIZONTAL & VERTICAL \\
\hline ALIBRATION INT & RVAL $\quad$ N/A & & \\
\hline
\end{tabular}

MANIPULATOR

CRANE

$\mathrm{N} / \mathrm{A}$

N/A
LOAD CAPACITY

LOAD CAPACITY
$L B$ MAX

LB MAX

ADDITIONAL DATA 


\section{TECHNICAL SUMMARY}

PROVISIONING LIST ITEM NUMBER 1334

DRAWING NUMBER

PART NUMBER

CONTRACTOR
NT650131

NT650131

WANL
FIRST PROVISIONED FOR NRX-AI GOVT. INV. CONTROL NUMBER NT650131-001

COST $\$ 197.00$

\begin{tabular}{|c|c|}
\hline USE LOCATION & QTY REQ'D \\
\hline A. AGC SACRAMENTO & \\
\hline B. WANL & \\
\hline C. & \\
\hline D. NRDS & 1 \\
\hline TOTAL & 1 \\
\hline
\end{tabular}

\section{DIMENSIONS AND CAPACITY}

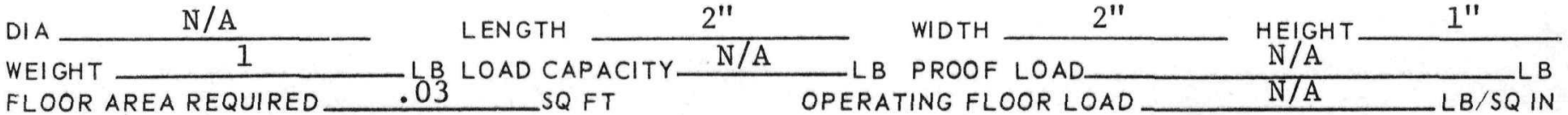

ADDITIONAL DATA

OPERATING DATA

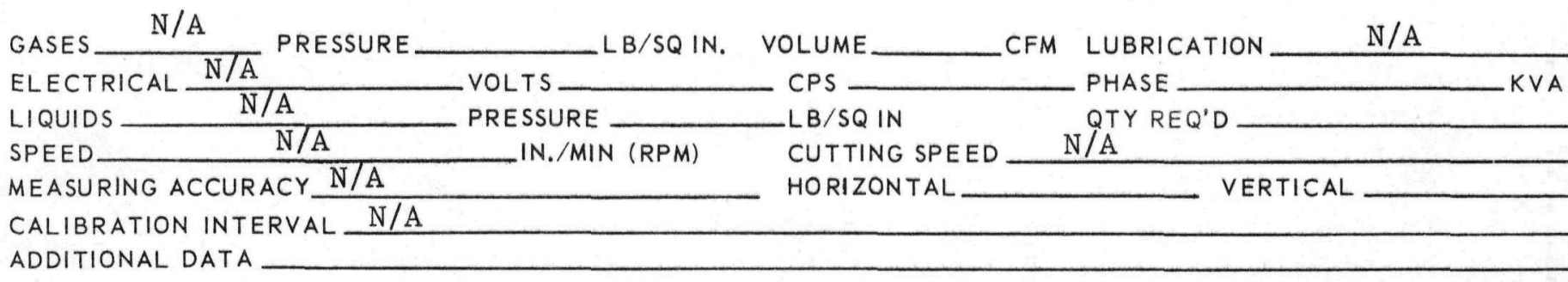

OPERATING EQUIPMENT

MANIPULATOR N/A

CRANE N/A

ADDITIONAL DATA
LOAD CAPACITY

LOAD CAPACITY
LB MAX

LB MAX

INTERFACES

EQUIPMENT_

Torque Wrench

PART OR ITEM Control Drum Scram Springs

DRAWING NO.

REMARKS 


\begin{tabular}{|l|l}
\hline DER & NERA \\
\hline PROGRAM & TECHNICAL DESCRIPTION HANDBOOK \\
\hline
\end{tabular}

EQUIPMENT TITLE

FIXTURE, RETAINING, TRUNNION CAGE
PROV, LIST

ITEM NO.

1337

DATE

January 1968

B

DESCRIPTION: The Trunnion Case Retaining Fixture is a cylindrical, tubular device which holds the outer reflector in place during removal of the outer reflector segment.

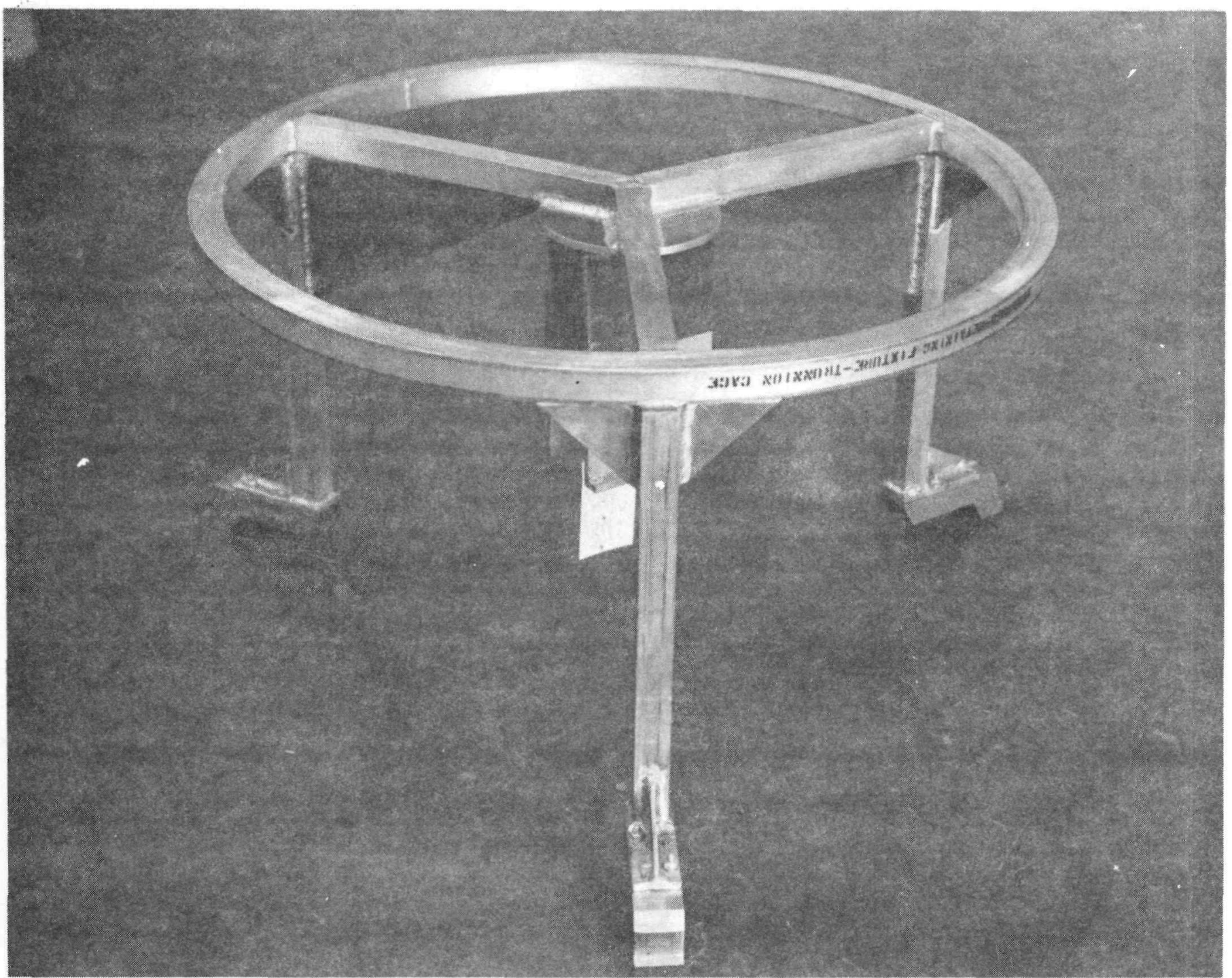


PROVISIONING LIST ITEM NUMBER 1337

DRAWING NUMBER NT650326

PART NUMBER N NT650326

CONTRACTOR — WANL
FIRST PROVISIONED FOR NRX-A2 GOVT. INV. CONTROL NUMBER NT650326

$\cos T \_\$ 750.00$

\begin{tabular}{|l||c|}
\hline \multicolumn{1}{|c||}{ USE LOCATION } & QTY REQ'D \\
\hline A. AGC SACRAMENTO & \\
\hline B. WANL & \\
\hline C. & 1 \\
\hline D. NRDS TOTAL & 1 \\
\hline
\end{tabular}

\section{DIMENSIONS AND CAPACITY}

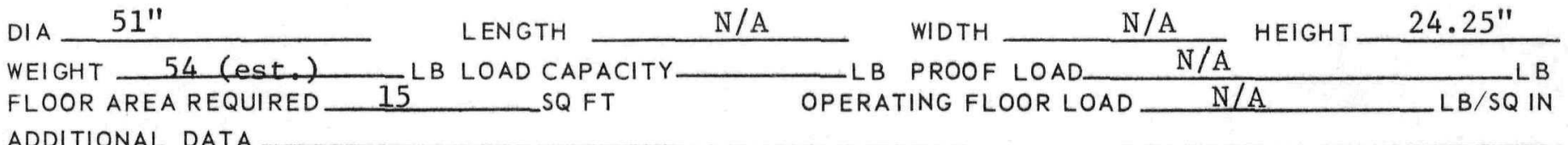

ADDITIONAL DATA

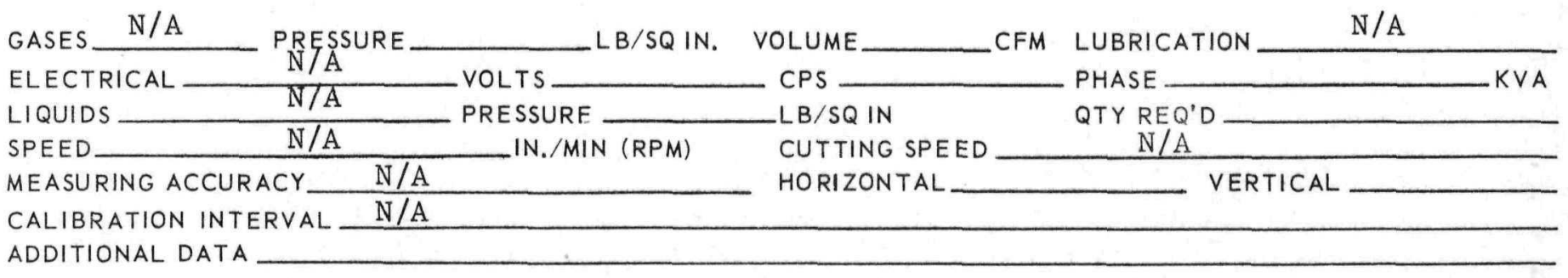

\section{OPERATING EQUIPMENT}

MANIPULATOR $\frac{\text { Class A }}{\text { N/A }}$

EQUIPMENT Trunnion Cage (ACFI Dwg, 3-509940-00)

PART OR ITEM Outer Reflector Sector DRAWING NO.

REMARKS 


\section{(1) NERVA \\ LIPROGRAM \\ SUPPORT EQUIPMENT TECHNICAL DESCRIPTION HANDBOOK}

EQUIPMENT TITLE

GAGE, DRIVE SHAFT LOCATION

PROV. LIST

ITEM NO.

DATE REVISION
1339

January 1968

B

DESCRIPTION: The Drive Shaft Location Gage is used to determine the proper shim thickness required during assembling of the spacer, actuator, and feedback assembly to the NRX test car privy roof. It is composed of a circular pilot plate (which bolts to the underside of the privy car roof) and a surface plate (which has a recess in its center to engage the end of the drive shaft). Three thumb screws are provided for adjustment.

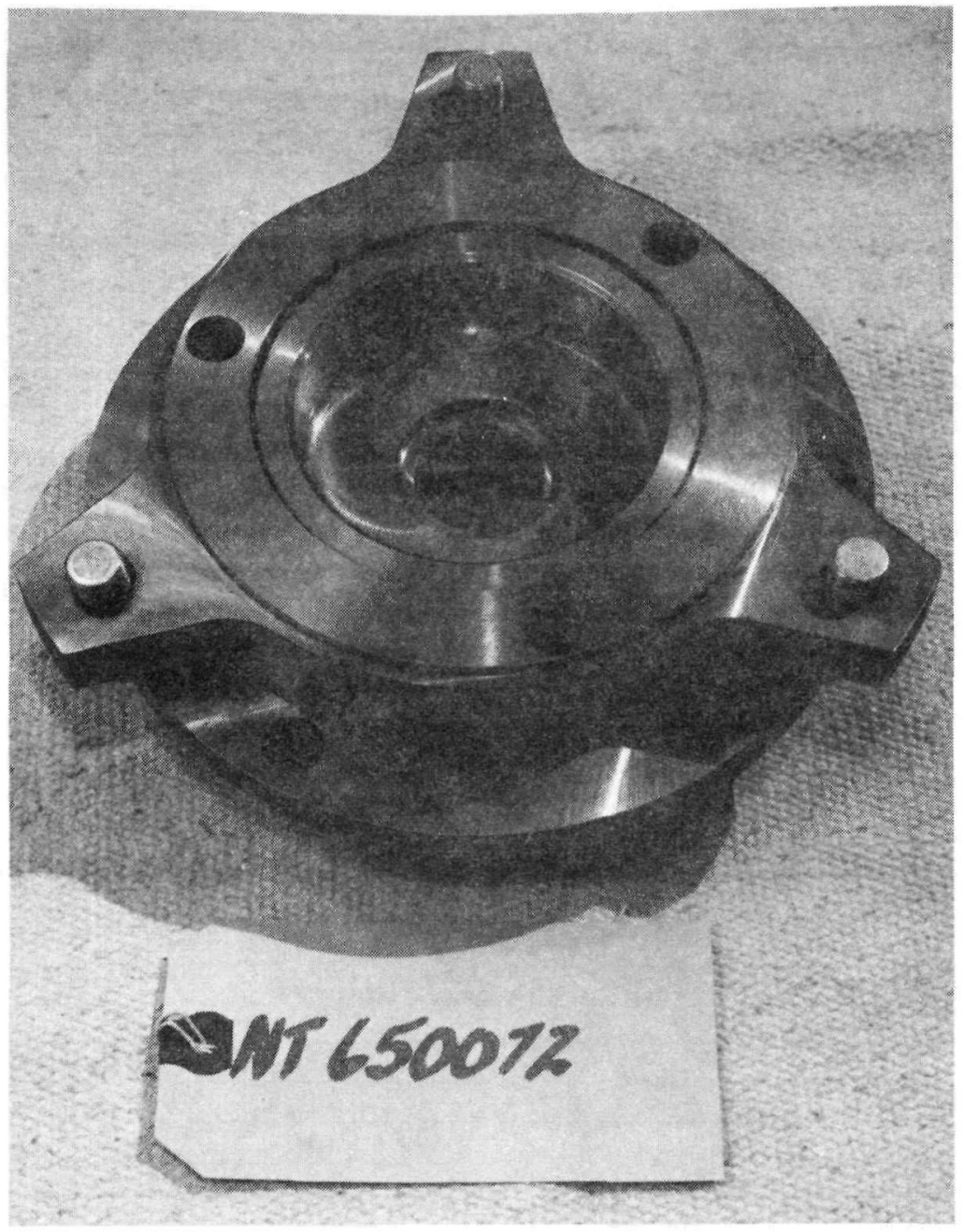


PROVISIONING LIST ITEM NUMBER

DRAWING NUMBER

PART NUMBER

CONTRACTOR
NT650072

NT650072

WANL
1339

FIRST PROVISIONED FOR

NRX-A]

GOVT. INV. CONTROL NUMBER NT650072-001

\begin{tabular}{|l||c|}
\hline \multicolumn{1}{|c||}{ USE LOCATION } & QTY REQ'D \\
\hline A. AGC SACRAMENTO & \\
\hline B. WANL & \\
\hline C. & \\
\hline D. NRDS TOTAL & 1 \\
\hline \multicolumn{2}{|c||}{} \\
\hline
\end{tabular}

DIMENSIONS AND CAPACITY

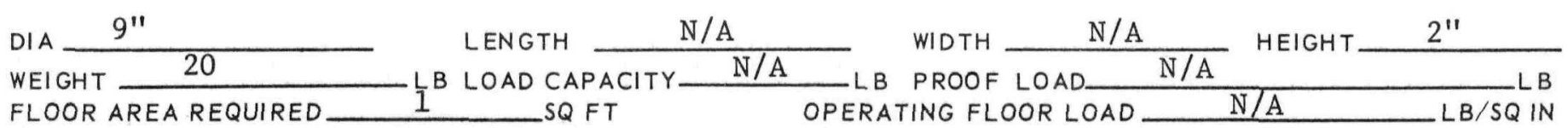

ADDITIONAL DATA

GASES N/A

ELECTRICAL

LIQUIDS

SPEED

MEASURING ACCURACY

CALIBRATION INTERVAL N/A

ADDITIONAL DATA
N/A

PRESSURE

$\mathrm{N} / \mathrm{A}$

N/A

N/A
VOLTS

PRESSURE IN./MIN (RPM)
LB/SQIN. VOLUME

CPS

$L B / S Q$ IN

CUTTING SPEED

HORIZONTAL
CFM LUBRICATION

PHASE

QTY REQ'D

$\mathrm{N} / \mathrm{A}$
MANIPULATOR $\frac{\text { N/A }}{\text { N/A }}$

CRANE
LOAD CAPACITY

LOAD CAPACITY
$\mathrm{N} / \mathrm{A}$ KVA 


\section{(3) NERVA \\ LIPROGRAM \\ SUPPORT EQUIPMENT TECHNICAL DESCRIPTION HANDBOOK}

EQUIPMENT TITLE

TOOL, SIMULATED SHIELD SUPPORT SLEEVE
PROV. LIST

ITEM NO. 1343

DATE January 1968

REVISION B

DESCRIPTION: The Simulated Shield Support Sleeve Tool is used to prevent twisting of electrical leads which extend through the instrumentation seal nut. It is used with the simulated shield nut tool (P/L 1211) and engages the slot in the dome end of the support sleeve.

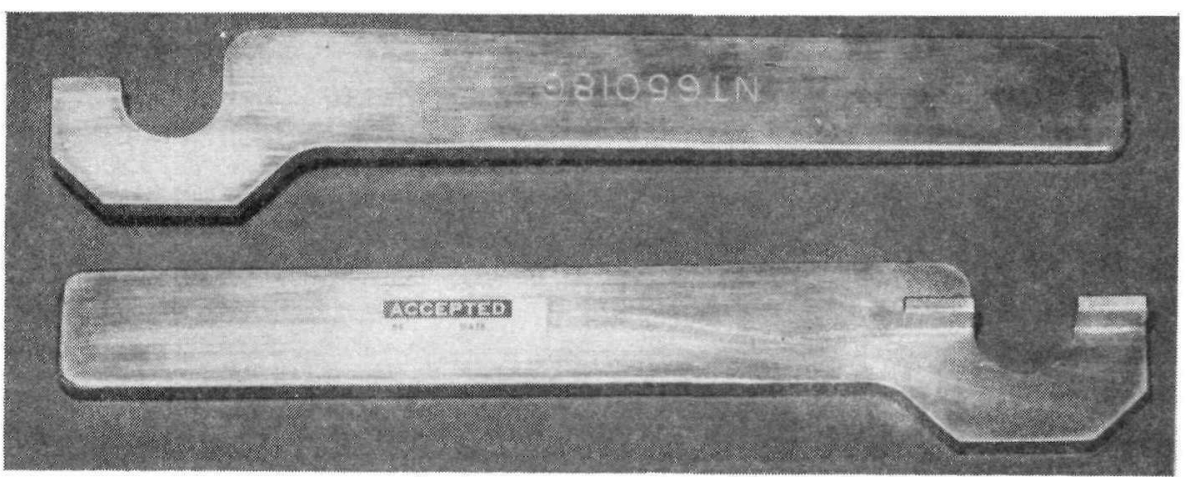


PROVISIONING LIST ITEM NUMBER

DRAWING NUMBER NT650186

1343

PART NUMBER

CONTRACTOR

NT650186

WANI

FIRST PROVISIONED FOR NRX-A1 GOVT. INV. CONTROL NUMBER NT650186-001 $\cos \mathrm{T}$

\begin{tabular}{|l||c|}
\hline \multicolumn{1}{|c||}{ USE LOCATION } & QTY REQ'D \\
\hline A. AGC SACRAMENTO & \\
\hline B. WANL & \\
\hline C. & \\
\hline D. NRDS TOTAL & 1 \\
\hline \multicolumn{2}{|c|}{1} \\
\hline
\end{tabular}

DIMENSIONS AND CAPACITY

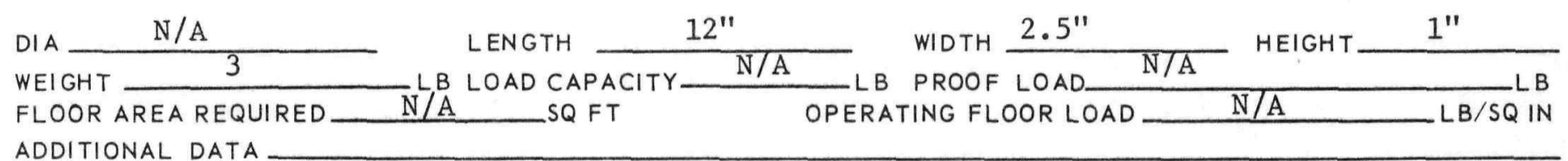

\begin{tabular}{|c|c|c|c|}
\hline GASES N N/A & \multirow{2}{*}{$\begin{array}{l}\text { PRESSURE LB/SQ IN. } \\
\text { N/A }\end{array}$} & \multirow{2}{*}{$\begin{array}{l}\text { VOLUME_ CFM } \\
- \text { CPS }\end{array}$} & LUBRICATION N/A \\
\hline ELECTRICAL & & & PHASE KVA \\
\hline LIQUIDS & PRESSURE & $-L B / S Q$ IN & QTY REQ'D \\
\hline SPEED_ & IN./MIN (RPM) & CUTTING SPEED & $\mathrm{N} / \mathrm{A}$ \\
\hline MEASURING AC & $\mathrm{N} / \mathrm{A}$ & HORIZONTAL & - VERTICAL \\
\hline CALIBRATION & $\mathrm{N} / \mathrm{A}$ & & \\
\hline
\end{tabular}

ADDITIONAL DATA This item is used during cold assembly operations

$\begin{array}{ll}\text { MANIPULATOR } & \mathrm{N} / \mathrm{A} \\ \text { CRANE LOAD CAPACITY L L LOA CAPACITY } & \mathrm{N} / \mathrm{A} \\ \text { ADDITIONAL DATA } & \end{array}$

ADDITIONAL DATA

EQUIPMENT Tool, Simulated Shield Nut Installation, P/I, 1211

PART OR ITEM Simulated Shield Nut

DRAWING NO. 
PROV. LIST

ITEM NO.

1355

(1) NERVA

SUPPORT EQUIPMENT

TECHNICAL DESCRIPTION HANDBOOK

EQUIPMENT TITLE

DATE

REVISION January 1968

A

STAND, ASSEMBLY AND INSTALLATION

DESCRIPTION: The Assembly and Installation Stand is a narrow platform, with protective railings, which fastens to three sides of an NRX test car privy roof. The stand increases roof working area to a reasonably large, protected working area for cold assembly operations with the reactor/pressure vessel assembly.

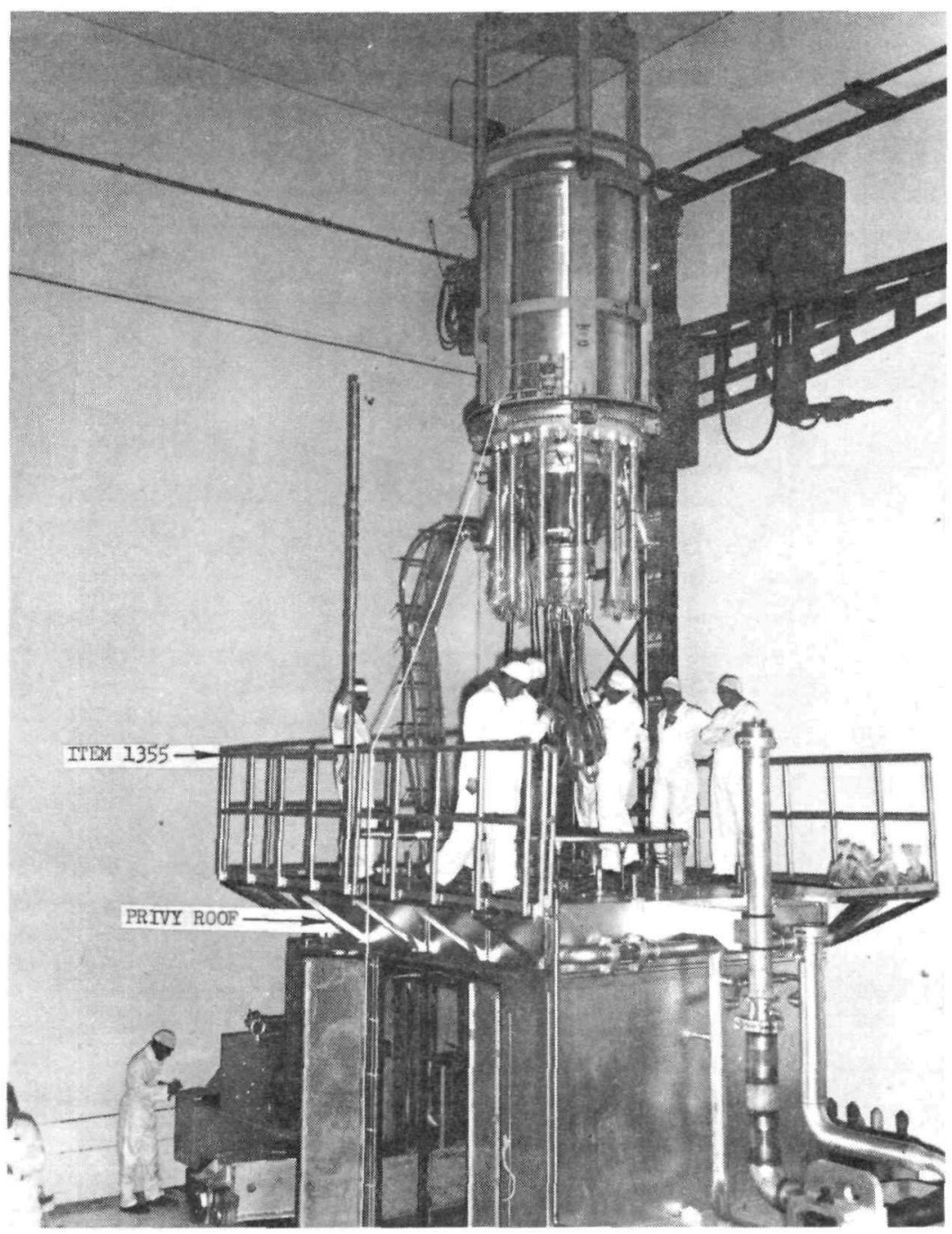


PROVISIONING LIST ITEM NUMBER

1355

DRAWING NUMBER 3-508159

PART NUMBER

CONTRACTOR
FIRST PROVISIONED FOR NRX-A2 GOVT. INV. CONTROL NUMBER

$\cos T$

\begin{tabular}{|l||c|}
\hline \multicolumn{1}{|c||}{ USE LOCATION } & QTY REQ'D \\
\hline A. AGC SACRAMENTO & \\
\hline B. WANL & \\
\hline C. & \\
\hline D. NRDS TOTAL & 1 \\
\hline
\end{tabular}

\section{DIMENSIONS AND CAPACITY}

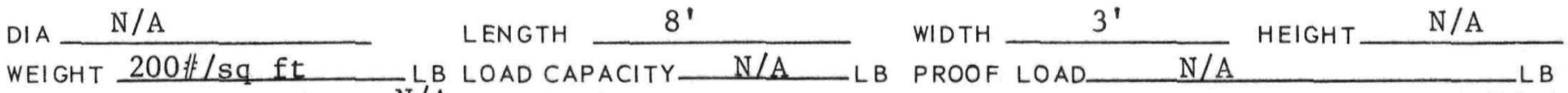
FLOOR AREA REQUIRED_N/A_SQ NT OPERATING FLOOR LOAD _ N ADDITIONAL DATA Stands that are suspended from the test car privy roof on the $90^{\circ}$, $180^{\circ}$, $270^{\circ}$ sides are normally used, 6 sections comprise the complete assembly.

GASES N/A PRESSURE ELECTRICAL_ N N/A LIQUIDS N/A SPEED N/A MEASURING ACCURACY CALIBRATION INTERVAL ADDITIONAL DATA VOLTS PRESSURE IN./MIN (RPM)
N/A

N/A
LB/SQ IN, VOLUME

CPS

LB/SQ IN CUTTING SPEED N N/A HORIZONTAL
CFM LUBRICATION

$\mathrm{N} / \mathrm{A}$

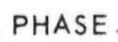

QTY REQ'D QT

-
MANIPULATOR CRANE R-MAD Facility

$N / A$ ADDITIONAL DATA
LOAD CAPACITY

LOAD CAPACITY
L B MAX

LB MAX

EQUIPMENT_ Test Car Privy Roof

PART OR ITEM

DRAWING NO.

REMARKS 


\section{(1) NERVA \\ LIPROGRAM \\ SUPPORT EQUIPMENT \\ TECHNICAL DESCRIPTION HANDBOOK}

EQUIPMENT TITLE

FIXTURE, HANDLING, POSTOPERATIVE, SECTOR
PROV. LIST

ITEM NO.

1358

DATE

January 1968

REVISION

B

DESCRIPTION: The Sector Postoperative Handling Fixture is used to handle the outer reflector sector in a horizontal position during disassembly operations and transport. It is a spring-loaded, positive drive, double-link, double-tong clamp, and is handled by a Class A manipulator.
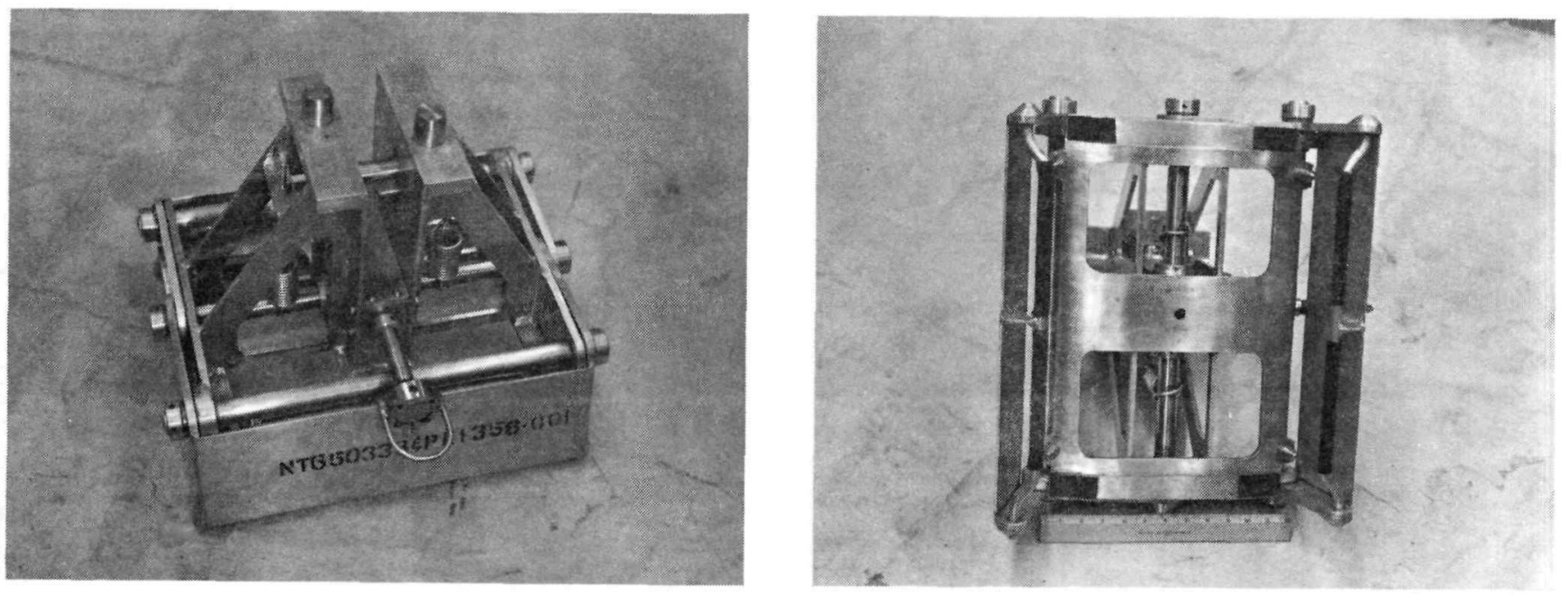
PROVISIONING LIST ITEM NUMBER

DRAWING NUMBER

PART NUMBER

CONTRACTOR
1358 NT650333

NT650333

WANL
FIRST PROVISIONED FOR

$\mathrm{NRX}-\mathrm{A} 2$ GOVT. INV. CONTROL NUMBER NT650333-001

\begin{tabular}{|l||c|}
\hline \multicolumn{1}{|c||}{ USE LOCATION } & QTY REQ'D \\
\hline A. AGC SACRAMENTO & \\
\hline B. WANL & \\
\hline C. & 1 \\
\hline D. NRDS TOTAL & 1 \\
\hline
\end{tabular}

\section{DIMENSIONS AND CAPACITY}

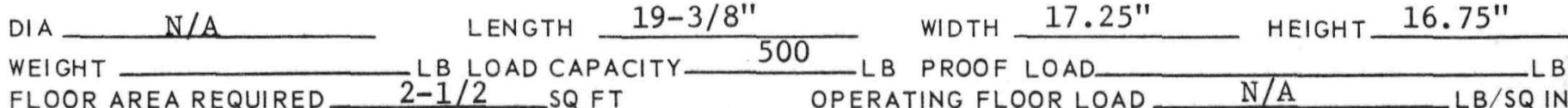
ADDITIONAL DATA

GASES N/A PRESSURE ELECTRICAL N/A

LIQUIDS

SPEED

MEASURING ACCURACY

$$
\text { N/A }
$$
$\mathrm{N} / \mathrm{A}$

ACCURACY N/A

CALIBRATION INTERVAL

ADDITIONAL DATA VOLTS LB/SQIN. VOLUME

PRESSURE IN./MIN (RPM)
CPS

$L B / S Q I N$

CUTTING SPEED HORIZONTAL
CFM

LUBRICATION

PHASE

$\mathrm{N} / \mathrm{A}$

QTY REQ'D

$\mathrm{N} / \mathrm{A}$ VERTICAL
MANIPULATOR Class A

CRANE

$\mathrm{N} / \mathrm{A}$
LOAD CAPACITY

LOAD CAPACITY
LB MAX

LB MAX

ADDITIONAL DATA

INTERFACES

EQUIPMENT

Class A Manipulators

PART OR ITEM Outer Reflector Sectors

DRAWING NO.

REMARKS 
CRADLE, POSTOPERATIVE, SECTOR

DESCRIPTION: The Postoperative Sector Cradle is used to support the sector on the universal length gage ( $P / L$ 1295) while measuring the sector length. It is provided with rollers to permit lateral positioning of the sector for measuring lengths at various points on the sector cross-section. A spacer frame is provided for insertion between the gage and cradle to position the sector for peripheral measurements. The cradle and spacer frames are capable of being locked in position on the gage.
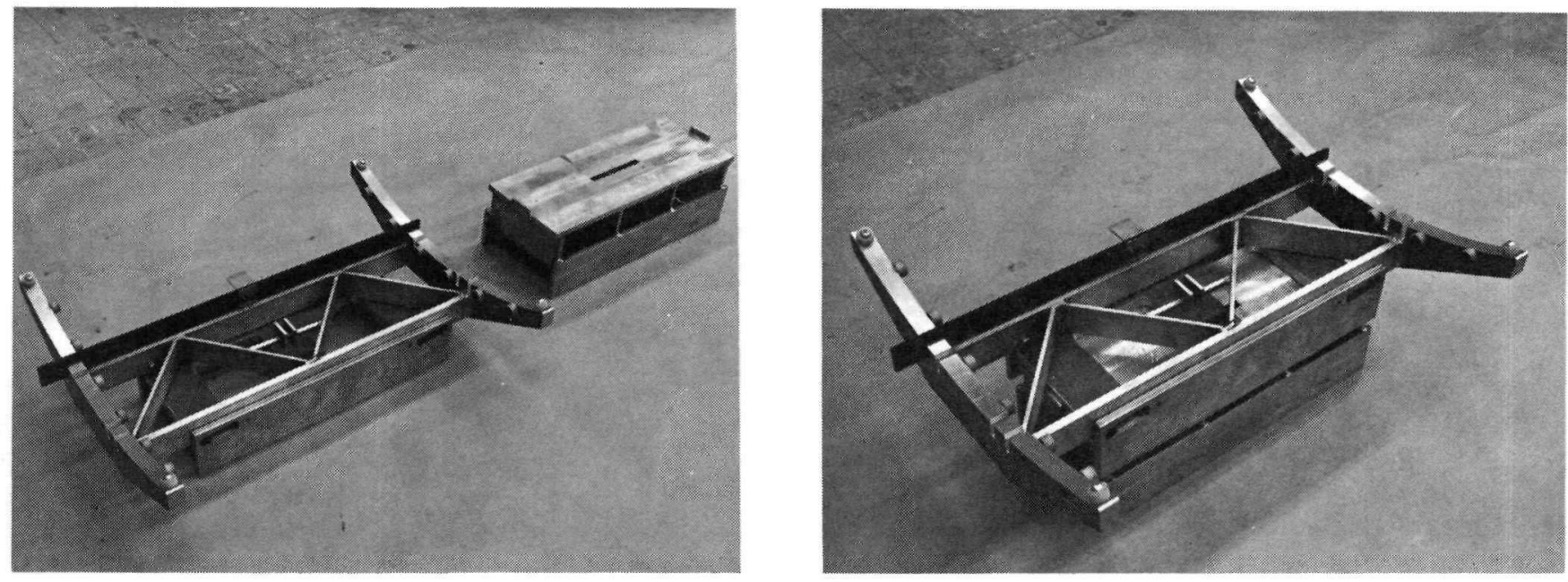


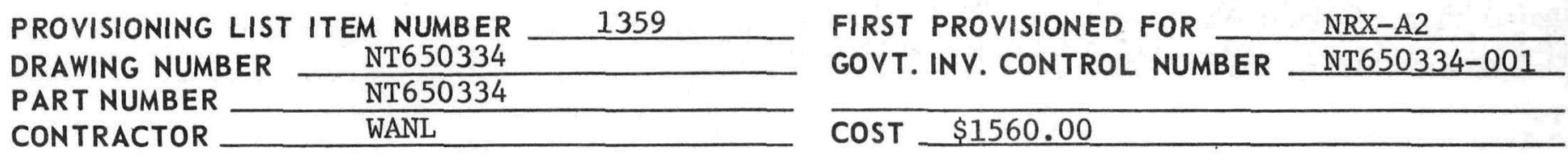

\begin{tabular}{|l||c|}
\hline \multicolumn{1}{|c||}{ USE LOCATION } & QTY REQ'D \\
\hline A. AGC SACRAMENTO & \\
\hline B. WANL & \\
\hline C. & 1 \\
\hline D. NRDS TOTAL & 1 \\
\hline \multicolumn{2}{|c|}{} \\
\hline
\end{tabular}

\section{DIMENSIONS AND CAPACITY}

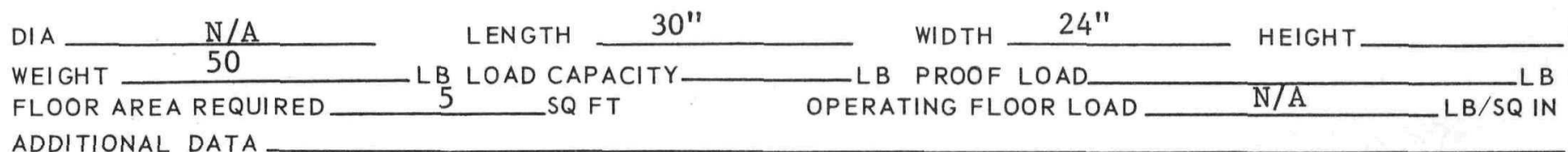

ADDITIONAL DATA

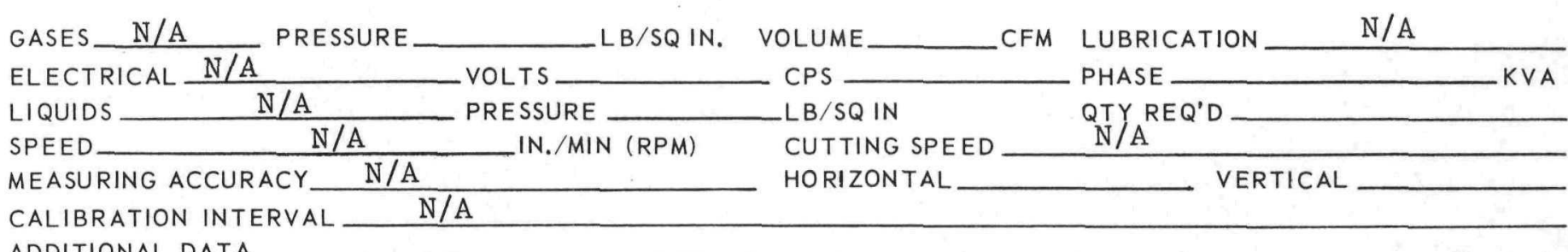
ADDITIONAL DATA

MANIPULATOR $\frac{\text { Class A }}{\text { N/A }}$ CRANE ADDITIONAL DATA
LOAD CAPACITY

LOAD CAPACITY
LB MAX LB MAX

EQUIPMENT_Gage, Universal Length, Measuring, Manipulators (P/L 1295) 


\section{(i) NERVA \\ LIPROGRAM \\ SUPPORT EQUIPMENT \\ TECHNICAL DESCRIPTION HANDBOOK}

EQUIPMENT TITLE

FIXTURE, HANDLING, POSTOPERATIVE, CONTROL DRUM
PROV. LIST

ITEM NO.

1360

DATE

January 1968

REVISION $B$

DESCRIPTION: The Control Drum Postoperative Handling Fixture is used for lifting and transferring the control drum assembly, housing, and cylinder to measuring and cutting stations during postoperative procedures. It has elastomer-padded clamshell arms, mechanically actuated and spring-loaded for positive closing action.

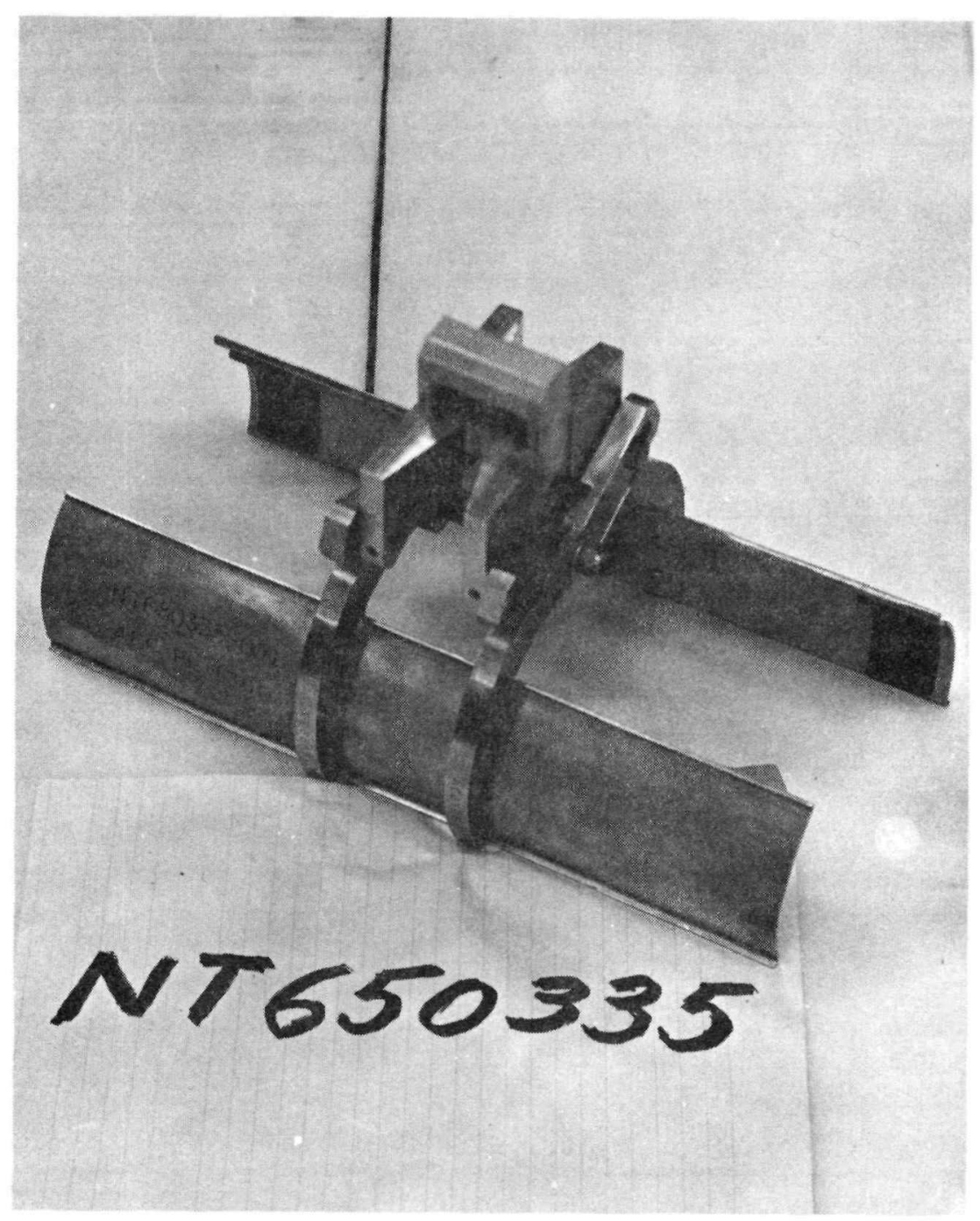


PROVISIONING LIST ITEM NUMBER 1360

DRAWING NUMBER

PART NUMBER

CONTRACTOR
NT650335

NT650335

WANL
FIRST PROVISIONED FOR NRX-A2 GOVT. INV. CONTROL NUMBER NT650335-001

$\operatorname{cosT} \$ 970.00$

\begin{tabular}{|c|c|}
\hline USE LOCATION & QTY REQ'D \\
\hline A. AGC SACRAMENTO & \\
\hline B. WANL & \\
\hline C. & \\
\hline D. NRDS & 1 \\
\hline TOTAL & 1 \\
\hline
\end{tabular}

DIMENSIONS AND CAPACITY

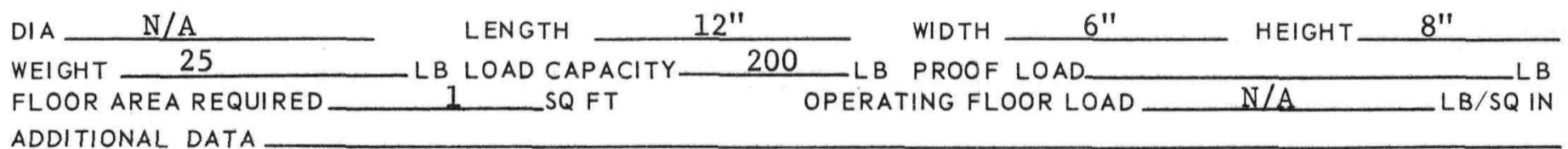

ADDITIONAL DATA

GASES N/A PRESSURE ELECTRICAL N/A

LIQUIDS N/A

SPEED.

MEASURING ACCURACY N/A

CALIBRATION INTERVAL N/A

ADDITIONAL DATA

\section{OPERATING DATA}

OPERATING EQUIPMENT

MANIPULLATOR Class A

CRANE N/A

LB/SQIN. VOLUME

VOLTS CPS

CFM LUBRICATION_ N/A

CPS PHASE KVA

PRESSURE

- $B / S Q$ IN

QTY REQ'D

IN./MIN (RPM)

CUTTING SPEED N/A

HORIZONTAL.

VERTICAL

ADDITIONAL DATA

LOAD CAPACITY

L B MAX

LOAD CAPACITY.

LB MAX

EQUIPMENT_

PART OR ITEM

REMARKS
Class A

Control Drum Assembly*

*Cylinder and Housing

DRAWING NO.

DRAWING NO. 


\section{() NERVA LIPROGRAM \\ SUPPORT EQUIPMENT TECHNICAL DESCRIPTION HANDBOOK}

EQUIPMENT TITLE

TOOL, RETRACTION, POISON AND CALIBRATION WIRE
PROV. LIST

ITEM NO. 1363

DATE

REVISION

DESCRIPTION: The Poison and Calibration Wire Retraction Tool is used to manually remove the poison wires, poison-wire retractor plate, calibration wires, and calibration-wire retractor plate from the reactor with the nozzle installed. It consists of a holder assembly (pole) which has a built-in battery-powered light, hook, head assembly, bails and plate. The combination of holder assembly and hook permits the retraction of the poison wires and poison-wire retraction plates by means of the addition of the bails to the poison-wire retractor plate. The combination of holder assembly and head assembly permits the retraction of the calibration wires and retractor plate. A lanyard, which attaches to the holder assembly during operation, restricts movement of the retraction device to prevent damage to the reactor assembly.

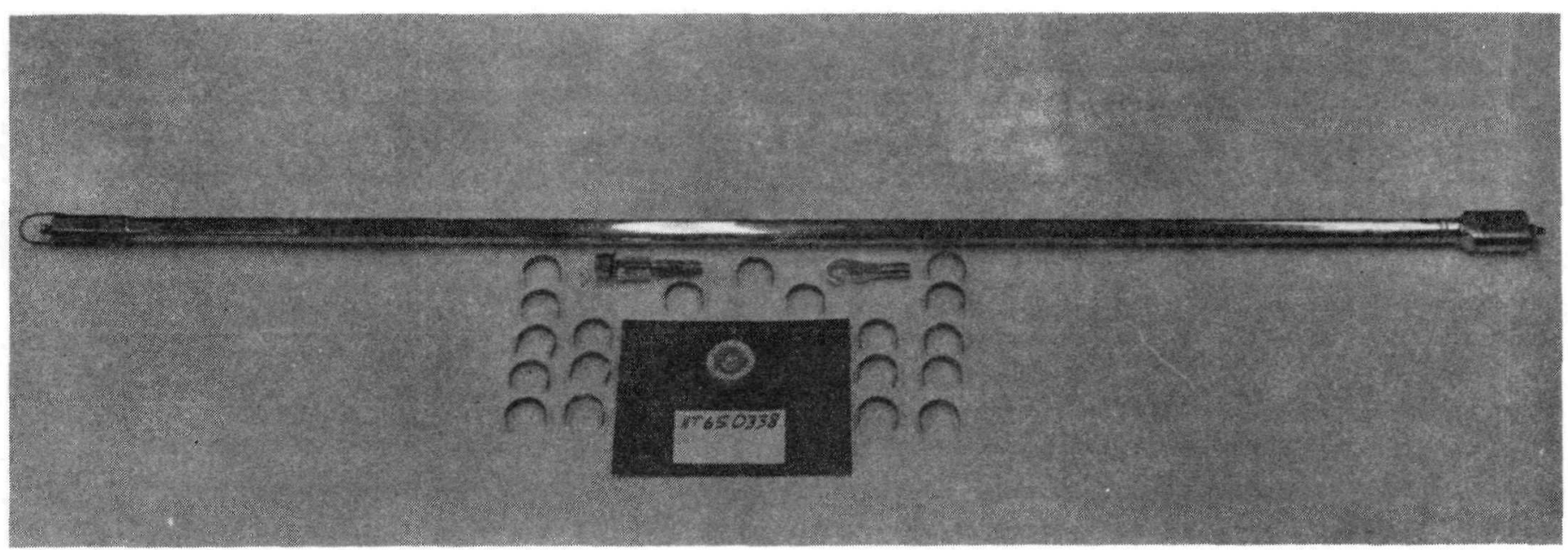


PROVISIONING LIST ITEM NUMBER 1363

DRAWING NUMBER NT650338

PART NUMBER

CONTRACTOR
NT650338

WANL
FIRST PROVISIONED FOR NRX-A2 GOVT. INV. CONTROL NUMBER

$\cos T$

\begin{tabular}{|l||c|}
\hline \multicolumn{1}{|c||}{ USE LOCATION } & QTY REQ'D \\
\hline A. AGC SACRAMENTO & \\
\hline B. WANL & \\
\hline C. & \\
\hline D. NRDS TOTAL & 1 \\
\hline \multicolumn{2}{|c|}{1} \\
\hline
\end{tabular}

\section{DIMENSIONS AND CAPACITY}

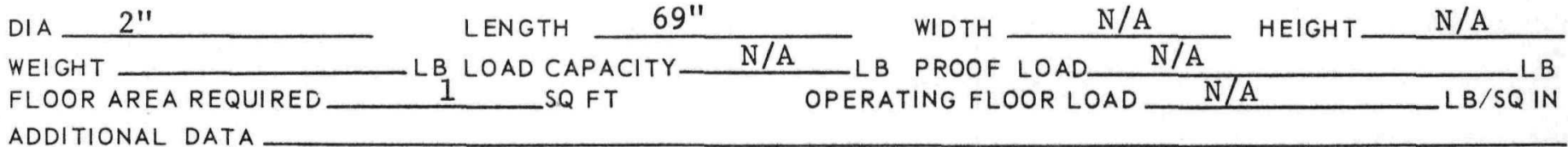

ADDITIONAL DATA

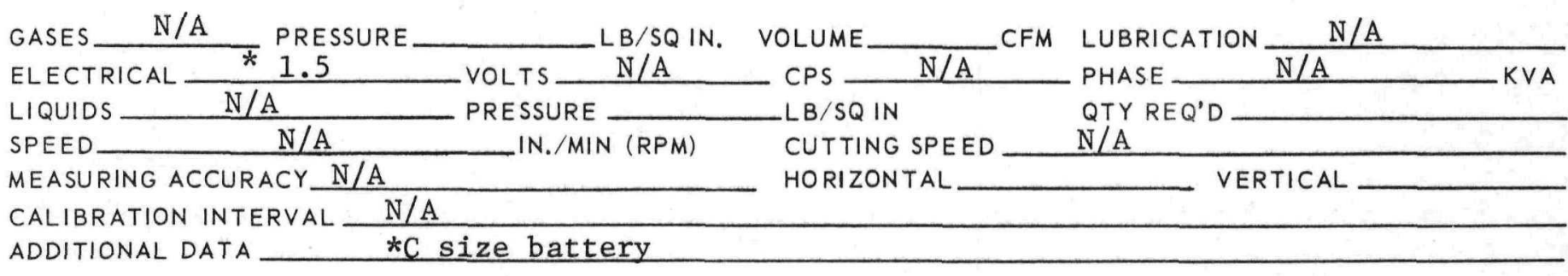

EQUIPMENT_ Monorail Hoist

PART OR ITEM Poison Wire Retractor Plate \& DRAWING NO. 977 D812

REMARKS Poison Wires, P/N 944C797, Calibration Wires and Retractor Plate 


\section{(1) NERVA \\ L. PROGRAM \\ SUPPORT EQUIPMENT TECHNICAL DESCRIPTION HANDBOOK}

EQUIPMENT TITLE

GAGE, REFLECTOR ASSEIBLY, BOW
PROV. LIST

ITEM NO.

DATE

REVISION

1364

January 1968

B

DESCRIPTION: The Bow Reflector Assembly Gage is used to measure the bowing which occurs in each sector during operation. It measures the changes of relationship of each sector to the dome end ring and nozzle end ring. This is accomplished by comparing data taken before and after reactor operation.

The vertical member of the gage is equipped with five dial indicators used to measure bowing along the center line of the sector. At each end of the vertical member there are dial indicators to contact the dome end and nozzle end rings for measurement of sector deformation. The upper end of the gage is fitted with rollers to support the gage from the top surface of the dome end ring. Pins are provided to prevent the gage from falling from the reflector assembly. At each end of each of the crossbars (which are fitted to the vertical member at the elevation of the rings) two dial indicators are mounted, one to contact the ring and the other to contact the sector. These determine the relationship of the sector to the rings. The gage is provided with a grip on the vertical member for handling by a Class A manipulator.

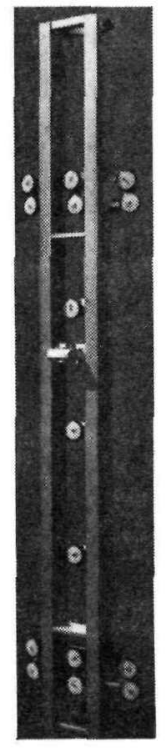


TECHNICAL SUMMARY

PROVISIONING LIST ITEM NUMBER 1364

DRAWING NUMBER

NT650339

PART NUMBER

NT650339

CONTRACTOR

WANL

FIRST PROVISIONED FOR

$\mathrm{NRX}-\mathrm{A} 2$ GOVT. INV. CONTROL NUMBER NT650339-001

$\operatorname{cosT} \$ 1000.00$

\begin{tabular}{|l||c|}
\hline \multicolumn{1}{|c||}{ USE LOCATION } & QTY REQ'D \\
\hline A. AGC SACRAMENTO & \\
\hline B. WANL & \\
\hline C. & 1 \\
\hline D. NRDS TOTAL & 1 \\
\hline \multicolumn{2}{|c|}{} \\
\hline
\end{tabular}

DIMENSIONS AND CAPACITY

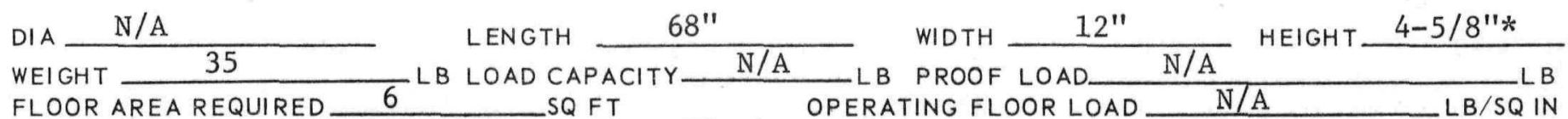
FLOOR AREA REQUIRED $\frac{6}{\text { SL }}$ SQ FT
ADDITIONAL DATA

GASES N/A PRESSURE ELECTRICAL N/A

LIQUIDS N/A

SPEED N/A

MEASURING ACCURACY N/A

CALIBRATION INTERVAL N/A

ADDITIONAL DATA
VOLTS LB/SQIN. VOLUM

$L B / S Q I N$

CUTTING SPEED

HORIZONTAL
IN./MIN (RPM)
CFM LUBRICATION

PHASE

QTY REQ'D

N/A

OPERATING EQUIPMENT

MANIPULATOR Class A

CRANE

$\mathrm{N} / \mathrm{A}$

LOAD CAPACITY

LOAD CAPACITY

LB MAX

ADDITIONAL DATA

INTERFACES

EQUIPMENT

Class A

PART OR ITEM

Outer Reflector

DRAWING NO.

REMARKS 


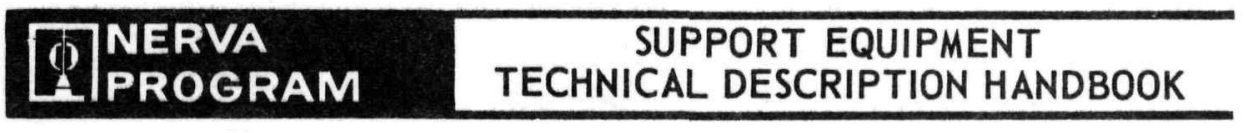

EQUIPMENT TITLE

SYSTEM, NOZZLE HOOD EMPLACEMENT
PROV. LIST

ITEM NO.

1369

DATE

January 1968

REVISION

B

DESCRIPTION: The Nozzle Hood Emplacement System is a remotely controlled jib boom with a vertical emplacement slide arm at the end of the boom. The vertical slide arm is provided with a rigid hook to hold a nozzle hood during emplacement and removal operations. All motions are controlled remotely by limit switches. Reversible electric motors are used to power all motions. The boom can be locked in any position. 
TECHNICAL SUMMARY

PROVISIONING LIST ITEM NUMBER 1369

DRAWING NUMBER

PART NUMBER

NT650341

CONTRACTOR

NT650341

WANL

FIRST PROVISIONED FOR

$\mathrm{NRX}-\mathrm{A} 2$ GOVT. INV. CONTROL NUMBER NT650341-001

COST $\$ 7917.00$

\begin{tabular}{|l||c|}
\hline \multicolumn{1}{|c||}{ USE LOCATION } & QTY REQ'D \\
\hline A. AGC SACRAMENTO & \\
\hline B. WANL & \\
\hline C. & 1 \\
\hline D. NRDS TOTAL & 1 \\
\hline \multicolumn{2}{|c|}{} \\
\hline
\end{tabular}

DIMENSIONS AND CAPACITY

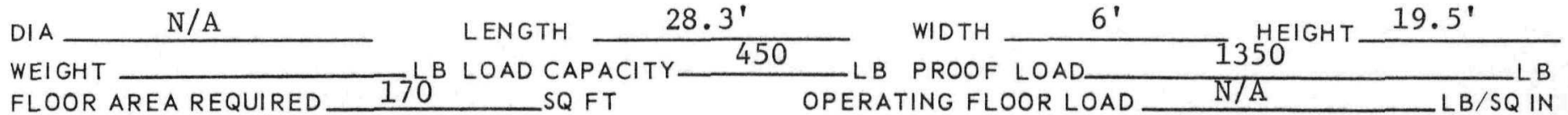

ADDITIONAL DATA

OPERATING DATA

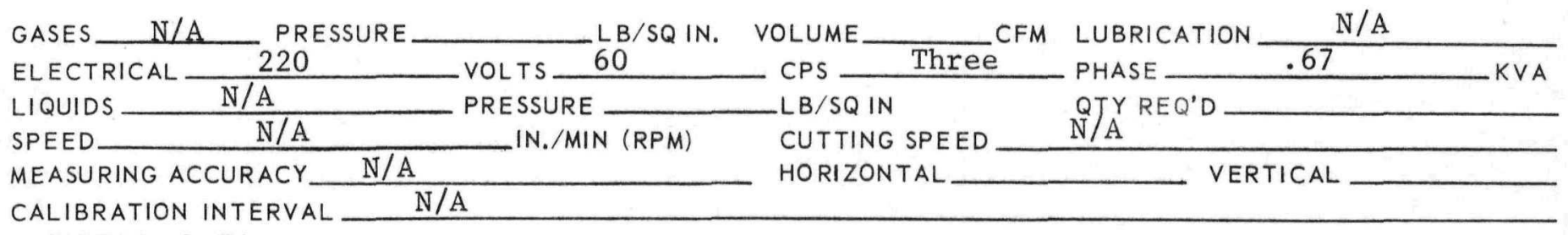

ADDITIONAL DATA

OPERATING EQUIPMENT

$\begin{array}{lll}\text { MANIPULATOR } & \text { N/A } & \text { LOAD CAPACITY } \\ \text { CRANE LOAD CAPACITY L B MAX } & \text { N/A L B MAX } \\ \text { ADDITIONAL DATA } & \end{array}$

ADDITIONAL DATA

INTERFACES

EQUIPMENT

N/A

PART OR ITEM

Nozzle Hood

DRAWING NO.

REMARKS 


\section{(1) NERVA LIPROGRAM \\ SUPPORT EQUIPMENT TECHNICAL DESCRIPTION HANDBOOK}

EQUIPMENT TITLE

FLAT CAR, REACTOR SHIPPING
PROV. LIST

ITEM NO. 1702

DATE

January 1968

REVISION B

DESCRIPTION: The Reactor Shipping Flat Car consists of a standard 50-foot railroad flat car, modified with tie-down brackets, bolts, and shoring to secure the reactor shipping container during transit. Two $5 \mathrm{kw}$ and one $10 \mathrm{kw}$ diesel generators, a diesel fuel storage tank, flood lights, safety rails, safety equipment, and power and instrumentation cabling are mounted on the deck and frame of the flat car. Heavy steel cables are used to secure the reactor shipping container to the tie-down brackets. The car remains coupled to the instrumentation car during reactor shipping.
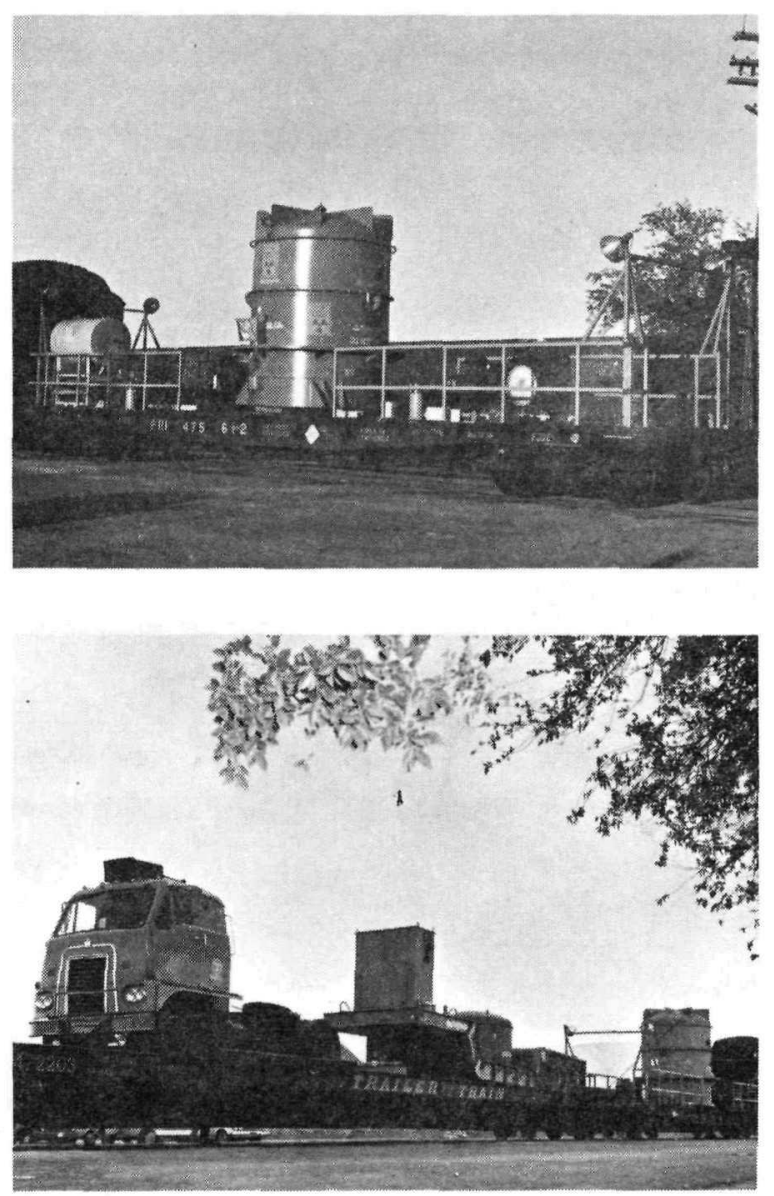
PROVISIONING LIST ITEM NUMBER DRAWING NUMBER

PART NUMBER

CONTRACTOR
1702 711J066 WANL
FIRST PROVISIONED FOR NRX-A1 GOVT. INV. CONTROL NUMBER

$\cos T$

\begin{tabular}{|c||c|}
\hline \multicolumn{1}{|c||}{ USE LOCATION } & QTY REQ'D \\
\hline A. AGC SACRAMENTO & \\
\hline B. WANL & 1 \\
\hline C. & \\
\hline D. NRDS TOTAL & 1 \\
\hline
\end{tabular}

DIMENSIONS AND CAPACITY

DIA N/A

WEIGHT 57,600

FLOOR AREA REQUIRED $\quad 400$

ADDITIONAL DATA * Load Limit 162,400 Pounds
LENGTH $\frac{50^{\prime}}{\text { LOAD CAPACITY } 140,000}$ WIDTH $\frac{8^{\prime}}{\text { LB PROOF LOAD *N/A }}$

OPERATING FLOOR LOAD

N/A

HEIGHT

N/A $-L B$ $L B / S Q I N$

\section{OPERATING DATA}

GASES Nitrogen PRESSURE * *

ELECTRICAL -

LIQUIDS

SPEED

MEASURING ACCURACY

CALIBRATION INTERVAL

ADDITIONAL DATA

* 2
- VOLTS

PRESSURE IN./MIN (RPM)
LB/SQIN. VOLUME

CPS

$L B / S Q I N$

CUTTING SPEED HORIZONTAL
CFM LUBRICATION Grease and Oils
PHASE KVA
QTYREQ'D

VERTICAL
MANIPULATOR N N/A

CRANE N/A

ADDITIONAL DATA
LOAD CAPACITY

LOAD CAPACITY
LB MAX

LB MAX

\section{INTERFACES}

EQUIPMENT Reactor Instrumentation Shipping Car, P/L 1703

PART OR ITEM Reactor Shipping Container,

REMARKS

$\mathrm{P} / \mathrm{L} 1706$

DRAWING NO. 


\section{(1) NERVA \\ 1. PROGRAM \\ SUPPORT EQUIPMENT \\ TECHNICAL DESCRIPTION HANDBOOK}

EQUIPMENT TITLE

INSTRUMENTATION CAR, REACTOR SHIPPING
PROV. LIST

ITEM NO.

1703

DATE

$\frac{\text { January } 1968}{\text { REVISION }}$

DESCRIPTION: The Reactor Shipping Instrumentation Car consists of a standard 50-foot railroad baggage car modified to provide, within a controlled environment, working space, power, lighting, and equipment mounts for monitoring instrumentation required during NRX reactor shipments. An insulated, air-conditioned room is constructed within the baggage car. The room contains fluorescent lighting, power receptacles, power panels, an exhaust fan system, instrumentation rack floor anchors, and an instrumentation cable raceway. Outside of the insulated room, storage space, cabinets, and work tables are provided.

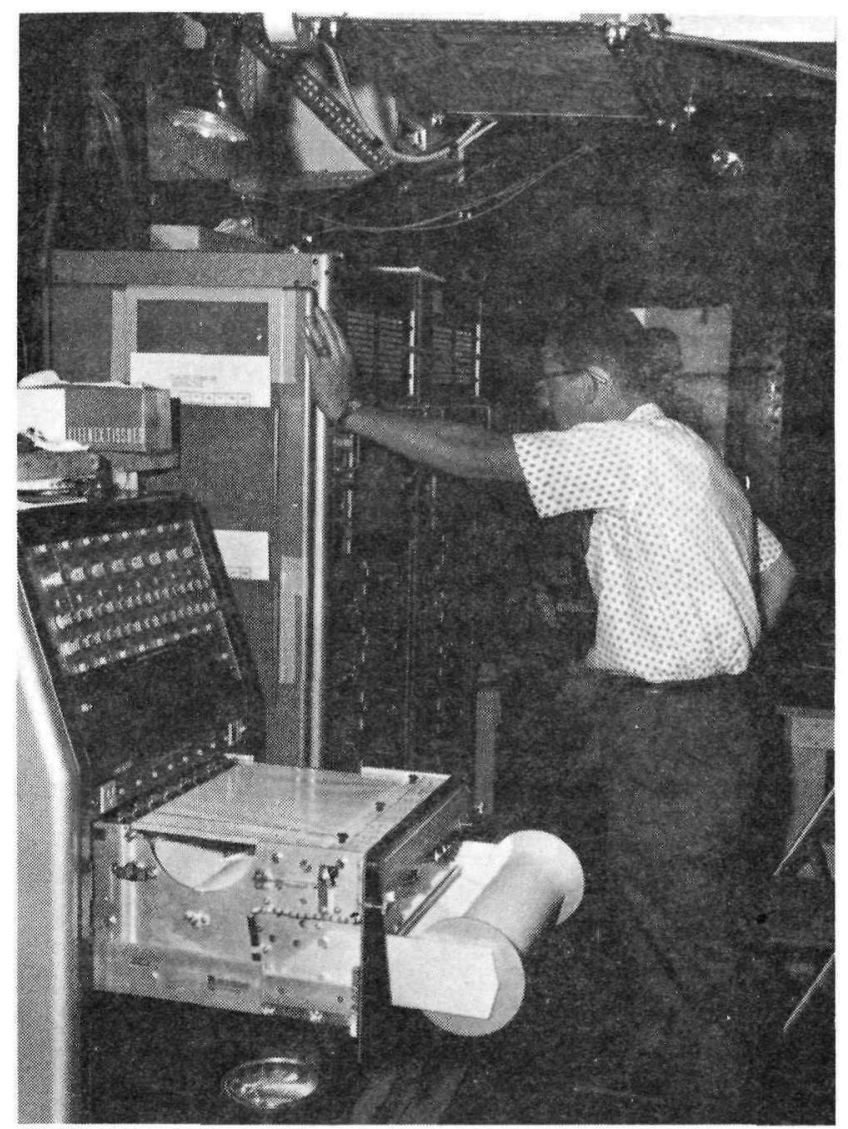


PROVISIONING LIST ITEM NUMBER DRAWING NUMBER 709J825

PART NUMBER

CONTRACTOR
1703

\section{WANL}

FIRST PROVISIONED FOR NRX-AI

GOVT. INV. CONTROL NUMBER

$\cos T$

\begin{tabular}{|l||c|}
\hline \multicolumn{1}{|c||}{ USE LOCATION } & QTY REQ'D \\
\hline A. AGC SACRAMENTO & \\
\hline B. WANL & 1 \\
\hline C. & \\
\hline D. NRDS TOTAL & 1 \\
\hline \multicolumn{2}{|c|}{} \\
\hline
\end{tabular}

DIMENSIONS AND CAPACITY

DIA N/A LENGTH $50^{\prime}$ WIDTH $8^{\prime}$ HEIGHT

\section{WEIGHT}

FLOOR AREA REQUIRED

LB LOAD CAPACITY N/A

400 SQ FT

N/A

ADDITIONAL DATA

MANIPULATOR N/A

CRANE N/A
LOAD CAPACITY LOAD CAPACITY
LB MAX

L B MAX

ADDITIONAL DATA

EQUIPMENT Reactor Shipping Flat Car, P/L 1702 


\begin{tabular}{l|l|}
\hline C. & NERVA \\
PROGRAM & TECHNICAL DESCRIPTION HANDBOOK \\
\hline
\end{tabular}

EQUIPMENT TITLE

VEHICLE, ENGINE INSTALLATION (EIV)
PROV. LIST

ITEM NO.

2001

DATE January 1968

REVISION A

DESCRIPTION: The Engine Installation Vehicle (EIV) is a special-purpose railway car for use at NRDS to insta11 a NERVA engine in the test stand, remove it, and convey it to or from the E-MAD building. It is propelled by the prime mover and/or the manned control car (MCC). During remote engine handling operations, the EIV is controlled from the MCC through an umbilical system: for "cold" engine operation, a portable controller is provided for use by "on-the-stand" personnel. The EIV is a railroad flatcar with a superstructure and tower to support and guide an engine-handling carriage system. An engine dust cover and actuator is located at the top of the tower to protect the engine interface during transport. A nozzle-closure actuator- is located at the bottom of the tower. A manipulator and boom system, which also mounts television cameras and lights, is mounted on each side of the tower for use during remote installation, checkout, and removal of the engine at the test stand. Outboard jacks level the engine during installation and removal. A counterbalance and electrical interface cabinet are located near the coupler end of the car.

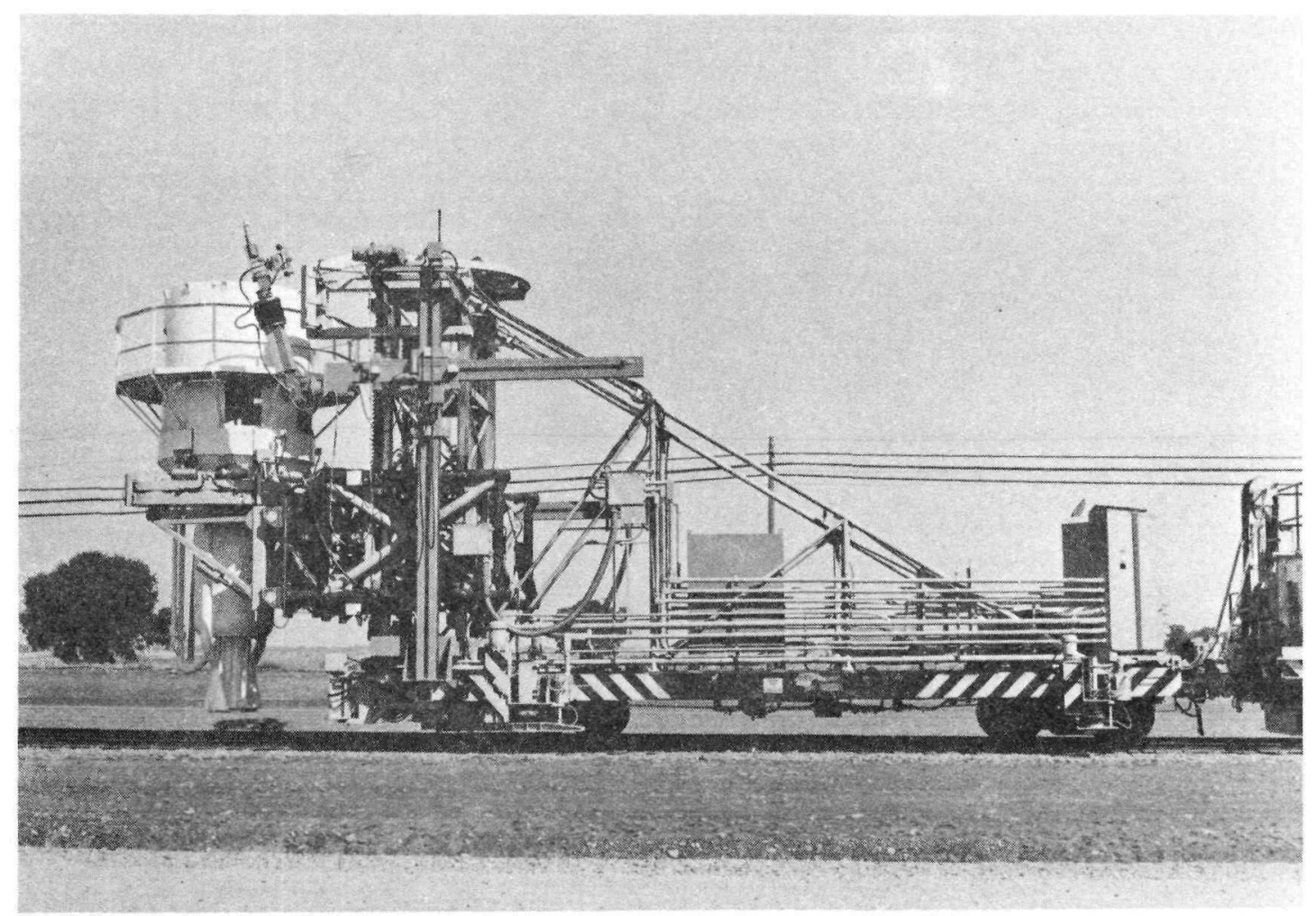


PROVISIONING LIST ITEM NUMBER 2001

DRAWING NUMBER

PART NUMBER

CONTRACTOR
89-71-1000

Same

AMF/AGC
FIRST PROVISIONED FOR XE GOVT. INV. CONTROL NUMBER SNP-1-L-1352

COST $\$ 1,060,000$

\begin{tabular}{|l||c|}
\hline \multicolumn{1}{|c||}{ USE LOCATION } & QTY REQ'D \\
\hline A. AGC SACRAMENTO & \\
\hline B. WANL & \\
\hline C. & 1 \\
\hline D. NRDS TOTAL & 1 \\
\hline
\end{tabular}

\section{DIMENSIONS AND CAPACITY}

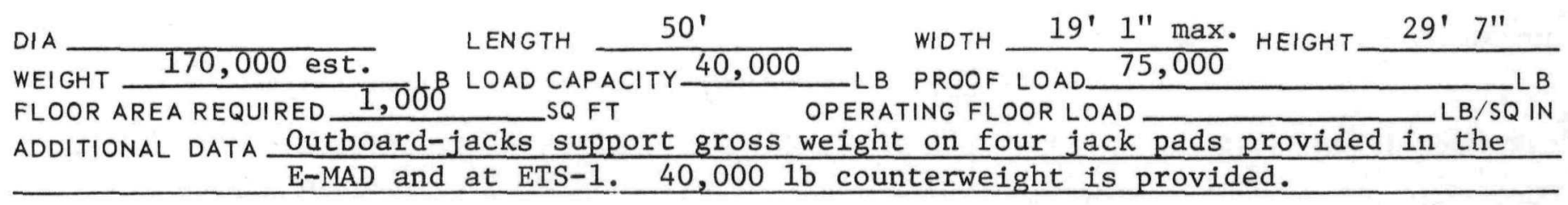

\section{OPERATING DATA}

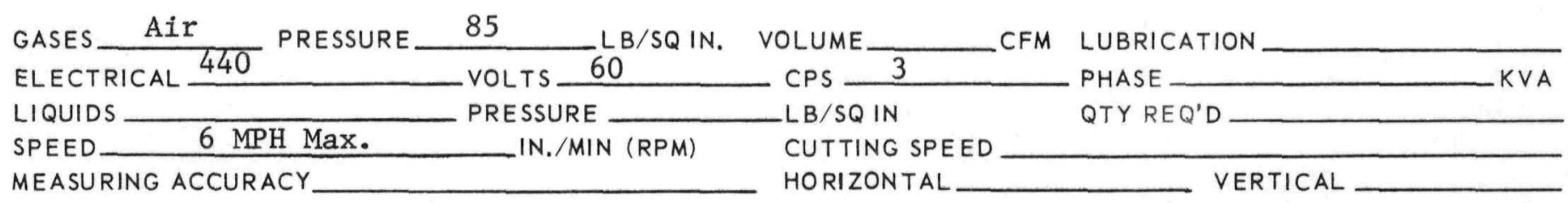

CALIBRATION INTERVAL Inching drive 12 inches/min. Standard AAR trucks and coupler. See RN-S-0362.

\section{OPERATING EQUIPMENT}

MANIPULATOR On BOom Assembly (2) LOAD CAPACITY 90 with TV camera \& lightE MAX CRANE LOAD CAPACITY ADDITIONAL DATA Vertical carriage trave1 10', longitudinal carriage trave1 $10^{\prime \prime}$ lateral carriage travel $+5^{\prime \prime}$, asimuth carriage travel $\pm 5^{\circ}$.

EQUIPMENT Manned Control Car, P/L 2002

PART OR ITEM XE Engine Assembly DRAWING NO.

REMARKS May also be propelled by the prime mover. The EIV carriage interfaces with the XE engine. The EIV must clear all ETS-1, E-MAD, and NRDS railroad trackage structures 


\section{(1) NERVA IPROGRAM \\ SUPPORT EQUIPMENT TECHNICAL DESCRIPTION HANDBOOK}

EQUIPMENT TITLE

CAR, CONTROL, MANNED (MCC)

PROV. LIST

ITEM NO.

2002

DATE

REVISION
January 1968

A

DESCRIPTION: The Manned Control Car (MCC) is a special railway locomotive with a shielded cab for protection of two operators who control the prime mover locomotive and EIV in a radioactive environment. The cab is provided with leaded window for direct observation during car operation: an electrically operated door, with a leaded window, is provided for access to the cab. The MCC contains an electrical power-supply (consisting of an electrical generator and internal-combustion engine), a cab air-conditioning unit, an emergency mechanical-drive system for moving the MCC and the prime mover, a closed-circuit television monitor, all controls for the MCC, EIV, and prime mover, and a two-way radio. An umbilical assembly connects the MCC to the EIV while the car is uncoupled and separated from the EIV to a maximum of 15 feet during $\mathrm{XE}$-engine handling.

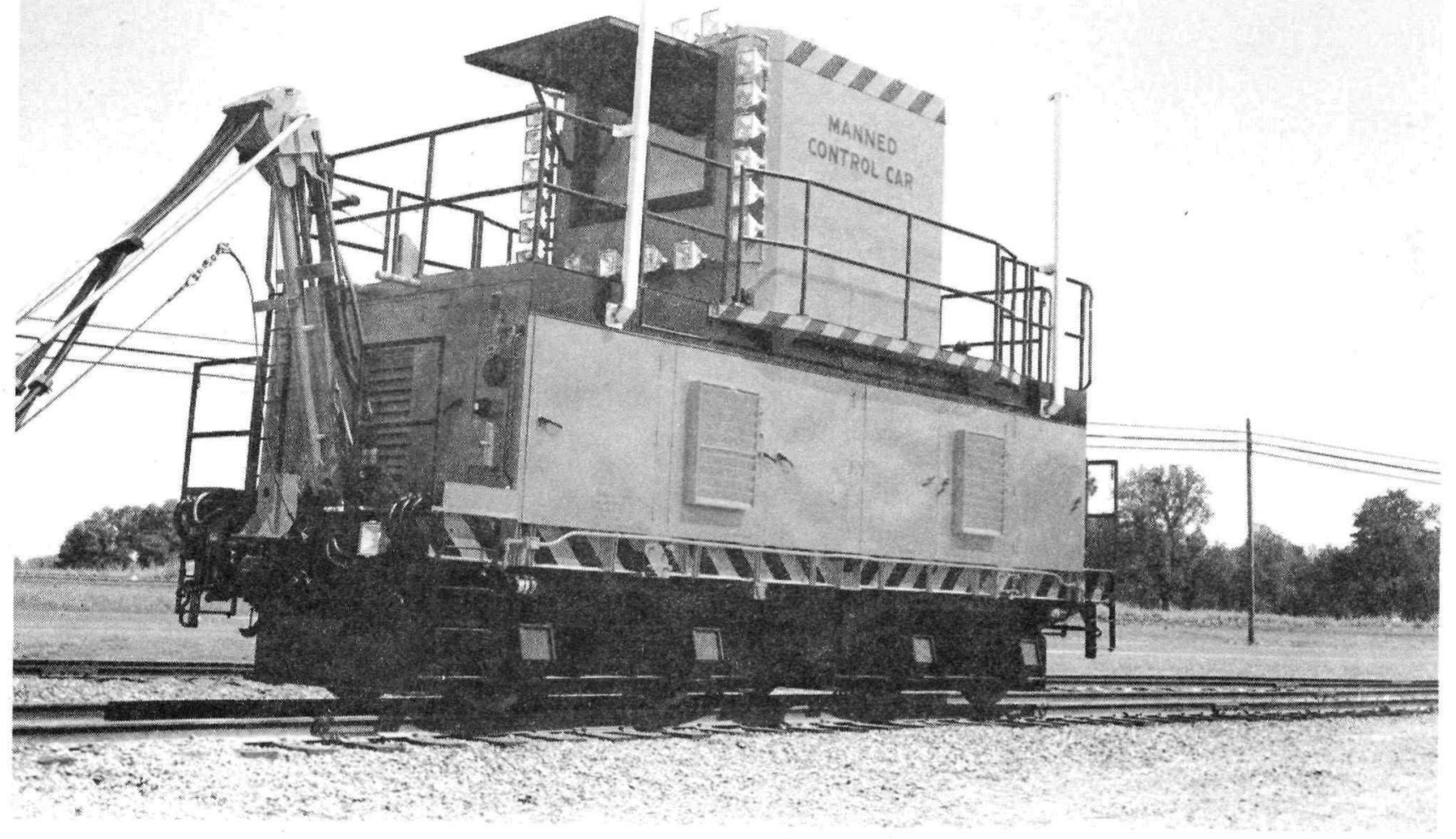


PROVISIONING LIST ITEM NUMBER 2002

DRAWING NUMBER

PART NUMBER

CONTRACTOR
89-73-1000

Same

AMF/AGC
FIRST PROVISIONED FOR XE GOVT. INV. CONTROL NUMBER SNP-1-L-1351

\begin{tabular}{|l||c|}
\hline \multicolumn{1}{|c||}{ USE LOCATION } & QTY REQ'D \\
\hline A. AGC SACRAMENTO & \\
\hline B. WANL & \\
\hline C. & 1 \\
\hline D. NRDS TOTAL & 1 \\
\hline
\end{tabular}

\section{DIMENSIONS AND CAPACITY}

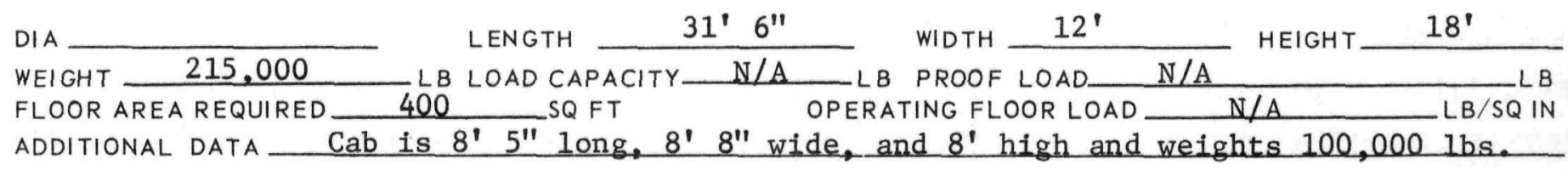

GASES Air

ELECTRICAL

LIQUIDS

SPEED

MEASURING ACCURACY

PRESSURE

440 Diese1 Fue1

$6 \mathrm{MPH}$ Max.

CALIBRATION INTERVAL

ADDITIONAL DATA

Operate

250 HP tra power. $32 \mathrm{~V}$ batteries for diesel starting and safety circuits. See RN-S-0362
CFM LUBRICATION

PHASE

75 QTY REQ'D 300 gal. VERTICAL

ADDITIONAL DATA

EQUIPMENT_EIV, P/L 2001 and Prime Mover 


\section{(1) NERVA \\ LIPROGRAM \\ SUPPORT EQUIPMENT \\ TECHNICAL DESCRIPTION HANDBOOK}

EQUIPMENT TITLE
PROV. LIST

ITEM NO.

2003

DATE January 1968

REVISION A

SYSTEM, OVERHEAD POSITIONING (OPS)

DESCRIPTION: The bridge, trolley, mast, and auxiliary manipulators are the principal components of the Overhead Positioning System (OPS). This system is capable of remotely handling the NERVA engine and its subassemblies in conjunction with the FMHS and WMHS during assembly and disassembly operations in the E-MAD Building. The traveling bridge spans the width of the main hot bay. The trolley travels the length of the bridge and supports the 3-section telescoping mast, which has an azimuth drive and a floating head in the lower section for adapting to special positioning-heads. The auxiliary manipulator is also mounted within the lower mast. Bridge and trolley movement permits the vertical axis of the mast to be positioned over any set of horizontal coordinates within its range of travel. A control system and consoles are provided for all remote operations of the bridge, trolley, mast, manipulator, and positioning heads.

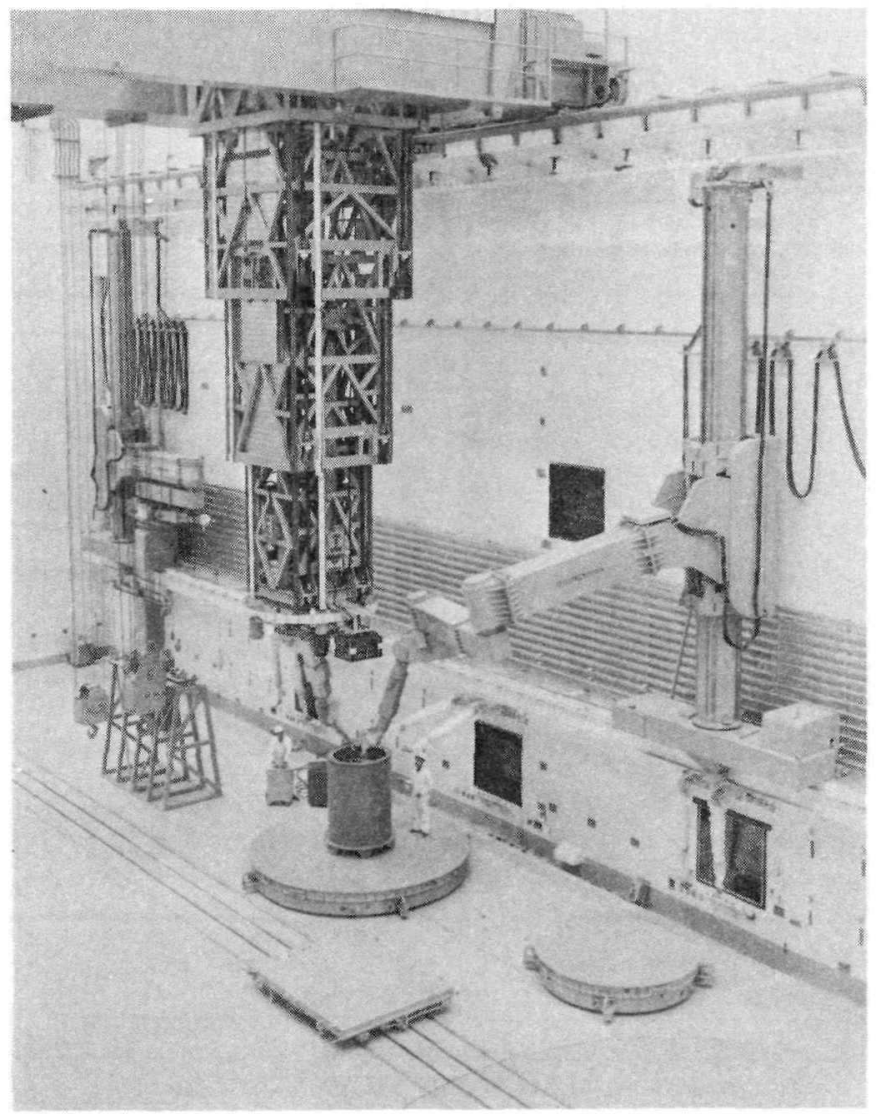




\begin{tabular}{ll} 
PROVISIONING LIST ITEM NUMBER & 2003 \\
DRAWING NUMBER & $89-80-1000$ \\
\cline { 2 - 2 } & SAMT \\
PART NUMBER & AMF \\
\hline
\end{tabular}

FIRST PROVISIONED FOR $\mathrm{XE}$ GOVT. INV. CONTROL NUMBER $\operatorname{cosT} \$ 2,100,000$

\begin{tabular}{|l||c|}
\hline \multicolumn{1}{|c||}{ USE LOCATION } & QTY REQ'D \\
\hline A. AGC SACRAMENTO & \\
\hline B. WANL & \\
\hline C. & 1 \\
\hline D. NRDS TOTAL & 1 \\
\hline
\end{tabular}

\section{DIMENSIONS AND CAPACITY}

57' Extended DIA WEI GHT 285,000 LENGTH 68' FLOOR AREA REQUIRED LB LOAD CAPACITY 40,000 WIDTH $\frac{24}{\text { LB PROOF LOAD }}$ OPERATING FLOOR LOAD HEIGHT 25' Retracted ADDITIONAL DATA Bridge travels the length of hot bay (E-MAD) to within $12^{\prime}$ of either end; trolley travels on the bridge to within $5^{\prime}$ of the east-west wall; the mast will travel 39' $6^{\prime \prime}$; the manipulator will handle $600 \mathrm{lb}$ in any position, or 5,000 1b on the elbow hook.

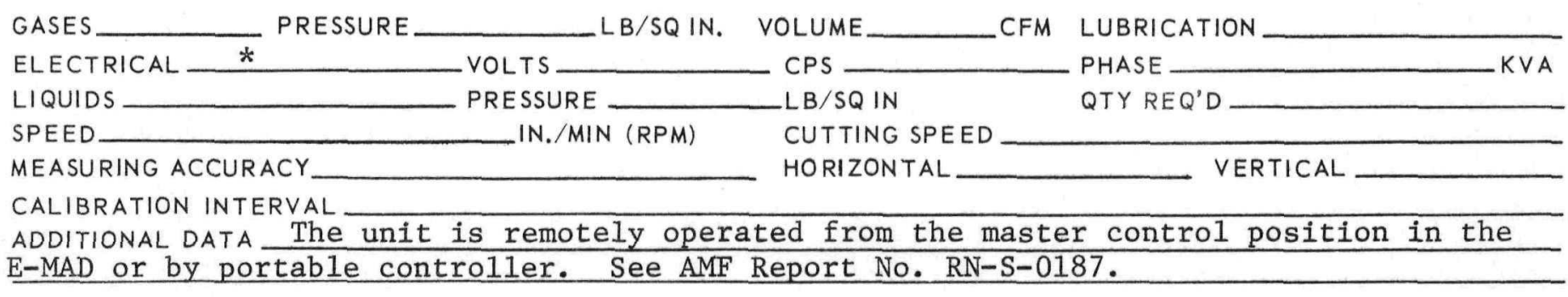

* 440 Vac, 3 Ph., 60 Cy

$220 \mathrm{Vac}, 3 \mathrm{Ph} ., 60 \mathrm{Cy}$

120 Vac, Single Phase, 60 Cy

\section{OPERATING EQUIPMENT}

EQUIPMENT_ Positioning head, upper thrust-structure

PART OR ITEM 4011 DRAWING NO. 1114421

REMARKS Also uses a reactor-positioning head provided as part of the OPS. The manipulator is utilized universally as required. 


\section{I}

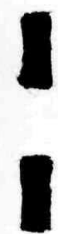

(1) NERVA LIPROGRAM

SUPPORT EQUIPMENT TECHNICAL DESCRIPTION HANDBOOK

EQUIPMENT TITLE

CARRIAGE, MOBILE, FLOOR MOUNTED HANDLING SYSTEM

DESCRIPTION: The Mobile Carriage is an electrically driven, four-whee1, standard-gage flat car for transporting engine subassemblies, the loaded nozzle-stand, or the reactor core and stand. It is operated remotely, and runs on the main track in the hot bay of the E-MAD building.

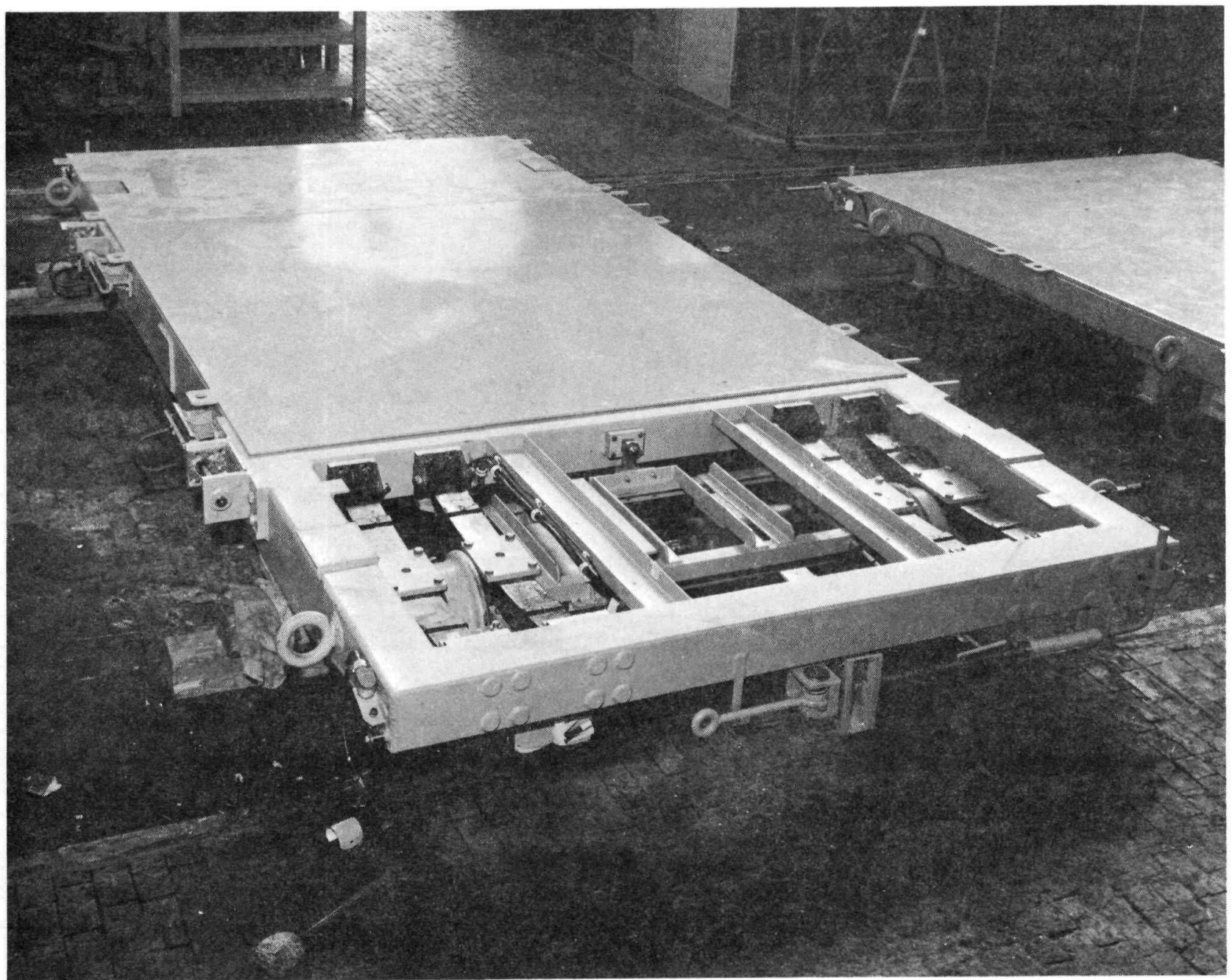


PROVISIONING LIST ITEM NUMBER 2012

DRAWING NUMBER

PART NUMBER

CONTRACTOR
$89-81-1100$

Same

AMF
FIRST PROVISIONED FOR $\mathrm{XE}$

\section{$\cos T \$ 160,000$}

\begin{tabular}{|c||c|}
\hline \multicolumn{1}{|c||}{ USE LOCATION } & QTY REQ'D \\
\hline A. AGC SACRAMENTO & \\
\hline B. WANL & \\
\hline C. & \\
\hline D. NRDS TOTAL & 1 \\
\hline
\end{tabular}

\section{DIMENSIONS AND CAPACITY}

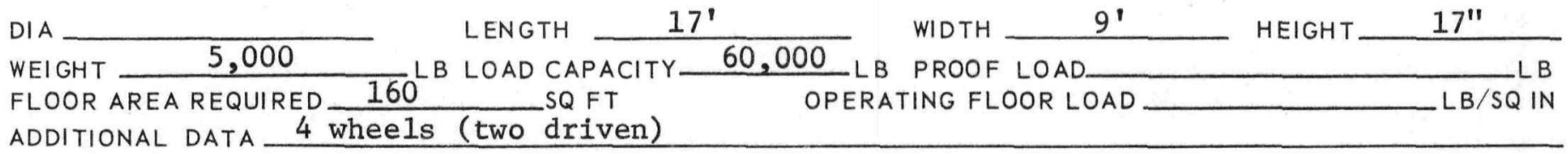

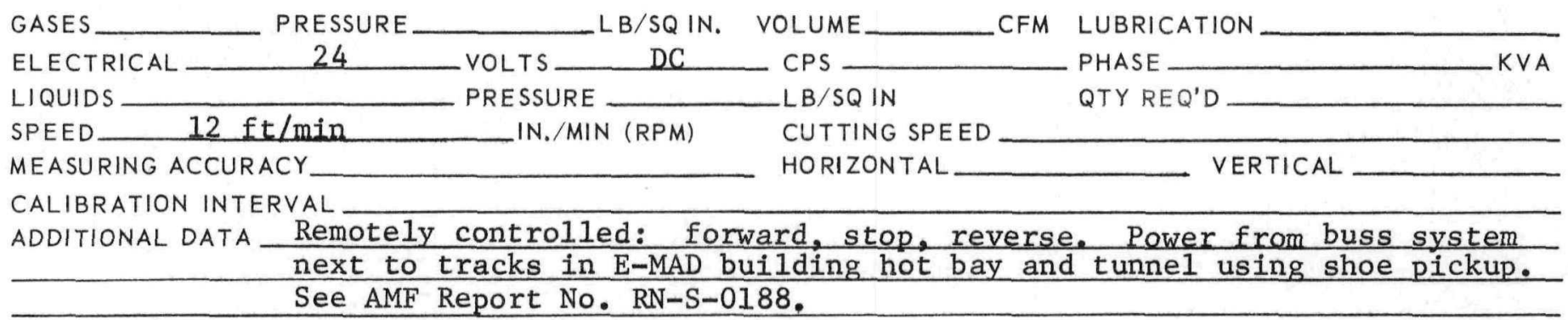

\section{OPERATING EQUIPMENT} ADDITIONAL DATA When loaded, can be lifted by adequate sing and crane.

EQUIPMENT_Various stands (e.g., engine, reactor, and nozzle) 
PROV. LIST

ITEM NO.

2013

DATE TECHNICAL DESCRIPTION HANDBOOK

EQUIPMENT TITLE

\begin{tabular}{lc} 
& January 1968 \\
\hline REVISION & A
\end{tabular}

DOLLY, REMOTE HANDLING, FLOOR MOUNTED HANDLING SYSTEM

DESCRIPTION: The Remote Handling Dolly is an electrically driven 4-wheel, standard-gage, flat car for transporting a shield-fuel cask, engine components, or core components. It runs on tracks in the E-MAD Building and is operated remotely from a control panel in the E-MAD control room.

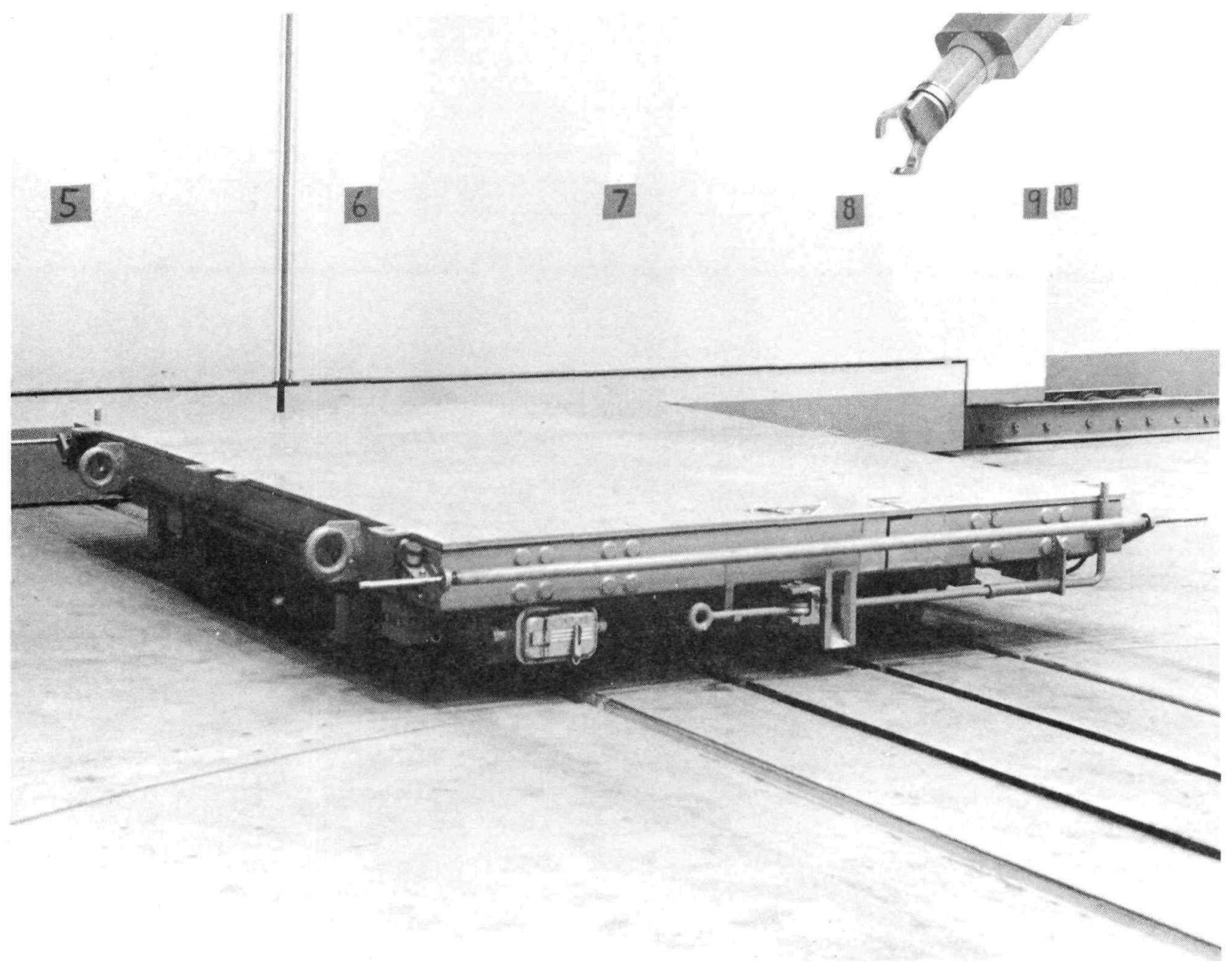


PROVISIONING LIST ITEM NUMBER 2013

DRAWING NUMBER

PART NUMBER

CONTRACTOR
$89-81-1200$

Same

AMF
FIRST PROVISIONED FOR XE GOVT. INV. CONTROL NUMBER

COST $\$ 120,000$

\begin{tabular}{|l||c|}
\hline \multicolumn{1}{|c||}{ USE LOCATION } & QTY REQ'D \\
\hline A. AGC SACRAMENTO & \\
\hline B. WANL & \\
\hline C. & 1 \\
\hline D. NROS TOTAL & 1 \\
\hline
\end{tabular}

DIMENSIONS AND CAPACITY

DIA

WEIGHT $\quad 4,000$

FLOOR AREA REQUIRED

ADDITIONAL DATA
4 Wheels

LENGTH 10'

WIDTH

$9^{\prime}$ SQ FT

WO driven)
GASES

ELECTRICAL $\quad 24$

LIQUIDS

SPEED. $12 \mathrm{ft} / \mathrm{min}$

MEASURING ACCURACY

CALIBRATION INTERVAL

ADDITIONAL DATA Remotely controlled: forward, stop, reverse. Power is from the buss system next to the tracks in the E-MAD Building using a shoe pickup. See AMF Report No. $\mathrm{RN}-\mathrm{S}-0188$.
CFM PHASE

QTY REQ'D
CUTTING SPEED

HORIZONTAL
VERTICAL

\section{OPERATING EQUIPMENT}




\section{(1) NERVA LIPROGRAM \\ SUPPORT EQUIPMENT TECHNICAL DESCRIPTION HANDBOOK}

EQUIPMENT TITLE
PROV. LIST

ITEM NO.

2014

DATE

January 1968

REVISION A

TURNTABLE ASSEMBLY, PORTABLE, 9 FOOT, 6 INCH DIAMETER,

FLOOR MOUNTED HANDLING SYSTEM

DESCRIPTION: The Portable Turntable Assembly is used in the remote assembly and disassembly of major engine subassemblies. It is capable of rotating major component of the engine mounted in their support stands. It will support and rotate a concentrically placed load of 30,000 pounds and through an electrical drive-system, is capable of continuous rotation in either direction at a constant speed of one-eighth $\mathrm{rpm}$. The turntable is controlled remotely and is provided with pneumatic and electrical outlets. Lifting devices are provided to permit its transportation by the overhead crane. The assembly can be moved into the core and engine disassembly cells by the FMHS carriage or dolly.

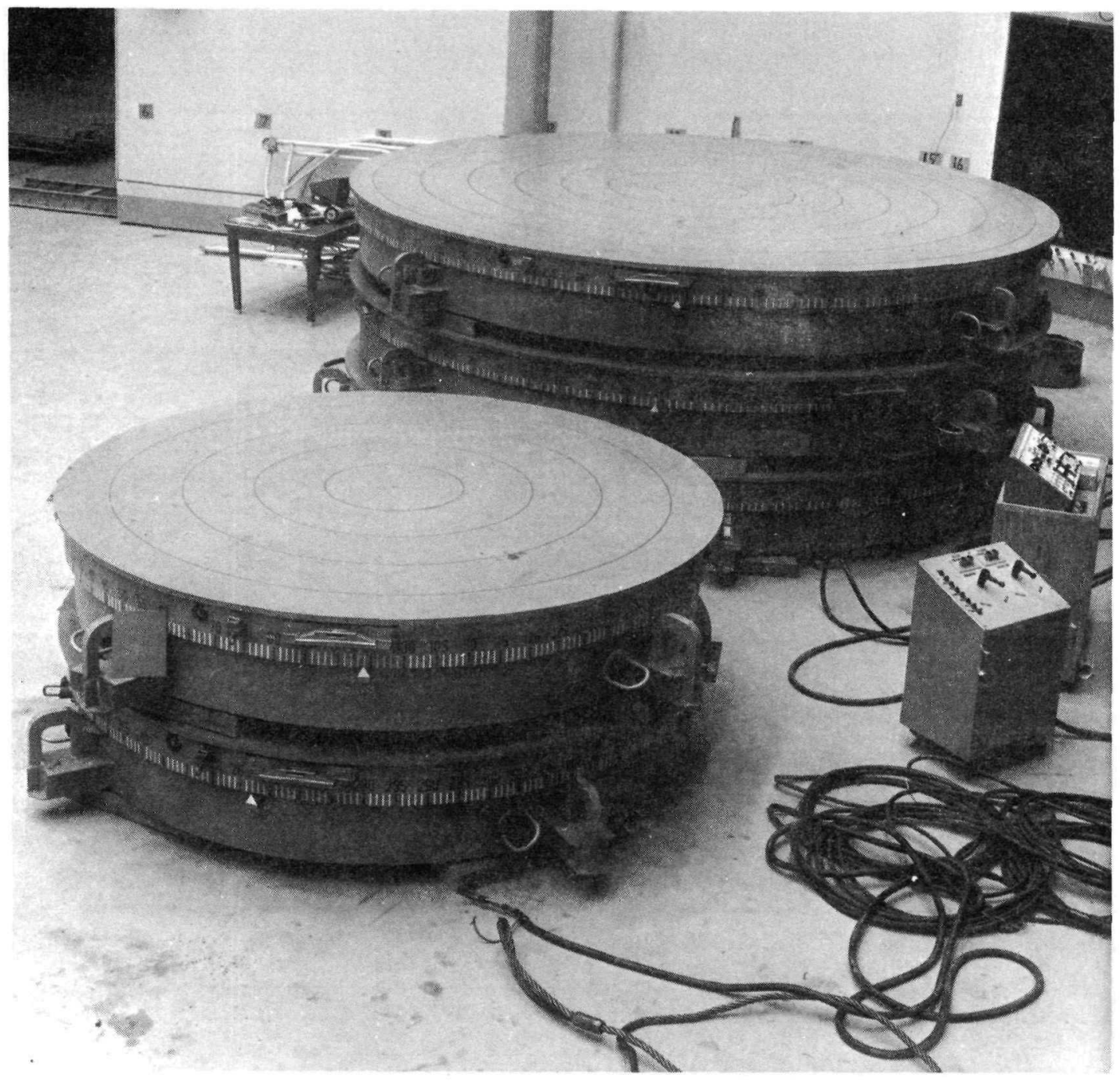




\begin{tabular}{l} 
PROVISIONING LIST ITEM NUMBER \\
DRAWING NUMBER \\
$\begin{array}{l}\text { PART NUMBER } \\
\text { CONTRACTOR }\end{array}$ \\
\hline
\end{tabular}

FIRST PROVISIONED FOR $\quad$ XE
GOVT, INV CONTROL NUMBER $\cos T+50,000$

\begin{tabular}{|c|c|}
\hline USE LOCATION & QTY REQ'D \\
\hline A. AGC SACRAMENTO & \\
\hline B. WANL & \\
\hline C. & \\
\hline D. NRDS & 2 \\
\hline TOTAL & 2 \\
\hline
\end{tabular}

\section{DIMENSIONS AND CAPACITY}

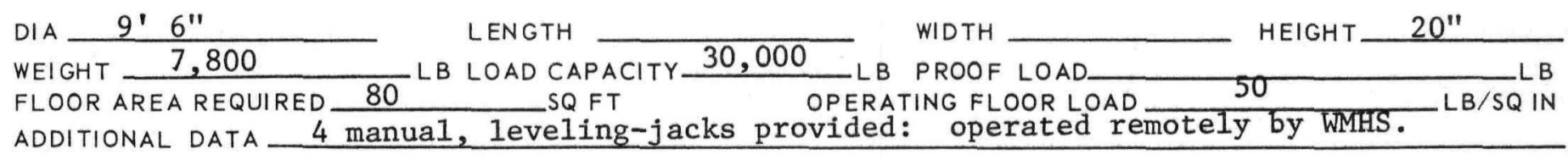

\section{OPERATING DATA}

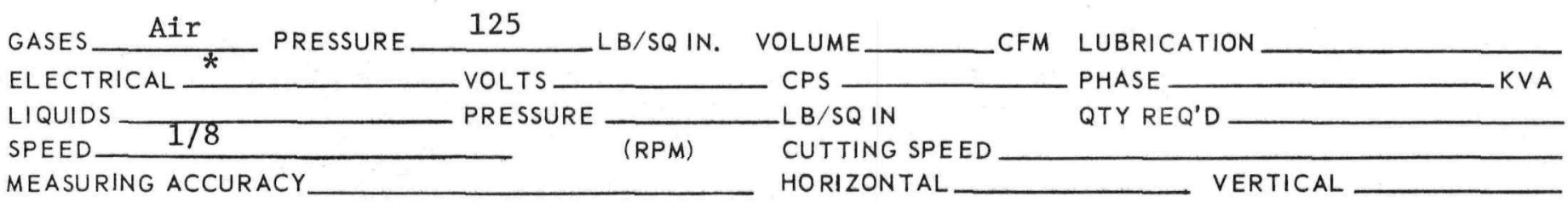

CALIBRATION INTERVAL Continuous rotation provided. A peripheral scale and pointer indicate

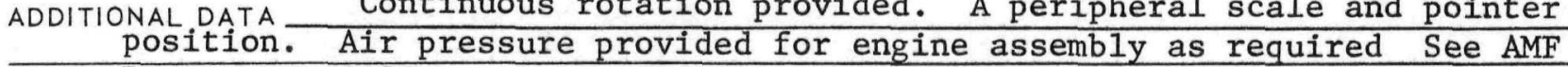
Report No. 0188 . *440VAC, $3 \mathrm{Ph}, 60$ cy (motor) 110VAC, $1 \mathrm{Ph} ., 60$ cy (receptacles)

OPERATING EQUIPMENT ADDITIONAL DATA May be lifted by sling and crane.

EQUIPMENT_Stands for engine, UTSM, nozzle and reactor components 


\section{(1) NERVA \\ LIPROGRAM \\ SUPPORT EQUIPMENT \\ TECHNICAL DESCRIPTION HANDBOOK}

EQUIPMENT TITLE

TURNTABLE ASSEMBLY, PORTABLE, 15 FOOT DIAMETER,

FLOOR MOUNTED HANDLING SYSTEM

DESCRIPTION: The Portable Turntable Assembly is used in the remote assembly and disassembly of major engine subassemblies. It is capable of rotating major subsystems or components of the engine mounted in their support stands. It will support and rotate a concentrically placed load of 30,000 pounds through an electrical drive-system, is capable of continuous rotation in either direction at a constant speed of one-eighth rpm. The turntable is controlled remotely and is provided with pneumatic and electrical outlets. Lifting devices permit its transportation by an overhead crane. 
PROVISIONING LIST ITEM NUMBER 2017

DRAWING NUMBER

PART NUMBER $80-81-1850$

CONTRACTOR
Same

AMF
FIRST PROVISIONED FOR X XE GOVT. INV. CONTROL NUMBER

$\cos T$

\begin{tabular}{|l||c|}
\hline \multicolumn{1}{|c||}{ USE LOCATION } & QTY REQ'D \\
\hline A. AGC SACRAMENTO & \\
\hline B. WANL & \\
\hline C. & 3 \\
\hline D. NRDS TOTAL & 3 \\
\hline \multicolumn{2}{|c|}{} \\
\hline
\end{tabular}

DIMENSIONS AND CAPACITY

DIA $15^{\prime}$

WEIGHT 15,500 FLOOR AREA REQUIRED 175 ADDITIONAL DATA Four manual, leveling-jack
LENGTH

WIDTH PROOF LOAD OPERATING FLOOR LOAD 50

\begin{tabular}{|c|c|c|c|c|}
\hline GASES Air & \multirow{2}{*}{ PRESSURE } & $125 \quad L B / S Q I N$ & VOLUME_CFM & LUBRICATION \\
\hline ELECTRICAL & & (2) & CPS & PHASE KVA \\
\hline LIQUIDS & _ PRESSURE. & 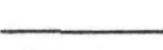 & $-L B / S Q I N$ & QTY REQ'D - \\
\hline SPEED $\quad 1 / 8$ & & $(R P M)$ & CUTTING SPEED & \\
\hline EASURING ACCUR & & & HORIZONTAL_ & $\longrightarrow$ VE \\
\hline
\end{tabular}

CALIBRATION INTERVAL ADDITIONAL DATA Continuous rotation provided. A peripheral scale and pointer indicate position. Air Report No. 0188 .

*440 VAC, $3 \mathrm{Ph} .60$ cy (motor)

$110 \mathrm{VAC}, 1 \mathrm{Ph} .60 \mathrm{cy}$ (receptacle)

\section{OPERATING EQUIPMENT}

EQUIPMENT_Various stands, as required. PART OR ITEM

REMARKS
DRAWING NO. 


\section{NERVA \\ LIPROGRAM \\ SUPPORT EQUIPMENT \\ TECHNICAL DESCRIPTION HANDBOOK}

EQUIPMENT TITLE

STAND, REACTOR POSITIONING HEAD,

FLOOR MOUNTED HANDLING SYSTEM

DESCRIPTION: The Reactor Positioning Head Stand is a three-legged structure supporting a 5-foot, 4-inch diameter positioning head nesting ring. It serves as a receptacle for the reactor positioning head when the head is not in use.

NOTE: This item is no longer required for the purpose intended (see P/L 2006).

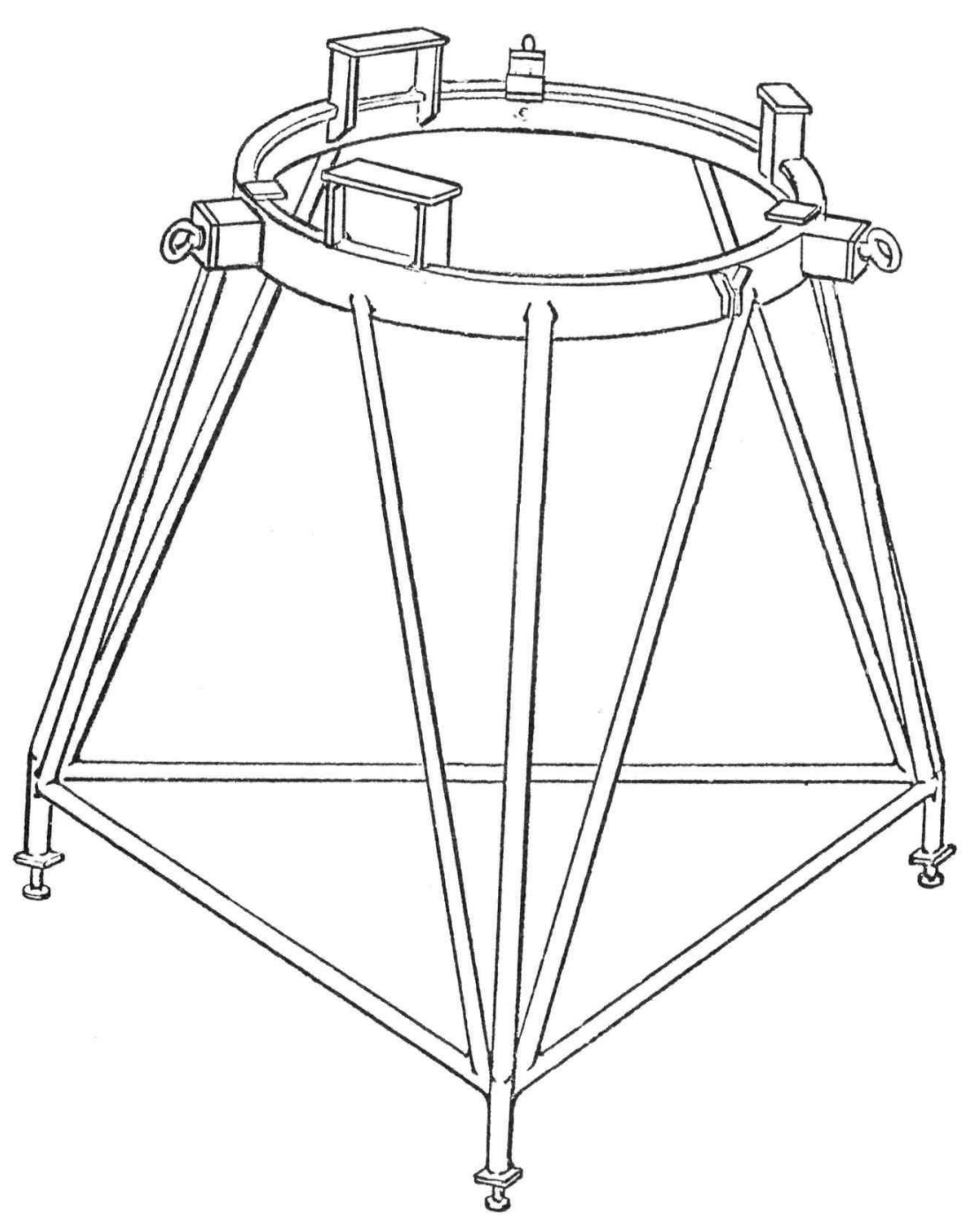


PROVISIONING LIST ITEM NUMBER 2031

DRAWING NUMBER

PART NUMBER

CONTRACTOR
89-80-1950

Same

AMF
FIRST PROVISIONED FOR XE GOVT. INV. CONTROL NUMBER

$\cos T \_\$ 5,000$

\begin{tabular}{|l||c|}
\hline \multicolumn{1}{|c||}{ USE LOCATION } & QTY REQ'D \\
\hline A. AGC SACRAMENTO & \\
\hline B. WANL & \\
\hline C. & 1 \\
\hline D. NRDS TOTAL & 1 \\
\hline \multicolumn{2}{|c|}{} \\
\hline
\end{tabular}

\section{DIMENSIONS AND CAPACITY}

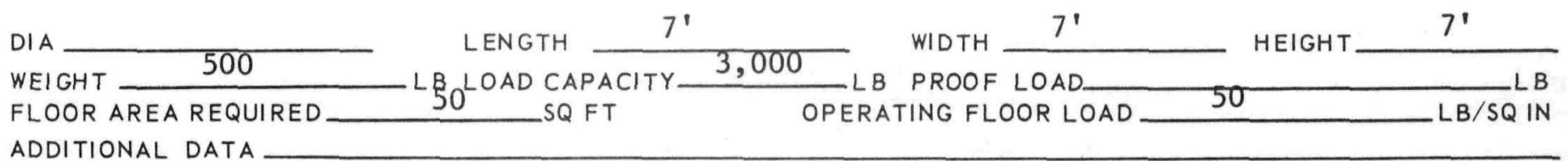

\section{OPERATING DATA}

GASES

ELECTRICAL

LIQUIDS

SPEED

MEASURING ACCURACY

CALIBRATION INTERVAL

ADDITIONAL DATA Leveling
PRESSURE VOLTS

PRESSURE IN./MIN (RPM)

LB/SQIN. VOLUME

CPS

$L B / S Q I N$

CUTTING SPEED HORIZONTAL
CFM LUBRICATION

PHASE

QTY REQ'D

EQUIPMENT_Reactor Positioning Head, P/L 2006

PART OR ITEM DRAWING NO.

REMARKS

May be lifted through 3 eyelets by sling and crane. 


\section{(1) NERVA IPROGRAM SUPPORT EQUIPMENT TECHNICAL DESCRIPTION HANDBOOK}

EQUIPMENT TITLE

STAND, UTS/TSA ASSEMBLY
PROV. LIST

ITEM NO.

4000

DATE January 1968

REVISION

A

DESCRIPTION: The UTS/TSA Assembly Stand is a circular, open steel-structure with a UTS support and personnel platform on the top. A removable guard rail and ladder for access to the UTS are provided for personnel use. A separate TPA stand, which sets on the structure platform, supports the TPA during cold assembly. The stand permits the UTS assembly to be lowered over the TPA module for installation and alignment of the TPA.
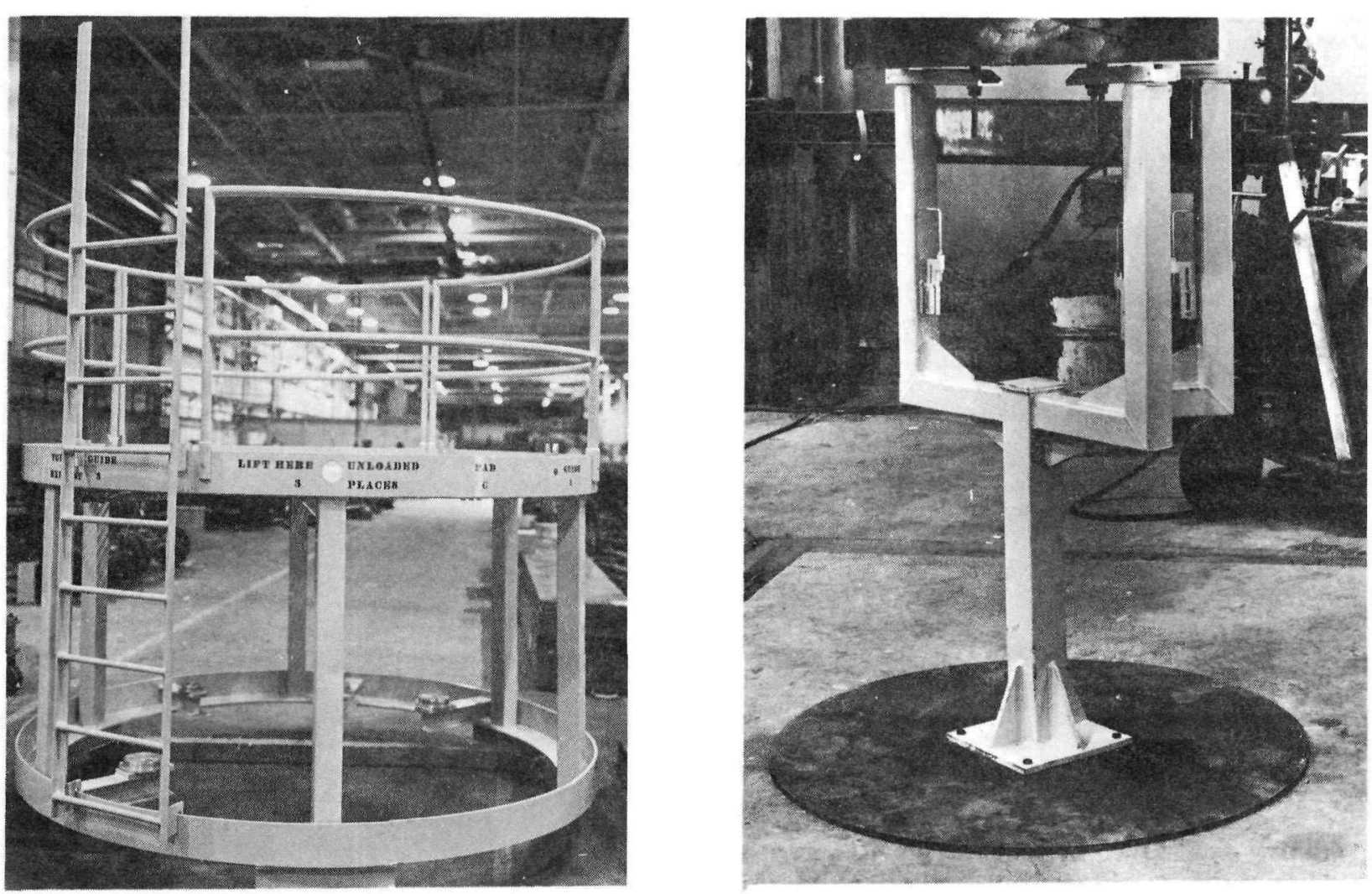
PROVISIONING LIST ITEM NUMBER 4000

DRAWING NUMBER

PART NUMBER

CONTRACTOR
$1117448-9$

Same

AGC
FIRST PROVISIONED FOR GOVT. INV. CONTROL NUMBER

$\mathrm{XE}$

\begin{tabular}{|l||c|}
\hline \multicolumn{1}{|c||}{ USE LOCATION } & QTY REQ'D \\
\hline A. AGC SACRAMENTO & 1 \\
\hline B. WANL & \\
\hline C. & \\
\hline D. NRDS TOTAL & 1 \\
\hline \multicolumn{2}{|c|}{} \\
\hline
\end{tabular}

\section{DIMENSIONS AND CAPACITY}

\begin{tabular}{|c|c|c|c|c|}
\hline $9^{\prime}$ & LENGTH & & WIDTH & $8-1 / 2^{\prime}$ \\
\hline NEIGHT. & LOAD CAPACIT & LB & PROOF LOAD 5000 & \\
\hline $\begin{array}{l}\text { FLOOR AREA REQUIRED }-60^{\circ} \\
\text { ADDITIONAL DATA Dimension }\end{array}$ & $\begin{array}{l}\text { SQ FT } \\
\text { is with guard rails. }\end{array}$ & $\begin{array}{l}\text { OPERA } \\
\text { Unit }\end{array}$ & $\begin{array}{l}\text { TING FLOOR LOAD } \\
\text { also provides a } 1\end{array}$ & $\frac{25}{\text { der and TPA }} \mathrm{LB/SQ}$ IN \\
\hline
\end{tabular}
support stand as associated items.

GASES

ELECTRICAL

LIQUIDS

SPEED

MEASURING ACCURACY

PRESSURE VOLTS

PRESSURE IN./MIN (RPM)
LB/SQIN. VOLUME

CPS

LB/SQ IN

CUTTING SPEED HORIZONTAL
CFM LUBRICATION

PHASE KVA

QTY REQ'D

CALIBRATION INTERVAL

ADDITIONAL DATA 


\section{(c) NERVA \\ LIPROGRAM \\ SUPPORT EQUIPMENT \\ TECHNICAL DESCRIPTION HANDBOOK}

EQUIPMENT TITLE

STAND, EXTERNAL SHIELD
PROV. LIST

ITEM NO.

4008

DATE

January 1968

REVISION

A

DESCRIPTION: The External Shield Stand is a three-legged pedestal with shield retainer clamps on each pedestal. The clamps may be positioned manually or with a manipulator. The stand supports the external shield during cold assembly and hot disassembly operations. It supports the shield completely loaded with steel balls and can provide required clearance below the shield for the control-drum shafts.

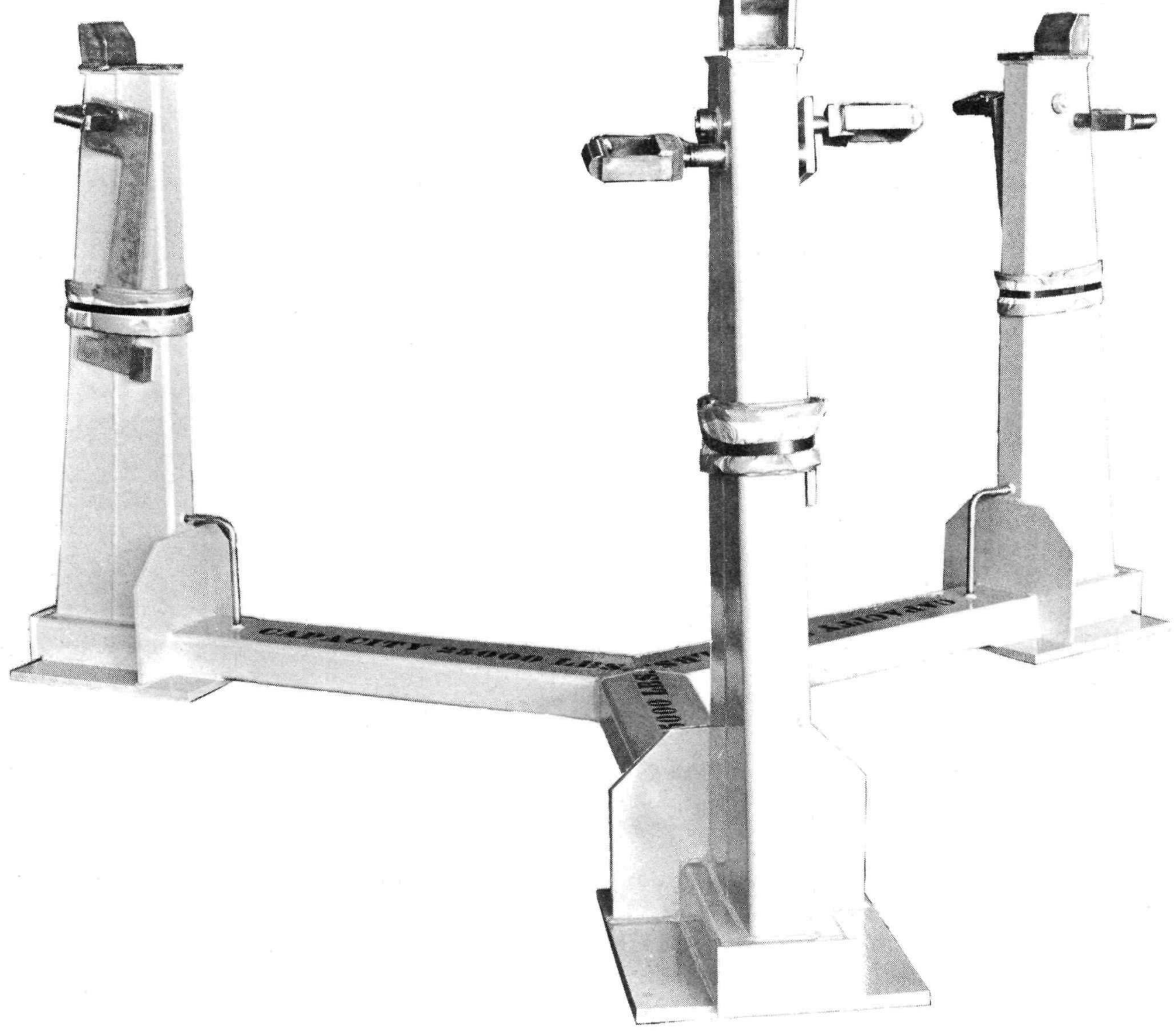


PROVISIONING LIST ITEM NUMBER 4008

DRAWING NUMBER

PART NUMBER

CONTRACTOR

\section{$1117127-9$}

Same

AGC
FIRST PROVISIONED FOR XE GOVT. INV. CONTROL NUMBER SNP-1-L-1916 $\cos T \quad \$ 3,700$

\begin{tabular}{|l||c|}
\hline \multicolumn{1}{|c||}{ USE LOCATION } & QTY REQ'D \\
\hline A. AGC SACRAMENTO & \\
\hline B. WANL & \\
\hline C. & 1 \\
\hline D. NRDS TOTAL & 1 \\
\hline
\end{tabular}

DIMENSIONS AND CAPACITY

DIA

WEIGHT FLOOR AREA REQUIRED 100 L ADDITIONAL DATA
LENGTH

$10^{\prime}$
WIDTH $10^{\prime}$

LB PROOF LOAD 50,000

OPERATING FLOOR LOAD 25
HEIGHT $5^{\prime}$
GASES

ELECTRICAL PRESSURE

LIQUIDS

SPEED

MEASURING ACCURACY

CALIBRATION INTERVAL

ADDITIONAL DATA
LB/SQ IN. VOLUME

VOLTS

PRESSURE IN./MIN (RPM)
CPS

LB/SQ IN

CUTTING SPEED HORIZONTAL
CFM

LUBRICATION

PHASE

QTY REQ'D

\section{OPERATING EQUIPMENT}

MANIPULATOR E-MAD/WMHS

CRANE

ADDITIONAL DATA
LOAD CAPACITY_ 600

LOAD CAPACITY
L B MAX

LB MAX 


\section{(1) NERVA \\ LIPROGRAM \\ SUPPORT EQUIPMENT \\ TECHNICAL DESCRIPTION HANDBOOK}

EQUIPMENT TITLE

FIXTURE, LIFTING, EXTERNAL SHIELD
PROV. LIST

ITEM NO.

4009

\section{DATE}

January 1968

REVISION

DESCRIPTION: The External Shield Lifting Fixture is a three-legged strongback with rigid legs which permit the lower surface of the shield to be engaged by manually or remotely operated locators. The fixture is used to lift and position the external shield both manually and remotely.

\section{CAPACITY 88000 LBS.}


PROVISIONING LIST ITEM NUMBER 4009

DRAWING NUMBER 1117216-9

PART NUMBER

CONTRACTOR
FIRST PROVISIONED FOR XE GOVT. INV. CONTROL NUMBER SNP-1-L-1915

\begin{tabular}{|l||c|}
\hline \multicolumn{1}{|c||}{ USE LOCATION } & QTY REQ'D \\
\hline A. AGC SACRAMENTO & \\
\hline B. WANL & \\
\hline C. & 1 \\
\hline D. NRDS TOTAL & 1 \\
\hline
\end{tabular}

DIMENSIONS AND CAPACITY

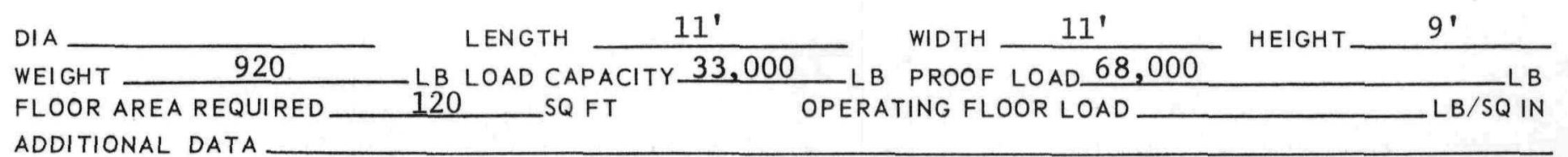

ADDITIONAL DATA

GASES

ELECTRICAL

LIQUIDS

SPEED

MEASURING ACCURACY

PRESSURE VOLTS LB/SQIN. VOLUME PRESSURE IN./MIN (RPM)

CALIBRATION INTERVAL ADDITIONAL DATA
CPS

$L B / S Q I N$

CUTTING SPEED HORIZONTAL
CFM LUBRICATION

PHASE

QTY REQ'D
MANIPULATOR E-MAD/WMHS

CRANE E-MAD

LOAD CAPACITY LOAD CAPACITY
600

80,000

VERTICAL

EQUIPMENT_E-MAD 40 Ton Crane and WMHS Manipulators

PART OR ITEM Engine External Shield DRAWING NO. 1013372

REMARKS 


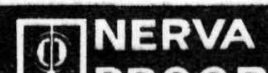

LIPROGRAM

SUPPORT EQUIPMENT

TECHNICAL DESCRIPTION HANDBOOK

EQUIPMENT TITLE

HEAD ASSEMBLY, POSITIONING, THRUST STRUCTURES
PROV. LIST

ITEM NO.

4011

DATE

REVISION

DESCRIPTION: The Thrust Structures Positioning Head Assembly is a circular box-beam ring with three equally spaced holes for engaging and securing the assembly to the OPS floating head. Twelve linkage-driven grippers are equally spaced about the periphery of the lower surface. Grippers are actuated by a manipulator handle and drive system. One handle is located internally for actuation by the OPS manipulators. The other handle is located on the ring periphery for either manual or remote operation by the WMHS manipulator. A sling is provided for cold handling operations. The assembly is used to lift and position the UTS, LTS, and the complete XE engine into and out of the EIV, the engine assembly stand, and the engine hold stand.

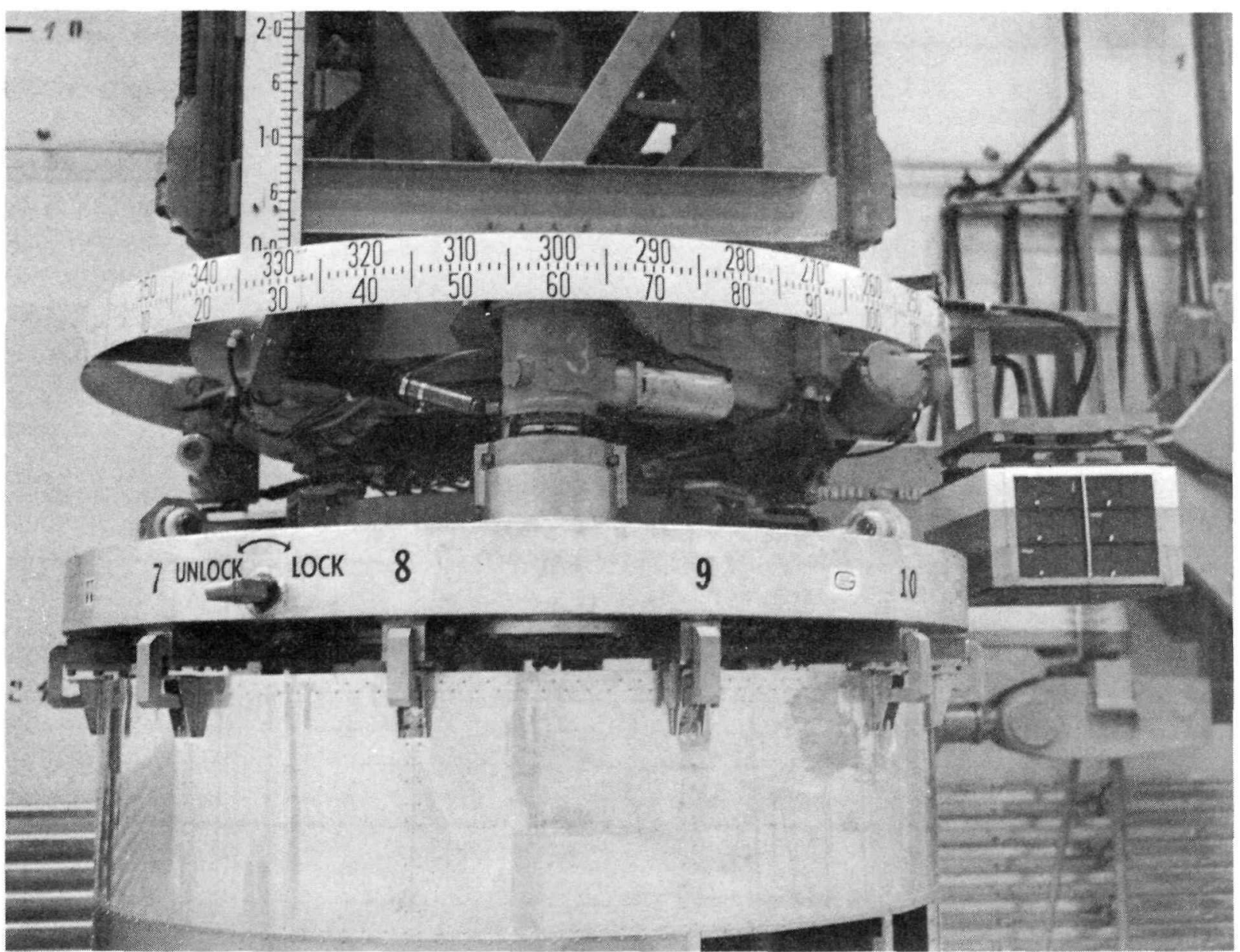


PROVISIONING LIST ITEM NUMBER 4011 DRAWING NUMBER 1114421-9

PART NUMBER CONTRACTOR

\section{Same} AGC
FIRST PROVISIONED FOR XE GOVT. INV. CONTROL NUMBER SNP-1-L-1356 $\cos T$

\begin{tabular}{|c|c|}
\hline USE LOCATION & QTY REQ'D \\
\hline A. AGC SACRAMENTO & 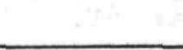 \\
\hline B. WANL & \\
\hline c. & \\
\hline D. NRDS & 1 \\
\hline TOTAL & 1 \\
\hline
\end{tabular}

\section{DIMENSIONS AND CAPACITY}

\begin{abstract}
DIA $10^{\prime} \quad$ LENGTH WIDTH WEIGHT $\frac{3,000}{\text { FLOOR AREA REQUIRED } 800}$ LB LOAD CAPACITY $\frac{40,000}{\text { SQ FT }}$ LB PROOF LOAD 80,000 ADDITIONAL DATA A separate 1-1/8' diameter cable sling and three legs, each $8^{\prime} 4^{\prime \prime}$ long, are provided for cold handling.

*Without sling

OPERATING DATA

\section{OPERATING EQUIPMENT}

MANIPULATOR OPS Auxiliary

CRANE E-MAD

LOAD CAPACITY

LOAD CAPACITY

600

80,000

L B MAX

ADDITIONAL DATA VOLTS

$L B / S Q$ IN

PHASE

QTY REQ'D

EQUIPMENT_OPS or Crane (Floating Head) PART OR ITEM UTS/LTS DRAWING NO.1114122/1113854

REMARKS Is set into and stored in stand, P/L 4012 


\section{(1) NERVA \\ LIPROGRAM \\ SUPPORT EQUIPMENT \\ TECHNICAL DESCRIPTION HANDBOOK}

EQUIPMENT TITLE

PROV. LIST

ITEM NO.

4012

DATE January 1968

REVISION

STAND, POSITIONING HEAD, THRUST STRUCTURE

DESCRIPTION: The Thrust Structure Positioning Head Stand is a triangular, three-legged steel structure with three support pads and guides at the top to support the positioning head when not in use. Its height permits the opS to engage the positioning head when required for remote operations in the E-MAD Building hot bay. A lifting bail is provided at the center of a structural spider for lifting the stand with or without the positioning head.

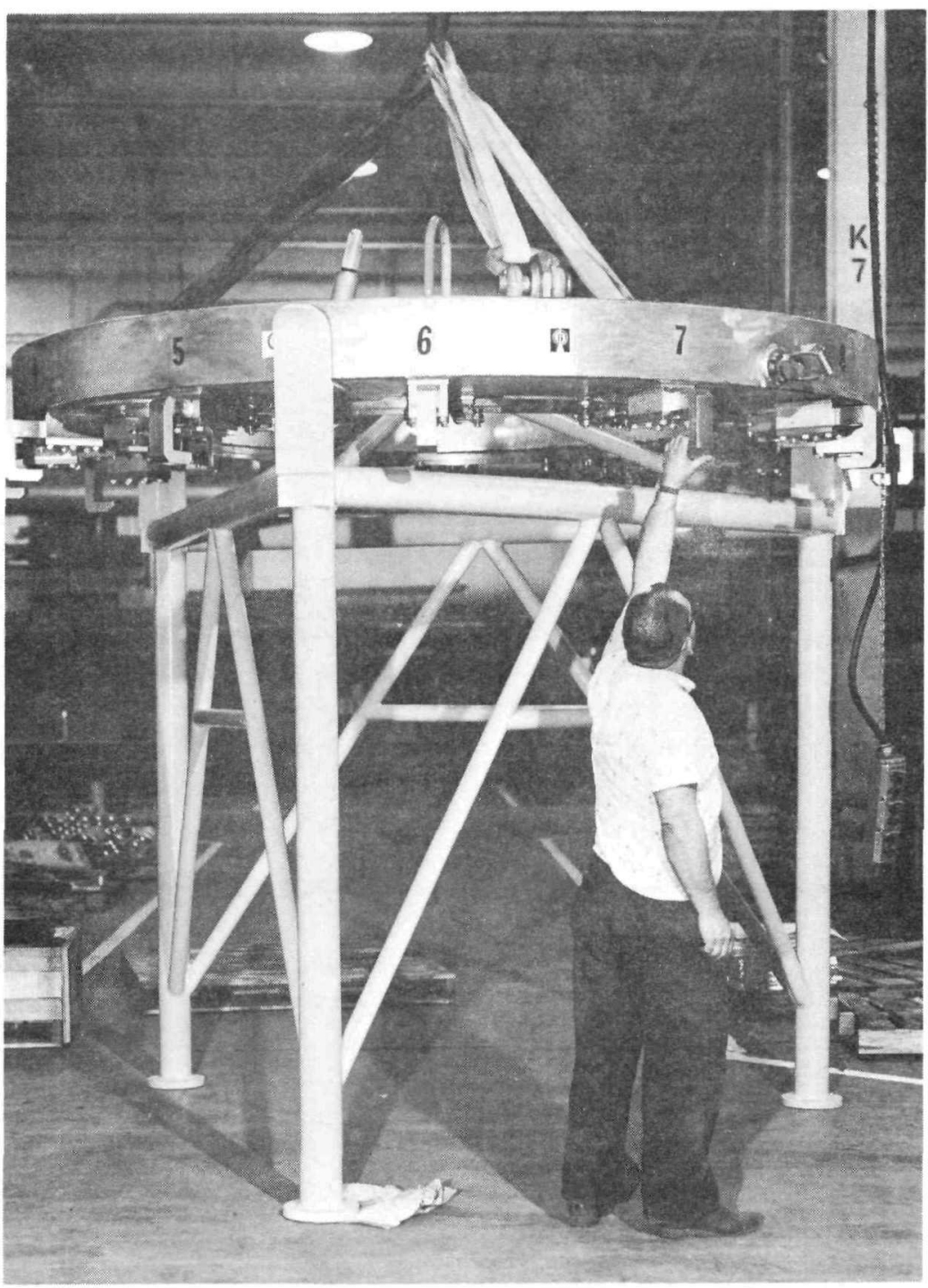


PROVISIONING LIST ITEM NUMBER 4012

DRAWING NUMBER 1114447-9

PART NUMBER S Same

CONTRACTOR _ AGC
FIRST PROVISIONED FOR XE GOVT. INV. CONTROL NUMBER SNP-1-L-1357

$\cos T \_\$ 2,100$

\begin{tabular}{|l||l|}
\hline \multicolumn{1}{|c||}{ USE LOCATION } & QTY REQ'D \\
\hline A. AGC SACRAMENTO & \\
\hline B. WANL & \\
\hline C. & \\
\hline D. NRDS TOTAL & 1 \\
\hline \multicolumn{2}{|c|}{1} \\
\hline
\end{tabular}

\section{DIMENSIONS AND CAPACITY}

DIA

WEIGHT 1,000 FLOOR AREA REQUIRED ADDITIONAL DATA
LENGTH

$9^{\prime}$

WIDTH $9^{\prime}$

HEIGHT $8^{\prime}$ LB LOAD CAPACITY SQ FT LB PROOF LOAD OPERATING FLOOR LOAD $\quad 50$ $L B / S Q$ IN

GASES ELECTRICAL

LIQUIDS

SPEED

MEASURING ACCURACY

PRESSURE VOLTS

PRESSURE IN./MIN (RPM)

ADDITIONAL DATA
LB/SQIN. VOLUME

CPS

$-L B / S Q$ IN

CUTTING SPEED

HORIZONTAL
CFM LUBRICATION

PHASE KVA
MANIPULATOR

CRANE

ADDITIONAL DATA
LOAD CAPACITY

LOAD CAPACITY

30,000
LB MAX

LB MAX

EQUIPMENT_ E-MAD Crane - 15 Ton

PART OR ITEM Positioning Head, P/L 4011 DRAWING NO.1114421

REMARKS 
EQUIPMENT TITLE

STAND, ENGINE ASSEMBLY

DESCRIPTION: The Engine Assembly Stand is a steel frame with an electrically driven, single-axis C-shaped rotating head which engages the XE engine external shield. Its height permits rotation of the engine "end-for-end" through $360^{\circ}$. It is used to hold and position the engine during cold assembly operations.

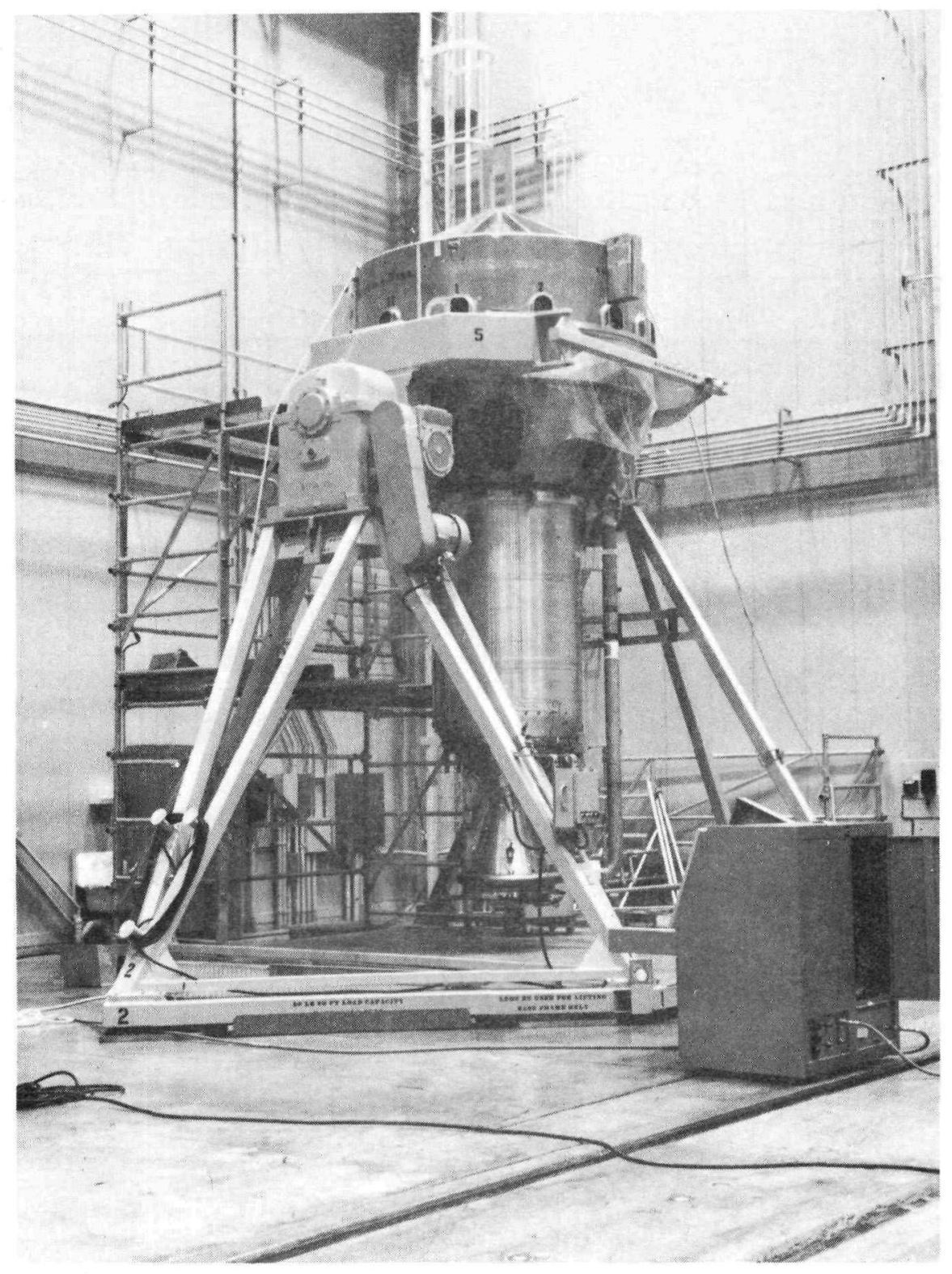


PROVISIONING LIST ITEM NUMBER 4021

DRAWING NUMBER $1117307-9$

PART NUMBER

CONTRACTOR
FIRST PROVISIONED FOR GOVT. INV. CONTROL NUMBER SNP-1-L-1918

$\cos T \quad \$ 80,000$

\begin{tabular}{|l||c|}
\hline \multicolumn{1}{|c||}{ USE LOCATION } & QTY REQ'D \\
\hline A. AGC SACRAMENTO & \\
\hline B. WANL & \\
\hline C. & 1 \\
\hline D. NRDS TOTAL & 1 \\
\hline \multicolumn{2}{|c|}{} \\
\hline
\end{tabular}

\section{DIMENSIONS AND CAPACITY}

DIA

WEIGHT 25,000

FLOOR AREA REQUIRED 350

ADDITIONAL DATA The head-drive
LENGTH 29' 10" LB LOAD CAPACITY 40,000

mech
GASES

ELECTRICAL $\quad 440$ AC

LIQUIDS

SPEED *

MEASURING ACCURACY

CALIBRATION INTERVAL

ADDITIONAL DATA *Rotates engine end-for-end through $360^{\circ}$ in 7.5 minutes. See Operation and Maintenance Instructions (No report No. assigned - see NRO GSE Engineering)

EQUIPMENT_ Facility 440 VAC, 3 Phase Power Receptacle DRAWING NO. 


\begin{tabular}{l|l}
\hline C) & NERVA \\
PROGRAM & SUPPORT EQUIPMENT \\
\hline
\end{tabular}

EQUIPMENT TITLE

STAND, ASSEMBLY, STORAGE, UPPER THRUST STRUCTURE MODULE
PROV. LIST

ITEM NO.

DATE

REVISION

DESCRIPTION: The UTSM Storage Stand Assembly is a four-legged structure with an eight-foot diameter top-ring which is the base and guide for the UTSM. Its height permits lines projecting from the UTSM to clear the floor. The assembly also provides access to these lines. The stand is used for UTSM storage prior to remote reassembly and after removal of the UTSM from the engine assembly.

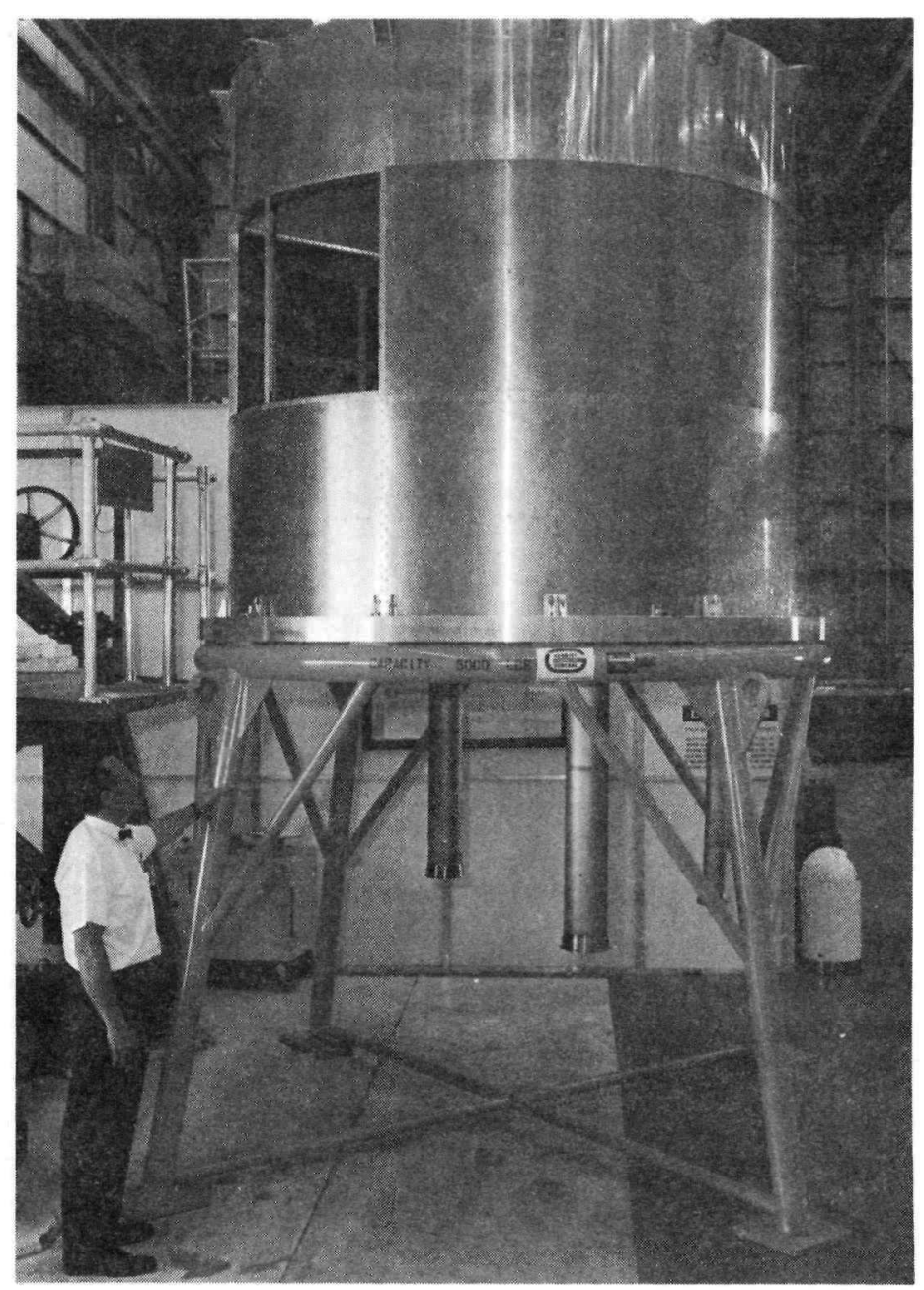


PROVISIONING LIST ITEM NUMBER 4027 DRAWING NUMBER $1116300-9$

PART NUMBER CONTRACTOR
FIRST PROVISIONED FOR GOVT. INV. CONTROL NUMBER SNP-1-L-1360/1804

\begin{tabular}{|l||c|}
\hline \multicolumn{1}{|c||}{ USE LOCATION } & QTY REQ'D \\
\hline A. AGC SACRAMENTO & \\
\hline B. WANL & \\
\hline C. & \\
\hline D. NRDS TOTAL & 2 \\
\hline \multicolumn{2}{|c|}{} \\
\hline
\end{tabular}

DIMENSIONS AND CAPACITY

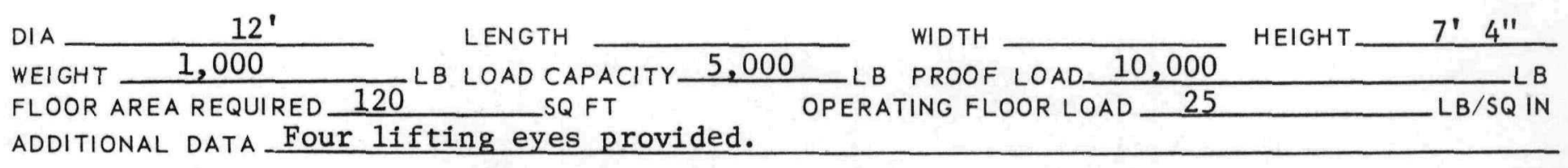

ADDITIONAL DATA Four lifting eyes provided.

GASES

ELECTRICAL

LIQUIDS

SPEED

MEASURING ACCURACY

CALIBRATION INTERVAL

ADDITIONAL DATA
PRESSURE VOLTS

PRESSURE IN./MIN (RPM)
LB/SQIN. VOLUME

CPS

$L B / S Q I N$

CUTTING SPEED

HORIZONTAL
CFM LUBRICATION

PHASE

QTY REQ'D
MANIPULATOR

CRANE E-MAD LOAD CAPACITY LOAD CAPACITY
LB MAX LB MAX

ADDITIONAL DATA

INTERFACES

EQUIPMENT_Crane/OPS and Sling

PART OR ITEM Upper Thrust Structure DRAWING NO. 1115459-29

REMARKS 
DESCRIPTION: The Remote Checkout Adapter Kit, is used in the E-MAD Building hot bay for remote leak and electrical checkout of the XE engine after remote replacement of the UTSM. The remote connecting interface is at Engine Station 42.89 (top). Manipulators are used to handle the cable and pneumatic line adapters. Kit operation utilizes other checkout equipment located in the operator area. 
PROVISIONING LIST ITEM NUMBER 4043

DRAWING NUMBER 1117850

PART NUMBER

CONTRACTOR

Same

AGC
FIRST PROVISIONED FOR $\mathrm{XE}$ GOVT. INV. CONTROL NUMBER

$\cos T \_\$ 30,000$

\begin{tabular}{|l||c|}
\hline \multicolumn{1}{|c||}{ USE LOCATION } & QTY REQ'D \\
\hline A. AGC SACRAMENTO & \\
\hline B. WANL & \\
\hline C. & 1 \\
\hline D. NRDS TOTAL & 1 \\
\hline
\end{tabular}

\section{DIMENSIONS AND CAPACITY}

DIA N/A LENGTH N/A WIDTH N/A HEIGHT_N/A WEIGHT $\frac{600}{6 B}$ LOAD CAPACITY LB PROOF LOAD—LB FLOOR AREA REQUIRED OPERATING FLOOR LOAD
ADDITIONAL DATA. The kit consists of several sma11 parts as listed. Remote cables and hoses are $85^{\prime}$ long. The pneumatic control box is $14^{\prime \prime} \times 27^{\prime \prime} \times 21^{\prime \prime}$ and weighs 901 b.

\section{OPERATING DATA}

GASES Helium PRESSURE 50-100 LB/SQIN. VOLUME ELECTRICAL 110 VAC LIQUIDS SPEED MEASURING ACCURACY VOLTS 60 PRESSURE IN./MIN (RPM)

CALIBRATION INTERVAL ADDITIONAL DATA Leak-test gas and control is provided by P/L Item 4400. Engine electrical checkout control is provided by P/L Item 4401. See RN-DR-0120.
CFM LUBRICATION

CPS

$L B / S Q$ IN CUTTING SPEED HORIZONTAL
PHASE

QTY REQ'D KVA

VERTICAL
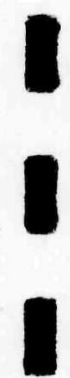

OPERATING EQUIPMENT

MANIPULATOR E/MAD/WMHS Or OPS

LOAD CAPACITY

600

LB MAX

CRANE

LOAD CAPACITY

LB MAX

EQUIPMENT__ E-MAD/WMHS or OPS Manipulator PART OR ITEM XE Engine (Sta. 42.89) DRAWING NO.

REMARKS Connects to the electrical test set, $\mathrm{P} / \mathrm{L} 4401$, and functional valve and leak test set, P/L 4400. 
TMERVA

SUPPORT EQUIPMENT

TECHNICAL DESCRIPTION HANDBOOK

EQUIPMENT TITLE

SYSTEM, MATERIALS TRANSFER, POST-OPERATIVE CELL

DESCRIPTION: The Post-Operative Ce11 Materials Transfer System (POCMTS) consists of a hot-cell materials transfer subsystem (HCMTS) and an intercell transfer subsystem (ITS), together with associated busrails, car rails, power supplies, and control panels. The HCMTS includes a powered table in each hot cell which travels between the cell and the adjacent cell service-area, together with electrical controls at each operating position. The ITS includes powered cars which travel between adjacent cells through openings in the intercell walls. Cargo trays can be elevated and aligned with cell tables and controlled from a control panel at each operating position. The system consists of the following: Intercell Transfer Subsystem Cars (3); Control Panel (16); Power Supplies (4); Car Rails (as required); Hot Cells Materials Transfer Subsystem Powered Tables (13); Busrail System (2); Miscellaneous Brackets and Connectors.
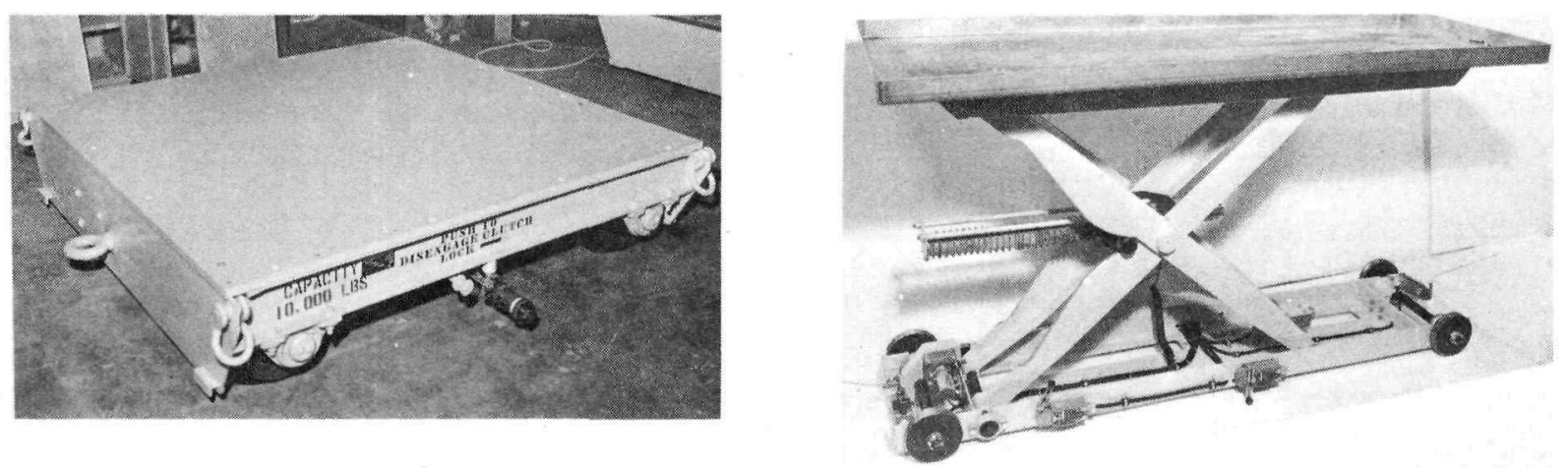
PROVISIONING LIST ITEM NUMBER 4045

DRAWING NUMBER

PART NUMBER

CONTRACTOR
1115585

Same

AGC
FIRST PROVISIONED FOR GOVT. INV. CONTROL NUMBER

$\cos T \_\$ 120,000$

\begin{tabular}{|c||c|}
\hline \multicolumn{1}{|c||}{ USE LOCATION } & QTY REQ'D \\
\hline A. AGC SACRAMENTO & \\
\hline B. WANL & \\
\hline C. & \\
\hline D. NRDS TOTAL & 1 \\
\hline \multicolumn{2}{|c||}{1} \\
\hline
\end{tabular}

DIMENSIONS AND CAPACITY

DIA N/A

WEIGHT 70,000

FLOOR AREA REQUIRED

FLOOR AREA REQUIRED
ADDITIONAL DATA Equipment permanen

LENGTH

LB LOAD CAPACITY

CAPACITY LB PROOF LOAD
SQFT OPERATING FLOOR LOAD

$\mathrm{X}$

HEIGHT

ITS car track, ITS cars, and HCMTS cars in hot area. Control boxes and power supplies in operator area. ITS car is 64" 1 ong, $26^{\prime \prime}$ wide, and 9 to $37^{\prime \prime}$ high, and weighs 3801 . The HCMTS table is $6^{\prime}$ square, $16^{\prime \prime}$ high, and weighs 3500 1b. *ITS Car Weight: 750 1b. HCMTS car weight: $10,0001 \mathrm{~b}$.

\section{OPERATING DATA}

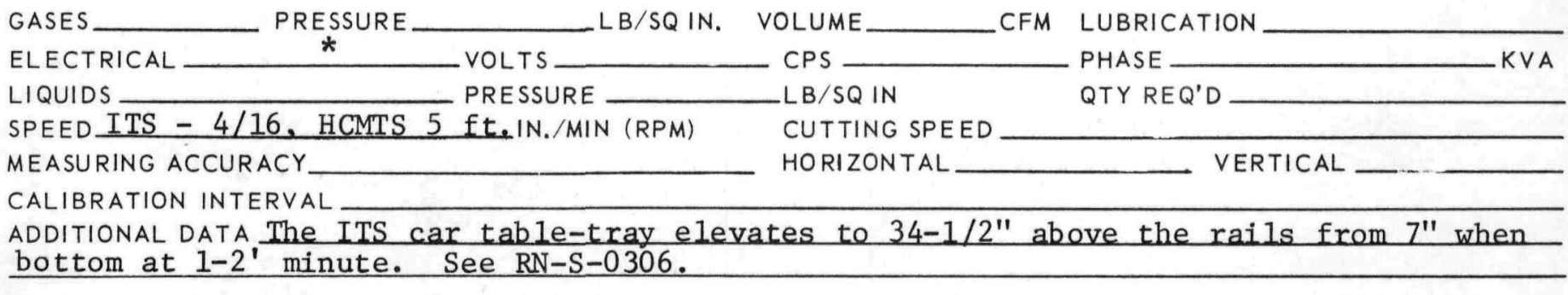

*ITS Car - 110 VAC, single phase, 60 cy.

HCMTS Car - 208 VAC, 3 phase, 60 cy/110 VAC, single phase, 60 cy

\section{OPERATING EQUIPMENT}

MANIPULATOR

CRANE

E-MAD Post Mortem Area

ADDITIONAL DATA
LOAD CAPACITY

LOAD CAPACITY

10,000

LB MAX L B MAX

EQUIPMENT_ E-MAD Post Mortem Area

PART OR ITEM Reactor and Engine Components DRAWING NO.

REMARKS The ITS car is handled with a crane using sling, P/L 4046. The HCMTS tables are handled with a crane using sling, P/L 4048. 
PROV. LIST

ITEM NO.

4046
(1) NERVA

SUPPORT EQUIPMENT

TECHNICAL DESCRIPTION HANDBOOK

EQUIPMENT TITLE

\section{DATE}

REVISION

SLING, INTERCELL TRANSFER CAR

DESCRIPTION: The Intercell Transfer Car Sling is a light, box-beam strongback with a lifting bail and four solid-bar legs (two legs at each end) free to swing parallel to the beam axis. Each leg is formed with a hook at the end so it can be attached and removed remotely. The sling lifts and positions the car during maintenance or if a malfunction occurs. It can pick up an empty or loaded car with the tray retracted or extended. 
PROVISIONING LIST ITEM NUMBER 4046

DRAWING NUMBER

PART NUMBER

CONTRACTOR
1115598

Same AGC
FIRST PROVISIONED FOR GOVT. INV. CONTROL NUMBER

$\cos T \_\$ 1,000$

\begin{tabular}{|l||c|}
\hline \multicolumn{1}{|c||}{ USE LOCATION } & QTY REQ'D \\
\hline A. AGC SACRAMENTO & \\
\hline B. WANL & \\
\hline C. & \\
\hline D. NRDS TOTAL & 1 \\
\hline \multicolumn{2}{|c|}{1} \\
\hline
\end{tabular}

DIMENSIONS AND CAPACITY

DIA

WEI GHT 150

FLOOR AREA REQUIRED 6

ADDITIONAL DATA
LENGTH $\frac{5-1 / 2^{\prime}}{1,000}$ WIDTH $\frac{1^{\prime}}{}$ LOAD CAPACITY PROOF LOAD 2,000 $S Q F T$

\section{XE}




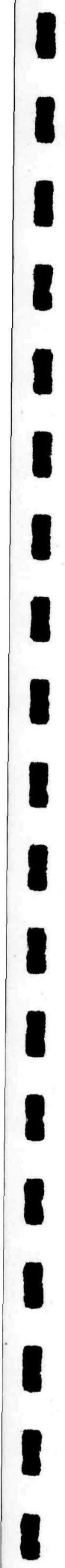

PROV. LIST

ITEM NO.

4048

\begin{tabular}{l|l|l}
\hline C) & NERVA & SUPPORT EQUIPMENT \\
PROGRAM & TECHNICAL DESCRIPTION HANDBOOK \\
\hline
\end{tabular}

EQUIPMENT TITLE

DATE January 1968

REVISION

SLING, HANDLING, MOBILE TABLE

DESCRIPTION: The Mobile Table Handling Sling is a beam strongback with a fiveposition bail and four chain legs (two with hooks) on each end. It is used to lift and position mobile table bases with or without load. It is also capable of remote attachment and removal. 
PROVISIONING LIST ITEM NUMBER 4048

DRAWING NUMBER

PART NUMBER

CONTRACTOR 1115589

Same AGC
FIRST PROVISIONED FOR GOVT. INV. CONTROL NUMBER

$\cos T+\$ 3,000$

\begin{tabular}{|l||c|}
\hline \multicolumn{1}{|c||}{ USE LOCATION } & QTY REQ'D \\
\hline A. AGC SACRAMENTO & \\
\hline B. WANL & \\
\hline C. & 1 \\
\hline D. NRDS TOTAL & 1 \\
\hline \multicolumn{2}{|c||}{} \\
\hline
\end{tabular}

DIMENSIONS AND CAPACITY

DIA

WEIGHT

300

LENGTH

WIDTH

6' 30,000 HEIGHT $8^{\prime}$ FLOOR AREA REQUIRED_ 151 OPERATING FLOOR LOAD ST ADDITIONAL DATA

GASES PRESSURE

ELECTRICAL

LIQUIDS

SPEED

MEASURING ACCURACY

CALIBRATION INTERVAL

ADDITIONAL DATA
LB/SQ IN. VOLUME

VOLTS

PRESSURE

IN./MIN (RPM)

OPERATING EQUIPMENT

MANIPULATOR

CRANE E-MAD

ADDITIONAL DATA.

\section{CPS}

LB/SQ IN

CUTTING SPEED

HORIZONTAL
CFM LUBRICATION

PHASE

QTY REQ'D KVA

VERTICAL

EQUIPMENT__E-MAD Crane

PART OR ITEM_HCMTS Table

REMARKS
LOAD CAPACITY

LOAD CAPACITY
LB MAX

30,000

L B MAX 


\begin{tabular}{l|l|c}
\hline CPERVA & SUPPORT EQUIPMENT \\
\hline PROGRAM & TECHNICAL DESCRIPTION HANDBOOK \\
\hline
\end{tabular}

EQUIPMENT TITLE
PROV. LIST

ITEM NO.

4049

DATE

January 1968

COVER, FLUID LINE, REMOTE

DESCRIPTION: The Remote Fluid Line Cover is a set of four, welded aluminum cup-assemblies, each with a five-inch long, one-inch Hex bar handle. They are used to protect open lower-line sections from contamination during remote replacement of the UTS/TPA assembly on XE engines. They can be installed and removed remotely with a manipulator.

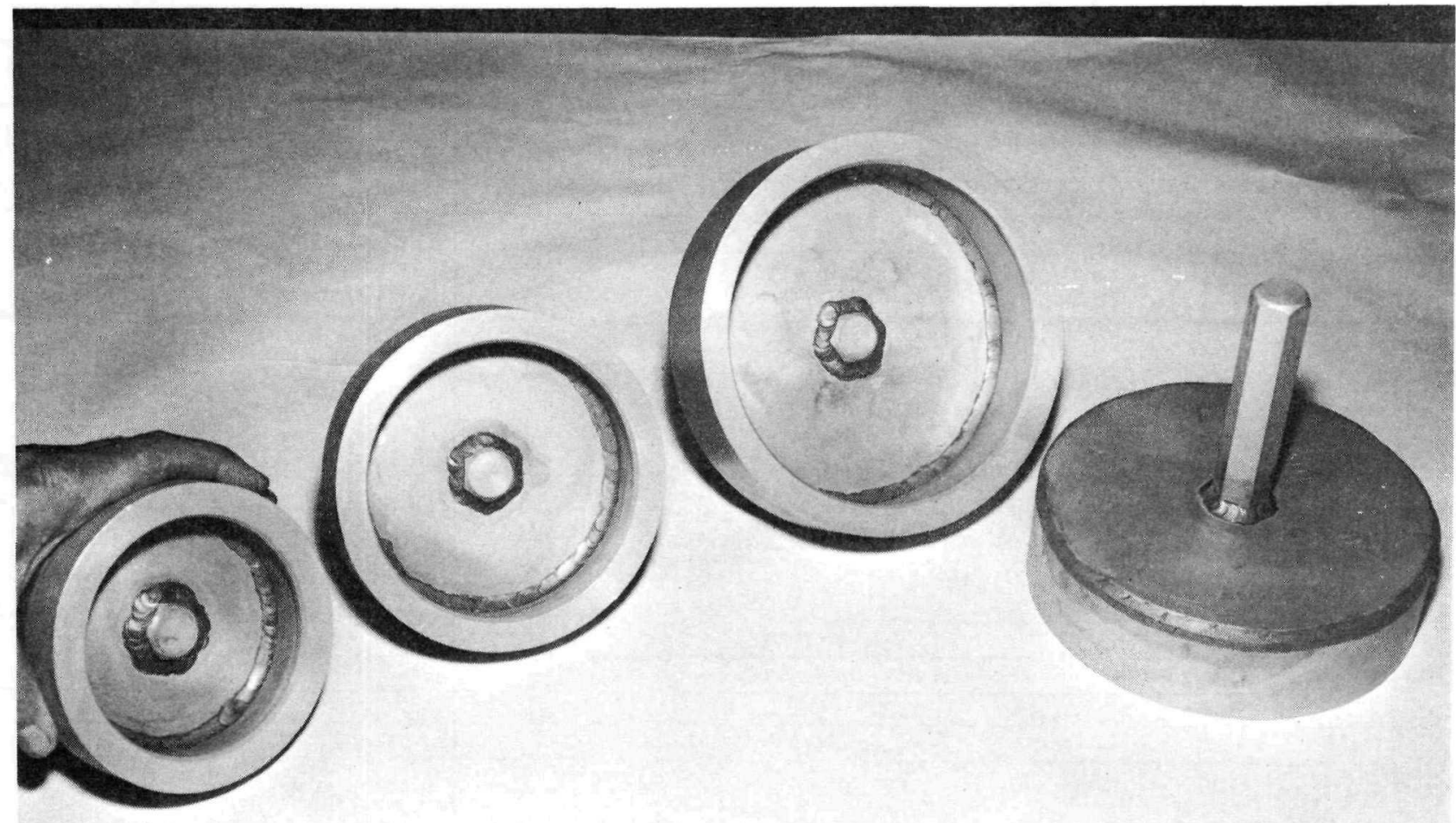


TECHNICAL SUMMARY

PROVISIONING LIST ITEM NUMBER 4049

DRAWING NUMBER

$1115155-9$

PART NUMBER

Same

CON IRACTOR AGC

FIRST PROVISIONED FOR

$X E$ GOVT. INV. CONTROL NUMBER

$\cos T$ $\$ 1,300$

\begin{tabular}{|l||c|}
\hline \multicolumn{1}{|c||}{ USE LOCATION } & QTY REQ'D \\
\hline A. AGC SACRAMENTO & \\
\hline B. WANL & \\
\hline C. & 1 \\
\hline D. NRDS TOTAL & 1 \\
\hline \multicolumn{2}{|c|}{} \\
\hline
\end{tabular}

(2) $8^{\prime \prime}$

DIMENSIONS AND CAPACITY

(1) $6-1 / 2^{\prime \prime}$

DIA (1) $5-1 / 2^{\prime \prime}$

WEIGHT 15

15

LENGTH

WIDTH

HEIGHT

FLOOR AREA REQUIRED 2 SQ FT

LB PROOF LOAD

OPERATING FLOOR LOAD

ADDITIONAL DATA

GASES

ELECTRICAL

LIQUIDS

SPEED

MEASURING ACCURACY

CALIBRATION INTERVAL

ADDITIONAL DATA
PRESSURE VOLTS PRESSURE IN./MIN (RPM)
LB/SQIN. VOLUME

CPS

- $B$ /SQ IN

CUTTING SPEED

HORIZONTAL
CFM LUBRICATION PHASE QTY REQ'D
MANIPULATOR E-MAD/WMHS

CRANE

ADDITIONAL DATA
LOAD CAPACITY

LOAD CAPACITY
600

LB MAX

LB MAX

INTERFACES

EQUIPMENT__ E-MAD/WMHS

PART OR ITEM Engine Fluid Lines DRAWING NO.

REMARKS 


\begin{tabular}{|l|l}
\hline NERVA & SUPPORT EQUIPMENT \\
\hline PROGRAM & TECHNICAL DESCRIPTION HANDBOOK \\
\hline
\end{tabular}

EQUIPMENT TITLE
PROV. LIST

ITEM NO. 4059

DATE January 1968 REVISION

PLATFORM, MAINTENANCE, ETS-1

DESCRIPTION: The ETS-1 Maintenance Platform is a square, three-leve1, open-grating, aluminum personnel stand which provides access to all levels of the XE engine and the TSA in ETS-1. The stand is mounted on the ETS-1 mobile duct cover shield. A removable section permits the stand to be positioned around the engine when the shield is rolled into place. Access stairways, protective railing, and kickplates are provided.

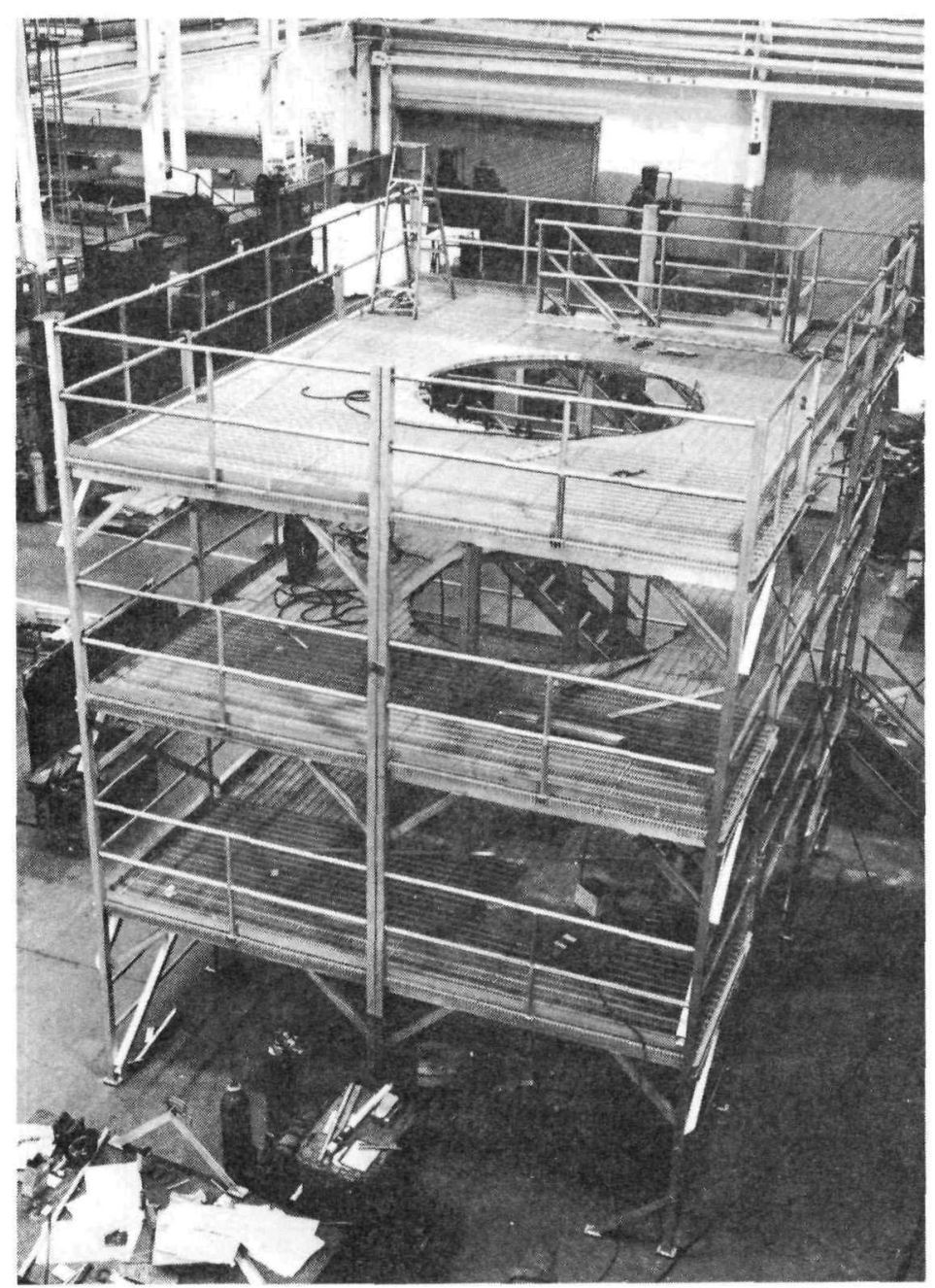


PROVISIONING LIST ITEM NUMBER 4059

DRAWING NUMBER 1118696-9

PART NUMBER

CONTRACTOR
Same AGC
FIRST PROVISIONED FOR GOVT. INV. CONTROL NUMBER

$\cos T \_\$ 25,000$

\begin{tabular}{|l||c|}
\hline \multicolumn{1}{|c||}{ USE LOCATION } & QTY REQ'D \\
\hline A. AGC SACRAMENTO & \\
\hline B. WANL & \\
\hline C. & 1 \\
\hline D. NRDS TOTAL & 1 \\
\hline
\end{tabular}

DIMENSIONS AND CAPACITY

\begin{tabular}{|c|c|c|c|c|}
\hline$D I A$ & LENGTH & $26^{\prime}$ & WIDTH $19^{\prime}$ & HEIGHT_ \\
\hline WEI GHT & LOAD CAPACITY & $5,000 \mathrm{LB}$ & PROOF LOAD & 10,000 LB \\
\hline$=\angle O O R$ AREA REQUIRED & $500 S Q F T$ & OPERA & TING FLOOR LOAD & $L B / S Q I N$ \\
\hline
\end{tabular}

GASES PRESSURE

ELECTRICAL

LIQUIDS

SPEED

MEASURING ACCURACY

CALIBRATION INTERVAL

ADDITIONAL DATA
VOLTS

PRESSURE

IN./MIN (RPM)
LB/SQIN. VOLUME

CPS

$L B / S Q$ IN

CUTTING SPEED

HORIZONTAL
CFM LUBRICATION

PHASE

QTY REQ'D
SE

\section{R}




\section{(1) NERVA \\ LPROGRAM \\ SUPPORT EQUIPMENT TECHNICAL DESCRIPTION HANDBOOK}

EQUIPMENT TITLE

LIFTING DEVICE, TURBOPUMP ASSEMBLY
PROV. LIST

ITEM NO. 4087

DATE

REVISION

DESCRIPTION: The Turbopump Assembly Lifting Device is a stainless-steel, bent-bar sling with a rigid interface-attachment point at each end. The attachments bolt to the TPA. The device is used to handle the TPA, and to lift and position the TPA during its installation into the UTS/TPA assembly stand.

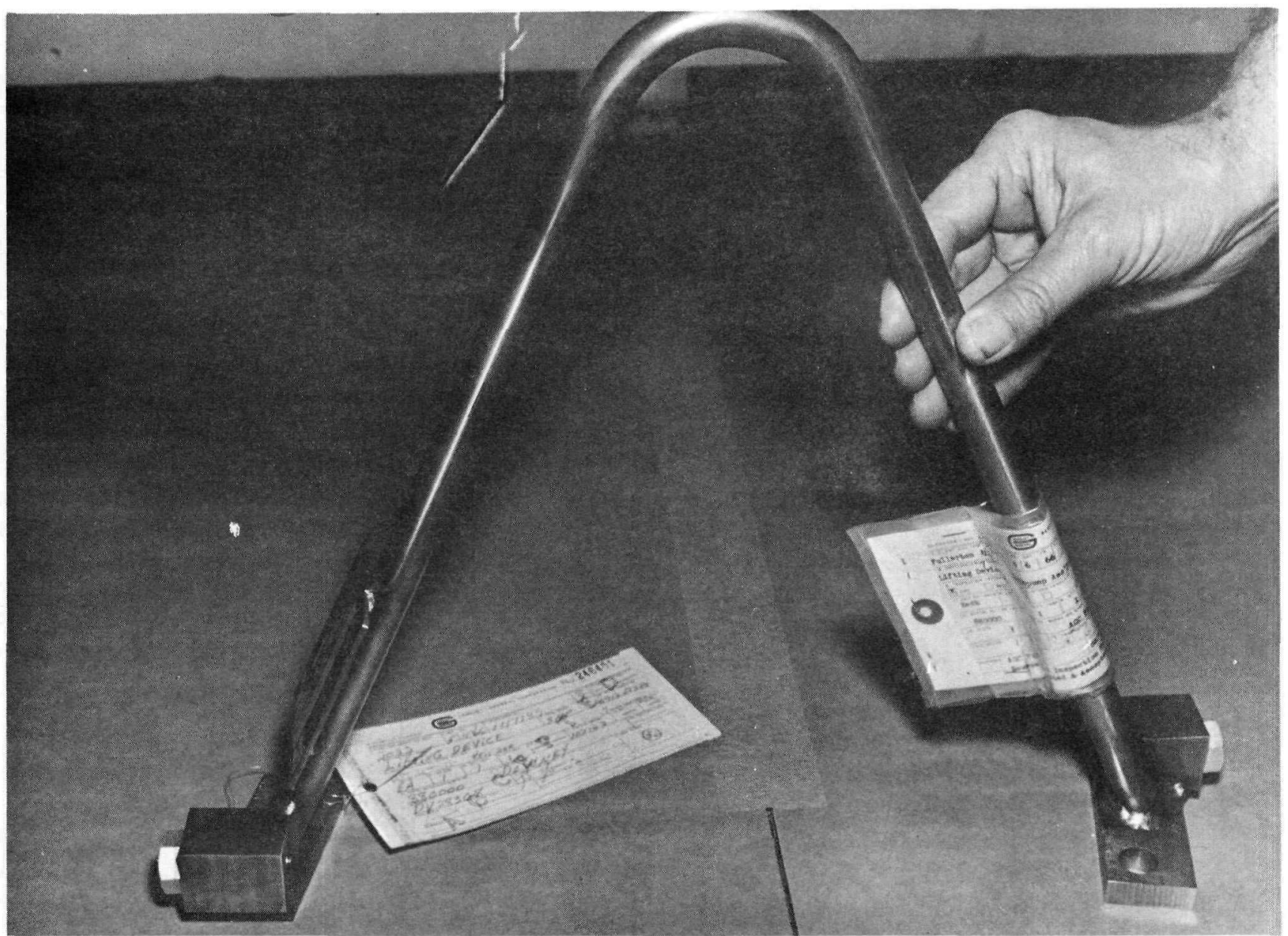


PROVISIONING LIST ITEM NUMBER 4087

DRAWING NUMBER 1117189-19

PART NUMBER

CONTRACTOR
Same

AGC
FIRST PROVISIONED FOR $\mathrm{XE}$ GOVT. INV. CONTROL NUMBER SNP-1-L-1917 $\operatorname{cosT} \$ 600$

\begin{tabular}{|c||c|}
\hline \multicolumn{1}{|c||}{ USE LOCATION } & QTY REQ'D \\
\hline A. AGC SACRAMENTO & \\
\hline B. WANL & \\
\hline C. & \\
\hline D. NRDS TOTAL & 1 \\
\hline \multicolumn{2}{|c||}{1} \\
\hline
\end{tabular}

DIMENSIONS AND CAPACITY

DIA

LENGTH

\begin{tabular}{l} 
WEIGHT 20 LB LOAD CAPACITY \\
FLOOR AREA REQUIRED \\
\hline
\end{tabular} ADDITIONAL DATA Bolts to the TPA
GASES

ELECTRICAL

LIQUIDS

SPEED

MEASURING ACCURACY

CALIBRATION INTERVAL

ADDITIONAL DATA

\section{PRESSURE} VOLTS

PRESSURE IN./MIN (RPM)
LB/SQIN. VOLUME

CPS

$-L B / S Q I N$ CUTTING SPEED HORIZONTAL
CFM LUBRICATION PHASE QTY REQ'D
HEIGHT $15^{\prime \prime}$ 1,000 LB LB/SQ IN
MANIPULATOR

CRANE E-MAD/with Hydraset ADDITIONAL DATA
LOAD CAPACITY LOAD CAPACITY
LB MAX 10,000

LB MAX 
PROVISIONING LIST ITEM NUMBER 4088

DRAWING NUMBER 1116894

PART NUMBER

CONTRACTOR
Same AGC
FIRST PROVISIONED FOR XE GOVT. INV. CONTROL NUMBER

$\cos T \$ 20,000$

\begin{tabular}{|l||c|}
\hline \multicolumn{1}{|c||}{ USE LOCATION } & QTY REQ'D \\
\hline A. AGC SACRAMENTO & \\
\hline B. WANL & \\
\hline C. & 1 \\
\hline D. NRDS TOTAL & 1 \\
\hline \multicolumn{2}{|c|}{} \\
\hline
\end{tabular}

\section{DIMENSIONS AND CAPACITY}

DIA $\frac{54^{\prime \prime} \text { (plate) }}{170}$ LENGHT LB LOAD CAPACITY $\frac{7^{\prime} 8^{\prime \prime}}{100 \mathrm{pSi}}$ WIDTH $\frac{6^{\prime} 5^{\prime \prime}}{\text { PROOF LOAD } 125 \mathrm{psi}}$ HEIGHT $7^{\prime \prime}$

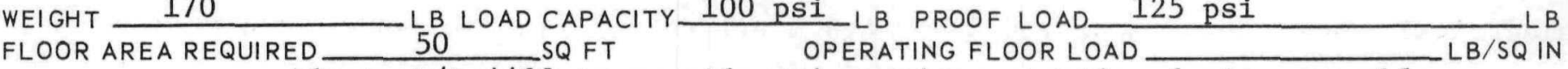
ADDITIONAL DATA Adapts P/L 4408 to provide poison-wire retention during assembly.

MANIPULATOR E-MAD/WMHS or EIV

CRANE LOAD CAPACITY 600 LB MAX LB MAX ADDITIONAL DATA_Clamp and solenoid operate remotely through interface coupling from MCC. Operates from facility air and power for cold operations in the E-MAD Building.

\section{INTERFACES}

EQUIPMENT_EIV Closure Boom and Hose and Cable Interface Coupling. PART OR ITEM Engine Nozzle DRAWING NO. 706988 REMARKS Use 278580 sling to lift nozzle closure, with or without the nozzle, during cold operations. 


\section{(1) NERVA \\ LIPROGRAM \\ SUPPORT EQUIPMENT \\ TECHNICAL DESCRIPTION HANDBOOK}

EQUIPMENT TITLE
PROV. LIST

ITEM NO.

4090

DATE

REVISION

SPACER, INSTALLATION, TEST STAND ADAPTER

DESCRIPTION: The Test Stand Adapter Installation Spacer is a welded, steel, three-legged stand on a ring-beam base. Each of the trussed legs has a pad at its top. The bottom ring is the same diameter as the engine external shield and nests in the EIV-carriage engine mounting-blocks. It is secured to the carriage with four hook/turnbuckles. The top three pads bolt to the TSA at three of the 12 TSA/UTS mounting bolt holes. The spacer holds the TSA during EIV transportation to ETS-1 and facilitates its installation into the test stand.

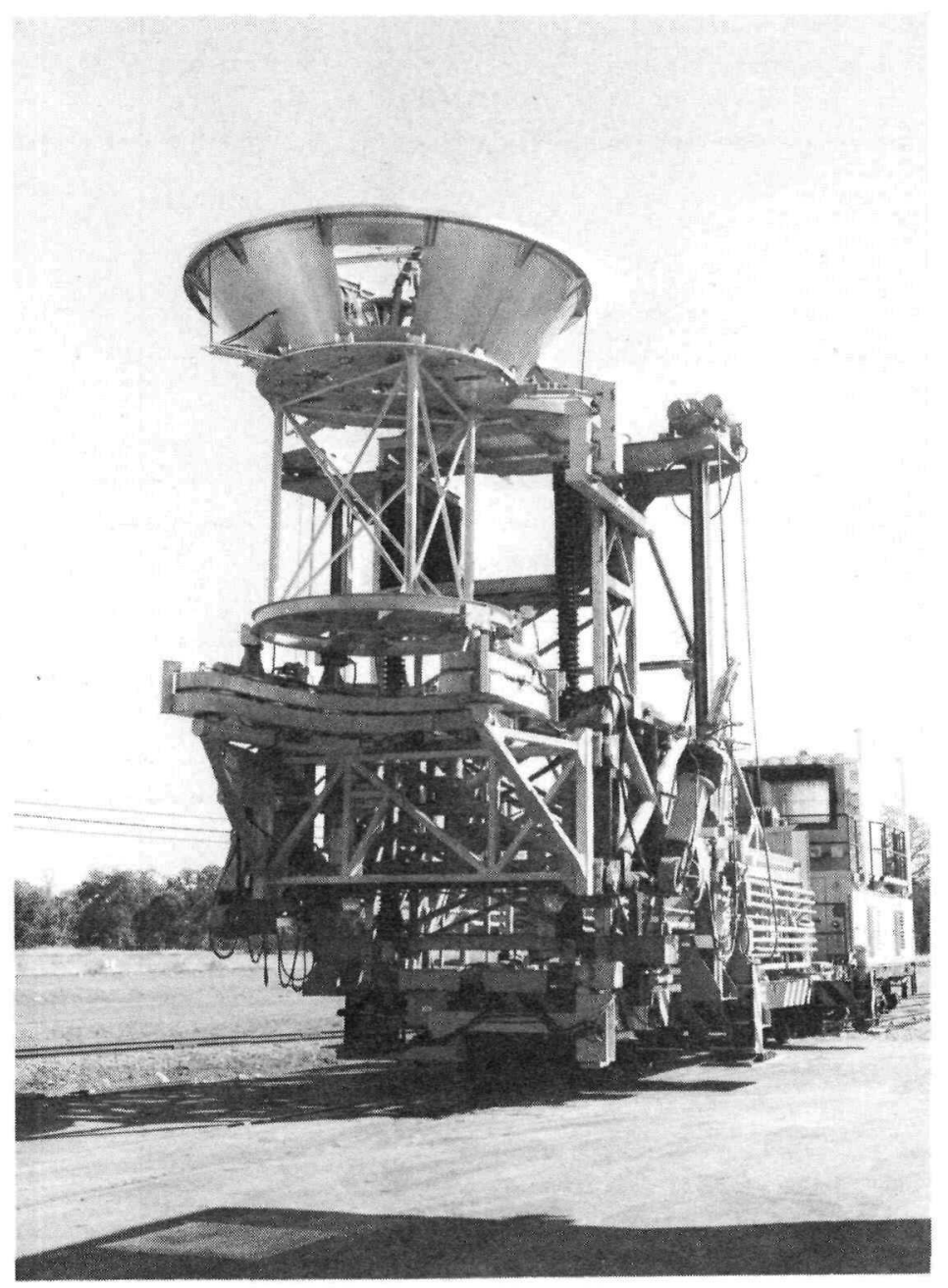


PROVISIONING LIST ITEM NUMBER 4090

DRAWING NUMBER

PART NUMBER

CONTRACTOR
1116912

Same

AGC
FIRST PROVISIONED FOR XE

GOVT. INV. CONTROL NUMBER

$\cos T \$ \$ 800$

\begin{tabular}{|l||c|}
\hline \multicolumn{1}{|c||}{ USE LOCATION } & QTY REQ'D \\
\hline A. AGC SACRAMENTO & \\
\hline B. WANL & \\
\hline C. & 1 \\
\hline D. NRDS TOTAL & 1 \\
\hline \multicolumn{2}{|c||}{} \\
\hline
\end{tabular}

\section{DIMENSIONS AND CAPACITY}

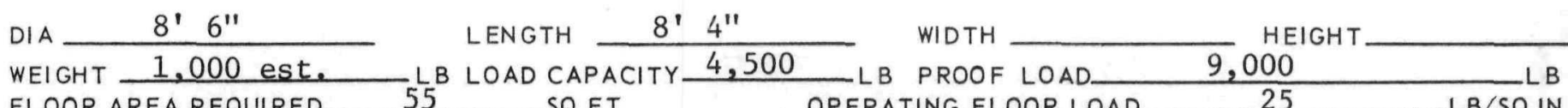
FLOOR AREA REQUIRED_ 55 SQ FT OPERATING FLOOR LOAD $\quad 25$ ADDITIONAL DATA Hinging hooks with turnbuckles are provided in four places to secure the spacer to the EIV carriage.

OPERATING DATA

GASES PRESSURE

ELECTRICAL

LIQUIDS

SPEED

MEASURING ACCURACY

CALIBRATION INTERVAL

ADDITIONAL DATA

VOLTS

PRESSURE

IN./MIN (RPM)
LB/SQIN. VOLUME CPS

$L B / S Q$ IN

CUTTING SPEED

HORIZONTAL
CFM LUBRICATION

PHASE KVA

QTY REQ'D

VERTICAL
MANIPULATOR

CRANE

ADDITIONAL DATA
LOAD CAPACITY LOAD CAPACITY
LB MAX

LB MAX

INTERFACES

EQUIPMENT EIV Carriage

PART OR ITEM Test Stand Adapter DRAWING NO.

REMARKS 


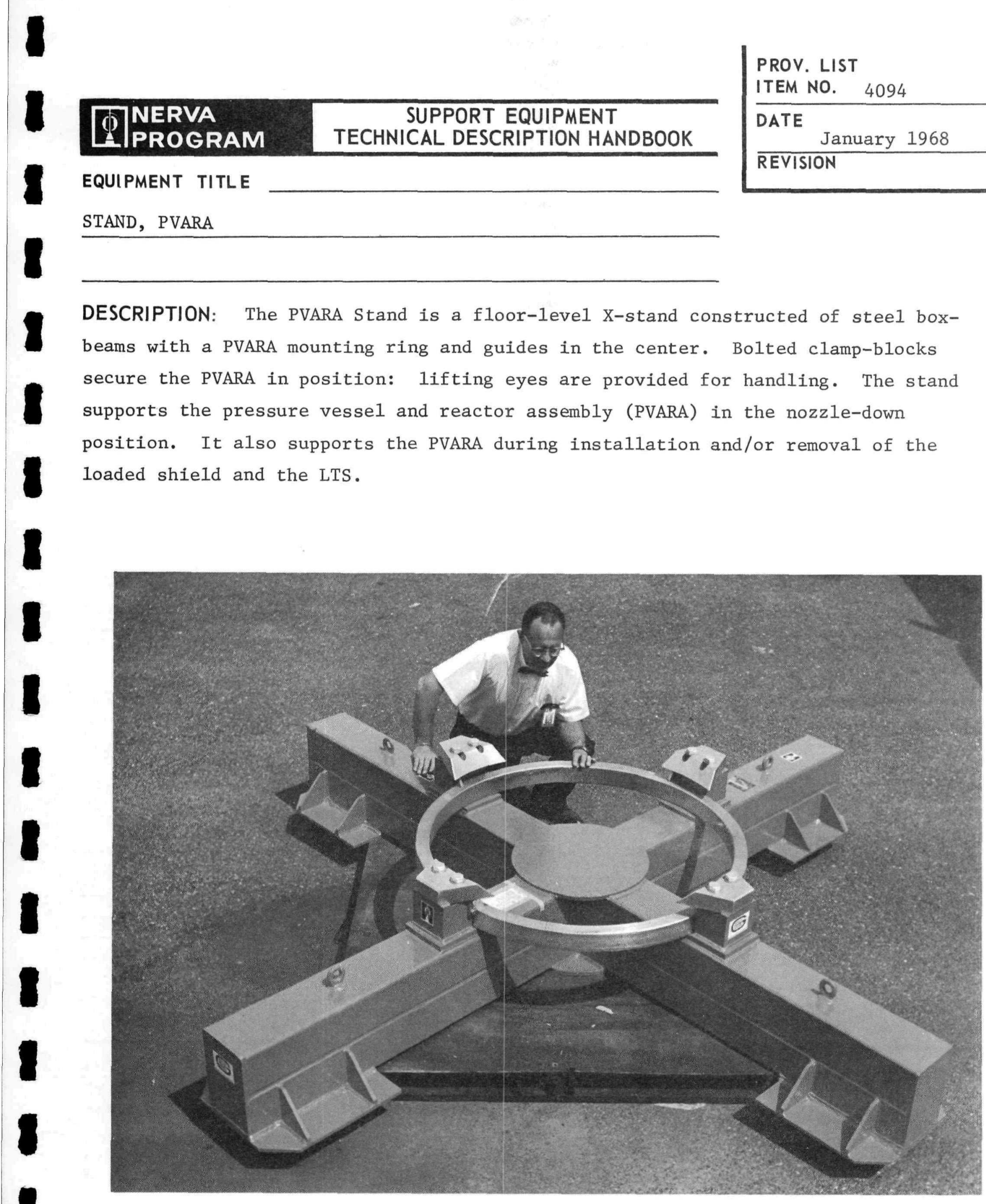


PROVISIONING LIST ITEM NUMBER 4094

DRAWING NUMBER

PART NUMBER

CONTRACTOR
1116098

Same

AGC
FIRST PROVISIONED FOR XE GOVT. INV. CONTROL NUMBER SNP-1-L-1358/13 59

$\cos T-\$ 5,100$

\begin{tabular}{|c|c|}
\hline USE LOCATION & QTY REQ'D \\
\hline A. AGC SACRAMENTO & \\
\hline B. WANL & \\
\hline C. & \\
\hline D. NRDS & 2 \\
\hline TOTAL & 2 \\
\hline
\end{tabular}

\section{DIMENSIONS AND CAPACITY}

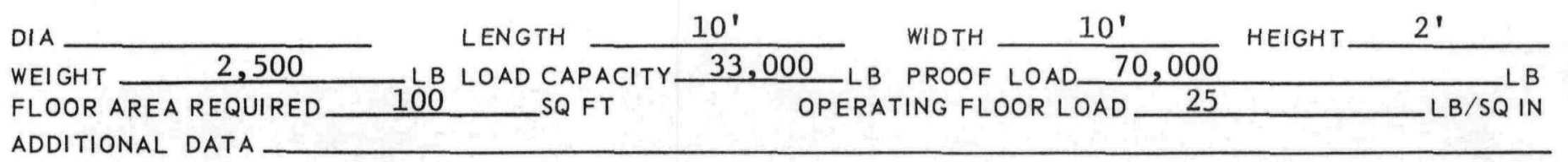
ADDITIONAL DATA

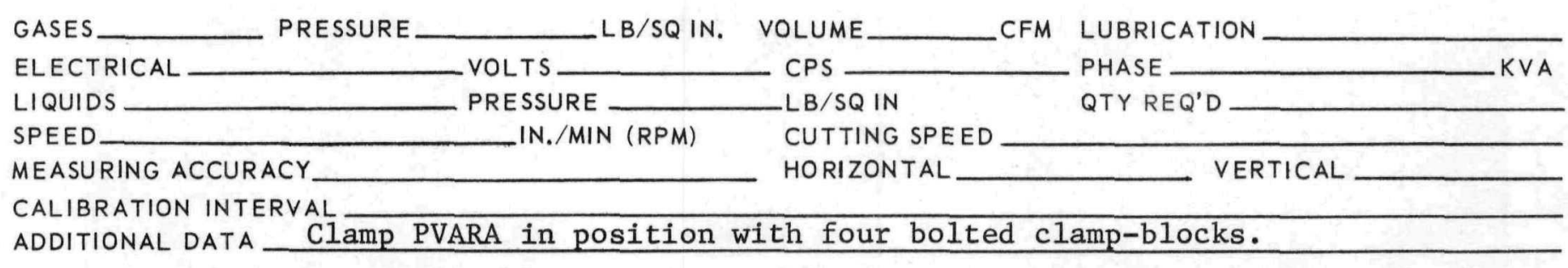

MANIPULATOR

CRANE_ E-MAD

LOAD CAPACITY

LOAD CAPACITY 10,000
LB MAX

LB MAX

ADDITIONAL DATA

\section{INTERFACES}

EQUIPMENT E-MAD Crane/Facility Sling

PART OR ITEM PVARA DRAWING NO.

REMARKS 


\section{() NERVA \\ LIPROGRAM \\ SUPPORT EQUIPMENT TECHNICAL DESCRIPTION HANDBOOK}

EQUIPMENT TITLE

COVER, AUXILIARY DUCT, ETS-1
PROV. LIST

ITEM NO.

4095

DATE

January 1968

REVISION

DESCRIPTION: The ETS-1 Auxiliary Duct Cover is an aluminum-faced, aluminumhoneycomb disk with two folding handles. It is used to cover the ETS-1 duct opening during periods when the duct cover shield is not in place. Its thin section provides clearance for the EIV to install the engine into the stand, and permits removal of nozzle closures.

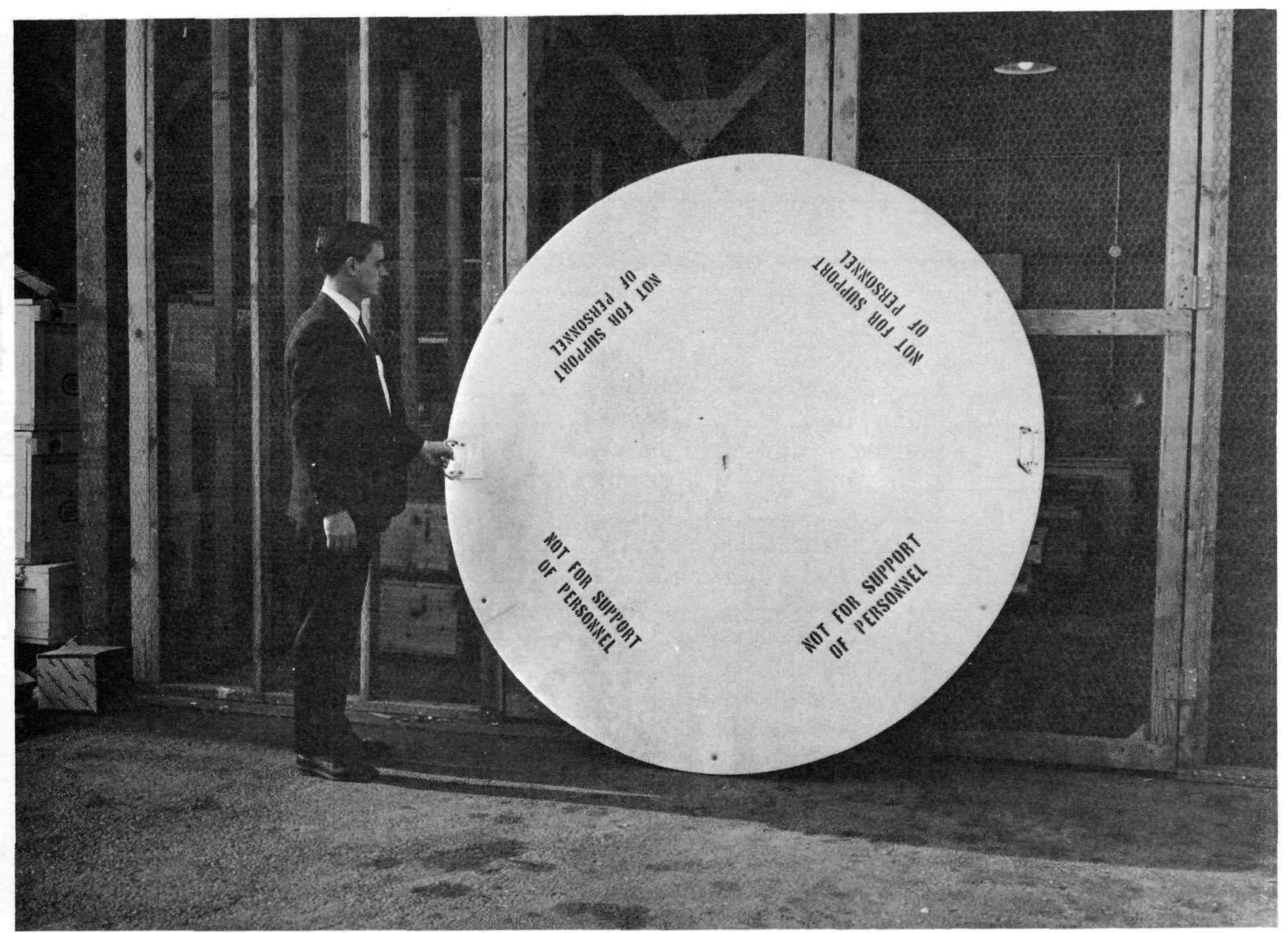


PROVISIONING LIST ITEM NUMBER 4095 DRAWING NUMBER 1117881

PART NUMBER CONTRACTOR
Same AGC
FIRST PROVISIONED FOR GOVT. INV. CONTROL NUMBER

COST $\$ 1,500$

\begin{tabular}{|l||c|}
\hline \multicolumn{1}{|c||}{ USE LOCATION } & QTY REQ'D \\
\hline A. AGC SACRAMENTO & \\
\hline B. WANL & \\
\hline C. & 1 \\
\hline D. NRDS TOTAL & 1 \\
\hline
\end{tabular}

DIMENSIONS AND CAPACITY

DIA 85"

WEIGHT 75 FLOOR AREA REQUIRED $\quad 50$ LENGTH LB LOAD CAPACITY SQ FT OPERATING FLOOR LOAD
WIDTH LB PROOF LOAD HEIGHT 600 May be removed remotely with EIV.
GASES

ELECTRICAL

LIQUIDS

SPEED

MEASURING ACCURACY

CALIBRATION INTERVAL

ADDITIONAL DATA
PRESSURE VOLTS PRESSURE IN./MIN (RPM)
LB/SQIN. VOLUME

CPS

$L B / S Q I N$

CUTTING SPEED

HORIZONTAL
CFM LUBRICATION

PHASE

QTY REQ'D
MANIPULATOR EIV Manipulator

CRANE ADDITION
LOAD CAPACITY

LOAD CAPACITY
WOESONS.
90

LB MAX LB MAX

INTERFACES

EQUIPMENT__EIV Manipulator

PART OR ITEM ETS-1 Exhaust Duct DRAWING NO.

REMARKS 


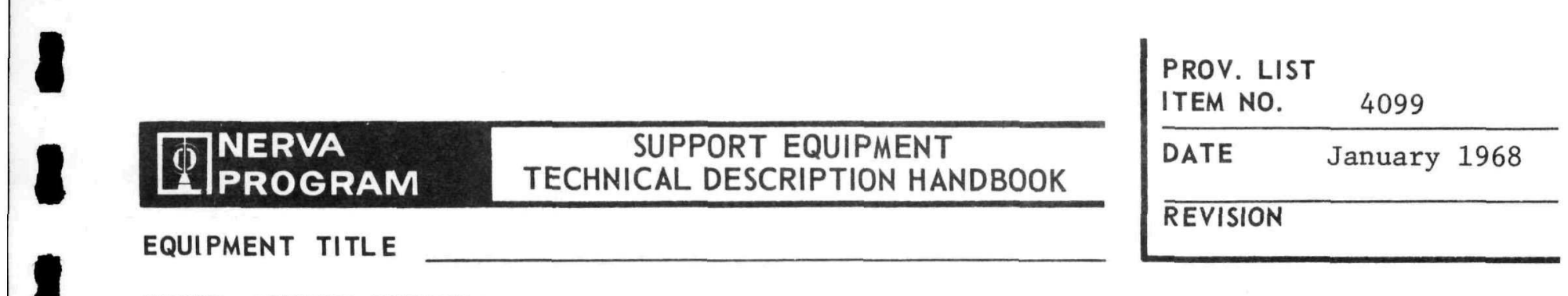

STAND, ENGINE HOLDING

DESCRIPTION: The Engine Holding Stand is a four-legged, trussed steel structure sitting on two integral-base skids. The three-sided top structure mounts three engine support pads which engage the lower periphery of the engine external shield. The stand's height and openings at the top and one side provide access to the nozzle and lines and permit installation of the complete engine assembly without excessively high engine-handling crane heights. The stand stores the XE engine or subassemblies in the E-MAD Building in the nozzle-down position. A sling is provided for handling the empty, assembled stand.

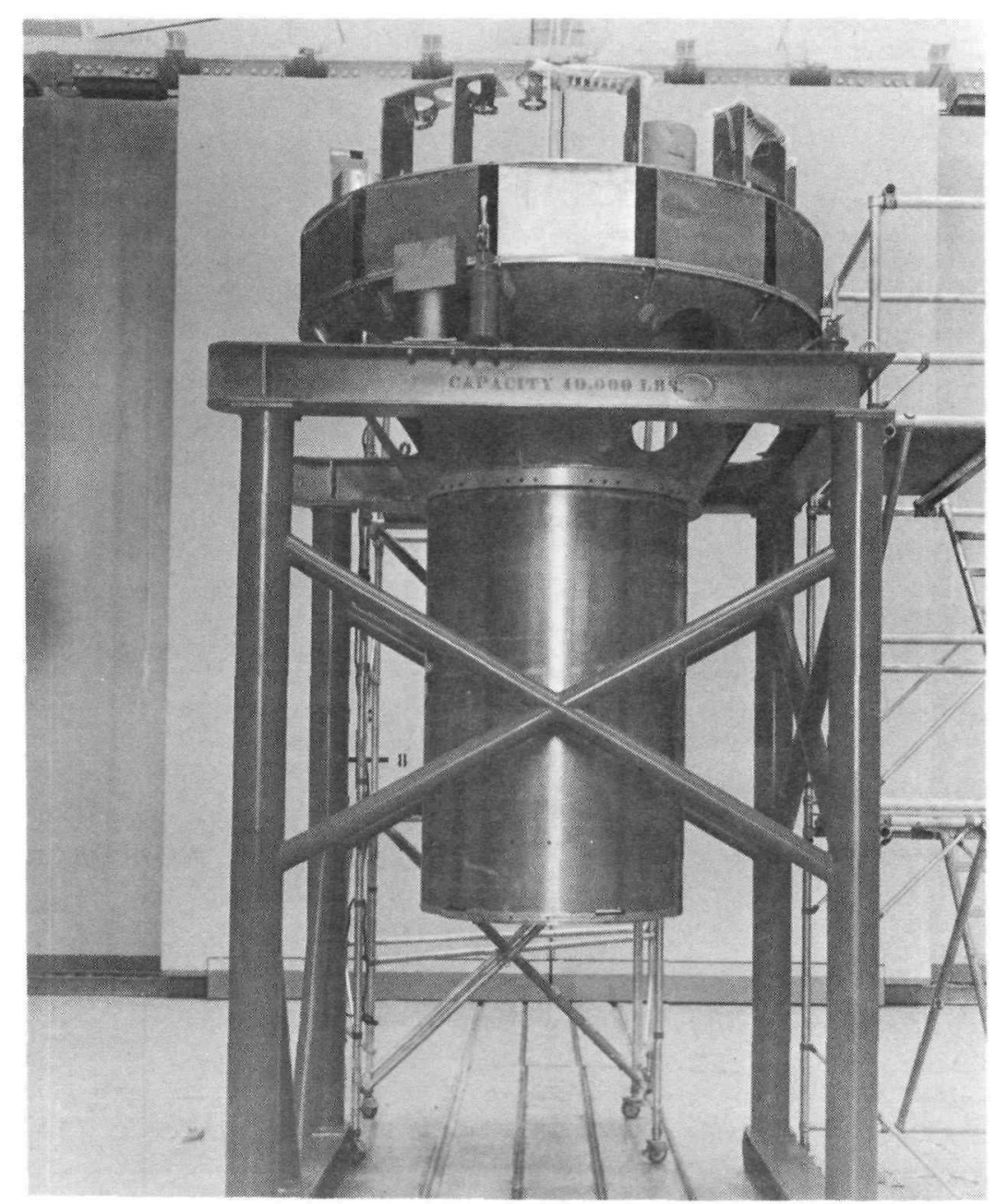


PROVISIONING LIST ITEM NUMBER

4099

DRAWING NUMBER

PART NUMBER 1116222

CONTRACTOR
Same

AGC
FIRST PROVISIONED FOR XE GOVT. INV. CONTROL NUMBER SNP-1-L-13551

$\cos T$
$\$ 7,500$

\begin{tabular}{|l||c|}
\hline \multicolumn{1}{|c||}{ USE LOCATION } & QTY REQ'D \\
\hline A. AGC SACRAMENTO & \\
\hline B. WANL & \\
\hline C. & 1 \\
\hline D. NRDS TOTAL & 1 \\
\hline
\end{tabular}

* Three units delivered. One unit converted to P/L 4122 in 1967.

DIMENSIONS AND CAPACITY

DIA

WEIGH 5,800 FLOOR AREA REQUIRED

LENGTH $10^{\prime}$ WIDTH LB LOAD CAPACITY 40,000 LB PROOF LOAD OPERATING FLOOR LOAD $S Q F T$ Special retainer clamps are provided for use with the RADA engine only; may be removed when not required.
GASES

PRESSURE

ELECTRICAL

LIQUIDS

SPEED

MEASURING ACCURACY VOLTS PRESSURE IN./MIN (RPM)

CALIBRATION INTERVAL ADDITIONAL DATA -9 configuration is bolted construction and can be disassembled. -19 configuration is welded construction and cannot be disassembled. See Aerojet Report TDI-0004.

LB/SQIN. VOLUME CPS

$B / S Q I N$ CUTTING SPEED HORIZONTAL
CFM LUBRICATION PHASE KVA

ADDITIONAL DATA

\section{INTERFACES}

EQUIPMENT_ E-MAD Crane - Cold Bay

PART OR ITEM XE Engine (Shield) DRAWING NO.

REMARKS Use provided sling to lift unloaded stand only. 
PROVISIONING LIST ITEM NUMBER

DRAWING NUMBER

PART NUMBER

CONTRACTOR
1117105

Same

AGC
4101

FIRST PROVISIONED FOR GOVT. INV. CONTROL NUMBER SNP-I-L-1914

$\cos T$ $\$ 1,000$

\begin{tabular}{|c||c|}
\hline USE LOCATION & QTY REQ'D \\
\hline A. AGC SACRAMENTO & 1 \\
\hline B. WANL & \\
\hline C. & \\
\hline D. NRDS TOTAL & 1 \\
\hline
\end{tabular}

DIMENSIONS AND CAPACITY

\begin{tabular}{|c|c|c|c|c|c|}
\hline & LENGTH & $12^{\prime \prime}$ & & $4^{\prime \prime}$ & $13^{\prime \prime}$ \\
\hline WEIGHT $\quad 15$ & & 300 & & PROOF LOAD & 700 \\
\hline
\end{tabular}
ADDITIONAL DATA

GASES

ELECTRICAL

LIQUIDS

SPEED

MEASURING ACCURACY
PRESSURE - VOLTS

PRESSURE IN./MIN (RPM)
LB/SQIN. VOLUME

CPS

$L B / S Q$ IN CUTTING SPEED HORIZONTAL
CFM LUBRICATION

PHASE

QTY REQ'D
CALIBRATION INTERVAL

ADDITIONAL DATA
MANIPULATOR

CRANE ADDITIONAL DATA.
LOAD CAPACITY

Sacto. Assemb1y Area

LOAD CAPACITY
LB MAX

VERTICAL

\section{INTERFACES}

EQUIPMENT PART OR ITEM

Sacto. Assembly Area Crane/Hydraset

REMARKS
DRAWING NO.

1114124 
PROVISIONING LIST ITEM NUMBER 4102 DRAWING NUMBER PART NUMBER . CONTRACTOR
1115073

Same

AGC
FIRST PROVISIONED FOR XE GOVT. INV. CONTROL NUMBER

$\cos +\$ 1,000$

\begin{tabular}{|l||c|}
\hline \multicolumn{1}{|c||}{ USE LOCATION } & QTY REQ'D \\
\hline A. AGC SACRAMENTO & \\
\hline B. WANL & \\
\hline C. & 1 \\
\hline D. NRDS TOTAL & 1 \\
\hline
\end{tabular}

DIMENSIONS AND CAPACITY

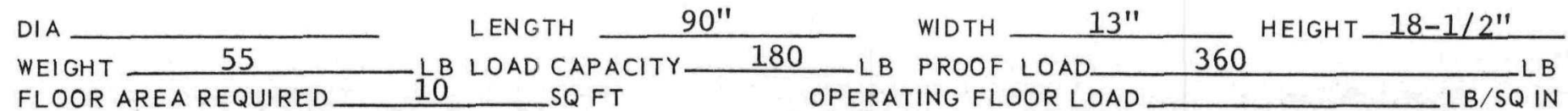

ADDITIONAL DATA Item consists of two parts: (1) through platform; and (2) cross

platform. Weight $(1)=35 \mathrm{lb},(2)=20 \mathrm{lb}$.

GASES PRESSURE

ELECTRICAL

LIQUIDS

SPEED

MEASURING ACCURACY

CALIBRATION INTERVAL

ADDITIONAL DATA The through platform is installed in the UTS. Its installation is followed by that of the cross platform. See RN-TDI-0032.
CFM LUBRICATION

PHASE

QTY REQ'D

$L B / S Q I N$

CUTTING SPEED

HORIZONTAL

VERTICAL

\section{OPERATING EQUIPMENT}

MANIPULATOR

CRANE

ADDITIONAL DATA
LOAD CAPACITY

LOAD CAPACITY

LB MAX

LB MAX

EQUIPMENT

PART OR ITEM UTS and External Shield

DRAWING NO.

REMARKS

Item rests on the UTS access-opening sill and the shield 18-inch interface. 


\begin{tabular}{|l|l|}
\hline C) & NERVA \\
PROGRAM & SUPPORT EQUIPMENT \\
\hline
\end{tabular}

EQUIPMENT TITLE

KIT, GUIDE, FLANGE, FLUID LINES
PROV. LIST

ITEM NO.

4103

DATE

REVISION

DESCRIPTION: The Fluid Lines Flange Guide Kit consists of four, circular lineflange caps. Each cap has a handle and three equally spaced, normally closed, spring-loaded, external clamping-jaws. The jaws are opened by cam-action when the handle pins are compressed manually or remotely. When used with a manipulator, the handle also provides a means for remote handling and positioning. The kit contains two storage boxes, each containing two guides. The kit guides the lower sections of the XE engine pump discharge line (5-inch), turbine inlet line (4-inch), and two turbine exhaust lines (6-inch) through their openings in the external shield during manual or remote assembly of the UTSM with the engine lower module assembly and their disassembly. The guides also protect line flanges during penetration and retraction as well as act as dust covers when the lines are not connected.

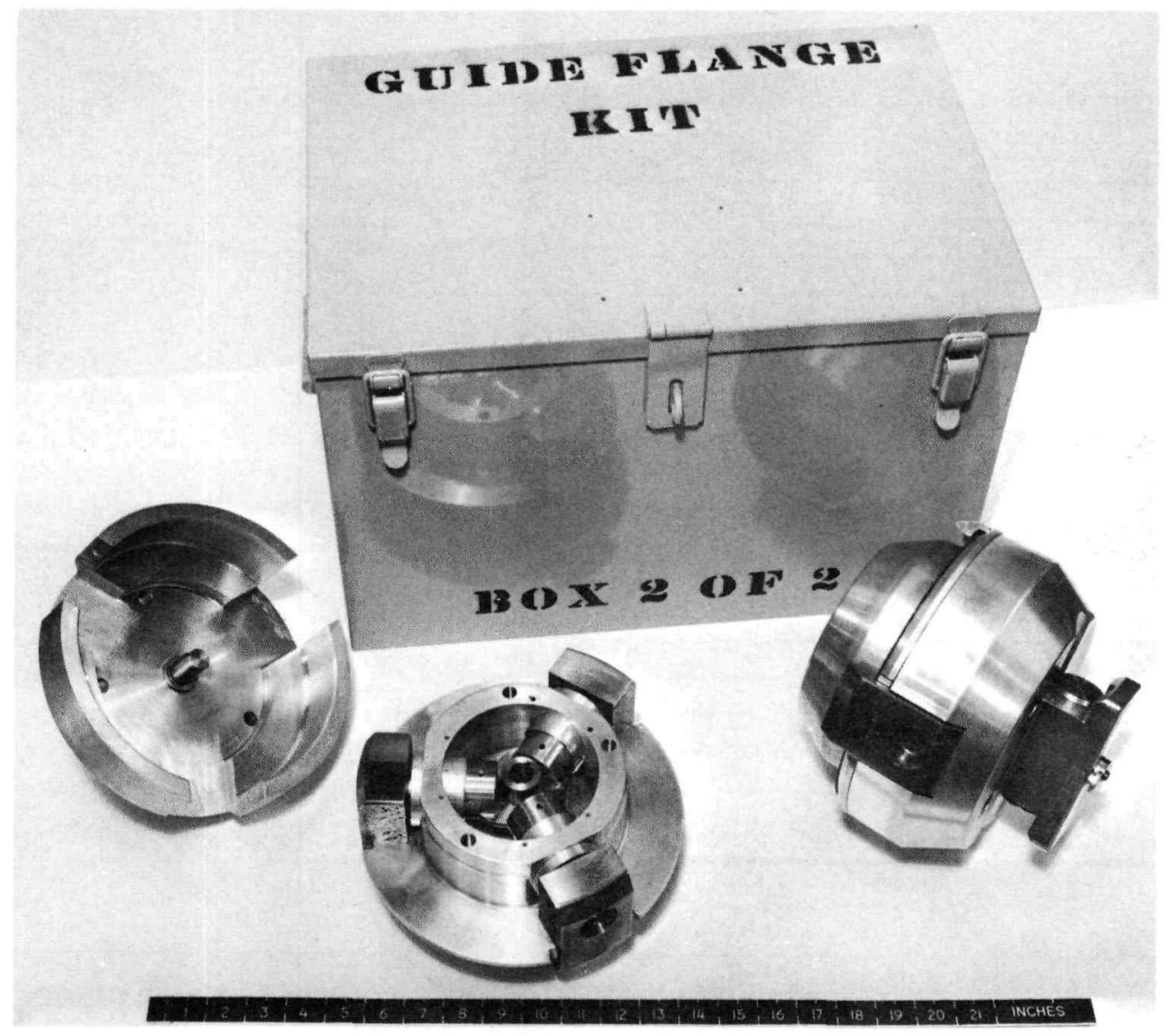


PROVISIONING LIST ITEM NUMBER 4103

DRAWING NUMBER
PART NUMBER

CONTRACTOR
1117996

Same

AGC
FIRST PROVISIONED FOR $\mathrm{XE}$ GOVT. INV. CONTROL NUMBER SNP-1-L-1802

$\cos T-\$ 4,500$

\begin{tabular}{|l||c|}
\hline \multicolumn{1}{|c||}{ USE LOCATION } & QTY REQ'D \\
\hline A. AGC SACRAMENTO & \\
\hline B. WANL & \\
\hline C. & 1 \\
\hline D. NRDS TOTAL & 1 \\
\hline
\end{tabular}

DIMENSIONS AND CAPACITY

DIA $\frac{6-8-1 / 2^{\prime \prime}}{50}$ LEIGHT LENGTH LB LOAD CAPACITY_ WIDTH HEIGHT FLOOR AREA REQUIRED 3 S SQFT OPERATING FLOOR LOAD LB/SQ IN ADDITIONAL DATA The kit contains three sizes of guides: (1) $6^{\prime \prime}$ dia (1) $7^{\prime \prime}$ dia and (2) 8" dia.

GASES PRESSURE

ELECTRICAL

LIQUIDS

SPEED

MEASURING ACCURACY

CALIBRATION INTERVAL

ADDITIONAL DATA Handling and operation of the clamp jaws is performed manually or with manipulator para11e1-jaw hand. See Aerojet Report TDI-0017.
PRESSURE IN./MIN (RPM) VOLTS_ CPS
$L B / S Q I N$

CUTTING SPEED HORIZONTAL
LUBRICATION

PHASE

QTY REQ'D

VERTICAL

OPERATING EQUIPMENT

MANIPULATOR__ E-MAD/WMHS/OPS

LOAD CAPACITY

600

LB MAX

CRANE

LOAD CAPACITY

LB MAX

ADDITIONAL DATA

INTERFACES

EQUIPMENT_ E-MAD/WMHS

PART OR ITEM Engine Fluid Lines DRAWING NO.

REMARKS Engine lines openings at Station 185. Two turbine exhaust pump discharge and turbine inlet lines. 


\section{TECHNICAL SUMMARY}

PROVISIONING LIST ITEM NUMBER 4104 DRAWING NUMBER

PART NUMBER CONTRACTOR
1116315

Same AGC
FIRST PROVISIONED FOR GOVT. INV. CONTROL NUMBER

$\cos T$
$\mathrm{XE}$ $\$ 5,000$

\begin{tabular}{|l||c|}
\hline \multicolumn{1}{|c||}{ USE LOCATION } & QTY REQ'D \\
\hline A. AGC SACRAMENTO & \\
\hline B. WANL & \\
\hline C. & 1 \\
\hline D. NRDS & 1 \\
\hline \multicolumn{2}{|c||}{ TOTAL } \\
\hline
\end{tabular}

DIMENSIONS AND CAPACITY

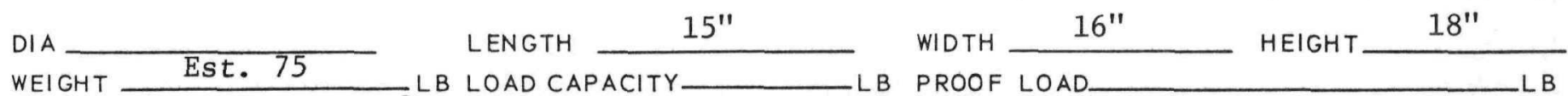
\begin{tabular}{ll} 
WEIGHT $\frac{\text { ESt. } 75}{\text { FLOOR AREA REQUIRED }} 2^{\text {LB LOAD CAPACITY }}$ LQ PROOF LOAD & OPERATING FLOOR LOAD \\
\hline
\end{tabular} ADDITIONAL DATA To provide to 700 in. $-1 \mathrm{~b}$ torque to line clamp-screw to engage or open remote line joints.

\begin{tabular}{|c|c|c|c|}
\hline Air & PRESSURE & VOLUME_CFM & LUBRICATION \\
\hline LECTRICAL & \multicolumn{3}{|c|}{ VOLTS C CPS PHASE KVA } \\
\hline QUID & \multirow{3}{*}{$\begin{array}{l}\text { - PRESSURE } \\
\text { IN./MIN (RPM) }\end{array}$} & $-L B / S Q$ IN & QTY REQ'D \\
\hline SPEED & & CUTTING SPEED. & \\
\hline IEASURING A & & HORIZONTAL & VERTICAL _ \\
\hline
\end{tabular}

CALIBRATION INTERVAL ADDITIONAL DATA

MANIPULATOR E-MAD/WMHS

CRANE ADDITIONAL DATA
LOAD CAPACITY

600 LOAD CAPACITY
$L B$ MAX

LB MAX

INTERFACES

EQUIPMENT

PART OR ITEM

DRAWING NO.

REMARKS

* Item was prototype only and was not used. It has been superseded by $\mathrm{P} / \mathrm{L}$ 4117, 4118, 4119, and 4121. 
PROV. LIST

ITEM NO.

4105

DATE

TECHNICAL DESCRIPTION HANDBOOK

EQUIPMENT TITLE

\section{REVISION}

CLAMP, LINE ALIGNMENT, REMOTE

DESCRIPTION: The Remote Line Alignment Clamp consists of two separate but similar devices: one used with the engine pump discharge line (5-inches diameter) and the other with the turbine inlet line (4-inches diameter). The clamp incorporates a base (which has a remote handling bracket) and a saddle with two clamps which secure the upper line to the saddle. The base also contains a slide assembly with a saddle and two clamps for for holding the lower line. The clamps and the slide are actuated by air cylinders remotely controlled by solenoid valves. In operation, the lower-line section on the engine is engaged to the lower line clamp and secured. The upper-line section is then engaged by the upper clamp, mounted on the slide and secured. This aligns the mating line sections. The slide is then driven as required to mate or separate the line sections: the slide provides five inches of travel. The clamps hold, align, and assist in remote mating or separating of the upper and lower sections of the pump discharge and turbine inlet lines during the remote disassembly and reassembly of the UTSM with the ELM at Station 185.14. It may also be used during cold assembly.

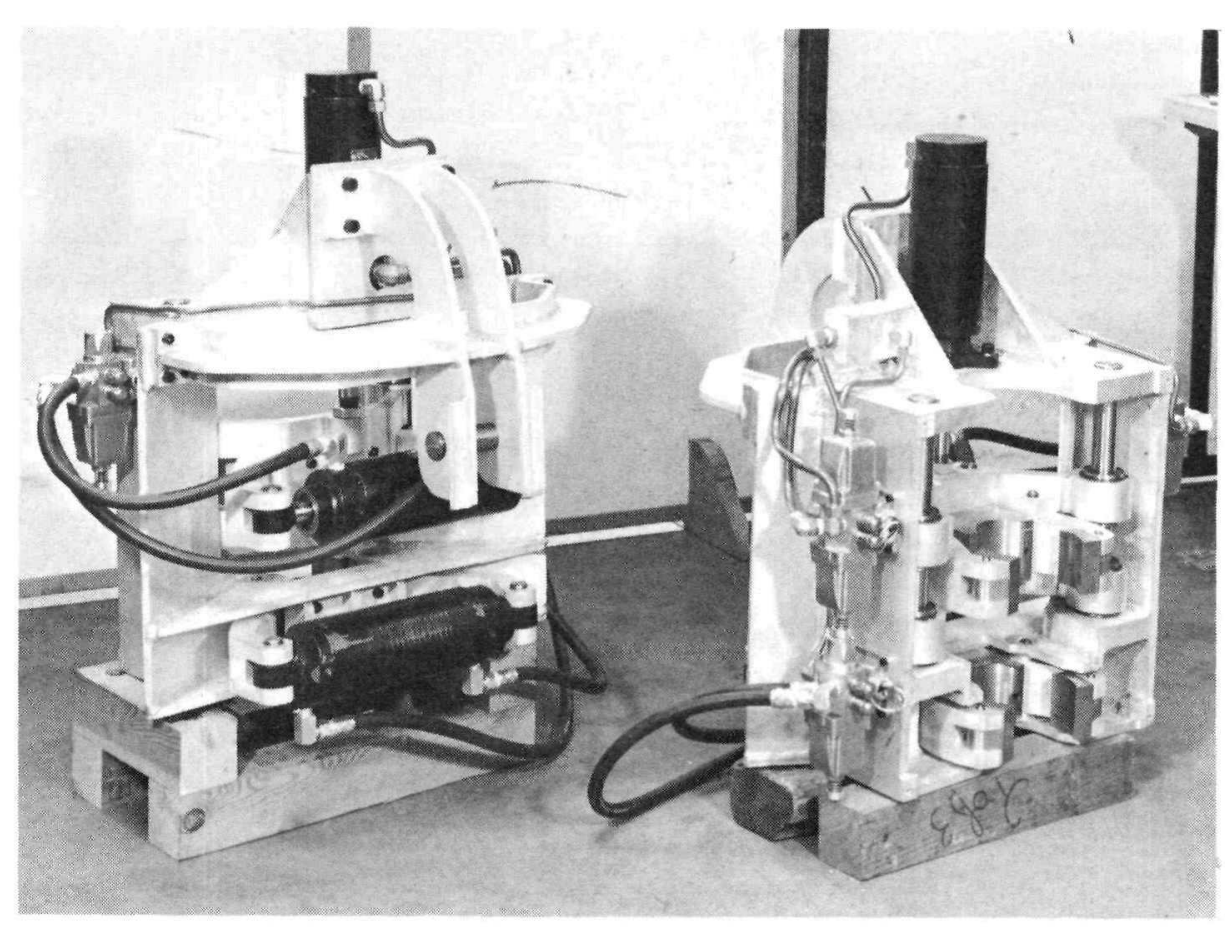


PROVISIONING LIST ITEM NUMBER 4105

DRAWING NUMBER

PART NUMBER

CONTRACTOR
1116852

Same

AGC
FIRST PROVISIONED FOR $\mathrm{XE}$ GOVT. INV. CONTROL NUMBER

COST $\$ 16,000$

\begin{tabular}{|l||c|}
\hline \multicolumn{1}{|c||}{ USE LOCATION } & QTY REQ'D \\
\hline A. AGC SACRAMENTO & \\
\hline B. WANL & \\
\hline C. & 1 \\
\hline D. NRDS TOTAL & 1 \\
\hline
\end{tabular}

DIMENSIONS AND CAPACITY

DIA

WEIGHT

FLOOR AREA REQUIRED__ 8 _ SQFT

LENGTH

$34^{\prime \prime}$

B LOAD CAPACITY $S Q F T$

\section{CAPACITY}

FLOOR AREA REQUIRED
ADDITIONAL DATA The item consists of two clamps: -19 for the pump

WIDTH $28^{\prime \prime}$

LB PROOF LOAD

50

HEIGHT

24"

-29 for the turbine inlet line. The data shown are for each clamp assembly.

\section{OPERATING DATA}

GASES_Air PRESSURE 90-120 LB/SQIN. VOLUME ELECTRICAL $110 \mathrm{AC}$

LIQUIDS

SPEED

MEASURING ACCURACY

CALIBRATION INTERVAL

ADDITIONAL DATA Will align the lines to within $0.020^{\prime \prime}$. The slide and clamp actuating-air pistons are electrically, remotely controlled valves which also have manual controls for emergency use by the manipulator. See Aerojet Report TDI-0011.

\section{OPERATING EQUIPMENT}

MANIPULATOR E-MAD/WMHS

LOAD CAPACITY

600

LB MAX

CRANE Facility

LOAD CAPACITY

ADDITIONAL DATA Electrical wiring to the control valves on the clamps from the operator area.

\section{INTERFACES}

EQUIPMENT

E-MAD/WMHS Manipulator

PART OR ITEM Engine Propellant Lines as noted DRAWING NO.

REMARKS Facility air 90-120 psi required. Connection to remote electrical control

circuitry. 


\section{(1) NERVA}

LIPROGRAM

SUPPORT EQUIPMENT TECHNICAL DESCRIPTION HANDBOOK

EQUIPMENT TITLE

DATE January 1968

CLOSURE, TURBINE EXHAUST NOZZLE

DESCRIPTION: Each Turbine Exhaust Nozzle Closure consists of an outer shell, or body, and an inner plug. The outer body mounts the retainer clamps and the pneumatic coupling and gage: it also has a manipulator handle to position and actuate the clamps mounted on one side. The inner plug, which bolts to the outer body, contains a pneumagrip seal around its recessed peripheral groove. The pneumagrip is connnected through a flexible line to the pneumatic quick-disconnect coupling and gage on the outer shell. In operation, the oval-shaped turbine exhaust nozzle opening fits into the gap between the shell and plug and seats at the bottom of the shell base. The clamps are engaged and the pneumagrip inflated to establish a rubber seal between closure and the nozzle inner surface. Two turbine exhaust nozzle closures are used to close the two XE-engine turbine exhaust line nozzles for all engine system leak tests and for engine inerting at ETS-1. It is used and handled under both cold and hot conditions. 
PROVISIONING LIST ITEM NUMBER 4108

DRAWING NUMBER

PART NUMBER

CONTRACTOR
1118799

Same

AGC
FIRST PROVISIONED FOR XE

GOVT. INV. CONTROL NUMBER

$\operatorname{cosT} \underset{\$ 6,000}{ }$

\begin{tabular}{|l||c|}
\hline \multicolumn{1}{|c||}{ USE LOCATION } & QTY REQ'D \\
\hline A. AGC SACRAMENTO & \\
\hline B. WANL & \\
\hline C. & 1 \\
\hline D. NRDS TOTAL & 1 \\
\hline \multicolumn{2}{|c|}{} \\
\hline
\end{tabular}

DIMENSIONS AND CAPACITY

DIA

WEIGHT Each 30

LENGTH

$18^{\prime \prime}$

LB LOAD CAPACITY

SQ FT

WIDTH

$8^{\prime \prime}$

LB PROOF LOAD

OPERATING FLOOR LOAD

75 HEIGHT

$\frac{9^{\prime \prime}}{1 b / s q . ~ i n . ~}$

FLOOR AREA REQUIRED _

ADDITIONAL DATA Has 1/4-inch Wiggins pneumatic line quick-disconnect fitting to inflate and deflate the pneumagrip. A pressure gage is also provided.

GASES_Air PRESSURE $75-85$ LB/SQIN. VOLUME

ELECTRICAL

LIQUIDS

SPEED

MEASURING ACCURACY

CALIBRATION INTERVAL

ADDITIONAL DATA Pneumagrip may be leak tested at $20-25$ psi:

on separate equipment. See RN-DR-0122.
CPS

$L B / S Q I N$

CUTTING SPEED

HORIZONTAL
CFM LUBRICATION

PHASE

QTY REQ'D

VERTICAL

\section{OPERATING EQUIPMENT}

MANIPULATOR E-MAD/WMHS and EIV

LOAD CAPACITY

90

LB MAX

CRANE

LOAD CAPACITY

LB MAX

ADDITIONAL DATA Facility and MCC/EIV air supply and control are required.

EQUIPMENT_E-MAD and EIV Manipulators

PART ORITEM Turbine Exhaust Line Nozzles

REMARKS A separate pneumatic line with 1/2-inch Wiggins disconnect must be provided for pneumagrip inflation. 


\section{(0) NERVA LIPROGRAM \\ SUPPORT EQUIPMENT TECHNICAL DESCRIPTION HANDBOOK}

EQUIPMENT TITLE

STAND, EXTERNAL SHIELD, BALL LOADING

DESCRIPTION: The Ball Loading External Shield Stand is a commercial weldingpositioner with an adapter to hold the shield. The adapter consists of a steel ring with six equally spaced, rectangular steel-tube radial arms mounted on the center of the positioner table. Each arm has a locating pad at the end and a shear block located on the lower side to index the table diameter. In operation, the shield is secured to the ring by four bolts. The locating pad at the end of each arm is wedged to the shield periphery to support the shield in the tilted position. The shield may be rotated and tilted during cold assembly operations to load the shielding balls into the 12 shield-segments.

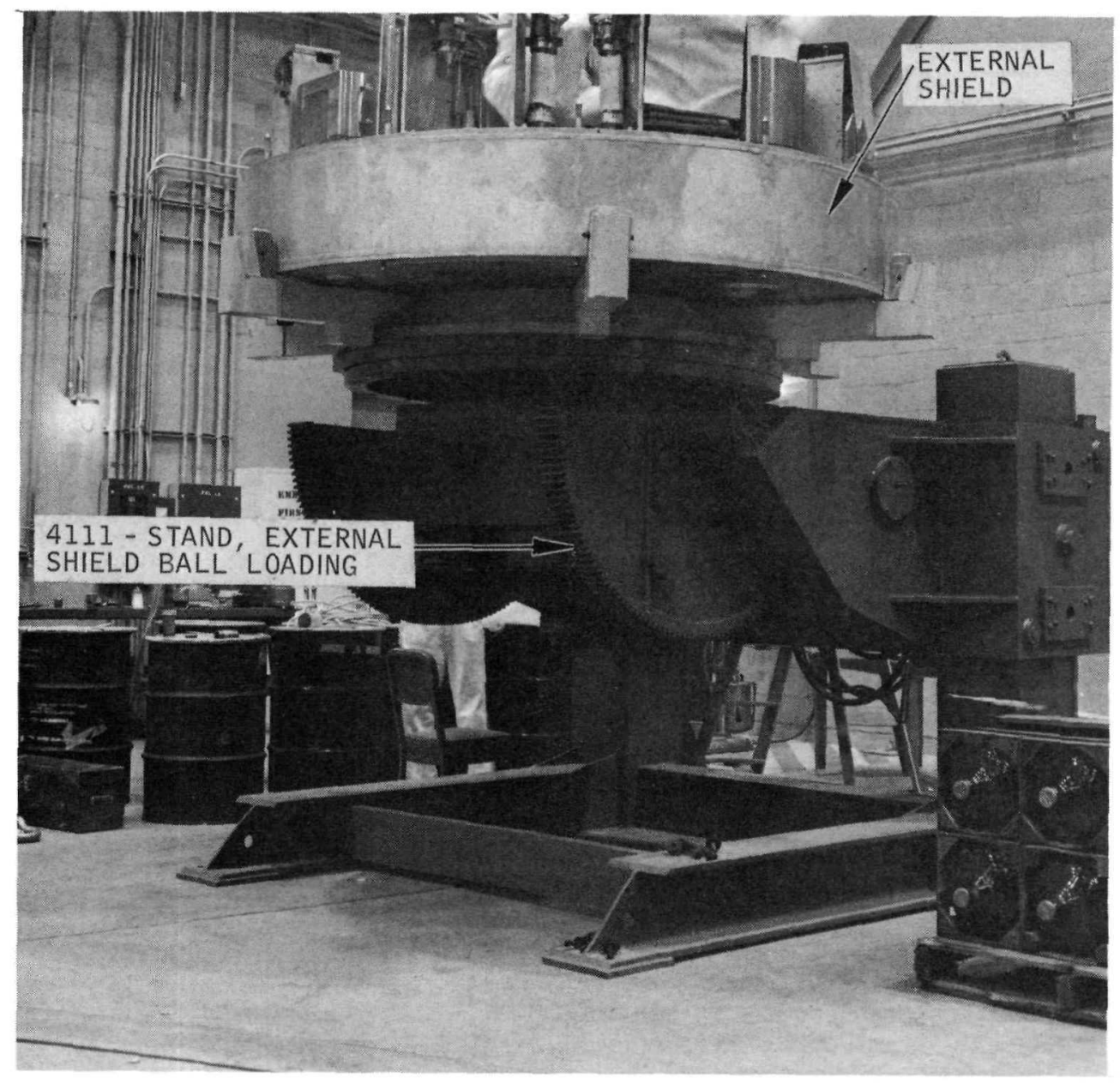


PROVISIONING LIST ITEM NUMBER 4111

DRAWING NUMBER

PART NUMBER

CONTRACTOR
1117236

Same

AGC
FIRST PROVISIONED FOR

$\mathrm{XE}$ GOVT. INV. CONTROL NUMBER SNP-1-L-1083

$\cos T$

\begin{tabular}{|l||c|}
\hline \multicolumn{1}{|c||}{ USE LOCATION } & QTY REQ'D \\
\hline A. AGC SACRAMENTO & \\
\hline B. WANL & \\
\hline C. & 1 \\
\hline D. NRDS TOTAL & 1 \\
\hline
\end{tabular}

DIMENSIONS AND CAPACITY

DIA

WEIGHT 16,500

LENGTH

$13^{\prime}$

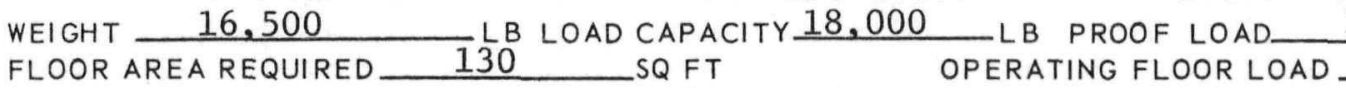
-LB PROOF LOAD $\frac{10^{\prime}}{36,000}$ HEIGHT -LB PROOF LOAD $\frac{10^{\prime}}{36,000}$ HEIGHT

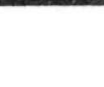
FLOOR AREA REQUIRED_ 130 SQ FT OPERATING FLOOR LOAD

$9^{\prime}$ $L B$ ADDITIONAL DATA The item is an adaptation of a Ransome Company welding positioner, $30,000 \mathrm{lb}$ rated load. Table and tilt are electrically driven and controlled from a box on the positioner.

\section{OPERATING DATA}

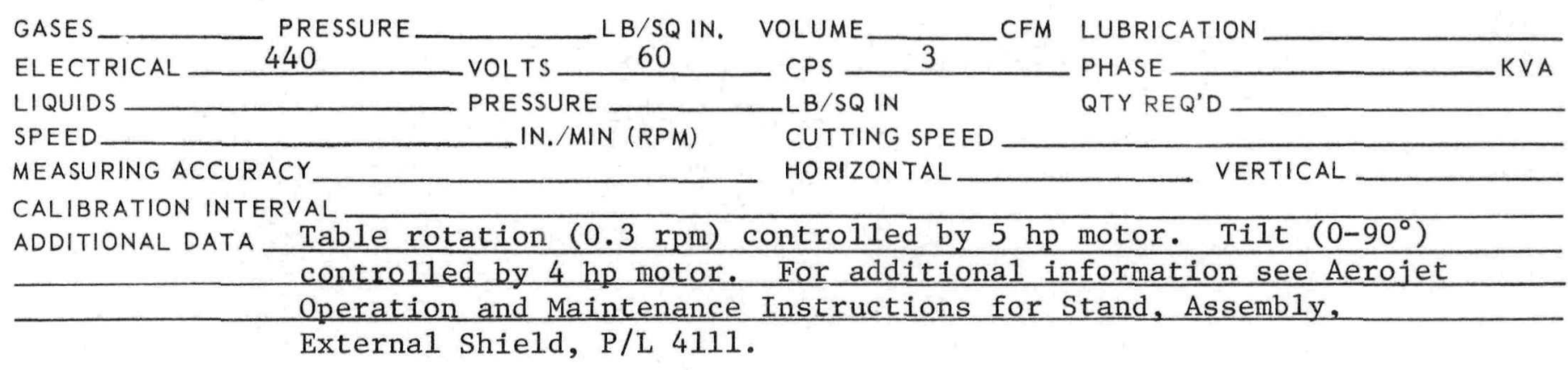

\section{OPERATING EQUIPMENT}

MANIPULATOR

LOAD CAPACITY

CRANE

LOAD CAPACITY

LB MAX

ADDITIONAL DATA 


\begin{tabular}{l|c}
\hline T. NERVA & SUPPORT EQUIPMENT \\
\hline PROGRAM & TECHNICAL DESCRIPTION HANDBOOK \\
\hline
\end{tabular}

PROV. LIST

ITEM NO.

4112

DATE January 1968

REVISION

EQUIPMENT TITLE

TOOL, UTS/TSA NUT REMOVAL, REMOTE

DESCRIPTION: The Remote UTS/TSA Nut Removal Tool is a standard, electrical impactwrench with a manipulator adapter and tool power-receptacle replacing the handle. The wrench drive-end is adapted with an offset drive and socket to fit and work with the UTS/TSA nuts. In operation, the tool is remotely engaged, positioned, and driven by the EIV manipulators at ETS-1 under hot conditions. This tool is needed only in emergencies when the integral TSA nut drive-motors fail.

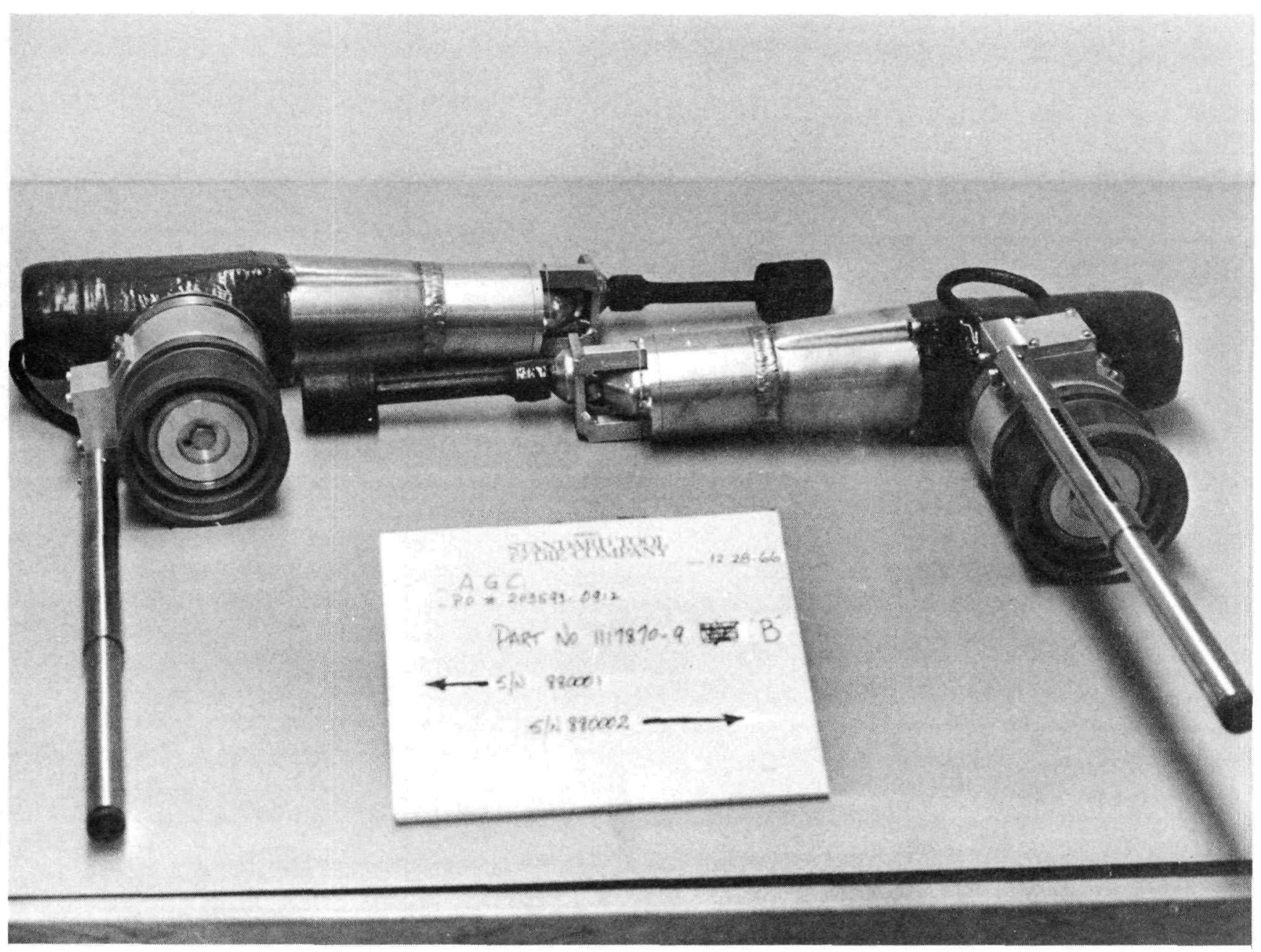


PROVISIONING LIST ITEM NUMBER DRAWING NUMBER

PART NUMBER CONTRACTOR
1117870

Same

AGC
4112

FIRST PROVISIONED FOR GOVT. INV. CONTROL NUMBER

$\cos \mathrm{T}$

$\$ 8,000$

\begin{tabular}{|c|c|}
\hline USE LOCATION & QTY REQ'D \\
\hline A. AGC SACRAMENTO & \\
\hline B. WANL & \\
\hline C. & \\
\hline D. NRDS & 2 \\
\hline TOTAL & 2 \\
\hline
\end{tabular}

DIA

WEIGHT FLOOR AREA REQUIRED _ 2

LENGTH

$23^{\prime \prime}$ B L

\section{CAPACITY}

WIDTH $\frac{21^{\prime \prime}}{\text { PROOF LOAD }}$
$\mathrm{XE}$

ER
SQ FT $O P E R A T I N G$ FLOOR LOAD/T"drive, electrical $L / S Q$ ADDITIONAL DATA The tool is an adaptation of an Ingersol Rand 3/11"-drive, electrical impact-wrench. The handle and power inlet is replaced with a PaR manipulator hand adapter and power take-off.

\section{OPERATING DATA}

\section{GASES} ELECTRICAL $\quad 0-115$

LIQUIDS

SPEED

MEASURING ACCURACY

CALIBRATION INTERVAL
ADDITIONAL DATA Control for the tool installation and operation is from the manipulator console in the MCC.

LB/SQ IN. VOLUME VOLTS_DC

PRESSURE IN./MIN (RPM) CPS Variable

LB/SQ IN CUTTING SPEED HORIZONTAL
LUBRICATION

PHASE

QTY REQ'D

VERTICAL 
EQUIPMENT TITLE

GUIDES, CONTROL DRUM DRIVE SHAFT HOUSING

DESCRIPTION: The Control Drum Drive Shaft Housing Guides are a set of 12 aluminum plugs with tapered heads ranging in length from 5-1/2 to $16-1 / 2$ inches. They fit into the upper end of the control-rod line assemblies to pilot and protect the lines as they pass through the shield penetration during LTS shield installation. A wooden container is provided for storage.

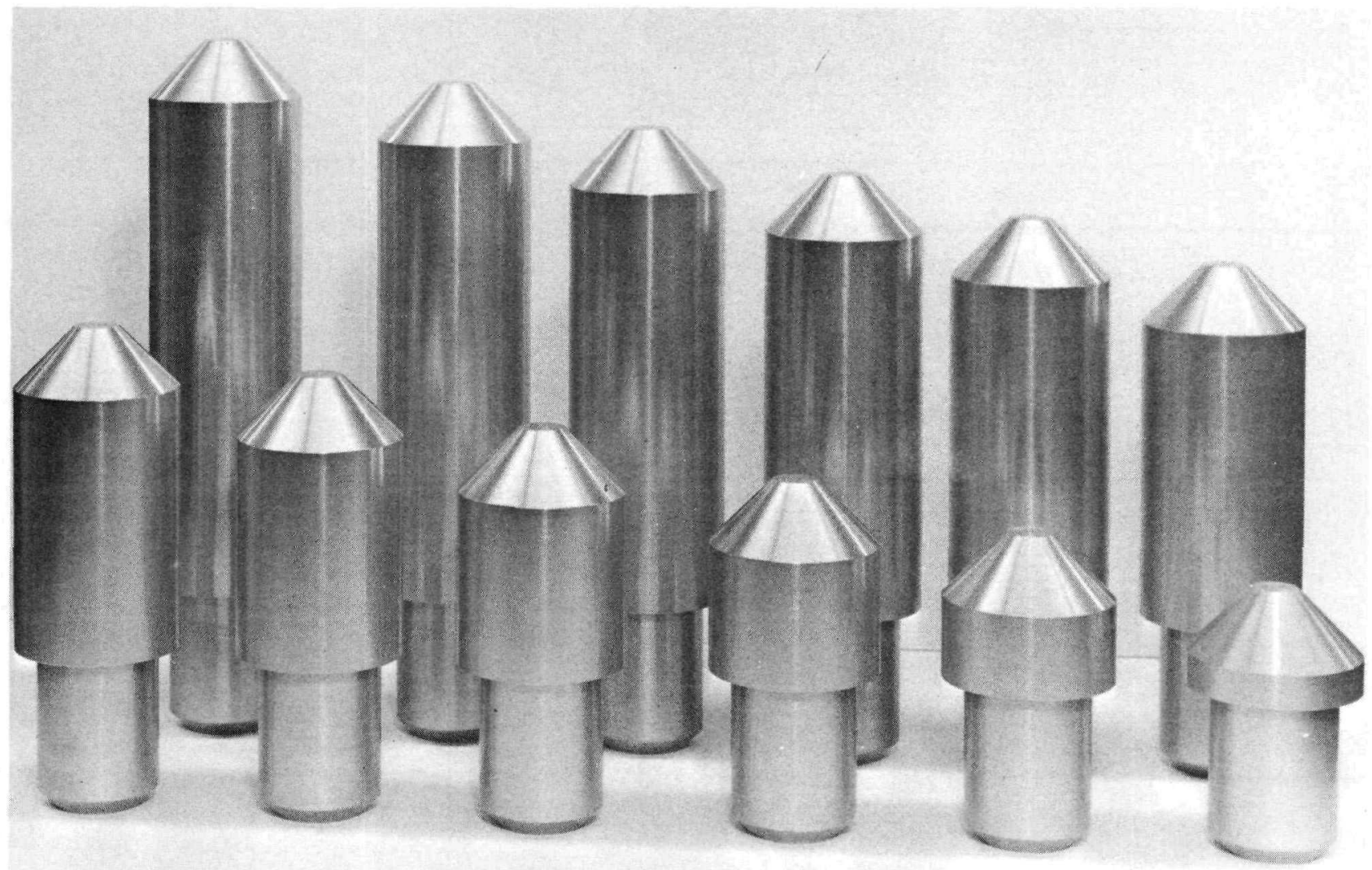


PROVISIONING LIST ITEM NUMBER

DRAWING NUMBER

PART NUMBER

CONTRACTOR
4115

$111766 \overline{6}$

Same

AGC
FIRST PROVISIONED FOR X XE GOVT. INV. CONTROL NUMBER SNP-1-L-1920

$\cos T$ $\$ 600$

\begin{tabular}{|l||c|}
\hline \multicolumn{1}{|c||}{ USE LOCATION } & QTY REQ'D \\
\hline A. AGC SACRAMENTO & \\
\hline B. WANL & \\
\hline C. & \\
\hline D. NRDS TOTAL & 1 \\
\hline
\end{tabular}

\section{DIMENSIONS AND CAPACITY}

DIA $3-3 / 4^{\prime \prime}$

WEIGHT 125

FLOOR AREA REQUIRED

LENGTH $5-1 / 2$ to $16-1 / 2^{\prime \prime}$ WIDTH LB LOAD CAPACITY

\section{AREA REQUIRED S SQFT OPERATING FLOOR LOAD \\ OPERATING FLOOR LOAD}

HEIGHT

A wooden container holds the 12 pieces which range from 5-1/2 to 16-1/2 inches in length. The container is $25^{\prime \prime} \times 16^{\prime \prime} \times 10^{\prime \prime}$ with hinging top.

\section{OPERATING DATA}

GASES

ELECTRICAL

LIQUIDS

SPEED

MEASURING ACCURACY

CALIBRATION INTERVAL

ADDITIONAL DATA
PRESSURE VOLTS

PRESSURE IN./MIN (RPM)
LB/SQIN. VOLUME

CPS

$L B / S Q I N$

CUTTING SPEED HORIZONTAL
CFM LUBRICATION

PHASE

QTY REQ'D

\section{VERTICAL}




\section{I \\ () NERVA \\ LIPROGRAM \\ SUPPORT EQUIPMENT \\ TECHNICAL DESCRIPTION HANDBOOK}

FQUIPMENT TITLE

FIXTURE, LIFTING, XE LOWER MODULE
PROV. LIST

ITEM NO.

4116

DATE REVISION

DESCRIPTION: The XE Lower Module Lifting Fixture is an aluminum structure consisting of a short, cylindrical section which matches and attaches to the UTS, shield, or LTS. The cylindrical section is sufficiently long to clear the connectors, couplings, and fittings on the external shield. The upper end of the cylinder is supported by a spider structure with a single centered lifting-bail. The fixture has two bins for storing the hand knobs, studs, and bolts used during attachment and the ten counterweights used in various combinations to compensate for the weigh eccentricities of the hardware to be lifted. The fixture is used during engine assembly operations in the cold bay of the E-MAD building to transfer the XE engine lower module for the PVARA stand to the engine assembly stand. It will also lift the shield, shield-with-LTS, LTS alone, or the complete engine assembly when attached to the UTS.

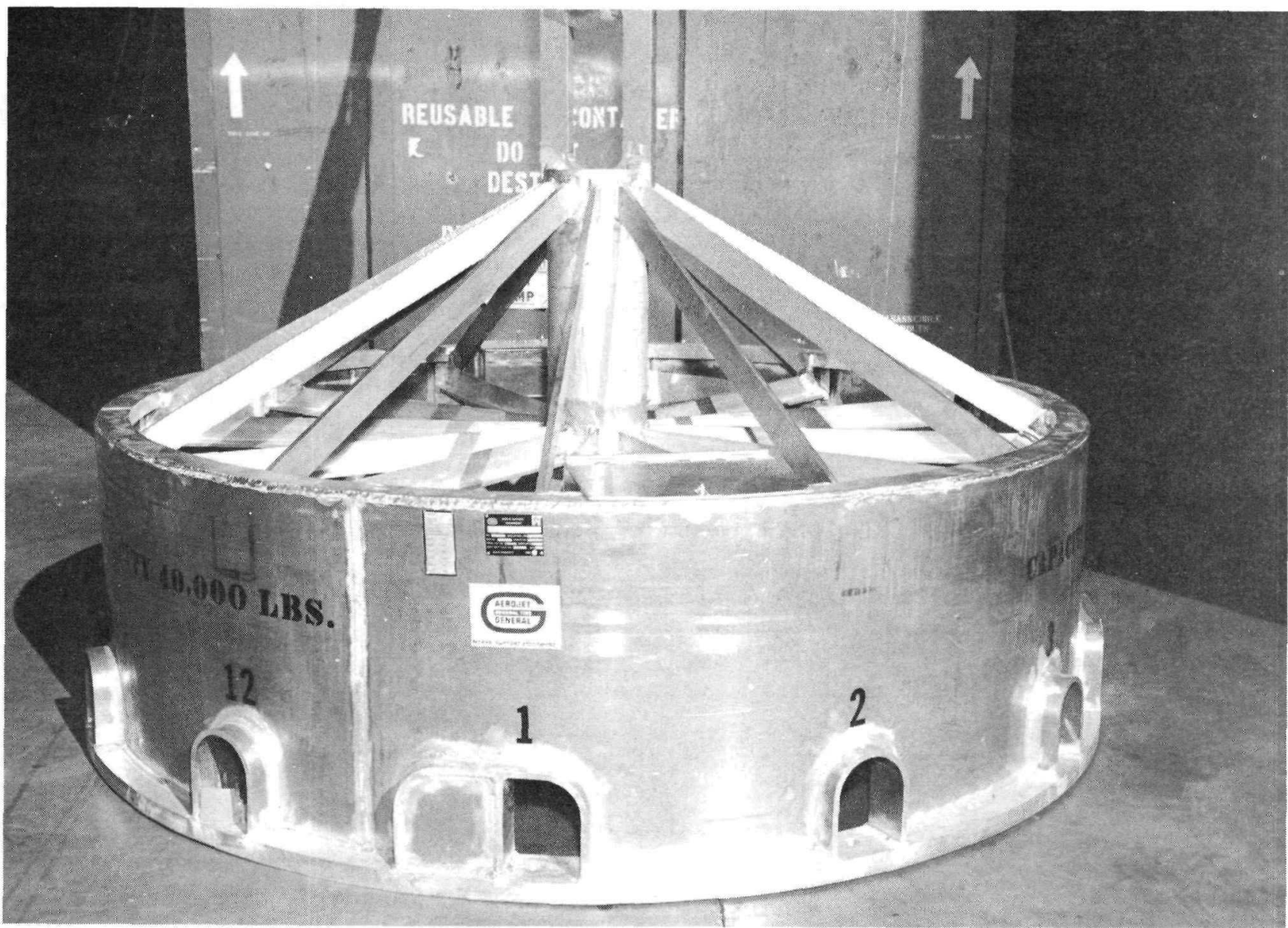


PROVISIONING LIST ITEM NUMBER 4116

DRAWING NUMBER 1116340

PART NUMBER

CONTRACTOR
1116340 AGC
FIRST PROVISIONED FOR XE

GOVT. INV. CONTROL NUMBER

SNP-1-L-1913

$\cos T \quad \$ 8,000$

\begin{tabular}{|l||c|}
\hline \multicolumn{1}{|c||}{ USE LOCATION } & QTY REQ'D \\
\hline A. AGC SACRAMENTO & \\
\hline B. WANL & \\
\hline C. & 1 \\
\hline D. NRDS TOTAL & 1 \\
\hline \multicolumn{2}{|c|}{} \\
\hline
\end{tabular}

\section{DIMENSIONS AND CAPACITY}

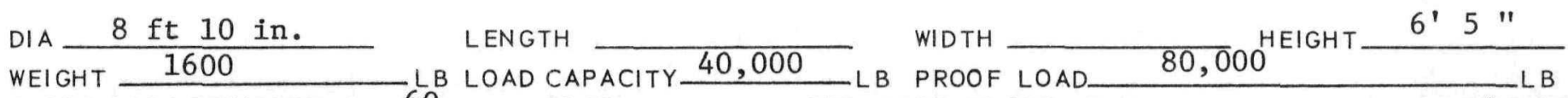

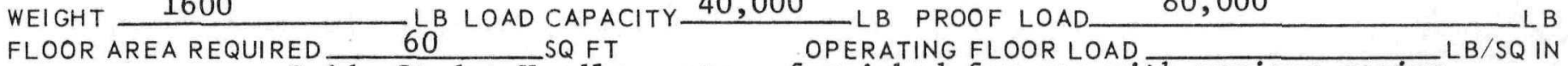
ADDITIONAL DATA Guide Studs, Handles, etc., furnished for use with various engine components. Counterweights are also furnished to level the fixture as required when used with various engine components.

\section{OPERATING DATA}

GASES PRESSURE

ELECTRICAL

LIQUIDS

SPEED.

MEASURING ACCURACY

CALIBRATION INTERVAL

ADDITIONAL DATA

Attaches manually to component in E-MAD Cold Bay
VOLTS

PRESSURE IN./MIN (RPM)
LB/SQIN, VOLUME

CPS

$-L B / S Q$ IN

CUTTING SPEED

HORIZONTAL
CFM LUBRICATION

PHASE

QTY REQ'D

\section{OPERATING EQUIPMENT}

MANIPULATOR CRANE E-MAD Cold Bay

ADDITIONAL DATA
LOAD CAPACITY

LOAD CAPACITY 80,000

LB MAX

LB MAX
EQUIPMENT_ PART OR ITEM

E-MAD Crane

REMARKS
UTS, External Shield and LTS

DRAWING NO. 

PROVISIONING LIST ITEM NUMBER 4117

DRAWING NUMBER

PART NUMBER

CONTRACTOR
$\mathrm{A}-06771-\mathrm{D}$

A-06771-D

AGC (PAR)
FIRST PROVISIONED FOR

$\mathrm{XE}$

GOVT. INV. CONTROL NUMBER

$\cos T$

\begin{tabular}{|l||c|}
\hline \multicolumn{1}{|c||}{ USE LOCATION } & QTY REQ'D \\
\hline A. AGC SACRAMENTO & \\
\hline B. WANL & \\
\hline C. & 1 \\
\hline D. NRDS TOTAL & 1 \\
\hline \multicolumn{2}{|c|}{} \\
\hline
\end{tabular}

DIMENSIONS AND CAPACITY

DIA

WEIGHT

100

FLOOR AREA REQUIRED

LENGTH 48"

WIDTH

$16^{\prime \prime}$

LB LOAD CAPACITY $300 / 600$ in./Ib PROOF LOAD

6

$S Q F T$

OPERATING FLOOR LOAD

HEIGHT

$17^{\prime \prime}$

$-L B$

ADDITIONAL DATA The coupling engaging bal1 hex-studs on the end of each drive shaft are $7 / 8^{\prime \prime}$ across flats and permit $7-1 / 2^{\circ}$ misalignment. Fifty $f t$ air lines are provided. Electrical control power is from facility. Drive position-sensor is provided between shafts.

OPERATING DATA
MANIPULATOR E-MAD/WMHS

CRANE

ADDITIONAL DATA or less as required for desired torque.

GASES Air TIO PRESSURE

LIQUIDS VOLTS AC $\quad$ AC PRESSURE CPS CFM LUBRICATION PHASE KVA IN./MIN (RPM)

$L B / S Q$ IN CUTTING SPEED HORIZONTAL

CALIBRATION INTERVAL Air and electrical connections are made remotely when picking up the tool. See Programmed and Remote Systems Corp. Operators ${ }^{1}$ Manua1 66600. \\ OPERATING EQUIPMENT}

LOAD CAPACITY LOAD CAPACITY
LB MAX LB MAX
EQUIPMENT PART OR ITEM REMARKS
E-MAD Manipulator - WMHS Class-A, 3 Finger Hand

\section{Turbine Inlet Line Remote}

Uses facility remote air-supply regulated to 90 psi maximum. 
EQUIPMENT TITLE

COUPLING DEVICE, FLUID LINE, REMOTE, 7.62" C-C HEX

DESCRIPTION: The 7.62-inch C-C Remote Fluid Line Coupling Device is air powered and has dual torque-heads with ball-shaped hex-studs at the end capable of simultaneously operating both sockets on the fluid-line Marman coupling. Torque is adjusted by varying air pressure. Air-motor control is by a remotely controlled solenoid valve: direction of rotation is preset by a master-slave manipulator. An automatic shutoff arm senses a "coupling-open" position to stop the tool before the coupling is opened too far. The tool is handled by a manipulator and has connecting hoses and cable. The air motors drive 1.73:1 gear-reduction sets which, in turn, are gear-timed for 1:1 synchronization of the hex-studs. The projecting drive shafts have spring-loaded universal joints to permit a maximum of $7-1 / 2^{\circ}$ misalignment of the studs. The tool body incorporates level indicators. The device remotely couples and uncouples the remote Marman coupling located on the pump discharge line at Engine Station 185.14.

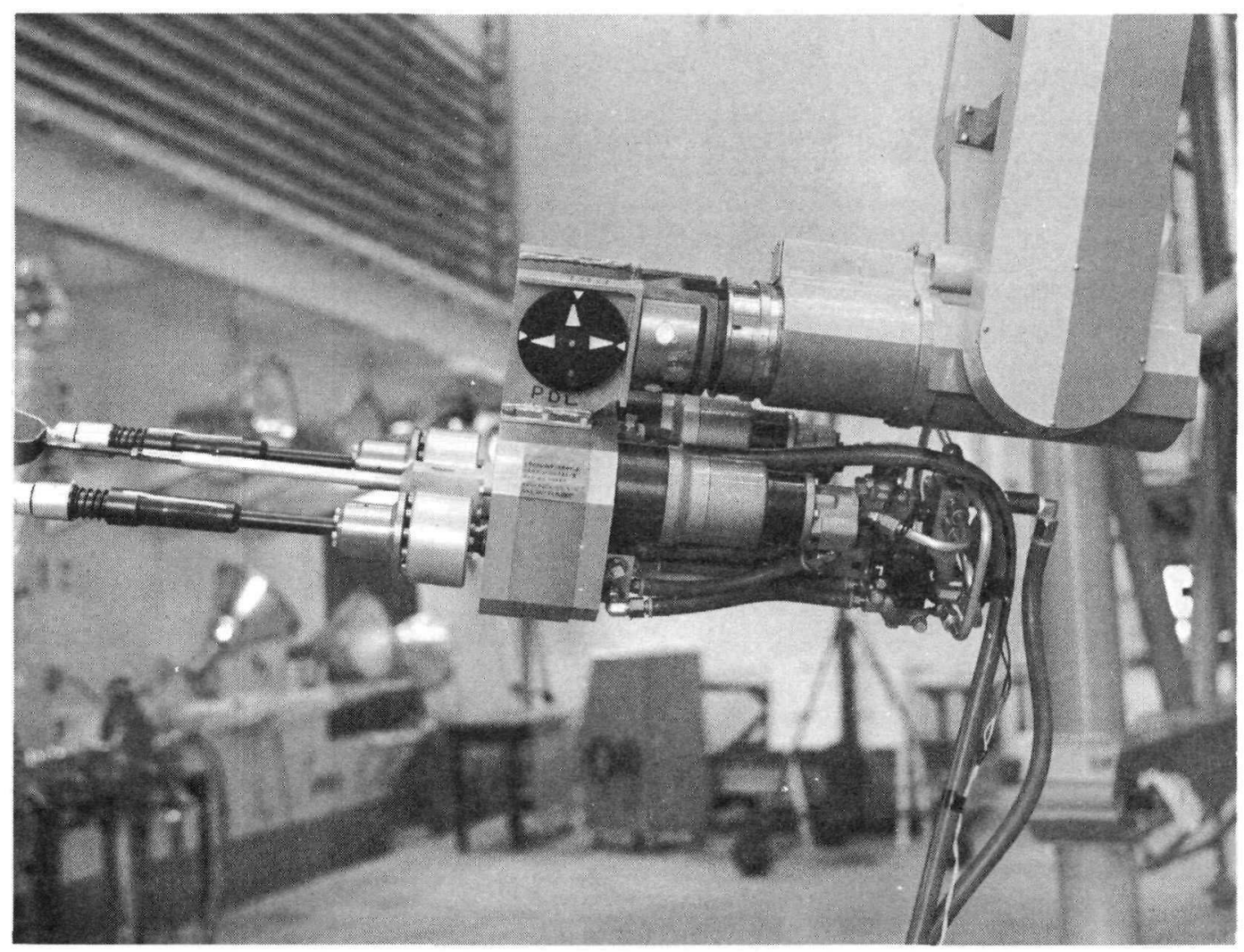


PROVISIONING LIST ITEM NUMBER 4118

DRAWING NUMBER

PART NUMBER

CONTRACTOR
A-06728-D

A-06728-D

AGC (PAR)
FIRST PROVISIONED FOR

$\mathrm{XE}$ GOVT. INV. CONTROL NUMBER

$\cos T+\$ 5,500$

\begin{tabular}{|l||c|}
\hline \multicolumn{1}{|c||}{ USE LOCATION } & QTY REQ'D \\
\hline A. AGC SACRAMENTO & \\
\hline B. WANL & \\
\hline C. & 1 \\
\hline D. NRDS TOTAL & 1 \\
\hline \multicolumn{2}{|c|}{} \\
\hline
\end{tabular}

\section{DIMENSIONS AND CAPACITY}

DIA

WEIGHT 100

LENGTH 48"

in./1b Proof Load

FLOOR AREA REQUIRED $\quad 5$ LB SQ FT

HEIGHT $16^{\prime \prime}$

The coupling engaging ball hex-studs on the end of each drive shaft ar $7 / 8^{\prime \prime}$ across flats and permit $7-1 / 2^{\circ}$ misalignment. Fifty ft air lines are provided. Electrical control power is from facility. Drive is offset $3-1 / 4^{\prime \prime}$ through a 1.73:1.0 reduction and synchronizing gear drive. A shutoff sensor is provided.

\section{OPERATING DATA}

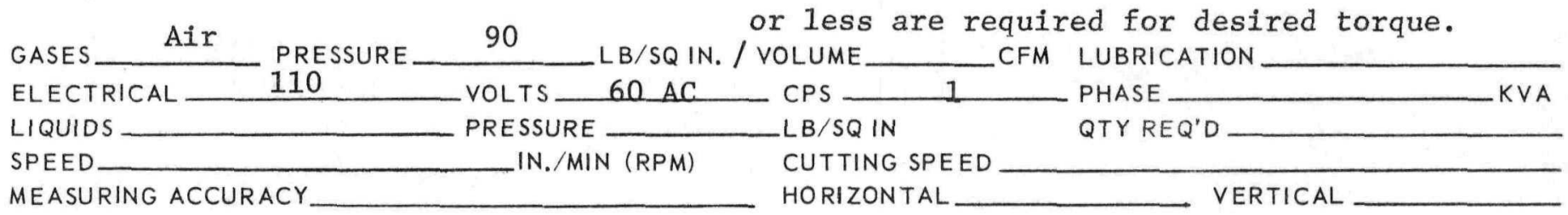

CALIBRATION INTERVAL ADDITIONAL DATA Air and electrical connections are made remotely when picking up the tool.

OPERATING EQUIPMENT

MANIPULATOR E-MAD/WMHS

CRANE

ADDITIONAL DATA
LOAD CAPACITY

600

LOAD CAPACITY
L B MAX

LB MAX

INTERFACES

EQUIPMENT.

E-MAD Manipulator - WMHS Class-A, 3 Finger Hand

PART ORITEM Pump Discharge Line Remote Coupling.

REMARKS Uses facility remote air supply regulated to 90 psi maximum. 
EQUIPMENT TITLE

COUPLING DEVICE, FLUID LINE, REMOTE, 6.50" C-C HEX

DESCRIPTION: The 6.50-inch C-C Fluid Line Coupling device is air powered and has dual torque heads with ball-shaped hex-studs at the end capable of simultaneously operating both sockets on the fluid-line Marman coupling. Torque is adjusted by varying air pressure. Air-motor control is by a remotely controlled solenoid valve: direction of rotation is preset by a master-slave manipulator. An automatic shutoff arm senses a "coupling-open" position to stop the tool before the coupling is opened too far. The tool is handled by a manipulator and has connecting hoses and cable. The driving air-motors are gear-timed for 1:1 synchronization of the hex-studs. The projecting drive shafts have spring-loaded universal joints to permit a maximum of $7-1 / 2^{\circ}$ misalignment of the studs. The tool body incorporates level indicators. The device remotely couples and uncouples the remote Marman coupling located on the turbine inlet line at Engine Station 185.14.

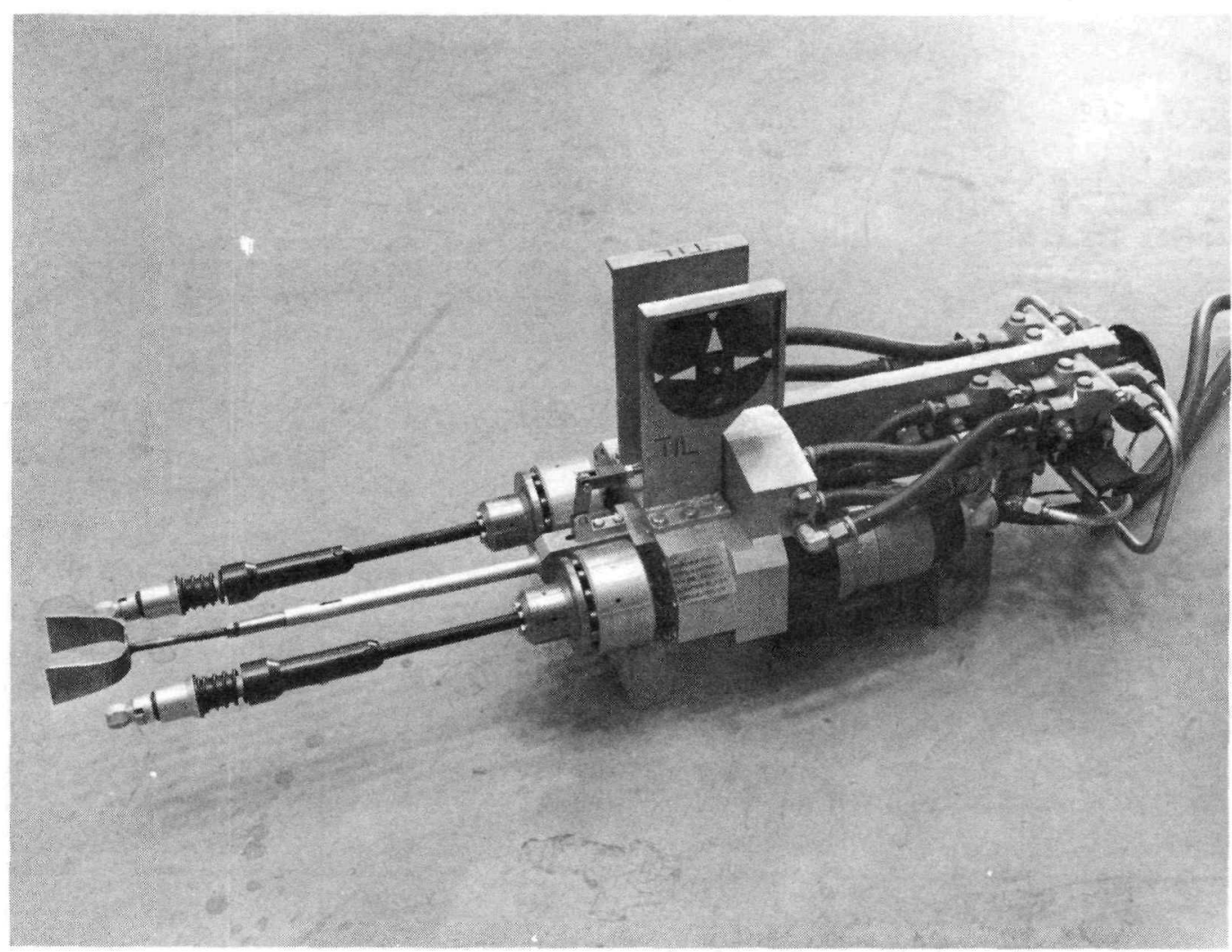


TECHNICAL SUMMARY

PROVISIONING LIST ITEM NUMBER

DRAWING NUMBER

PART NUMBER

CONTRACTOR
4119 A-06726-D A-06726-D AGC (PAR)
FIRST PROVISIONED FOR

GOVT. INV. CONTROL NUMBER

$\cos T-\$ 5,000$

\begin{tabular}{|l||c|}
\hline \multicolumn{1}{|c||}{ USE LOCATION } & QTY REQ'D \\
\hline A. AGC SACRAMENTO & \\
\hline B. WANL & \\
\hline C. & 1 \\
\hline D. NRDS TOTAL & 1 \\
\hline
\end{tabular}

\section{DIMENSIONS AND CAPACITY}

DIA

WEIGHT 100

FLOOR AREA REQUIRED

LENGTH 48"

LB LOAD CAPACITY $300 / 600$ in L $L$ PROOF LOAD SQ FT

The coupling engaging ball hex studs on the en

Electrical control power is from facility. Drive-position sensor is provided between shafts.

\section{OPERATING DATA}

\begin{tabular}{|c|c|c|c|}
\hline GASES & $90-L B / S Q I N$. & VOLUME & \multirow{3}{*}{$\begin{array}{l}\text { LUBRICATION } \\
\text { PHASE KVA } \\
\text { QTY REQ'D }\end{array}$} \\
\hline ELECTRICAL & $110 \mathrm{AC}$ & - CPS 1 & \\
\hline LIQUIDS & PRESSURE & $-L B / S Q$ IN & \\
\hline SPEED & IN./MIN (RPM) & CUTTING SPEED & \\
\hline MEASURING & 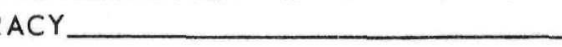 & HORIZONTAL & VERTICAL \\
\hline
\end{tabular}

CALIBRATION INTERVAL

ADDITIONAL DATA Air and electrical connections are made remotely when picking up the tool. See Programmed and Remote System Corp: Operators' Manual 66600.

OPERATING EQUIPMENT

MANIPULATOR _ E-MAD/WMHS

CRANE

ADDITIONAL DATA
LOAD CAPACITY

600

LOAD CAPACITY
LB MAX

LB MAX

- ADDITIONAL DATA

\section{INTERFACES}

EQUIPMENT E-MAD Manipulator WMHS Class-A, 3 Finger Hand.

PART OR ITEM Turbine Inlet Line Remote Coupling.

REMARKS Uses facility remote air-supply regulated to 90 psi maximum. 


\section{EQUIPMENT TITLE}

\section{REVISION}

COUPLING DEVICE, REMOTE, 4.75" C-C HEX

DESCRIPTION: THe 4.75-inch C-C- Remote Coupling Device is air powered and has dual torque-heads with ball-shaped hex-studs at the end capable of simultaneously operating both sockets on the pedestal remote Marman coupling. Torque is adjusted by varying air pressure. Air-motor control is by a remotely controlled solenoid valve: direction of rotation is preset by a master slave manipulator. The tool is handled by a manipulator and has connecting hoses and cable. The driving airmotors are gear-timed for 1:1 snychronization of the hex-studs. The short driveshafts are at the outboard end of each offset, enclosed, chain-driven drive. Power is from the air-motor take-off in the gearbox. The tool body incorporates level indicators. The device uncouples the remote Marman coupling located on the actuator pedestal base at Engine Station 136.20.

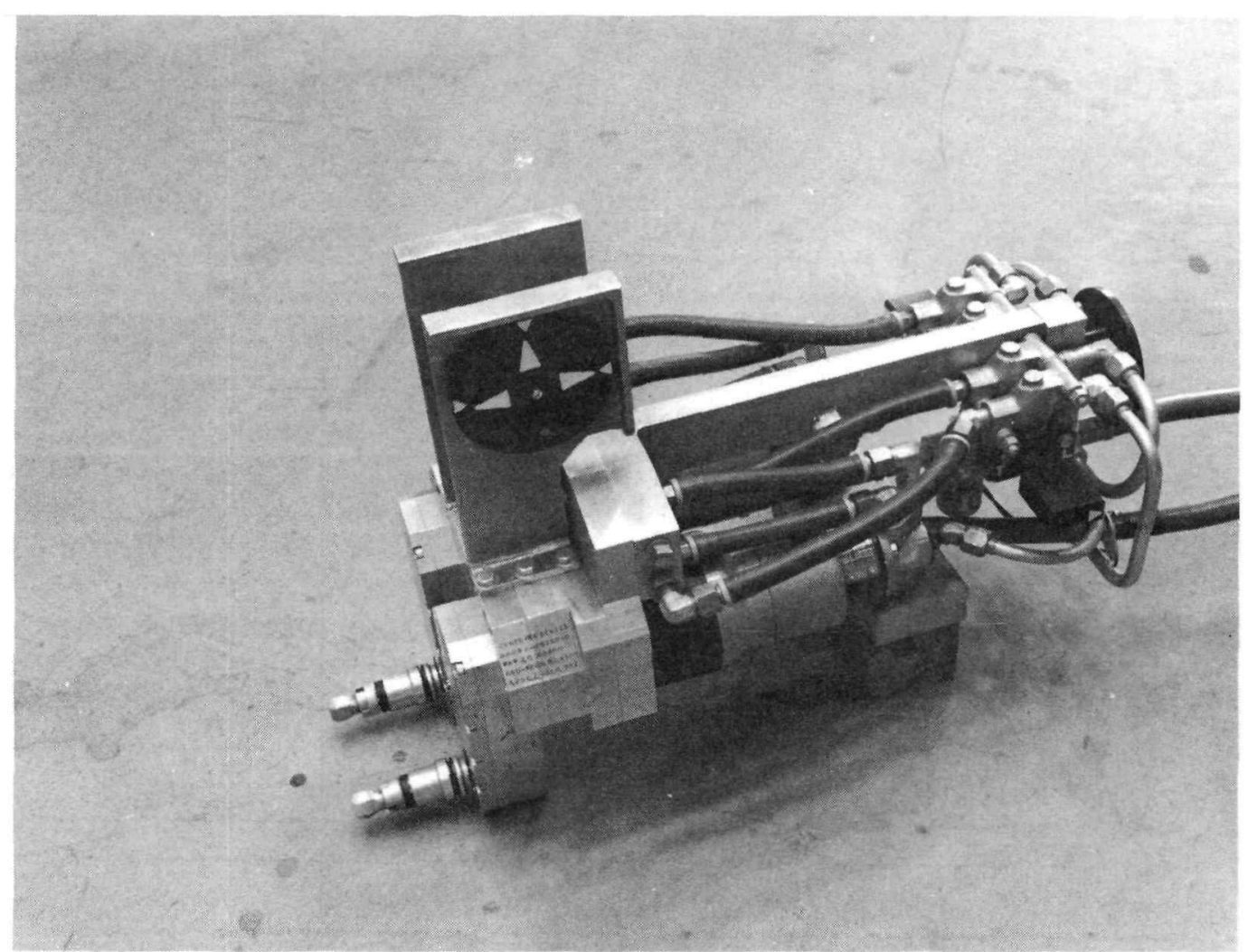


PROVISIONING LIST ITEM NUMBER 4120

DRAWING NUMBER

PART NUMBER

CONTRACTOR
$\mathrm{A}-067 \overline{60-\mathrm{D}}$

A-06760-D AGC (PAR)
FIRST PROVISIONED FOR $\mathrm{XE}$ GOVT. INV. CONTROL NUMBER

$\cos \mathrm{T}$ $\$ 5,000$

\begin{tabular}{|l||c|}
\hline \multicolumn{1}{|c||}{ USE LOCATION } & QTY REQ'D \\
\hline A. AGC SACRAMENTO & \\
\hline B. WANL & \\
\hline C. & 1 \\
\hline D. NRDS TOTAL & 1 \\
\hline
\end{tabular}

\section{DIMENSIONS AND CAPACITY}

DIA

WEIGHT 100

FLOOR AREA REQUIRED

LENGTH $3_{3}^{\beta}$ $30^{\prime \prime}$

LOAD CAPACITY 300/600in. $/$ WIDTH $\frac{14^{\prime \prime}}{\text { WROOF LOAD }}$ SQ FT OPERATING FLOOR LOAD
HEIGHT $20^{\prime \prime}$ $L B / S Q I N$ ADDITIONAL DATA The coupling engaging ball hex-studs on the two drive shafts are $7 / 8$ " across flats. Fifty $\mathrm{ft}$. air lines provided. Electrical control power is from the facility. The drive is short coupled and is offset $5-1 / 2^{\prime \prime}$.
GASES Air PRESSURE_ 90 LB/SQIN, VOLUME ELECTRICAL 110

LIQUIDS

SPEED

MEASURING ACCURACY PRESSURE IN./MIN (RPM)

CALIBRATION INTERYAL

ADDITIONAL DATA Air and electrical connections are made remotely when picking up the tool. See Programmed and Remote Systems Corp. Operator's Manual 66600.

\section{OPERATING EQUIPMENT}

MANIPULATOR E-MAD/WMHS

CRANE

ADDITIONAL DATA
LOAD CAPACITY

600

LOAD CAPACITY
CFM LUBRICATION

PHASE

QTY REQ'D

$L B / S Q$ IN

CUTTING SPEED HORIZONTAL
VERTICAL 
DEVICE, NUT ACTUATION REMOTE, UTSM/TSA LINES

DESCRIPTION: The Remote UTSM/TSA Lines Nut Actuation Device is a commercial electrical impact-tool adapted to fit and receive power from the EIV manipulator. The tool drive-end incorporates a self-aligning hex-nut socket. The adapter bracket has a coupling removal hook. In operation, the tool is remotely engaged to the manipulator wrist: the hook is engaged by the manipulator to the drive platform to retract the line-clamp primary drive and drop it free. The socket is engaged alternately to the coupling-drive studs to evenly loosen the remote clamp. The device is required only when the propellant and cooldown line remoteclamp mechanism at Engine Station 42.89 fails to operate at ETS-1 after an engine firing.

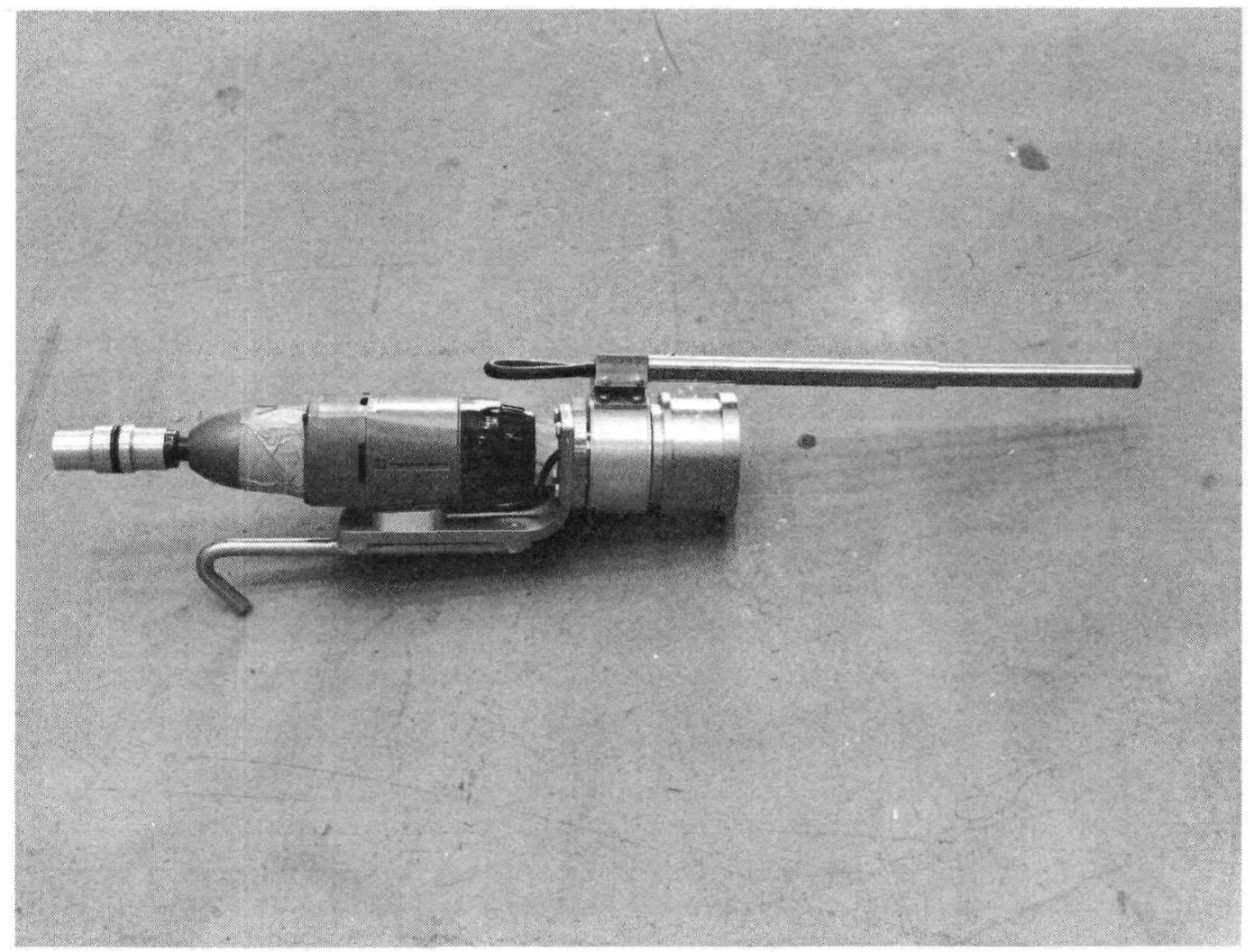


PROVISIONING LIST ITEM NUMBER 4121

DRAWING NUMBER

PART NUMBER

CONTRACTOR
$A-86799-D$ (PAR)

A-06799-D (PAR)

ACC
FIRST PROVISIONED FOR GOVT. INV. CONTROL NUMBER

$\cos T$ $\$ 1,500$

\begin{tabular}{|l||c|}
\hline \multicolumn{1}{|c||}{ USE LOCATION } & QTY REQ'D \\
\hline A. AGC SACRAMENTO & \\
\hline B. WANL & \\
\hline C. & 1 \\
\hline D. NRDS TOTAL & 1 \\
\hline \multicolumn{2}{|c|}{} \\
\hline
\end{tabular}

\section{DIMENSIONS AND CAPACITY}

DIA 4 " LENGTH $\frac{28^{\prime \prime}}{15}$ WIDTH WEIGHT LB LOAD CAPACITY $95-130 \mathrm{ft} /$ Ib PROOF LOAD

HEIGHT FLOOR AREA REQUIRED $\frac{2}{2}$ SQ FT OPERATING FLOOR LOAD $L B / S Q I N$ ADDITIONAL DATA The tool has a $9 / 16^{\prime \prime}$ hex socket attached to the drive through a Universal joint to permit up to $71 / 2^{\circ}$ misalignment: a hook is provided to withdraw the primary drive unit.

\section{OPERATING DATA}

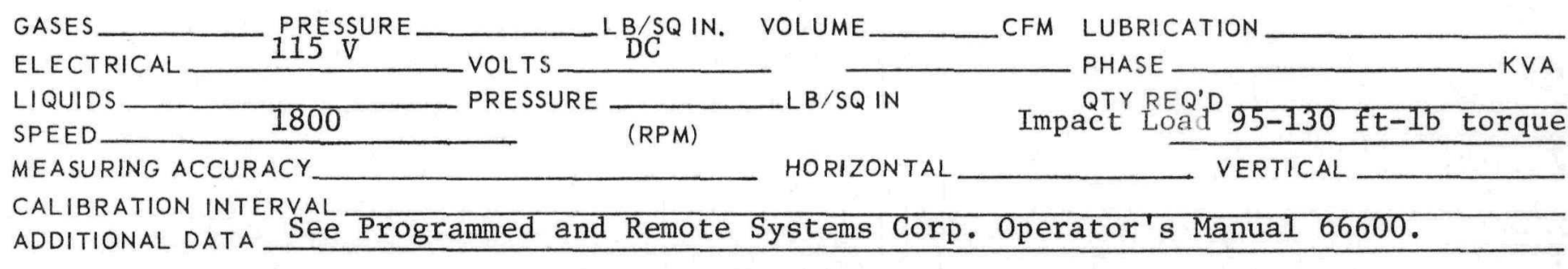

OPERATING EQUIPMENT

MANIPULATOR EIV

CRANE ADDITIONAL DATA MEC/ETV Manipulator Control Circuitry
LOAD CAPACITY

100 LOAD CAPACITY
LB MAX LB MAX

INTERFACES

EQUIPMENT

EIV Manipulator(s) Tool/Hand Socket

PART OR ITEM Remote Fluid Line Marman Coupling at Engine Station 42.89, Dwg. No. 1116947 REMARKS 


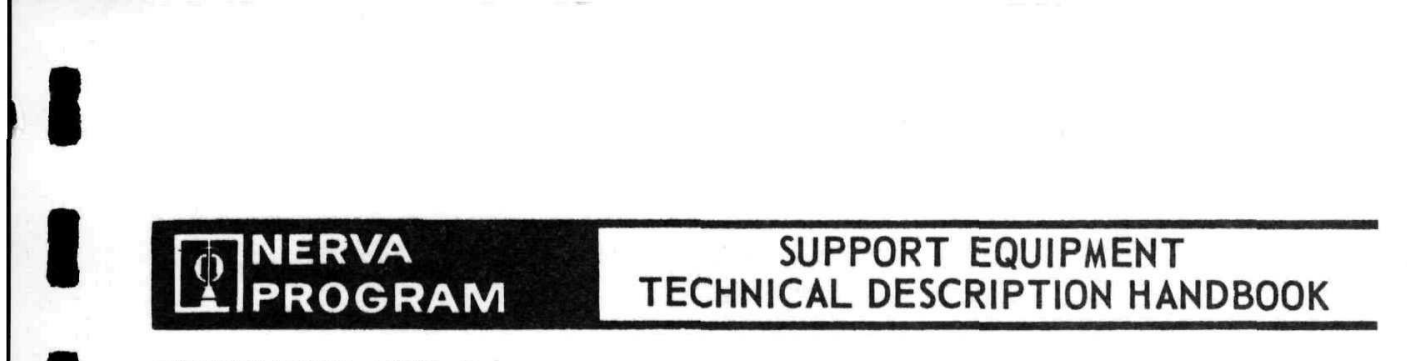

EQUIPMENT TITLE

STAND, ENGINE REASSEMBLY

DESCRIPTION: The Engine Reassembly Stand is a modification of the engine holding stand, P/L 4099. The modification includes addition of four remotely operated engine propellant-line supports and a floor spacer. The stand is a four-legged, trussed steel structure with a base formed of skids which are, in turn, mounted on a floor spacer. The three-sided top structure mounts three engine support-pads which engage the lower periphery of the engine external shield. The stand's height and openings at the top and one side provide access to the nozzle and lines and permit installation of the complete engine assembly without excessively high engine handling-crane heights. The remote line-clamps are hinged to the side and top structure. A manipulator is used to swing them into line position and grip the lower line-segments below the joint flange. They hold the line segment and return it to position within 0.020 inch for reassembly. The stand supports the $\mathrm{XE}$ engine and lower line-segments during remote removal and reinstallation of the UTSM in the E-MAD Building.

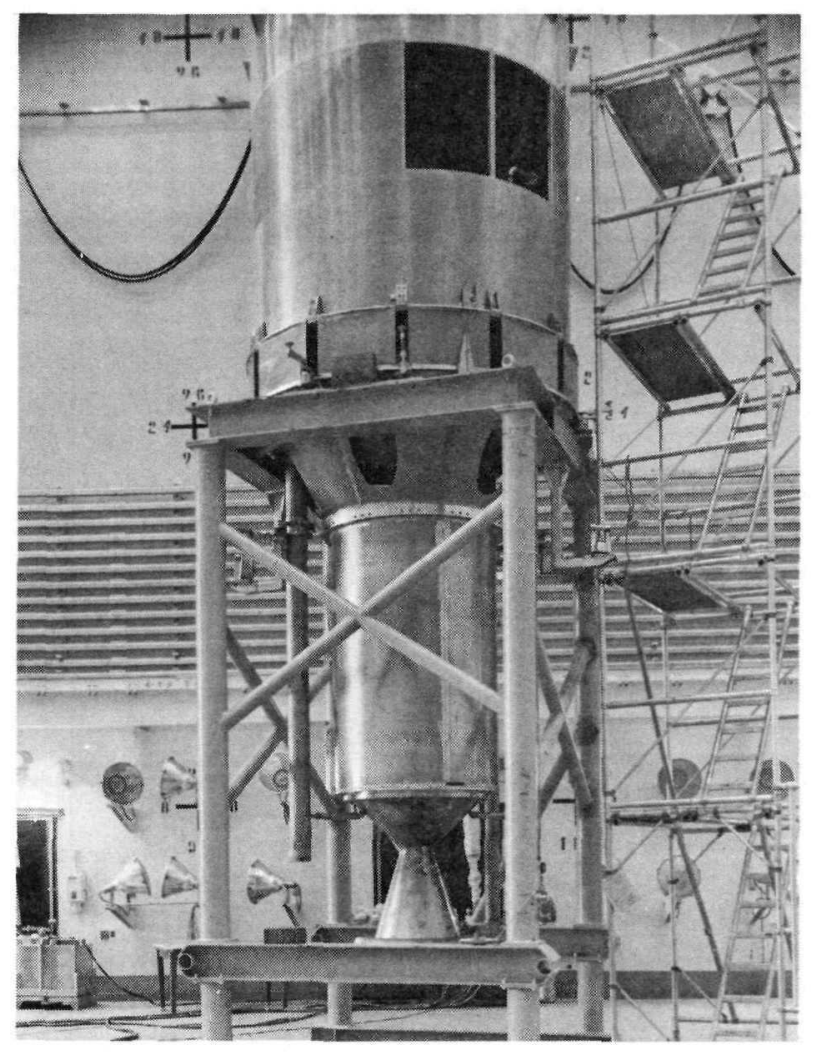


PROVISIONING LIST ITEM NUMBER 4122

DRAWING NUMBER

PART NUMBER

CONTRACTOR
1118465

1118465

AGC
FIRST PROVISIONED FOR $\mathrm{XE}$ GOVT. INV. CONTROL NUMBER $\cos T$ * Cost of modification of $\mathrm{P} / \mathrm{L} 4099$

\begin{tabular}{|l||c|}
\hline \multicolumn{1}{|c||}{ USE LOCATION } & QTY REQ'D \\
\hline A. AGC SACRAMENTO & \\
\hline B. WANL & \\
\hline C. & \\
\hline D. NRDS TOTAL & 1 \\
\hline
\end{tabular}

DIMENSIONS AND CAPACITY

DIA

WEIGHT 7200

FLOOR AREA REQUIRED
LENGTH $10^{\prime}$ LB LOAD CAPACITY 40,000 $100 \quad S Q F T$
WIDTH $10^{\prime}$

B PROOF LOAD

OPERATING FLOOR LOAD

$80,000^{\text {HEIGHT }}$

25 $17^{\prime}$

L B engine stand P/L 4099; a floor spacer is also provided to give greater nozzle-tofloor space. Clamps - 2 position each; vertical load 150 1b; radial $10 a d 4001 b$.

\section{OPERATING DATA}

GASES

ELECTRICAL

LIQUIDS

SPEED

MEASURING ACCURACY

CALIBRATION INTERYAL

ADDITIONAL DATA See Aerojet Report TDI-0022.
$L B / S Q I N$. VOLUME VOLTS PRESSURE IN./MIN (RPM)

\section{CPS}

LB/SQ IN

CUTTING SPEED

HORIZONTAL
CFM LUBRICATION

PHASE KVA
QTY REQ'D

VERTICAL $L B / S Q I N$ 


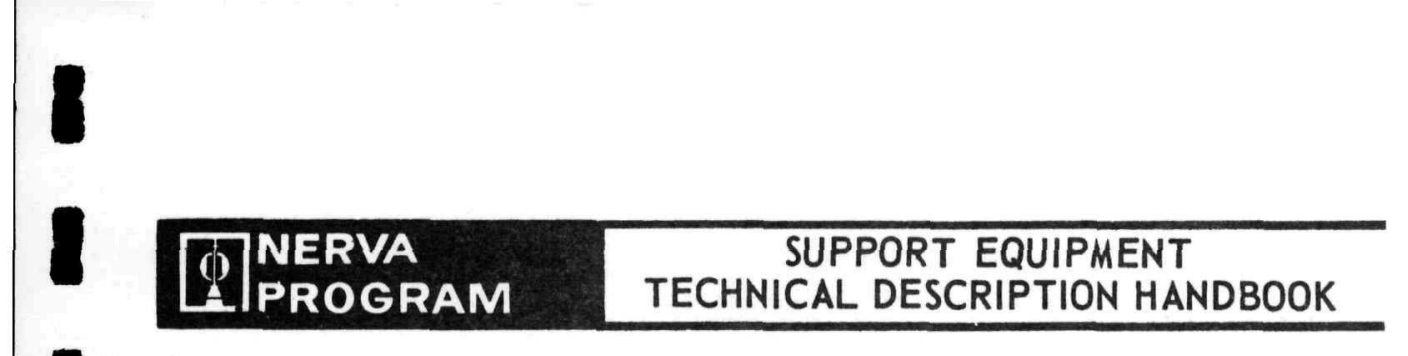
EQUIPMENT TITLE TOOL, UTS/SHIELD NUT, REMOTE

DESCRIPTION: The Remote UTS/Shield Nut Tool is an adaptation of a commercial air impact-tool for remote handling by a manipulator hand. It provides an offset, right-angle drive to a 3/4-inch Hex self-aligning socket. It also has pneumatic drive and exhaust lines and a solenoid-valve control cable. The tool is used in the E-MAD Building with the WMHS to remotely remove and reset the UTSM/shield nuts. ON-OFF power is remotely controlled: forward, reverse, and torque adjustments are mechanically preset.

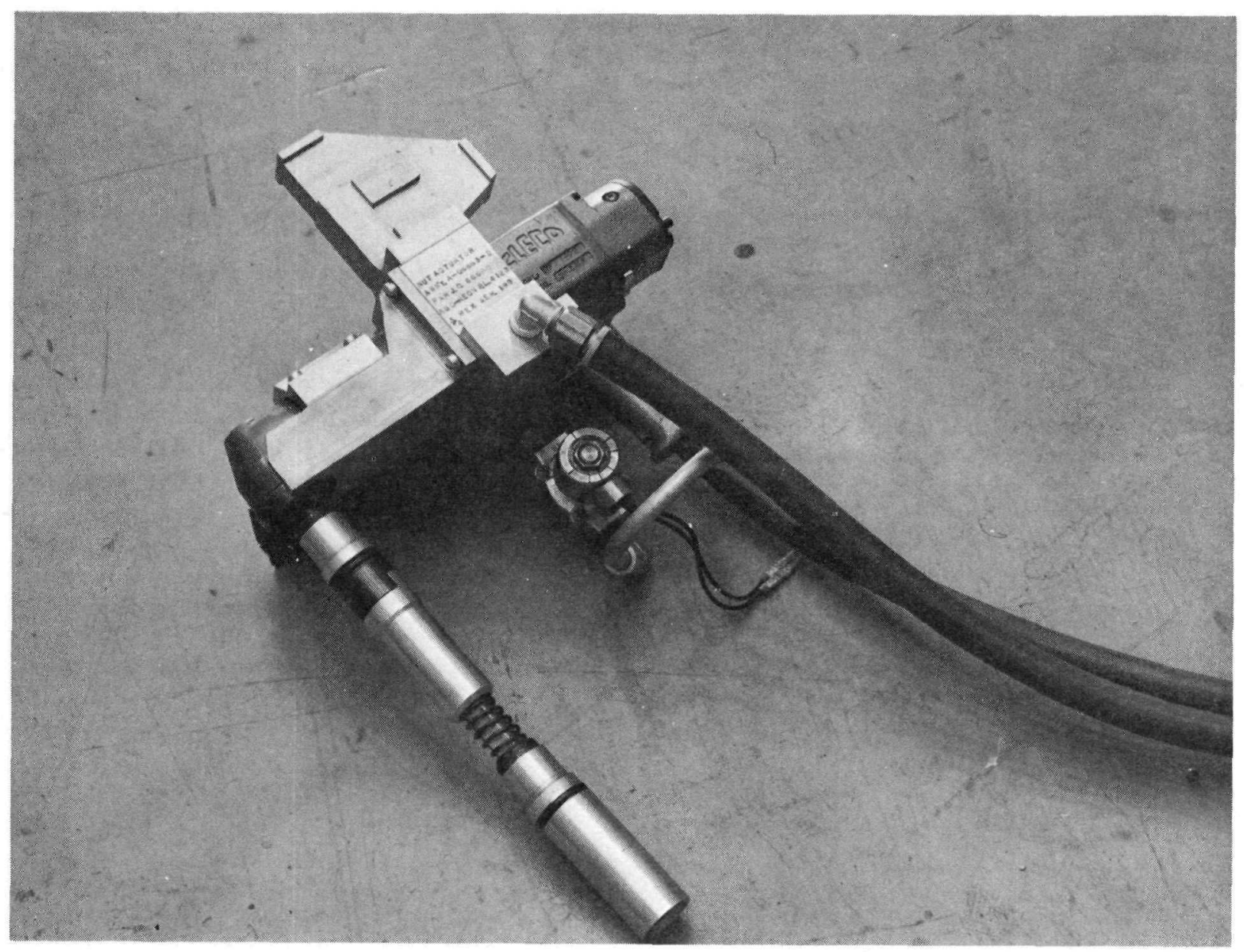


PROVISIONING LIST ITEM NUMBER 4123 DRAWING NUMBER

PART NUMBER CONTRACTOR
$A-068 \overline{63-D(P A R)}$ A-06863-D (PAR) AGC (PAR)
FIRST PROVISIONED FOR $\mathrm{XE}$ GOVT. INV. CONTROL NUMBER

$\cos T$ $\$ 2,500$

\begin{tabular}{|l||c|}
\hline \multicolumn{1}{|c||}{ USE LOCATION } & QTY REQ'D \\
\hline A. AGC SACRAMENTO & \\
\hline B. WANL & \\
\hline C. & 1 \\
\hline D. NRDS TOTAL & 1 \\
\hline
\end{tabular}

DIMENSIONS AND CAPACITY

DIA

WEIGHT

LENGTH 14 "

FLOOR AREA REQUIRED 2

LB LOAD CAPACITY $30-185 \mathrm{ft} / L B$

WIDTH 6"

OPERATING FLOOR LOAD

torque

$22^{\prime \prime}$

$S Q F T$

$L B$

ADDITIONAL DATARight-angle drive extension with a $3 / 4 "$ hex socket attached provided at a $6^{\prime \prime}$ offset from the manipulator handle. Wrench is driven by an air impact-tool with torque and direction mechanically adjustable.

\section{OPERATING DATA}

GASES Air PRESSURE_ $90 \quad$ LB/SQ IN. VOLUME ELECTRICAL IIOAC VOLTS 60 CPS LIQUIDS SPEED 1700 Impacts Per MEASURING ACCURACY

CALIBRATION INTERYAL PRESSURE IN./MIN (RPM)

$L B / S Q I N$ CUTTING SPEED HORIZONTAL
CFM LUBRICATION PHASE KVA

QTY REQ'D

VERTICAL

ADDITIONAL DATA Air and electrical connections are made remotely when picking up the tool. See Programmed and Remote Systems Corp. Operator's Manual No. 66600

MANIPULATOR E-MAD/WMHS

CRANE

ADDITIONAL DATA
LOAD CAPACITY

600

LOAD CAPACITY
LB MAX

LB MAX

INTERFACES

EQUIPMENT_E-MAD/WMHS Class C - Parallel Jaw Hand

PART OR ITEM 12 UTS/Shield Nuts DRAWING NO.

REMARKS Uses facility air regulated to $90 \mathrm{psi}$. 
EQUIPMENT TITLE

\section{REVISION}

KIT, TOOL, SEAL INSTALLATION

DESCRIPTION: The Seal Installation Tool Kit consists of six different, remote seal-installation tools and eight seal dispensers (three of one size are required). The seal-installation tool consists of a housing, pilot, manipulator-handle assembly and three, equally spaced, spring-loaded brass hooks. The handle provides a "floating" universal joint between the manipulator and the tool. The dispensers are cup-shaped with a contoured lip to facilitate removal of the replacement seal. In operation, the tool, with a pre-installed seal, is handled by a manipulator to insert the tool pilot into the inside of the line flange. When properly positioned into the flange, the hook automatically operates to drop the seal in place. The kit permits remote installation of the propellant-line seals after remote removal of the UTSM, and prior to remote installation of the original or replacement UTSM on the XE-engine lower module.

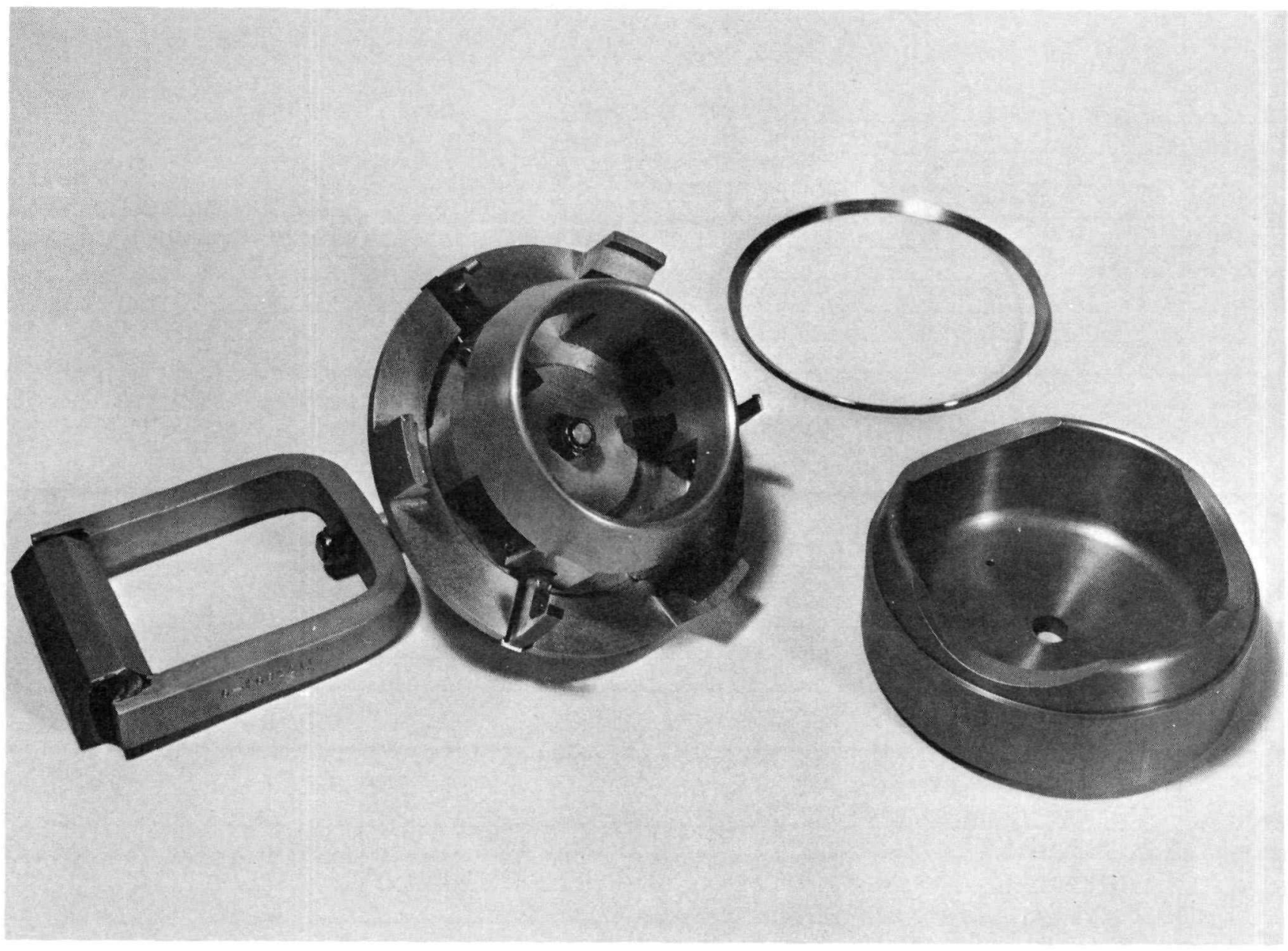


TECHNICAL SUMMARY

PROVISIONING LIST ITEM NUMBER 4124

DRAWING NUMBER

PART NUMBER

1133893

CONTRACTOR

1133893

AGC

FIRST PROVISIONED FOR

$\mathrm{XE}$ GOVT. INV. CONTROL NUMBER

$\operatorname{cosT}$

\begin{tabular}{|l||c|}
\hline USE LOCATION & QTY REQ'D \\
\hline A. AGC SACRAMENTO & \\
\hline B. WANL & \\
\hline C. & 1 \\
\hline D. NRDS TOTAL & 1 \\
\hline
\end{tabular}

\section{DIMENSIONS AND CAPACITY}

DIA $\frac{* 5.5 \text { to } 9.5^{\prime \prime}}{\text { Total } 55}$

FLOOR AREA REQUIRED

ADDITIONAL DATA
LENGTH $12-1 / 2^{\prime \prime}$ WIDTH LB PROOF LOAD OPERATING FLOOR LOAD

HEIGHT

LB LOAD CAPACITY SQ FT
$-L B$ $L B / S Q$ IN

*Tool sizes - Dispensers 4-3/4 to 8-3/4" dia; all 2-1/2" long.

\section{OPERATING DATA}

GASES PRESSURE

ELECTRICAL

LIQUIDS

SPEED

MEASURING ACCURACY

CALIBRATION INTERVAL

ADDITIONAL DATA See AGC Report TD1-0027
CPS

$L B / S Q$ IN

CUTTING SPEED

HORIZONTAL
CFM LUBRICATION

PHASE

QTY REQ'D
KVA 
PROV. LIST

ITEM NO.

4125

DATE

TECHNICAL DESCRIPTION HANDBOOK

EQUIPMENT TITLE

TARGET ASSEMBLY, PARALLEL

DESCRIPTION: The Parallel Target Assembly consists of three optical targets used to indicate parallelism between the UTSM and the engine external shield prior to mating these units during remote reassembly of an $\mathrm{XE}$ engine. Each target consists of a window with a visual centering pattern on a spring-loaded target plate which moves vertically back of the window when a force is applied at its top. The assembly base supports the window-frame assembly, indicator lights, limit switches, a battery, and a handle. One light indicates center position; two lights indicate 0.030 inch below center.

In operation, the target assemblies are remotely placed, equally spaced, on the external shield studs on the top of the shield. This provides visual observation of the centering pattern and indicator lights from assigned E-MAD Building hot bay windows as the UTSM is lowered in preparation for mating. When the UTSM contacts the targets, it is leveled by the OPS until all targets read the same, indicating that the UTSM and external shield surfaces are parallel. The UTSM is then raised by the OPS hoist and the targets are removed by a manipulator.

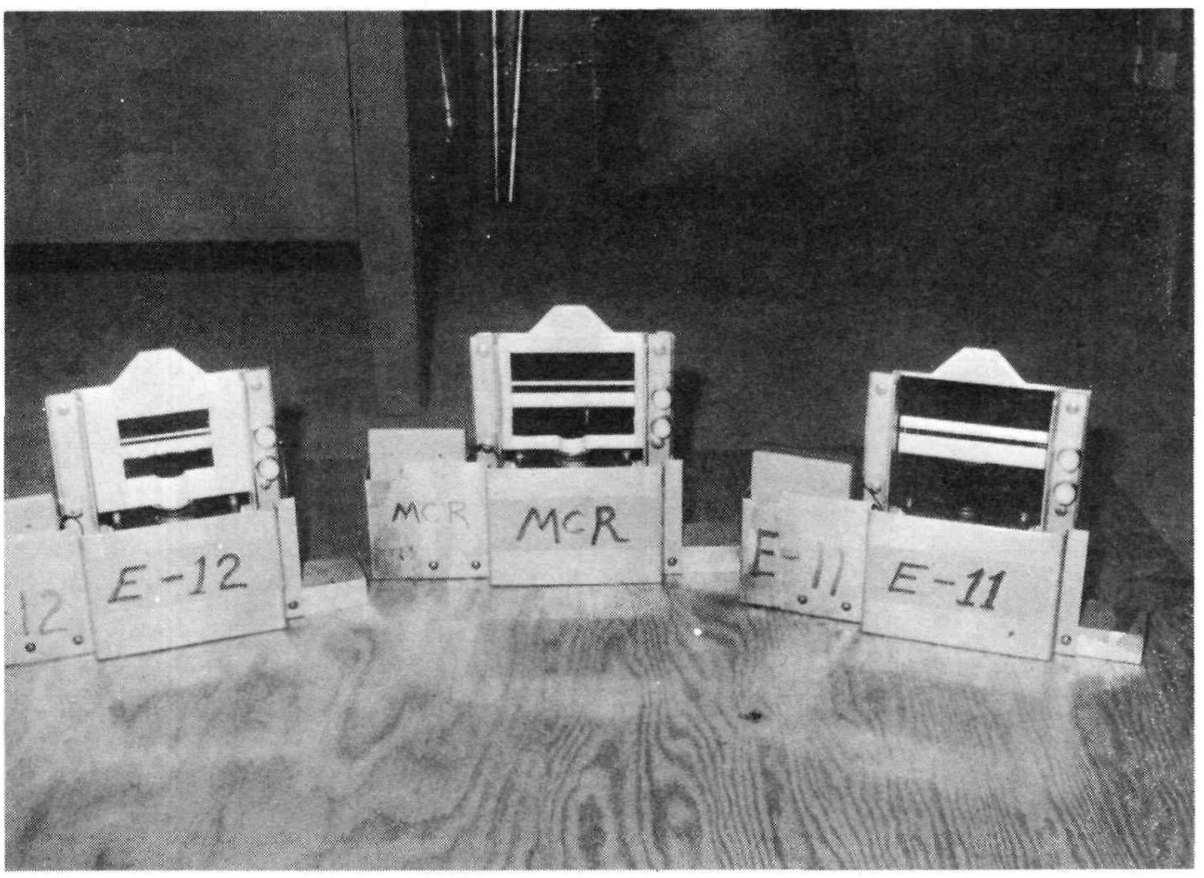


PROVISIONING LIST ITEM NUMBER 4125

DRAWING NUMBER 1117337

PART NUMBER

CONTRACTOR
1117337

AGC
FIRST PROVISIONED FOR XE GOVT. INV. CONTROL NUMBER

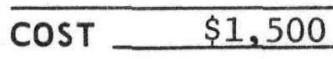

\begin{tabular}{|l||c|}
\hline \multicolumn{1}{|c||}{ USE LOCATION } & QTY REQ'D \\
\hline A. AGC SACRAMENTO & \\
\hline B. WANL & \\
\hline C. & \\
\hline D. NRDS TOTAL & 1 \\
\hline
\end{tabular}

DIMENSIONS AND CAPACITY*

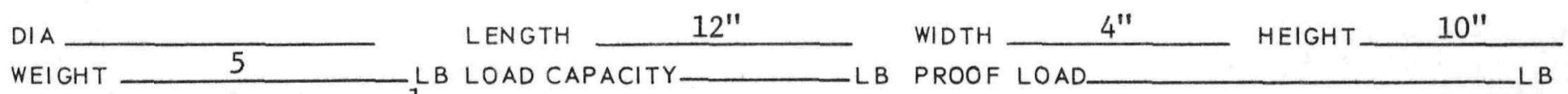
FLOOR AREA REQUIRED $\frac{1}{1}$ SQFT OPERATING FLOOR LOAD LB/SQ IN ADDITIONAL DATA Indicator lights: One indicates center position; two indicate center $+0.030^{\prime \prime}$ low

*For each of three target assemblies. OPERATING DATA

GASES

ELECTRICAL

LIQUIDS

SPEED

MEASURING ACCURACY

CALIBRATION INTERVAL

ADDITIONAL DATA

RN-TM-0398.

12
PRESSURE

Each target is set onto a VOLTS DC PRESSURE IN./MIN (RPM)
VOLUME CPS $-L B / S Q I N$ CUTTING SPEED HORIZONTAL
CFM LUBRICATION PHASE QTY REQ'D KVA VERTICAL shield stud using a manipulator. See OPERATING EQUIPMENT

MANIPULATOR _ E-MAD/WMHS

CRANE

ADDITIONAL DATA
LOAD CAPACITY

600

LB MAX LOAD CAPACITY

INTERFACES

EQUIPMENT PART OR ITEM E-MAD/WMHS Manipulator REMARKS
ELM/UTSM DRAWING NO. 


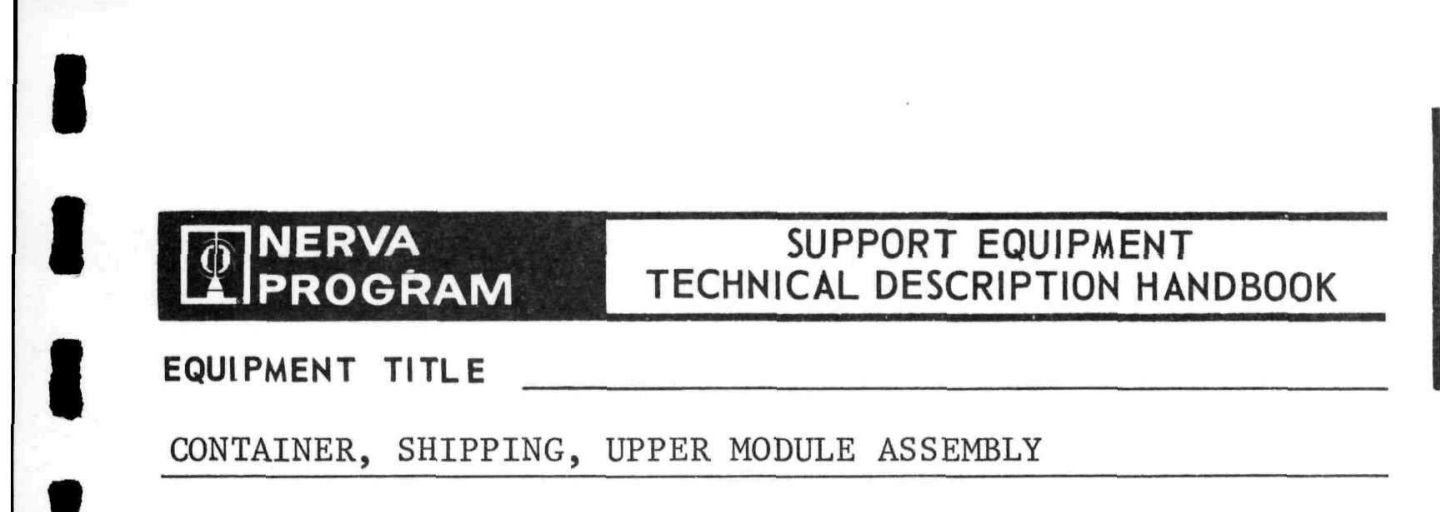

PROV. LIST

ITEM NO.

4126

DATE

REVISION

DESCRIPTION: The Upper Module Assembly Shipping Container consists of four structural steel elements: a cradle; a lower support; an upper support; and a cover frame. The upper- and lower-supports bolt to the upper module at the 12 bolt-interfaces. The lower support also terminates the propellant lines extending below the upper module. The upper- and lower-supports bolt to the cradle at four rubber isolation blocks. The upper module is installed vertically into the support and cradle: the assembly is placed horizontally on the vehicle bed. The cover frame fits over, and is secured to, the assembly on the truck bed: it is covered with a tarp for protection during transportation. The shipping container handles and transports the UTSM from the factory to the engine assembly and test facility. It provides the required shock isolation, structural support, tie-down, and environmental protection during transport.

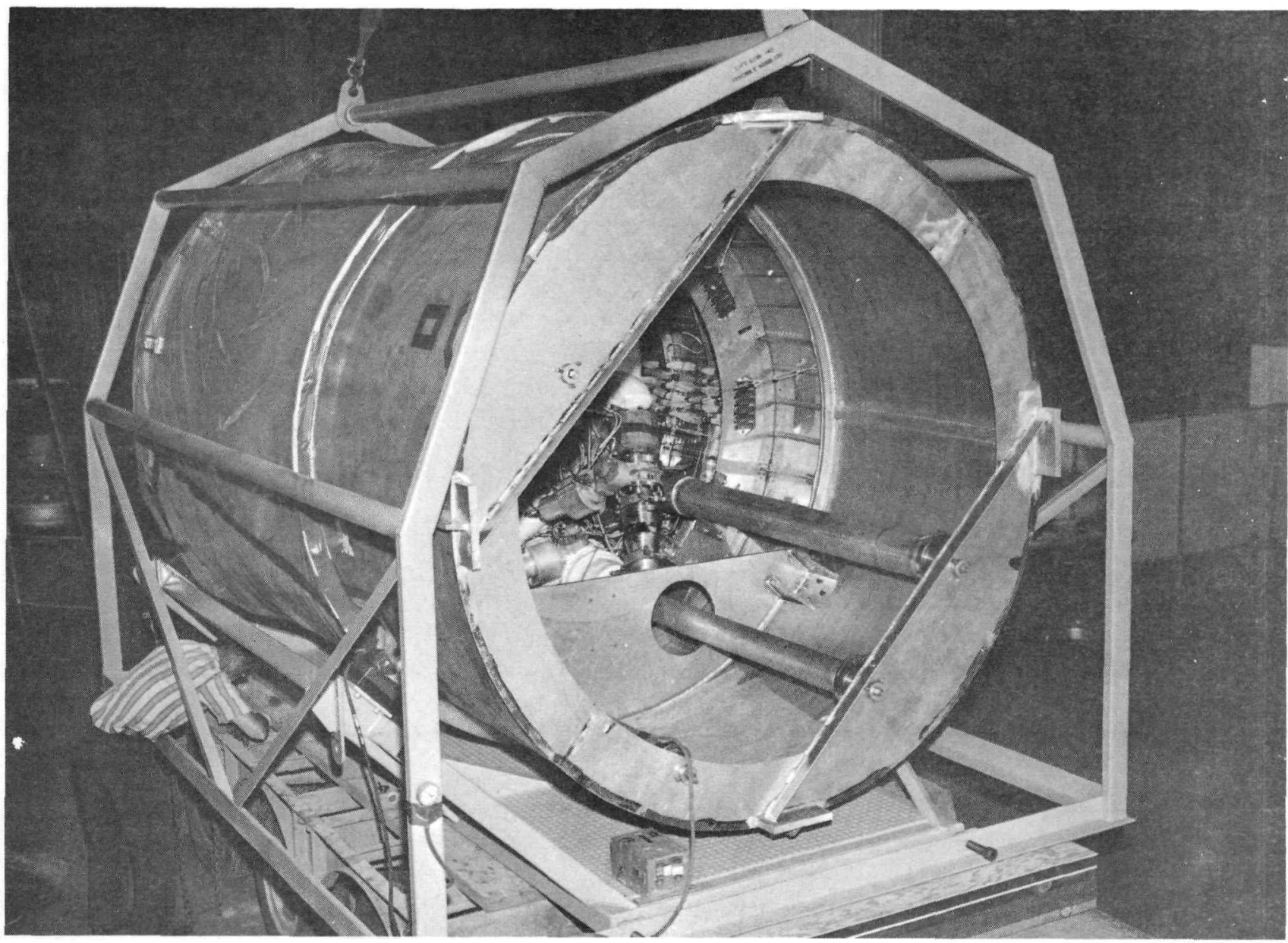




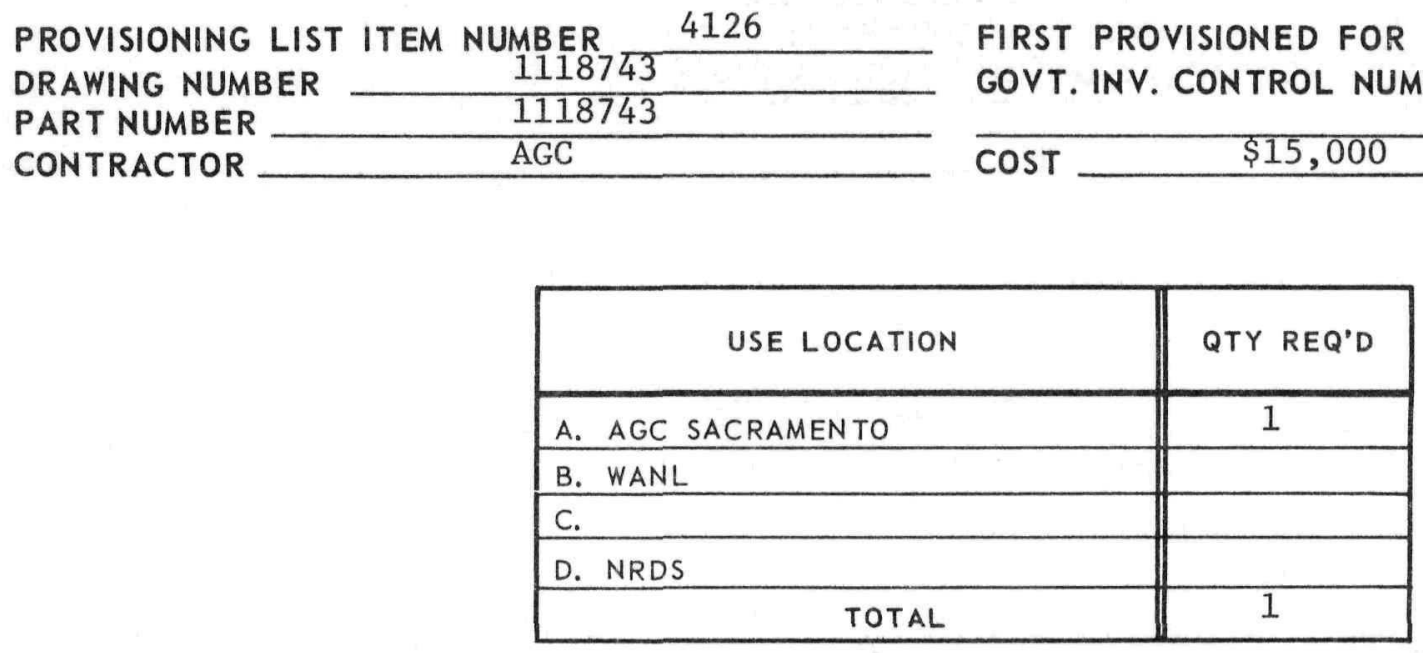

\section{DIMENSIONS AND CAPACITY}

DIA

WEIGHT 4500

FLOOR AREA REQUIRED.

LENGTH

$13^{\prime} 10^{\prime \prime}$

WIDTH $10^{\prime}$ $S Q F T$

$6800^{H E I G H T}$

$10^{\prime}$ LB ADDITIONAL. DATA Supports UTSM at 12 bolt-interfaces at Stations 42.87 and 137.64 ; supports lines at Stations 158.64 and 185.14 . Has shock isolation to $2 \mathrm{~g}$ transverse and $0.7 \mathrm{~g}$ horizontal. Limits horizontal vibration to 6 cps. Has protective cover.

\section{OPERATING DATA}

GASES

ELECTRICAL

LIQUIDS

SPEED

MEASURING ACCURACY

CALIBRATION INTERVAL

ADDITIONAL DATA See RN-TD1-0030.
LB/SQIN, VOLUME VOLTS PRESSURE IN. /MIN (RPM)

\section{CPS}

$L B / S Q I N$

CUTTING SPEED

HORIZONTAL
CFM LUBRICATION

PHASE

QTY REQ'D

VERTICAL
MANIPULATOR

CRANE

Sacto/E-MAD

ADDITIONAL DATA
LOAD CAPACITY

LOAD CAPACITY
LB MAX LB MAX

EQUIPMENT_2-1egged Sling - Facility - 10,000 1b/min. PART OR ITEM UTSM DRAWING NO.

REMARKS Base interfaces with a 40,000-1b truck flatbed. May be lifted by 10,000-1b capacity fork lift. 
PROVISIONING LIST ITEM NUMBER 4133

DRAWING NUMBER

PART NUMBER

CONTRACTOR
1118664

1118664

AGC
FIRST PROVISIONED FOR

$\mathrm{XE}$

GOVT. INV. CONTROL. NUMBER

$\cos T$

\begin{tabular}{|l||c|}
\hline \multicolumn{1}{|c||}{ USE LOCATION } & QTY REQ'D \\
\hline A. AGC SACRAMENTO & \\
\hline B. WANL & \\
\hline C. & 1 \\
\hline D. NRDS TOTAL & 1 \\
\hline
\end{tabular}

DIMENSIONS AND CAPACITY

DIA

WEIGHT 150

FLOOR AREA REQUIRED
LENGTH 14" WIDTH 17" 4 LB LOAD CAPACIT

OPERATING DATA

GASES IRESSURE

ELECTRICAL

LIQUIDS

SPEED

MEASURING ACCURACY

CALIBRATION INTERVAL

ADDITIONAL DATA

TRESSURE

\section{Removable shear bolts facilitate connecting to crane hook and GSE.}

VOLTS

PRESSURE

IN./MIN (RPM)

LB/SQIN. VOLUME

CPS

$L B / S Q I N$

CUTTING SPEED

HORIZONTAL
CFM LUBRICATION

PHASE

QTY REQ'D 


\begin{abstract}
SUPPORT EQUIPMENT TECHNICAL DESCRIPTION HANDBOOK

EQUIPMENT TITLE

FIXTURE, LIFTING, INSULATING SHIELD, XE

PROV. LIST

ITEM NO.

4134

DATE

REVISION

DESCRIPTION: The XE Insulating Shield Lifting Fixture is a three-legged, steel strongback with a manipulator handle as the lifting bail at the center. The legs are essentially equally spaced and have a horizontal member at each lower end. When the legs are lowered with a manipulator through three 5-inch-diameter control-drum actuator access holes in the shield and the fixture rotated a few degrees, the horizontal members engage the underside, and a manipulator can be used to lift the insulating shield from the external shield. The fixture is required for remote removal of the $\mathrm{XE}$ insulating-shield from the external shield after remote removal of the UTSM during postfire engine disassembly operations.
\end{abstract}

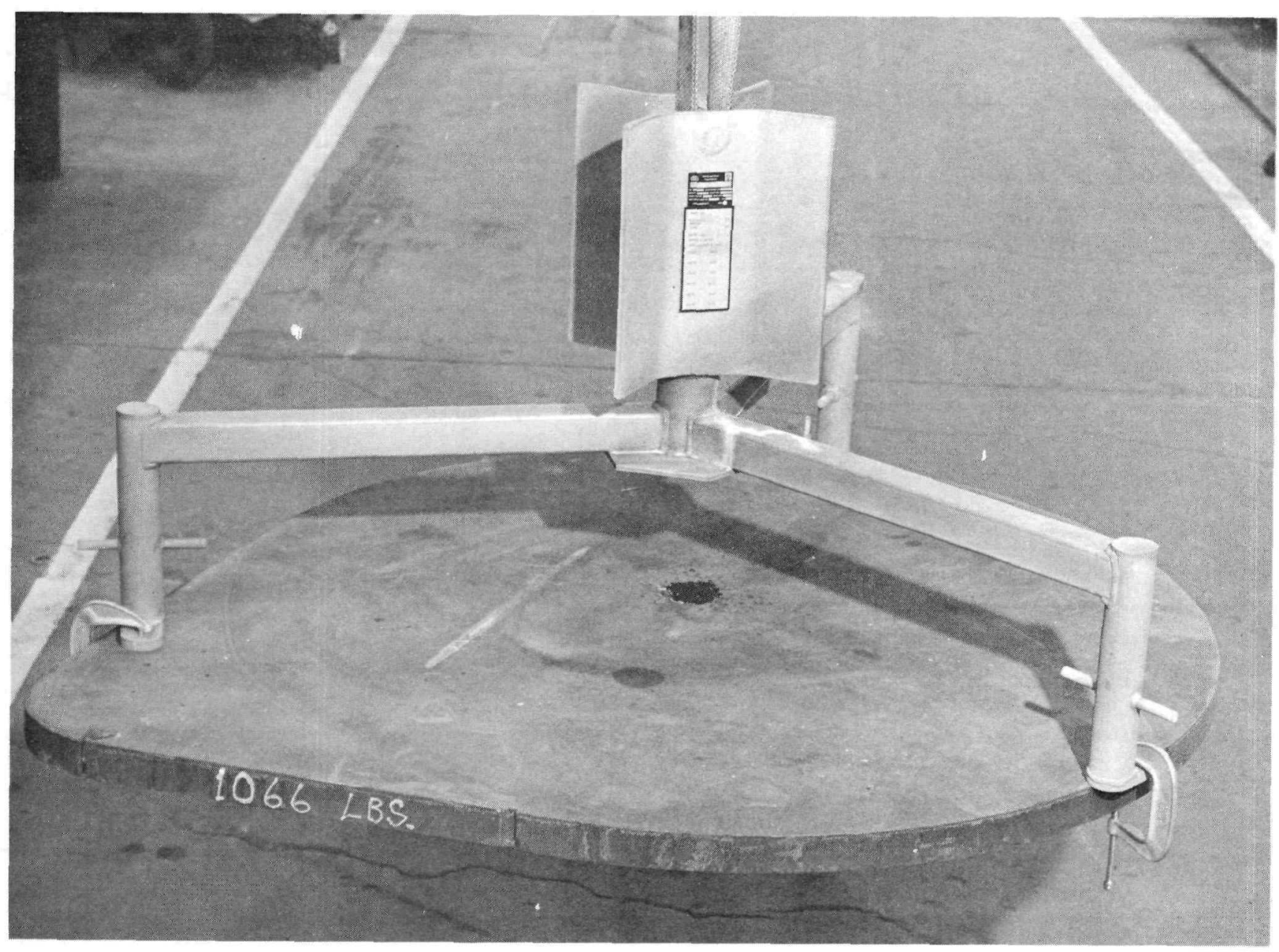


PROVISIONING LIST ITEM NUMBER 4134

DRAWING NUMBER $11174 \overline{58}$

PART NUMBER

CONTRACTOR
1117458

AGC
FIRST PROVISIONED FOR

$\mathrm{XE}$ GOVT. INV. CONTROL NUMBER

$\cos T$ $\$ 700$

\begin{tabular}{|r||c|}
\hline \multicolumn{1}{|c||}{ USE LOCATION } & QTY REQ'D \\
\hline A. AGC SACRAMENTO & \\
\hline B. WANL & \\
\hline C. & 1 \\
\hline D. NRDS TOTAL & 1 \\
\hline \multicolumn{2}{|c|}{} \\
\hline
\end{tabular}

DIMENSIONS AND CAPACITY

DIA WEIGHT 100 FLOOR AREA REQUIRED ADDITIONAL DATA
LENGTH

$45^{\prime \prime}$ LB LOAD CAPACITY SQ FT

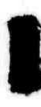

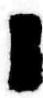

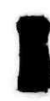

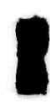

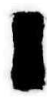

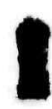

OPERATING DATA

GASES

ELECTRICAL

LIQUIDS

SPEED

MEASURING ACCURACY

CALIBRATION INTERVAL

ADDITIONAL DATA
PRESSURE VOLTS

PRESSURE IN./MIN (RPM)
LB/SQIN. VOLUME

CPS

$L B / S Q$ IN

CUTTING SPEED

HORIZONTAL
CFM LUBRICATION

PHASE

QTY REQ'D

VERTICAL $24^{\prime \prime}$ $-L B$ $L B / S Q$ IN
MANIPULATOR _ E-MAD/WMHS

CRANE

ADDITIONAL DATA
LOAD CAPACITY LOAD CAPACITY
600

LB MAX

LB MAX
EQUIPMENT. PART OR ITEM E-MAD/WMHS Manipulator, Class A REMARKS
DRAWING NO.

1118621 
PROV. LIST

ITEM NO.

EQUIPMENT TITLE REVISION

PROTECTOR, FLANGE, PRESSURE VESSEL

DESCRIPTION: The Pressure Vessel Flange Protector is a flat, three-segment plastic ring which bolts to the pressure-vessel forward closure flange. It protects the pressure-vessel forward flange and the forward-closure seal surface during reactor and shield installation and other operations performed prior to installation of the forward closure. 
PROVISIONING LIST ITEM NUMBER 4135

DRAWING NUMBER

PART NUMBER

CONTRACTOR
1118755

1118755

AGC
FIRST PROVISIONED FOR

GOVT. INV. CONTROL NUMBER

$\cos T$
$\mathrm{XE}$

$\$ 900$ (Set)

\begin{tabular}{|l||c|}
\hline \multicolumn{1}{|c||}{ USE LOCATION } & QTY REQ'D \\
\hline A. AGC SACRAMENTO & \\
\hline B. WANL & 3 \\
\hline C. & \\
\hline D. NRDS TOTAL & 3 \\
\hline \multicolumn{2}{|c|}{} \\
\hline
\end{tabular}

DIMENSIONS AND CAPACITY

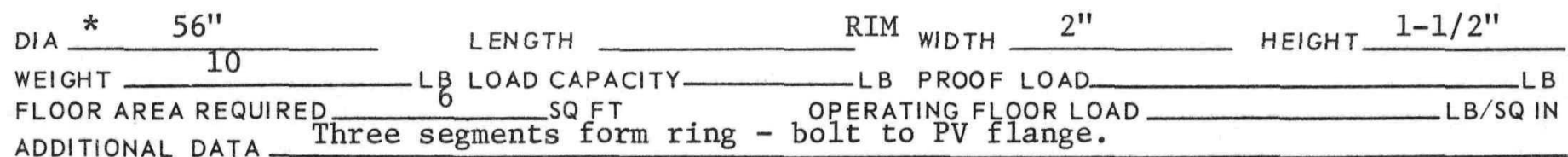

*Dimensions of 3 equal-segments in form of a ring.

OPERATING DATA

GASES PRESSURE

ELECTRICAL

LIQUIDS

SPEED

MEASURING ACCURACY

CALIBRATION INTERVAL

ADDITIONAL DATA

VOL.TS

PRESSURE

IN./MIN (RPM)
LB/SQIN. VOLUME

\section{CPS}

$L B / S Q I N$

CUTTING SPEED

HORIZONTAL.
CFM LUBRICATION

PHASE

QTY REQ'D

PART OR ITEM Pressure VesseI Forward Flange DRAWING NO. 
PROV. LIST

ITEM NO.

4142

DATE

SUPPORT EQUIPMENT

TECHNICAL DESCRIPTION HANDBOOK

January 1968

EQUIPMENT TITLE

REVISION

KIT, MODIFICATION, HANDLING FIXTURE FORWARD CLOSURE, REMOTE

DESCRIPTION: The Remote Forward Closure Handling Fixture Modification Kit consists of replacement feet and retainers to adapt the reactor assembly handling fixture, $\mathrm{P} / \mathrm{L}$ 1143, for remote handling of the XE forward-closure during XE-engine disassembly in the E-MAD Building hot bay. The feet engage the forward closure 36-inch-diameter flange. Handling and operation procedures are identical with those for P/L 1143 . 
PROVISIONING LIST ITEM NUMBER 4142

DRAWING NUMBER

PART NUMBER

CONTRACTOR
1134013

1134013

AGC
FIRST PROVISIONED FOR $\mathrm{XE}$ GOVT. INV. CONTROL NUMBER

\begin{tabular}{|l||c|}
\hline \multicolumn{1}{|c||}{ USE LOCATION } & QTY REQ'D \\
\hline A. AGC SACRAMENTO & \\
\hline B. WANL & \\
\hline C. & 1 \\
\hline D. NRDS TOTAL & 1 \\
\hline
\end{tabular}

\section{DIMENSIONS AND CAPACITY}

DIA

WEIGHT 20 (Kit)

FLOOR AREA REQUIRED

LENGTH
LB LOAD CAPACITY
I0 SQFT

ADDITIONAL

plates and six shims to modify P/L 1143 for remote use with the XE forward-

closure.
WIDTH 500 LB PROOF LOAD OPERATING FLOOR LOAD $1000^{\mathrm{HEIGHT}}$ LB/SQ IN $-$
GASES PRESSURE

ELECTRICAL

LIQUIDS

SPEED

MEASURING ACCURACY

CALIBRATION INTERVAL

ADDITIONAL DATA 
DESCRIPTION: The Nozzle Throat Plug Poison Wire Retention Adapter is an aluminum column with a rubber-covered disk top. The column fits over and attaches to the plug projection-end (after cap removal) of the nozzle-throat plug assembly, P/L 453. It retains $\mathrm{XE}$-engine central poison wires during final assembly operations when the $\mathrm{P} / \mathrm{L}$ 4088-P/L 4408 combination is not available. 
PROVISIONING LIST ITEM NUMBER 4143

DRAWING NUMBER

PART NUMBER

CONTRACTOR
1134556

1134556

AGC
FIRST PROVISIONED FOR $\mathrm{XE}$ GOVT. INV. CONTROL NUMBER

$\operatorname{cosT} \$ 500$

\begin{tabular}{|c|c|}
\hline USE LOCATION & QTY REQ'D \\
\hline A. AGC SACRAMENTO & \\
\hline B. WANL & \\
\hline C. & \\
\hline D. NRDS & 1 \\
\hline TOTAL & 1 \\
\hline
\end{tabular}

\title{
DIMENSIONS AND CAPACITY
}

DIA $8-1 / 2^{\prime \prime}$

WEIGHT 10

FLOOR AREA REQUIRED

\section{LATA}

\begin{abstract}
LENGTH
\end{abstract} $29^{\prime \prime}$ B LOAD CAPACITY $2 \quad S Q F T$ WIDTH LB PROOF LOAD OPERATING FLOOR LOAD HEIGHT to retain central poison wires. Secures to P/L 453 with set screws.

\section{OPERATING DATA}

GASES

ELECTRICAL

LIQUIDS

SPEED.

MEASURING ACCURACY

CALIBRATION INTERVAL

ADDITIONAL DATA
PRESSURE VOLTS PRESSURE IN./MIN (RPM)
LB/SQIN. VOLUME

\section{CPS}

$L B / S Q I N$

CUTTING SPEED

HORIZONTAL
CFM LUBRICATION

PHASE

QTY REQ'D . 
EQUIPMENT TITLE

SET, FUNCTIONAL VALVE AND LEAK TEST

DESCRIPTION: The Functional Valve and Leak Test Set is a console unit containing electrical controls and indicating meters, a power supply, and a pneumatic controlpanel. The set also includes the connecting cable assemblies for connection to the engine/component; pneumatic hose assemblies for leak and functional check of the engine/component; fluid hoses for filling and draining of the external shield, and various adapters and tools for attachment to the engine/component. A separate TPCV actuator test-set is provided which, when used with the console, requires a separate power supply, recorder, and function generator. The console provides cable and hose connections on the rear panel. Storage for some cables, hoses, and accessories is provided in the back. A desk top is provided on the front. Front drawers store miscellaneous equipment and data. Doors cover and protect the operating panels when the set is not in use. The set leak tests the XE-engine pneumatic lines and system modules during and after assembly. It also provides the electrical controls, interconnection system, and pneumatic supply and control system to functionally check engine valves and actuators.

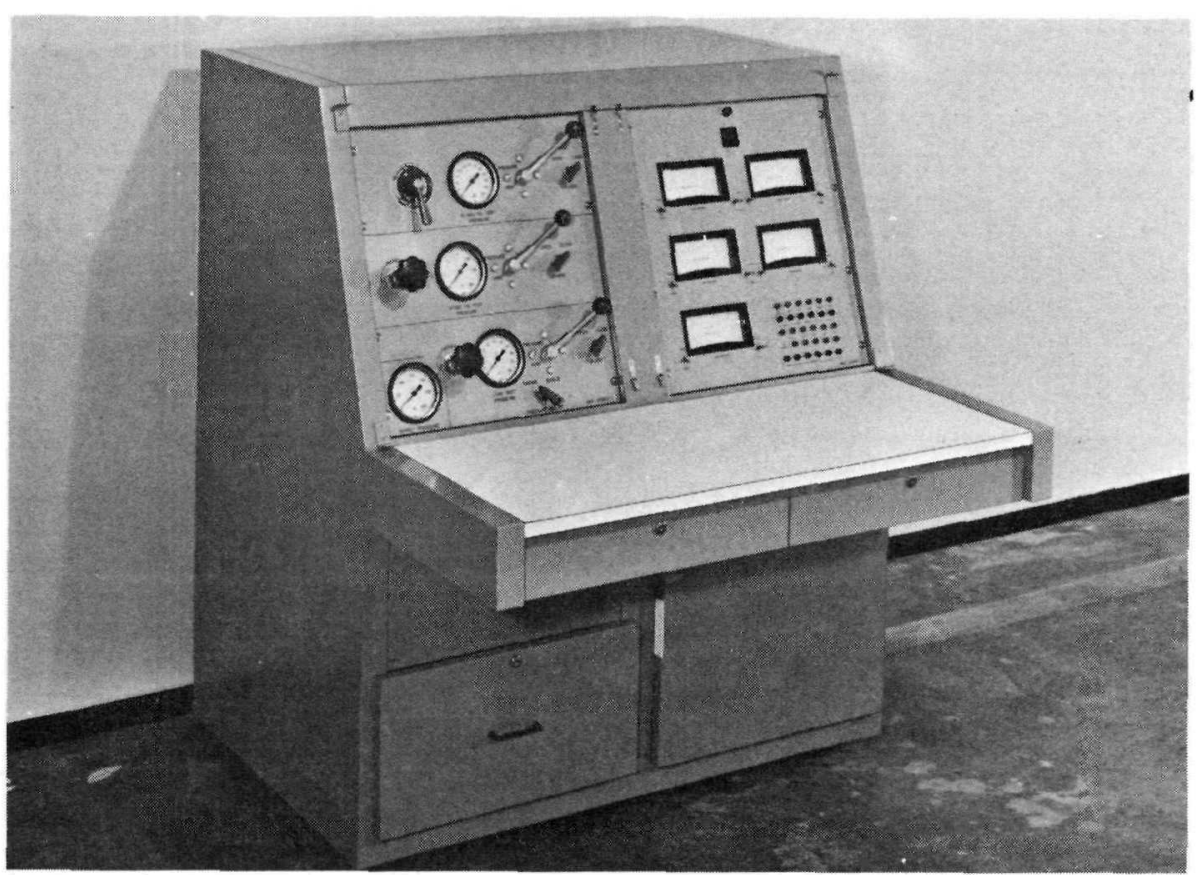


PROVISIONING LIST ITEM NUMBER

DRAWING NUMBER

PART NUMBER

CONTRACTOR
1117286

1117286

AGC
FIRST PROVISIONED FOR $\mathrm{XE}$

GOVT. INV. CONTROI NUMBER SNP-1-L-1861

\begin{tabular}{|l||c|}
\hline \multicolumn{1}{|c||}{ USE LOCATION } & QTY REQ'D \\
\hline A. AGC SACRAMENTO & \\
\hline B. WANL & \\
\hline C. & \\
\hline D. NRDS TOTAL & 1 \\
\hline
\end{tabular}

\section{DIMENSIONS AND CAPACITY}

DIA

WEIGHT

*

FLOOR AREA REQUIRED

LENGTH 46" *

- LB LOAD CAPACITY

$15^{S Q F T}$
WIDTH 44" *

LB PROOF LOAD

OPERATING FLOOR LOAD

HEIGHT

$52^{\prime \prime} *$

$-L B$

$L B / S Q$ IN

ADDITIONAL DATA Includes eight electrical cable assemblies, four pneumatic hose assemblies, and ten adapter and tools, including the TPCV actuator test set.

*Console Only

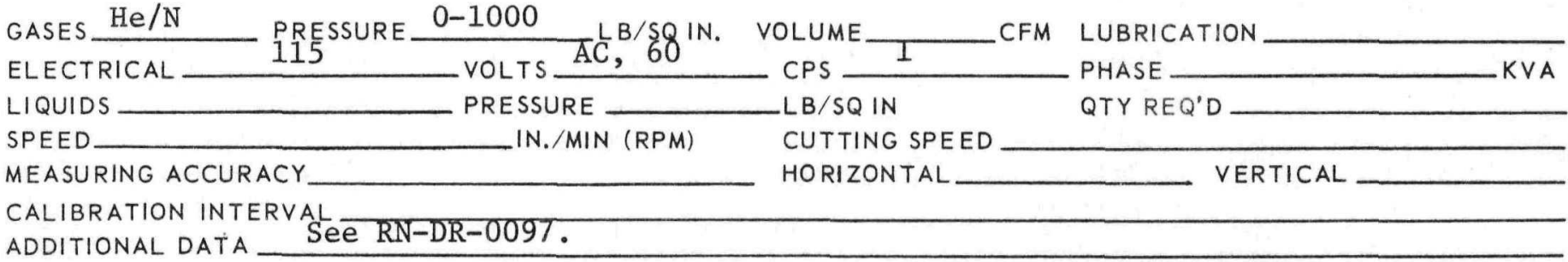

EQUIPMENT Facility Helium/Nitrogen Supplies. Facility Power PART OR ITEM XE Engine/Components Electrical/Pneumatic Connectors. REMARKS Requires external facility power-supply, recorder, and function generator for check of TPCV with the TPCV actuator test set. 
EQUIPMENT TITLE

SET, ELECTRICAL TEST

DESCRIPTION: The Electrical Test set is a console unit containing a patch board, coaxial cable terminals, dual-resistance decade box, and an impedance (RLC) bridge. The set also includes cable assemblies for connection to the engine/component, transducer-checkout cables and hose, and a connector removal-tool. The console provides cable connections on the rear panel. Storage shelves for some cables are provided in the back of the console. A desk top is provided on the front: drawers are provided on the front for patch cords, tools, and data storage. Doors cover and protect the operating panels when the set is not in use. The test set verifies operation of the XE engine's electrical control-harness, electrical instrumentation, and electrical controls when used in conjunction with the WANL-provisioned car wire-and-transducer checker, and the portable transducer checker.

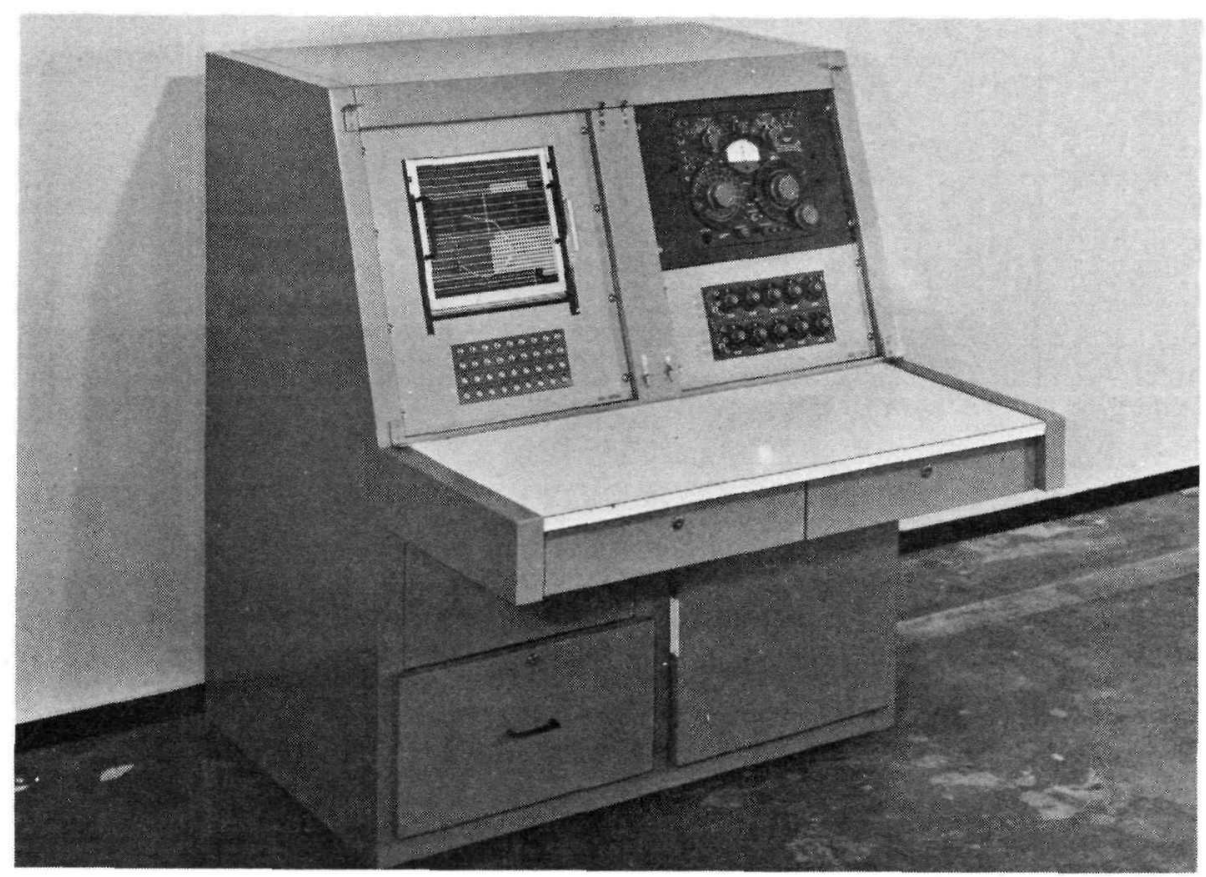


PROVISIONING LIST ITEM NUMBER 4401

DRAWING NUMBER

PART NUMBER

CONTRACTOR
1117297

1117297

AGC
FIRST PROVISIONED FOR $\mathrm{XE}$
GOVT. INV. CONTROL NUMBER

SNP-1-L-1860

\begin{tabular}{|l||c|}
\hline \multicolumn{1}{|c||}{ USE LOCATION } & QTY REQ'D \\
\hline A. AGC SACRAMENTO & \\
\hline B. WANL & \\
\hline C. & 1 \\
\hline D. NRDS TOTAL & 1 \\
\hline \multicolumn{2}{|c|}{} \\
\hline
\end{tabular}

DIMENSIONS AND CAPACITY

DIA LENGTH WIDTH $46^{\prime \prime *} \quad 44^{\prime \prime *}$ HEIGHT_ $52^{\prime \prime *}$ WEIGHT FLOOR AREA REQUIRED 15 SQ FT OPERATING FLOOR LOAD $L B / S Q I N$ ADDITIONAL DATA Two electrical cable assemblies and a hose assembly for transducer test, eleven engine checkout cable assemblies, and a connector removal tool are a part of this item.

*Dimension for the Console only

\section{OPERATING DATA}

GASES PRESSURE

ELECTRICAL

LIQUIDS SPEED MEASURING ACCURACY

CALIBRATION INTERVAL

ADDITIONAL DATA See Aerojet Report RN-DR-0119, Operating and Maintenance Instructions for Electrical Test Set $=4401$
LB/SQ IN. VOLUME VOLTS PRESSURE IN./MIN (RPM)
CPS

$L B / S Q$ IN CUTTING SPEED HORIZONTAL
CFM LUBRICATION

PHASE

QTY REQ'D 
DESCRIPTION: The Remote Helium Leak Detector Set is a modified USON Series-500 leak detector consisting of a remote detector head with a sampling hose, manipulator adapter, and a 100-foot electrical control cable. It also includes a meter and control box, a power-supply box, connecting cables, and a storage or carrying case. The set remotely determines the leakage rates from specific XE-engine line joints and fittings after remote replacement of the UTSM on a hot XE engine. The leakage indication, when compared with specification limits, determines the acceptability of the specific engine-line joint or fitting. 
PROVISIONING LIST ITEM NUMBER 4402

DRAWING NUMBER

PART NUMBER

CONTRACTOR
1118395

1118395

AGC (USON)
FIRST PROVISIONED FOR $\mathrm{XE}$

\begin{tabular}{|l||c|}
\hline \multicolumn{1}{|c||}{ USE LOCATION } & QTY REQ'D \\
\hline A. AGC SACRAMENTO & \\
\hline B. WANL & \\
\hline C. & 1 \\
\hline D. NRDS TOTAL & 1 \\
\hline \multicolumn{2}{|c|}{} \\
\hline
\end{tabular}

\section{DIMENSIONS AND CAPACITY}

DIA Carrying Case

FLOOR AREA REQUIRED
LENGTH

Y

$20^{\prime \prime}$ LB LOAD CAPACITY $S Q F T$
WIDTH

$16 "$ LB PROOF LOAD OPERATING FLOOR LOAD
HEIGHT $8^{\prime \prime}$ $-L B$ $L B / S Q I N$ ADDITIONAL DATA Set consists of detector head assembly with 100 cable, a control box, a power supply, and connecting cables. The 100-foot cable is installed through the E-MAD wall so the control is in the operator area.

GASES

ELECTRICAL

PRESSURE 110

LIQUIDS

SPEED

MEASURING ACCURACY

CALIBRATION INTERVAL

ADDITIONAL DATA See RN-DR-0137.
LB/SQIN. VOLUME VOLTS AC PRESSURE IN./MIN (RPM) 60

\section{$L B / S Q I N$}

CUTTING SPEED HORIZONTAL
CFM LUBRICATION

PHASE

QTY REQ'D
KVA

\section{OPERATING EQUIPMENT}

MANIPULATOR _ E-MAD/WMHS

CRANE

ADDITIONAL DATA
LOAD CAPACITY

LOAD CAPACITY
600

LB MAX

LB MAX

INTERFACES

EQUIPMENT

E-MAD/WMHS

PART OR ITEM Equipment Rack P/L

DRAWING NO.

REMARKS Used with a manipulator to place near and sense leakage from Marman clamp/ conoseal line joints. 
EQUIPMENT TITLE

KIT, CLOSURE, ENGINE LEAK TESTING

DESCRIPTION: The Engine Leak Testing Closure Kit consists of 12 small closures and couplings (2-3/4 inch), 14 large line-and-port closures and couplings ( 4 to 8 inch), a security clamp for the nozzle hot-bleed-port closure, and two storage boxes.

Except for two, dish-shaped nozzle port closures, all closures are shallow disks made of CRES or aluminum with hex-bar pedestal handles. The couplings are Marman $\mathrm{V}$-band or two-section V-clamps. The large 8-inch line closure contains a pneumatic fitting for engine pressure-testing. A set of conoseal gaskets are included. The kit is used to close ports and lines in the engine propellant system for leak testing of the engine and engine subassemblies during and after cold assembly operations.

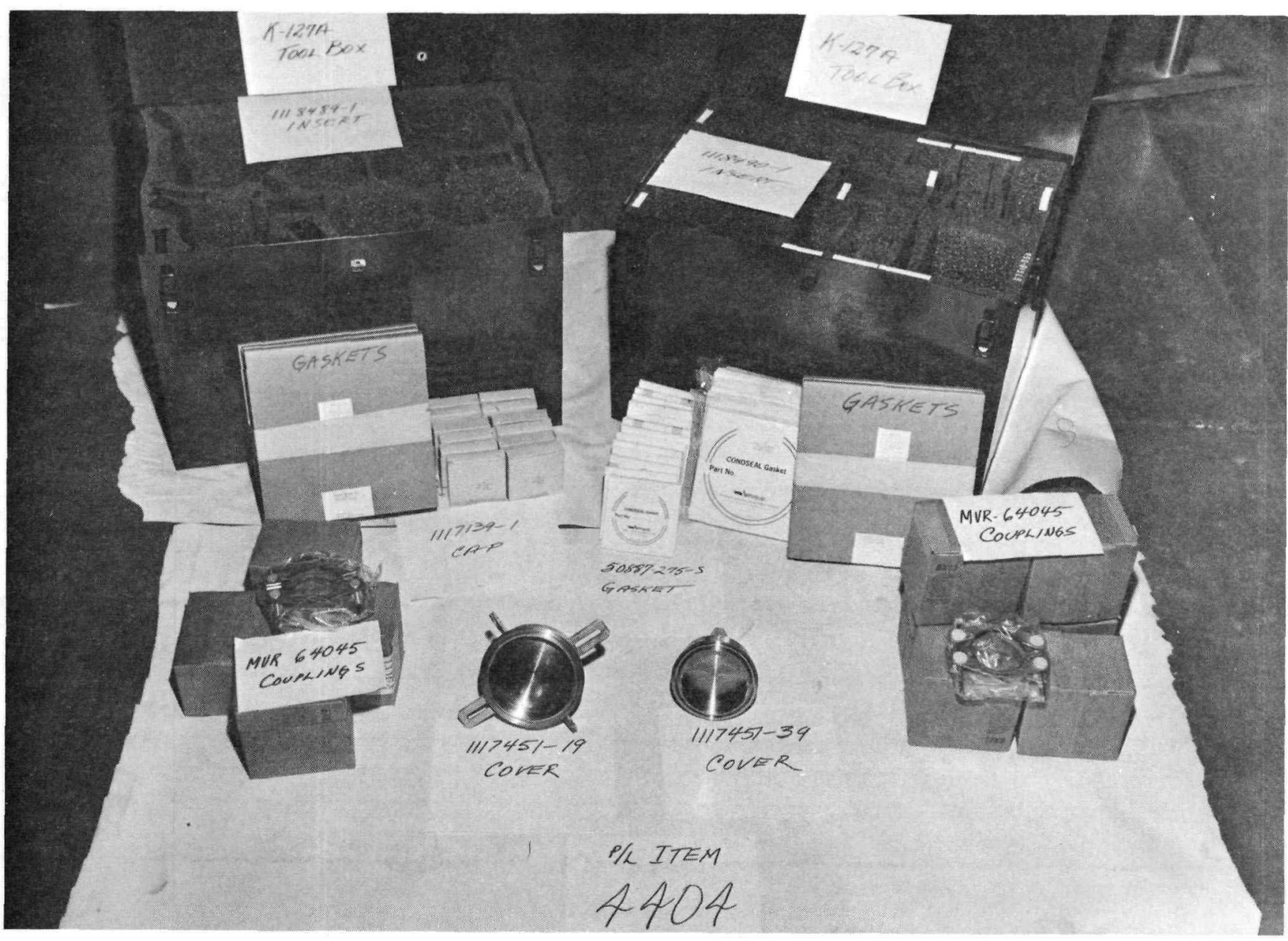


PROVISIONING LIST ITEM NUMBER

DRAWING NUMBER

PART NUMBER

CONTRACTOR
4404

1117450

1117450

AGC
FIRST PROVISIONED FOR $\mathrm{XE}$ GOVT. INV. CONTROL NUMBER

$\operatorname{cosT} \quad \$ 10.000$

\begin{tabular}{|l||c|}
\hline \multicolumn{1}{|c||}{ USE LOCATION } & QTY REQ'D \\
\hline A. AGC SACRAMENTO & \\
\hline B. WANL & \\
\hline C. & \\
\hline D. NRDS TOTAL & 1 \\
\hline
\end{tabular}

\section{DIMENSIONS AND CAPACITY}

DIA 2 Boxes Each WEIGHT 100

FLOOR AREA REQUIRED _ 5
LENGTH 28" LB LOAD CAPACITY 5

\section{$S Q F T$}

WIDTH $12^{\prime \prime}$ LB PROOF LOAD OPERATING FLOOR LOAD
HEIGHT_ 18" $-L B$ $L B / S Q$ IN

ADDITIONAL DATA Closures used during leak testing of engine assembly or subassemblies to 50 psi. Proof test of closures is 100 psi. Seals are normally supplied from facility stock.

GASES PRESSURE

ELECTRICAL

LIQUIDS

SPEED

MEASURING ACCURACY

CALIBRATION INTERVAL

ADDITIONAL DATA SEe RN-DR-0121.
LB/SQIN. VOLUME

VOLTS

PRESSURE

IN./MIN (RPM)
CPS

$-L B / S Q$ IN

CUTTING SPEED

HORIZONTAL
CFM LUBRICATION

PHASE

QTY REQ'D

\section{VERTICAL}

ADDITIONAL DATA All manual operations Derformed With standard tools.

\section{INTERFACES}

EQUIPMENT.

PART OR ITEM Engine/Subassembly Line Ports and Lines

REMARKS Closures and couplings provided for $5^{\prime \prime}$ and $8^{\prime \prime}$ line ports at Engine Station 41.42 ; contro1-drum actuator ports, Station $136.47 ; 4^{\prime \prime} 5^{\prime \prime}$ and $6-1 / 2^{\prime \prime}$ ports/1ines, Station 185.14; and two hot-bleed-ports. 


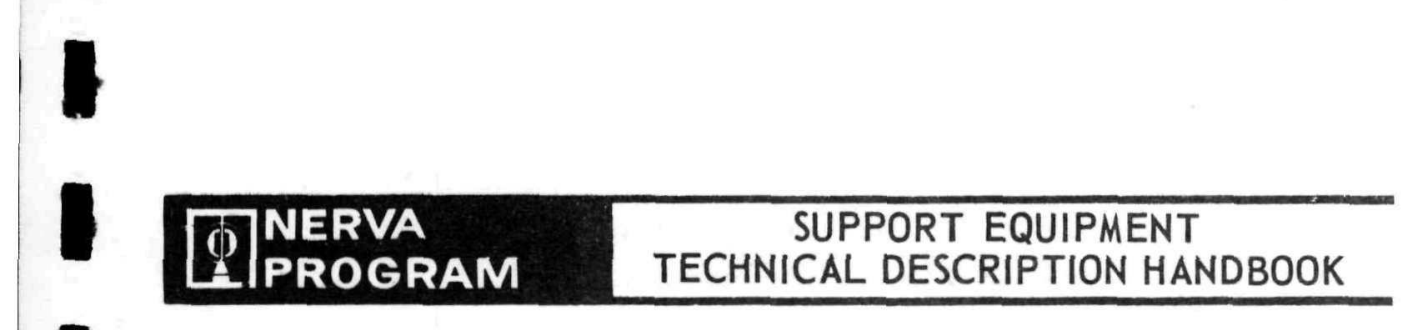

EQUIPMENT TITLE

PROV. LIST

ITEM NO.

4408

DATE

January 1968

REVISION

FIXTURE, RETENTION, CENTRAL CORE POISON WIRE

DESCRIPTION: The Central Core Poison Wire Retention Fixture is a tubular aluminum assembly with a mounting plate on one end and a rubber-covered disk on the other. The mounting-plate-end bolts to the inner face of the nozzle closure, P/L 4088, when the fixture is required to retain the central-core poison wires during final engine assembly operations (i.e., after peripheral wire removal and prior to central-wire removal). The rubber-covered disk extends through the nozzle throat to support and retain the central-core poison wires.

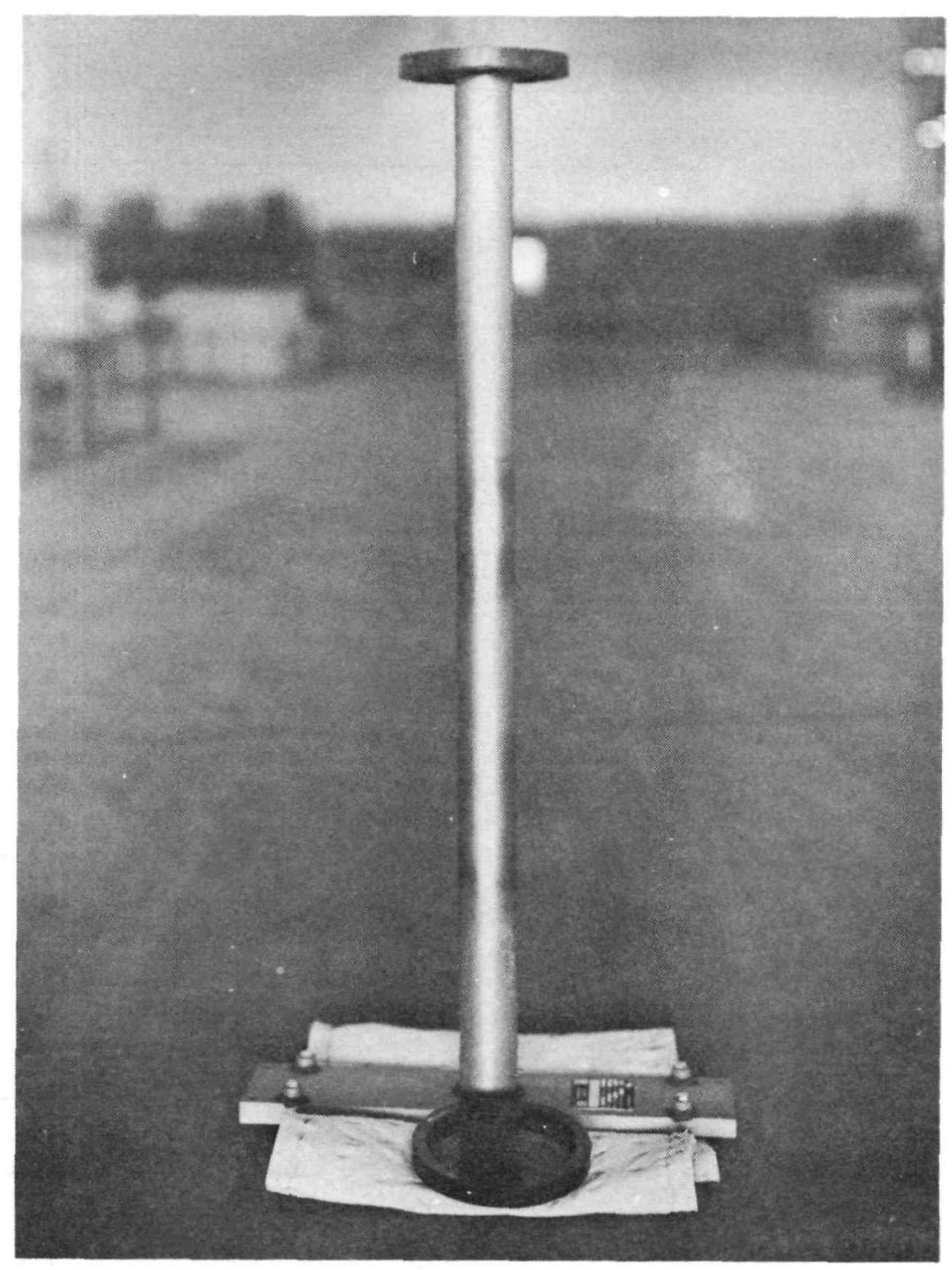


TECHNICAL SUMMARY

PROVISIONING LIST ITEM NUMBER

DRAWING NUMBER

PART NUMBER

CONTRACTOR
$111744 \overline{6}$

Same

AGC
4408

Same

FIRST PROVISIONED FOR

$\mathrm{XE}$

\begin{tabular}{|l||c|}
\hline \multicolumn{1}{|c||}{ USE LOCATION } & QTY REQ'D \\
\hline A. AGC SACRAMENTO & \\
\hline B. WANL & \\
\hline C. & 1 \\
\hline D. NRDS TOTAL & 1 \\
\hline
\end{tabular}

\section{DIMENSIONS AND CAPACITY}

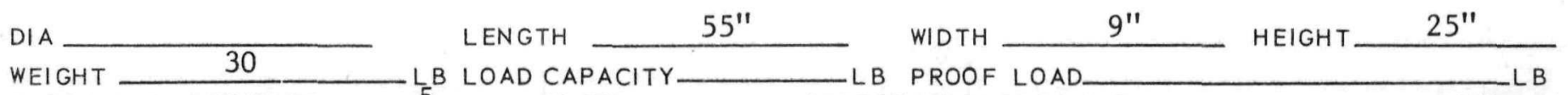

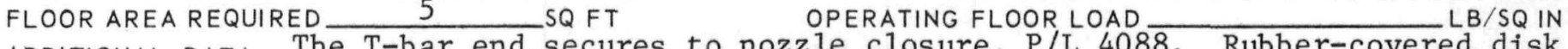
ADDITIONAL DATA The T-bar end secures to nozzle closure, P/L 4088. Rubber-covered disk supports central core poison wires when the fixture and closure are installed.

GASES

ELECTRICAL

LIQUIDS

SPEED

MEASURING ACCURACY

CALIBRATION INTERVAL

ADDITIONAL DATA
PRESSURE VOLTS

PRESSURE IN./MIN (RPM)
LB/SQIN. VOLUME.

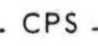

CPS

$L B / S Q$ IN

CUTTING SPEED

HORIZONTAL
CFM LUBRICATION

PHASE

QTY REQ'D

VERTICAL

ADDITIONAL DATA Manually installed to nozzle closure, $\mathrm{P} / \mathrm{L} 4088$.

EQUIPMENT Nozzle Closure, P/L 4088.

PART OR ITEM NOzzle/PVARA Assembly DRAWING NO.

REMARKS 
PROV. LIST

ITEM NO.

4409

DATE

TECHNICAL DESCRIPTION HANDBOOK

\section{REVISION}

EQUIPMENT TITLE

SIMULATOR, ELECTRICAL

DESCRIPTION: The Electrical Simulator is a portable test unit containing a patch panel, special test-equipment binding posts, millivolt power supply, compatible electrical connectors, and electrical resistance, inductance, capacitance, and resistance bridges equated to engine components for checkout and verification purposes. The unit sets on a table and has two recessed handles for lifting and a panel cover for protection when not in use. The simulator electrically represents the engine to verify the electrical system and interconnecting cables of Functional Valve and Leak Test Set, P/L 4400; Electrical Test Set, P/L 4401; and Remote Checkout Adapter Kit, $\mathrm{P} / \mathrm{L}$ 4043. It also verifies interconnection of WANL-supplied equipment as required for the overall checkout system. It also establishes cable resistance and capacitance constants, serves as a "trouble-shooting" tool, and electrically verifies equipment after modification.

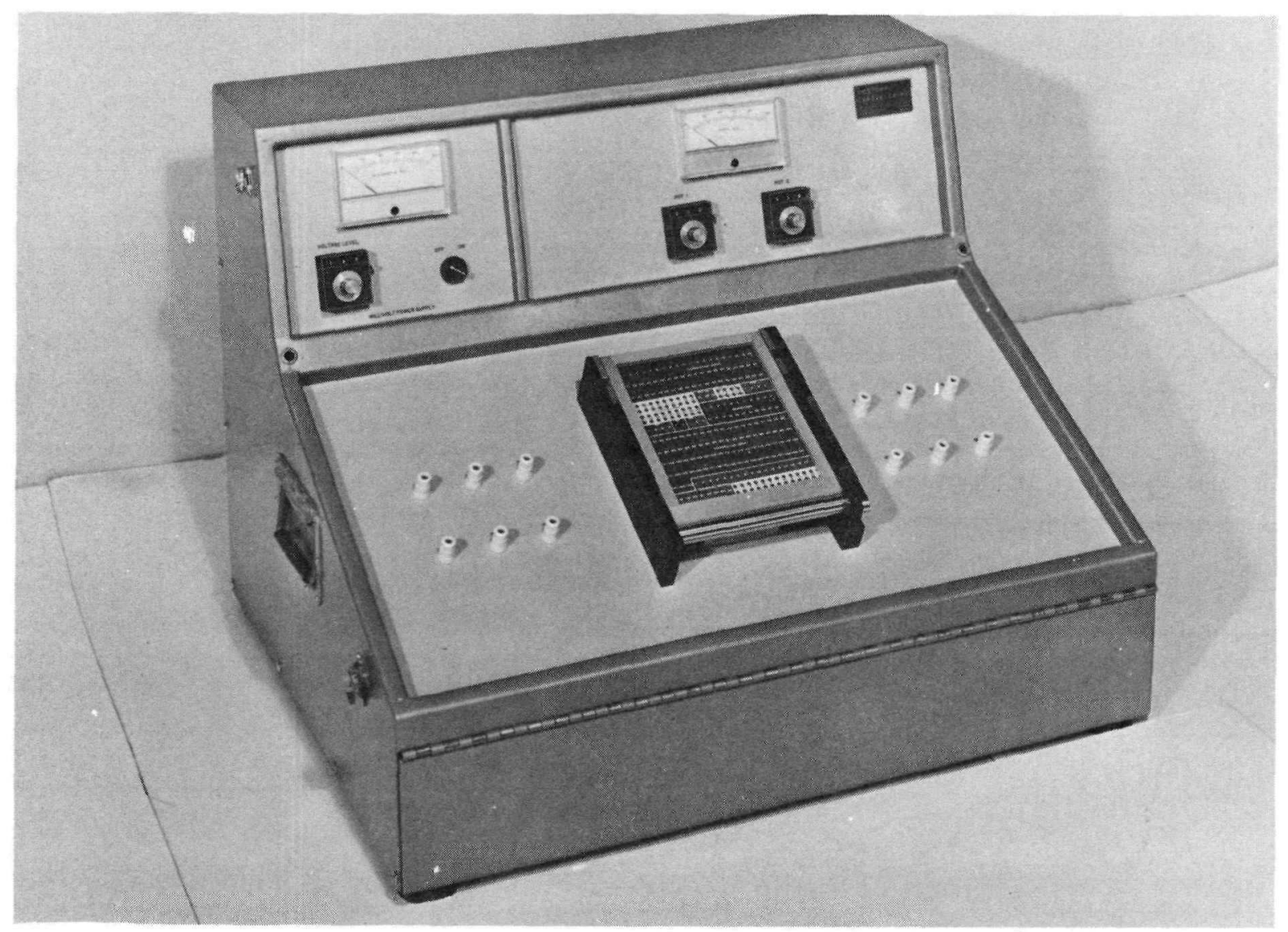


PROVISIONING LIST ITEM NUMBER

DRAWING NUMBER

PART NUMBER

CONTRACTOR
4409 1118560

Same

AGC
FIRST PROVISIONED FOR

$\mathrm{XE}$

$\operatorname{cosT}$ $\$ 6,000$

\begin{tabular}{|l||c|}
\hline \multicolumn{1}{|c||}{ USE LOCATION } & QTY REQ'D \\
\hline A. AGC SACRAMENTO & \\
\hline B. WANL & \\
\hline C. & 1 \\
\hline D. NRDS TOTAL & 1 \\
\hline
\end{tabular}

\section{DIMENSIONS AND CAPACITY}

DI A

LENGTH $30^{\prime \prime}$

WIDTH 24" HEIGHT

$22^{\prime \prime}$ WEIGHT 120 LB LOAD CAPACITY FLOOR AREA REQUIRED 5 SQ FT ADDITIONAL DATA Connectors are the same as on the engine. Circuits are patched through a panel to represent any engine-component electrical parameter. A millivolt meter and variable resistances with a voltmeter are also provided. Binding-post terminals are used with external equipment.

\section{OPERATING DATA}

GASES PRESSURE

\section{ELECTRICAL}

LIQUIDS

SPEED

MEASURING ACCURACY

CALIBRATION INTERVAL

ADDITIONAL DATA See RN-DR-0099.
LB/SQIN. VOLUME VOLTS

PRESSURE IN./MIN (RPM)

\section{OPERATING EQUIPMENT}

CFM LUBRICATION

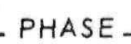

CUTTING SPEED HORIZONTAL VERTICAL $\longrightarrow L$ $L B / S Q$ IN 


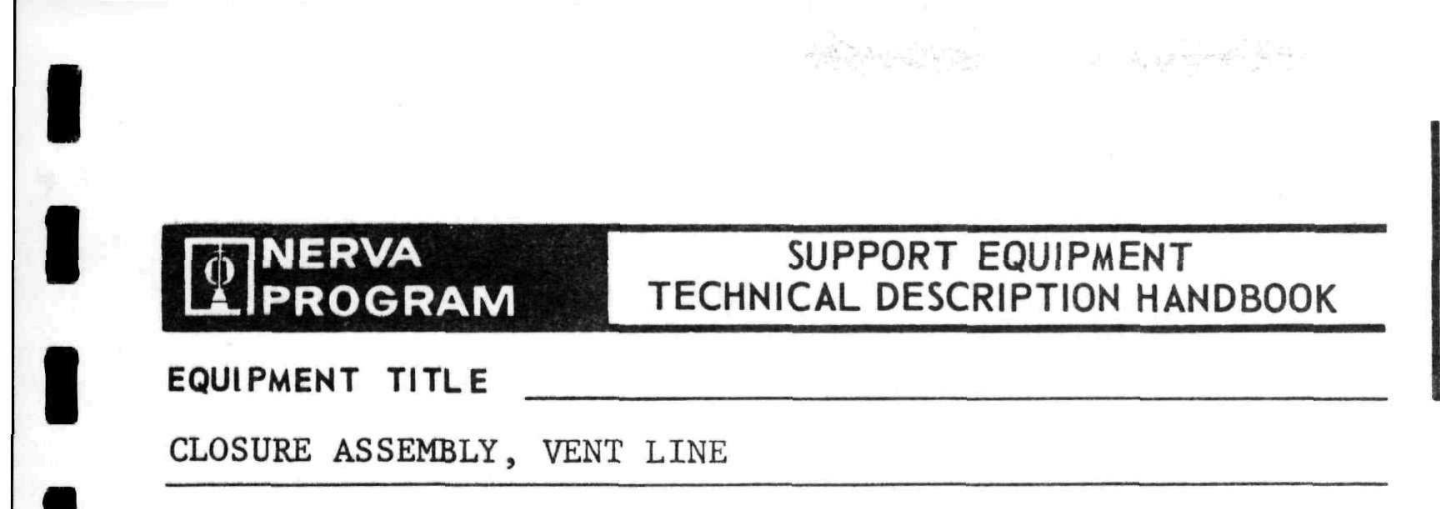

ITEM NO.

4412

DATE

REVISION

January 1968

DESCRIPTION: The Vent Line Closure Assembly is a modified 1-1/4-inch Wiggins quick-disconnect hydraulic coupling using a solid plug, with an 0-ring seal, and a remote adapter-sleeve. To seal the actuator vent line, the closure may be manually or remotely installed and removed from the engine control-drum actuator during engine leak tests and inerting operations.

NOTE: The unit currently provided to NRDS and shown here is for manual operation only. Modification, including the remote adapter sleeve, will be provided during CY 1968.

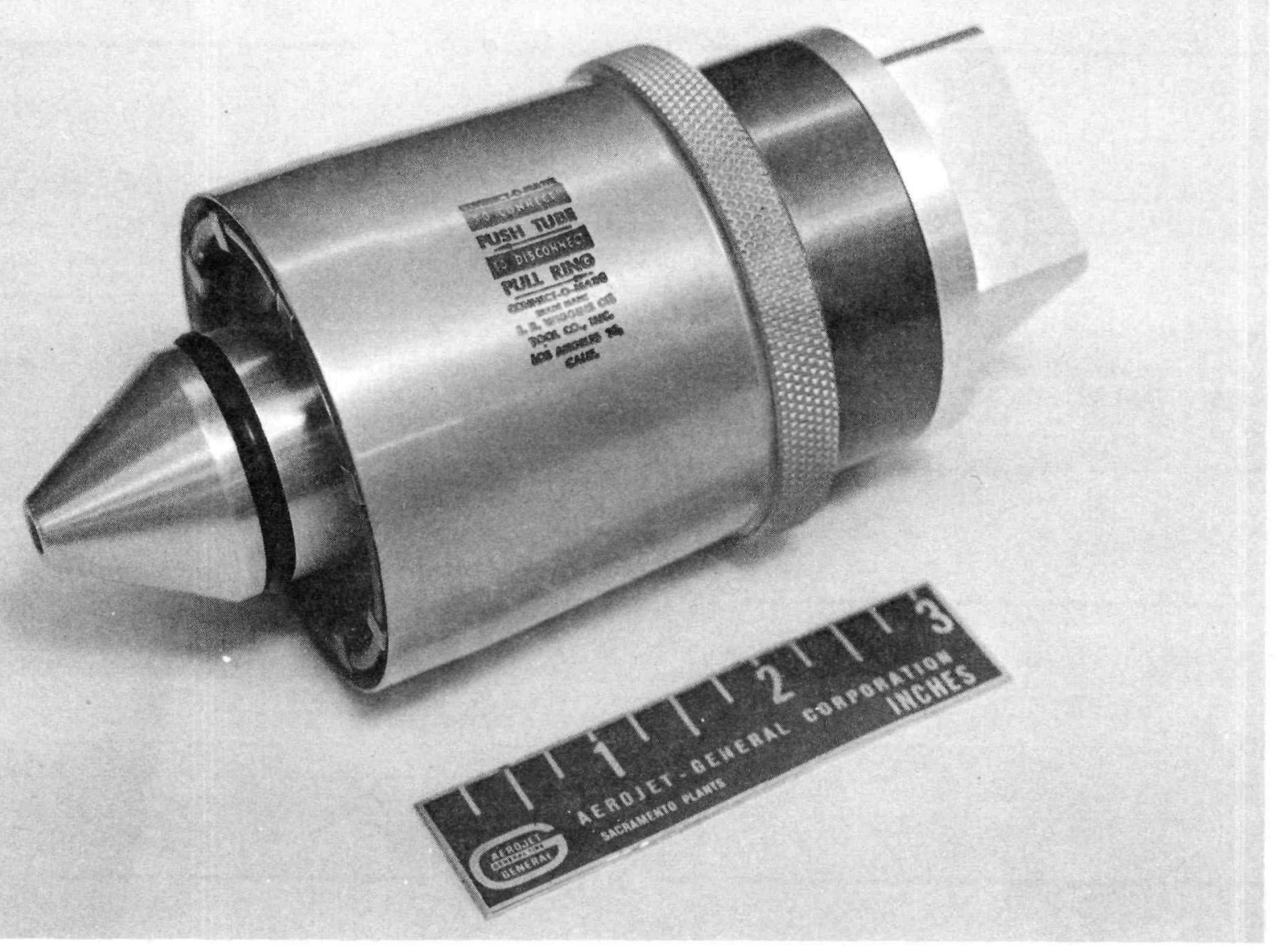


PROVISIONING LIST ITEM NUMBER

DRAWING NUMBER

PART NUMBER

CONTRACTOR
4412 1134414

Same AGC
FIRST PROVISIONED FOR XE
GOVT. INV. CONTROL NUMBER

$\cos T-\$ 300$

\begin{tabular}{|l||c|}
\hline \multicolumn{1}{|c||}{ USE LOCATION } & QTY REQ'D \\
\hline A. AGC SACRAMENTO & \\
\hline B. WANL & \\
\hline C. & 1 \\
\hline D. NRDS TOTAL & 1 \\
\hline
\end{tabular}

\section{DIMENSIONS AND CAPACITY}

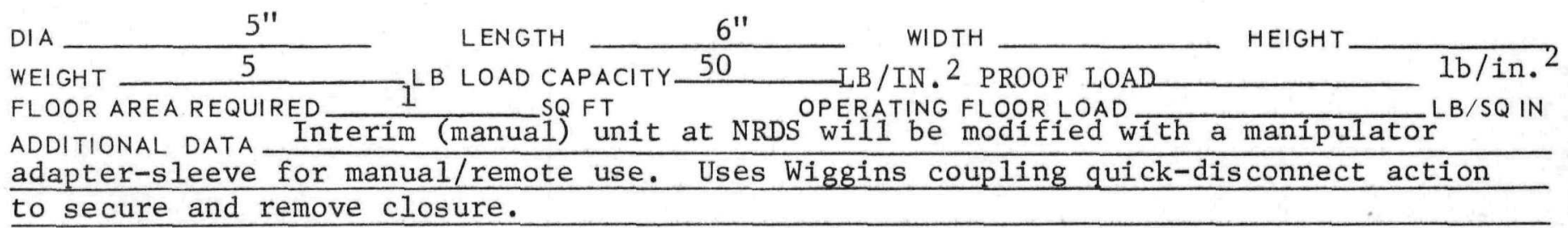

GASES PRESSURE

ELECTRICAL

LIQUIDS

SPEED

MEASURING ACCURACY

CALIBRATION INTERVAL

ADDITIONAL DATA

\section{OPERATING DATA}




\section{(1) NERVA PROGRAM \\ SUPPORT EQUIPMENT TECHNICAL DESCRIPTION HANDBOOK}

EQUIPMENT TITLE
PROV. LIST

ITEM NO.

4420

DATE

$\frac{\text { January } 1968}{\text { REVISION }}$

SIMULATED ENGINE TEST STAND NO. 1

DESCRIPTION: The Simulated Engine Test Stand No. 1 dimensionally represents ETS-1 with respect to engine installation and the standard-gage railroad facility. It is a four-column, steel structure with top peripheral and cross members to which are mounted four engine test-stand attachment fittings. Tie braces are provided on three sides; the fourth side, open to the rail end, is braced externally by cables to facility deadmen. The structure sits on four foundation-pads. The columns adjacent to the open end have sheet-metal skirts to simulate ETS-1 column diameter. The stand is used to develop engine/stand handling procedures with the MCC/EIV prior to ETS-1 availability.

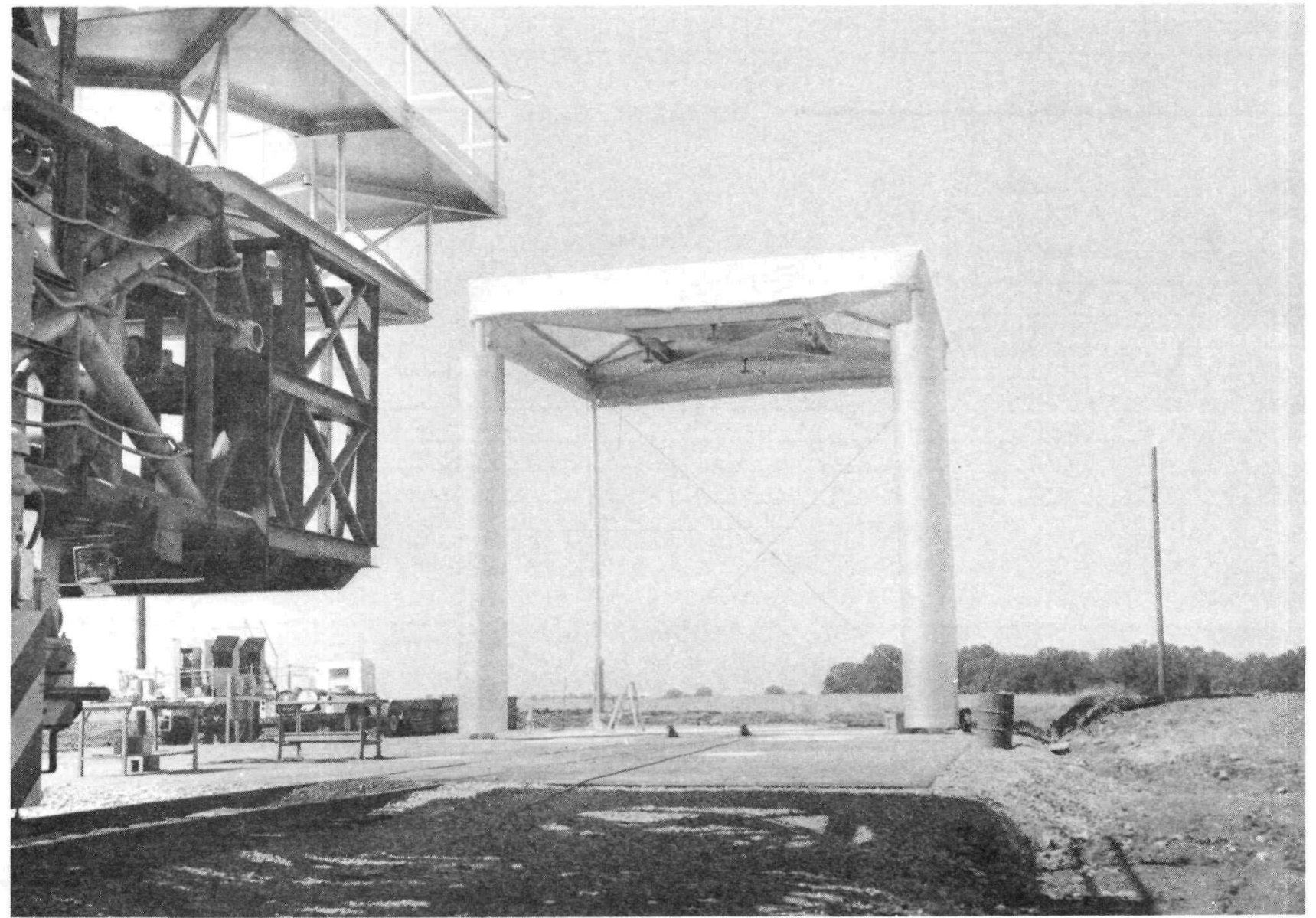


PROVISIONING LIST ITEM NUMBER 4420

DRAWING NUMBER

PART NUMBER

CONTRACTOR
SPE 69-1-65

Same

AGC
FIRST PROVISIONED FOR

$\mathrm{XE}$

GOVT. INV. CONTROL NUMBER SNP-i-L-1391

CosT $\$ 5,000$

\begin{tabular}{|c|c|}
\hline USE LOCATION & QTY REQ'D \\
\hline A. AGC SACRAMENTO & \\
\hline B. WANL & \\
\hline C. & \\
\hline D. NRDS & 1 \\
\hline TOTAL & 1 \\
\hline
\end{tabular}

DIMENSIONS AND CAPACITY

DIA

WEIGHT

FLOOR AREA REQUIRED

ADDITIONAL DATA

\section{OPERATING DATA}

GASES PRESSURE

\section{ELECTRICAL}

LIQUIDS

SPEED

MEASURING ACCURACY

CALIBRATION INTERVAL

ADDITIONAL DATA

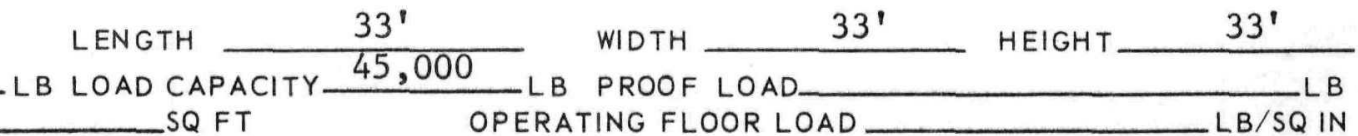

LB/SQIN. VOLUME

VOLTS

PRESSURE

IN./MIN (RPM)

ADDITIONAL DATA

LB MAX LB MAX

EQUIPMENT

PART OR ITEM XE Engine TSA

DRAWING NO. $\quad 1115459$

REMARKS Stand is located at NRDS near the E-MAD Building at the end of the

turn-around railroad spur. 


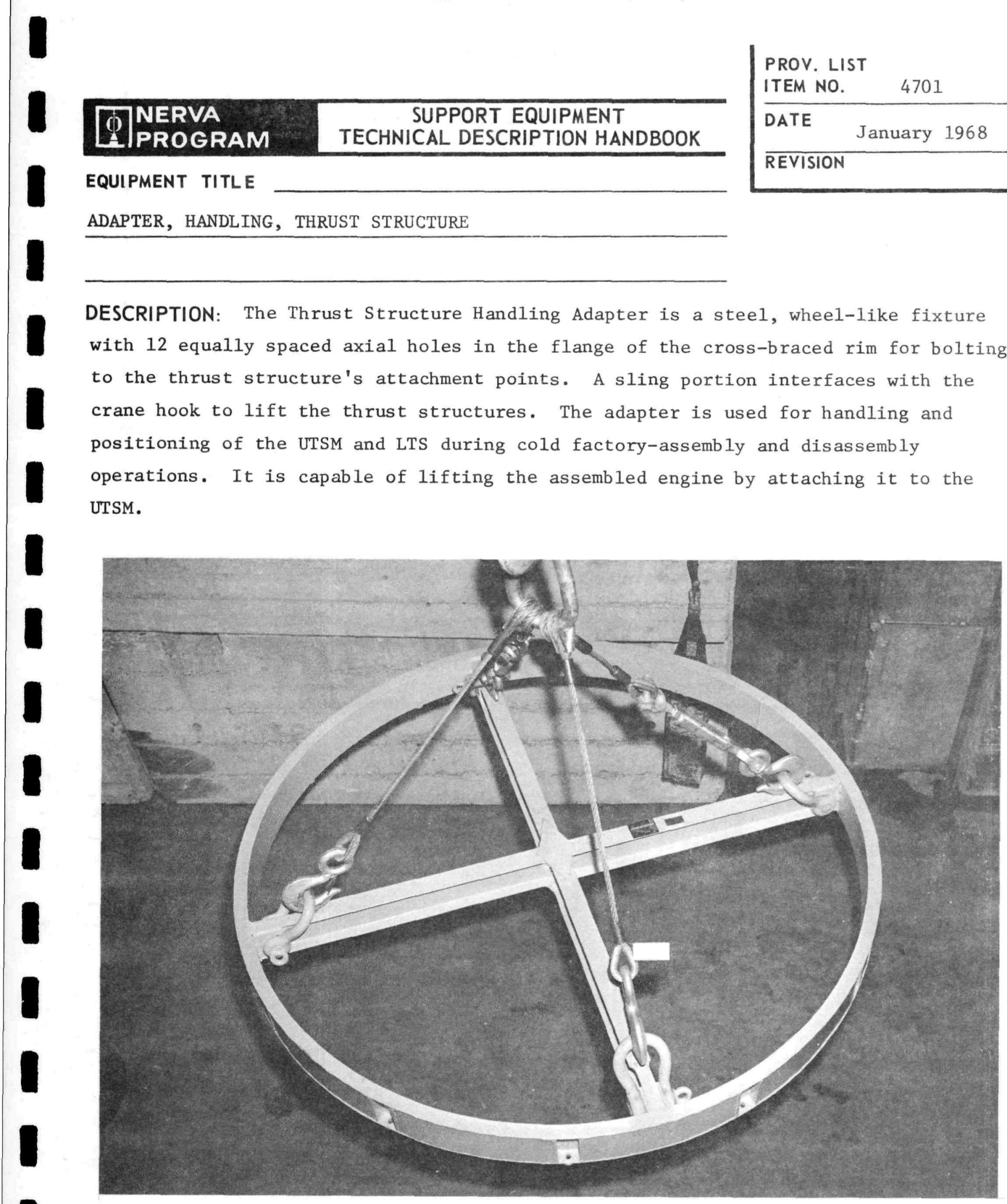


PROVISIONING LIST ITEM NUMBER DRAWING NUMBER

PART NUMBER CONTRACTOR
4701 278930 278930-39 AGC
FIRST PROVISIONED FOR $\mathrm{XE}$ GOVT. INV. CONTROL NUMBER

COST $\$ 1,800$

\begin{tabular}{|l||c|}
\hline \multicolumn{1}{|c||}{ USE LOCATION } & QTY REQ'D \\
\hline A. AGC SACRAMENTO & 1 \\
\hline B. WANL & \\
\hline C. & \\
\hline D. NRDS TOTAL & 1 \\
\hline
\end{tabular}

\section{DIMENSIONS AND CAPACITY}

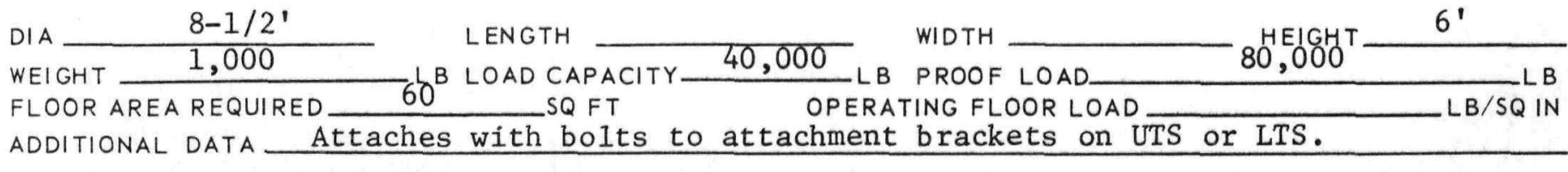

GASES

ELECTRICAL

LIQUIDS

SPEED

MEASURING ACCURACY

CALIBRATION INTERVAL

ADDITIONAL DATA See RN-S-0155.
LB/SQIN. VOLUME

VOLTS

PRESSURE

IN./MIN (RPM)
CPS

$L B / S Q I N$

CUTTING SPEED

HORIZONTAL
CFM LUBRICATION

PHASE

QTY REQ'D
MANIPULATOR

CRANE

ADDITIONAL DATA
High Bay - Sacramento
LOAD CAPACITY
- LOAD CAPACITY

80,000

LB MAX

LB MAX

INTERFACES

EQUIPMENT 40-ton Crane, Sacramento

PART OR ITEM UTSM Or LTS DRAWING NO.

REMARKS 


\section{DATE}

EQUIPMENT TITLE

PLATFORM, MAINTENANCE, ENGINE

DESCRIPTION: The Engine Maintenance Platform is constructed of welded aluminum tubing and plate with aluminum-grate platforms at two levels. An auxiliary stand is located atop the second level for work on the engine nozzle. The platform gratings contain clearance holes for the engine and four propellant-lines. The stand can be dismantled and is equipped with stairs and guard rails which are removable. The platform is used in the E-MAD Building cold bay in conjunction with the engine assembly stand, P/L 4021, to provide personnel access during $\mathrm{XE}$-engine assembly and checkout operations.
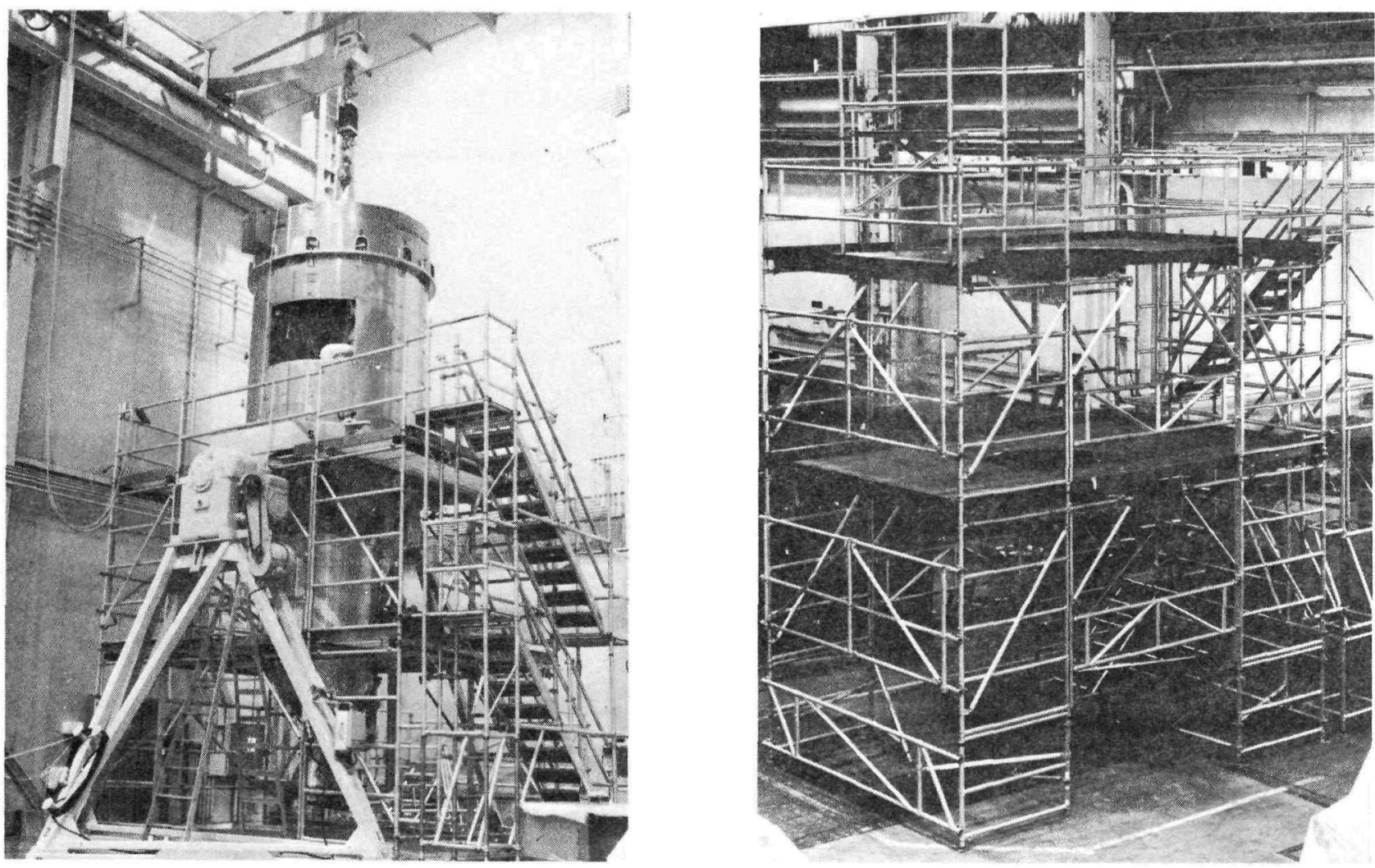
PROVISIONING LIST ITEM NUMBER 4708 DRAWING NUMBER

PART NUMBER CONTRACTOR 1118630

Same AGC
FIRST PROVISIONED FOR $\mathrm{XE}$

$\operatorname{cosT} \_\$ 20,000$

\begin{tabular}{|l||c|}
\hline \multicolumn{1}{|c||}{ USE LOCATION } & QTY REQ'D \\
\hline A. AGC SACRAMENTO & \\
\hline B. WANL \\
\hline C. & \\
\hline D. NRDS TOTAL & 1 \\
\hline \multicolumn{2}{|c|}{1} \\
\hline
\end{tabular}

DIMENSIONS AND CAPACITY

DIA

WEIGHT 3,000

FLOOR AREA REQUIRED

\section{ADDITIONAL DATA ThE}

LENGTH

$20^{\prime}$

240 LOAD CAPACI
SQ FT
GASES

ELECTRICAL

LIQUIDS

SPEED

MEASURING ACCURACY

CALIBRATION INTERVAL

ADDITIONAL DATA See Aerojet Report TD1-0033.
LB/SQ IN. VOLUME

VOLTS

PRESSURE

IN./MIN (RPM)
CPS

$L B / S Q I N$

CUTTING SPEED

HORIZONTAL.
CFM LUBRICATION

PHASE

QTY REQ'D $22^{\prime}$

HEIGHT 3,000 10 (1) 
EQUIPMENT TITLE

FIXTURE, LIFTING, ROCKET ENGINE

DESCRIPTION: The Rocket Engine Lifting Fixture is a four-legged sling, the frame of which is composed of a main beam with adjustable positions for two cross-beams. Each beam has adjustable-sling leg positions. The adjustable-sling leg position also serves as the pickup point for the four-legged, apex-type lifting sling which provides the interface to the crane for lifting the fixture with its load. Standard sling-rope and hooks are used with standard clevises: adjustment is made by securing a shear pin through the clevis at the selected hole of a series of holes in the beam element. The fixture is used to lift the engine with the UTS lifting fixture, $\mathrm{P} / \mathrm{L}$ 4701, or the PVARA with the pneumatic pressure vessel handling adapter, P/L 921.

NOTE: Basic use of this fixture was for CFDTS

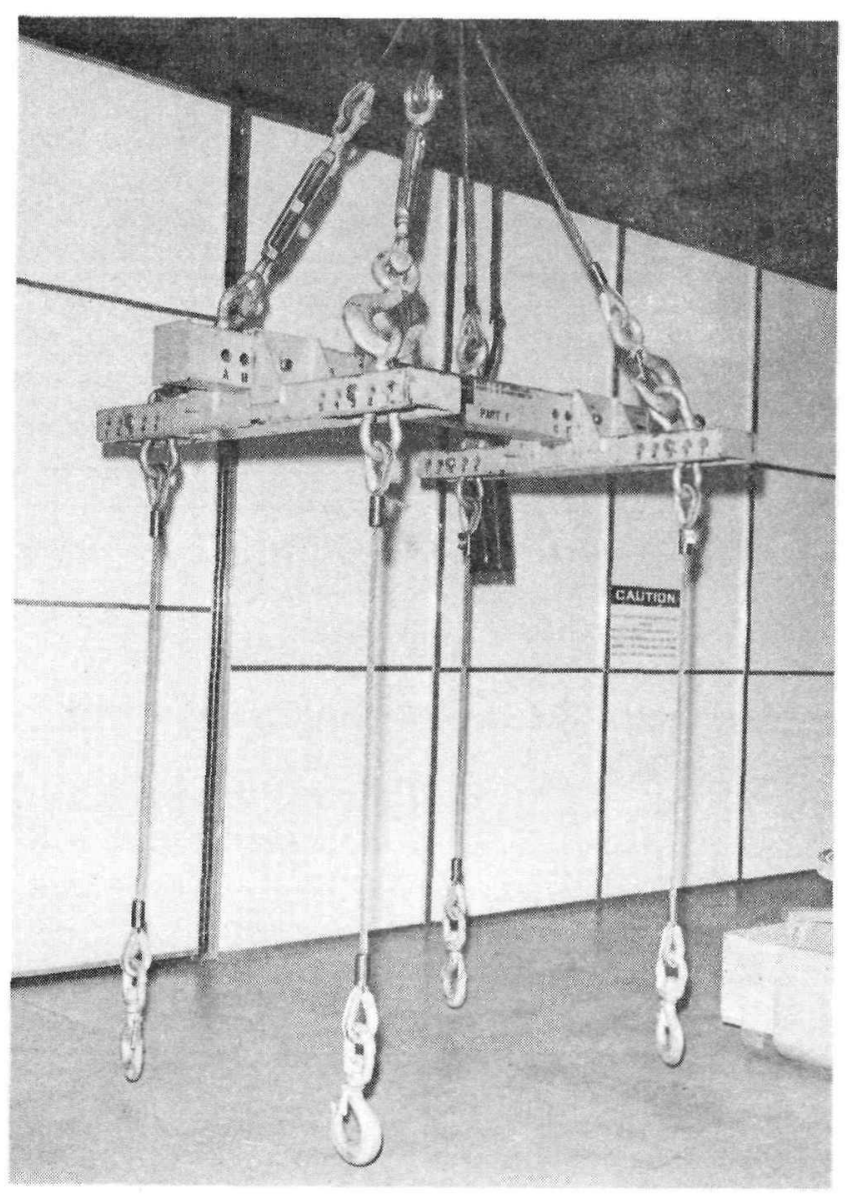


PROVISIONING LIST ITEM NUMBER 4709

DRAWING NUMBER

PART NUMBER

CONTRACTOR 278850

Same

AGC
FIRST PROVISIONED FOR

$\mathrm{XE}$

$\cos T$

\begin{tabular}{|l||c|}
\hline \multicolumn{1}{|c||}{ USE LOCATION } & QTY REQ'D \\
\hline A. AGC SACRAMENTO & 1 \\
\hline B. WANL & \\
\hline C. & \\
\hline D. NRDS TOTAL & 1 \\
\hline \multicolumn{2}{|c||}{} \\
\hline
\end{tabular}

\section{DIMENSIONS AND CAPACITY}

DIA

WEIGHT 1000

FLOOR AREA REQUIRED

LENGTH $79^{\prime \prime}$

WIDTH $54^{\prime \prime}$

LB LOAD CAPACITY 25,000 LB PROOF LOAD

OPERATING FLOOR LOAD

ADDITIONAL DATA The 4-point pickup is variable from 29 to $49^{\prime \prime}$ by 40 to $70^{\prime \prime}$.

OPERATING DATA

GASES

PRESSURE

ELECTRICAL

LIQUIDS

SPEED

MEASURING ACCURACY

CALIBRATION INTERVAL

ADDITIONAL DATA
VOLTS

PRESSURE

IN./MIN (RPM)
LB/SQIN. VOLUME

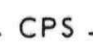

$L B / S Q$ IN

CUTTING SPEED

HORIZONTAL
CFM

LUBRICATION

PHASE

QTY REQ'D

VERTICAL
MANIPULATOR

CRANE

ADDITIONAL DATA
LOAD CAPACITY

Sacramento-High Bay

LOAD CAPACITY

80,000

LB MAX LB MAX

INTERFACES

EQUIPMENT_ 40-Ton Crane, Sacramento

PART OR ITEM P/L 4701 and P/L 921

DRAWING NO.

REMARKS 


\begin{tabular}{l|l}
\hline CI NERVA & SUPPORT EQUIPMENT \\
PROGRAM & TECHNICAL DESCRIPTION HANDBOOK \\
\hline
\end{tabular}

EQUIPMENT TITLE
PROV. LIST

ITEM NO.

4746

DATE January 1968

REVISION

SLING, TEST STAND ADAPTER

DESCRIPTION: The Test Stand Adapter Sling is a four-legged, standard wire-rope sling. Four lifting eyes bolt to the upper flange-surface of the ETS-1 test-stand adapter. The sling is used to handle the test-stand adapter during fabrication, shipping, and for required UTS "fit-checks". It is also used to lift the adapter into position on the TSA installation spacer, P/L 4090 (located on the EIV carriage) for ETS-1 installation of the adapter.

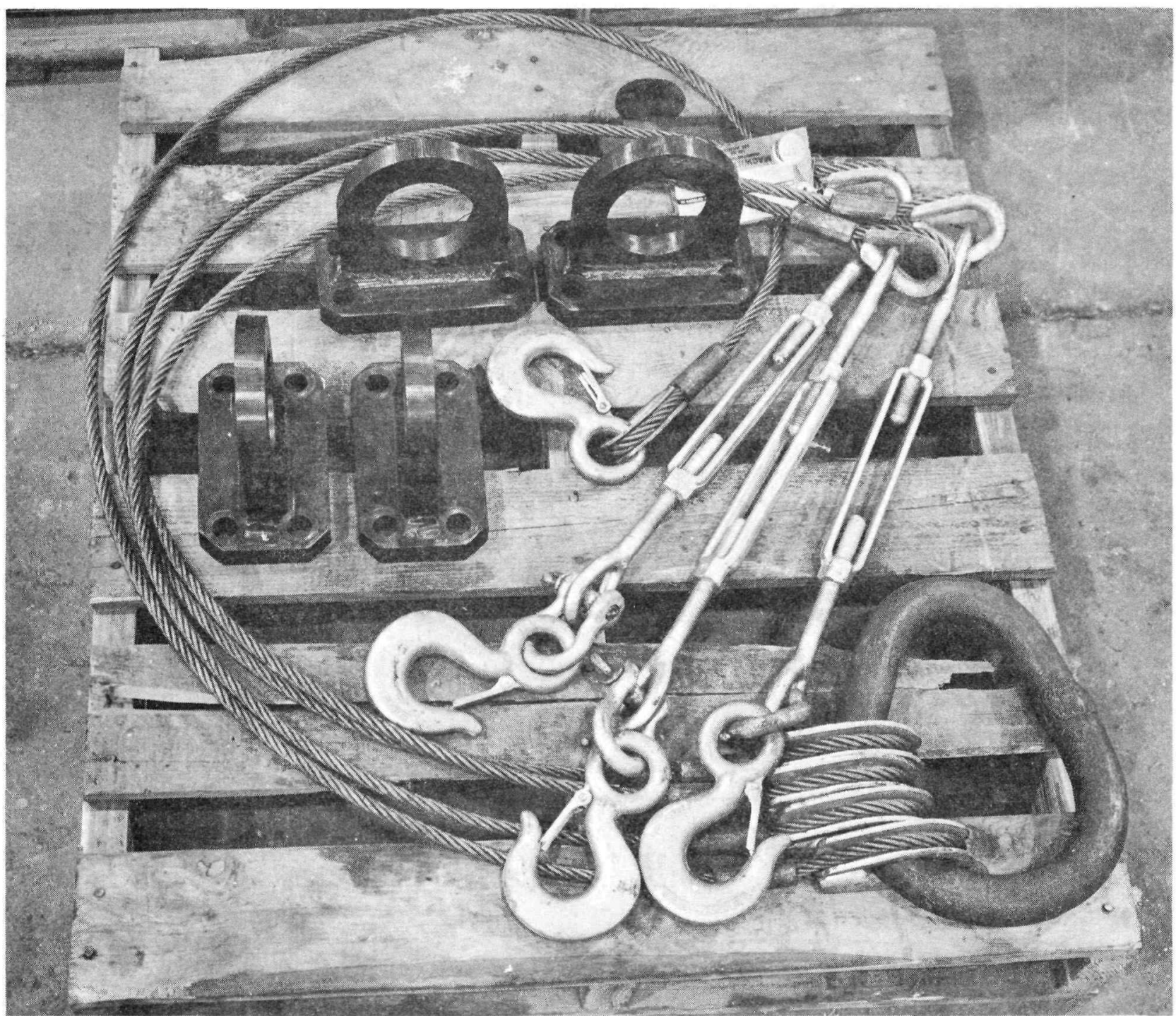


PROVISIONING LIST ITEM NUMBER 4746

DRAWING NUMBER

PART NUMBER

CONTRACTOR
1117077

Same AGC
FIRST PROVISIONED FOR $\mathrm{XE}$ GOVT, INV. CONTROL NUMBER COST $\$ 450.00$

\begin{tabular}{|l||c|}
\hline \multicolumn{1}{|c||}{ USE LOCATION } & QTY REQ'D \\
\hline A. AGC SACRAMENTO & \\
\hline B. WANL & \\
\hline C. & 1 \\
\hline D. NRDS TOTAL & 1 \\
\hline \multicolumn{2}{|c||}{} \\
\hline
\end{tabular}

\section{DIMENSIONS AND CAPACITY}

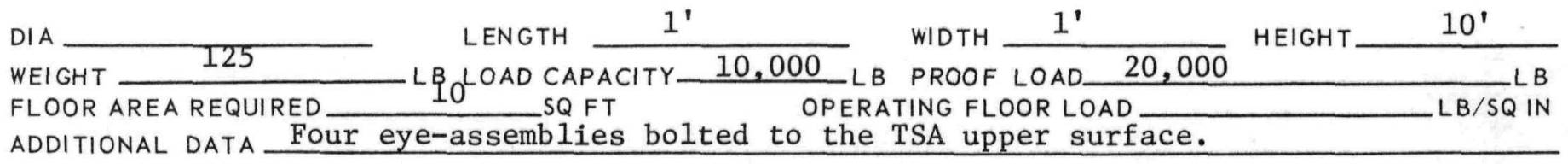

\section{OPERATING DATA}

GASES

ELECTRICAL

LIQUIDS

SPEED

MEASURING ACCURACY

CALIBRATION INTERVAL

ADDITIONAL DATA
PRESSURE

VOLTS

LB/SQIN. VOLUME

PRESSURE

IN./MIN (RPM)
CP

$L B / S Q$ IN

CUTTING SPEED

HORIZONTAL
CFM LUBRICATION

PHASE

QTY REQ'D

EQUIPMENT___ Crane E-MAD/NRDS

PART OR ITEM Test Stand Adapter DRAWING NO. 1010020

REMARKS 
SUPPORT EQUIPMENT TECHNICAL DESCRIPTION HANDBOOK

DATE January 1968 REVISION

EQUIPMENT TITLE

FIXTURE, HANDLING, FLUID LINE, REMOTE

DESCRIPTION: The Remote Fluid-Line Handling Fixture is a modified PaR Class "A" parallel hand-assembly. One jaw-face is replaced with a yoke assembly to accept and hold cylindrical shapes from three to 6-5/8-inch diameter. The hand assembly is compatable with the WMHS manipulator. The fixture is used to remotely handle engine propellant-lines during remote disassembly and reassembly of the engine in the E-MAD Building.

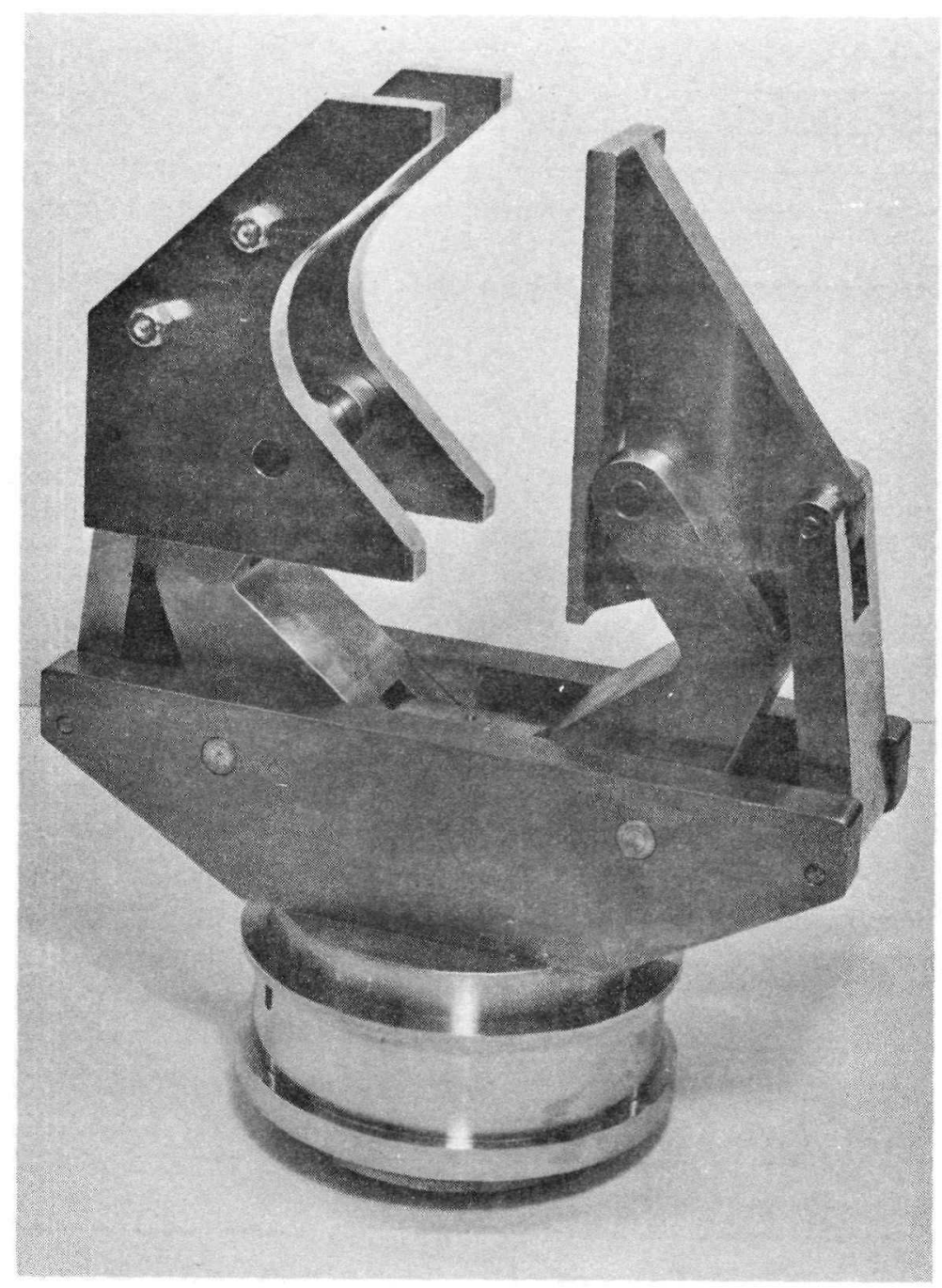


PROVISIONING LIST ITEM NUMBER 4749

DRAWING NUMBER

PART NUMBER

CONTRACTOR
1117682

Same

AGC
FIRST PROVISIONED FOR GOVT. INV. CONTROL NUMBER

$\cos T$
$\mathrm{XE}$

\begin{tabular}{|r||c|}
\hline \multicolumn{1}{|c||}{ USE LOCATION } & QTY REQ'D \\
\hline A. AGC SACRAMENTO & \\
\hline B. WANL & \\
\hline C. & 1 \\
\hline D. NRDS TOTAL & 1 \\
\hline
\end{tabular}

\section{DIMENSIONS AND CAPACITY}

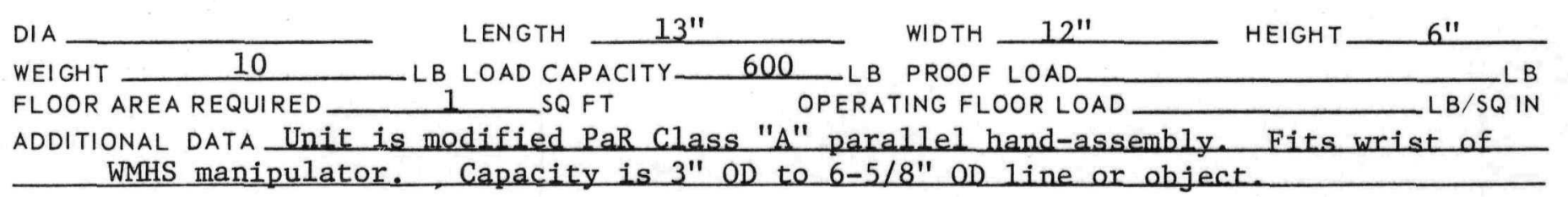

GASES

ELECTRICAL

LIQUIDS

SPEED

MEASURING ACCURACY

CALIBRATION INTERVAL

ADDITIONAL DATA
PRESSURE

VOLTS

PRESSURE

IN./MIN (RPM)
$L B / S Q I N$, VOLUME

CPS

$L B / S Q I N$

CUTTING SPEED

HORIZONTAL
CFM LUBRICATION

PHASE

QTY REQ'D
MANIPULATOR E-MAD/WMHS

CRANE

ADDITIONAL DATA
LOAD CAPACITY

600

LOAD CAPACITY
LB MAX

LB MAX

INTERFACES

EQUIPMENT_Manipulator wrist/tool socket - WMHS

PART OR ITEM Engine Lines

DRAWING NO.

REMARKS 


\section{(1) NERVA \\ LIPROGRAM}

EQUIPMENT TITLE

SHEAR, BENCH, HYDRAULIC
PROV. LIST

ITEM NO.

5002

DATE

January 1968

REVISION

DESCRIPTION: The Hydraulic Bench Shear is a commercial bench shear modified by the adaptation of a hydraulic cylinder to power the shears for remote operations. The shear incorporates a spring-loaded clamping bar to clamp the workpiece to be cut. The hydraulic cylinder is a double-acting cylinder capable of approximately a 30-ton shear force when used with a 2000-psi, single-acting hand pump. A hydraulic hand-valve is supplied with the hand pump for use in the operating gallery. The shear is used for cutting test specimens from engine parts during post-operative examination. It is capable of shearing stainless steel sheet 0.06-inch thick and 20-inches wide. The blades can be remotely replaced. 
PROVISIONING LIST ITEM NUMBER 5002

DRAWING NUMBER

PART NUMBER

P-03339-D (PaR)

CONTRACTOR AGC

FIRST PROVISIONED FOR E-MAD ADD-ON GOVT. INV. CONTROL NUMBER

$\operatorname{cosT} \$ 1,500$

\begin{tabular}{|l||c|}
\hline \multicolumn{1}{|c||}{ USE LOCATION } & QTY REQ'D \\
\hline A. AGC SACRAMENTO & \\
\hline B. WANL & \\
\hline C. & \\
\hline D. NRDS TOTAL & 1 \\
\hline
\end{tabular}

\section{DIMENSIONS AND CAPACITY}

DIA

LENGTH 30"

WIDTH 12"

HEIGHT

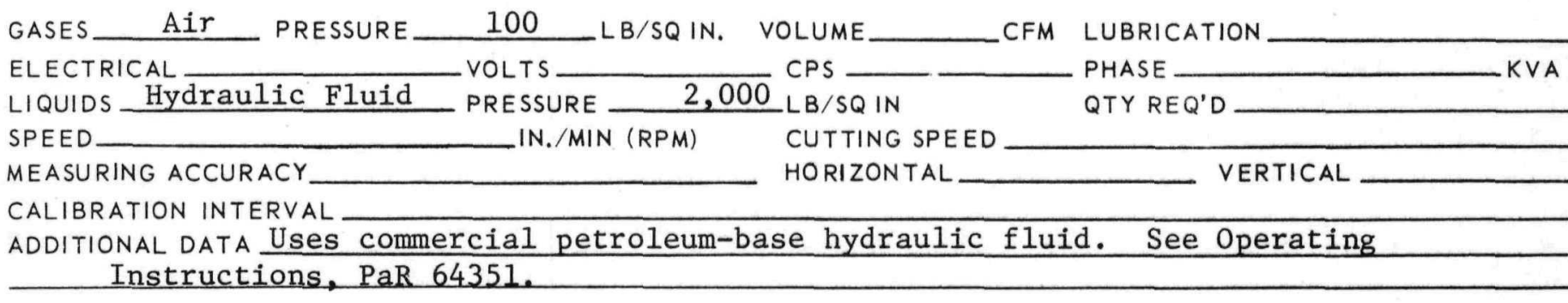

Miscellaneous engine hardware to be cut 
(1) NERVA

LIPROGRAM

SUPPORT EQUIPMENT

TECHNICAL DESCRIPTION HANDBOOK

EQUIPMENT TITLE

CLEANER, VACUUM, REMOTE
DATE

January 1968

REVISION

DESCRIPTION: The Remote Vacuum Cleaner is a standard tank-type, upright vacuum cleaner equipped with an absolute filter. It is operated by manipulators in the E-MAD Building remote disassembly bays or post-operative cells for dust and chip collection in the facility decontamination processes and to remove radioactive dust and particles from engine components during remote disassembly or postoperative examination. 
PROVISIONING LIST ITEM NUMBER 5003

DRAWING NUMBER

PART NUMBER

CONTRACTOR

\section{*} AGC
FIRST PROVISIONED FOR E-MAD ADD-ON GOVT. INV. CONTROL NUMBER

\begin{tabular}{l}
\hline $\cos T$ \\
$\$ 590.00$
\end{tabular}

\begin{tabular}{|l||c|}
\hline \multicolumn{1}{|c||}{ USE LOCATION } & QTY REQ'D \\
\hline A. AGC SACRAMENTO & \\
\hline B. WANL & \\
\hline C. & 3 \\
\hline D. NRDS TOTAL & 3 \\
\hline \multicolumn{2}{|c|}{} \\
\hline
\end{tabular}

DIMENSIONS AND CAPACITY

DIA

WEIGHT

FLOOR AREA REQUIRED

LENGTH

LB LOAD CAPACITY $10 \mathrm{gal}$

SQ FT

WIDTH OPERATING FLOOR LOAD ADDITIONAL DATA 10-gallon capacity, shop-type, upright vacuum with an absolute filter.
GASES

ELECTRICAL $\quad 115$

LIQUIDS

SPEED

MEASURING ACCURACY

CALIBRATION INTERVAL

ADDITIONAL DATA
PRESSURE VOLTS_ 60 PRESSURE IN./MIN (RPM)
LB/SQ IN. VOLUME CPS single

$L B / S Q I N$ CUTTING SPEED HORIZONTAL.
CFM LUBRICATION

PHASE KVA

QTY REQ'D VERTICAL

ADDITIONAL DATA The remote vacuum cleaner can be operated with any of the manipulators available at NRDS. 

PROVISIONING LIST ITEM NUMBER 5006

DRAWING NUMBER

PART NUMBER

CONTRACTOR
ACEI 3-513645-000

AGC
FIRST PROVISIONED FOR E-MAD $\triangle D D-O N$ GOVT. INV. CONTROL NUMBER

$\cos T$

\begin{tabular}{|l||c|}
\hline \multicolumn{1}{|c||}{ USE LOCATION } & QTY REQ'D \\
\hline A. AGC SACRAMENTO & \\
\hline B. WANL & \\
\hline C. & 1 \\
\hline D. NRDS TOTAL & 1 \\
\hline
\end{tabular}

\section{DIMENSIONS AND CAPACITY}

DIA

WEIGHT

FLOOR AREA REQUIRED

ADDITIONAL DATA
LENGTH

LB LOAD CAPACITY SQ FT
WIDTH

LB PROOF LOAD

OPERATING FLOOR LOAD
HEIGHT

LB $L B / S Q I N$

\section{OPERATING DATA}

Oxygen \&

GASES Acetylene PRESSURE

ELECTRICAL 115

LIQUIDS

SPEED

MEASURING ACCURACY

CALIBRATION INTERVAL

ADDITIONAL DATA
VOLTS

LB/SQIN. VOLUME 60

PRESSURE

IN./MIN (RPM)

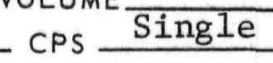

$L B / S Q$ IN

CUTTING SPEED

HORIZONTAL
CFM LUBRICATION PHASE KVA
QTY REQ'D

VERTICAL

OPERATING EQUIPMENT

MANIPULATOR

CRANE

ADDITIONAL DATA
*

*Can be used with any of the facility manipulators
LOAD CAPACITY

LOAD CAPACITY

LB MAX

LB MAX

\section{INTERFACES}

EQUIPMENT Facility "through-wall" requirements for gas hoses and electric controls.

PART OR ITEM DRAWING NO.

REMARKS 
DATE

EQUIPMENT TITLE

MOUNTS, BINOCULAR

DESCRIPTION: The Binocular Mounts are used for holding and positioning binoculars at all viewing windows in the E-MAD Building. They provide smooth horizontal and vertical movement with provisions for binocular positioning, swivelling, and locking. The mounts consist of a set of vertical slide-bars mounted to wall brackets on each side of a viewing window. A horizontal bar slides on the vertical members for vertical positioning. The vertical positioning movements are provided with a weighted counterbalance system for ease of operation. The binocular mounting-bracket slides on the horizontal bar for horizontal positioning and provides a ball swivel-joint for positioning the binoculars. All movements can be locked at any position.

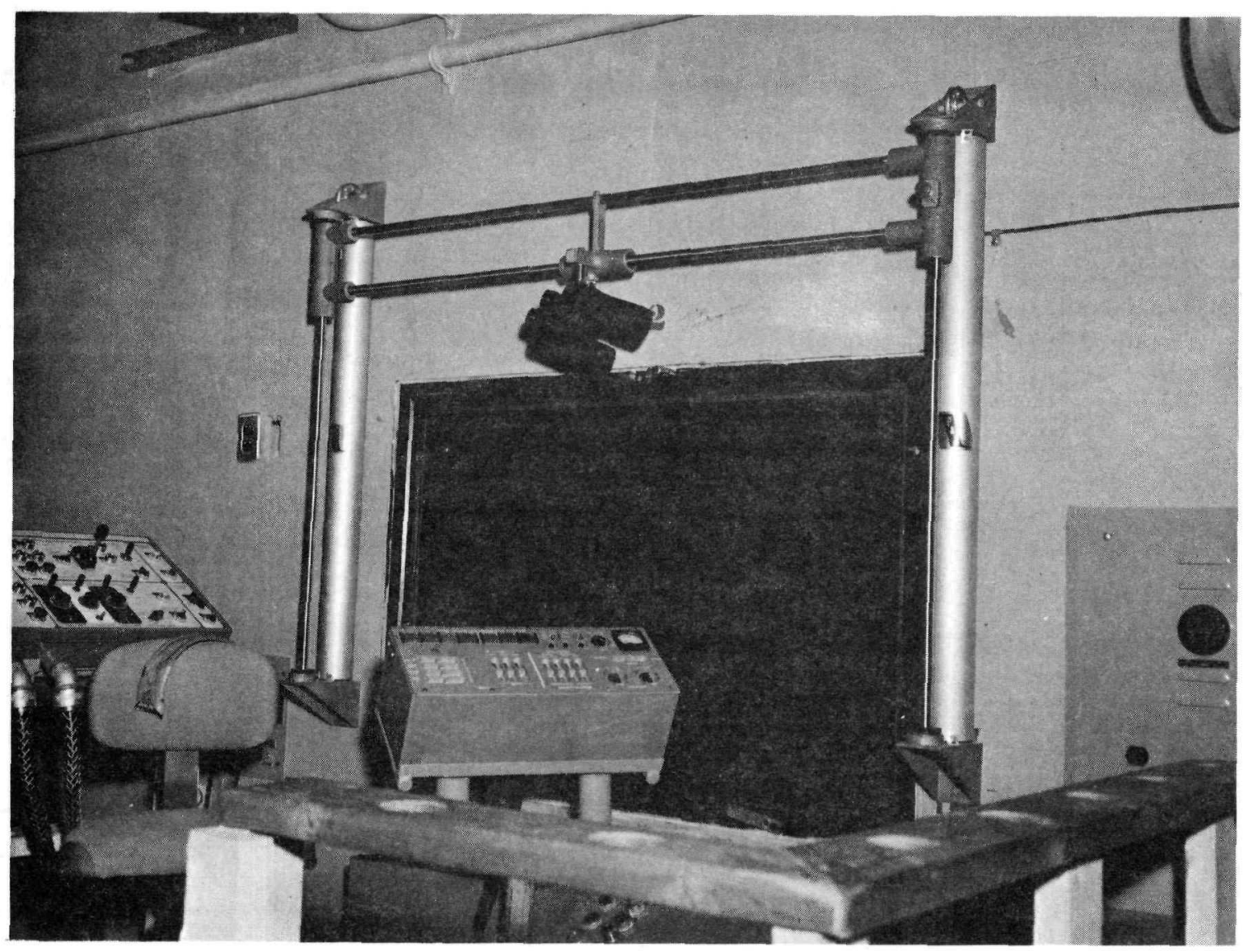


PROVISIONING LIST ITEM NUMBER

5007

DRAWING NUMBER

PART NUMBER PaR AI-06251-D

CONTRACTOR AGC
FIRST PROVISIONED FOR E-MAD ADD-ON GOVT. INV. CONTROL NUMBER Cost $\$ 445.00$ Each

\begin{tabular}{|c|c|}
\hline USE LOCATION & QTY REQ'D \\
\hline A. AGC SACRAMENTO & \\
\hline B. WANL & \\
\hline C. & \\
\hline D. NRDS & 20 Sets. \\
\hline TOTAL & 20 Sets \\
\hline
\end{tabular}

\section{DIMENSIONS AND CAPACITY}

DIA

WEIGHT

FLOOR AREA REQUIRED

LENGTH

LB LOAD CAPACITY SQ FT

WIDTH

LB PROOF LOAD

HEIGHT

ADD at which they are installed. The outer extreme of the binocular mount is 24 " from the window surface
GASES PRESSURE

ELECTRICAL

LIQUIDS

SPEED

MEASURING ACCURACY

CALIBRATION INTERVAL

ADDITIONAL DATA
LB/SQIN. VOLUME VOLTS PRESSURE IN. /MIN (RPM)

\section{CPS}

$L B / S Q I N$

CUTTING SPEED

HORIZONTAL
CFM LUBRICATION

PHASE

QTY REQ'D 

PROVISIONING LIST ITEM NUMBER 5009

DRAWING NUMBER

PART NUMBER Wilson Mode1 5.5TY

CONTRACTOR AGC
FIRST PROVISIONED FOR E-MAD ADD-ON GOVT. INV. CONTROL NUMBER

$\cos T$ $\$ 9,500$

\begin{tabular}{|l||c|}
\hline \multicolumn{1}{|c||}{ USE LOCATION } & QTY REQ'D \\
\hline A. AGC SACRAMENTO & \\
\hline B. WANL & \\
\hline C. & \\
\hline D. NRDS TOTAL & 1 \\
\hline
\end{tabular}

\section{DIMENSIONS AND CAPACITY}

DIA

WEIGHT

FLOOR AREA REQUIRED LB LOAD CAPACITY
5 SQFT

LENGTH 26-7/8"

con

\section{OPERATING DATA}

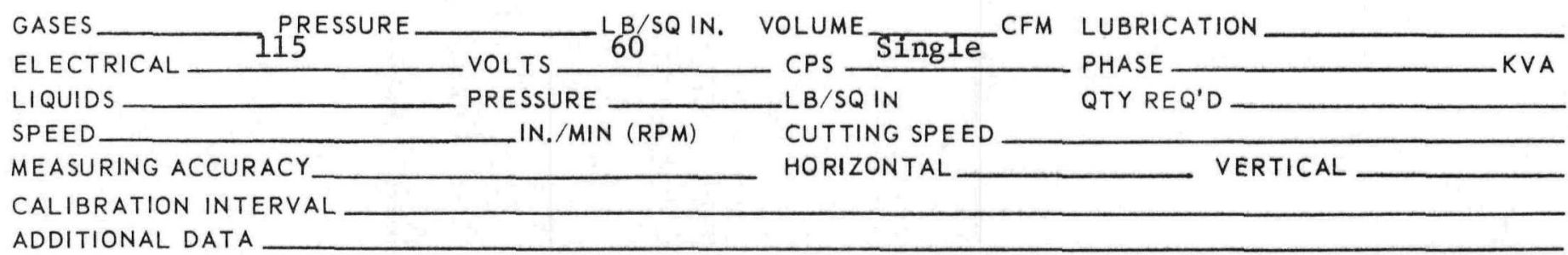

MANIPULATOR_ Master/Slave CRL-8

CRANE

ADDITIONAL DATA
LOAD CAPACITY

LB MAX

LOAD CAPACITY

LB MAX

INTERFACES

EQUIPMENT-

PART OR ITEM

Miscellaneous test specimens.

REMARKS
DRAWING NO. 


\section{(1) NERVA \\ LIPROGRAM SUPPORT EQUIPMENT TECHNICAL DESCRIPTION HANDBOOK}

EQUIPMENT TITLE

SHIELD, PERSONNEL
PROV. LIST

ITEM NO.

5014

DATE January 1968

DESCRIPTION: The Personnel Shield is a lead-shielded box structure with three sides and a top. The front side is provided with a radiation-shielding window. The top of the shield provides a bail for lifting with a remote overhead crane. The shield is used to provide radiation shielding for one man in the event that it is necessary to send a man into the E-MAD Building disassembly bay for visual inspection of radioactive hardware.
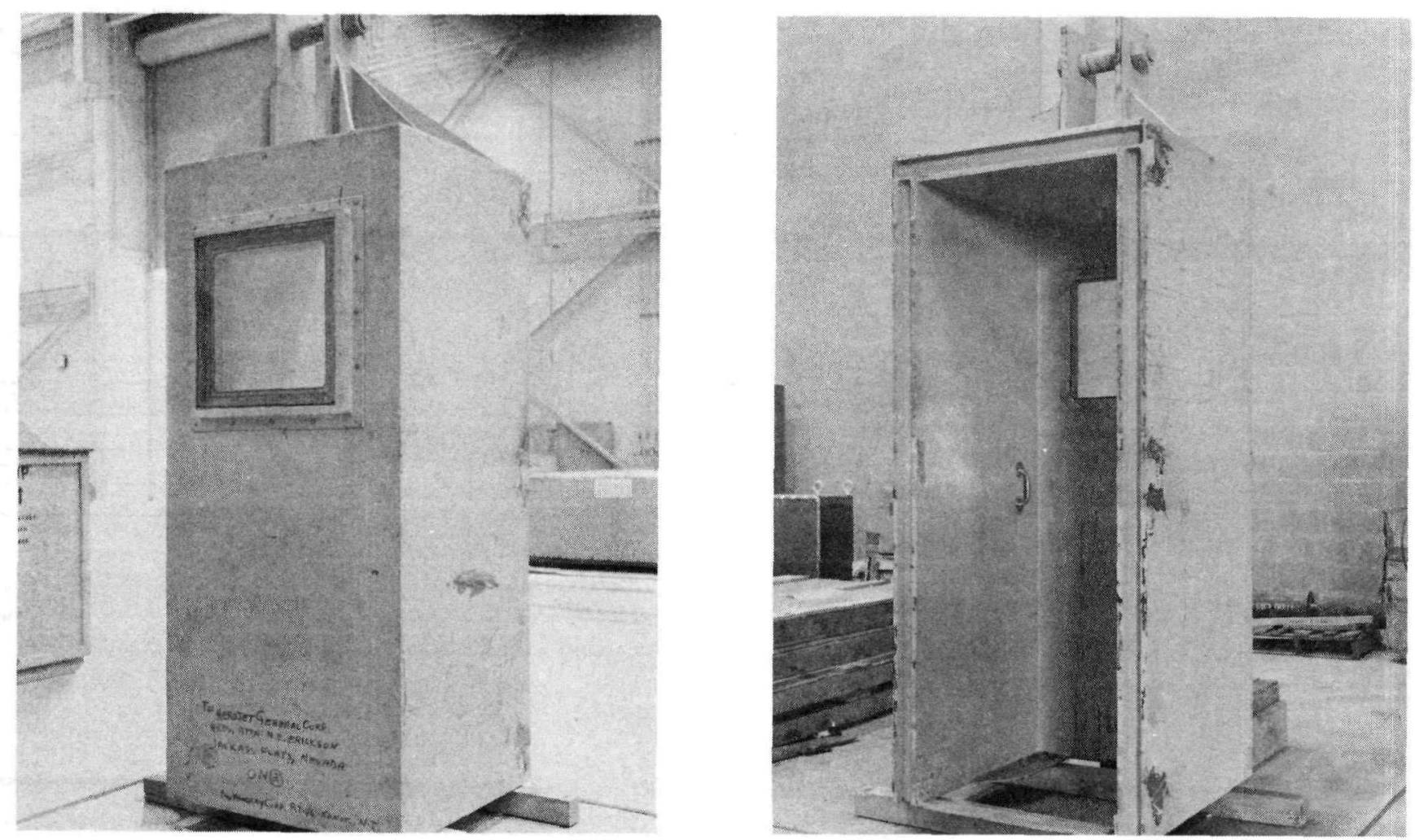
PROVISIONING LIST ITEM NUMBER 5014 DRAWING NUMBER

PART NUMBER CONTRACTOR Ameray Corp. AM 2714-1 AGC
FIRST PROVISIONED FOR E-MAD ADD-ON GOVT. INV. CONTROL NUMBER

$\cos T+\$ 2,000$

\begin{tabular}{|l||c|}
\hline \multicolumn{1}{|c||}{ USE LOCATION } & QTY REQ'D \\
\hline A. AGC SACRAMENTO & \\
\hline B. WANL & \\
\hline C. & 1 \\
\hline D. NRDS TOTAL & 1 \\
\hline \multicolumn{2}{|c||}{} \\
\hline
\end{tabular}

\section{DIMENSIONS AND CAPACITY}

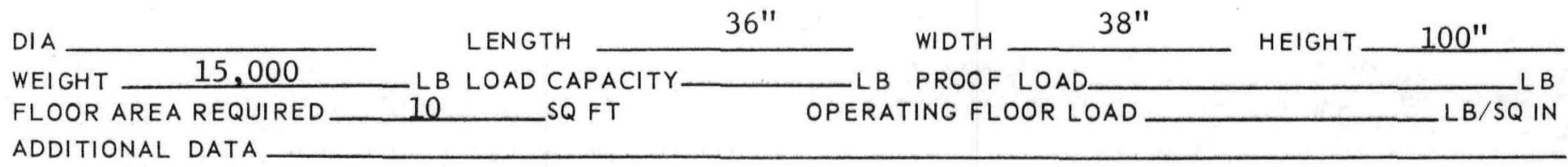

\section{GASES}

ELECTRICAL

LIQUIDS

SPEED

MEASURING ACCURACY

CALIBRATION INTERVAL

ADDITIONAL DATA
PRESSURE VOLTS

PRESSURE IN./MIN (RPM)
LB/SQ IN. VOLUME

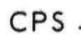

CPS

$L B / S Q I N$

CUTTING SPEED

HORIZONTAL
CFM LUBRICATION

PHASE

QTY REQ'D

\section{VERTICAL}

MANIPULATOR

CRANE E-MAD Remote Crane ADDITIONAL DATA
LOAD CAPACITY LOAD CAPACITY 80,000

LB MAX LB MAX 


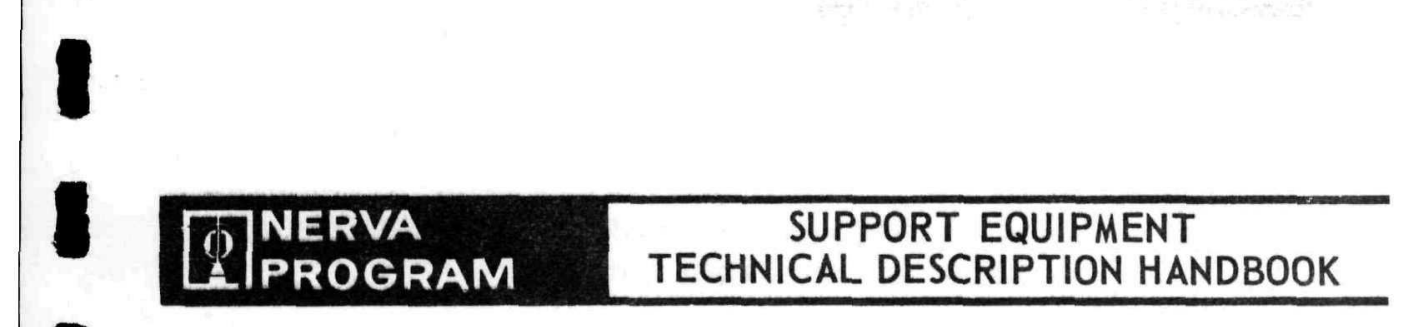

EQUIPMENT TITLE

TELEVISION SYSTEM EQUIPMENT

DESCRIPTION: The Television System Equipment provides the necessary components for a closed-circuit television system for viewing operations within the E-MAD Building remote disassembly bay and cells. The system consists of the following components: 5 Television Monitors; 7 Vidio Distribution Amplifiers; 11 Camera Control Units; 11 Accessory Control Panel Modules; 7 Mobile Television Monitor Consoles; 13 Television Cameras; 13 Zoom Lens Assemblies; 13 Pan and Tilt Units; 103 Video Distribution Cables; and 7 Portable Camera Mount Assemblies.
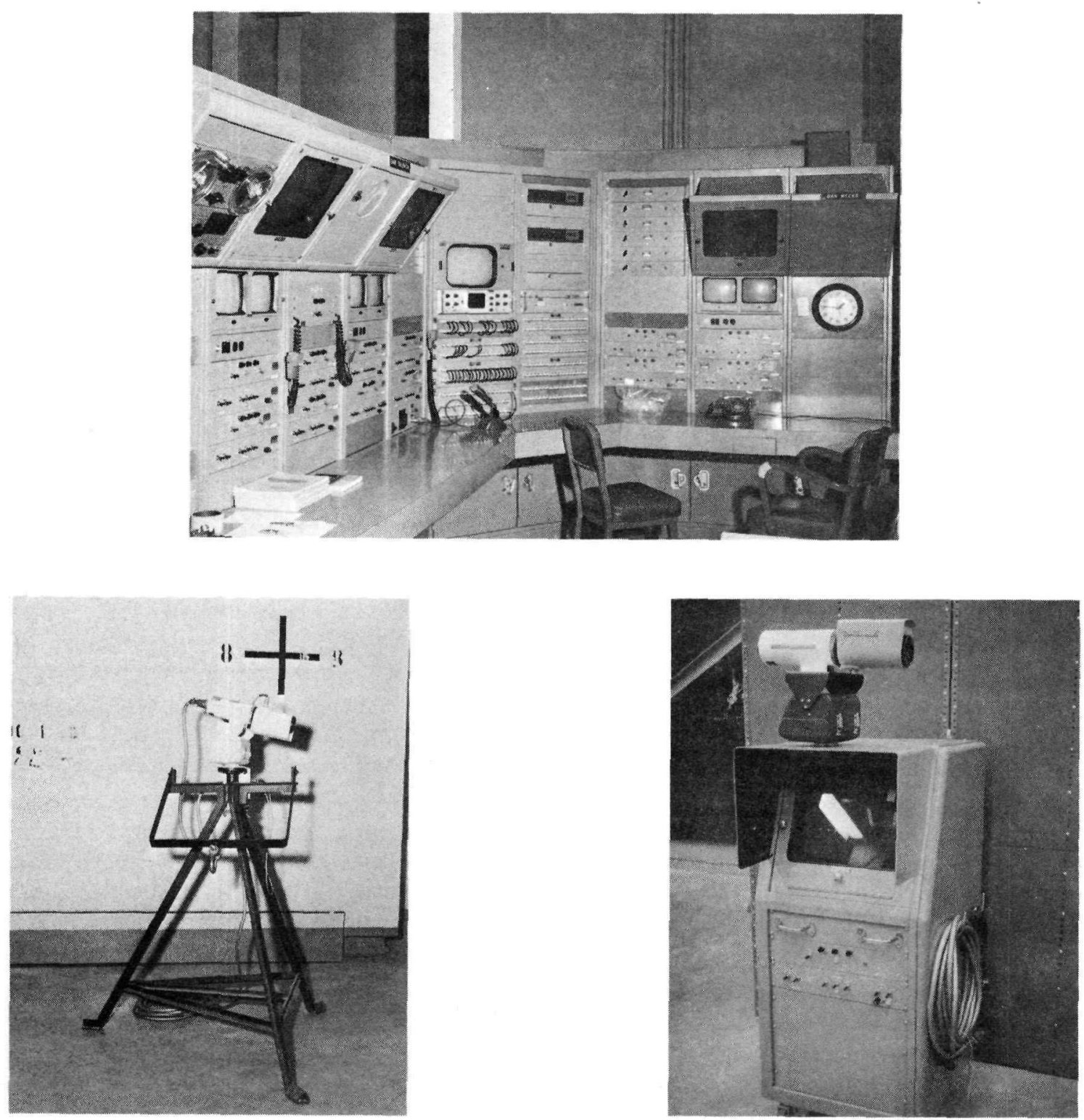
PROVISIONING LIST ITEM NUMBER 5015

DRAWING NUMBER

PART NUMBER

CONTRACTOR AGC
FIRST PROVISIONED FOR E-MAD ADD-ON GOVT. INV. CONTROL NUMBER

$\cos T+\$ 75,000$

\begin{tabular}{|c|c|}
\hline USE LOCATION & QTY REQ'D \\
\hline A. AGC SACRAMENTO & \\
\hline B. WANL & \\
\hline C. & \\
\hline D. NRDS & \\
\hline TOTAL & \\
\hline
\end{tabular}

\section{DIMENSIONS AND CAPACITY}

DIA N N

WEIGHT N/A

FLOOR AREA REQUIRED

NPA LOAD CAPACIT

LENGTH SQ FT OPERATING FLOOR LOAD HEIGHT WIDTH LB PROOF LOAD L. B $L B / S Q I N$ ADDITIONAL DATA Equipment supplied by Systems Design Corporation, Las Vegas, Nevada
GASES N/A PRESSURE

ELECTRICAL 115

LIQUIDS

SPEED

MEASURING ACCURACY

CALIBRATION INTERVAL

ADDITIONAL DATA VOLTS 60 IN./MIN (RPM)

ADDITIONAL DATA 


\section{(1) NERVA \\ LEIPROGRAM}

EQUIPMENT TITLE

PERISCOPE, WALL TYPE, HOT DISASSEMBLY BAY
SUPPORT EQUIPMENT

TECHNICAL DESCRIPTION HANDBOOK
PROV. LIST

ITEM NO.

DATE

January 1968

DESCRIPTION: The Periscope is an L-shaped instrument designed for remote viewing of operations within the E-MAD Building disassembly bay. It consists of a swiveling objective at the hot-bay end of a horizontal "through-wa1l" arm, and a swiveling eyepiece in the lower end of a vertical arm. The horizontal arm is mounted in a radiation-tight outer tube and flange and extends through the hot-bay wall in such a manner that it is free to rotate 360 degrees. This allows the height of the eyepiece to vary to suit an individual observer. The swiveling objective and eyepiece are mechanically coupled to provide a hemispheric scan capability. The periscope is provided with a camera adapter for remote photography and a filar eyepiece to measure objects on the hot-bay side of the wall within a minimum solid-angle of 180 degrees centered about the objective end.

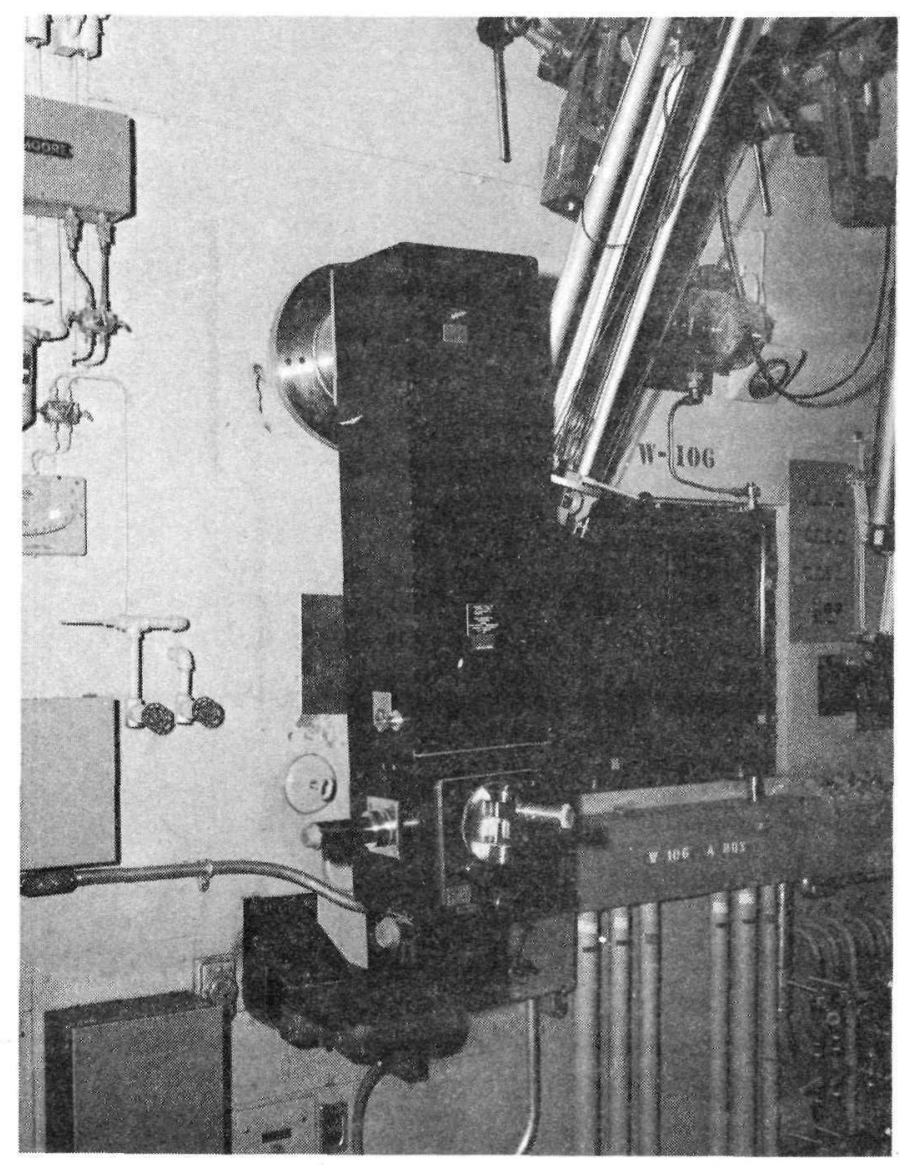


PROVISIONING LIST ITEM NUMBER 5019

DRAWING NUMBER

PART NUMBER

CONTRACTOR
Lennox Instr. Co. No. 120000

$$
\text { AGC }
$$

FIRST PROVISIONED FOR E-MAD ADD-ON GOVT. INV. CONTROL NUMBER

\begin{tabular}{|r||c|}
\hline \multicolumn{1}{|c||}{ USE LOCATION } & QTY REQ'D \\
\hline A. AGC SACRAMENTO & \\
\hline B. WANL & \\
\hline C. & \\
\hline D. NRDS TOTAL & 1 \\
\hline \multicolumn{2}{|c||}{1} \\
\hline
\end{tabular}

DIMENSIONS AND CAPACITY

DIA

WEIGHT

920

FLOOR AREA REQUIRED

LENGTH $68-7 / 16^{\prime \prime}$ LB LOAD CAPACITY

SQ FT

Man

Specification $\mathrm{S}-5019$

\section{OPERATING DATA}

GASES

ELECTRICAL

LIQUIDS

SPEED

MEASURING ACCURACY

CALIBRATION INTERVAL

ADDITIONAL DATA Operating and Maintenance Instructions LICO 4958

$L B / S Q$ IN

CUTTING SPEED

HORIZONTAL
LB/SQIN. VOLUME

VOLTS CPS

PRESSURE IN./MIN (RPM)
CFM LUBRICATION

PHASE

QTY REQ'D

VERTICAL

\section{OPERATING EQUIPMENT}

MANIPULATOR $\frac{\text { N/A }}{\text { N/A }}$

LOAD CAPACITY

LB MAX

CRANE

LOAD CAPACITY

LB MAX

ADDITIONAL DATA

Manually positioned and adjusted by operator.

EQUIPMENT_E-MAD 6' thick wall section 
EQUIPMENT TITLE

CAR, STORAGE, HIGH ACTIVITY

DESCRIPTION: The High Activity Storage Car consists of a railroad flat-car modified by the addition of a metal plate deck and three removable top covers. The car provides a portable storage facility for radioactive engine parts. The car is loaded in the hot disassembly bay and covers placed into position to cover the radioactive load. The car is then pushed or pulled over the facility railroad system to the high-activity storage area and parked. The prime mover may be either the LASL electric locomotive or the locomotive-MCC-space-car train. 
PROVISIONING LIST ITEM NUMBER 5021 DRAWING NUMBER

PART NUMBER ACFI 3-513745-000

CONTRACTOR AGC
FIRST PROVISIONED FOR E-MAD ADD-ON GOVT. INV. CONTROL NUMBER

COST $\$ 16,875$

\begin{tabular}{|l||c|}
\hline \multicolumn{1}{|c||}{ USE LOCATION } & QTY REQ'D \\
\hline A. AGC SACRAMENTO & \\
\hline B. WANL & \\
\hline C. & 1 \\
\hline D. NRDS TOTAL & 1 \\
\hline \multicolumn{2}{|c|}{} \\
\hline
\end{tabular}

DIMENSIONS AND CAPACITY

DIA

WEIGHT

FLOOR AREA REQUIRED

ADDITIONAL DATA
LENGTH LB LOAD CAPACITY SQ FT
WIDTH

$10^{\prime}$
HEIGHT

$12^{\prime}$
GASES PRESSURE

ELECTRICAL

LIQUIDS

SPEED

MEASURING ACCURACY

CALIBRATION INTERVAL

ADDITIONAL DATA
LB/SQ IN. VOLUME

VOLTS

PRESSURE IN./MIN (RPM)
CPS

$L B / S Q$ IN

CUTTING SPEED HORIZONTAL
CFM

LUBRICATION

PHASE

QTY REQ'D

\section{OPERATING EQUIPMENT}

MANIPULATOR

LOAD CAPACITY

L B MAX

CRANE

LOAD CAPACITY

LB MAX

ADDITIONAL DATA 40-Ton overhead crane used for lifting and positioning covers.

\section{INTERFACES}

EQUIPMENT_LASL Locomotive or Locomotive-MCC-Spacer Car Train 
() NERVA

I PROGRAM

SUPPORT EQUIPMENT

TECHNICAL DESCRIPTION HANDBOOK

EQUIPMENT TITLE

DATE

January 1968

REVISION

REMOTE DUROMETER

DESCRIPTION: The Remote Durometer is a standard durometer modified by the addition of adjustment handles that are compatible for use with remote manipulators. The durometer is used to periodically check the hardness of critical rubber components of equipment that is utilized within the radioactive environment of the engine disassembly areas.

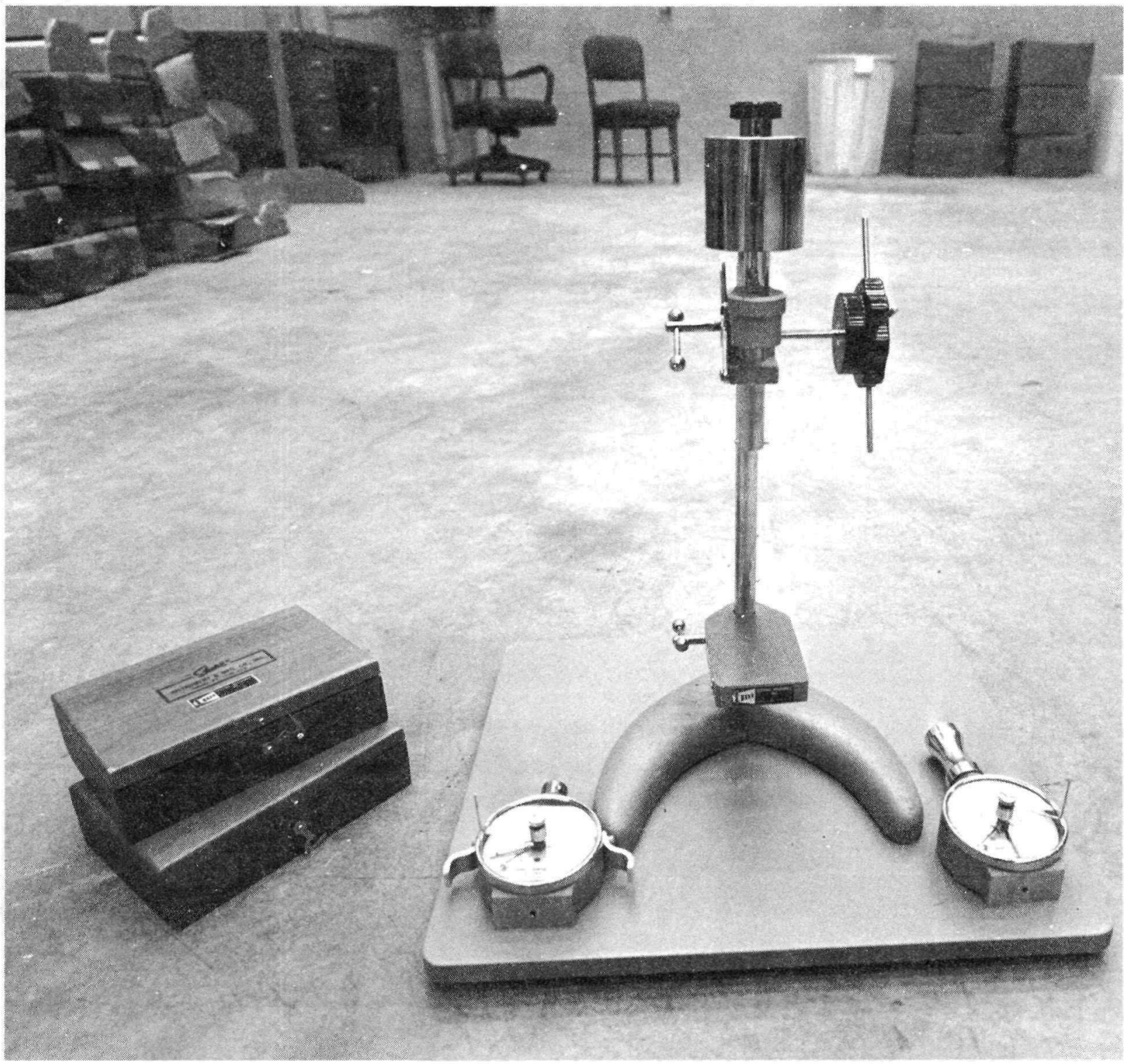


PROVISIONING LIST ITEM NUMBER

5022

DRAWING NUMBER

PART NUMBER

CONTRACTOR
FIRST PROVISIONED FOR E-MAD ADD-ON GOVT. INV. CONTROL NUMBER

$\cos T+\$ 600.00$

\begin{tabular}{|c|c|}
\hline USE LOCATION & QTY REQ'D \\
\hline A. AGC SACRAMENTO & \\
\hline B. WANL & \\
\hline C. & \\
\hline D. NRDS & 1 \\
\hline TOTAL & 1 \\
\hline
\end{tabular}

DIMENSIONS AND CAPACITY

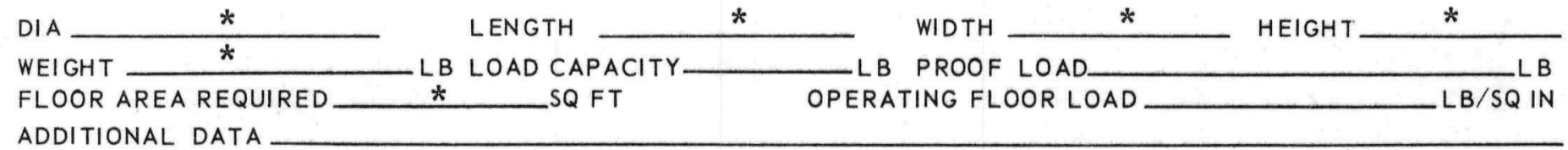

GASES PRESSURE

ELECTRICAL

LIQUIDS

SPEED

MEASURING ACCURACY

CALIBRATION INTERVAL

ADDITIONAL DATA
VOLTS

PRESSURE IN./MIN (RPM)
LB/SQIN. VOLUME

CPS

$L B / S Q$ IN

CUTTING SPEED

HORIZONTAL
CFM LUBRICATION

PHASE

QTY REQ'D
MANIPULATOR Master/Slave

CRANE

ADDITIONAL DATA
LOAD CAPACITY

LOAD CAPACITY

L B MAX

LB MAX

INTERFACES 


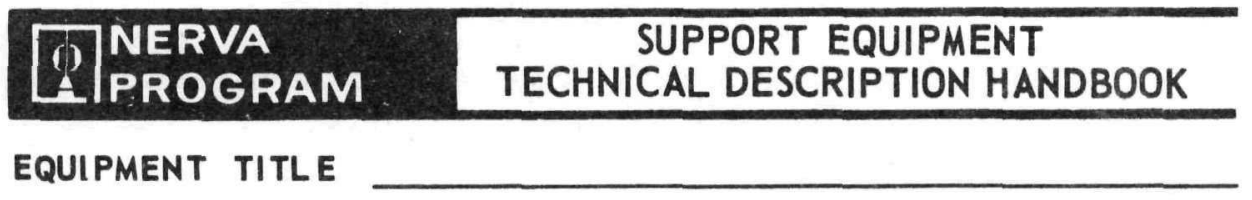

PROV. LIST

ITEM NO.

5023

DATE

January 1968

REVISION

PERISCOPE, WALL TYPE, POST MORTEM CELL

DESCRIPTION: The Hot Disassembly Bay Wall Type Periscope is an L-shaped instrument designed for remote viewing of operations within an E-MAD post-operative examination ce11. It consists of a swiveling objective at the hot-bay end of a horizontal through-wall arm, and a swiveling eyepiece in the lower end of a vertical arm. The horizontal arm is mounted in a radiation-tight outer tube and flange through the hot-bay wall and rotates 360 degrees. This allows the height of the eyepiece to vary to suit the individual observer. The swiveling objective and eyepiece are mechanically coupled to give the periscope a hemispheric scan capability. The periscope is provided with a camera adapter for remote photography and a filar eyepiece to measure objects on the hot-bay side of the wall within a minimum solidangle of 180 degrees centered about the objective end. 
PROVISIONING LIST ITEM NUMBER 5023

DRAWING NUMBER

PART NUMBER Lennox Instr. Co. No. 120000

CONTRACTOR AGC
FIRST PROVISIONED FOR E-MAD ADD-ON GOVT. INV. CONTROL NUMBER

$\cos T-\$ 14.500$

\begin{tabular}{|c|c|}
\hline USE LOCATION & QTY REQ'D \\
\hline A. AGC SACRAMENTO & \\
\hline B. WANL & \\
\hline C. & \\
\hline D. NRDS & 1 \\
\hline TOTAL & 1 \\
\hline
\end{tabular}

DIMENSIONS AND CAPACITY

DIA

LENGTH
LOAD CAPACITY

$48^{\prime \prime}$

WIDTH $217 / 16^{\prime \prime}$

HEIGHT $283 / 8^{\prime \prime}$

WEIGHT 920

SQ FT

LB PROOF LOAD

FLOOR AREA REQUIRED

OPERATING FLOOR LOAD $L B / S Q$ IN

ADDITIONAL DATA

OPERATING DATA

Manufactured by Lennox Inst. Co. per AGC Equipment Specification S-5019

GASES

ELECTRICAL

LIQUIDS

SPEED.

MEASURING ACCURACY

CALIBRATION INTERVAL

ADDITIONAL DATA See Operating and Maintenance Instructions LICO 4958
$L B / S Q I N$, VOLUME

VOLTS

PRESSURE

IN./MIN (RPM)
CPS

$L B / S Q$ IN

CUTTING SPEED

HORIZONTAL
CFM LUBRICATION

PHASE

QTY REQ'D

VERTICAL

\section{OPERATING EQUIPMENT}

MANIPULATOR $\frac{\mathrm{N} / \mathrm{A}}{\mathrm{N} / \mathrm{A}}$

LOAD CAPACITY

LB MAX

CRANE

N/A

LOAD CAPACITY

LB MAX

ADDITIONAL DATA

Manually positioned and adjusted by operator.

\section{INTERFACES}

EQUIPMENT_E-MAD 4-ft-thick wall section. 
() NERVA

LIPROGRAM

SUPPORT EQUIPMENT

TECHNICAL DESCRIPTION HANDBOOK

EQUIPMENT TITLE

TRANSFER SYSTEM, PLUG DOOR
DATE

January 1968

REVISION

DESCRIPTION: The Plug Door Transfer System consists of a sliding drawer assembly through the plug doors of E-MAD Building post-operative cells 165 and 166 . Each drawer extends into its respective cell to receive radioactive material to be transferred. When loaded, the drawer is pushed into the plug door with a manipulator and a shielding door on the cell side of the drawer opening is closed. A shielding door on the cell service side is then opened with a manipulator and the transfer drawer is withdrawn into the cell service area for unloading. This system allows the transfer of material between post-operative cells 165 and 166 .
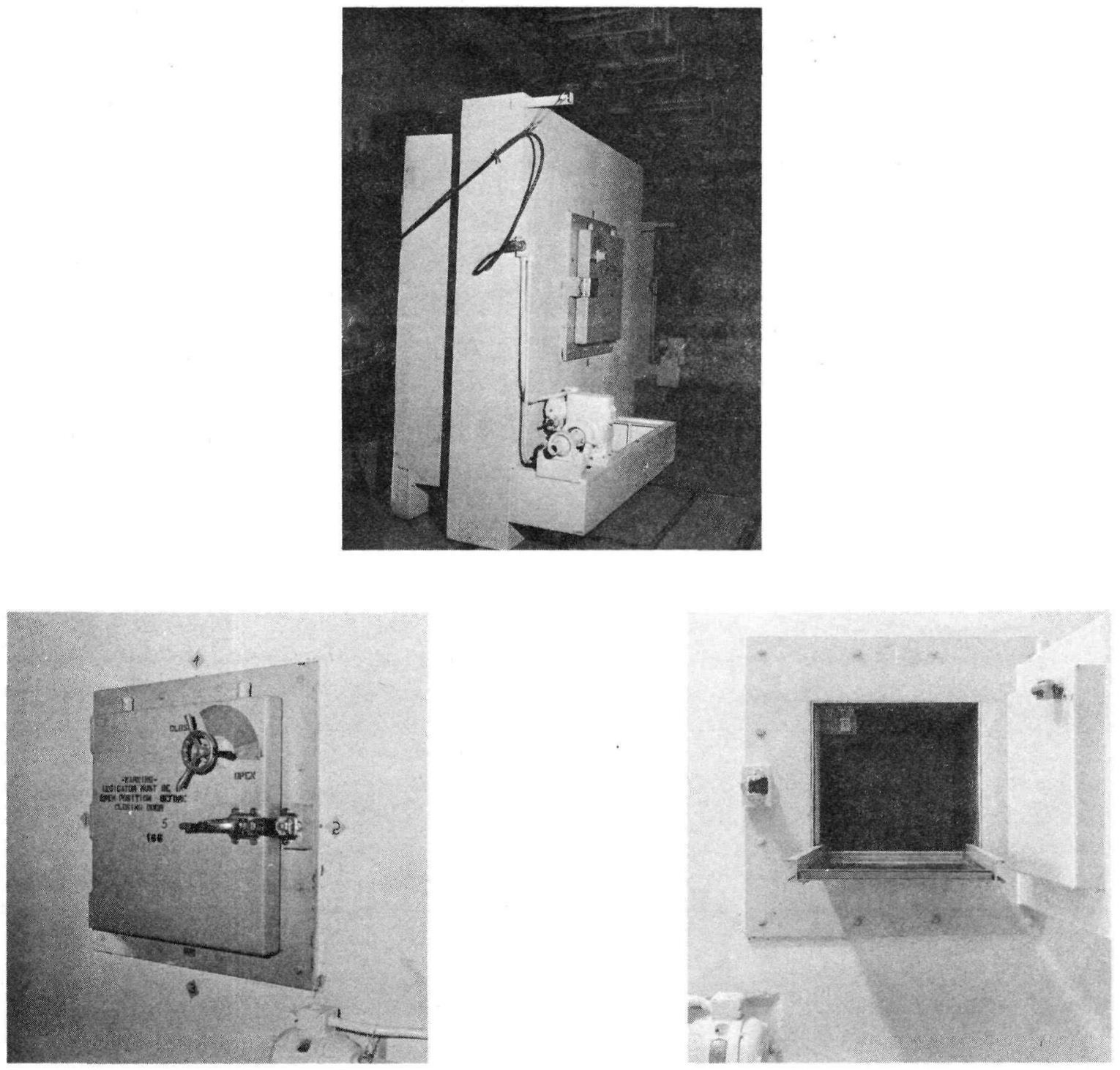
PROVISIONING LIST ITEM NUMBER 5026

DRAWING NUMBER

PART NUMBER Ameray Corp. AM-2715-1
AGC
FIRST PROVISIONED FOR E-MAD ADD-ON GOVT. INV. CONTROL NUMBER

$\cos T$

\begin{tabular}{|c|c|}
\hline USE LOCATION & QTY REQ'D \\
\hline A. AGC SACRAMENTO & \\
\hline B. WANL & \\
\hline C. & \\
\hline D. NRDS & 1 \\
\hline TOTAL & 1 \\
\hline
\end{tabular}

External overall dimensions:

\section{DIMENSIONS AND CAPACITY}

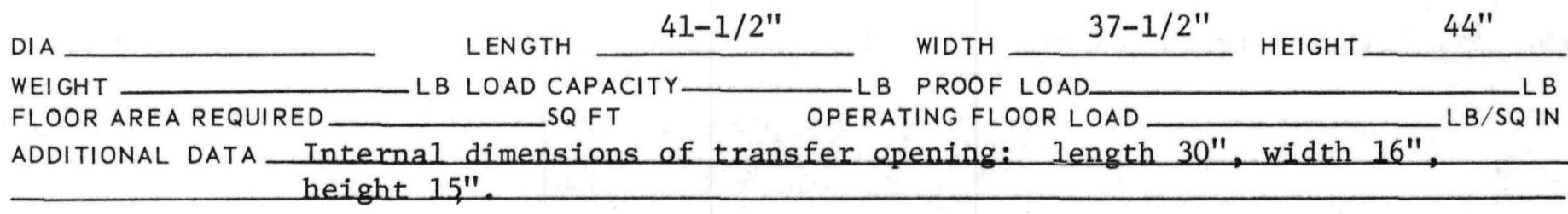

GASES N/A PRESSURE ELECTRICAL — N $/ A$

LIQUIDS N/A

SPEED

MEASURING ACCURACY

CALIBRATION INTERVAL

ADDITIONAL DATA VOLTS

PRESSURE IN./MIN (RPM)
LB/SQ IN, VOLUME

CPS

$L B / S Q$ IN

CUTTING SPEED

HORIZONTAL
CFM LUBRICATION

PHASE

QTY REQ'D 
EQUIPMENT TITLE

DESCRIPTION: The Spacer Car is a standard railroad flatcar modified by the addition of a 1/2-inch thick aluminum deck plate, a special railroad coupler (ACFI P/N 3-501192-00), and stainless-steel mirrors which permit visual observation of coupling operations. The car's primary function is to provide an additional 50 feet of space between a manned locomotive or the manned control car ( $P / L$ 2002) and a radioactively loaded railroad car (e.g., the engine installation vehicle, P/L 2001, or the highactivity storage car, P/L 5021). The Spacer car may also be used for transportation of material over the NRDS railway system. 
PROVISIONING LIST ITEM NUMBER 5029

DRAWING NUMBER

PART NUMBER Page \& Page 6512-4

CONTRACTOR AGC
FIRST PROVISIONED FOR E-MAD ADD-ON GOVT. INV. CONTROL NUMBER

None Assigned

\begin{tabular}{|l||c|}
\hline \multicolumn{1}{|c||}{ USE LOCATION } & QTY REQ'D \\
\hline A. AGC SACRAMENTO & \\
\hline B. WANL & \\
\hline C. & \\
\hline D. NRDS TOTAL & 1 \\
\hline \multicolumn{2}{|c||}{1} \\
\hline
\end{tabular}

\section{DIMENSIONS AND CAPACITY}

DIA

WEIGHT 34,300

FLOOR AREA REQUIRED

ADDITIONAL DATA

* Overall length of car and couplers is $44^{\prime} 3 \frac{1}{2}{ }^{\prime \prime}$

\section{OPERATING DATA}

GASES Air PRESSURE 80 LB/SQ IN. VOLUME

ELECTRICAL 110 VOLTS D.C. CPS

LIQUIDS

PRESSURE

IN./MIN (RPM)

MEASURING ACCURACY

CALIBRATION INTERVAL

ADDITIONAL DATA
$L B / S Q$ IN

CUTTING SPEED

HORIZONTAL
CFM LUBRICATION

PHASE

QTY REQ'D 


\begin{tabular}{|l|l}
\hline Ci] NERVA & SUPPORT EQUIPMENT \\
\hline PROGRAM & TECHNICAL DESCRIPTION HANDBOOK \\
\hline
\end{tabular}

EQUIPMENT TITLE

SHEARS, PNEUMATIC, HEDGE TYPE
PROV. LIST

ITEM NO.

DESCRIPTION: The Hedge Type Pneumatic Shears consist of a pneumatic actuator which operates a set of sliding hedge-type cutters. The shears are supplied with the necessary interconnecting hoses, an electrically operated air-control value, and a manipulator grip. The shears are used for severing small instrumentation wires during remote disassembly.

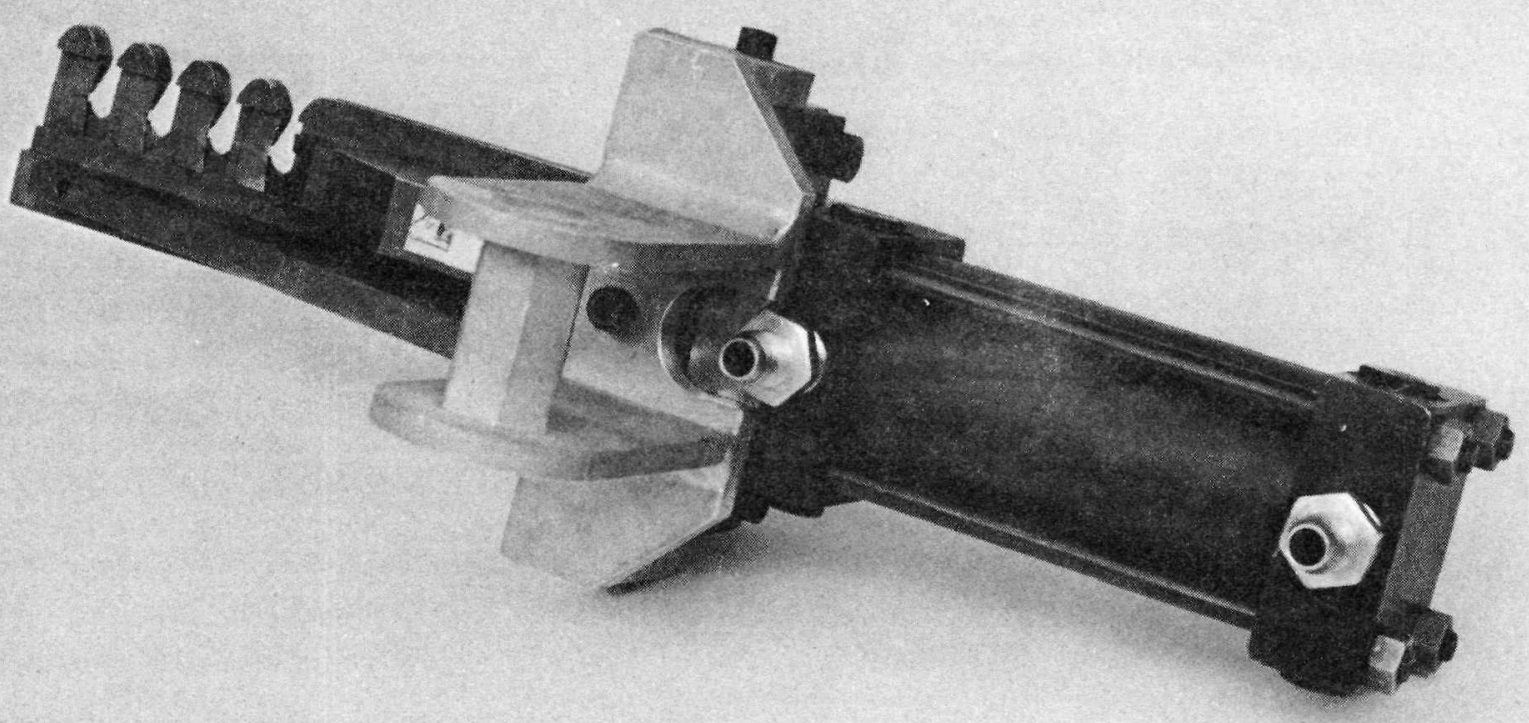


PROVISIONING LIST ITEM NUMBER

5035

DRAWING NUMBER

PART NUMBER ACFI 3-511557-000

CONTRACTOR AGC
FIRST PROVISIONED FOR E-MAD ADD-ON GOVT, INV. CONTROL NUMBER None

\begin{tabular}{|c||c|}
\hline \multicolumn{1}{|c||}{ USE LOCATION } & QTY REQ'D \\
\hline A. AGC SACRAMENTO & \\
\hline B. WANL & \\
\hline C. & 1 \\
\hline D. NRDS TOTAL & 1 \\
\hline
\end{tabular}

\section{DIMENSIONS AND CAPACITY}
DIA 3 " LENGTH 20" WIDTH WEIGHT LB LOAD CAPACITY LB PROOF LOAD FLOOR AREA REQUIRED SQ FT

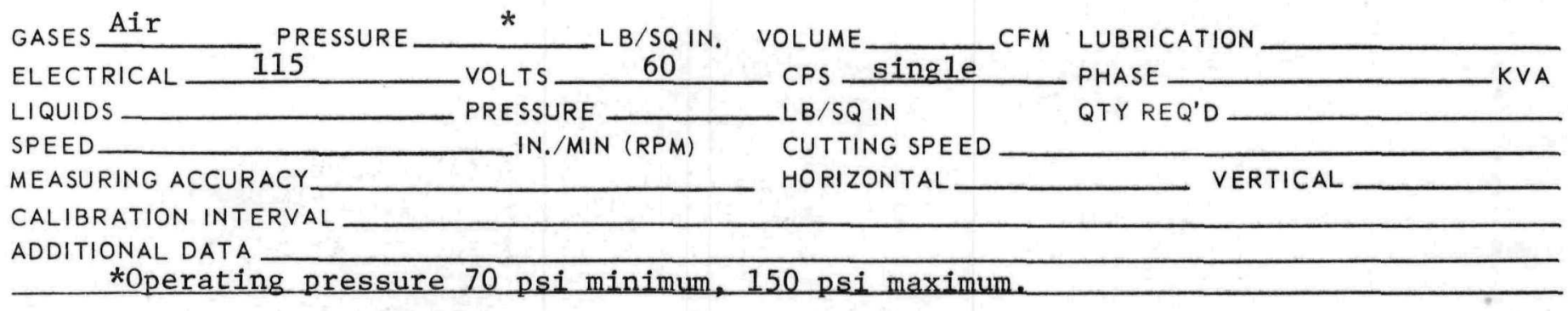

\section{OPERATING EQUIPMENT}

MANIPULATOR _ WMHS, OPS, O-MAN

LOAD CAPACITY

LB MAX

CRANE LOAD CAPACITY LB MAX ADDITIONAL DATA 


\section{(i) NERVA \\ LIPROGRAM}

EQUIPMENT TITLE

SHEARS, PNEUMATIC, HOOK TYPE
SUPPORT EQUIPMENT

TECHNICAL DESCRIPTION HANDBOOK
PROV. LIST

ITEM NO. 5036

January 1968

\section{REVISION}

DESCRIPTION: The Hook Type Pneumatic Shears consists of a pneumatic actuator which operates a single hook-type cutter head. The shears are supplied with the necessary interconnecting hoses, an electrically operated air-control valve, and a manipulator grip. The shears are used for severing instrumentation wires during remote disassembly.

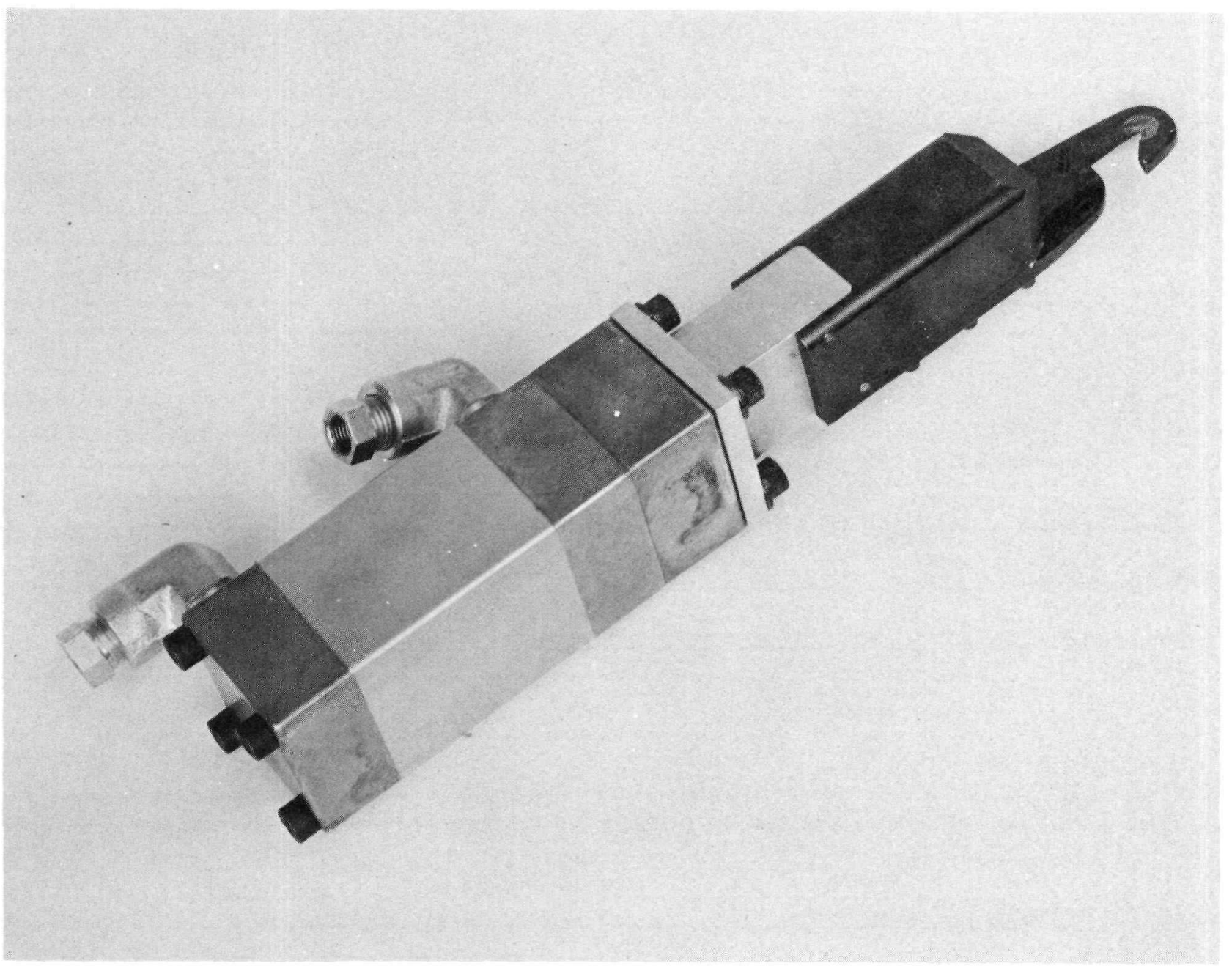




\section{TECHNICAL SUMMARY}

PROVISIONING LIST ITEM NUMBER 5036

DRAWING NUMBER

PART NUMBER ACFI 3-511057-00

CONTRACTOR
FIRST PROVISIONED FOR E-MAD ADO-ON GOVT. INV. CONTROL NUMBER

$\cos T \quad \$ 650.00$

\begin{tabular}{|l||c|}
\hline \multicolumn{1}{|c||}{ USE LOCATION } & QTY REQ'D \\
\hline A. AGC SACRAMENTO & \\
\hline B. WANL & \\
\hline C. & 1 \\
\hline D. NRDS TOTAL & 1 \\
\hline
\end{tabular}

\section{DIMENSIONS AND CAPACITY}

DIA $3^{\prime \prime}$

WEIGHT

FLOOR AREA REQUIRED

ADDITIONAL DATA
LENGTH 16" LB LOAD CAPACITY SQ FT
WIDTH LB PROOF LOAD OPERATING FLOOR LOAD
HEIGHT

\section{OPERATING DATA}

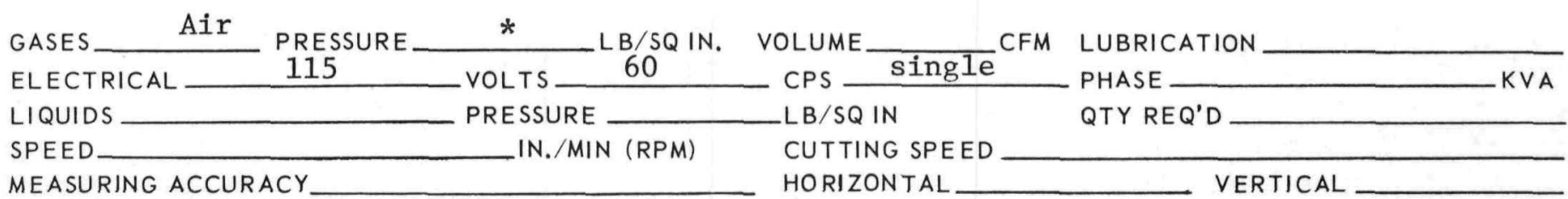

CALIBRATION INTERVAL

ADDITIONAL DATA

*Operating pressure 70 psi minimum, 150 psi maximum.

MANIPULATOR WMHS, OPS, O-MAN

CRANE

ADDITIONAL DATA
LOAD CAPACITY

LOAD CAPACITY
LB MAX

LB MAX

INTERFACES 
(1) NERVA

SUPPORT EQUIPMENT TECHNICAL DESCRIPTION HANDBOOK

'EQUIPMENT TITLE

SCREWDRIVER, REMOTE
PROV. LIST

ITEM NO. 5038

DATE January 1968

\section{REVISION}

DESCRIPTION: The Remote Screwdriver is a modified Ingersoll-Rand electrical power tool equipped with a PaR A-03494-D tool power adapter and a screwdriver bit adapter.

Various sizes of remotely interchangeable screwdriver bits are provided for the following types of screw heads: slotted head, phillips head, reed and prince, clutch head, and hex socket head. Power is provided through the manipulator wrist adapter and is controlled at the manipulator control console. The screwdriver incorporates a telescoping barrel assembly which permits screw runout through a distance of $1-1 / 2$ inches without tool repositioning. 
PROVISIONING LIST ITEM NUMBER 5038 DRAWING NUMBER

PART NUMBER

\section{PaR A-03788-D}

FIRST PROVISIONED FOR E-MAD ADD-ON GOVT. INV. CONTROL NUMBER None

\begin{tabular}{|l||c|}
\hline \multicolumn{1}{|c||}{ USE LOCATION } & QTY REQ'D \\
\hline A. AGC SACRAMENTO & \\
\hline B. WANL & \\
\hline C. & \\
\hline D. NRDS TOTAL & 1 \\
\hline \multicolumn{2}{|c||}{1} \\
\hline
\end{tabular}

\section{DIMENSIONS AND CAPACITY}

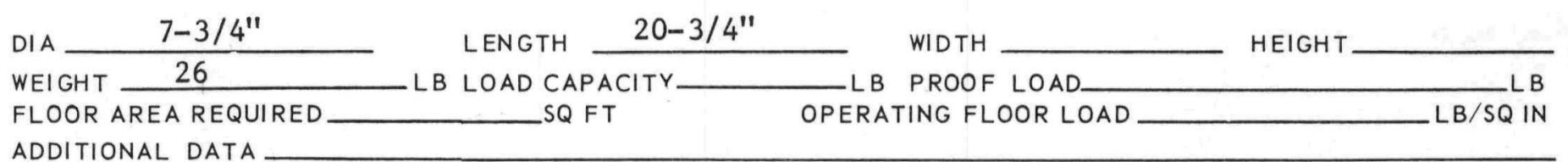
ADDITIONAL DATA

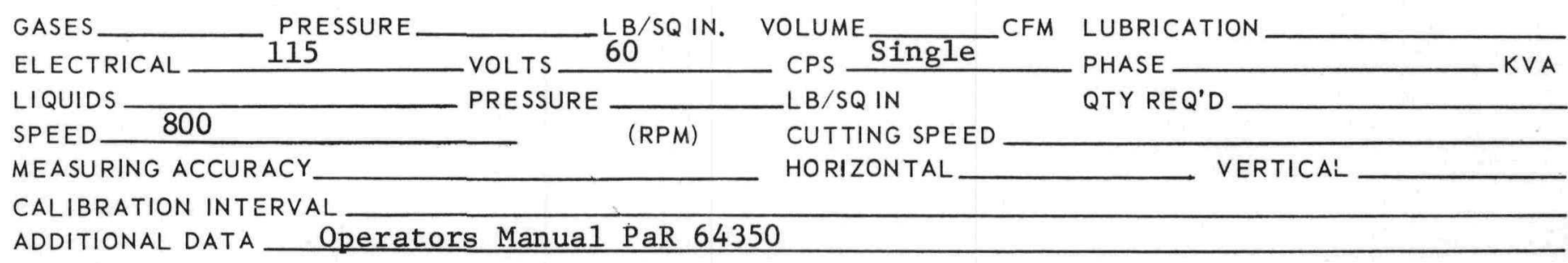

MANIPULATOR E-MAD Class A \& B

CRANE

ADDITIONAL DATA
LOAD CAPACITY LOAD CAPACITY
L B MAX LB MAX 


\section{RECEIVED}

1068 iE8 1.6 AHII: 30

Stipo-c

CLEVELAHD, OHIO 
